\title{
Linguistic justice
}

Citation for published version (APA):

Fidahic, B. (2018). Linguistic justice: Translation and interpretation at the International Criminal Tribunal for the former Yugoslavia. [Doctoral Thesis, Maastricht University]. Maastricht University. https://doi.org/10.26481/dis.20181214bf

Document status and date:

Published: 01/01/2018

DOI:

10.26481/dis.20181214bf

Document Version:

Publisher's PDF, also known as Version of record

\section{Please check the document version of this publication:}

- A submitted manuscript is the version of the article upon submission and before peer-review. There can be important differences between the submitted version and the official published version of record.

People interested in the research are advised to contact the author for the final version of the publication, or visit the DOI to the publisher's website.

- The final author version and the galley proof are versions of the publication after peer review.

- The final published version features the final layout of the paper including the volume, issue and page numbers.

Link to publication

\footnotetext{
General rights rights.

- You may freely distribute the URL identifying the publication in the public portal. please follow below link for the End User Agreement:

www.umlib.nl/taverne-license

Take down policy

If you believe that this document breaches copyright please contact us at:

repository@maastrichtuniversity.nl

providing details and we will investigate your claim.
}

Copyright and moral rights for the publications made accessible in the public portal are retained by the authors and/or other copyright owners and it is a condition of accessing publications that users recognise and abide by the legal requirements associated with these

- Users may download and print one copy of any publication from the public portal for the purpose of private study or research.

- You may not further distribute the material or use it for any profit-making activity or commercial gain

If the publication is distributed under the terms of Article $25 \mathrm{fa}$ of the Dutch Copyright Act, indicated by the "Taverne" license above, 


\section{LINGUISTIC JUSTICE:}

TRANSLATION AND INTERPRETING AT THE INTERNATIONAL CRIMINAL TRIBUNAL FOR THE FORMER YUGOSLAVIA

\section{DISSERTATION}

to obtain the degree of Doctor at the Maastricht University, on the authority of the Rector Magnificus, Prof. Dr. Rianne Letschert, in accordance with the decision of the College of the Deans of the University of Maastricht, to be defended in public on the $14^{\text {th }}$ day of December 2018, at 10:0o hours

by

Besmir Fidahić 


\section{Supervisors:}

Prof. Mr. Gerard-René de Groot

Prof. Mr. André Klip

\section{Assessment Committee:}

Prof. Dr. G.P.M.F. Mols

Prof. Dr. R. Letschert

Dr. Mr. R. Moerland

Prof. Dr. V. Friedman

Prof. Dr. S. Freeland 
My first engagement with the ICTY was early in 1996 on when the mass graves containing the bodies of Srebrenica men and boys were discovered. I was working at the mass graves sites, interpreting for the spokesperson. I felt a strong connection with the Srebrenica cause from the very beginning of my engagement at the ICTY and have stayed with the ICTY Srebrenica Team ever since mainly because of their inspiring legal and investigatory leadership. No matter what other investigation team I was assigned to, I made sure to make time whenever the ICTY Srebrenica Team needed me.

In the late 2010s, I was called by the ICTY Srebrenica Team to interpret for drivers who drove Srebrenica men and boys to the execution site and who were appearing as witnesses for the prosecution. One of the drivers said he took a liking to a small boy aged about 13-14. He took him aside and put him on the front seat with him in the truck. "Together" they transported many other Srebrenica men and boys from detention locations to the execution site where they were all killed. Their journey lasted all day and all night and consisted of about 10-12 different rounds. They passed the time by talking and singing together. The driver described this boy as beautiful, happy, engaging, and chatty.

Once the transports and executions were completed, the driver found the boy sleeping on the front seat. He sneaked out and went into the Main Staff Office of the Army of Republika Srpska Drina Corps. There he woke up the Army of Republika Srpska Drina Corps Duty Officer, a Major. This Duty Officer got into a car and drove to the location where he found the driver's truck. He pulled the sleeping boy out and shot him dead in the bushes. He then returned to the headquarters. The driver said he didn't know what else to do.

I am dedicating this book to the children of all those in Bosnia and Herzegovina who "didn't know what else to do." 


\section{ACKNOWLEDGMENTS}

I am very pleased that a little over 20 years of my engagement with the UN as a staff and freelance translator, interpreter, and editor in a combination of Bosnian, English, French, and Arabic has brought me to a stage where I could summarize my professional experiences in the form of a coherent academic study targeting legal and language professionals working together. I was educated in Bosnia and Herzegovina, the United States of America, Lebanon, France, United Kingdom, and the Netherlands. My work took me to six of the seven continents of the world. I would like to thank the Universe for bringing me to all those places.

I was barely 19 years old when I signed my first freelance contract with the ICTY OTP and I am 40 in the year of publication of this this study, so I practically grew up with the UN. My first engagements took place next to the mass graves, watching the excavation of bodies of men and boys killed during the Army of Republika Srpska's murder in Srebrenica, interpreting for an occasional journalist who covered the event. My last engagement was in the ICTY Detention Unit where some of my duties included taking the accused to the doctor and monitoring their private telephone conversations. I have been blessed and cursed to see all sides to the conflict completely stripped down to the bone. I would like to thank every investigator and lawyer I ever worked with for showing me that there are no isolated events or actions in life and that context matters above all. You have bestowed on me the greatest and the most horrifying gift of all: to see the issue for what it is from all sides and concentrate on what is important for me.

First and foremost, I would like to thank my promotors: Prof. de Groot for taking on this project and for making the perfect selection of a co-supervisor in Prof. Klip. I can honestly say I have never worked with anyone as intellectually generous as the two of you. The relationship I had with the two of you on this project has been the most beautiful, fulfilling, and productive I have had in my life. I would also like to thank my mom, and my brothers and sisters for all their support, understanding, care, and love. I thank my five stay-aslong-as-you-want, dinner-making, out-to-restaurant-taking, here's-5o-to-tie-you-over, and getting-drunkand-You-Tube-videos-together-dancing sweet lady friends from The Hague who are obviously so hot they could be comfortably wearing black all the time and playing guitars in any Robert Palmer video. I thank my colleagues from AITC and AIIC who provided invaluable insight into UN translation and interpreting practices as far back as the 1970s. I thank Suada Katana-Imširpašić-Bonjaš, my very own Bosnian Alexis minus one last name, for all the material, emotional, and drinking support she has provided me and this project. I thank Aida Bajrić, Liya Chernishkaya, Ana Katalinić, Azra Kovačević, and Denis Kulenović for all the help they provided over the years. I thank my legal and language professionals' colleagues Amir Čengić, Christine Dahl, Alex Demirdjian, Stefanie Frease, John Hodgson, Ivana Mlikota, Bob Reid, and Janet Stewart for their support, leads, patience, and clarity. I thank the two hottest ladies from ICTY Defense, Tatjana Čmerić and Jesenka Rešidović, as this study would be lacking in so many ways and on so many levels if it weren't for them. And, finally, I thank Atdhe Hetemi and Victor Friedman for all their support and encouragement. 


\section{PROPOSITIONS}

1. The official languages of international criminal tribunals must be limited to a minimum to provide for the least expensive, the most effective, and the most practical translation, interpreting and transcription combination: English into the language of the situation country and vice versa. Should the international criminal tribunal adjudicate on crimes that occurred in a bi- or multilingual country, both or all relevant languages must be made official.

2. In addition to making official the language of the situation country, the rules and regulations of international criminal tribunals adjudicating on ethnic crimes must also include the different language variants spoken in the situation country when these variants are invested with ethnic and/or political significance because they reflect on the provision of language services to defendants, defense attorneys from the situation country, victims and witnesses, and posterity. Moreover, when the dialect/language of victims differs significantly from the standard language, these differences must be taken into account and accommodated.

3. Defendants' rights to translation and interpreting must be absolute: they need to be provided with the essential documents of the court record in a language they understand.

4. The way the selection procedure of defense attorneys is conducted affects the free choice of defense attorneys. Defense attorneys who do not speak the languages of the court and defense attorneys who do not speak the languages of defendants must be afforded exactly the same translation and interpreting rights as defendants.

5. The relationship between legal and language professionals and that between language professionals engaged in legal transactions or legal professionals and their non-legal clients from the investigations phase via proofing to testifying must be firmly regulated and it must be binding on both parties in the form of actual written standards of translation, interpreting, and transcription at international criminal tribunals.

6. The recruitment of language professionals at international criminal tribunals adjudicating on ethnic crimes must be entirely governed by citizenship and ethnicity concerns.

7. The UN, in general, and international criminal tribunals in particular, must start recruiting professionally educated translators and interpreters. It must be made clear that staff recruited to language positions at international criminal tribunals should never perform any other jobs: the use of Language Assistants must disappear from international criminal tribunals.

8. Language services at international criminal tribunals are seriously lagging behind in the use of CAT. There is no reason not to fully migrate to using CAT when translating documents submitted in soft copy.

9. As a quality check on language professionals' output, international criminal tribunals must reinstate the IMT's institution of appointing an Interpretation Monitor. 
TABLE OF CONTENTS

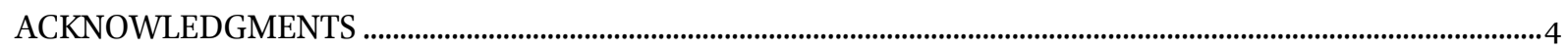

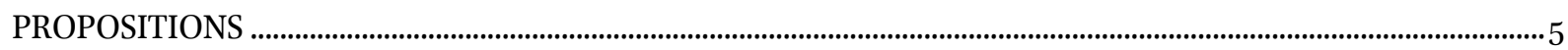

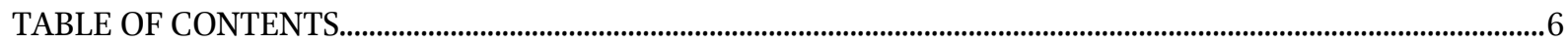

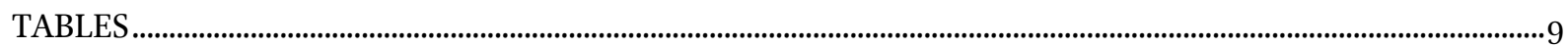

FIGURES

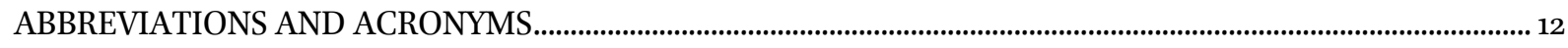

Chapter 1: May we have the appearances, please ..................................................................................................... 15

1.1. Problem statement and the main research question .................................................................................16

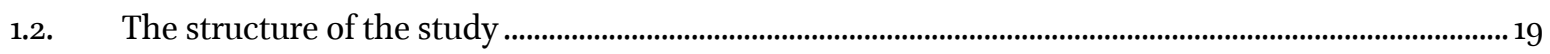

Chapter 2: May the institution of justice take the stand, please .............................................................................26

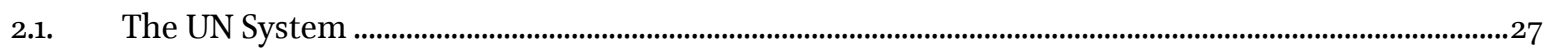

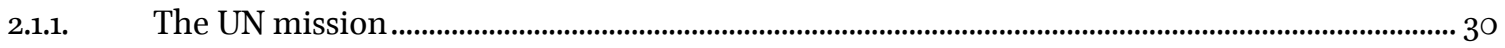

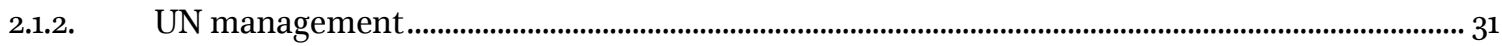

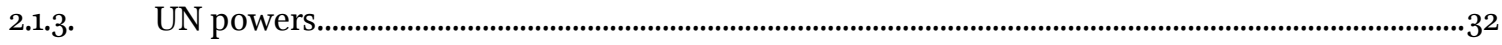

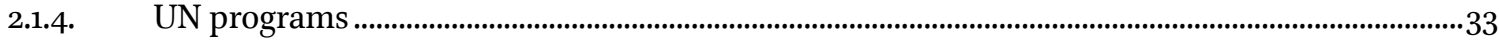

2.2. The UN System and international criminal tribunals …............................................................................34

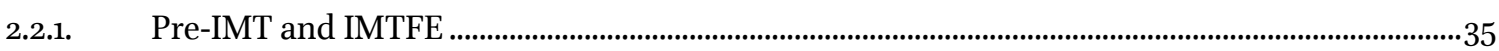

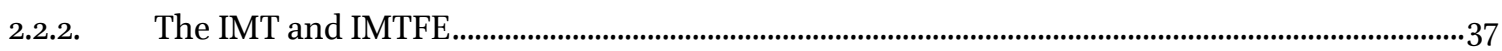

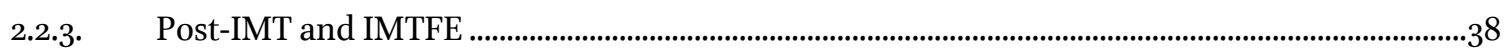

2.2.4. The ICTY and subsequently established international criminal tribunals ................................... 41

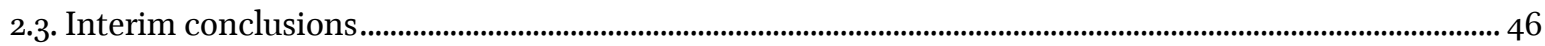

Chapter 3: May the local context take the stand, please ........................................................................................47

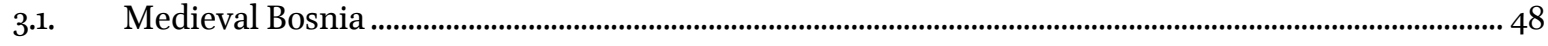

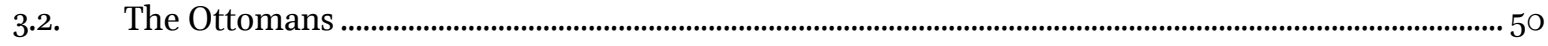

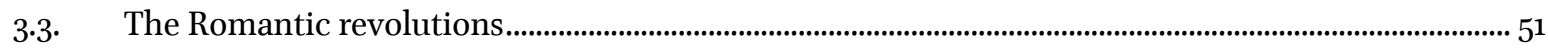

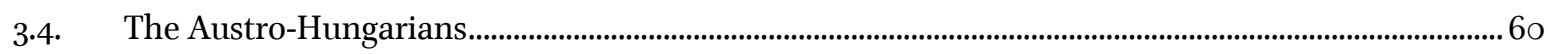

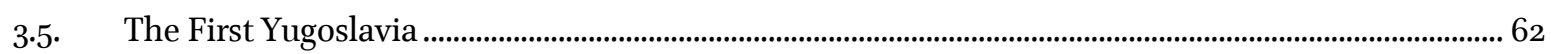

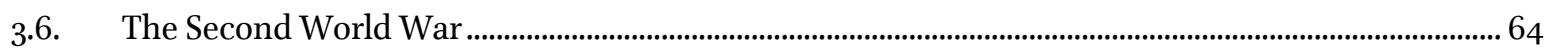

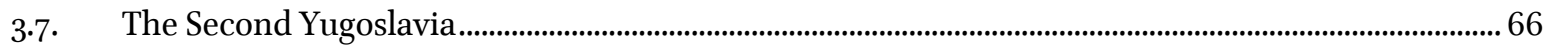

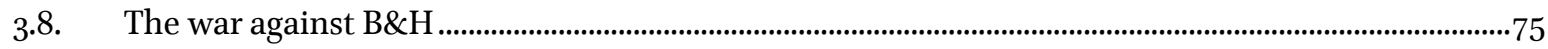

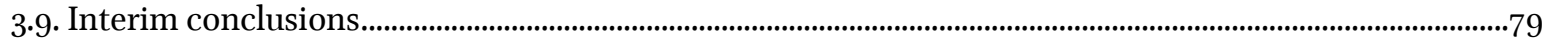

Chapter 4: May the legal institution take the stand, please .......................................................................................... 81

4.1. Due process and language-related rights, obligations, and requirements ............................................82

4.1.1. Pre-ICTY due process language-related rights, obligations, and requirements ............................... 88 
4.1.2. Post-ICTY due process language-related rights, obligations, and requirements ........................ 91

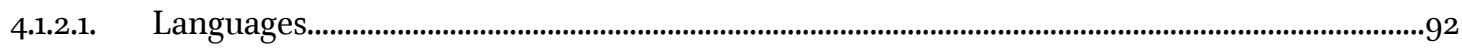

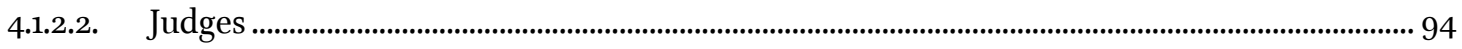

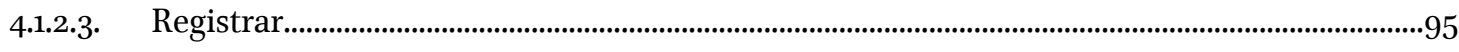

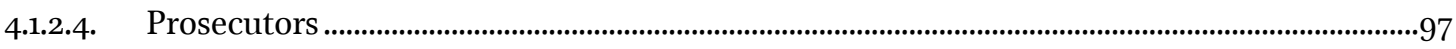

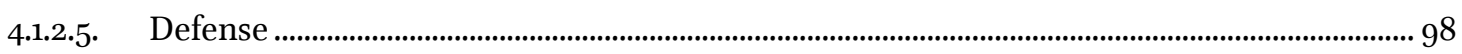

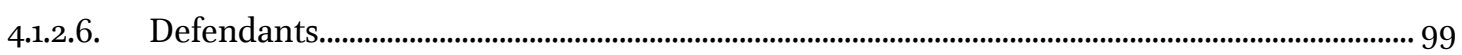

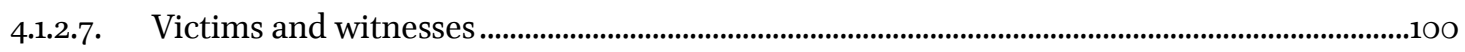

4.2. ICTY case law on language-related rights, obligations, and requirements ...........................................103

4.3. Procedural equality of arms between the ICTY Prosecution and Defense ............................................110

4.4. Legal background to the engagement of translators and interpreters at international criminal

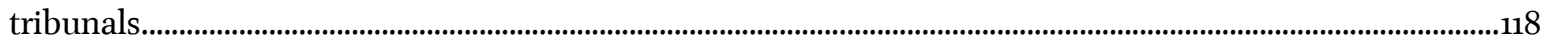

4.5. Legal background to translation and interpreting at international criminal tribunals .....................130

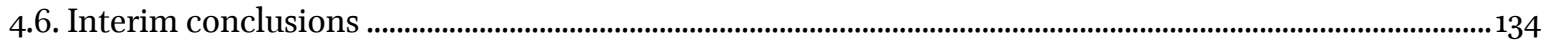

Chapter 5: May UN language professionals take the stand, please .......................................................................... 137

5.1. UN staff categories, rules and regulations, and partnerships affecting language professionals..............138

5.2. Mechanisms governing UN language professionals' entry examinations ...................................................142

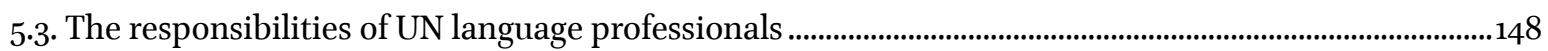

5.4. Competencies required of UN language professionals..............................................................................153

5.5. UN language professionals: translation and interpreting output standards..............................................157

5.6. Interim conclusions................................................................................................................................................... 159

Chapter 6: May ICTY language professionals take the stand, please ........................................................................161

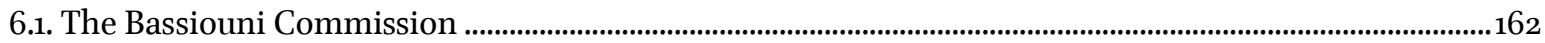

6.2. Transferring cases to domestic jurisdictions: Rules of the Road project .....................................................167

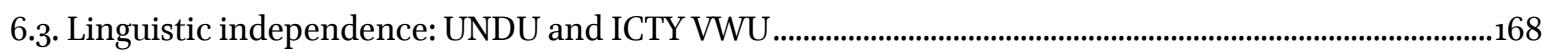

6.4. Servicing the public, the professionals, and posterity: court reporters........................................................169

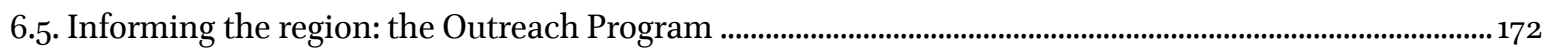

6.6. Editing and proofreading judicial documents: The Chamber Support Unit .............................................. 173

6.7. The UN and ICTY language philosophy vs the CLSS language philosophy.................................................175

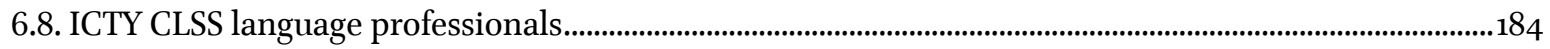

6.8.1. ICTY CLSS language professionals: recruitment .....................................................................................185

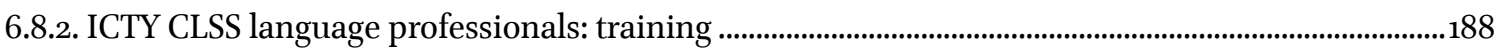

6.8.3. ICTY CLSS language professionals: staff retention ................................................................................197

6.8.4. ICTY CLSS language professionals: translation and interpreting output ..........................................202

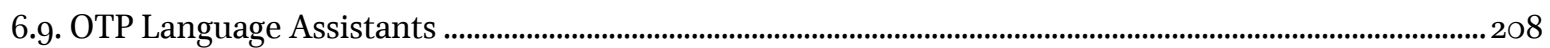

6.9.1. The legality of the use of Language Assistants...................................................................................209

6.9.2. Language Assistants and existing professional resources ...................................................................... 213 
6.9.3. Language Assistants and document management ..................................................................................216

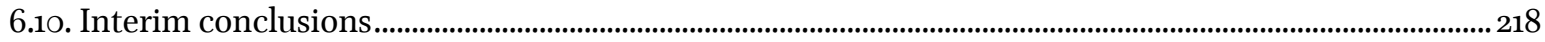

Chapter 7: May translation and interpreting take the stand, please ........................................................................ 221

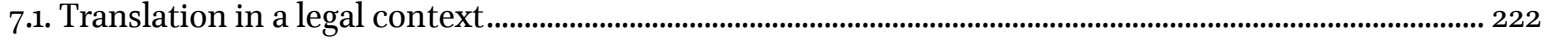

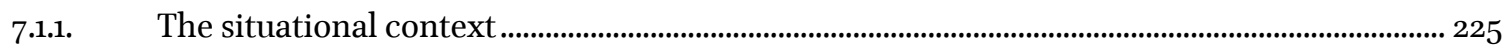

7.1.1.1. Type of text production ................................................................................................................226

7.1.1.2. Time of text production............................................................................................................ 222

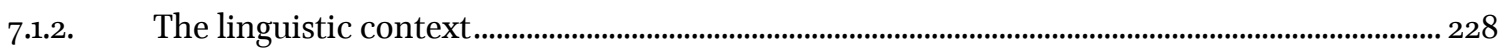

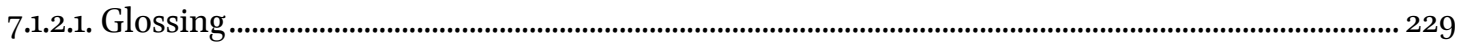

7.1.2.2. Negotiation of meaning ........................................................................................................................23

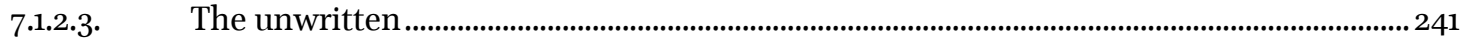

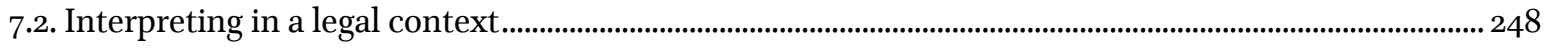

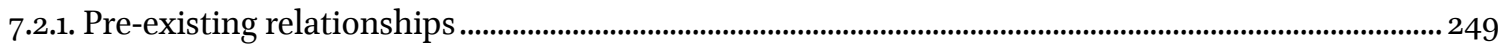

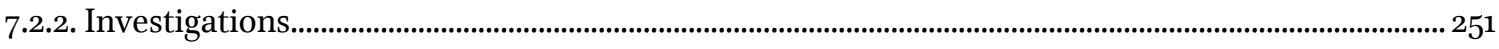

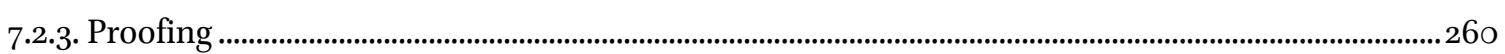

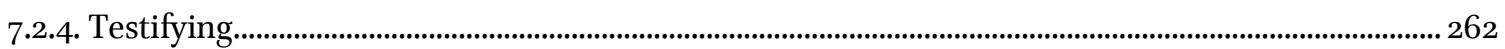

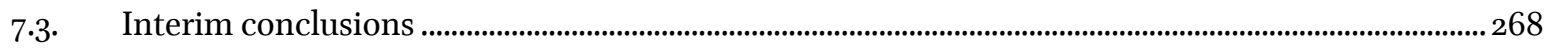

Chapter 8: May posterity approach the bench, please? ….............................................................................................. 271

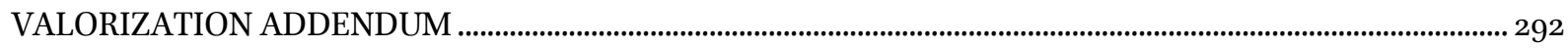

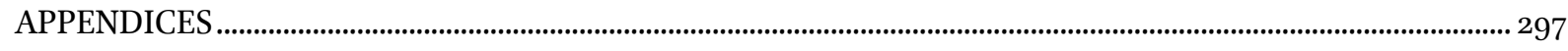

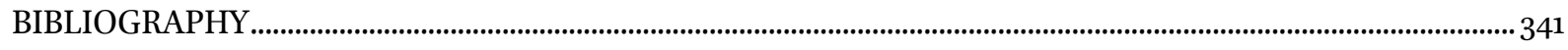

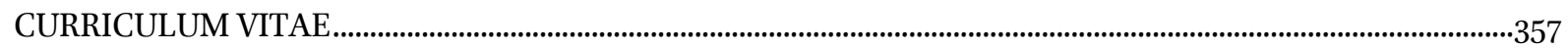




\section{TABLES}

Table 1. Overlapping responsibilities between $\mathrm{UN}$ entities in relation to $21^{\text {st }}$ century buzzwords .......................33

Table 2. Major international criminal tribunals ........................................................................................................83

Table 3. Due process rights at the IMT, IMTFE, ICTY, ICTR, SCSL, STL and ECCC ................................................87

Table 4. ICTY, ICTR, SCSL, STL and ECCC language-related rights and obligations................................................. 91

Table 5. Documents pending translation after the completion of the English-speaking trial (Stanišić and

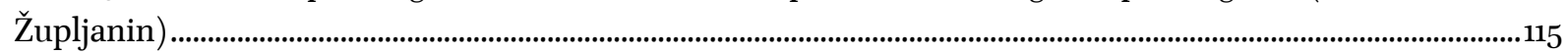

Table 6. Documents pending translation after the completion of the French-speaking trial (Šešelj) ...............116

Table 7. Citizens of UN Security Council permanent member countries in UN DGACM between 2013 and

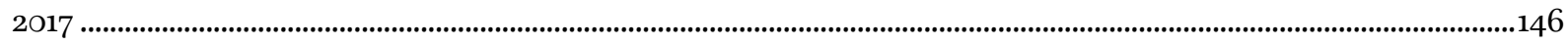

Table 8. Citizens of UN Security Council permanent member countries at $\mathrm{P}-1$ to $\mathrm{P}-5$ language positions in

UN DGACM as at 31 December 2016 ...........................................................................................................................146

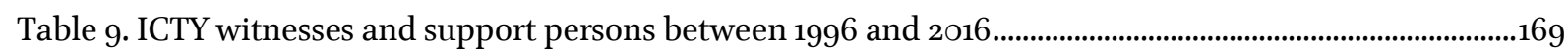

Table 10. Short-term, SSA and consultants and individual contractors' agreements between 2000 and 2007

.198

Table 11. UN-wide annual, monthly, and daily remuneration of internal and external language professionals

Table 12. AITC 2013 contractual rates..................................................................................................................201

Table 13. CLSS production vs. minimum, median and maximum output................................................................ 203

Table 14. Vallianatou production with CAT tools......................................................................................................... 207

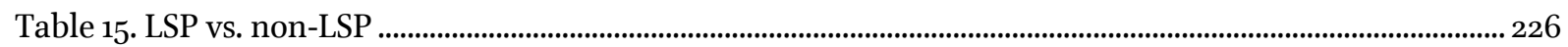

Table 16. Mistakes in interpreting during an interview with a suspect .................................................................. 256

Table 17. Mistakes in interpreting during the initial appearance of a defendant.................................................. 263

Table 18. Mistakes in interpreting during the testimony of a witness .................................................................. 266 


\section{FIGURES}

Figure 1. UN System chart as of March 2017 ....................................................................................................................29

Figure 2. Waiver form for applicants to GS-level posts with graduate degree ...........................................................211 


\section{APPENDICES}

Appendix 1. Full list of pre-trial, final and appeal briefs

298

Appendix 2. Language-related requests, decisions, and orders ................................................................................ 303

Appendix 3. Ethnicity of the accused vs. languages of interpreters ........................................................................ 326

Appendix 4. Language of interpreters vs. location of crimes and ethnicity of victims........................................... 331

Appendix 5. Ethnicity of testifying victims and witnesses vs. languages of interpreters....................................... 338 


\section{ABBREVIATIONS AND ACRONYMS}

AIIC

AITC

AR

AT ILO

$\mathrm{B} \& \mathrm{H}$

$\mathrm{B} / \mathrm{C} / \mathrm{S}$

CAT

CIS

CLSS

DGACM

DSA

ECCC

ECHR

EDS

ERN

EU

FIT

FS

GS

IAMLADP

ICC

ICCPR

ICJ

ICRC

ICSC

ICTR

ICTY
International Association of Conference Interpreters

International Association of Conference Translators

ICTY Annual Report

Administrative Tribunal of the International Labour Organisation

Bosnia and Herzegovina

Bosnian/Croatian/Serbian

Computer-Assisted Translation

Case Information Sheet

Conference and Language Services Section

Department for General Assembly and Conference Management

Daily Subsistence Allowance

Extraordinary Chambers in the Courts of Cambodia

European Convention on Human Rights and Freedoms

Electronic Disclosure System

Evidence Registration Number

European Union

International Federation of Translators

Field Service category

General Service category

International Annual Meeting on Language Arrangements, Documentation and Publications

International Criminal Court

International Covenant on Civil and Political Rights

International Court of Justice

International Committee of the Red Cross

International Civil Service Commission

International Tribunal for the Prosecution of Persons Responsible for Genocide and Other Serious Violations of International Humanitarian Law Committed in the Territory of Rwanda and Rwandan Citizens Responsible for Genocide and Other Such Violations Committed in the Territory of Neighboring States, between 1 January 1994 and 31 December 1994

International Tribunal for the Prosecution of Persons Responsible for Serious Violations of International Humanitarian Law Committed in the Territory of the Former Yugoslavia since 1991 
IICI

IIIC

ILC

ILO

IMT

IMTFE

IR

JIAMCATT

JIU

LCE

LLP

LSP

MICT

MT

ODIHR

ODM

OIOS

OKO

OPCW

OSCE

OTP

$\mathrm{R}_{2} \mathrm{P}$

RoP

RPE

SANU

SCSL

SFOR

SPDD

SSA

STL

UDHR

UK

UN BoA
Institute for International Criminal Investigations

UN International Independent Investigation Commission

International Law Commission

International Labour Organisation

International Military Tribunal at Nuremberg

International Military Tribunal for the Far East at Tokyo

ECCC Internal Rules

International Annual Meeting on Computer-Assisted Translation and Terminology

Joint Inspection Unit

Language Competitive Examination

Language for Legal Purposes

Language for Special Purposes

UN Mechanism for International Criminal Tribunals

Machine Translation

OSCE's Office for Democratic Institutions and Human Rights

Office of Document Management

Office of Internal Oversight Services

B\&H Court Criminal Defense Section

Organization for the Prohibition of Chemical Weapons

Organization for Security and Cooperation in Europe

ICTY Office of the Prosecutor

Right to Protect

Rules of Procedure

Rules of Evidence and Procedure and Evidence

Serbian Academy of Arts and Sciences

Special Court for Sierra Leone

NATO Stabilization Forces

Special Panels of the Dili District

Special Service Agreement

Special Tribunal for Lebanon

Universal Declaration of Human Rights

United Kingdom

UN Board of Auditors 
UN entities

UN

UNDP

UNDT

UNDU

UNESCO

UNHCR

UNICEF

UNPROFOR

USA

VRS

VWU

WHO

WMO
UN subsidiary bodies, funds and programs, related organizations and specialized agencies

United Nations

UN Development Program

UN Dispute Tribunal

UN Detention Unit

UN Educational, Scientific and Cultural Organization

Office of the UN High Commissioner for Refugees

UN Children's Fund

UN Protection Forces

United States of America

Vojska Republike Srpske (Army of Republika Srpska)

Victims and Witnesses Unit of the ICTY

World Health Organization

World Meteorological Organization 
Chapter 1: May we have the appearances, please

Chapitre 1 : Veuillez faire la présentation des parties

Prvo poglavlje: Neka se predstave strane u postupku 
This study deals with linguistic justice in the delivery of translation, interpreting, and transcription services at the International Tribunal for the Prosecution of Persons Responsible for Serious Violations of International Humanitarian Law Committed in the Territory of the Former Yugoslavia since 1991 (ICTY). The ICTY was an ad hoc tribunal established for specific purposes by the United Nations (UN) Security Council Resolution 827 on 25 May 1993. It was set up as an impermanent UN body to prosecute perpetrators of serious crimes committed during the wars in the former Yugoslavia which were waged in Croatia, Bosnia and Herzegovina (B\&H), and Kosovo between 1991 and 1999.

The ICTY was the first international criminal tribunal to emerge after the closure of the International Military Tribunal at Nuremberg (IMT) in 1946 and the International Military Tribunal for the Far East at Tokyo (IMTFE) in 1948. The ICTY set in motion changes in the political and legal landscape by challenging what had become almost a tradition of impunity for war crimes and led to the establishment of many other international criminal tribunals, such as: the International Tribunal for the Prosecution of Persons Responsible for Genocide and Other Serious Violations of International Humanitarian Law Committed in the Territory of Rwanda and Rwandan Citizens Responsible for Genocide and Other Such Violations Committed in the Territory of Neighboring States, between 1 January 1994 and 31 December 1994 (ICTR), the Special Court for Sierra Leone (SCSL), the Extraordinary Chambers in the Courts of Cambodia (ECCC), the Special Tribunal for Lebanon (STL), and, most importantly, the first permanent international criminal tribunal, the International Criminal Court (ICC) which, after having been established in 2002, saw the beginning of its first trial in 2009 . The ICTY closed its doors on 31 December 2017.

1.1. Problem statement and the main research question

This study focuses on the realm of the international criminal law and examines the concept of linguistic justice that was supposed to be served by international criminal tribunals, most specifically ICTY. The ethnic conflict in the former Yugoslavia was the one that was anchored in language where language quarrels have been used as a proxy for unresolved issues of national identity. The fact that the ICTY was an international criminal tribunal adjudicating on ethnic crimes had a paramount bearing on the undertakings of this study because perpetrators of ethnic crimes deny other's identity, history, and language as part of their overall criminal enterprise. Since this entails manipulation of language-related matters, this study will focus on the nascent concept of linguistic justice examining whether the nationalist discourse that led to the conflict and that was anchored in language had any bearing on normative arrangements and practical delivery of language, and translation, interpreting, and transcription services, by extension, at the ICTY. In that sense, this is the first study to examine international criminal law standards that should govern an interplay between, on the one side, language, translation, and interpreting, and, on the other, an international criminal tribunal adjudicating on ethnic crimes. The study will also reflect on normative arrangements relating to linguistic justice at subsequently established international criminal tribunals.

Van Parijs is the first scholar who addressed language-related conflicts and quarrels and failures to handle them correctly. In discussion of linguistic justice for Europe and for the world, Van Parijs claimed that such failures can seriously impair the pursuit of social justice. ${ }^{2}$ Van Parijs proposed the first normative theory of linguistic justice that rests on two normative pillars: an argument for English as a global lingua franca, and an argument that each language group be entitled to a policy of official multilingualism within its territory. Mowbray is the first scholar who brought the discussion of linguistic justice into the realm of international law reminding that language-related conflicts remain a concern both at the national and the international level. Mowbray points that language policy remains a global matter, that the questions of language confront

\footnotetext{
${ }^{1}$ The war against Slovenia was brief, lasted a mere ten days, and did not "produce" any indictments at the ICTY. However, ICTY trials also included one that adjudicated on ethnic skirmishes revolving around Albanian resurrection in Macedonia in 2001. See ICTY, Prosecutor v. Ljube Boškoski and Johan Tarčulovski, Public Judgment, paras. 61o-613, for discussion on challenges to the territorial, temporal, and subject-matter jurisdiction over these crimes: https://goo.gl/jBKsqe.

${ }^{2}$ Van Parijs, P. (2011), Linguistic justice for Europe and for the world. Oxford University Press: Oxford, UK.
} 
us with many issues and concerns, but that there is no generally accepted theory explaining prevailing intuitions in terms of linguistic justice or a set of normative guidelines for realizing and institutionalizing linguistic justice in the realm of the international law. ${ }^{3}$

Philosophically, Mowbray's study takes a very important approach to linguistic justice in the realm of the international law subscribing under the tenets of Pierre Bourdieu's philosophy of language: more than just a means of communication, language is a mechanism of power, where it matters who sets the language policies. This study will follow in its stead because the purpose of language is communication. Indeed, as soon as one enters an international criminal tribunal, one discovers that there are strict rules about communication revolving around the languages that may be used to address the court, when one can talk and write, what one can talk and write about, how long one can talk and write, and to whom and how one can talk and write. This also entails several lines of communication at international criminal tribunals:

- First line: the founding institution towards the working institution,

- Second line: the working institution towards the parties to the proceedings,

- Third line: the working institution towards the situation country,

- Fourth line: the founding institution and the working institution towards language services providers,

- Fifth line: the language service providers towards the parties to the proceedings and the situation country.

The first line of communication examined is that between the founding institution, UN, towards the working institution, ICTY. The ICTY was established under the auspices of the UN and falls under the Subsidiary Organs of the UN Security Council. The UN has six official languages, namely Arabic, Chinese, English, French, Russian, and Spanish. The UN Department for General Assembly and Conference Management (DGACM) is the main body that recruits UN language professionals. However, UN DGACM language professionals service only the principle organs of UN in offices in Addis Ababa, Bangkok, Beirut, Geneva, Nairobi, New York, Santiago, and Vienna. Such provision of language services is done through the policies of multilingualism where at least one of official UN languages is proclaimed as the official language in all UN subsidiary bodies, funds and programs, related organizations, and specialized agencies (UN entities). The UN DGACM can accommodate language services in these combinations only.

But, the languages of the situation country, the former Yugoslavia, do not figure among the official languages of the UN and cannot be accommodated by the UN DGACM. Although working under the auspices of the UN, the ICTY is an independent institution, meaning it could deliver its own rules and regulations or adopt the existing ones on, inter alia, official and working languages through its governing documents: the ICTY Statute (ICTY-S) and ICTY Rules of Procedure and Evidence (RPE). This line of communication will be examined to establish how well the general UN policies of multilingualism work in the context of international criminal tribunals.

The second line of communication examined is that between ICTY towards the parties to the proceedings. This study subscribes under the Black's Law Dictionary definition that the party to the proceedings is a person who takes part in legal transaction or proceeding. In the case of the ICTY, this would mean: ICTY Chambers, ICTY Office of the Prosecutor (OTP), ICTY defense, but also defendants, and victims and witnesses. ${ }^{4}$ As an independent institution, the ICTY delivered their own ICTY-S and ICTY RPE which addressed

\footnotetext{
${ }^{3}$ Mowbray, J. (2012), Linguistic justice: International Law and Language Policy. Oxford University Press: Oxford, UK.

${ }^{4}$ Gardner, B. (2010), The Black's Law Dictionary (ninth edition). West: St. Paul, p. 1232.
} 
the language-related rights, obligations, and requirements incumbent on the use of official and working languages, the judges, registrar, prosecutor, defense, defendants, victims and witnesses, and language professionals.

But, did these language-related rights, obligations, and requirements encroach on the communication between the ICTY OTP and ICTY Defense? It is important to examine this issue for two reasons. First, OTP is a part of the institution of ICTY, but defense is not. So did ICTY-S and ICTY RPE cover the procedural linguistic equality of arms between ICTY OTP and Defense, with bearing on the rights of defendants, by proxy?5 Second, the OTP and Defense do not have to speak the same language or the official and working languages of the ICTY. So did ICTY-S and ICTY RPE make sure language policies do not discriminate against any of them in terms of professional expertise and growth or benefits? This line of communication will be examined to establish whether the Defense, and defendant by proxy, had the right to free, unimpeded, and timely translation, interpreting, and transcription.

The third line of communication examined is that between the working institution towards the situation country. The ICTY focused on ethnic crimes committed in the former Yugoslavia. Ethnic crimes committed in the territory of the former Yugoslavia, here restricted only to those occurring in $\mathrm{B} \& \mathrm{H},{ }^{6}$ could be said to be motivated by the language and identity-related hate campaigns against the peoples of B\&H by their neighbors, Croatia and Serbia. ${ }^{7}$ In that sense, it must be examined whether the ICTY cut to the root of ethnic conflict resulting in genocide investigating and prosecuting the philosophy of hate which was anchored in language and which led to the conflicts in the first place?

The standard or official or literary official language of the former Yugoslavia was Serbo-Croatian. Normally, the standard or official or literary language is conditioned by distribution of dialects. Dialect(s) that will prevail as standardized is chosen by a political or a cultural elite. Political and cultural elites in the former Yugoslavia are evident from the very name of the official language of former Yugoslavia: the Serbs and the Croats, hence Serbo-Croatian. Their imposition of the name of the language was led by the concept of the target national community: who they want and who they do not want in their corpus. ${ }^{8}$ In that, B\&H Muslims, stood in their way. The only thing that the Serbians and the Croatians ever agreed on since the nineteenthcentury Romantic revolutions is that the $\mathrm{B} \& \mathrm{H}$ Muslims are the atavism of gory Ottoman past, religious renegades and imposters without any language or identity that is their own. ${ }^{9}$ Identity-wise, they wanted B\&H Muslims to come to, for a lack of a better term, and reconvert either to one or the other side ever since the Ottomans left. During Yugoslavia, they celebrated the crimes the Serb and the Croat populations committed against the Ottomans under the garb of patriotism. Once the war against B\&H started, the Serbs and the Croats simply wanted the Muslims gone altogether. The Muslims found themselves on their target only and exclusively because they were Muslims. As to the language, on a popular level, the fact of ekavian (Serbia) or

${ }^{5}$ This study suggests that just like regular procedural equality of arms, the procedural linguistic equality of arms should be understood as the equal rights, finances, resources, facilities, and other material conditions for adequate provision of language services to the Defense, and absolute translation, interpreting, and transcription rights to the defendants.

${ }^{6}$ Disclaimer must be made right at the beginning of this study. The relationship between the Serbians and the Croatians never stopped being a hot topic in the former Yugoslavia. However, this study only has time, space, and patience to dedicate to the effects of Croatian and Serbian philosophies of hate, nationalism, and expansionism in B\&H and among its peoples. This study does not have ample space to dedicate to minutest detail of any of the many conflicts between the Croatians and the Serbians throughout the First and the Second Yugoslavia. These will, hopefully, be evident from many examples furnished throughout discussions.

${ }^{7}$ Serbia appropriated the name "Yugoslavia" following its disintegration forming a loose confederation with Montenegro called "Federal Republic of Yugoslavia" in 1992. That country was officially renamed "Serbia and Montenegro" in 2003. Once Montenegro declared independence in 2006, Serbia, comprising of Serbia proper and provinces Vojvodina and Kosovo, continued under the name "Republic of Serbia." All these state formations that came into existence following the disintegration of Yugoslavia will be dubbed "Serbia" to avoid general confusion.

${ }^{8}$ Detrez, R. (2002), Language or nation: what came first? Lexicography and Language Policy in South-Slavic Languages after 1989. Verlag Otto Sagner: Munich, p. 11.

${ }^{9}$ Hajdarpašić, E. (2015), Whose Bosnia? Nationalism and political imagination in the Balkans 1840-1914. Cornell University Press: Ithaca and London. 
ijekavian (B\&H and Croatia) speech became strongly associated with national, ethnic, and political identity during the nineteenth-century and it continues to be associated as such to this day, so language variant became a political statement. ${ }^{10}$ This third line of communication will be examined to establish whether ICTY took notice or prosecuted the philosophy of hate that led to ethnic cleansing and genocide over Yugoslavian Muslims.

The fourth line of communication examined is that between the founding institution and the working institution towards language services providers. To remind, the founding institution, UN, provides select UN entities with select language services in select language combinations through the select variety of language professionals through the UN DGACM. However, the languages of the situation country do not figure among the official languages of the UN and cannot be accommodated by the UN DGACM.

But, does that mean that the UN DGACM had no obligations toward the ICTY language services in terms of language staff recruitment, training, outputs, professional standards, retention, etc.? As for the working institution, the ICTY, the Conference and Language Services Section (CLSS) was set in the early days of ICTY to provide it with language services. In the examination of linguistic justice, this study will explore whether the CLSS informed the clients about the language-related conflicts and the bearing it had on provision of language services and staff recruitment, training, outputs, professional standards, retention, etc.

The fifth line of communication examined is that between the language service providers towards the parties to the proceedings and the situation country. Here, it becomes obvious that the purpose of CLSS language services was twofold. First, CLSS was supposed to inform the ICTY language-related rules and regulations applicable to the parties in the proceedings. This was necessary because just like the legal professionals were supposed to set the rules and regulations incumbent on their peers and clients, it is logical that the CLSS management were to set the same rules incumbent on their peers regarding the conduct of language professionals with their clients legal and non-legal professionals alike.

Second, CLSS was supposed to plan and provide the least expensive, the most effective, and the most practical translation, interpreting, and transcription services. In that, they were supposed to deliver or adopt a series of rules of regulations regarding the recruitment, training, retention, and output of language professionals.

It follows from the above that the general research question of this study is:

What are the conditions for the delivery of linguistic justice at international criminal tribunals in a context in which language plays a role in the conflict?

This is a very complex issue that will be tackled in four separate reviews: an institutional review, a local review, a legal review, and a practical review. This introductory chapter presents several sub-research questions and these are addressed in the chapters that follow.

1.2. The structure of the study

This study addresses both legal and language professionals. It takes them on a non-exhaustive top-down journey toward the linguistic justice that is supposed to be served at international criminal tribunals adjudicating on ethnic crimes. This journey will be non-exhaustive because this study does not have ample space to dedicate to any other international criminal tribunal and can mention international criminal tribunals established subsequent to the ICTY only peripherally. The way the chapters of this study have been entitled may

${ }^{10}$ Alexander, R. (2013), Language and identity: the faith of Serbo-Croatian. Entangled histories of the Balkans, Vol. 1: National ideologies and language policies. Koninklijke Brill NV: Leiden, p. 349. 
seem a priori accusatory because it directly names the parties who participated in the establishment, functioning, or aftermath of the ICTY's activities. However, all agents in the titles are presumed innocent and are merely subjected to an examination of their contributions to linguistic justice.

This journey is a top-down journey because it starts with all relevant sources. The first leg of the journey traverses the UN via the situation country to the ICTY rules and regulations applicable to the parties in the proceedings. This leg looks at the realities of the situation country, and the founding organization (the UN) and the working (ICTY) institutional arrangements behind language, translation, and interpreting with a view to examining what is the position in which international criminal legal professionals put language, translation, and interpreting. The second leg traverses UN language services via ICTY language services to translation and interpreting in a legal context. This is done with a view to examine the position in which UN language professionals find themselves. This study is perhaps the first of its kind to consider the local context, but it is also unique in that it breaks away from the tradition of examining legal translation in bulk and explores contemporary trends in translation such as glossing, negotiation of meaning, etc.

Chapter 2 which opens this study takes the reader to the source, introducing the UN as the overall institution where linguistic acts take place and where the overarching legal rules and regulations examined in this study are enacted. Chapter 2 introduces the $\mathrm{UN}$ as the founding organization of international criminal tribunals through a discussion of the UN's mission, management, powers, and programs, providing a brief history of legal precedents to the establishment of the ICTY. Chapter 2 thus examines institutional problems and engages in a comparison between the ICTY and subsequently established international criminal tribunals with IMT and IMTFE. Within this discussion, bearing in mind the 1993 context when the ICTY was established and the subsequent emergence of international criminal tribunals, Chapter 2 explores whether the UN was logistically prepared for the work of international criminal tribunals. Who at the UN has the main say when something like an international criminal tribunal is prepared? How did the preparedness on the part of the UN contribute to the main substantive achievements and criticism of the ICTY and subsequently established international criminal tribunals? How were initial obstacles to the creation of ICTY addressed? To what extent do they hinder the work of international criminal tribunals established in the path of the ICTY?

Chapter 3 introduces the subject of this study: the language as understood and practiced in the situation country through history. Chapter 3 discusses the often overlooked situation country, examining the historical development of the language and identity-related conflicts in the former Yugoslavia, with an accent on $\mathrm{B} \& \mathrm{H}$, which might have motivated the wars in the former Yugoslavia. The reader is taken through the history of languages and perceptions of linguistic, national, and ethnic identity, starting from Medieval Bosnia and resuming through commonly accepted historical benchmarks to stop at what the ICTY investigators found in the aftermath of language and identity-related crimes in B\&H and at what the ICTY prosecutors and defense did about it. Did language and identity-related issues motivate the commission of ethnic crimes against B\&H and Yugoslavian Muslims? How did the ICTY deal with language and identity-related issues that may have cropped up during trials? What statements has the ICTY made on language and identity-related issues for posterity in the situation country or case law? What is the current position of international criminal justice on language and identity-related issues in relation to ethnically motivated crimes?

Then the stage is set for Chapter 4 to start answering the first sub-research question in this study:

Did the working legal institution provide for language-related rights, obligations, and requirements relating to on all persons participating in judicial processes?

Chapter 4 discusses the normative legal background to language, translation, and interpreting at international criminal tribunals, with a focus on the ICTY. This chapter takes the reader directly to the legal sources 
of language matters: the ICTY's and subsequently established international criminal tribunals' rules and regulations relating to languages. After the Second World War, which could be argued to be an ethnic conflict since the major victims have been prosecuted only and exclusively because of their ethnic background, the world at that time started on a mission to set universal rules of conduct in, inter alia, language use at international criminal courts. Although there were no international criminal courts in existence at that time, the international community did recognize the importance of language and other rights in determining criminal charges against defendants, thus setting the scene for due process rights in any future international criminal tribunal. Chapter 4 consists of three parts: a description and analysis of language-related rights, obligations, and requirements on the judges, registrar, prosecutors, defendants, and defense; a description and analysis of the procedural equality of arms between prosecution and defense at the ICTY from the point of view of language-related rights, obligations, and requirements; and, finally, a description and analysis of the languagerelated case law at the ICTY. This discussion concludes the first leg of this top-down journey toward linguistic justice that is supposed to be served at international criminal tribunals adjudicating on ethnic crimes as it defines language use, and translation and interpreting priorities at international criminal tribunals leading to the delivery of linguistic justice.

Chapter 5 starts the second leg of the top-down journey toward linguistic justice by examining the enforcers of UN language policies: UN translators and interpreters. The purpose of this chapter is to show what language professionals did in a situation in which they were put by the international law policy-makers. Chapter 5 provides an overview of the general UN approach to language staff examining, first and foremost, the recruitment of UN language professionals. Who are UN language professionals? How are they recruited? What are UN rules governing mechanisms to test language professionals? What are UN language professionals' responsibilities, competencies, education, and work experience before they start working for the UN? Who do they turn to for guidance? How well do they keep up with technology?

Then the stage is set for Chapter 6 to start answering the second sub-research question:

Does the fact that language is a tool in conflict require specific standards and qualities among language professionals engaged to perform translation, interpreting, and transcription at international criminal tribunals?

Chapter 6 explores the history of ICTY translation, interpreting, and transcription efforts, from the first investigations with the assistance of interpreters conducted during the war in the former Yugoslavia to the present day. The UN recognizes six languages, but the languages spoken in the former Yugoslavia do not figure among those six. How was this problem resolved? How were ICTY language professionals recruited? What language of the three major languages spoken in the territory of former Yugoslavia did they speak? Which of those languages had translation and interpreting priority, if any? Which of those speakers had priority in recruitment, if any? What was the job of ICTY language professionals? How was their translation, interpreting, and transcription output? How much did they contribute to advancing the field of translation, interpreting, and transcription in legal context for their colleagues working in international criminal tribunals?

Chapter 7 examines the work of the ICTY enforcers of language policies and starts answering the third and final sub-research question:

Have the legal truths established by ICTY through translation, interpreting and transcription been properly communicated for posterity? 
Chapter 7 takes a practical look at translation and interpreting at the ICTY. This chapter touches on the nature of relationship between language and legal professionals, professional boundaries, and the image they reflect to their clients. How well does the legal background to engagement between legal and language professionals at international criminal tribunals enable a productive relationship? What is the task of a legal professional when engaged with interpreters and translators? What is the task of a language professional in criminal proceedings? To what extent is it necessary that language professionals are qualified as both translators and criminal lawyers? In what ways do language professionals participate in establishing legal truths? How can we know whether something went wrong in translation and interpreting at international criminal tribunals?

Chapter 8, the final chapter, answers the main and sub-research questions and presents a series of conclusions and recommendations.

Each chapter of this study closes with interim conclusions on underlying issues affecting translation, interpreting, and transcription at international criminal tribunals.

\subsection{Methodology}

This study is a practical interdisciplinary study examining the relationship between international criminal law and language. Target audiences are both legal professionals and language professionals: legal professionals will be explained the basics of translation and interpreting, language professionals will be explained the basics of international criminal law, and they will both be shown how all that works in practice at the UN, the ICTY, and other subsequently established international criminal tribunals. Since both professionals are reading about linguistic justice at international criminal tribunals, they will learn more about the whole subject. As they read, they will realize how little work has been done on translation and interpreting in the UN context, how underexplored the interplay between law and language is, and how little is known about the relationship between legal and language professionals. They will come to realize that both language and legal parties believed their language-related rights, responsibilities, and duties did not need codification, although the medium of language is the main tool at their disposal to do the business. The author of this study is a professionally educated legal translator, interpreter, and editor with more than 20 years of hands-on experience in the realm of international criminal justice. The supervisors of this study are not language experts, but legal professionals, with the exception of one, which is the reason why this study went to the roots of legal translation, viewing it as a legal professionals-oriented exercise and examining normative aspects of legal translation, rather than the mechanics of translation and interpreting. 
Documentary constraints are addressed in detail at the point where they first appear in this study. Here, it will suffice to say that the UN-originating documentary material has been taken either from the official UN document system ${ }^{\text {"1 }}$ or from the official Internet sites of custodian organizations. All ICTY-related evidentiary documents and materials have been taken from ICTY Court Records online database ${ }^{12}$ official ICTY YouTube channel, ${ }^{13}$ and ICTY official web pages. ${ }^{14}$

Overall, the basic concepts governing international criminal tribunals were learned from Bassiouni. ${ }^{15}$ This author was preferred to others because of his involvement in establishing the ICTY and his readerfriendly style, although Cryer et al. have also been used. ${ }^{16}$

Alexovičková was consulted about the issues concerning recruitment into the UN and matters relating to all stages of the recruitment process into the UN System from hiring to firing. ${ }^{17}$ Discussion of basic problems relating to the UN in general were informed by Weiss, ${ }^{18}$ Bertrand,${ }^{19}$ Kille, ${ }^{20}$ and Warah. ${ }^{21}$ Practical institutional arrangements concerning the overall UN System relating to language professionals were taken from numerous internal UN documents.

\footnotetext{
${ }^{11} \mathrm{UN}$, Official document system. Unfortunately, official UN document system has proved imperfect. When I was checking links, at the end of the project, I discovered the links towards documents on the official UN document system expired. Apparently, as UN authorities explained, one must have username and password to prevent from such expiry and one cannot get a username and password unless one is UN staff member on a fulltime contract. I went back and rewrote footnotes linking to documents on the official UN document system to include the searchable symbol (for example, A/RES/71) thus enabling researchers to find referenced documents on their own.

${ }^{12}$ ICTY, ICTY Court Records. Unfortunately, not all documents have been stored into the online ICTY Court Records system at the time this research has been completed (2017). Those documents that have been stored only include court exhibits, not supporting documents. This proved to be enabling and disabling in the same time: it was enabling because it prevented me from unintentionally discussing classified documents I remembered from my work, and disabling because some documents I wanted to discuss have not yet been fed into the system.

${ }^{13}$ ICTY, ICTY YouTube channel. Unfortunately, videos posted on the ICTY official YouTube channel have been posted in such a botched way that it completely impacted the entire visual presentation of my study. Videos that could have been uploaded as a single file have been broken down into at least one and at most nine different video segments regardless of their duration. Links to these videos could not have been left in the original form because they would have significantly added to the length of the entire study, as some of them were two or three lines long, so I had to resort to shortening them using Ow.ly. This proved a success: my study looks much cleaner and neater, and it is much shorter than if I posted original links. The only downside to this entire process of shortening links to online material was that it took me a whole month to do so as once being assured that I am not a robot, Ow.ly insisted on posing at least two visual tests before shortening the actual link.

${ }^{14}$ ICTY, ICTY official web page.

${ }^{15}$ Bassiouni, C. (2011), Crimes against humanity: historical evolution and contemporary application. Cambridge University Press: New York.

${ }^{16}$ Cryer, R., Friman, H., Robinson, D. and Wilmshurst, E. (2013), An introduction to international criminal law and procedure (second edition). Cambridge University Press: New York.

${ }^{17}$ Alexovičková, I. (2012), From hiring to firing: a comparative study on selected legal safeguards for the independence and impartiality of international civil servants serving in the United Nations Secretariat and in the European Commission. Wolf Legal Publishers: Nijmegen.

${ }^{18}$ Weiss, T. G. (2012), What's wrong with the United Nations and how to fix it. Polity Press: Cambridge, UK.

${ }^{19}$ Bertrand, M. (1995), The UN as an organization. A critique of its functioning. European Journal of International Law 6, p. 349-359.

${ }^{20}$ Kille, K. J. (2006), The Secretary-General of the United Nations. Palgrave Macmillan: London, p. 254.

${ }^{21}$ Warah, R. (2016), UNsilenced: Unmasking the United Nations' culture of cover-ups, corruption and impunity. AuthorHouse: UK.
} 
Discussion of language-related conflicts in the former Yugoslavia is informed by Alexander, ${ }^{22}$ Imamović $^{23}{ }^{23}$ Sipka, ${ }^{24}$ and the yearbooks published by the B\&H Academy of Arts and Sciences ${ }^{25}$ and Gazi Husref-begova Medresa ${ }^{26}$ (published mostly before the collapse of the former Yugoslavia). Legal and institutional material concerning B\&H and former Yugoslavia has been taken directly from the contemporary rules and regulations. Quoting from the available material was preferred to interpretation.

Discussion of the ICTY and subsequently established international criminal tribunals language-related rules and regulations and the case law, UN rules and regulations relating to language staff, and ICTY language arrangements and services was informed both by annual reports produced by the UN and the ICTY, and inspection reports made by UN System's Joint Inspection Unit (JIU), ${ }^{27}$ UN Office of Internal Oversight Services (UN OIOS), ${ }^{28}$ and UN Board of Auditors (UN BoA). ${ }^{29}$ ICTY Annual Reports could not have been used alone to give a realistic picture of ICTY and its language services. However, financial and audit reports are straightforward because they mostly deal with the organizational and financial realities of the organization concerned and are geared toward straightening out that organization's shortcomings. Additionally, ICTY and AITC colleagues have been consulted for their understanding of practices and experiences in translation, interpreting, and transcription, and overall UN policies and practices relating to language professionals. These discussions were conducted over email, semi-structured and followed the basic principles of qualitative research where a problem was discussed from the perspectives of practitioners whom it involved. Permissions to quote were obtained from all participants in the research (on file with the author). It is hoped that these three groups of sources will provide a balanced holistic analysis of ICTY language services.

Finally, this study also engages in a series of analyses of actual translation and interpreting delivered at the ICTY, targeting the implementers of language power, i.e. the interplay between the parties with an interest on the one hand and language staff, on the other. This study does not draw heavily on the existing theoretical background on translation and interpreting and ethics in translation and interpreting at international criminal tribunals because such material is scarce. General papers authored by translation and interpreting theorists were avoided because the focus of this study was on practical examples, not on existing theory, and especially not from non-in-depth researchers and/or commentators. Šarčević was consulted for general legal translation theory, ${ }^{30}$ Baker was consulted for general translation issues, ${ }^{31}$ and Seleskovitch and Lederer were consulted for general interpreting issues. ${ }^{32}$ Former ICTY managerial staff (Draženović-Carrieri, ${ }^{33}$ Hepburn, ${ }^{34}$ Elias-Bursać, ${ }^{35}$ and Nikolici $\left.{ }^{36}\right)$ were consulted for their managerial take on ICTY translation and interpreting-related issues. Whereas Draženović-Carrieri, Hepburn, and Nikolić addressed their experiences at the ICTY in passing, Elias-Bursać is the first and, so far, the only former managerial ICTY staff who wrote about translation and practice at the ICTY. This is the reason why she is widely quoted throughout the study.

\footnotetext{
${ }^{22}$ Alexander, R. (2013), Language and identity: the faith of Serbo-Croatian. Entangled histories of the Balkans, Vol. 1: National ideologies and language policies. Koninklijke Brill NV: Leiden.

${ }^{23}$ Imamović, M. (2014), Historija države i prava Bosne i Hercegovine. University Press: Sarajevo.

${ }^{24}$ Šipka, M. (1999), Standardni jezik u Bosni i Hercegovini u dokumentima jezičke politike. Open Society Institute: Budapest.

${ }^{25}$ Academy of Arts and Sciences of B\&H, Yearbooks.

${ }^{26}$ Gazi Husrev-begova Medresa, Yearbooks.

${ }^{27} \mathrm{UN}$, JIU Statute.

${ }^{28} \mathrm{UN}$ OIOS.

${ }^{29} \mathrm{UN} \underline{\mathrm{BoA}}$.

3o Šarčević, S. (1997), New approach to legal translation. Kluwer Law International: The Hague.

${ }^{31}$ Baker, M. (2011), In Other Words: A Coursebook on Translation (second edition), Routledge: London and New York.

${ }^{32}$ Seleskovitch, D. and Lederer, M. (1993), Interpreter pour Traduire (3e edition). Didier Erudition: Paris.

${ }^{33}$ Draženović-Carrieri, M. (2002), B/C/S-A practical approach. Lexicography and Language Policy in South-Slavic Languages after 1989. Verlag Otto Sagner: Munich.

${ }^{34}$ Hepburn, P. (2012), The Translation of Evidence at the ICTY: A Groundbreaking Institution. Translation and Interpreting Studies, 7(1):54-71.

${ }^{35}$ Elias-Bursać, E. (2015), Translating evidence and interpreting testimony at a war crimes tribunal. Palgrave Macmillan: London.

${ }^{36}$ Nikolić, M. (2005), Interpreting after the Nuremberg: international war crimes trials. Proteus 14 1: 1 and 6-8.
} 
The ethics in translation were viewed through existing international criminal tribunals' rules and regulations on ethics, cross-referenced with Gaiba's take on IMT and IMTFE practices, ${ }^{37}$ and tested by hands-on practical examples. Mechanisms to test the ethics have been adopted from Mulayim and Lai. ${ }^{3}$

In all this, legal professionals, i.e. the clients of legal translation and interpreting, commenting on language professionals and their output were preferred and these include De Groot and Van Laer, ${ }^{39} \mathrm{Klip}$ and Sluiter, ${ }^{40}$ Jordash, ${ }^{41}$ Wald,${ }^{42}$ and others.

This research was concluded by $3^{1}$ October 2017. Developments after that date have not been included in the analysis. This study comes in the age of digital communication and, whatever its substantive merits, its author also wants to contribute to paperless digitalization. All the links from footnotes were also last accessed on 31 October 2017. In view of minimizing environmental impact, this will not be repeated elsewhere after every link. Links from the Appendices have not been included in the Bibliography, and all other links have been hyperlinked.

\footnotetext{
${ }^{37}$ Gaiba, F. (1998), The origins of simultaneous interpreting: the Nuremberg trial. University of Ottawa Press: Ottawa.

${ }^{38}$ Mulayim, S. and Lai, M. (2016), Ethics for police translators and interpreters. CRC Press, Taylor \& Francis Group: Boca Raton.

${ }^{39}$ De Groot, G.R. and Laer, C.J.P. van. (2006), The Dubious Quality of Legal Dictionaries. International Journal of Legal Information: Vol. 34: Iss. 1, Article 6.

${ }^{40}$ Klip, A. and Sluiter, G. (eds.) (2008), Annotated leading cases of international criminal tribunals, Volume XIII, Timor Leste, The Special Panels for serious crimes 2001-2003. Intersentia: Cambridge, UK.

${ }^{41}$ Jordash, W. (2009), The Practice of 'Witness Proofing' in International Criminal Tribunals: Why the International Criminal Court Should Prohibit the Practice. Leiden Journal of International Law, 22, p. 501-523.

${ }^{42}$ Wald, P. (2002), Dealing with witnesses in war crimes trials: lessons from the Yugoslav Tribunal. Yale Human Rights and Development Law Journal, 5: 217-239.
} 
Chapter 2: May the institution of justice take the stand, please

Chapitre 2 : Le système de justice est prié de venir à la barre

Drugo poglavlje: Neka pristupi institucija pravde 
The journey on the road to linguistic justice begins with the non-exhaustive top-to-bottom overview of the institution of justice. Since the main audiences for this study are legal and language professionals, the first stop on the road to linguistic justice is the $\mathrm{UN}$ as the founding organization of international criminal tribunals. The UN deserves this title because it is the only supranational organization in the world with the power to establish international criminal tribunals. The purpose of Chapter 2 is to introduce the UN and summarize historical development of international criminal law affecting both legal and language professionals.

Chapter 2 consists of two main sections: a section on the UN System as in whole and a section on the UN System in relation to international criminal tribunals. The section on the UN System as in whole discusses the UN's mission, management, powers, and programs to the extent that these are relevant to translation and interpreting. Throughout this chapter, the reader will come to realize how, through who, and under what conditions the UN may communicate with its Member States. What is the UN, really? Who has the main say at the UN? Who makes the policies that affect the whole world and who keeps those policy-makers in balance? How effective are those policies on the international and local level when it comes to the main mission of the UN: to prevent war? And, in that prevention, who is the UN responsible to and how? The section on the UN System in relation to international criminal tribunals discusses how well these two respond to questions that may arise about the international criminal tribunals' jurisdiction, apprehension of perpetrators, methods of justice, and budgets. Was the UN supportive of international criminal tribunals? Was the UN logistically prepared to support the work of international criminal tribunals? How did the preparedness on the part of the UN contribute to the main substantive achievements and criticism of the ICTY and subsequently established international criminal tribunals? Were there any obstacles to the creation of the ICTY and how were they addressed? Do they hinder the work of international criminal tribunals established in the path of the ICTY and, if so, to what extent?

\subsection{The UN System}

The UN is an intergovernmental organization whose members are sovereign states to which the UN administration refers as the "UN Member States." The UN was created just after the Second World War and can exercise its powers across national borders. The purposes of the UN are to:

1. To maintain international peace and security, and to that end: to take effective collective measures for the prevention and removal of threats to the peace, and for the suppression of acts of aggression or other breaches of the peace, and to bring about by peaceful means, and in conformity with the principles of justice and international law, adjustment or settlement of international disputes or situations which might lead to a breach of the peace;

2. To develop friendly relations among nations based on respect for the principle of equal rights and self-determination of peoples, and to take other appropriate measures to strengthen universal peace;

3. To achieve international cooperation in solving international problems of an economic, social, cultural, or humanitarian character, and in promoting and encouraging respect for human rights and for fundamental freedoms for all without distinction as to race, sex, language, or religion; and

4. To be a center for harmonizing the actions of nations in the attainment of these common ends. ${ }^{43}$

Often, when the public refers to the UN, they mean the UN headquarters in New York City. Alongside the six principal organs of the UN set up at the UN Charter, namely the General Assembly, Security Council, Economic and Social Council, the defunct Trusteeship Council, the International Court of Justice (ICJ), and the

${ }^{43}$ UN, Charter (1945), Article 1.1-4. 
Secretariat, ${ }^{44}$ the principal organs also have many UN entities. In the literature, these are collectively called the "system of UN organizations" or "the UN System." The UN Department for General Assembly and Conference Management (DGACM) is the main body that recruits UN language professionals. However, UN DGACM language professionals service only the abovementioned principle organs of UN in offices in Addis Ababa, Bangkok, Beirut, Geneva, Nairobi, New York, Santiago, and Vienna. They do not necessarily service all UN entities provided for at the UN Charter. ${ }^{45}$ The latter are left to their own devices to find, test and recruit language professionals and set essential responsibilities, competencies, education, and work experience. The correlation between UN principal organs and UN entities is best represented in the following diagram: 


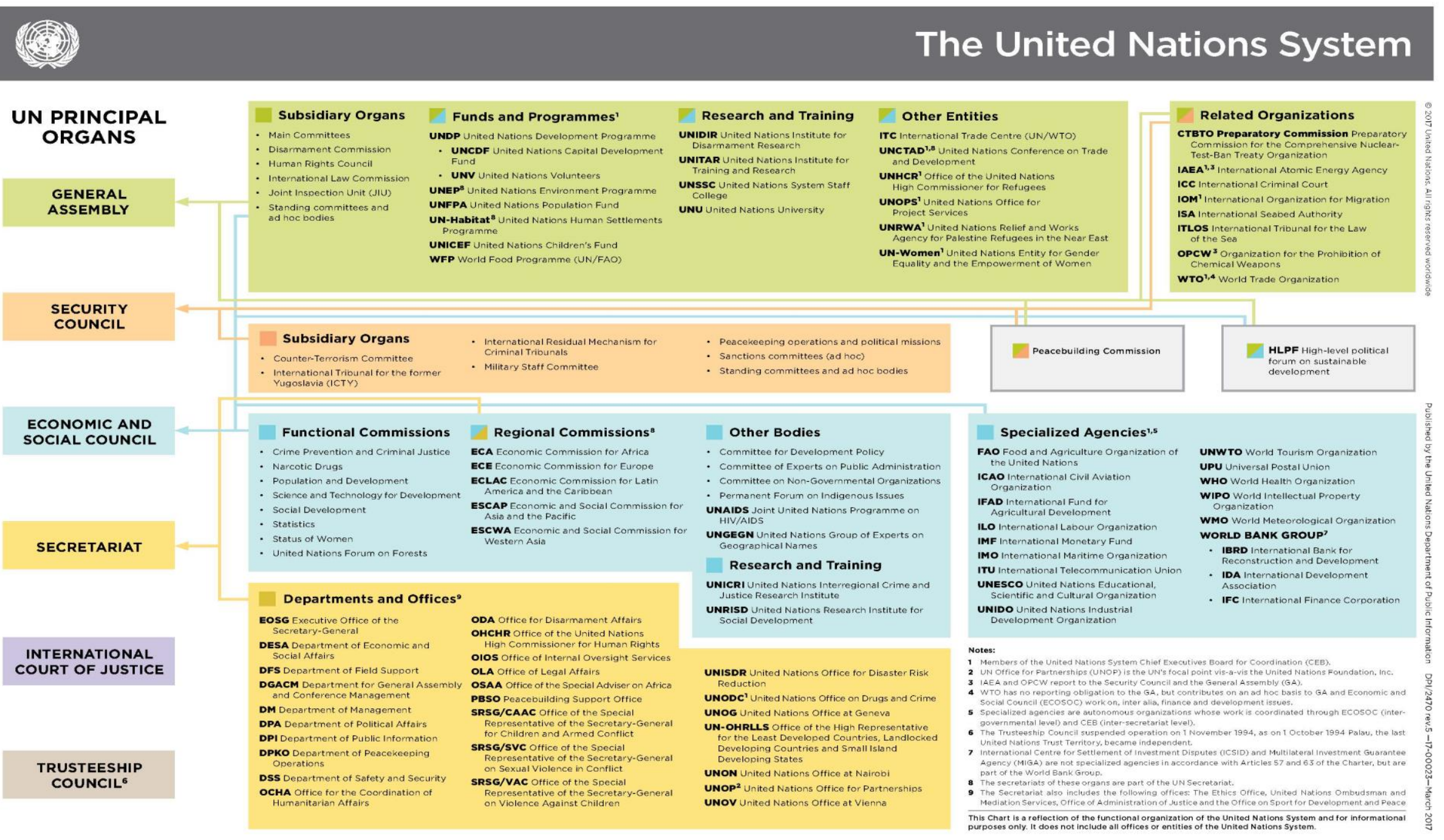


The above organization also implies that the UN should take a lead in establishing international criminal tribunals and monitoring their performance, recruitment, on-the-job training, and every other aspect of their work. Unfortunately, the UN did very little of that. The first reason why is that the creation of an independent international criminal tribunal took too long and, once established, the ICTY and the subsequent international criminal tribunals confronted the UN with something entirely new. The other reason is that the establishment of the ICTY and its breakthrough results in the field of impunity shook the balance of powers within the UN Security Council even further, revealing the full extent of polarization between permanent members of the UN Security Council. Finally, the general poor use of existing internal and external resources by UN entities, especially whenever they are called to step up to the plate, reveals an ambitious UN mission but a poorly thought-out vision for the ICTY. But, let us first examine the legal background behind the overall UN mission, management, powers, and programs.

\subsubsection{The UN mission}

The UN was established with the ratification of the UN Charter in San Francisco in 1945. According to the UN Charter, the reason behind the establishment of such a supranational organization was to prevent a Third World War through promotion of international cooperation. ${ }^{46}$ Although references to the protection of human rights were made and the foundations of the entire body of the international human rights law is said to stem from the UN Charter and the Universal Declaration of Human Rights (UDHR), ${ }^{47}$ the UN has only gradually expanded human rights law to encompass specific standards for women, children, persons with disabilities, minorities, and other vulnerable groups, who now possess rights that protect them from discrimination that had long been common in many societies. ${ }^{48}$ Obviously, the UN was not set to be a human rights body, but, as will be shown later, the establishment of the ICTY and subsequently established tribunals demonstrate an emerging human rights element to the UN General Assembly and the UN Security Council decisions.

The UN General Assembly is the main deliberative, policymaking, and representative organ of the UN. It includes all 193 recognized countries of the world which vote together on peace and security, admission of new members, budgetary, and other matters. However, if UN Member States fail to pay their dues to UN, they lose their right to vote. ${ }^{49}$

The UN Security Council has a primary responsibility to maintain international peace and security. It consists of 15 Member States: five permanent members and ten non-permanent members elected for a period of two years..$^{50}$ Permanent members of the UN Security Council are: China, France, Russia, United Kingdom, and United States of America (USA). The first difference between permanent members of the UN Security Council and other UN Member States is that permanent members of the UN Security Council are considered the major victors of the Second World War. The second difference is that permanent members of the UN Security Council have the power of veto. This is the first glitch to fair representation at the level of international community: the fact some Member States have more rights than others. However, the power of veto given to the permanent members of the UN Security Council is not explicitly mentioned at the UN Charter. Indeed, the UN Charter proclaims that all the substantive decisions of the UN Security Council require the "affirmative vote of seven members including the concurring votes of the permanent members. ${ }^{.1}$ This phrase has been interpreted to mean that if all the permanent members of the UN Security Council fail to concur on an issue, the deal is off. This is worrying because permanent members of the UN Security Council determine the existence of a threat to the peace or an act of aggression, call the parties to solve the disagreement peacefully, and issue a set of recommendations in that regard, and - if it all fails - they can impose sanctions or

\footnotetext{
${ }^{46}$ Ibid, Article 1.

${ }^{47}$ UN, UDHR (1948).

${ }^{48} \mathrm{UN}$, Human rights.

${ }^{49}$ UN General Assembly Homepage.

${ }^{50} \mathrm{UN}$, Charter (1945), Chapter V, Articles 23(1) and (2).

${ }^{51}$ Ibid, Chapter V, Article 27(3).
} 
authorize the use of force.$^{5^{2}}$ Given these duties and obligations, it could be said that permanent members of the UN Security Council have de facto power at the UN.

Notwithstanding such a de facto situation, the UN does have a de jure boss: the UN Secretary-General. The UN Charter describes the UN Secretary-General as "chief administrative officer" who is appointed by the General Assembly on the recommendation of Security Council..$^{53}$ The UN Secretary-General acts in that capacity in all meetings of the General Assembly, Security Council, Economic and Social Council, and Trusteeship Council, performs such other functions as are entrusted to him by these organs, and makes an annual report to the General Assembly on the work of the UN. According to the UN Charter, the UN Secretary-General may bring to the attention of the Security Council "any matter which in his opinion may threaten the maintenance of international peace and security".$^{54}$ This restrictive language makes it clear the UN SecretaryGeneral does not have any executive powers. However, although de jure absence of executive powers suggests the de facto absence of a single leader of the UN, this does not mean that the UN functions on orders issued by just anyone. In the performance of their duties, the UN Secretary-General and his staff are forbidden from seeking or receiving instructions from any government or from any other authority external to the UN and must refrain from any action which might reflect on their position as international officials responsible only to the UN. ${ }^{55}$ This means that the UN Secretary-General and his staff are independent in their work, but that their powers are administrative, rather than executive. How does this work in practice?

\subsubsection{UN management}

As to the top management, the UN Secretary-General's functions and responsibilities initially reflected the reality that surrounded him in that he ran the bureaucracy and passed moral judgments without exercising any significant executive powers. Operationally, the efficiency of the UN after the Second World War was limited by the East-West passive-aggressive conflict (Cold War) and South-North economic struggles. During the Cold War, waged by the permanent members of the UN Security Council and their zones of interest, colonies, and dominions against each other between, approximately, 1946 and 1991, the UN was expected not to meddle. In his inaugural speech as the first UN Secretary-General, Trygve Lie (Norway, 1946-1953) set the tone for the importance of tasks and responsibilities given to him, reminding his audience that the future of the whole civilized world was at stake. ${ }^{56}$ The second UN Secretary-General, Dag Hammarskjöld (Sweden, 19531961), also took a proactive role in exercising his duties and defined the work of the UN as reconciliation and realistic construction. ${ }^{57}$ However, it seems Lie and Hammarskjöld did not fully understand that the role envisioned for them was that of a rhetorical global peace surveyor and a commentator. Whereas Lie resigned, Hammarskjöld became the only UN Secretary-General who died in office under still unclear circumstances en route to negotiate a cease-fire in Congo.$^{58}$ The next UN Secretary-General, U Thant (Burma, 1961-1971), was busy negotiating between USA and Russia and averting global catastrophe (Cuban missile crisis). Kurt Waldheim (Austria, 1972-1981) promised not to meddle, pledging to conduct his duties with impartiality and a deep sense of personal commitment in his oath of office.$^{59}$ His successor, Javier Perez de Cuellar (Peru, 1982-1991), rhetorically discussed the disparity between the rich and the poor as a violation of the most fundamental

\footnotetext{
${ }^{52}$ UN Security Council Homepage.

${ }^{53}$ UN, Charter (1945), Chapter XV, Article 97.

${ }^{54}$ Ibid, Chapter XV, Article 99.

${ }^{55}$ Ibid, Chapter XV, Articles 98-10o.

${ }^{56} \mathrm{UN}$, Inaugural speech: Trygve Lie (1946).

${ }^{57} \mathrm{UN}$, Inaugural speech: Dag Hammarskjöld (1953).

${ }^{5}{ }^{8}$ Kille, K. J. (2006), The Secretary-General of the United Nations. Palgrave Macmillan: London, p. 15.

${ }^{59} \mathrm{UN}$, Inaugural speech: Kurt Waldheim (1971).
} 
human rights in the mid-1980s when he became UN Secretary-General.$^{60}$ The priority for the next UN Secretary-General, Boutros Boutros-Ghali (Egypt, 1992-1996), was democracy and building a new momentum for "this great UN."

The next UN Secretary-General, Kofi Annan (Ghana, 1997-2006) is the most important for contemporary UN management, including the ICTY. Although most structural problems at the UN discussed throughout this study existed before Annan assumed office, these could be said to be exacerbated during his tenure through his reforms. Annan wanted to prepare the UN to meet the challenges of the twenty-first century by building on UN strengths and creating a results-oriented, high performing, flexible, and responsive UN which would be ready to meet the ever-evolving needs of its Member States. Annan started a series of reforms with the accent on the quality of UN staff and managers. It was thought that an organizational environment that supports managers will also enable all staff to contribute to their maximum potential. Under Annan's 1998 reforms, responsibility for the management of human resources moved to those directly accountable for program delivery, the line managers. The purpose of this shift from several inter-departmental panels to one inner-department person put in charge of recruitment was to create a management culture that recognizes staff as UN's greatest resource. It was assumed that UN managers would be held accountable for making the most effective use of staff. The new Performance Appraisal System provided an important tool to assist in managing performance through jointly setting goals, agreeing on expected results, and engaging in an ongoing dialog about performance, emphasizing the importance of professional development and learning. All staff and managers were required to set development goals. Finally, UN managers were held accountable for staff development, which was defined as a responsibility shared by the UN, managers, and staff themselves. The budget for staff development and learning opportunities was increased as the UN promised to provide a framework of opportunities and to foster an environment conducive to learning. Within those efforts, UN managers were expected to keep themselves up to date, and to support their staffs development and career progress by providing on-the-job training, coaching and mentoring, and ensuring that staff are allowed and encouraged to take advantage of opportunities for learning and growth. The UN redoubled its efforts to ensure that merit, productivity, and achievement are rewarded by promotion and advancement at all levels. ${ }^{{ }^{2}}$ Obviously, Annan's reforms centralized all actions in UN around a single manager with subordinate managers merely providing some checks and balance. Unfortunately, this approach to management could be described as the main contributor to the creation of a self-protective managerial environment where top managers refrain from acting against their subordinate managers because misconduct of their subordinates implies their own misconduct. Warah documented just a few of the many post-1998 Annan reform sex scandals, corruption scandals, kickback scandals, and poor protection of whistleblowers who revealed them. ${ }^{63}$

\subsubsection{UN powers}

Clear top leadership in UN, embodied in a single person as a leader, is non-existent both on paper and in practice because the five permanent members of UN Security Council have the power of veto. Described as the power to quash any non-procedural matter, irrespective of its level of international support, ${ }^{64}$ incompatible with general interest ${ }^{65}$ a discriminatory and biased privilege given to five countries to dictate their own will to some 200 countries as they wish, ${ }^{66}$ throughout the years, the power of veto became the means to maintain a permanent state of flux and a reason for critics to call for reconsideration of the UN as in whole.

\footnotetext{
${ }^{60} \mathrm{UN}$, Inaugural speech: Javier Perez de Cuellar (1981).

${ }^{61} \mathrm{UN}$, Inaugural speech: Boutros Boutros-Ghali (1991).

${ }^{62}$ UN, Secretary-Generals' Bulletin: Building the future (ST/SGB/1998/6) (1998).

${ }^{6}$ Warah, R. (2016), UNsilenced: Unmasking the United Nations' culture of cover-ups, corruption and impunity. AuthorHouse: UK.

${ }^{64}$ Okhovat, S. (2012), UN Security Council: its veto power and its reform. Centre for Peace and Conflict Studies: Melbourne.

${ }^{65}$ Negalign, L. (2014), The need to reform the UN Security Council. Addis Ababa University: Addis Ababa.

${ }^{66}$ Ziabari, K. (2011), The UN Security Council: an organization for injustice. Global Research.
} 
Indeed, 282 vetoes ( 12 by China, 18 by France, 32 by the UK, 84 by the USA, and 137 by the USSR/Russia) passed by the UN Security Council permanent members between 1946 and 2017 affected the functioning of the world in many ways. ${ }^{67}$ Since this study is language-based, it is worth noting that the UN Security Council permanent members - in cahoots with the UN administration - stretched the limits of language, starting to describe pressing problems countries and their peoples were facing as mere "questions," but offering no solutions or answers. Here are some of those "questions" that became veritable political buzzwords for every generation from 1946 onwards: the 1946 Spanish question, the 1947 Greek question, the 1954, 1956, 1963, 1964, 1966, 1976, 1980, 2001, 2002, 2003, 2004, 2006, 2011 Palestinian question, the 1974, 1977, $1981,1986,1987,1988$ South Africa question, the 1982 Falkland Islands question, the 1980 Iran hostages question, the 1963, 1970, 1971, 1972, 1973 Southern Rhodesia question, the 1957, 1962, 1971 India-Pakistan question, the 1974 Cyprus "situation" where two NATO Allies, Greece and Turkey, fought each other, etc. Once tabled, all these "questions" and "situations" put international peace and security and international human rights in a state of flux where one permanent member of the UN Security Council would rise to take charge of the issue and others would criticize. Eventually, after a lot of back and forth, all permanent members of the UN Security Council would join the efforts of the veto-issuing country and reach a collective understanding on the issue with the emphasis on what works best for their own countries, dependent territories, and dominions. After major media outlets announced that the "breakout of the Third World War has been prevented," humanity would let out a deep sigh of relief. In the meantime, the situation in the country over which permanent members of UN Security Council disagreed in the first place would remain largely unchanged.

\subsubsection{UN programs}

The lack of clear mandates of UN entities along with the absence of clear leadership and the flux created by the power of veto in the hands of UN Security Council permanent members is the third major problem with the UN mission. Weiss likened the UN membership structure and its bureaucracy to a feudal kingdom. Weiss also criticized UN bureaucracy for the lack of central authority with the power to make decisions on organizational mandates and resource allocation. He warns that all this leads to a situation in which many UN entities have overlapping goals and compete against each other for patronage. ${ }^{68}$

Table 1. Overlapping responsibilities between UN entities in relation to $21^{\text {st }}$ century buzzwords

\begin{tabular}{|l|l|l|l|}
\hline UN entity & HIV/AIDS & $\begin{array}{c}\text { Human } \\
\text { rights }\end{array}$ & Women \\
\hline Joint UN Program on HIV and AIDS & $\checkmark$ & - & $\sqrt{ }$ \\
\hline Office of the UN High Commissioner for Refugees (UNHCR) & $\sqrt{ }$ & $\sqrt{ }$ & $\sqrt{ }$ \\
\hline World Food Program & $\sqrt{ }$ & - & $\sqrt{ }$ \\
\hline UN Development Program & $\sqrt{ }$ & $\sqrt{ }$ & $\sqrt{ }$ \\
\hline UN Population Fund & $\sqrt{ }$ & - & $\sqrt{ }$ \\
\hline UN Office on Drugs and Crime & $\sqrt{ }$ & - & - \\
\hline International Labor Organization (ILO) & $\sqrt{ }$ & - & - \\
\hline UN Educational, Scientific and Cultural Organization (UNESCO) & $\sqrt{ }$ & $\sqrt{ }$ & $\checkmark$ \\
\hline World Health Organization (WHO) & $\sqrt{ }$ & - & $\sqrt{ }$ \\
\hline World Bank & $\sqrt{ }$ & - & - \\
\hline Office of the UN High Commissioner for Human Rights & - & $\sqrt{ }$ & $\sqrt{ }$ \\
\hline UN Interregional Crime and Justice Research Institute & - & $\sqrt{ }$ & - \\
\hline UN Children's Fund (UNICEF) & - & $\sqrt{ }$ & - \\
\hline UN Entity for Gender Equality and the Empowerment of Women & $\sqrt{ }$ & $\sqrt{ }$ & $\sqrt{ }$ \\
\hline
\end{tabular}

\footnotetext{
${ }^{67} \mathrm{UN}$, Vetoes issued by UN Security Council permanent members.

${ }^{68}$ Weiss, T. G. (2012), What's wrong with the UN and how to fix it. Polity Press: Cambridge, UK.
} 
The overlapping responsibilities between UN entities and their fractured approach to issues is mostly blamed on the polarization and lack of constructive dialog between developing and developed countries on issues of economic governance after the end of the Cold War. ${ }^{69}$ Nine of these 14 UN entities have segments of their mandates dealing with women, 11 have segments of their mandates dealing with HIV/AIDS, and seven have segments of their mandates dealing with human rights. None of them have a single segment dedicated to advice, knowledge or lessons learned.

2.2. The UN System and international criminal tribunals

In the meantime, scholars argue that the twentieth-century was the most murderous in recorded history, with the total number of victims caused by or associated with wars at 187 million.

Taken as having begun in 1914, it was a century of almost unbroken war, with few and brief periods without organised armed conflict somewhere. It was dominated by world wars: that is to say, by wars between territorial states or alliances of states. The period from 1914 to 1945 can be regarded as a single 'thirty years' war' interrupted only by a pause in the 1920s - between the final withdrawal of the Japanese from the Soviet Far East in 1922 and the attack on Manchuria in 1931. This was followed, almost immediately, by some forty years of Cold War, which conformed to Hobbes's definition of war as consisting 'not in battle only or the act of fighting, but in a tract of time wherein the will to contend by battle is sufficiently known'. It is a matter for debate how far the actions in which US Armed Forces have been involved since the end of the Cold War in various parts of the globe constitute a continuation of the era of world war. There can be no doubt, however, that the 199os were filled with formal and informal military conflict in Europe, Africa and Western and Central Asia. The world as a whole has not been at peace since 1914 and is not at peace now. ${ }^{\circ}$

On the one hand, international justice, underlying political problems, and institutional difficulties revolve around discussions concerning countries that have the power to block whatever other countries are doing on the international level in the aftermath of their open or obscure conflicts. On the other hand, global disagreement on the basic concepts that govern the rights of states in general, namely the right to sovereignty, the right to self-determination, legal equality between states, and non-intervention in each other's affairs, continue. The first set of problems stems from the UN's inability to self-regulate and could be solved with thorough substantive reforms in leadership and executive action. This would lead to the abolition of the power of veto that would provide at least increased, if not full equality between the UN Member States. Consequently, the UN Secretary-General could start acting in the interest of humanity, not merely reacting to the interests of UN Security Council permanent Member States.

The problems related to the rights of states stem from the Westphalian system of state sovereignty. In practice, UN powers boil down to the question of the (balance of) power between the five permanent members of UN Security Council. The Westphalian system has been discussed at length by scholars, the media, and politicians and is seen as elitist, obsolete, ${ }^{71}$ and fundamentally unjust. ${ }^{72}$ This system, described as "the world order" by Kissinger, was imposed after the Thirty-Year War (1618-1648), which established the current European balance of power. Kissinger points out that the Westphalian order was established without the involvement or even the awareness of most other continents or civilizations as a practical accommodation

\footnotetext{
${ }^{69}$ Lunde, L. (2000), Coherence or dissonance in the international institutional framework. ECON, Centre for Economic Analysis.

${ }^{70}$ Hobsbawm, E. (2002), War and peace in the twentieth-century.

${ }^{71}$ Ringmar, E. (2010), Performing international relations: two East Asian alternatives to the Westphalian order. CenPRIS Working Paper No. 125/10.

${ }^{72}$ Recchia, S. and Welsh, J. M. (eds.) (2013), Just and Unjust Military Intervention: European Thinkers from Victoria to Mill. Cambridge University Press: Cambridge, UK.
} 
to the reality at the time..$^{73}$ This could be taken to mean that the question of the balance of powers is, essentially, Eurocentric, plus the US. At times in history, five or six countries did put the interests of humanity before their own, but, with hindsight, one must wonder whether that was just fortuitous. As the Second World War started and then ended, some of these five or six countries became "victorious powers" or "allied and associated powers", which gave them further legitimacy to do as they pleased. The proverbial "unsolvable problems and insurmountable obstacles" arose once these powers disagreed among themselves. Where was international criminal justice for all other countries? Did (a lack of) international criminal justice allow history to repeat itself?

\subsubsection{Pre-IMT and IMTFE}

The Hague Convention (II) with Respect to the Laws and Customs of War on Land, and its annex Regulations concerning the Laws and Customs of War on Land, dated 29 July 1899 was established to seek the means to preserve peace and prevent armed conflicts among nations, and it was animated by a desire to serve the interests of humanity and the ever increasing requirements of civilization. ${ }^{74}$ This Convention was established because it was important to revise the laws and general customs of war, either with a view to defining them more precisely, or laying down certain limits for the purpose of modifying their severity as far as possible. The Hague Convention (IV) respecting the Laws and Customs of War on Land - and its annex - dated 18 October 1907 was animated by a sincere desire to work for the maintenance of general peace, resolved to promote the friendly settlement of international disputes and aimed to extend the empire of law and to strengthen the appreciation of international justice..$^{75}$ These two conventions presented the first formal statements of the laws of war and war crimes. Very soon these two were put to the test in the First World War.

After the end of the war, the Treaty of Versailles was signed on 28 June 1919 between five Principal Allied Powers and 22 Associated Allied Powers on one side, and Germany, on the other. ${ }^{76}$ On the level of leaders, the Treaty of Versailles provided that Kaiser Wilhelm II of Germany could be tried before "a special tribunal" for a supreme offense against international morality and the sanctity of treaties with a view to vindicating the solemn obligations of international undertakings and the validity of international morality. ${ }^{77}$ However, "a special tribunal" never materialized due to political reasons: American President Woodrow Wilson insisted that, in order to achieve the "honorable peace" with Germany, Kaiser Wilhelm II must abdicate, because his punishment would only destabilize peace further. Kaiser Wilhelm II abdicated and sought refuge in the Netherlands, which remained neutral throughout the First World War. The government of the Netherlands viewed the charges against the Kaiser as a "political offence," because a Head of State's decision to go to war was within the prerogative of national sovereignty. ${ }^{78}$ The Dutch promised that Kaiser Wilhelm II would not leave Huis Doorn and its surrounding area where he was staying without prior notice, would desist from all political activity, and agreed to censor his correspondence. Kaiser Wilhelm II called this stand, which the Dutch Queen Wilhelmina was forced to take due to overwhelming international pressure "absolutely scandalous" and spent the rest of his days entertaining, sketching, and hunting, occasionally flirting with the Nazis. $^{79}$

\footnotetext{
${ }^{73}$ Kissinger, H. (2015), World Order: Reflections on the Character of Nations and the Course of History. Penguin Press: London.

${ }^{74}$ Convention (II) with Respect to the Laws and Customs of War on Land and its annex: Regulations concerning the Laws and Customs of War on Land (1899).

${ }^{75}$ Convention (IV) respecting the Laws and Customs of War on Land and its annex: Regulations concerning the Laws and Customs of War on Land (1907).

${ }^{76}$ Treaty of Versailles (1920).

${ }^{77}$ Ibid, Part VII, Penalties, Article 227.

${ }^{78}$ Bassiouni, C. (1994), Former Yugoslavia: Investigating Violations of International Humanitarian Law and Establishing an International Criminal Tribunal. Fordham International Law Journal, 18/4, p. 1198-1199.

${ }^{79}$ Röhl, J. C. G. (2014), Wilhelm II: into the abyss of war and exile, 190o-1941. Cambridge University Press: Cambridge, UK, p. 1199. Clark, C. (2009), Kaiser Wilhelm II: A life in power. Taylor and Francis: New York, p. 251.
} 
On the level of command responsibility and base-crime perpetrators, the Treaty of Versailles provided that Germany must hand over all persons accused of having committed an act in violation of the laws and customs of war before military tribunals composed of members of the military tribunals of the Allied and Associated Powers concerned and that Germany must furnish all documents and information of every kind, the production of which may be considered necessary to ensure full knowledge of the incriminating acts, the discovery of offenders, and the just appreciation of responsibility. ${ }^{80}$ However, there were no formal "military tribunal[s] in Germany or in the territory of her allies" to prosecute these war criminals at the international level. Therefore, the Allied and Associated Powers allowed Germany to prosecute a limited number of war criminals at a local Supreme Court in Leipzig. The Commission on the Responsibilities of the Authors of War and on Enforcement of Penalties was established at the Preliminary Peace Conference at Paris in 1919 as an investigative body into atrocities committed during the First World War (1919 Commission). ${ }^{81}$ However, the 1919 Commission had no institutional links with judicial bodies subsequently established by the Treaty of Versailles on the German level and its findings were not binding. The 1919 Commission investigated 20,000 people, identified 895 individuals believed to have committed war crimes, but only 12 military officers were convicted, and the maximum sentence imposed was three years. These 12 military officers were cheered by the crowds attending the courtroom trials and outside the courtrooms and, instead of being recognized and punished as war criminals, they were celebrated as national heroes and martyrs to foreign oppression. ${ }^{82}$

The 1919 Commission report did not stop at Kaiser Wilhelm and German perpetrators, but also sought to charge persons for crimes against the laws of humanity based on the preamble to the 1907 Hague Convention, i.e. they wanted to create the first international criminal tribunal. However, USA and Japan were opposed to the creation of such a tribunal and "expressed reservations." The trend of "reservations" continued and the same lack of political will affected the prosecution of the mass killing of Armenians by Ottoman military and political officials in 1915. Charges brought against Ottoman military and political officials were based on the authority of the Treaty of Sèvres signed on 10 August 1920 between four Principal Allied Powers and nine Allied Powers on the one side, and Turkey, on the other. Article 143 of the Treaty of Sèvres authorized the first great ethnic cleansing of the twentieth-century in the shape of a "population exchange", as it provided for Greece and Turkey "to enter into a special arrangement relating to the reciprocal and voluntary emigration of the populations of Turkish and Greek race in the territories transferred to Greece and remaining Turkish, respectively." ${ }^{83}$ The Treaty also provided for Turkey's surrender of persons accused of having committed acts contrary to the laws and customs of war. ${ }^{84}$ However, the Principal and other Allies changed their mind due to the political considerations. The Ottoman Empire ceased to exist, the new national hero Mustafa Kemal Atatürk toppled the sultan and the sultanate, thereby establishing a brand new country. Consequently, the provisions of the Treaty of Sèvres were never carried out because Turkey never ratified the Treaty. Instead, Atatürk requested different terms. In 1923, the Treaty of Sèvres was replaced by the Treaty of Lausanne, ${ }^{{ }^{5}}$ which did not mention prosecutions, and, in fact, contained an annex that gave Turkish officials amnesty ${ }^{86}$ Despite that, trials were held in Turkey against the Ottoman leadership, leading to stiff sentences, including the death penalty, for crimes committed against Armenian civilian population. Whereas the most notorious leaders (Enver Pasha, Talaat Pasha, and Djemal Pasha) fled to Germany and were never tried, several Istanbul-based leaders, including many regional leaders, were tried between 1919 and 1920. The momentum fell apart as the

\footnotetext{
${ }^{80}$ Treaty of Versailles (1920), Part VII, Penalties, Articles 228-230.

${ }^{81}$ The Report of the Commission on the Responsibility of the Authors of the War and on Enforcement of Penalties from 29 March 1919, The American Journal of International Law 14.1/2 (1920): 95-154.

${ }^{82}$ Bassiouni, C. (1994), Former Yugoslavia: Investigating Violations of International Humanitarian Law and Establishing an International Criminal Tribunal. Fordham International Law Journal, 18/4, p. 1194.

${ }^{8_{3}}$ Treaty of Sèvres (1920), Part IV, Protection of minorities, Article 143.

${ }^{84} \mathrm{Ibid}$, Part VII, Penalties, Article 229.

${ }^{85}$ Treaty of peace with Turkey signed at Lausanne (1923), Preamble.

${ }^{86}$ Treaty of peace with Turkey signed at Lausanne: Declaration of amnesty (1923).
} 
Greeks invaded Turkey and the nationalists took over, ending these trials. ${ }^{87}$ Each of the three Pashas were killed by exiled Armenian while abroad.

On 10 January 1920, an intergovernmental organization, the League of Nations, emerged as a yet another result of the Paris Peace Conference. The Covenant of the League of Nations, stipulating that its principal mission was to achieve international peace and security, was signed on 28 June 1919, became effective from 10 January 1920, and was adopted in December 1924 by all Member States. ${ }^{88}$ However, the League of Nations did not have its own military powers and it greatly depended on the will of the Allied and Associated Powers to enforce its resolutions on verbal, financial, and physical sanctions it may have imposed on certain countries. Successful interventions by the League of Nations include: The Aaland Islands (1921), Upper Silesia (1921), Memel (1923), Turkey (1923), Greece and Bulgaria (1925), and unsuccessful ones include: Italy (1919), Teschen (1919), Vilna (1920), the war between Russia and Poland (1920-1921), the invasion of the Ruhr (1923), Italy and Albania (1923). In the end, the League of Nations proved utterly incapable of preventing the Second World War, which lasted from 1939 to 1945 whereupon the IMT and IMTFE were created to prosecute war crimes committed by the Axis powers during the Second World War. The IMT and the IMTFE were supposed to deal with, inter alia, ending the celebration of war criminals as national heroes, and bringing top leadership and base-crime perpetrators to justice.

\subsubsection{The IMT and IMTFE}

The IMT and IMTFE were military tribunals set up by the Allied Forces: the IMT was established by a treaty and the IMTFE by a special proclamation of the Supreme Commander of Japan, General McArthur. The difference between a treaty and a special proclamation is that the treaty is an international agreement concluded between two or more States in written form governed by international law, whereas a special proclamation is a one-sided declaration on a subject. ${ }^{89}$ IMT and IMTFE trials was based on findings of the UN War Crimes Commission established "by a meeting of Government representatives of seventeen of the Allied Nations, including all of the major powers except the USSR. ${ }^{{ }^{\circ \circ}}$ Obviously, the trend of excluding certain states from discussions about the benefits to overall humanity and a certain level of heavy-handedness continued, but events in the aftermath of the Second World War also brought about several other trends. Hitler, Himmler, and Goebbels committed suicide and were not prosecuted before the IMT, while many other high-ranking Nazi officials escaped and settled in countries with absolutist regimes. At the IMTFE, Emperor Hirohito was not prosecuted because his immunity was necessary for Japan's post-war stability. ${ }^{91}$ Some other members of the Japanese imperial family and high-ranking officers were also not prosecuted, such as Prince Asaka (Rape of Nanking) or Nobosuke Kishi (a politician), including some industrialists who were responsible for biological welfare and people who were responsible for the institution of the "comfort women system. ${ }^{\text {g2 }}$ Picking and choosing who to prosecute and who to leave alone at the level of the top leadership was soon extended to other segments of society. The Allies started the denazification process to remove former Nazi members from public offices and other influential positions. Yavnai explains:

In the aftermath of World War II, the United States embarked on the largest-scale war crimes punishment program in its history. In addition to the well-publicized trials of the Nazi leadership at Nuremberg the U.S. Army prosecuted 1,676 lesser war criminals in the American zone of occupation in Germany. The Dachau trials,

\footnotetext{
${ }^{87}$ Dadrian, V. N. and Akçam, T. (2012), Judgment at Istanbul: the Armenian genocide trials. Berghahn Books: New York City.

${ }^{88} \mathrm{UN}$, Covenant of the League of Nations.

${ }^{89}$ Grant, J.P. and Barker C.B. (2009), Parry \& Grant encyclopaedic dictionary of international law. Oxford University Press: Oxford, UK.

${ }^{90} \mathrm{UN}$, United Nations War Crimes Commission (1943-1948).

${ }^{91}$ Cryer, R., Friman, H., Robinson, D. and Wilmshurst, E. (2013), An introduction to international criminal law and procedure (second edition). Cambridge University Press: New York, p. 119 .

${ }^{92}$ Rothe, D. L., Meernik, J. D. and Ingadóttir, T. (eds.) (2013), The Realities of International Criminal Justice. Martinus Nijhoff Publishers: Leiden, p. 37 .
} 
as they later became known, were the culmination of the Army's concentrated effort to investigate, apprehend, and interrogate suspected war criminals in the last months of the war. The trials revived the American tradition of war crimes prosecution in military courts. Their purpose was to punish the perpetrators, educate the public about the crimes of the Nazi regime, and help democratize the Germans. The defendants included Nazi military and state officials, concentration camp personnel, as well as German civilians accused of killing and mistreating allied nationals in violation of the laws of war. The trials provided the earliest glimpse into the identity of individual perpetrators, life in the Nazi concentration camps, and the attitudes of the German population toward captured American prisoners of war. ${ }^{93}$

The denazification process, characterized by punishment of perpetrators and the education of the public leading to democratization, extended to all segments of society and everyone in post-Nazi Germany. However, this process cannot be said to be comprehensive or extended uniformly outside post-Nazi Germany. In France, for example, some domestic Nazi collaborators were left intact until the then French President Chirac purged them in $1995 \cdot{ }^{94}$ The USA government is said to have attracted Nazi scientists to come to the USA and work on weapons development programs.${ }^{95}$ In the former Yugoslavia, the winning troops rounded up escaping Nazi remnants and domestic Nazi collaborators when they failed to surrender to allies in the border town Bleiburg and executed them en masse while escorting them back into the country. Those who remained in the country were encouraged to defect by a declaration of amnesty issued before the Bleiburg events and, once they did, they simply put on the uniforms of the victorious Yugoslav People's Army ${ }^{96}$ These and similar examples of disproportionality in the prosecution of Second World War crimes, include the fact that suspected events and individuals on the side of Allies were never even investigated. This presented an obstacle to the work of the ICTY even before the ICTY was established, as will be explained later.

\subsubsection{Post-IMT and IMTFE}

Kastner argues that IMT did not prevent other wars or war crimes, but it marked the birth of the practice of international law. ${ }^{97}$ Indeed, IMT and IMTFE trials unequivocally established that the gravest international crimes and the crimes against peace will not go unpunished, that celebrating war criminals will no longer be acceptable, that human rights are inalienable, and that States' claims about violation of their sovereignty and prerogatives have limits. All pre-IMT and IMTFE "local international criminal tribunals" failed to do that.

Despite all the controversies and shortcomings relating to their establishment, their achievements, and the aftermath of their efforts, both the IMT and the IMTFE sent several very important legal and humane messages that still resonate. In 1946, IMT judges set in writing a statement which marked the birth of the international criminal law:

Crimes under international law are committed by men, not abstract entities, and only by punishing individuals who commit such crimes can the provisions of international law be enforced [...] individuals have international duties which transcend the national obligations of obedience imposed by the individual state..$^{8}$

\footnotetext{
${ }^{93}$ Yavnai, E. M. (2014), Military Justice: The U.S. Army War Crimes Trials in Germany. ProQuest LLC: Ann Arbor, MI, p. 5.

${ }^{94}$ Carrier, P. (2006), Holocaust Monuments and National Memory Cultures in France and Germany Since 1989. Berghahn Books: New York City, p. 74

${ }^{95}$ NPR book reviews, The secret operation to bring Nazi scientists to America (2014).

${ }_{96}^{6}$ Bougarel, X., Helms E. and Duijzings G. (eds.) (2007), The New Bosnian Mosaic Identities, Memories and Moral Claims in a PostWar Society. Ashgate: Burlington, VT.

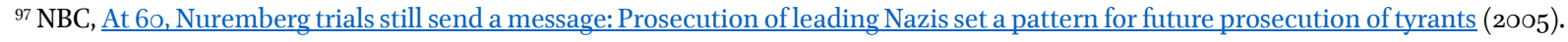

${ }_{98}^{8}$ Principles of International Law of the Charter and Judgment of the Nuremberg Tribunal, Formulated by the International Law Commission, Second Session. International Organization, vol. 4, no. 4, 1950, pp. 714-721.
} 
This is a maxim of individual criminal responsibility that has led to prosecutions at every international criminal tribunal ever since. The IMT and IMTFE findings took a brief momentum and went above and beyond the usual status quo in international affairs and put in writing the Nuremberg Principles on what constitutes a war crime. IMT judges pointed to the inadequacy of the existing laws for prosecuting war crimes in that they publicly acknowledged that The Hague Convention nowhere designated methods of waging war as criminal, nor prescribed or mentioned any sentence or a court to try and punish offenders. ${ }^{99}$

In 1947, the UN General Assembly established the International Law Commission (ILC) to undertake the mandate of General Assembly under the UN Charter initiating studies and making recommendations on promoting international cooperation in the political field and encouraging the progressive development of international law and its codification. ${ }^{100}$ In other words, the UN wanted the ILC to draft a series of laws on international criminal law and international human rights stemming from IMT and IMTFE findings and establish a permanent international criminal tribunal with universal jurisdiction to try crimes against humanity. However, the Cold War had begun and the ILC's concrete work was halted until the creation of the ICTY in 1993. In 1994, once the ICTY began to operate, the ILC received a green light to draft a statute for the ICC. ${ }^{101}$ The ICC was established in 2002 and declared to be "in a relationship" with the UN. ${ }^{102}$ This relationship means that they recognize each other's independence, international legal personalities, legal mandates, etc. ${ }^{103}$

The UN was established to prevent the war and maintain international peace and security, but those tasks also imply the protection of international human rights. However, there were no UN entities fully dedicated to that task until the establishment of the ICTY in 1993. Instead, prevention of war and the protection of international human rights were discussed by the UN Security Council permanent members and their working groups set up to debate all these "questions" and "situations" from above. Scholars criticized this approach to problems and pointed out the challenges of traditional UN peacekeeping predicated on the postCold War experience of swift global changes when the world started experiencing unprecedented ethnic nationalism and civil wars (B\&H, Kosovo, Chechnya, East Timor, Afghanistan, Somalia, Algeria, Rwanda, Burundi, Congo, Sierra Leone). They claimed that this rendered the UN peacekeeping obsolete and warned that the entire UN approach to the issue was disastrous when coupled with the UN's "turtle-paced" diplomacy. ${ }^{104}$

Heads of states, politicians, former staff and the media have never stopped criticizing UN efficiency when it comes to maintaining international peace and security, hinting at flaws in its internal structure. During the Cold War, the world leaders called the UN "le machin" (Charles De Gaulle) ${ }^{105}$ and "obsolete and inadequate [...] damned debating society" (Nixon).$^{106}$ At the end of the Cold War, certain politicians started openly questioning the role of the UN Secretary-General. According to Holbrooke, just before the genocide in Srebrenica (1995), the UN Secretary-General Boutros-Ghali who was in office throughout the war on B\&H, stated: "Bosnia has created a distortion in the work of the [UN]." ${ }^{107}$ That statement and sentiments throughout the crisis in B\&H, according to Holbrooke, "made us feel he did not deserve a second term." And Boutros-Ghali did not get the second term. Former staff summarizing past UN efforts in relation to international peace and stability pointed out that "during the [50] years of its existence, the UN has not been able either 'to maintain international peace and security', or 'to achieve international cooperation in solving international problems

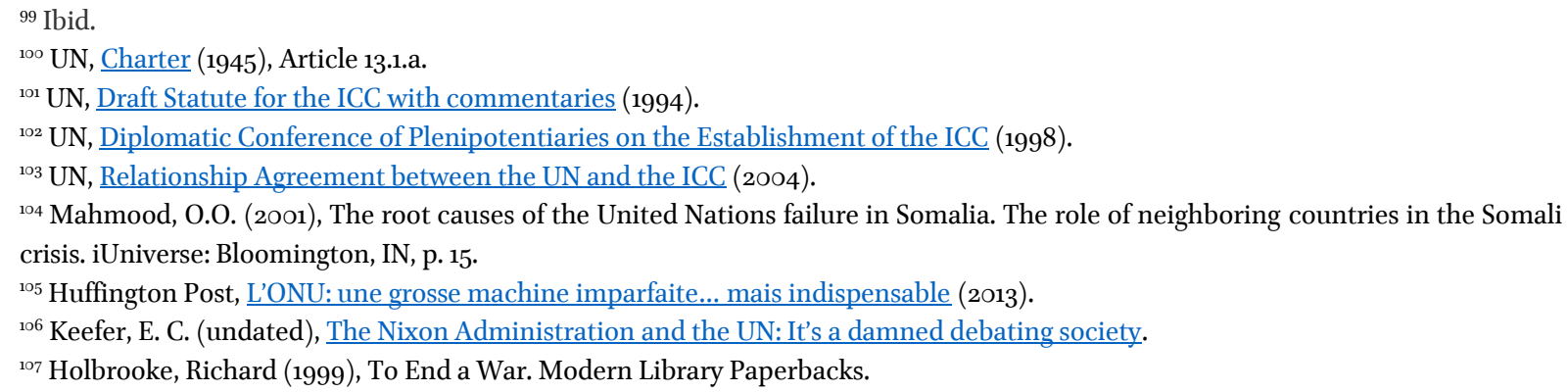


of an economic, social, cultural or humanitarian character'."108 Franz Baumann, former Assistant SecretaryGeneral, Special Adviser on Environment and Peace Operations, blamed the "antiquated, paper-based processes at the UN Secretariat" warning that "[b]uying a new IT solution does not equal reform" concluding that "corporate management is weak, fragmented, duplicated and incoherent. It is often said that micromanagement on the part of UN Member States impedes sound administration. This is certainly a concern, yet it cannot explain or excuse internal incoherence. ${ }^{\text {"109 }}$ Many other high-ranking staff called for reforms of the UN in the area of peacekeeping, management, and funding. Albeit once they retired. Recently, the media started openly questioning whether the UN is heading the way of the League of Nations."

At the same time, setting a common standard for international human rights applicable to all UN Member States and in all situations, has not been easy. Weiss notes that during deliberations at the UN Security Council the principle of state sovereignty frequently overrides the principles of human welfare. ${ }^{\mathrm{II}}$ Walling claims that defense of human rights in certain countries depends on the UN Security Council's view of the cause and character of the conflict, but also on the source of sovereign authority in those countries where human rights are purported to be violated. ${ }^{112}$ In other words, only because the regime is considered despicable does not mean that foreign intervention is justifiable or that an overthrow of a regime leader is legitimate. In illustration of that point, Walling provides a brief history of deliberations of human rights at the UN Security Council from the time when it could not intervene to stop violations of human rights because this was not within its purview, opting, instead, to criticize the use of foreign military force to topple the regimes that engaged in egregious violations of human rights (Vietnam toppling Khmer Rouge in Cambodia) to the time when UN Security Council started favoring humanitarian interventions to end violence, protect civilians against violence perpetrated by their own governments, and allowing people to determine their own future (Kosovo). Ms. Louise Arbour, the ICTY prosecutor between 1996 and 1999, clarifies:

\begin{abstract}
Whether one likes it or not, the fact is that the global web of our interdependence makes it altogether unpersuasive for anyone to claim a status of 'impotent and powerless bystander' in the face of gross violations of human rights. Moreover, indifference or inaction in the knowledge of violence, deprivation and abuse allow exclusion and resentment to fester. Those are the conditions that will ultimately affect everybody's rights, security and welfare, even if they never make a serious call on our conscience. ${ }^{13}$
\end{abstract}

The responsibility to protect $(\mathrm{R} 2 \mathrm{P})$ is the idea entertained by some $\mathrm{UN}$ policy-makers that came to the fore in the aftermath of NATO intervention in Kosovo. It revolves around the fact that sovereignty is as much about responsibility as the exercise of authority; that sovereign states have the primary responsibility to protect their own people from serious harm; that if they are unable or unwilling to exercise that responsibility, it shifts to the wider international community; and that the international community's responsibility in these circumstances, to be exercised with maximum restraint but as forcefully as ultimately proves necessary, extends very much to prevention as well and, in the event of coercive intervention, to subsequent societal reconstruction. ${ }^{114}$

\footnotetext{
${ }^{108}$ Bertrand, Maurice (1995), The UN as an organization. A critique of its functioning. EJIL (1995), 349-359.

${ }^{109}$ Pass Blue, Franz Baumann: UN Bureaucracy? No, thanks. (2016).

"1o The Guardian, The UN is failing. Is it heading the way of League of Nations? (2016).

${ }^{11}$ Weiss, T. G. (2012), What's wrong with the UN and how to fix it. Polity Press: Cambridge, UK.

${ }^{112}$ Walling, C. B. (2013), All necessary measures: UN and humanitarian intervention. University of Pennsylvania Press: Philadelphia.

${ }^{{ }^{113}}$ Arbour, L. (2008), The responsibility to protect as a duty of care in international law and practice. Review of International Studies, $34(3): 445-45^{8}$.

${ }^{114}$ The challenges to the implementation of the $\mathrm{R}_{2} \mathrm{P}$ and it becoming an effective policy of the UN are numerous. Some of them have to do with the notion of "excess state violence," the territorial integrity of UN Member States vs. the maintenance of international peace and security on that basis, and the fact that most contemporary armed conflicts are internal, not interstate, and that civilians comprise the dominant proportion of casualties. All this presents the UN with a great difficulty: how to reconcile its foundational
} 


\subsubsection{The ICTY and subsequently established international criminal tribunals}

In 1993 when the UN Security Council passed Resolution 827 to establish the ICTY, the world and the region of the former Yugoslavia were very different to today. The region of the former Yugoslavia was an active war theater with thousands of internally displaced persons, and refugees and asylum seekers dispersed throughout the world. The world was recovering from the Cold War, which has just ended with the lifting of the Iron Curtain in 1991 and, although triumphant, it was still very much divided into zones of interest. The conflict in the former Yugoslavia was the first conflict on European soil after the Second World War and it generated feeling of fear and insecurity. The international community was not well informed about the events in the former Yugoslavia. Malcolm reports that the then UK Prime Minister, Mr. John Major, told the UK House of Commons that the biggest single element behind what had happened in B\&H was the collapse of the Soviet Union and of the discipline that had suppressed the ancient hatreds in the old Yugoslavia. This uninformed statement misled the entire international community as to the causes and effects of the war. ${ }^{115}$ Once the first investigators into the causes and effects of the war returned from the former Yugoslavia, the ICTY was established, the situation became "clearer," and everybody was in shock, albeit for different reasons. There had been pressure for the establishment of a permanent international criminal tribunal for such a long time that, once something remotely resembling it was set up, people either did not know what to make of it or they found solace in parroting the similar arguments that prevented the establishment of an international criminal tribunal right after the IMT and IMTFE closed their doors.

The Russian-speaking world was perturbed by the establishment of the ICTY, describing it as innovative method of intervention in government affairs. ${ }^{116}$ The Spanish-speaking world reacted to the establishment of the ICTY with pessimism, describing it as an "unlucky project" that was incapable of solving an armed conflict, claiming that no country in the former Yugoslavia was militarily occupied, and that it was not likely that war criminals would be handed over by the factions involved in the conflict. The Spanish-speaking media blamed the international community for a lack of strength and authority to put the real culprits in the dock. ${ }^{117}$ The Arabic-speaking world was cheerful and optimistic toward the establishment of the ICTY, hoping it would finally put a stop to inhumane acts and widespread massacres. The Arab countries were very positive about the prospects of fair trials for offenders guilty of inhumane crimes, stating that they were ready to provide financial support, if needed. ${ }^{118}$ The English-speaking world met the establishment of the ICTY with great reluctance, claiming that the blending of international courts, judges, and legal systems had never worked before and that there was a lack of international cooperation with the ICTY. ${ }^{119}$ The French-speaking world considered the ICTY "impossible as a new Nuremberg" first because the notions of war crimes and crimes against humanity were still unclear and varied per country, and, second, because the situation in the former Yugoslavia had nothing to do with the end of the Second World War. The French-speaking critics also criticized the ICTY's limited jurisdiction in space (the former Yugoslavia), time (since 1991), and ratione materiae

\footnotetext{
principle of Member States' sovereignty with the primary mandate to maintain international peace and security. The $\mathrm{R}_{2} \mathrm{P}$ seeks to do three principal things: change the conceptual language from "humanitarian intervention" to "responsibility to protect," pin the responsibility on state authorities at the national and the UN Security Council at the international level, and ensure that interventions, when they do take place, are done properly. Thakur, R. (2007), The United Nations, Peace and Security. From Collective Security to the Responsibility to Protect. Cambridge University Press: Cambridge, UK. However, even 17 years after being formally committed to paper, the $\mathrm{R}_{2} \mathrm{P}$ remains the work in progress. Current UN Secretary General, António Guterres has recently stated that although genocide, war crimes, ethnic cleansing and crimes against humanity remain as strong as ever and are not on the retreat, the $\mathrm{R}_{2} \mathrm{P}$ still generates some discomfort for a number of UN Member States who are concerned that the principle will be used to impose international approaches on national problems in ways that may harm national sovereignty. UN, Statement by the UN Secretary General (2017), Secretary-General Urges Move beyond Conceptual Debate towards Better Protection against Atrocity Crimes, at Informal Dialogue on Responsibility to Protect.

${ }^{115}$ The Independent, Bosnian guilt: ancient hatreds or wicked leaders? (1994).

${ }^{16}$ PolitPros, Югославия - первая жертва германского реваншизма (undated).

${ }^{117}$ La Vanguardia, La OTAN no asume el plan aliado para Bosnia por ser poco preciso (1993).

${ }^{118}$ E-life, New War Crimes Tribunal (1993).

${ }^{19}$ Center on law and globalization, Politics and Justice in Creating the International Criminal Court (2003).
} 
in their field of charge: war crimes, crimes against humanity, and genocide. ${ }^{120}$ The Chinese-speaking world generally saw the establishment of the ICTY as a new milestone in international criminal justice. It hailed it as an unprecedented move, being the first court that was not set up by victors, and as having a high degree of autonomy in its judgments. More importantly, the Chinese-speaking media approved the establishment of such an independent tribunal, because it was breaking with the tradition of heads of state being immune from prosecution and bringing both heads of state and high-ranking government officials to justice. ${ }^{121}$

The media in B\&H was in disbelief. At a popular level, it was believed that an international criminal tribunal for the prosecution of Serb(ian) and Croat(ian) perpetrators had not so far been established because the major victims were unrecognized: European Muslims. B\&H officials warned the Great Powers against "losing" or "sealing" crucial documents for prosecution of Serb(ian) and Croat(ian) perpetrators, reminding them that international troops, military monitors, and media have been in B\&H throughout the conflict and that their reports speak volumes about the atrocities committed. ${ }^{122}$ The media in Serbia mirrored the official stand of the then-government which described the ICTY as illegal because it has been established by the UN Security Council, not the UN General Assembly. It also dubbed it an illegitimate political instrument of pressure against the Serbs, established with the sole purpose of proclaiming that the Serbs were the sole guilty party. They claimed that the lack of cooperation between Serbia and the ICTY was because the ICTY is an institution that cannot have precedence over domestic laws which consider extradition of suspects unconstitutional. ${ }^{123}$ The media in Croatia pointed out that the founders of the ICTY were uncertain about their mission and vision themselves. ${ }^{124}$

Obviously, as with everything new, the media in the five major UN language communities considered the ICTY almost as an extravagant experiment and pointed to a number of issues that are still relevant for the functioning of the political world that surrounds the UN, the ICTY, and subsequently established international criminal tribunals: jurisdiction, bringing real culprits to trial, the limitations of innovative methods of justice, dealing with problems unresolved by the IMT and IMTFE, and, of course, the budget. All these will now be considered in turn.

First of all, as to jurisdiction, many who promote the idea of "victors' justice" often ask why the Allied Forces took over the prosecution of war crimes committed during the Second World War and created the IMT and IMTFE or why the ICTY was established to try crimes committed in the former Yugoslavia when the ICJ already existed? Was the UN engaged in double work and wasting resources? The ICJ - the primary judicial organ of UN, inherited from the League of Nations - was established in 1945. The ICJ Statute (ICJ-S) vests this institution with power only to settle disputes on matters that transpire between states or issue advisory opinions when so requested by one of the UN organs which can request such an opinion on a legal matter. ${ }^{125}$ This means that the ICJ is not a criminal tribunal and does not have jurisdiction over individuals. Consequently, the ICJ never had any criminal jurisdiction over the conflict in the former Yugoslavia. ${ }^{126}$

Secondly, as to the bringing the real culprits to trial, it is obvious that the failure to bring to justice the major guilty parties that led the world into the Second World War was still fresh in collective memory in 1993. Bringing any suspect before an international criminal tribunal is regulated in the rules and regulations on international cooperation and judicial assistance. UN Member States are obliged to cooperate with international criminal tribunals. Enforcement of obligations on international cooperation enabled the ICTY and

\footnotetext{
${ }^{120}$ L'express, L'impossible nouveau Nuremberg (1993).

${ }^{121}$ Tavnier, 前南斯拉夫和卢旺达国际刑事法庭的经验 (1993).

${ }^{122}$ Bošnjaci Agency, Pravda je zakasnila, ali nije opovrgnuta (1993).

${ }^{123}$ Republika, Medjunarodni krivicni tribunal za bivsu Jugoslaviju (Haski tribunal) (1998).

${ }^{124}$ Političke analize, Problemi i pogreške Haškog suda (undated).

${ }^{125} \mathrm{UN}$, ICJ Statute, Articles 34 and 65.

${ }^{126}$ As such, ICJ did adjudicate on a number of cases revolving around the conflict in the former Yugoslavia and involvement of the individual states.
} 
all subsequently established international criminal tribunals to contribute to the aim of abolishing impunity for the most atrocious crimes. Getting a country to actually arrest and surrender suspected war criminals to the international criminal tribunal is a major bottleneck as the arrest of the former Serbian president, Mr. Slobodan Milošević, has shown. Milošević's arrest by his own people, extradition by his own people, and his subsequent trial by the international community is the first case in history where a leader of a country has been brought before the UN court to explain his involvement in mass crimes committed by a large number of people under his authority. This means that, before the ICTY, world leaders were, in fact, primus inter pares, and that, from the moment Milošević was arrested and tried, no one was any longer immune to being answerable to international criminal justice. This lack of immunity could, for example, apply to President Bashar Al-Assad of Syria.

Remember that, prior to Milošević, the only head of state who had been tried for war crimes was Mr. Karl Dönitz, Hitler's successor, but the main difference between these two is that Dönitz was tried at a military tribunal (see Chapter 4). The trial of Saddam Hussein and the demise of Muammar Gaddafi cannot really be viewed through the same prism of international criminal law, because the former never appeared before an international criminal tribunal and the latter was lynched by rebels. Following the execution of Saddam Hussein, Philip Alston, UN Special Rapporteur on extrajudicial, summary, or arbitrary executions, stated that "the trial and execution of Saddam Hussein were tragically missed opportunities to demonstrate that justice can be done, even in the case of one of the greatest crooks of our time. ${ }^{127}$ Similarly, following the death of Gaddafi, UN human rights spokesman Rupert Colville said it was a fundamental principle of international law that people accused of serious crimes should be tried if possible, adding that "summary executions are strictly illegal under any circumstances." ${ }^{128}$ Indeed, should somebody be arrested for crimes against humanity, it would be proper that humanity, embodied at the UN, should decide on that person's fate. The impact of the ICTY's contributions to the field of international criminal law can be seen in public reactions to the death of Hussein and of Gaddafi, which were very different to reactions to the arrest of Milošević, when commentators wondered whether Milošević could be arrested and tried at all. The question was: what is the extent of impunity. Partly thanks to the ICTY, international criminal law has come a long way in the nearly two decades since the arrest of Milošević.

Next, innovative methods of justice. It could be said that the IMT and IMTFE merely broached the subject of international criminal law, while the ICTY and subsequently established tribunals started developing it to fit the needs of the twenty-first century. The ICTY was the first international criminal tribunal that established that rape in times of war represents a war crime: it pointed to occurrences of often overlooked rape of men, it shed light on rape as a means of torture, alerted the public to overwhelming sexual violence in the times of war, established sexual enslavement and rape as crimes against humanity, and made a link to rape as a means of ethnic cleansing. ${ }^{129}$ SCSL ${ }^{130}$ ECCC, ${ }^{131}$ and STL ${ }^{132}$ developed the field of international criminal justice even further. However, there was still the issue of prosecuting the philosophy of hate: the underlying reason for commission of crimes.

The ICTY did not try to tackle the main source of hatred in the former Yugoslavia: Radio and Television of Serbia, because it cannot try organizations. The ICTR tried individuals for hate speech, as it recognized the importance of words and other verbal and semiotic messages (signs and symbols) in the time of conflict and brought to justice the main media leaders for their role in crimes committed in Rwanda. ${ }^{133}$ There was,

\footnotetext{
${ }^{127}$ UN News Centre, UN human rights expert deplores Saddam's trial and execution (2007).

${ }^{128}$ Voice of America, Gaddafi burial delayed (2011).

${ }^{129}$ ICTY, Landmark cases.

${ }^{130}$ Xinhua News Agency, UN chief hails achievements as SCSL closes (2014).

${ }^{131}$ OSISA, Lessons for Africa from Cambodia's genocide trials (2012).

${ }^{132}$ International Law Middle East and North Africa Programmes, The STL and the Quest for Truth, Justice and Stability (2010).

${ }^{133}$ ICTR, Nahimana et al CIS.
} 
however, no process similar to denazification or lustration. Prosecuting the philosophy of hate without denazification or lustration is closely related to sentiments about the impossibility of any new Nurembergs. Although making sure that defendants have access to all the rights guaranteed by due process, even at the expense of other participants in the legal process, it seems that the main criticism of substantive work at all international criminal tribunals has always been political and directed at the lack of reciprocity and unreasonable fears of renewed 'decroatization', 'demuslimanization', or 'deserbization' campaigns in the former Yugoslavia. As to the latter, no countries created in place of the former Yugoslavia have been militarily occupied by anyone, so there could be no one to organize such campaigns. However, such fears persisted among Serbs, Croats, and Muslims, and became an argument against the system of international criminal tribunals. In the best traditions of Munchausen's trilemma, their defenses mostly centered around arguments that either the reason to commit crimes was predicated on a series of sub-reasons leading to an infinite regression, or, that those reasons were tracked back to arbitrary axiomatic statements, or, that the reasons were circular, i.e. crimes were committed because they were committed. ${ }^{134}$

But, such "defenses" did echo both locally and internationally and many people actually believed them. Moerland points out that those who deny genocide present their denialist accounts under the cover of legitimate critiques. ${ }^{135}$ As far as the ICTY is concerned, it seems the critics want(ed) to say that there should be equal numbers of Muslims, Croats, and Serbs tried. For example, the media in Serbia was very pleased at the prosecution of Muslim and Croat perpetrators, but agitated at the prosecution of Serb perpetrators. The same held true for media in $\mathrm{B} \& \mathrm{H}$ and Croatia when it came to prosecution of perpetrators from those countries. The politics of identity have also influenced denialism. The discovery of the first confirmed concentration camps in $\mathrm{B} \& \mathrm{H}$ led to some disparaging comments on the nature of crimes committed in the former $\mathrm{Yu}-$ goslavia from the most unlikely audiences. Elie Wiesel, Auschwitz and Buchenwald survivor, stated the following:

Only Auschwitz was Auschwitz. I went to Yugoslavia [Belgrade, Sarajevo, Banja Luka, and the Manjača concentration camp] when reporters said that there was a Holocaust starting there. There was genocide, but not an Auschwitz. ${ }^{136}$

Moerland further points out that uncritical and decontextualized statements are problematic because they help denialism to become more mainstream and more acceptable. ${ }^{137}$ Qualifying a human tragedy like this in non-legal terms and fetishizing victimhood does not change the fact that all these victims were killed exclusively because they were of a specific religion and/or of a specific ethnicity.

And, finally, the budget. Naturally, since international criminal justice is very expensive, there has been much discussion about the budget. Some sections of the ICTY are fully budgeted by the UN, but entire sections and projects depend solely on donations (see Chapter 6). Not all subsequently established international criminal tribunals that have been conjointly established by the UN and their local governments have not received full financial and administrative support from UN. This gave rise to another type of tribunal: the hybrid tribunal. These are international criminal tribunals that are funded by the UN and by their national administrations (SCSL, ECCC, and STL). Fitchelberg describes hybrid tribunals as a unique development in the history of international law and international criminal justice where international and domestic law have been closely integrated in an institutional form. The hybrid tribunals sought to integrate foreign laws and personnel with domestic ones to different degrees and to different extents. As to their challenges, Fitchelberg

\footnotetext{
${ }^{134}$ Committee on Collection of Data on Crimes against Humanity and International Law (1998), BH Muslim and Croat's preparations for violent separation from Yugoslavia and organized character of genocide against the Serbs in Sarajevo.

${ }^{135}$ Moerland, C.A.R. (2015), The killing of death: denying the genocide against the Tutsi. Intersentia: Cambridge, UK, p. 14.

${ }^{136}$ Rave utopia, Elie Wiesel: Bosnia was not Auschwitz, but it was genocide (2012).

${ }^{137}$ Moerland, C.A.R. (2015), The killing of death: denying the genocide against the Tutsi. Intersentia: Cambridge, UK, p. 14.
} 
explains that hybrid tribunals must be seen in relation to the international courts in existence at that time (the ICTY, ICTR, and ICC). However, the latter have been extremely expensive, requiring large numbers of highly paid legal personnel, including support staff, logistical expenses, and facilities. Although, at first, courts akin to the ad hoc tribunals (the ICTY and ICTR) were proposed by interested parties, they were invariably rejected because the international community's experience with ad hoc tribunals left many with a great reluctance to return to such a high-profile and high-cost approach. On the other hand, using a conventional domestic court was not a viable option, either. This is because hybrid tribunals' defendants were not ordinary criminals accused of minor crimes, but rather high-profile individuals who played a central role in mass atrocities, politically powerful individuals who often had legions of followers who remained loyal to them even after they had been defeated. As to the situation countries, Fitchelberg suggests they were uniquely bad candidates for conducting domestic trials because they remained too economically and politically weak to carry out the complex and far-reaching procedures necessary after intense conflicts that lasted for several years. The international community had a deep distrust of domestic justice institutions that were associated with "the other side" of the conflict and did not believe trials would be fair and impartial as bitter ethnic and other fighting in all these situation countries ran too deep and touched too many lives. A solution came in a shape of a tribunal that is at least partially a domestic court. It was believed that such court could have a legitimacy that foreign courts cannot provide. Such a court would be recognizably local, trials would be conducted in local languages, and it would include a significant number of local personnel. As such, it would have a better chance of being recognized as legitimate by the local populations who could, then, claim ownership over these proceedings and their outcomes in a way that they do not in international proceedings. Last, but not the least, local personnel would receive vital training and skills that would help them establish the rule of law in nations that were in desperate need of stability and development. At the same time, the international presence in the court would help reassure skeptics that the court would function in a fair, impartial manner. Obviously, whereas money has not been the only reason for the establishment of hybrid tribunals, it was one of the major reasons behind their establishment in their current form. Unfortunately, money reigns supreme as SCSL ${ }^{138}$ ECCC, ${ }^{139}$ and STL ${ }^{140}$ are facing immense difficulties which, sometimes, prevent them even paying salaries to their staff. ${ }^{141}$

\footnotetext{
${ }^{138}$ UN, Security Council Press Release, SCSL faces funding crisis as Charles Taylor gets under way (2007).

${ }^{139}$ The New York Times, No way to fund a war crimes tribunal (2012).

${ }^{140}$ Daily Star (Lebanon), 2017 state budget still has to clear major hurdles (2016).

${ }^{141}$ The financing of hybrid tribunals, according to Fitchelberg, is the point of intersection of all practical and normative considerations because the funding issues have a played a crucial role in their structure and operation. In order to function, many tribunals have had to rely on the contributions of states or on UN. However, states can withhold funds if they are unsatisfied with the directions the tribunals are taking. As a result, prosecutors have had to shape their strategies in response to financial concerns which led sceptics to charge that the tribunals are either underfunded or are operating at the behest of their financial backers. All this led Fitchelberg to argue that hybrid tribunals should first and foremost be understood as political institutions. This is because they were created largely to serve a number of different goals which are, for the most part, political in nature. Supporters claim hybrid tribunals were created to place the blame for a conflict clearly on the shoulders of one group and accrue the resulting political benefits. Others saw them as crucial for political stability and as a tool for transitional justice. Still others, saw them as part of a campaign to get into the good graces of the international community and help clear the way for international financial support. Only a few of the actors behind these tribunals saw them primarily in terms of the traditional goals of criminal justice (such as deterrence, reform, or incapacitation) when they advocated for their creation. Finally, Fitchelberg reminds that, along with financial considerations, hybrid tribunals are also hamstrung by their reliance on the cooperation of states because none have extraterritorial enforcement powers and therefore cannot locate witnesses abroad, conduct investigations, or arrest an accused person living abroad. Fitchelberg concludes that whatever the aims of their supporters, the hybrid tribunals themselves are not designed to produce "political" outcomes because criminal tribunals are created to determine the liability of specific people for specific actions and to give these defendants adequate opportunities to defend themselves against the charges. Also, the legal process is not good at the proportionate distribution of blame as it focuses on violations rather than root cause. Finally, Fitchelberg offers that hybrid tribunals are bad at politics because they are not good at developing broader historical narratives that may aid in transitional justice or at tailoring their outcomes to serve the interests of the political elites that support them. Fichtelberg, A. (2015), Hybrid Tribunals. A Comparative Examination. Springer: New York.
} 


\subsection{Interim conclusions}

It was very important to start the journey to linguistic justice from the institution of justice, embodied in the $\mathrm{UN}$, because the UN presents the main venue where the prevention of war and protection of human rights are discussed and is the only institution that can set up international criminal tribunal with limited or universal jurisdiction. However, discussion of the UN mission, management, powers, and programs pointed to a set of problems revolving around the absence of clear leadership, the flux created by the power of veto in the hands of the UN Security Council permanent members, and the lack of clear mandates governing the work performed by UN entities. Annan's 1998 reforms turned the UN into self-protective bureaucratic machine ran by managers. This is problematic, because the UN is not a purpose unto itself or unto individuals, but an interactive entity with a duty to respond.

The section on the UN System in relation to international criminal tribunals removed certain confusions that arise from frequent comparison between the ICTY and subsequently established international criminal tribunals and the IMT and IMTFE. Discord between the UN Security Council permanent members and worldwide disagreement on the basic concepts that govern the rights of states in general also had an effect on jurisdiction, the apprehension of perpetrators, and methods of justice practiced at international criminal tribunals. For the most part, in collaboration with the UN, ICTY continued in a tradition that celebration of war criminals is objectionable and that international crimes will not go unpunished. The biggest achievement of this collaboration is the rejection of impunity.

However, this collaboration has not been particularly successful in making universal statements on the philosophy of hate and on the budget. As to the philosophy of hate, it has not been prosecuted by any international criminal tribunal other than by the ICTR, so utter and partial denialism remain a problem. Charged with the prevention of war and adjudicating on ethnic crimes, both the UN and the ICTY failed to come up with a statement distinguishing between denialism and historical revision thereby failing to prevent future ethnic conflict in $\mathrm{B} \& \mathrm{H}$ anchored in philosophies of hate. As to the budget, once international criminal tribunals gained momentum, the UN started picking and choosing which ones to finance and gave birth to an incompletely financed institution of international justice: the hybrid tribunal.

That is how the things stand internationally. Next, this study will discuss the trigger of the whole mechanism of language as power: the conflict in the former Yugoslavia, most specifically in B\&H. The discussion will center on history, language, and identity-related issues in the former Yugoslavia because these are relevant to understanding the philosophy of hate in the background to ethnic conflict and genocide affecting B\&H Muslims in the 199os. 
Chapter 3: May the local context take the stand, please

Chapitre 3 : Le contexte local est prié de venir à la barre

Treće poglavlje: Neka pristupi lokalni kontekst 
The journey on the road to linguistic justice makes a second stop in the situation country. This is a very important stop because the situation country, the former Yugoslavia, is the locale where crimes adjudicated by ICTY have been committed in the first place and where the motivation for crimes needs to be sought. Surprisingly, as it will be explained throughout this study, the situation countries are very often overlooked by international criminal justice authorities when it comes to the intricacies relating to local cultures, customs, languages, etc. The ICTY was established to adjudicate on ethnic crimes that have been committed in the former Yugoslavia. Ethnic crimes do not just happen, and it is important to examine the behavior of perpetrators in the years leading up to ethnic cleansing of B\&H Muslims and genocide. Inevitably, language, notions of ethnicity, and a blurred line between nationality and national alliances have to be discussed. The nineteenth-century Romantic revolutions imposed language as a measure of national and ethnic identity, but it became evident that such identities were established by cultural and political elites and highly exclusive. The nineteenth-century Romantic revolutions also blurred the line between nationality and national alliances. The purpose of Chapter 3 is to introduce the former Yugoslavia and the historical development of language and identity-related issues in the case of $\mathrm{B} \& \mathrm{H}$. Chapter 3 consists of eight sections, each addressing a particular period in $\mathrm{B} \& \mathrm{H}$ history and pertinent language and identity-related issues: Medieval Bosnia, $\mathrm{B} \& \mathrm{H}$ under the Ottomans, $\mathrm{B} \& \mathrm{H}$ during the Romantic revolutions, $\mathrm{B} \& \mathrm{H}$ under the Austro-Hungarians, and $\mathrm{B} \& \mathrm{H}$ under the First and the Second Yugoslavia with reflections on the Second World War and the war against $\mathrm{B} \& \mathrm{H}$. In the following sections, this study will examine whether language and identity-related issues contributed to the commission of ethnic crimes against B\&H Muslims. How did the ICTY deal with language and identity-related issues that may have cropped up during trials? What statements has the ICTY made on language and identity-related issues for posterity in the situation country? What is the current take of international criminal justice on this underbelly of ethnically motivated crimes?

\subsection{Medieval Bosnia}

In medieval times, Europe was divided between the Catholic and the Orthodox church. The line of demarcation between these two churches ran along the river Drina on the eastern border of B\&H and was, unknowingly, established by the Roman Emperor Theodosius when he divided the Roman Empire into East and the West in 395 .

Until it fell under the Ottomans, B\&H was surrounded by the Hungarian Empire and its tributaries on the north and failing Serbian states on the east. Both wanted its territory. The medieval times in the whole of Europe were times of religious fanaticism, so belonging to the proper religion was mot du jour in/around $\mathrm{B} \& \mathrm{H}$, as well. The sources of religious and, therefore, political legitimacy, were either Rome, the seat of the Pope and the Catholic church, or Constantinople, the capital of the Byzantine Empire and the seat of Orthodox church. In that climate, B\&H decided it did not want to belong to any of the offered churches and established its own: the Bosnian Church. ${ }^{142}$ This was a largely unorganized church in a classical territorial sense. The members of the Bosnian Church called themselves simply "Christians" (Krstjani) or "Good Bosnians" (Dobri Bošnjani). Imamović claims that the Bosnian Church emerged as a reaction to the forced spread of Christianity documented in many anti-feudal movements among the Balkanic Slavs and various other political and religious teachings targeting the official church teachings. ${ }^{143}$ Naturally, both the Catholic and Orthodox churches considered the members of the Bosnian Church to be heretics. Bosnia at that time was "a refuge for all those who were perishing elsewhere due to their religious beliefs and those who sought a way out of their difficult situation to which they were brought by exploitation and oppression of feudal lords and rich city men finding solace in heretical religious teachings" [BF's translation]. ${ }^{144}$ In 1299, the then super power menacing Bosnia, the Hungarians, were so alarmed by the rise of the Bosnian Church that they relocated the seat

\footnotetext{
${ }^{142}$ Fine, John V. A. (1985), The Bosnian Church: A new interpretation: A study of the Bosnian Church and its place in state and society from the $13^{\text {th }}$ to the $15^{\text {th }}$ centuries. Boulder: East European quarterly; New York: distributed by Columbia University Press.

${ }^{143}$ Imamović, M. (2014), Historija države i prava Bosne i Hercegovine. University Press: Sarajevo, p. 35.

${ }^{144}$ Babić, A. (1946), Istorija naroda Jugoslavije. Svjetlost: Sarajevo, p. 75.
} 
of the Catholic church in the Balkans from Brdo around Sarajevo to Đakovo in present-day Croatia. Both the Catholic and the Orthodox churches waged several crusades against Bosnia without much success. The peoples of B\&H at that time seem to have promised the Catholic enforcers that they would denounce their heretical ways but, once they left, the peoples of B\&H seem never to have done what they had promised. ${ }^{145}$

Although present in the area since the mid-13oos, the Ottoman Empire took full control of Bosnia in 1464, Herzegovina in 1482, Serbia in 1521, never gaining full control over the whole of Croatia, but keeping a presence in various towns and cities, mostly in Dalmatia and Slavonia. In their expansion, the Ottomans took full advantage of the weakness of Byzantium, the extreme discord between the Bosnian and Serbian gentry that led to feudal anarchy in those countries, and, more or less, the passive control by the Catholic states of that time. Although unwilling to bow to anyone's religious authority, Medieval Bosnia was very much interested in receiving assistance for defense from the invading Ottomans. The Bosnian king Stjepan Tomaš was frantically trying to gain whatever support he could from the Rome to protect him from the expansionist Ottoman Empire. However, Rome blamed Stjepan Tomaš for the loss of Christian territories to the Ottomans and cast doubts on Stjepan Tomaš's faith. Stjepan Tomaš "tried to display his orthodoxy, at the very least" ordering "all heretics in his kingdom either to convert to the Catholic faith or to emigrate" [BF's translation]. ${ }^{146}$ The "people fled their homeland in masses" [BF's translation] $]^{147}$ as the king started persecuting the followers of the Bosnian Church who did not want to convert. In 1462, the last Bosnian king, Stjepan Tomašević, the son of Stjepan Tomaš, wrote the following letter to Pope Pious II.

I have been informed that the Turkish Emperor Mohamed [sic] plans to strike against me with his armies next summer and that he has already mobilized the troops and the cannons. I cannot resist such a force alone. I have already requested assistance from the Hungarians, the Venetians and Juraj Arbanas. Now, I am requesting it from you. I am not asking for the impossible, but I would be glad if my enemies and my compatriots knew that they will not come short of your keenness. [...] Should the Bosniaks learn I won't be left alone in the war, they would become braver, and, in turn, the Turks wouldn't dare strike against my lands because the entry points are difficult, and the cities are almost unconquerable in many places, as it is. [...] Your predecessor Eugene offered a crown to my father and wanted to build churches in Bosnia. My father was reluctant because he did not want to bring the Turkish wrath on himself. He was a new Christian who has not expelled Manicheans from the Kingdom. However, I have been baptized as a child, have studied the Christian book, have firmly accepted the Christian faith, and do not share my father's fears. I wish you would send me a crown and holy bishops as a sign that you won't leave me if the war breaks out. Your crown on my head shall instill confidence in my subjects and fear in my enemies. [...] The Turks erected several forts in my kingdom and are showing themselves to the peasants as kind. They are promising freedom to each who defects. The simple mind of a peasant does not see through their deceitful ways, thinking the freedom will last forever. Should they not see me protected by your authority, once tricked, they will easily defect from me. The gentry did not remain long in the cities left by the peasants, either. [...] This letter is sent to you by Stjepan. Father of Christianity: send me advice and help [BF's translation]. ${ }^{148}$

Although Stjepan Tomašević hoped the Pope would send him troops to salvage whatever was left of Bosnia, the Pope just sent him a crown. Indeed, this symbolically put him in the ranks of Catholic countries that deserved help with defense against the Ottomans, but the Catholic armies never came to his rescue. Having caught him for the second time and having trounced his resistance, the Ottomans killed Stjepan Tomašević in 1463. Obviously, his forced conversions and the related violence took its toll: the local populace, fed up with

\footnotetext{
${ }^{145}$ Journal of articles (2005), Fenomen 'krstjani' u srednjovjekovnoj Bosni i Humu. Institut za istoriju, Sarajevo, and Hrvatski institut za povijest, Zagreb.

${ }^{146}$ Vukšić, T. (2005), Papa Pio II i kralj Stjepan Tomaš. Fenomen 'krstjani' u srednjovjekovnoj Bosni i Humu, Institut za istoriju, Sarajevo, and Hrvatski institut za povijest, Zagreb, p. 305 .

${ }^{147}$ Babić, A. (1946), Istorija naroda Jugoslavije. Svjetlost: Sarajevo, p. 8o.

${ }^{148}$ Klaić, V. (1899), Povijest Hrvata. Knjižara Lav Hartmana (Kugli i Deutsch): Zagreb.
} 
all sorts of Catholic, Orthodox, and royal persecutions, under the strong influence of Ottoman spies present in the country, offered little, if any, resistance to the Ottomans, giving rise to the popular expression "Bosnia was subdued in a whispering campaign" (Bosna je šapatom pala). The Ottomans and Islam became a force to be reckoned with. Bosnia remained at the border between the two worlds.

The medieval B\&H populations, like all Slavic speakers, wrote in the Glagolitic script (glagoljica), which was invented specifically for translating the Scriptures and other religious works into Slavic. The language itself is now known as Old Church Slavonic. In the Orthodox Slavic-speaking world, Glagolitic script was replaced by the Cyrillic script, which was based on Greek and named for St. Cyril, but probably invented by St. Naum in Ohrid. ${ }^{199}$ In Bosnia, a variant of chancery Cyrillic developed into the Bosnian Cyrillic script, known as Bosančica. Although based on the Cyrillic that developed originally to the south of Bosnia, Bosančica became a distinct form of Cyrillic. The Bosančica script was used in various trading agreements Bosnian rulers concluded with surrounding countries, religious texts, other written documents, and at the medieval Bosnian Church tombstones called Stećak. The Bosančica script remained in use among selected B\&H elites, especially Franciscans, and women until the 1980 s and it is experiencing a popular revival. ${ }^{150}$

\subsection{The Ottomans}

The Ottomans, who were on their way to toppling the Hungarian Empire, were exhausted by the Bosnian campaign. ${ }^{.51}$ They felt grateful that they did not have to employ much military force to conquer Bosnia and that they had found troops willing to fight their wars. Unlike other conquerors, the Ottomans did not care whether their religion, Islam, spread with their expansion or not. Their ultimate goal was to build a kingdom bigger than that of Genghis Khan, their military idol. The Ottomans were very different from other conquerors throughout the history in that they relied greatly on local leadership, not on the sword and fire. The Ottoman Sultan was the absolute owner of the land his troops conquered and could give conquered lands to whomever he pleased. The Ottoman Sultan opted to give the land to local people who proved to be loyal to him, regardless of the recipients' religion. Those possessions were called timar; timar owners and their ownership of the land continued until the mid-nineteenth century. Advocates of Ottoman rule and their proxy rulers, the new timar owners were both Christians and Muslims. However, the fact that Islam was the official religion of the Ottoman Empire did affect the way Ottomans saw themselves in relation to others.

The Ottoman law, based on Islamic Sharia law, did not recognize notions of ethnicity or citizenship, but rather Muslim and non-Muslim subjects. Non-Muslims could live in the Ottoman Empire if they were People of the Book (Muslims, Christians, Jews, and later Zoroastrians, Mandaeans, and Sikhs); polytheists and renegades were not protected. Free non-Muslims were called dhimmis. The Muslim leader would pass specific regulations applying to their protection, taxation, and jurisdiction, and an official declaration that he would protect them called berat (record on appointment). The Muslim leader protected dhimmis from other dhimmis, from Muslims, and from foreigners. The Ottomans would install the local timar owners/leaders to govern the conquered territories in their name and, in return, the local timar owners/leaders would organize the local populace to fight Ottoman wars. The Ottomans used religion as the defining criterion for nationality. They gradually developed a system that defined groups of non-Muslim peoples living in their territories as millet (lit. "nationality") which was actually defined as confessional communities. In legal terms, members of a specific millet community would be tried according to the religious laws of their own religious groups (Canon law). In social terms, the Ottomans formed communities distinct from the Muslim majority. The religion served as the principal organizational and ideological focus of the millets and was treated as such by the authorities. The local timar owners/leaders exerted both religious and civil power over their respective millet. It could be argued that this allowed the millet leaders to feel autonomous: they could, after all, judge

\footnotetext{
${ }^{149}$ Lunt, H. G. (1974), Old Chruch Slavonic Grammar. The Hague: Mouton.

${ }^{150}$ Hadžijahić, M. (1985), Građa o posljednjim ostacima bosančice u nas. Anali Gazi Husrev-begove biblioteke, Sarajevo.

${ }^{151}$ Imber, C. (2002), The Ottoman Empire, 1300-165o: the structure of power. Palgrave Macmillan: London, p. 32.
} 
their millet compatriots as they pleased, without much interference from the Ottomans, political manipulations excluded. The millet leaders had a great interest in preserving Ottoman rule because it endorsed their rule, as well. As a consequence of the 1839 reforms (Tanzimat), the millet communities reorganized to start closely corresponding to today's model of ethnic minorities. ${ }^{1{ }^{2}}$

After a lengthy period of military victories, it can be argued that the Ottomans started having their own worries after the second unsuccessful siege of Vienna (1683) and the subsequent territorial losses and wars with Austria-Hungary and, later, Russia. These Ottoman troubles became known as the "Eastern question" or the question as to which European Great Power would get most of the Ottoman lands once the Empire collapsed under political and economic instability. This "question" became a pressing issue for Europeans of the late eighteenth and throughout the nineteenth-century. In addition to external pressures, the Ottoman Empire was shaking under a series of uprisings and internal liberation movements. The European powers at that time claimed to be concerned about the peoples living under Ottoman rule, most specifically the Christians. As a consequence, the weakening Ottoman Empire was forced to concede to many European requests designed to protect non-Muslims in the Ottoman Empire. After the end of the Russo-Turkish War (1768-1774), the Russians received a right of protectorate over the Orthodox population in the Ottoman Empire. On the other hand, the Sultan also received a right of religious jurisdiction over Muslims who came under non-Muslim authority as a khalif, the ruler of all Muslims. The segmentation of society in Bosnia had begun.

\subsection{The Romantic revolutions}

The nineteenth-century Romantic revolutions are frequently credited with giving birth to phenomena such as nation, national identity, and national language. National identity is a mix of several real and imagined factors, such as: territory, common descent, common history, religion, customs, and traditions, and, especially, language. Normally, the standard or official or literary language is conditioned by the distribution of dialects. Dialect(s) that prevail as standardized are chosen by political or cultural elites. This imposition depends on the concept of the target national community: who they want and who they do not want in their corpus. ${ }^{153}$ The nationalist discourse of the eighteenth-century onwards considers that at the time of the Ottoman conquest, the members of the Bosnian Church - autochthonous Slavic populations of Catholics (according to Croat(ian)s) or of the Orthodox religion (according to Serb(ian)s) - accepted Islam because of various privileges and claimed that tax exemption was the most important one. However, once the contemporary Ottoman tax registers recording the local populace by religion were discovered in the 1950s, it became clear that the process of the acceptance of Islam by local populations was a process that lasted for about 250 years and that it was simultaneous to the process of conversion to Catholicism and Orthodoxy. ${ }^{154}$

The Romantic cum nationalist discourse of the eighteenth-century onwards considers the former members of the Bosnian Church and others who accepted Islam as renegades, actively advocating their inclusion in the ranks of either the Croatian or the Serbian populace by means of conversion. The alternative was expulsion or annihilation. This discourse affected B\&H for many reasons, perhaps the most important of which was that, in addition to remaining on the border between the two major religions, B\&H was also frequently a border region of the Ottoman Empire, which continually expanded and retreated in the Balkans. People in the countries beyond B\&H which the Ottomans conquered accepted Islam at the same pace and for the same reasons as others. However, once the Ottomans retreated, those new Muslims were either converted, killed, or forced to withdraw into B\&H and other areas of the Ottoman Empire. This was nothing

\footnotetext{
${ }^{152}$ Parolin, G. P. (2009), Citizenship in the Arab world: kin, religion and the nation-state. Amsterdam University Press: Amsterdam.

${ }^{153}$ Fletcher, R. (1999), Interview: Converting by the sword. Christian History Issue \#63.

${ }^{154}$ Imamović, M. (2014), Historija države i prava Bosne i Hercegovine. University Press: Sarajevo, p. 125.
} 
unusual as forced conversion to Christianity "was the method of choice among Christian rulers and missionaries. The conversion of much of Europe and of Latin America is unimaginable without the sword." ${ }^{\prime 155}$ The first such large Ottoman retreat occurred between 1683 and 1699 following the defeat of the Ottoman Empire in the Balkans by the Austrians. All the new and settled Muslims from Hungary, Slavonija, Lika, Krbava (presentday Croatia), Dalmatia, and Boka Kotorska (Montenegro) who did not withdraw with the Ottomans were either killed, expelled, or assimilated by forceful conversions to Christianity. Local Christians, those who returned to the freshly liberated territories, or those who gained autonomy or independence from the Ottomans, called local Muslims poturs.

Poturs, or converts to Islam who continued to practice their Christian rituals and were incompletely integrated into the Ottoman-Muslim world, were emblematic of the syncretic-crypto-Christianity that prevailed in Ottoman Bosnia. By the end of the $16^{\text {th }}$ century the number of poturs in Bosnia was marginal and the term potur was primarily used as a pejorative term, referring to the Muslim rural population. ${ }^{15^{6}}$

These poturs would be called "first-generation Muslims" using the contemporary politically correct terminology. The Christians truly despised the poturs and had no reservations about committing their disgust to paper. ${ }^{157}$

Ethnic crimes are preceded by what this study proposes is a philosophy of hate. The following analyses may, from a strictly academic point of view of literary analysis, be inadequately nuanced. However, the purpose of the following sections is not to provide literary analysis, but rather to point out that ethnic crimes do not just happen and that belles lettres can, indeed, be used as instruments of war. Considering that the sources used for this discussion mostly consist of books describing fictional events, the examination of philosophy of hate will start with an explanation of what might have created the murderous mindset that enabled the easy killing of thousands of Bosnian Muslims exclusively because they were Muslims between 1992 and 1995 in the former Yugoslavia. It is important to examine the following works of fiction because they set the stage for ethnic cleansing and genocide. Although underlying ideas of individual states' nationalism blended into collective nationalism under the garb of collectivism (when those states were incorporated into former Yugoslavia between 1918 and 1991), they later turned back into nationalism. This occurred when the former Yugoslavia was about to cease to exist (between the late 1980s and 1991), whereas the target of all propaganda and hate speech remained the same throughout the process: the Muslims in Yugoslavia. Gordon reminds us that speech and atrocity are constant companions on the battlefield where armed actors seek to kill one another and that atrocity speech that results in genocide and crimes against humanity has been criminalized, proposing that advocacy to commit war crimes should be criminalized, too. Gordon proposes seven elements as a test for determining whether hate speech constitutes incitement : (1) purpose, (2) text, (3) context, (4) the relationship between speaker and subject, (5) the channel of communication, (6) temporality, and (7) instrumentality where (6) and (7) apply only in cases where prerecorded speech is disseminated..$^{158}$ The items of this test (1) through (5) are applied in the analysis below.

\footnotetext{
${ }^{155}$ Detrez, R. (2002), Language or nation: what came first? Lexicography and Language Policy in South-Slavic Languages after 1989. Verlag Otto Sagner: Munich, p. 11.

${ }^{156}$ Ágoston, G. and Masters, B. (2009), Encyclopedia of the Ottoman Empire. Facts On File, Inc.: New York, p. 27.

${ }^{157}$ Mirko Žeželj was one of the most prolific authors of didactical books for children in the former Yugoslavia in the form of encyclopedias or textbooks for primary school children. His "Prošlost u slikama" (The past in images) history textbook, says that the Montenegrins were the first to get rid of the Ottomans. "They began their struggle for liberation by the extermination of poturs in the beginning of the XVIIIth century. Poturs were traitors who converted to Islam and served the Turks." Žeželj, M. (1967), Prošlost u slikama. Školska Knjiga: Zagreb, p. 119 .

${ }^{158}$ Gregory S. Gordon (2017), Speech Atrocity Crimes: Foundation, Fragmentation, Fruition. Oxford University Press: Oxford, p. 296.
} 
A poem and a play "The Mountain Wreath" (Gorski vijenac) was on the obligatory elementary, secondary, and college education reading list throughout the former Yugoslavia. Students were obliged to memorize certain sections of the poem and encouraged to draw lessons from it. It was written by the Montenegrin prince-bishop Petar Petrović Njegoš (1813-1851) in 1846. Given that nineteenth-century Montenegro was a loose and semi-independent confederation of warring tribes, the primary purpose of "The Mountain Wreath" was to unify these tribes into a functioning state against the common enemy, namely Muslims and non-Serb Christians, under the leadership of prince-bishop Petar Petrović Njegoš. ${ }^{159}$ "The Mountain Wreath" describes a pseudo-historical event that took place at the end of the seventeenth-century where Montenegrins engaged in "extermination of poturs"160 (istraga poturica) ${ }^{161}{ }^{16}$ Essentially, "The Mountain Wreath" is the story about how Montenegrins killed en masse every living Turk, Turkish convert and Latin (Catholic) living in Montenegro of that time. ${ }^{162}$ Selection for the killings was made according to the religion as a way of determining who was a "Turk" and a "Latin." This poem and play seems to have started the trend of incitement and glorification of violence against the Yugoslavian Muslims. It considers ethnic violence justifiable and necessary because "[o]ur struggle won't come to an end until we or the Turks are exterminated." The perpetrators were motivated to killings because "[m]ay God strike you, loathsome degenerates, why do we need the Turk's faith among us?" This xenophobic description of "others" also contains overpowering tones of Orthodox religious fundamentalism. Although a work of fiction, it is disturbing because of the day that had been chosen for the killings: the Serb Orthodox Christmas. ${ }^{163}$ In that vein, this work is unsettling because Njegoš openly claims that religious holidays, Christmas here, are appropriate for mass killings, asking: "Is today not a festive occasion on which you have gathered Montenegrins to cleanse our land of loathsome infidels?" The description of the aftermath of the alleged operation is equally disturbing: "We put under our sharp sabers all those who did not want to be baptized by us." However, all this was considered an expression of patriotism by the powers that started ruling over the territory of the former Yugoslavia once the Ottomans left B\&H in 1878.

"The Mountain Wreath" will be mentioned at the ICTY in Mrkšić and Popović in passing, Simić, and Karadžić. The defense in Simić had started the questioning of the Prosecution witness about the merits of this poem, but never seemed to have finished the questioning or countering the thesis advanced by the witness that the poem was, indeed, calling for genocide. In that sense, this questioning did not lead to any intellectual culmination on the issue of incitement to genocide and "The Mountain Wreath."164 In his closing argument, Karadžić pointed out that "the Prosecution portrays the Serbs as vagabonds, who are sticking a thorn into a healthy leg in peacetime" offering that "when I quote Njegoš's verses, if you were to put them all in one pot, a broth could not be blended together" to conclude that the prosecution "should have made an effort to get

\footnotetext{
${ }^{159}$ Indeed, these tribes were first unified into the Principality of Montenegro (1852-1910) and then the Kingdom of Montenegro (19101918) ruled by princes-bishops from Petrović family. Montenegro will lose state and ecclesiastical independence to Serbia and get incorporated into the First Yugoslavia in 1918. The last king of Montenegro, Nikola I Petrović, will petition the Paris Conference to return Montenegro its independence but will be completely ignored.

${ }^{160}$ Njegoš uses the word istraga which, if it was used today, would be translated into investigation, but, in the context of the 1800 s Montenegrin language, the archaic meaning of istraga stood for destruction (cf. Skok's dictionary under trag). Skok, P. (1971), Etimologijski rječnik hrvatskoga ili srpskoga jezika. Zagreb: Jugoslovenska akademija znanosti i umjetnosti.

${ }^{161}$ Petrović, Petar II Njegoš, The mountain wreath (James W. Wiles, translator).

${ }^{162}$ Most of the non-Serb Christians were Albanian-speaking Catholics who Njegoš describes as "Arbanasi," rendered into "Albanian" in translation used here.

${ }^{163}$ Unfortunately, killing non-Serbs during religious and national holidays became a tradition. For example, Gavrilo Princip assassinated Archduke Franz Ferdinand of Austria on the Serb Orthodox holiday, St. Vidus Day (Vidovdan), 28 June 1914. St. Vidus is traditionally celebrated as the Memorial Day to Prince Lazar and Serbian Holy Martyrs who fell defending Serbia from the Ottomans during Kosovo Polje battle in 1389 where Serbian principalities lost their independence to Ottomans. The Serb paramilitaries and loyalist troops of the Yugoslav People's Army charged against B\&H cities closest to the Drina river bordering with Serbia, Bijeljina, Zvornik, Vlasenica, and Brčko, on Muslim religious holiday, Ramadan Eid, 4 April 1992. The Second Markale Shelling resulting in 118 victims ( 43 dead, 75 injured) occurred on 28 August 1995 right after the truce coinciding with another great Serb Orthodox religious holiday, Dormition of the Mother of God (the death of Virgin Mary, Velika Gospojina), traditionally commemorating the end of 14-day fast period. The Shelling of Tuzla City Center resulting in 311 victims ( 71 dead, 240 injured) fell on 25 May 1995 celebrating Tito's birthday which was universally celebrated in the former Yugoslavia as a Youth Day (Dan mladosti).

${ }^{164}$ ICTY transcripts, Simić, T. 1197-1198.
} 
[my quoting of Njegoš] interpreted properly, rather than dragging Njegoš through court..165 The reason why Njegoš was mentioned in Karadžić in the first place was because defense witnesses mentioned that Karadžić often quoted the following line from "The Mountain Wreath" to his closest associates: "A timid chief has no business ruling." ${ }^{m 6}$ When it appeared from the prosecution's questioning of those defense witnesses that Karadžić would quote "The Mountain Wreath" and that particular line before making autocratic and heavyhanded decisions in the context of ethnic cleansing and genocide, Karadžić and his defense suggested that the whole poem should be admitted as evidence. "The Mountain Wreath" is not mentioned in the Karadžić Trial Judgment.

Linguistically, the nineteenth-century Serbians and Croatians were trying to define their own language(s) and, along the way, led by the ideas of unification of all South Slavs into one country, tried to concentrate on what is common to the languages these two groups spoke and wrote. They identified various dialects of, essentially, the same language, basing the names of those dialects on the words meaning "what" (šta), namely štokavian (šta/što?), kajkavian (kaj?), and čakavian (ča?), and various dialects within štokavian based on the reflex of Common Slavic, namely ikavian (mliko, milk), ijekavian (mlijeko), and ekavian (mleko). Territorial distribution of these pronunciations and dialects did not correspond to any clear-cut physical or other borders or, for the most part, potential national identities - especially in the case of štokavian. Štokavian was present in all of Serbia, most of B\&H, all of Montenegro, and much of Croatia, and čakavian and kajkavian in parts of Croatia. ${ }^{167}$ Ikavian was pronounced in parts of B\&H and Croatia, ijekavian in parts of $\mathrm{B} \& \mathrm{H}$, Croatia, Montenegro, and Serbia, and ekavian in parts of Serbia. To a certain degree, these nineteenthcentury linguists and language activists were willing to ignore all these differences, but the problem that they faced then, and are facing now, was how to name what is essentially the same language. They named it to correspond to their own newly found identities, calling it "Serbian" in Serbia and "Croatian" in Croatia.

Clearly, the nineteenth-century Herderian ideology of celebrating the relationship between language and nation found fertile ground here. In 1772, German philosopher, theologian, poet, and literary critic Johan Gottfried Herder published his "Treatise on the origin of language." Herder claimed that each nation is defined, in part, by having its own language because "what else is language's whole manner of construction than a mode of development of this creature's spirit, a history of its discoveries?" Herder defines this theory in the "Third natural law on human suitability and obligation to invent language for themselves", claiming that "[j]ust as the whole human species could not possibly remain a single herd, likewise it could not retain a single language either. So there arises a formation of different national languages." Herder recommends "[a] new language in every new world, [a] national language in every nation."168 I have my own language; therefore, I am entitled to a nation which will stretch wherever my language is spoken was the mot du jour of nineteenth-century Serbian and Croatian Romantic idealism. The Herderian ideology remains strong in the former Yugoslavia, as in much of Europe.

Whereas the nineteenth-century Serbian language activists, ${ }^{169}$ led by Vuk Karadžić, struggled to establish language based on people's expression and to replace the existing written language that was based on the church language, Slaveno-Serbian. The main effort of the nineteenth-century Croatians was not to create

\footnotetext{
${ }^{165}$ ICTY transcripts, $\underline{\text { Karadžić, T. } 47846 .}$

${ }^{166}$ ICTY transcripts, Karadžić, T. 46877-4689o.

${ }^{167}$ The Slovene word for what is also kaj and kajkavian is transitional to Slovenian. Since Zagreb was in the center of the kajkavian area, there was a movement to create a single Croato-Slovene language. In the end, however, kajkavian writers went with Vuk and Gaj.

${ }^{168}$ Herder, J.G. (2002), Philosophical Writings (Michael N. Forster, translator). Cambridge University Press: Cambridge, UK, p. 100-150.

${ }^{169}$ This term needs clarifying because it will be used alongside the term linguist until the end of this section. There is a real difference between linguistics and language activism. Linguistics is an academic discipline that analyzes language. For example, that one Slovenian, Miklošič, was a linguist, which is why he was included in the Vienna Agreement, but Vuk and Gaj were nineteenth-century polymaths for whom language was at the center of their concern.
} 
the language of the people, because the literature in the language of the people had co-existed with the literature in the language of the church, Latin, for centuries. The nineteenth-century Croatians wanted to create a sufficiently broad, and regionally unmarked language that would still correspond to the vernacular and would be acceptable to all. In this, they faced more problems than Serbs, since the dialects of Croatia were and are much more diverse. Of the three major divisions mentioned above, two are spoken entirely and only in what is today Croatia. The two main nineteenth-century language reformers were Vuk Karadžić (17871864), a Serbian, and Ljudevit Gaj (1809-1872), the leader of the Illyrian movement in Croatia. Vuk collected contemporary folk songs from the territory of Serbia, $\mathrm{B} \& \mathrm{H}$, Montenegro, and Dalmatia, with special attention to Herzegovina, which he called the "land of the people." As to who were these people in the land of people, Hajdarpašić explains:

Vuk [...] articulat [ed] a broadly assimilationist stance that insisted on the primacy of language, not religion, as the national marker. In regard to the rather large Bosnian Muslim population, he insisted that these "Turks" are in fact "Serbs" because they spoke "Serbian," and spoke it "most purely" and "beautifully" at that. [...] There was, for instance, Vuk's insistence on the proper national name, recognizing Bosnian Muslims as members of the South Slavic national community under the condition that they would eventually "realize and admit that they were not Turks, but Serbs." ${ }^{170}$

The folk songs Vuk collected were either "heroic songs" (junačke pjesme) that were more or less similar to "The Mountain Wreath," about the local populace ambushing, looting, and killing the Ottoman troops, or "women songs" (ženske pjesme), which were about love, nature, longing, etc. Vuk discovered that all these "heroic songs" are in the same language and concluded that all those people living in the territory of Serbia, B\&H, Montenegro, and Dalmatia at that time must have been Serbs. This faulty parallelism led him to conclude "[They are] all Serbs everywhere" (Srbi svi i svuda). Hajdarpašić provides the following analysis of Vuk's work and affinities:

[Vuk's] subsequent publications, including the second revised edition of the Serbian Dictionary (1852), continued to make the case for the superiority of a specifically Herzegovinian dialect and spirit. This campaign allowed Vuk to revisit (in 1845) the recurring question about the proper location of the exemplary national attributes: 'Now that I have shown where Serbian is spoken the worst, anyone can ask me: But where is it spoken the best? Here is the answer to that. Serbian is spoken in the purest and most correct way in Herzegovina and in Bosnia. ${ }^{171}$

In reality, what Vuk discovered wherever he went was the ijekavian or ikavian version of the štokavian dialect. Hajdarpašić concludes:

What makes [Vuk's] dedication to Herzegovina and Bosnia remarkable — and significant for the forging of new understandings of nationhood-is that he never visited or traveled through this "land of the people." This obvious fact of Vuk's work has become strangely invisible and curiously forgotten in the subsequent assessments of his career. Indeed, it is not even mentioned in any English-language studies. ${ }^{172}$

\footnotetext{
${ }^{170}$ Hajdarpašić, E. (2015), Whose Bosnia? Nationalism and political imagination in the Balkans 1840-1914. Cornell University Press: Ithaca and London, p. 32-33.

${ }^{171}$ Ibid, p. 23-24.

${ }^{172}$ Ibid, p. 35 .
} 
Eventually, two representatives of the nineteenth-century Serbians, five representatives of the nineteenthcentury Croatians, and one nineteenth-century Slovene met up in Vienna in 1850 to agree on a common literary language for Serbs and Croats. They agreed that the new common language should be the ijekavian version of the štokavian dialect. Croatians preferred this to all the existing regional versions (also because their most famous writer at the time wrote in that language) and Vuk, who represented the Serbians, preferred it because he considered it a "pure" language of Eastern Herzegovina where his own ancestors hailed from. Vuk was born in Tršić, which is in precisely in that part of Serbia where Herzegovinian ijekavian štokavian was spoken. In Serbia, Vuk proposed a single language, both in written and spoken form, which would also unite the Serbs over a broad area. Finally, Vuk reformed the Serbian Cyrillic and Ljudevit Gaj reformed the Croatian Latin script. However, not all Croatians or Serbians agreed with them, albeit for different reasons, and the Realpolitik of all their efforts very much differed. As to B\&H, Serbian and Croatian language activists cum political activists and political activists cum language activists and artists of the Romantic revolutions onwards engaged in a series of campaigns. These appropriated, mystified and, ultimately, misunderstood B\&H and its peoples to the point that it could be understood from Hajdarpašić's study into these issues that they created their own "B\&Hisms", fashioned after contemporary theories that Said would later label "Orientalism.. ${ }^{173}$ In theory and practice, Serbians called this language Serbian, and Croatians called it Croatian. On a popular level, the fact of Serbian ekavian or Croatian ijekavian speech became strongly associated with national, ethnic, and political identity. ${ }^{174}$ Naturally, the language became a political statement in the territories that became Yugoslavia even before its peoples united.

Obviously, in all those discussions about a common language, a common identity, and a common new country, no one bothered to ask the peoples of B\&H anything. They were aware that they were being ignored and were largely annoyed by Serbian and Croatian assertions of linguistic, ideological, and political continuity, uniqueness, and authority. People in $\mathrm{B} \& \mathrm{H}$ at that time considered that a small group of linguists and writers got together in Vienna and decided that whoever lived in the territory of what later became Yugoslavia was a South Slav speaking one language but were vexed that the group did not bother to inquire what they had to say or contribute in that regard. Although aware of these Croatian and Serbian expansionist trends, it seems the peoples of B\&H did not feel like they had to refute systematically, extensively, and constantly something which, to them, was self-evident: that discussions about the common language in what became Yugoslavia ignored B\&H's unique identity and language. Their annoyance could be best portrayed by the following excerpt from Fra Antun Knežević's rebuttal published in 1870 in "Bosanski prijatelj” (Bosnian Friend), the oldest B\&H magazine for culture and language:

Some of our neighbors are enraged that we proudly rejoice in our ancient name, language, and customs, and that we wouldn't embrace their labels for nationality and language for the life of us. These attacks are launched against us in concerted action by our neighbors whom we shall call Jovo [typical Serbian name, BF] and Ivo [typical Croatian name, BF], for better understanding. Still, each of them asks something different of us, because they cannot - for the life of them - agree between themselves. Friend Jovo tells us to take his label, whereas friend Ivo says: "Jok [Ottoman Turkish for "Nope," BF], Bosniak, you are mine and you have to embrace my label." Pull us here, pull us there, without any input from us. Our friends wish to break us apart claiming love, but they are motivated by their own endless quarrels; if we were not already aware of it all since long ago, we would find ourselves caught marveling at their wonders. But, as things stand, we ask our friends of letters and pen: why are you fighting for our sake when you know very well that the Bosniak is proud of the language and the name that is his own, faithfully holding to traditions and memories of his grandparents, from antiquity. The celebrated tarih [Ottoman Turkish for "history," BF] of our beloved fatherland reminds us of those times when our local nobility clearly and openly expressed their nationality, calling themselves a proud and a heroic name Bosniak every chance they got. Looking at many a document penned by the local writers from the past

\footnotetext{
${ }^{173}$ Ibid.

${ }^{174}$ Alexander, R. (2013), Language and identity: the faith of Serbo-Croatian. Entangled histories of the Balkans, Vol. 1: National ideologies and language policies. Koninklijke Brill NV: Leiden, p. 349-353.
} 
centuries who unfailingly mention our correct national name Bosniak we find that to be the reason why we, their grateful and true descendants, call ourselves by the glorious name Bosniak. And from that we cannot and dare not depart; we shall keep this name loyally and at all times. We are proud that it is precisely our language of our fatherland that is taken as the basis for the literary language of our neighbors the Serbs and the Croats. Renowned linguists Vuk Karadžić, Daničić, and Ljudevit Gaj, too, passed on our beautiful language to the literatures of the both said nations, calling it as they pleased, one "Serbian" and the other "Croatian," failing to mention us anywhere. We certainly have a right to rejoice that our friends Ivo and Jovo use our language in their literatures, but that is the least they should recognize. We cannot understand why they want the label that they stuck on our language at their will and without our permission imposed on us no matter what, forbidding us to name our language of our people in our own home. It is as if someone else would try to name your own child. We do not condone such treatment and such a tendency and we shall not make kail [Ottoman Turkish for "to consent," BF]. Well done to both our friends, Serb and Croat alike. We do not despise their peoples, we do not hold any grudges, we will never deny that we are of the Yugoslav tribe, but we only want to show clearly to everyone that we are, firstly, Bosniaks of illustrious lineage. We shall always be Bosniaks like our great-grandparents who have been and nothing else. Therefore, take a good look around, our brothers residing and living in B\&H for many centuries, still wishing you were Serbs or Croats. May you study this and think hard about it [BF's translation]. ${ }^{175}$

Sadly, even 148 years after this text was written, the same message could be sent today "to our brothers residing and living in B\&H for many centuries, still wishing [they] were Serbs or Croats".

Obviously, identity is a relational concept that depends on self-identification and social ascription. We are what we think we are $n o t .{ }^{176}$ Since they very clearly proclaimed they were not Serbians or Croatians, what else did the peoples of $\mathrm{B} \& \mathrm{H}$ at that time think they were not? Contemporary B\&H linguists point out that the arrival of Ottomans in the Balkans did lead to Islamization, but that this did not, in any way, take the Islamized Slavs out of their language communities because their Islamization did not imply their deslavicization. The peoples of $\mathrm{B} \& \mathrm{H}$ who accepted Islam never likened themselves to Turks. ${ }^{177}$ On the contrary, those who accepted Islam called people from Turkey Turkards (Turkuše), which has the same pejorative sting as the potur when used to describe "Turks," meaning "converts to Islam." Skender Kulenović and his "Ponornica" (The Lost River) dated 1977 describe B\&H during the Austro-Hungarian occupation at the time when the Ottoman past was still fresh in the memory of its peoples. The peoples of B\&H at that time were struggling to reconcile their Ottoman worldview with their Austro-Hungarian Weltanschauung as they increasingly found themselves sailing down a philosophical lost river.

“Turkušas," says Husrev Bey, "must remember this well!" - uncle resumed as though never hearing father's question. "Ogling my daughter - if they could only get their hands on our beauties! I won't give her to them even if their whole house was made of precious stones! I'll give her to an Armenian, to a Georgian; she definitely won't be laying in the same bed with a Turkuša. Spineless people! Ever since the Iron Pole sent them on their way from Vienna, they've become spineless; they uprooted me from my own, made a refugee of me in here. I'll lay down in their ground like it was a poison! Euw!" he said.

"I know very well what Turkuša means, I heard it mentioned a hundred times in my family: it's an expression of extreme disgust toward the representatives of the Empire that is no more. Even our man, if he is calculated

\footnotetext{
${ }^{175}$ Fra Antun Knežević, Bosanski prijatelj. Duh Bosne (2012).

${ }^{176}$ Barker, C. and Galasin, A.D. (2011), Cultural studies and discourse analysis. SAGE: London, p. 123.

${ }^{177}$ Pečo, A. (2001), Muslimanski narodni govori i standardizacija našeg jezika. Anali Gazi Husrev-begove biblioteke XIX-XX, Sarajevo, p. 243-246.
} 
or if he is spineless or unaccountable, is called Turkuša. Even women are disgusted by such a man. That should tell you enough." [BF's translation]. ${ }^{178}$

Linguistically, the Ottomans allowed for the preservation of both the Bosnian identity and language by integrating the full country with its original name and borders into the Ottoman Empire as one of its constituting provinces. The Bosnian language was called as such and was widely spoken in the Ottoman court, becoming the second diplomatic and official language. This was because many Ottoman officials and Janissaries were originally from $\mathrm{B} \& \mathrm{H}$, recruited through the Devsirme process (collection of males between the ages of 8 and 18). ${ }^{179}$ An Ottoman traveler touring the Balkans, Evliya Çelebi, wrote that the local populations "speak Bosnian, Turkish, Serbian, Latin, Croatian, and Bulgarian" and that they are called Bosniaks, but prefer it "when one calls them Bosnians." ${ }^{180}$ The difference between the two terms stems from the use of two different names for a single term: Ottoman Turkish Boşnak (Bosniak) and Arabic Bosnewi (Bosnian) vs preferred Bošnjan. Arabic script was the official script that was used to write the official language of the Ottoman Empire, Ottoman Turkish. However, the peoples of $\mathrm{B} \& \mathrm{H}$, ostensibly trying to differentiate the original population from the newcomers and the Ottomans, in general, adapted an Arabic script and called it Arebica. Arebica, Bosnian Arabic script, was the Arabic script used to transcribe the Bosnian language. It was used in everyday communications and in literature, thus preserving the language. The literature written using Arebica is called Aljamiado literature. Aljamiado literature is mostly religious and didactical literature that became popular from the fifteenth-century onwards. The poet and writer Muhamed Hevaji Uskufi Bosnevi assembled the first dictionary of Bosnian and Turkish language in $1631 .{ }^{181}$ Aljamiado literature flourished until the end of the nineteenth-century. The peoples of B\&H started experiencing a true renaissance in the nineteenth-century, witnessed by a host of magazines promoting B\&H national interests: the abovementioned "Bosanski prijatelj" from 185 o started by Jukić, "Bosanski vjestnik" (Bosnian Herald) in 1866, "Bosna” in 1866, "Sarajevski cvjetnik" (Sarajevo Flower) in 1868. The provincial press (vilajetska štamparija) opened in 1866.

Contemporary $\mathrm{B} \& \mathrm{H}$ linguists point out that the nineteenth-century and the later standardization of the Serbo-Croatian language between the Serbians and the Croatians did not at all move to credit the popular speech in $\mathrm{B} \& \mathrm{H}$ for any of its contributions to the language that was claimed to be common to all. These contributions to the Serbo-Croatian language by the Bosnian language could be best seen in:

- retention of the phoneme $h$ (Bosnian literary orah, dođoh, pođoh vs. the older Serbo-Croatian literary ora (I was plowing), dođo (I arrived), pođo (I set off to)),

- retention of consonant clusters dje i tje (Bosnian literary djevojka vs. the older Serbo-Croatian literary đevojka, the Bosnian literary htjelo vs. the Serbo-Croatian literary hćelo or šćelo), and

- retention of the consonant cluster $j r$ in words originating from Oriental languages (Bosnian literary Bajram, bajrak vs. the Serbo-Croatian literary barjam, barjak).

Another contribution to the study of language used as political statement can be found in a very interesting example of the Serbo-Croatian linguists who seemed to be very much against the letter "h." This letter and a sound is widely associated with Muslims and Islam as there were three " $h$ " letters in the Ottoman Turkish alphabet ( $ح-$ ha, $\dot{\tau}-$ hı and he - ॰). Isaković gives a very interesting, almost political evolution of the word

\footnotetext{
${ }^{178}$ Kulenović, S. (1977), Ponornica (Lost River). Nolit: Beograd.

${ }^{179}$ Božič, I., Ekmečić, M. and Dedijer, V. (1970), Istorija Jugoslavije. Prosveta: Beograd, p. 141.

${ }^{180}$ Çelebi, E. (1979), Putopis (Hazim Šabanović, translator). Veselin Masleša: Sarajevo, p. 116-12o.

${ }^{181}$ Alvestad, S. S. (2016), The Uppsala Manuscript of Muhammed Hevā’̄üskūfı̀ Bosnevī's Maḳbūl-i 'ārif (1631) from a Turcological Perspective: Transliteration, Transcription, and an English Translation, Abhandlungen für die Kunde des Morgenlandes, Band 105, Harrassowitz Verlag: Wiesbaden.
} 
"aždaha" (dragon), which has a Turkish origin. This is how this word has been recorded in the "Dictionary of the Serbo-Croatian language" by the author Aleksandar Belić:

- aždaha (aždaja) in 1923,

- aždaha=aždaja in 1934,

- aždaja=aždaha in 1950, and, finally,

- $\quad$ aždaha, no see $a \check{d} d a j a$, in $1960 .{ }^{182}$

While some contemporary B\&H linguists blame the trend of general undecidedness among the Bosniak population that was also reflected in the language ${ }^{183}$ others point out that the $\mathrm{B} \& \mathrm{H}$ populations, especially the Muslims, had no reason to agree to the existing linguistic and literary agreements between Croatians, Serbians, and that one Slovene because they were not included in the agreement and its conclusions had no bearing on them. However, not inviting the peoples of $\mathrm{B} \& \mathrm{H}$ to get involved in literary agreements led to a lack of recognition of the Bosnian language, the un-naming of the Bosnian nation, and thus to the entire "Bosnian Muslims issue," by inference. ${ }^{184}$

Expansionism, sweeping statements, and monopolism did not stop at language. Politically, Ilija Garašanin (1812-1874) was the first Serbian politician with any political plans. His "Načertanije" (The Draft) from 1844 offered a political program and platform for the newly semi-independent (autonomous) Principality of Serbia at that time. The idea of Yugoslavia, the country that would unify all Southern Slavs, was nascent. However, Garašanin had a different idea. He started his exposé with an affirmation that "the bustle and the welter among the Slavs has already begun and shall, indeed, never cease," warning that "the facts and foundations of such a background command the Serbian contemporary politics to un-limit itself from its present boundaries and to nestle all the Serbian peoples around it, instead." Garašanin considered Serbia to be very well entitled to nestle all the Serbian peoples around it because "both the same origins and the single language indicate a continuity and a great future [of the new Serbian state in the south]." He believed the process of nestling thus implied would be completely painless because "the Serbian peoples are so good that anything can be achieved with us as long as it is reasonable." After the successful completion of this unification "we, the Serbs, will face the world as true descendants of our great forefathers who did not do anything novel, but rather continued our ancestry." Garašanin concludes:

In short, Serbia must endeavor to take stone by stone from the construction of the Turkish state and use this good material to rebuild and resurrect a great new Serbian state on the old and good foundations of the ancient Serbian Empire [BF's translation]. ${ }^{185}$

Garašanin went on to summarize political reality around him, embarking on a series of recommendations to approach the peoples of surrounding and distant countries with Serb minorities with the same idea.

In practical terms, none of this remained at the level of platitudes: the annexation of countries or regions bordering on Serbia, such as B\&H, Croatia, Montenegro, Kosovo, and Macedonia was successful because these countries were incorporated into a single state with Serbia after 1918, for the most part, against

\footnotetext{
${ }^{182}$ Isaković, A. (2001), Vid bosanskog jezika. Anali Gazi Husrev-begove biblioteke XIX-XX, Sarajevo, p. 306.

${ }^{183}$ Kasumović, A. (2001), Bosanskohercegovački muslimani i njihov jezik. Anali Gazi Husrev-begove biblioteke XIX-XX, Sarajevo, p. 255 .

${ }^{184}$ Isaković, A. (2001), Vid bosanskog jezika. Anali Gazi Husrev-begove biblioteke XIX-XX, Sarajevo, p. 305.

${ }^{185}$ Garašanin, I. (1844), Načertanije.
} 
their will, except Croatia. Also, Serbia started a war with Bulgaria in 1885 and 1913 to assimilate freshly "liberated" territories from the Ottomans (parts of what became Serbia and Macedonia, respectively). Judah clarifies that "Načertanije" was, until 1906, a secret document, but it was the guiding light of foreign policy until at least 1914, if not until the founding of the Kingdom of the Serbs, Croats, and Slovenes in 1918, later renamed Yugoslavia. ${ }^{186}$ "Načertanije" is full of rhetoric and reasoning that could not be said to be an original Serbian invention, but rather contemporary European discourse at that time, with an emphasis on buzzwords from the Romantic revolutions. In addition to lacking continuity for its historical plans, "Načertanije" lacked a firm grounding in reality as it was entirely based on a false sense of entitlement. This view, of course, is found in every European nation-state's attempt to "resurrect" an imagined maximal medieval territorial extent, e.g. the so-called Third Reich of the German people, to name just one example. At the level of language of political philosophy, this work is full of words, expressions, and mentalities that still dominate contemporary Serb(ian) discourse, including the way the Serbs and Serbians see themselves in isolation, together, and in relation to others: rich and illustrious Serb history (bogata i slavna srpska istorija), [Serbia has a] holy historical right ([Srbija ima] sveto pravo istoričesko), [Serbs are] true patriots ([Srbi su] prave patrijote), let this be a sign and a warning for Serbia and let Serbia not forget that (neka ovo za Srbiju bude znak i opomena i neka ona ne zaboravi), [Serbia is] the only one that can ([Srbija] jedina može), [Serbia has an] obligation to incessantly ([Srbija je] dužna [da] neprestano), [Serbia is a] natural patron ([Srbijaje] prirodna pokroviteljica), [Serbia is an] unwilling tool ([Srbijaje] bezvoljno orudije), etc.

"Načertanije" will be mentioned at the ICTY in the context of Milošević and Šešelj. Milošević argued that looking for the roots of Serbian nationalism in "Načertanije" is methodologically incorrect because

the projection of one historical situation from the end of one century to the first half of another century is a methodological mistake in the science of history [and] many Serbian, Croatian and foreign historians who also wrote about Načertanije [...] did not consider it to be a great Serbian program [but] [...], rather, a Yugoslav program whose objective it was to create a great Yugoslav state. ${ }^{187}$

Neither the word Yugoslavia nor any of its derivatives have been explicitly or implicitly mentioned in "Načertanije" in a way that would even remotely suggest that "Načertanije" was a pan-Yugoslav project. As a word and a concept, "Yugoslavia" was in use since the late eighteenth-century and there was no impediment for Garašanin to use it or refer to it, especially in the "secret" document, if he wanted to do so. Instead, he geared "Načertanije" very straightforwardly and narrowly into the direction of the creation of "the new Serbian state in the South" (nova srbska država na jugu). Šešelj did not deny any of the commonly accepted claims about "Načertanije", but advanced arguments that it was not "the first" political platform for the unification of all Serbian lands, attempting to discredit an expert witness because he had not read the entire oeuvre on the issue. ${ }^{188}$ "Načertanije" was not mentioned at all in the Šešelj Trial Judgment.

\subsection{The Austro-Hungarians}

Alerted by the rise of nationalism in the territory that would become Yugoslavia with the aim of unifying all South Slavs in a single country, the Austro-Hungarian Empire took issue with the poor agrarian situation in B\&H as a proxy solution for the non-creation of a large Slavic country in that territory. In 1840, the Ottomans allowed an Austro-Hungarian protectorate over Bosnian Catholics. A new series of uprisings started in $\mathrm{B} \& \mathrm{H}$ with the aim of abolishing the existing agrarian system and creating a freehold peasantry. Newly independent Serbia and Montenegro, joined by Austria and Russia, took an active part in caring about what happened to $\mathrm{B} \& \mathrm{H}$, and, very soon, the uprising in $\mathrm{B} \& \mathrm{H}$ turned into a struggle between these four countries on whether to

\footnotetext{
${ }^{186}$ Judah, T. (1997), The Serbs: The Sweet and Rotten Smell of History. Daedalus, 126, p. 23-45.

${ }^{187}$ ICTY transcripts, Milošević, T. 24867-24910.

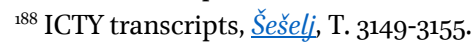


divide B\&H or to unify it with Serbia and Montenegro. ${ }^{189}$ On 4 July 1878 , in the wake of a Russo-Turkish war, six countries on the one side, and the Ottoman Empire on the other, met to decide the fate of B\&H, Bulgaria, Serbia, and Montenegro in Berlin. Bulgaria, Serbia, and Montenegro gained independence from the Ottoman Empire and the Berlin Treaty gave a mandate to the Austro-Hungarian Empire to occupy B\&H. ${ }^{19 \circ}$ The Ottomans agreed to this.

The peoples of $\mathrm{B} \& \mathrm{H}$ were outraged and took up arms, declaring "Bosnia is [our] vatan [Ottoman Turkish for "homeland," BF] and the Sultan may give away Istanbul, but not Bosnia." The invading troops issued a proclamation on behalf of the Austro-Hungarian Emperor, highlighting the fact that the European powers and the Sultan himself had decided to put the inhabitants of B\&H "under protection of his powerful friend the king and the emperor" promising all in $\mathrm{B} \& \mathrm{H}$, regardless of their religion, legal equality and protection of life, religion, property, and the right to use their own language. Local B\&H commander, Smail Haki Selmanović, issued his own proclamation to all in B\&H, namely "Islams, Christians, and Latins," to "jointly resist the enemy" without any reference to the Sultan. This could be taken to mean that he was trying to take this opportunity to gain independence for $\mathrm{B} \& \mathrm{H}$. The fighting lasted for about three months and there were about 6 o large battles and skirmishes, resulting in about 6,00o Austro-Hungarian losses. ${ }^{191}$

The official language of B\&H under the Austro-Hungarians was called Landessprache (zemaljskijezik, language of the Land), later to be renamed Bosnische Sprache (bosanskijezik, Bosnian language). The peoples of B\&H were collectively called "Bosniaks" and the Austro-Hungarians divided them into Muslims, Catholics, and Orthodox. ${ }^{192}$ Benjamin Kallay became the Austro-Hungarian governor of B\&H. Kallay's politics in B\&H were designed to strengthen $\mathrm{B} \& \mathrm{H}$ specificity and nationality under the inter-confessional 'Bosniakhood', i.e. whoever lived in B\&H should be called Bosniak, regardless of that person's religion. Croatian and Serbian circles were confused and outraged: they have been ignoring Bosniaks and, ostensibly, did not know what to do with them, other than try to assimilate them into their ranks. Naturally, they were scandalized by the favorable treatment $\mathrm{B} \& \mathrm{H}$ received from the Austro-Hungarian authorities. Croatians had already been in the Austro-Hungarian Empire for some time, but no Austro-Hungarian authorities promoted Croatian uniqueness and Croatian unity. On the contrary, the Croats had been subjected to a policy of Magyarization (making the populace more Hungarian-like) after $1848{ }^{193}$ On the other hand, Serbian foreign policy-makers wondered what to do with Muslims and how to accept that they were a majority anywhere or at least a factor with which to be reckoned. On the insistence of certain Serbian circles, in explanation of such a name, Benjamin Kallay, the Austro-Hungarian governor of $\mathrm{B} \& \mathrm{H}$ said the following:

The name 'Bosnian' was not invented, even less imported. This is the name of this Land and it was adopted as such by this government [BF's translation]. ${ }^{194}$

The Austro-Hungarian government issued several further orders regulating the language in schools as: Bosnian, language of the Land (Croatian or Serbian), Bosnian language of the Land (bosanskizemaljskijezik), and Bosnian or Serbo-Croatian language of the Land (bosanski ili srpskohrvatski zemaljskijezik) with equal representations in Cyrillic and Latin script. In 1884, a government commission started the project of writing the grammar of the Bosnian language with single phonetic rules which was, finally, published in 189o, and applied

\footnotetext{
${ }^{189}$ Imamović, M. (2014), Historija države i prava Bosne i Hercegovine. University Press: Sarajevo, p. 191-196.

${ }^{190}$ Treaty of Berlin (1878), Article 25.

${ }^{191}$ Imamović, M. (2014), Historija države i prava Bosne i Hercegovine. University Press: Sarajevo, p. 206.

${ }^{192}$ Joint Ministry of Finance, Decree 6687 (1880), Arhiv Bosne i Hercegovine: Sarajevo.

${ }^{193}$ Kamusella, T. (2009), The Politics of Language and Nationalism in Modern Central Europe. Palgrave Macmillan: London.

${ }^{194}$ Novi Horizonti, Profesor Amira Turbić-Handžić: Ako bosanski jezik nije postojao, zašto je Burian onda donio odluku o ukidanju

bosanskogjezika:(2015).
} 
in official documents and education. After Kallay's death in 1903, Stephan Burian von Rajecz became the new governor and protector of B\&H. On 4 October 1907, von Rajecz delivered the following order:

The Government of the Land hereby orders that the name Bosnian hitherto used for the language of the Land shall be purged entirely from official traffic and documents of the government, offices and institutes of the Land, including administration of the land registry, and shall be replaced by the name Serbo-Croatian language as an official language of the Land without any exception [BF's translation]. ${ }^{195}$

This put an end to the Austro-Hungarian sponsored policy of 'Bosniakhood'. The Government of the Land issued a separate decision on 29 November 1907 allowing the Bosnian Muslims to call their language Bosnian in their institutions. Bosnian Muslims wanted the equal use of Arebica, alongside Latin and Cyrillic script on the road signs and administration, because Arebica was the only source of literacy for most of them. In addition, Arebica was a script used by the Muslim religious institutions, magazines, and in about 500,000 different books. ${ }^{196}$ But, the wish to use Arebica was not granted, making most Muslims throughout the former Yugoslavia functionally illiterate. ${ }^{197}$ The term "Bosnian" or "Bosniak" as a designation of a citizen of B\&H was used only to denote Bosnian Muslims.

B\&H was annexed to Austro-Hungary on 6 October 1908. In 1912, the Government of the Land started the revision of Serbo-Croatian orthography, delivered a Law on the official language, and the language to be used in schools in B\&H, establishing Serbo-Croatian as the official language and the equality of Cyrillic and Latin script. When the First World War started in 1914, the Government of the Land issued an order that communication with the main government (Austro-Hungary) was to be done in German or Hungarian, whereas communication with the Government of the Land was to be done in Serbo-Croatian: should the respondent address the government in Cyrillic, he should receive an answer in Cyrillic, otherwise Latin script would be used. In 1915, the Government of the Land issued an order banning the use of Cyrillic script except within the Serbian Orthodox church. ${ }^{198}$

\subsection{The First Yugoslavia}

The idea of Yugoslavia is said to stem from ethnic and language similarities between the South Slavs, but, in reality, these diluted similarities were all they had in common with each other. Once the country was established, all differences were set aside for a while and interpreted as anomalies within the existing corpus of Serbians, Croatians, and Slovenes, who were the only constitutionally recognized peoples. Language- and identity-wise, some profited and some greatly lost due to the unification of South Slavs after the First World War. The Bosnian language was not recognized as one of the official languages of the new country and Bosnian identity was likened to that of Ottoman Turks. Montenegro lost its independence and subjugated its

\footnotetext{
${ }^{195}$ Joint Ministry of Finance, Decree 168539 (1907), Arhiv Bosne i Hercegovine: Sarajevo.

${ }^{196}$ Rizvić, M. (1996), Bosna i Bošnjaci: jezik i pismo. KDB Preporod: Sarajevo, p. 6 o.

${ }^{197}$ There is very little written locally and by international scholars about the loss of Arebica in the former Yugoslavia. Noting the lack of relevant research, here a parallel must be drawn to Atatürk and his language reforms as a backdrop to nationalist movements in 1928 Turkey. The goal of Atatürk's language reforms was to produce a language that was more Turkish and less Arabic or Persian, which were the major features of Ottoman Turkish. Atatürk's language reforms called for a drastic alteration of both the written and the spoken language, based on two major strategies: adopting a new alphabet and purifying the vocabulary. Abolishing the Ottoman script, Atatürk took power away from the religious community because clerics, and most literate people, became illiterate overnight, and by adopting the grammatical rules of the German language as a standard for the modern Turkish language, he sent a signal to all that Turkey was starting to look for a future in the West. With no national leader, the abolition of Arebica led to the disempowerment of Muslims in the former Yugoslavia.

${ }_{198}$ Šipka, M. (1999), Standardni jezik u Bosni i Hercegovini u dokumentima jezičke politike. Open Society Institute: Budapest, p. 5465.
} 
identity to the Serbian one. Macedonia, which was known as Old Serbia, was annexed in $1913^{199}$ and was subjected to policies of intense Serbianization in terms of politics, language, and identity. ${ }^{200}$ These policies were not particularly successful. Rather, they created deep resentments between the ethnicities living there. The First World War started in the summer 1914. On 7 December 1914, the People's Assembly of Serbia adopted a declaration highlighting the argument that they were fighting the war not only to preserve their own independence, but also to liberate all "the un-free brothers: Serbs, Croats, and Slovenes. ${ }^{201}$ Delegations from Serbia and Croatia met several times during the First World War to discuss the postbellum establishment and functioning of the future joint state. They agreed on minor issues (equality of religion and script, consolidation of the calendar, the state flag and the coat of arms, the right to vote, etc.), but did not agree on the internal administration of the country. On 29 October 1918, the Croatian Parliament announced its separation from Austria-Hungary and the creation of a new independent State of Slovenes, Croats, and Serbs, which also included B\&H. The precursor to the Kingdom of Yugoslavia, the State of Slovenes, Croats, and Serbs, issued a law on the official language and script in 1918 establishing Serbian or Croatian as the official languages in B\&H and the equality of the Cyrillic and Latin script. ${ }^{202}$ Finally, on 1 December 1918, the Kingdom of the Serbs, Croats, and Slovenes, the first Yugoslavia, was created.

The then ruling ideology was based on the idea of national unitarism and did not recognize any nations in the Constitution, but only three "tribes," the Serbs, the Croats, and the Slovenes, as parts of "a single Yugoslav people." They also recognized minorities of "a different race and language." The constitution was not delivered until 1921. Pursuant to this constitution, the full name of the country was the Kingdom of the Serbs, Croats, and Slovenes and the official language Serbo-Croatian-Slovene. The minorities of "a different race and language" were to be "accorded elementary education in their mother tongue according to rules to be set by a separate law." ${ }^{203}$ The 1929 Kingdom of the Serbs, Croats, and Slovenes Law on people's schools did not set these minority rights as a matter of principle, but as an issue to be resolved from case to case. ${ }^{204} \mathrm{Im}$ plementation of this Law greatly depended on international relations between the Kingdom and the home countries of these minorities of "a different race and language." Elementary schools for minorities were reserved for German, Hungarian, and Romanian minorities. Bosnian Muslims, or rather members of the Islamic religious community of the Kingdom of Yugoslavia, were not considered a minority; they were not considered to be members of the three original "tribes" that constitute Yugoslavia, or as minorities of "a different race and language", either. ${ }^{205}$

On 2 September 1929, the king delivered the Orthographic Instructions for all elementary, high and professional schools to regulate the two ways of writing, ijekavian and ekavian, because "often it happens that the teachers do not know which way of writing is better or which way of writing to practice" establishing the principle that "two way of writing should be avoided as much as possible." Teachers practicing in areas with two ways of writing were instructed to opt for one or the other. ${ }^{206}$ This meant that the authorities in the country were instructed to choose either the Serbian or the Croatian version which, effectively, killed the overlapping areas and created sharp boundaries. This is a typical example of a state octroyed language. After the assassination of a deputy in the Parliament, in 1929, the King Aleksandar Karađorđević abolished the 1921 Constitution and the Parliament and started a dictatorship. The king delivered a new Constitution and

\footnotetext{
${ }^{199}$ The Serbian Gazette LXXX/257 (1913), Decision to enact the following provisions of the Constitution of the Kingdom of Serbia of 5 June 1903 in the annexed Old Serbia.

${ }^{200}$ Grubić, M. (2013), Makedonska drama između dva rata. Croatica et Slavica Iadertina IX/I, p. 315-331.

${ }^{201}$ Niška deklaracija: ratni ciljevi Srbije (1914).

${ }^{202}$ Journal of Laws and Orders for Bosnia and Herzegovina, LI/1918 (1918): The law on official language and script, Article 1.

${ }^{203}$ Constitution of the Kingdom of the Serbs, Croats, and Slovenes (1921), Articles 1, 3 and 16.

${ }^{204}$ The Kingdom of Yugoslavia, Official Gazette CXIX/289 (1929), The Law on People's Schools.

${ }^{205}$ The Kingdom of Yugoslavia, Official Gazette LXIII/167 (1930), Constitution of the Islamic Religious Community of the Kingdom of Yugoslavia.

${ }^{206}$ The Kingdom of the Serbs, the Croats and the Slovenes, Official Gazette LXXXI/204 (1929), Orthographic Instructions for all elementary, high, and professional schools.
} 
brought a series of new laws changing the name of the country to "the Kingdom of Yugoslavia" and establishing new administrative borders in the country based on the names of the major rivers. ${ }^{207}$ This was the first time in history that B\&H found itself anywhere but inside its historical borders, as it was divided between the provinces (banovinas) of Drina (seat in Sarajevo), Vrbas (seat in Banja Luka), Primorje (Littoral) (seat in Split), and Zeta (seat in Cetinje), two of which were outside B\&H. Effectively, this unhappy marriage between the Serbs, the Croats, and the Slovenes, and the ensuing Serbian dictatorship forced the opposition, communists, and separatists, into illegality. The king was killed by a Macedonian separatist on 9 November 1934. The former deputy leader of the Croatian Pure Party of Rights and the future leader of the Croatian Nazi puppet state, the Independent State of Croatia, Ante Pavelić, went abroad and started organizing his Ustaša troops. ${ }^{208}$

\subsection{The Second World War}

The passive-aggressive conflict between the Serbs and the Croats, which was characteristic of the First Yugoslavia, culminated in the most violent way during the Second World War. ${ }^{209}$ The showdown between these two peoples was so extreme that contemporaries often reported that even Nazis were shocked. The lines between Croatian and Serbian Nazism and anti-Nazism are still a controversial topic among contemporary Serbians and Croatians, as both had openly Nazi elements in their ranks throughout the Second World War.

Under the occupation, the Nazis hacked up the territory of Serbia and reduced it to the territory of central Serbia, northern Kosovo, and Banat, which were part of the administration and authority of local Volksdeutsche. Under the system of Nazi military administration set up in Serbia, Serbian extremists started collaborating with Nazis and delivered a series of laws outlawing Jews, Roma, and other undesirables. There are certain suggestions that Nazis paid special attention to the re-education of the Serbian people by pressing on them the unique Serbian identity, glorious past, and patriarchal values, encouraging them to learn from the mistakes their government made after $1918 .{ }^{210}$ Serbian extremists engaged in a macabre en masse extermination of their own people who had defected to the communists in a series of reprisals for killing Nazi troops (10o Serbs for one killed Wehrmacht soldier and 50 Serbs for one wounded). The presence of a large number of Serb(ian) collaborators, the Četniks, cost the Yugoslavian royal family international support. The $\check{C}$ etniks started out as royal opponents to the Nazis, but some of them then started collaborating with the Nazis against the Partisans. The defection of these troops to the Nazis cost the royalists the support of the international community, which recognized the communist leader Josip Broz Tito and his partisan troops as the legal

\footnotetext{
${ }^{207}$ The Kingdom of Yugoslavia, Official Gazette LXVI/207 (1931), Constitution of the Kingdom of Yugoslavia.

${ }^{208}$ Čulinović, F. (1961), Jugoslavija između dva rata. Jugoslavenska akademija znanosti i umjetnosti: Zagreb, p. 5-16.

${ }^{209}$ The Nazi Croats occupied a very special place in the Nazi hearts as they were the only non-German Nazis who were allowed to run death camps. One of these, Jasenovac, was established in 1941 where the Serb concentration camp inmates certainly formed its major populations. The Nazi Croatian treatment of Serbs in Jasenovac and elsewhere was such that it even shocked the Nazis. The Nazi Croatians devised a special knife, srbosjek (Serb-cutter), which they used to kill the Serbs in Jasenovac as part of competitions. The true number of concentration camp inmates in Jasenovac, however, remains under the cloak of Communist, contemporary Serbian, and contemporary Croatian propaganda; the only thing that is clear is that this number was not small or insignificant. As to Serbians, in addition to clearly targeting the Jews, the Nazi Serbians very clearly targeted their own people, other Serbs, whatever their defecting affiliations, either in organized concentration camps throughout Serbia called "collection centers" or through massive reprisals for Partisan victories anywhere in the field. Since Jews were not as numerous in Serbia as in other parts of the Third Reich, the Jewish and Partisan victims were gassed in the moving Gaswagen dubbed Entlausungswagen (vehicle for destruction of lice) in Nazi documents or shipped to other Nazi death camps outside Serbia. This study must highlight the fact that the only instance where the Slovenes, the Croats, the Bosnian-Herzegovinians, the Serbs, the Montenegrins, and the Macedonians offered any comprehensive, organized, and planned genuine resistance to the Nazis was under the Communist leader Tito when they did, indeed, put all their differences aside and concentrated their efforts against the common enemy. This is also the only historical example of such a joint cooperation. All other individual resistance offered by these peoples during the Second World War was mostly in a shape of killing orgies affecting their own peoples, the Serbs, or the Muslims; the Serbs were targeted due to their role in the establishment and running of the First Yugoslavia and the Muslims were targeted because they were Muslim.

${ }^{210}$ Koljanin, D. (2010), U službi ‘novog poretka’' osnovno školstvo i udžbenici istorije u Srbiji (1941-1944). Istraživanja, br. XXI, 395-415, Novi Sad.
} 
representative of the Yugoslavian peoples, not the King Petar II Karađorđević, who went abroad at the beginning of the war nor his royalist troops who stayed behind. The Četnik troops were led by General Draža Mihajlović who was executed after the Second World War after having been convicted for treason and war crimes by the Yugoslav authorities.

The Republic of Serbia's Law on Rehabilitation came into force on 13 December 2011. ${ }^{211}$ This Law regulates the rehabilitation and legal consequences of rehabilitation of persons who have been executed, arrested, or deprived of their other rights due to their political, religious, ethnic, or ideological beliefs and affiliations. Subject to this Law are persons residing in and outside of the Republic of Serbia with citizenship or residence in the Republic of Serbia at the time of the alleged offense. ${ }^{212}$ Mihajlović was rehabilitated on 14 May 2015. The first hearing on the second request for rehabilitation of the Prime Minister of Nazi-occupied Serbia, Milan Nedić, was held in December 2015 .

In discussions on Croatian Nazism, scholars are increasingly using the term "Nazifascism" to describe the unique kind of Nazism and Fascism in Nazi Croatia during the Second World War. ${ }^{213}$ These extremists established a state under Nazi auspices incorporating large parts of present-day Croatia, all of B\&H, small parts of Serbia and they called it the Independent State of Croatia. Since some parts of the then-Croatia were annexed by Italy and Hungary, B\&H formed the major part of this puppet state until Italy's capitulation in 1943 when Dalmatia was incorporated into the Independent State of Croatia. Contributions to studies on the banality of evil are plentiful in the Nazi occupation of the former Yugoslavia. All the occupying sides immediately established concentration camps for Jews and Romas. In addition, Italy, which annexed or occupied Dalmatia and parts of Montenegro, established concentration camps for local Croatians and Montenegrins. The Independent State of Croatia and Nazi collaborators in Serbia each established concentration camps for local internal enemies who included the "enemies of the state" and "undesirables," such as Jews, Romas, Bolsheviks, homosexuals, degenerate artists, etc. In addition, the Serbs found themselves the major targets of the Ustaša policies in Croatia and the Muslims found themselves the major targets of Četnik raids in B\&H. The Nazi Croatians immediately began adopting a series of racist laws similar to those in other Nazi countries, such as the Law on the prohibition of Cyrillic script, the Law on race, the Law on the protection of Aryan blood and honor of the Croatian peoples, the Law on conversion from one faith to another, Instruction on conversion from one faith to another, the Law on the protection of Croatian people's and Aryan culture, the Order on the conversion of Jewish last names and the marking of Jews and Jewish businesses, the Order not to release deposited money and valuables to the immigrating Serb owners, whereas they can carry the cash and valuables to the concentration camp where it will be seized, the Law on the confiscation of properties belonging to the Serbian Bureaus and Institutions, the Memorandum on the conversion of Serbs to Catholicism, the Law on the Croatian language, its purity, and orthography, and others. ${ }^{214} \mathrm{~B} \& \mathrm{H}$ Muslims found themselves inside the Nazi Croatia who proclaimed them to be Aryans, i.e. Croat Muslims, and divided the territory of B\&H into six counties whose names were taken from the early feudal times of B\&H. The Nazi Croatian authorities instructed the media to use these new-old names of counties when referring to B\&H as much as possible. ${ }^{215}$

After he was recognized by the Allies as a military partner and ally in 1943, Josip Broz Tito became the only legitimate representative of Yugoslavia and its peoples. The country - named the Democratic Republic of Yugoslavia - was recognized by the international community in 1945. The political cadres of Tito's partisan troops were organized into committees whose representatives got together several times between 1942 and 1945 to set up an interim government. They formed the Presidency of the Anti-Fascist Council for

\footnotetext{
${ }^{211}$ Republic of Serbia, Official Gazette of the Republic of Serbia 92/2011 (2011), Law on Rehabilitation.

${ }^{212}$ Republic of Serbia, Higher Court in Belgrade, About rehabilitation.

${ }^{213}$ Blažević, R. and Alijagić, A. (2010), Antižidovsko i rasno zakonodavstvo u Fašističkoj Italiji, Nacističkoj Njemačkoj i Ustaškoj NDH.

Zbornik Pravnog fakulteta: Zagreb, p. 879-916.

${ }^{214}$ Dedijer, V. (1987), Vatikan i Jasenovac: dokumenti. Izdavačka radna organizacija Rad: Beograd.

${ }^{215}$ Imamović, M. (2014), Historija države i prava Bosne i Hercegovine. University Press: Sarajevo, p. 314.
} 
the National Liberation of Yugoslavia which later became the Presidency of Yugoslavia. This committee recognized six Yugoslavian republics, including B\&H, decided Yugoslavia would be a federal state that would "ensure full equality of Serbs, Croats, Slovenes, Macedonians, and Montenegrins, i.e. the peoples of Serbia, Croatia, Slovenia, Macedonia, Montenegro, and B\&H." Their decisions were published in Serbian, Croatian, Slovenian, and Macedonian. The highest body of this committee in B\&H was set up as the State Anti-Fascist Council for the National Liberation of B\&H which later became the People's Assembly of the Republic of B\&H. In its "Declaration on the rights of citizens [of B\&H]," this B\&H committee named Muslims, Serbs, and Croats as citizens of B\&H, declaring that it is the wish of these citizens of B\&H that B\&H be neither Serb, Croat, or Muslim, but of the Serbs, of the Croats, and of the Muslims. ${ }^{216}$ The official language of Yugoslavia was Serbo-Croatian.

\subsection{The Second Yugoslavia}

Once the Second World War ended, the peoples of Yugoslavia gave the idea of a single state of Southern Slavs another chance, albeit under a nondemocratic government.

The 1946 Constitution of the People's Republic of B\&H declared that national minorities have the right to use their own language and that court proceedings shall be held in the Serbian or Croatian language. The ${ }_{1963}$ Constitution of the People's Republic of B\&H declared that the peoples of Yugoslavia and certain minorities have the right to education in their own language, the minorities have the right to use their own language, all B\&H laws and other official documents shall be delivered in Serbo-Croatian and, although court proceedings shall be held in Serbo-Croatian, the minorities can use their own language. The 1974 Constitution of the People's Republic of B\&H declared the official language Serbo-Croatian/Croato-Serbian of ijekavian pronunciation and the equality of Latin and Cyrillic script, the equality of languages and scripts of all peoples and minorities in that the minorities have the right to education in their own language, all have been given the right to use their own language in the courts, and should territorial defense units (the lowest form of defense units at the local level) be composed of minority members, those minorities will have the right to use their own language in command and training.

Serbo-Croatian was one of the three official languages of the former Yugoslavia, alongside Macedonian and Slovenian - standard languages that are completely separate from Serbo-Croatian to the point these speakers often cannot understand one another. The reunified language, Serbo-Croatian as a national language of the Serbs, the Croats, and the Montenegrins, has two linguistic variants, the Western i.e. Croatian (ijekavian) and the Eastern i.e. Serbian (ekavian). These variants and the equality of Cyrillic and Latin script were affirmed in the Novi Sad Agreement of $1954 \cdot{ }^{217}$ This means that Serbo-Croatian, with its two linguistic variants, served as a politically correct lingua franca in communication among the peoples of the former $\mathrm{Yu}$ goslavia. It also means that B\&H remained unmentioned in language-related laws, rules, and regulations. Language and identity-related troubles started outside B\&H again when the passive-aggressive conflict between the Serbs and the Croats resurfaced.

The first two volumes of the unified Serbo-Croatian/Croato-Serbian dictionary by the cultural-scientific institutions Matica Srpska and Matica Hrvatska came as part of the 1954 Novi Sad Agreement. ${ }^{218}$ Croatian intellectuals denounced the dictionary and Matica Hrvatska withdrew from the project. In 1967, a group of Croatian authors and academics issued a "Declaration on the name and position of the Croatian literary language", complaining about the dominance of the Serbian language and calling for a larger representation of

\footnotetext{
${ }^{216}$ Šipka, Milan (1999), Standardni jezik u Bosni i Hercegovini u dokumentima jezičke politike. Open Society Institute: Budapest, p. $117-118$.

${ }^{217}$ Ibid, p. 119-122.

${ }^{218}$ Some argument could be made about these two institutions being the Serbian and the Croatian equivalent of the language institutes, such as British Council, Alliance Française, Instituto Cervantes, Goethe Institut, etc. which are established to promote these cultures and languages in the country and abroad. There was no Bosnian equivalent to these institutions.
} 
the Croatian language at the state level. In 1971, Dalibor Brozović wrote "Ten theses on the Croatian language", declaring Croatian to be a separate language. The group of Serbian writers responded by "Proposal for consideration" offering the annulment of the conclusions of Vienna and Novi Sad literary agreements, abolition of the name Serbo-Croatian/Croato-Serbian and calling for the equality of all Yugoslavian languages and scripts. Their proposal was considered to be a chauvinist match to the "Declaration on the name and position of the Croatian literary language." Whereas all these proposals may seem benign in today's context, Tito's Yugoslavia was a country governed by the concept of brotherhood and unity (bratstvo ijedinstvo) where any separatism or any form of national awakening was unacceptable. Besides, the whole discussion brought the issue back to $\mathrm{B} \& \mathrm{H}$, the proverbial name of the language spoken there, directly infringing on the rights of the peoples of B\&H. They responded accordingly.

\begin{abstract}
When considering the political implications and tendencies of the Declaration on the name and position of the Croatian literary language and the Proposal for consideration by a group of members of the Association of Writers of Serbia, the Executive Committee of the Central Committee of the League of Communists of B\&H, during a session held on 27 March 1967, assessed the ideological and political character of these documents and adopted a stand on literary and language policy in $\mathrm{B} \& \mathrm{H}$ [deciding that these two documents are] not only an expression of the nationalistic and chauvinistic attitudes of their signatories, but also an open attempt at political diversion against the brotherhood and unity, equality, and socialist patriotism of the peoples of Yugoslavia [and urged the Serbs, the Croats, and the Muslims] to fortify the brotherhood and unity as a guarantee of their socialist progress [BF's translation]. ${ }^{219}$
\end{abstract}

The University of Sarajevo professors reacted along the same lines. The Central Committee of the League of Communists of B\&H issued another series of conclusions on 15 March 1968: the peoples of B\&H - Serbs, Croats, and Muslims - can freely and equally use both variants of the Serbo-Croatian i.e. Croato-Serbian language. The Symposium on language tolerance was held between 23 and 25 April 1970 in Sarajevo to conclude that the name of the official language in $\mathrm{B} \& \mathrm{H}$ shall be Serbocroatian-Croatoserbian, both scripts shall be in equal use, and education in schools shall be delivered in the ijekavian dialect. The next decisions of the League of Communists affirmed all the earlier language policies and called for "mothering autochthonous literary, linguistic, and cultural values that are the commonwealth of all peoples in $\mathrm{B} \& \mathrm{H}$, bridging their cultures i.e. insisting on all that connects and brings us together" establishing that literary and linguistic expression in $\mathrm{B} \& \mathrm{H}$ "cannot be determined by a variant." The schools were instructed to use the Serbocroatian-Croatoserbian language and to use both scripts. ${ }^{220}$

The 1974 Constitution of the Socialist Federative Republic of Yugoslavia cemented all these decisions: equality of all regardless of, inter alia, language, freedom to affiliate with any people or minority and free use of, inter alia, language and script, including the freedom not to affiliate with anyone, minorities' right to use their language and script before official organs of the state and the freedom to educate in their language, guaranteed use of their own language in courts, the equality of the languages and scripts of people and minorities in the armed forces, the equality of languages and scripts of all peoples and minorities, guaranteed free use of language and script for all minorities, and the equal use of all official languages and scripts in communication at an international level. ${ }^{221}$

As far as language in the Yugoslav People's Army is concerned - the only venue where all peoples of the former Yugoslavia came together and had to communicate due to mandatory military service and where

\footnotetext{
${ }_{219}^{21}$ Šipka, Milan (1999), Standardni jezik u Bosni i Hercegovini u dokumentima jezičke politike. Open Society Institute: Budapest, p. 119-122.

${ }^{220}$ Ibid, p. 123-157.

${ }^{221}$ Constitution of the SFRY (1974), Articles 154, 170, 171, 214, 243, 246, 246, 271.
} 
Serbo-Croatian/Croato-Serbian was the mandatory language - the 1974 Constitution proclaimed the equality of the language and the script of peoples and minorities, stipulating that:

Pursuant to the Federal law, command and military instructions in the Yugoslav People's Army shall be in one of the languages of the peoples of Yugoslavia and the languages of peoples and minorities in its parts [BF's translation..222

However, all the commands, laws, and the rules and regulations in the Yugoslav People's Army remained, in fact, in the Serbian language. Although the 1974 Constitution and the Rules of Service of the Yugoslav People's Army define the language in the Yugoslav People's Army as Serbocroatian, former serving officers of the Yugoslav People's Army interviewed for the purposes of this study agree on the following: although not committed to paper in the form of a written rule, all official commands were given in ekavian because most officers and noncommissioned officers spoke that dialect as they were either Serbs or from Serbia. The others - nonSerbs and non-Serbians - merely conformed to this use of language. The following footnote taken from Blagojević Trial Judgment cites more than 10 different Rules of Service of the Yugoslav People's Army published between 197 os and 1990 in various republics of the former Yugoslavia. They were all uniformly originally written in the Serbian ekavian dialect, regardless of the location of the publication. ${ }^{223}$

When Tito died in 1980, a popular uprising of Albanians in Kosovo began in 1981 and resulted in the imposition of martial law, the first since the end of the Second World War, and the whole country was suffering from a severe economic crisis. The Draft Memorandum of the Serbian Academy of Arts and Sciences (SANU) was written between 1985 and $1986 .{ }^{224}$ This was yet another "secret" document which somehow leaked out and got published in the Serbian daily tabloid "Večernje Novosti" on 24 and 25 September 1986. It has been generally accepted that this was a political program of the "Serbian intelligentsia" that was authored by the Serbian writer/historian/politician Dobrica Ćosić who later became the President of [Serbia] and 14 members of the SANU. The SANU Memorandum consists of two parts: an overview of the state of politics and economy and overview of the condition of the Serbian peoples across the former Yugoslavia.

The SANU Memorandum is very hard to describe in clear academic terms in parts where it addressed the state of economy and politics because it is both for and against modernity, for and against political change, for and against social equality, and for and against a liberal market economy in a series of buzzwords that are still the Leitmotif of the Serb(ian) self-image: the difficult position of the Serbian peoples (težak položaj srpskog naroda), official politics avoiding admitting the real causes of conflict (zvanična politika izbegava da prizna prave uzroke), anti-historical routes to progress (antiistorijski putevirazvoja), the awareness of the people (svest ljudi), unjustified violence (neopravdano nasilje), gradual and unwilling recognition (postupno i nevoljno priznanje), insurmountable obstacles in conflict of interest (nesavladive prepreke u sukobima interesa), backstage games (zakulisne igre), unanimous decision-making (jednoglasno odlučivanje), separatism and nationalism (separatizam i nacionalizam), ideological oneness (idejno jedinstvo), the means of repression (sredstva represije), moral crisis (moralna kriza), ideological crisis (ideološka kriza), pressures by the Great Powers (pritisak velikih sila), etc. The drafters very clearly propagate Serbia's liberation from all the roles that Yugoslavia, allegedly, imposed on it: the role of a feeder, moral compass, and beacon of liberty for the whole country.

Soon, SANU Memorandum turns to the position of Serbs in the former Yugoslavia. Here, it very clearly defines the future battlefields in $\mathrm{B} \& \mathrm{H}$, Croatia, and Kosovo in a series of buzzwords that are still the Leitmotif of the Serb(ian) contemporary explanations of the conflict: genocide in Kosovo (genocid na Kosovu),

\footnotetext{
${ }^{222}$ Ibid, Article 243.contemporar

${ }^{223}$ ICTY, Prosecution Brief in Blagojević.

${ }^{224}$ Various authors (1986), Draft Memorandum of the Serbian Academy of Arts and Sciences. Serbian Academy of Arts and Sciences.
} 
the stability of Yugoslavia (stabilnost čitave Jugoslavije), the dismembering of Yugoslavia (razbijanje Jugoslavije), the Serbian peoples have an historically implanted feeling of guilt (srpski narod ima istorijski usaden osećaj krivice), the vital interests of the Serbian people (vitalni interesi srpskog naroda), the oppressing and the oppressed nation (ugnjetavačka i ugnjetena nacija), a referendum of the Serbian people (referendum srpskog naroda), the traditional discrimination of Serbia (tradicionalna diskriminacija Srbije), the historic moment (istorijski trenutak), the Serbs are the most populous nation (Srbi najbrojnija nacija), separatist tendencies (separatističke tendencije), the complex of unsolved problems (splet nerešenih odnosa), only Serbia does not have its own state (jedino Srbija nema svoju državu), the Ballist rebellion of 1944 (balistička pobuna), ${ }^{225}$ the physical, political, legal, and cultural genocide of the Serb population (fizički, politički, pravni, kulturni genocid nad srpskim stanovništvom), the darkest times of the Turkish impaling of people (najmračnija vremena turskog nabijanja na kolac), the historical home country (matična zemlja svog istorijskog postojanja), Ottoman paramilitaries (bašibozuk), violence and physical, moral, and psychological terror (zulum i fizički, moralni i psihološki teror), the fate of Kosovo remains the life issue of the entire Serbian people (sudbina Kosova ostaje životno pitanje čitavog srpskog naroda), achievements paid in blood (krvlju stečene tekovine), the disintegration of the Serbian people (dezintegracija srpskog naroda), the Serbian language is being pushed out and Cyrillic is gradually being lost (srpski jezik se potiskuje, a ćirilsko pismo postepeno gubi), ancestral hearths (vekovna ognjišta), fateful task and the obligation of history (sudbonosni zadatak inalog istorije), etc. The main message of the second part is completely unsubstantiated owing to a complete lack of factual examples. Whereas it is strikingly clear that the SANU Memorandum calls for Serb dominance in the former Yugoslavia in almost all segments, it remains unexplained why that should be the case. Given that the SANU Memorandum was written by 14 leading Serbian contemporary intellectuals some of whom were serious scholars in their respective fields, scientists whose work reposes on empirical data, if the wars had not happened the way they did, SANU Memorandum could have been written off as analytical fiction.

The SANU Memorandum was mentioned at the ICTY in the context of Aleksovski, Prlić, Mrkšić, Milošević, Brđanin, Kordić, Dokmanović, Mucić, and Šešelj. In Aleksovski, the Prosecution witness explained the basics of the SANU Memorandum, ${ }^{226}$ but the Defense in Dokmanovic took issue with the apparent official non-existence of the SANU Memorandum, given that it leaked out in draft form:

\begin{abstract}
No one ever said, 'the memorandum of the Serbian Academy of Sciences and Arts', but only, 'the draft memorandum', because a memorandum would be an official document whereas a draft memorandum which was stolen may be a document for someone else, but it is certainly not a document for me and that is where the difference is, and the Prosecutor, Mr. Niemann, is asking about the SANU Memorandum, which is something that does not exist.
\end{abstract}

The Prosecution responded they would be happy calling this document "a draft." ${ }^{227}$ In Milošević, a Defense witness, one of the authors of the SANU Memorandum, stated that the SANU Memorandum

insisted on equality, that Serbia -should be on an equal footing in the political sense and in other senses. Nothing more than that was required. Equality. And it was also mentioned that that might not be in keeping with Serbia's position or, rather, that Serbia was historically predestined to unite that portion of the population in

\footnotetext{
${ }^{225}$ The Balli kombëtare "national front" was the Albanian analogue of the Serbian Četniks. They were royalist-nationalists who ended up collaborating with the Nazis against the Partisans under Enver Hoxha. They were especially strong in northern Albania and Kosovo, most of which was annexed by Albania during the Second World War.

${ }^{226}$ ICTY transcripts, Aleksovski, T. 772-79o.

${ }^{227}$ ICTY transcripts, Dokmanović, T. 263.
} 
the Balkans and that it would have compromised its historical role had it asked for anything more than full equality with other nations, to be on a footing of equality with all other nations and nationalities. ${ }^{228}$

Milošević suggested to this witness that the SANU Memorandum was a synthesis of "what science has established up until that time."

Yes, that's right. And this synthesis -- and what is important here, I would like to note this, that there was an anticipatory note of events that might take place unless steps were taken. So it was a forecast of what might happen given the crisis unless certain steps and measures were taken to deal with it. So I think that the value of that document lies therein. It anticipated what might happen. It looked at where development might lead. And it also mentioned the possibility of Yugoslavia's disintegration and breakdown, and so it confirmed that the analyses and basic foundations leading to that conclusion were sound.

Q. Tell me, Professor, in view of the fact that the memorandum is said to have overly stressed the economic lagging behind of Serbia, as an economist, to what extent can you respond to such criticisms? Did the memorandum overstate the economic backwardness of Serbia?

A. Well, it could not be either overestimated or underestimated. If Serbia was truly falling behind according to its GDP, the value of its funds, if instead of maintaining its position at a little below average or rising to average, if it was falling lower and lower below average, according to all the indications, I don't know if that was cause for equanimity or whether something had to be done. ${ }^{229}$

This answer seems to confirm in short that the events that followed the publication of the SANU Memorandum, namely the attack of the Republic of Serbia on other republics of the former Yugoslavia under the pretext of the economic, social, and ethnic stagnation of Serbia and the Serbs, was based on entirely wrong beliefs.

In B\&H, Serbocroatian/Croatoserbian with a specific literary and linguistic expression which "cannot be determined by a variant" served as an umbrella language, although the language that was spoken and written was Bosnian all along. Serbocroatian/Croatoserbian was not a language that one could actually speak, because it has always been just a name, not a language. Although acknowledging that the language spoken in B\&H "cannot be determined by a variant," i.e. it is not just a version of the Serbian or the Croatian language, B\&H was the only area throughout the joint state of Yugoslavia where the Serbo-Croatian language ideology was consistently applied and where all the peoples of Yugoslavia mixed together. For example, the B\&H daily newspaper "Oslobođenje" would one day publish in Latin and another in Cyrillic script. Primary school students would learn one script the first year and the second script the second year of elementary school, and, according to some decisions discussed earlier, they were obliged to take notes and exams intermittently in Latin and in Cyrillic script throughout their education. Readers throughout the former Yugoslavia marveled at the wonders of the Serbo-Croatian literary expression of B\&H writers such as Meša Selimović and Ivo Andrić. On the level of identity, Yugoslav Muslims were not recognized as a people (narod), but as a narodnost (nationality) which is a communist term for minorities. The ${ }_{1963}$ SFRY Constitution uses the term nacionalna manjina (national minority), the 1974 SFRY Constitution uses the term narodnost but, although designed to avoid using the term "minority," this is what was meant when the concept of narodnost was mentioned. Up to 1974, Muslims could declare themselves in Yugoslavian Censuses as Muslims-Serbs, Muslims-Croats, Muslims-undeclared, or Yugoslavs, i.e. being a segment of a narodi, but not as a narod (people) in their own right. Naturally, this created many problems at the level of statistics, to name just one. It also created many problems at the level of identity: how Muslims view themselves and how others in Yugoslavia viewed the Muslims.

${ }^{228}$ ICTY transcripts, Milošević, T. 34735-34736.

${ }^{229}$ ICTY transcripts, Milošević, T. 34736-34737. 
For example, even at the ICTY, narodnosti has been consistently translated as "nationalities." Linguistically, this is nonsensical especially when the term is used alongside "nations" which is the couplet with which it usually appears (nations and nationalities, i.e. narodi i narodosti) because it should be "peoples and minorities." This loss in translation could even be described as political and it seems to be an extension of the pre1992 former Yugoslav mentalities discussed earlier: the Muslims are imposters or converts requiring reconversion, therefore they are not even a declarable minority, but "in transition" for a lack of a better expression. There is more about the ICTY language services and their translation, interpreting, and transcriptional philosophies in Chapter 6. Although gaining the right to call themselves Muslims in 196os, they could freely declare themselves as Muslims, the narod, from 1974 onwards in public documents, when needed. However, almost a century of cultural, identity, and political appropriation and/or distortion of what is theirs took a toll on how Muslims viewed themselves and how others viewed them.

Due to all legal restrictions on expressions of national and religious identity in the former pre-1974 Yugoslavia, one of the most persistent Serb(ian) canards is that Meša Selimović, a Muslim from B\&H, used to declare himself as a Serb. Meša Selimović was a prolific writer who also married a Serbian lady and moved to Belgrade where Serbians embraced him as his own. Serbian nationalists often declared then and now that Meša Selimović's "Dervish and the death" is the "greatest Serbian novel of the twentieth-century." B\&H writer Alija Isaković rebutted this saying "Isn't it a little bit strange that the greatest Serbian novel of the twentiethcentury begins with 'In the name of Allah, the Most Gracious, the most Merciful'?" However, the nationalists remained unfazed. Obviously, appropriation of all that is of $\mathrm{B} \& \mathrm{H}$ and faulty parallelisms that started during the Romantic revolutions resumed in the former Yugoslavia but under different affiliations: Meša Selimović is a Serb brother and rightfully ours because we live in brotherhood and unity. In reality, although situating some of his novels in the period of the Ottoman Empire, Meša Selimović was writing about B\&H during the cruelties of the communist regime centering around the sad faith of his own brother who was killed by the Communists. In 1944, Meša Selimović's brother, Šefkija Selimović, had been sentenced to death by firing squad and executed "because he took the bed, closet, chair, and several other knickknacks from the warehouse of the Main Administration of People's Goods. Such a harsh sentence has been delivered because he was from a prominent partisan family" [BF translation]. ${ }^{230}$ Unfortunately, due to persistent Serb appropriation and misinterpretation of his oeuvre and ideologies, Meša Selimović is nowadays seen by some in B\&H as a sellout and a self-hating Bosnian Muslim.

Meša Selimović is mentioned at the ICTY in the context of Šešelj, Karadžić, Milošević, and Župljanin. Šešelj, testifying in Milošević, best summarized the broadness of the appropriation of all non-Serbs to Serbs:

A. Yes. Mehmet Mesa Selimovic is a Muslim from Bosnia and one of the greatest Serb authors of all time. He said himself, "I am a Serb, my family is Serb, my father was a Serb, we're all Serbs." In his last will and testament he said that because he knew that after his death somebody would try to claim him, he was saying that he belonged to an invented nation. Mehmed Mesa Selimovic, Hasan Kikic, Skender Kulenovic, Camil Sijaric, and so on and so forth. All these top intellectuals, who were Muslims, emphasized that they were Serbs. And also among those alleged Croats, Ivan Gundulic and all the writers from Dubrovnik. Then Ivo Vojnovic, Ivan Stojanovic, Milan Resetar, Vladimir Dvornikovic, all the way up to Ivo Andric. All of them are Catholics, but they were proud of the fact that they belonged to the Serb nation. Artificially, later on, Serb Catholics were turned into Croats. First, they were forced to declare themselves as Croats, and, after brainwashing, they said that they were Croats en masse. And after several decades of brainwashing, now the Muslims are convinced that they are some kind of a nation in its own right, and now even that has been changed and they're called Bosniaks. ${ }^{231}$

\footnotetext{
${ }^{230}$ Selimović, M. (1976), Sjećanja. Svjetlost: Sarajevo.
}

${ }^{231}$ ICTY transcripts, Milošević, T. 43467. 
The same argument about unconscious Serbs among non-Serbs has been used by Karadžić.

What is relevant is to say that in a recent poll [of the greatest Serbs of all times] Mehmet-Paša Sokolović was near the very top with Nikola Tesla, Prince Lazar, not to speak of Emir Kusturica, who is alive and well and Meša Selimović, who is a renowned writer in Serbia. ${ }^{23^{2}}$

In a different session, Karadžić concluded "but we are proud of the fact that some of the most creative individuals of the Muslim faith preserved their Serb roots." ${ }^{233}$ The Prosecution saw no relevance in his arguments and did not take up the issue, not even to clarify the facts of the alleged poll or the "Serbian nature" of any of the individuals mentioned. This obscured several other problems with this argument: what are the actual contributions to the Serb(ian) cause made by Serbs such as Mehmet-Paša Sokolović, Nikola Tesla, and Prince Lazar, and what bearing does it have on the 1992-1995 ethnic cleansing of the B\&H Muslims? ICTY OTP had an opportunity but did not question further the appropriation of all that is non-Serb by the Serb(ian) nationalists. Naturally, this caused sophistry to take a garb of an agnus dei and such arguments only continued. For example, the Župljanin Defense mentioned that the Army of Republika Srpska (VRS) Commander Lisica, an ethnic Serb, christened a mixed unit composed of volunteer Muslims and Croats "Combat Group Meša Selimović." ${ }^{234} \mathrm{~A}$ witness clarified that it was "not customary at the time" to make such a unit, but those volunteer Muslims and Croats wanted to form such a unit of their own volition and it is of their own volition that they asked Commander Lisica to be its godfather. It is worth noting that none of those volunteer Muslims and Croats were called to testify to confirm or deny such claims or to confirm or deny whether they were actually volunteers, as Muslims and Croats who stayed in Republika Srpska during the war were often taken to the front lines, both to dig trenches and to serve as human shields in front of the advancing B\&H Army troops.

Although an ethnic Croat from B\&H, Ivo Andrić is said to have declared that he was a Serb, too. The times and writings of Ivo Andrić were the times and writings of unprecedented political incorrectness not only in the territory of former Yugoslavia, but all over the world. Ivo Andrić was a member of the literary elite throughout his life (during the First and the Second Yugoslavia), having been a political activist and diplomat who served in Germany, Vatican, Graz, Trieste, Madrid, Brussels, etc. Andrić dictated trends and topics of writing, but no matter how extremely well-traveled he was and how many people with different backgrounds he met in his lifetime, Andrić still found time to immortalize Yugoslavian Muslims as an atavism of a gory Ottoman past. Andrić was a Yugoslavian Ambassador to Germany but was allowed to return to Nazi-occupied Yugoslavia in 1941 where he spent the rest of the Second World War writing and, ultimately, producing "The Bridge on the Drina," among other works. In the 1950s and 196os, when this work saw its heyday, the "language of hatred" was felt, but legally unrecognized, the use of sexist expressions was acceptable, even encouraged, essentialization was ubiquitous and insufficiently informed writers-historians-philosophers cum political activists were free to publish whatever they wanted as long as they belonged to the right clique. Naturally, this was not unique to the former Yugoslavia. The world "then," was not what it is "now." Ivo Andrić re-found himself in the Second Yugoslavia and started experimenting with his new found Yugoslavianism and quasiSerb identity, explicitly or implicitly blaming "the Turks" for everything that ever went wrong in the territory of the former Yugoslavia. The educated took notice and the uneducated listened carefully. When the educated failed to refute some of these historical inaccuracies or call Ivo Andrić and other insufficiently informed writers-historians-philosophers cum political activists to account, the uneducated took Ivo Andrić's ramblings as undeniable truth and started taking revenge against "the Turks" the first time they had a chance. However, when the uneducated started their revenge in the 199os, the Turks had been long gone from the former Yu-

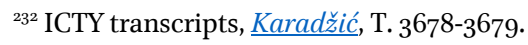

${ }^{233}$ ICTY transcripts, Karadžić, T. 22609.

${ }^{234}$ ICTY transcripts, Stanišić and Župljanin, T. 19675-19676.
} 
goslavia. What they found was local Muslim populations who were living on their own turf. Ivo Andrićs writings in the Nobel Prize Award winning "The Bridge on the Drina," in particular, gave rise to numerous incidents of destruction and killings during the war in B\&H. The nationalist readers of Ivo Andrić's oeuvre focused almost exclusively on extreme portrayals of Ottoman rule over $\mathrm{B} \& \mathrm{H}$, viewing the Muslims in the former $\mathrm{Yu}$ goslavia as aliens: the uneducated persecuted them worse in Višegrad than was described in Andrić's novel. ${ }^{235}$

"The bridge on the Drina" is a work of fiction situated in the sixteenth-century Ottoman B\&H and revolving around the alleged circumstances of building an actual bridge over the river Drina which included a grisly description of the impalement of a local man by the Ottomans and a description of Serb men, women, and children being mutilated on the bridge and thrown into the Drina river by the Ottomans. "The bridge on the Drina" directly juxtaposes the members of two ethnicities living together in the same community in that in one and the same sentence or in a related paragraph it makes a sharp distinction between the members of the two religions and their characters, intentions, and motivations: Serbian lands vs. the vizier's authority (srpske zemlje - vezirova vlast), Serbian children vs. Turkish children (srpska deca - turska deca), Radislav, a Serbian hero vs. one of [the vizier's] men, smart and skillful who bribed Radislav's aide and got information out of him (Radisav, srpskijunak - neki od [vezirovih] ljudi, mudar ivešt [kojije] podmitio i ispitao momka Radisavljevog), there were both Turks and Serbs in the town who claimed to have heard the sound of Karađorđe's cannons (but with diametrically opposed feeling, of course) [because] one often thinks to have heard what one fears or what one hopes for (bilo je u kasabi i Turaka i Srba koji su tvrdili da su svojim ušima čuli tutanj "Karađorđevog topa". (Naravno, sa potpuno oprečnim osećanjima.) [J]er čovek često misli da čuje ono čega se boji ili čemu se nada), a [Serbian] old man tied up vs. a Turkish commander getting ready to go downtown and miss watching him getting executed ([srpski] starac vezan $[a]$ turski komandir se spremao da ode u varoš ine gleda njegovo pogubljenje), Turkish homes vs. Serbian homes (i turske i srpske kuće), the Serbian language vs. the Turkish language ( $i$ na srpskom i na turskom jeziku), etc. Particularly odious is the frequency by which Andrić juxtaposes Serb children vs. Muslim/Turkish children almost on every second or third page, suggesting that they can never live together because they are divided by religion.

The tone of "The bridge on the Drina" is one of authority although Andric recounts legends about fairies and other supernatural forces in at least two thirds of the book. This tone could even be said to be cunning because Andrić identifies himself with legends, using expressions such as "as we will shortly see" as if he was relating historical facts all along. In one of those legends it is clear that Andrić also considered Bosnia as one of the "Serbian lands." According to Andrić, the building of the actual bridge was commissioned by a former Serb, Mehmet-Paša Sokolović. The bridge was erected by a great Serbian builder Rade Neimar (construction worker, Ottoman Turkish) who built all those beautiful and eternal Serbian buildings with the assistance of Serb workers. Rade Neimar encountered problems and, in order to neutralize the spells of a Ship Fairy who did not appreciate the bridge being built, the Ottomans had two Serb children entombed in the central pillars. The only historical fact here is that the bridge was, indeed, commissioned by a former Serb, Mehmet-Paša Sokolović, who spent his entire political and military career enforcing Ottoman politics and military aims, but the bridge itself was built by the great Mimar Sinan (architect, Ottoman Turkish) under Suleiman the Magnificent's administration. Culturally, the Ottomans were undeniably superstitious, but it is highly improbable that they would be moved to anything before the threat of a quintessential Slavic deity, such as a fairy. The pillars of the bridge have been destroyed several times throughout history and there were no bones found in any of their foundations. ${ }^{236}$ It needs to be clarified that the legend of human sacrifice by inhumation during the construction of a significant object occurs in the folklores of many peoples, not only in the Balkans, but from North Africa to India. Finally, it is most likely that freehold peasants constructed the bridge, rather than Serbs only.

\footnotetext{
${ }^{235}$ Andrić, I., The bridge on the Drina (Lovett F. Edwards, translator).

${ }^{236}$ Rizvić, M. (1995), Bosanski muslimani u Andrićevom svijetu. Ljiljan: Sarajevo.
} 
But, the uneducated took fiction for facts. The Milan Lukić and Sredoje Lukić trial was about two ethnic Serbs and cousins from Višegrad who formed a paramilitary group called the "Avengers" in Višegrad and then went on a spree killing local Muslims and Muslims in Serbia well into the end of the $1990 \mathrm{os}{ }^{237} \mathrm{Lukić}$ has been very interesting because the factual evidence sounded like it came off the pages of Ivo Andrićs books, albeit with switched roles: the Serbs were perpetrators now. Five centuries after the bridge over Drina has been erected, Witness VG21 testified in Lukić to crimes such as mutilation and hurling Muslims down the Višegrad bridge committed by the Serbs in 1992:

A. The bodies that we retrieved from the Drina Lake were in varying stages of decomposition. Some were whole, intact, some were without heads, without clothing, others were with clothing; younger people, older people, and even children.

Q. Did you find bodies which were mutilated or that had suffered abuse?

A. Yes. We retrieved bodies which had parts of noses cut off, ears, women with their breasts cut off, then legs tied, naked, both arms slung through the breasts and decomposing. It's indescribable. Some were killed with knives, sledge hammers. I don't know what to say. There were killings of all kind. But in the beginning, bodies mostly arrived that were with a nose cut off, ear cut off, hit with a hammer or a knife. There were few killed with firearms during the first few days. ${ }^{238}$

Five centuries after the bridge over Drina has been erected, Witness VG21 testified in Lukić to the crucifixion of Muslims in Višegrad by the Serbs in 1992:

Q. Among those bodies, did you find two bodies that were like crucified on a piece of wood?

A. Yes, there were bodies on a door. On one side of the door, a man was nailed to the door and, on the other, a woman. But I personally did not see this, but I was told about this by the person who was in charge of the exhumation or identification of those bodies. ${ }^{239}$

The killings in Višegrad amounted to extermination. Milan Lukić and his associates ushered 7o elderly men, women, and children into a house and burned them alive. Of the entire Višegrad branch of the Bosnian Kurspahić family only one member remained. All others were burned alive. Lukić's cousins followed this modus operandi on two occasions in Višegrad, once in Bikavac, and the other time in Pionirska Street. In Višegrad a total number of 140 victims were burned alive. In her expert report for Lukić on changes in the ethnic composition in the municipality of Višegrad between 1991 and 1997, Tabeau concluded the following:

In 1991 Višegrad had two main ethnic groups: Muslims (63.5\%) and Serbs (31.8\%). There were also Others mainly Yugoslavs (4.5\%), and Croats (0.2\%), that lived there.

The 1991, however, the population was unequally distributed within Višegrad: out of the total of 159 settlements within the municipality, 93 had a clear Muslim majority, 6o a clear Serb majority and only six could be considered as "mixed", including Višegrad town.

\footnotetext{
${ }^{237}$ ICTY, Milan Lukić and Sredoje Lukić CIS.

${ }^{238}$ ICTY transcripts, Lukić, T. 923 .

${ }^{239}$ Ibid.
} 
The post-war ethnic structure of Višegrad was dominated by Serbs (95.9\%). During the war Muslims entirely disappeared from Višegrad. This is also reflected at the level of settlements. ${ }^{240}$

Lukić was also related to Karadžić, Krajišnik, Milošević, Plavšić, Stanišić, and Vasiljević. When asked whether he is trying to justify burning 70 people alive as a provocation, Milošević answered that it was important to understand Ivo Andrić, "who is a writer, and the only Yugoslav Nobel prizewinner, a Serb, [because he and his oeuvre] fall $[. .$.$] within the context of the war in B\&H." { }^{241}$

None of the defendants mentioned in the context of books discussed in this chapter have been sentenced for genocide. All the above works of fiction and their philosophy of hate set the stage for ethnic cleansing and genocide in $\mathrm{B} \& \mathrm{H}$. These works shaped the mentality of the entire people, peddling the quasiknowledge that $\mathrm{B} \& \mathrm{H}$ and Yugoslavian Muslims were aliens who were threatening the Serbs to the point that they needed to be exterminated.

\subsection{The war against $\mathrm{B} \& \mathrm{H}$}

As soon as they got a chance to declare who they really were, once Yugoslavia was about to collapse, the B\&H populations did not hesitate to do that. According to the 1991 B\&H Census which, inter alia, asked respondents to declare their language, the peoples of $\mathrm{B} \& \mathrm{H}$ described their language in the following terms: ${ }^{242}$

$\begin{array}{lll}\text { - } \text { Bosnian } & 1,631,991 & 37.2853 \% \\ \text { - Serbo-Croatian } & 1,160,962 & 26.5239 \% \\ \text { - Serbian } & 824,871 & 18.8454 \% \\ \text { - Croatian } & 588,099 & 13.4360 \% \\ \text { - Croato-Serbian } & 61,165 & 1.3974 \% \\ \text { - Yugoslavian } & 11,575 & 0.2644 \% \\ \text { - Serbo-Croatian and Croato-Serbian } & 4,117 & 0.0941 \% \\ \text { - Muslim } & 2,545 & 0.0581 \% \\ \text { - Islamic } & 451 & 0.0103 \% \\ \text { - Serbo-Croatian and Croato-Serbian } & 427 & 0.0098 \% \\ \text { - Montenegrin } & 266 & 0.0061 \% \\ \text { - Orthodox } & 232 & 0.0053 \% \\ \text { - Bosnian Serbo-Croatian } & 190 & 0.0043 \% \\ \text { - Bosnian Croatian } & 148 & 0.0034 \% \\ \text { - Croatian Bosnian } & 120 & 0.0027 \% \\ \text { - Bosnian Muslim } & 104 & 0.0024 \% \\ \text { - Bosnian Serbian } & 89 & 0.0020 \% \\ \text { - Herzegobosnian-Croato-Serbian } & 73 & 0.0017 \% \\ \text { - Serbo-Croatian-Croato-Serbian-Bosnian } & 36 & 0.0008 \% \\ \text { - Bosnian Yugoslavian } & 19 & 0.0004 \% \\ \text { - Bosnian Croato-Serbian } & 15 & 0.0003 \% \\ \text { - Roma Bosnian } & 8 & 0.0002 \% \\ \text { - Croato-Bosnian-Serbian } & 4 & 0.0001 \%\end{array}$

\footnotetext{
${ }^{240}$ Tabeau, E. (ed.) (2009), Conflict in Numbers: Casualties of the 199os Wars in the Former Yugoslavia (1991-1999). Helsinki Committee for Human Rights in Serbia: Belgrade, p. 37.

${ }^{241}$ ICTY transcripts, Milošević, T. 25607.

${ }^{242}$ Republic of B\&H, Institute for Statistics of the Republic of B\&H, Statistical Bulletin 233, The 1991 Census of population, households, dwellings and agricultural lands, Ethnic characteristics of the population, The 1991 results on the level of the Republic and on the municipal level, Sarajevo, October 1993.
} 
There are two major categories of language-related responses to the $1991 \mathrm{~B} \& \mathrm{H}$ Census: language as determined by religion and language as determined by national identity. Language as a determinant of religion includes the following answers: the Muslim language, the Islamic language, the Orthodox language, and the Bosnian Muslim language; this notion of language was supported by $0.0761 \%$ of citizens of B\&H. Language as determined by national identity can be broken down into two further groups: group including a B\&H identity and group excluding a B\&H identity. Group including a B\&H identity provided answers such as: Bosnian, Bosnian Serb, Herzegovinian Bosnian Croato-Serbian, Serbo-Croatian-Croato-Serbian-Bosnian, Bosnian Yugoslavian, Bosnian Croato-Serbian, Roma Bosnian, Croato-Bosnian-Serbian, Bosnian Serbo-Croatian, Bosnian Croatian, Croatian Bosnian. This notion of language was supported by $37.3008 \%$ of citizens of $\mathrm{B} \& \mathrm{H}$. The group excluding B\&H identity could be broken down into separate Croatian and Serbian groups, and a common Serbo-Croatian or Yugoslavian group. The separate Croatian and Serbian group included: Serbian, Croatian, and Montenegrin; this notion of language was supported by $32.2875 \%$ of the citizens of B\&H. Common Serbo-Croatian or Yugoslavian groups included: Serbo-Croatian, Croato-Serbian, Yugoslavian, Serbo-Croatian and Croato-Serbian, and Croato-Serbian and Serbo-Croatian; this notion of language was supported by $28.2896 \%$ of B\&H citizens. In other words, the 1991 B\&H Census on the subject of language showed that $37.3008 \%$ of citizens of B\&H stated that they spoke a B\&H affiliated language, $32.2875 \%$ of citizens of B\&H stated that they spoke a Serbia and Croatia affiliated language, and that $28.2896 \%$ of citizens of B\&H stated that they spoke a Yugoslavia affiliated language. Not even $1 \%$ of the peoples of B\&H affiliated their language with religion, which is in keeping with their ancestral disdain of organized religion.

B\&H declared independence from Yugoslavia on 1 March 1992 and became a member state of the UN in May 1992. The Serb minority declared their own internationally unrecognized state in B\&H and called it Republika Srpska. The Croat minority also declared their own internationally unrecognized state in B\&H and called it Herceg-Bosna. Herceg-Bosna later "united" with B\&H Government held territory in what is today called the B\&H Federation.

On 14 March 1993, the B\&H Government delivered a Constitution establishing that the citizens of B\&H are Serb, Croats, Muslims, and members of other peoples, and that the Serbocroatian-Croatoserbian language of ijekavian pronunciation and both scripts are in official and equal use. Muslim intellectuals reacted, requesting the change of the name of the official language into "Bosnian, Croatian, and the Serbian language of ijekavian pronunciation." On 1 September 1993, the B\&H Government delivered a Law Decree on the name of the language in official use in $\mathrm{B} \& \mathrm{H}$ during the state of war, declaring that "Republic of B\&H recognizes the official use of the standard literary language of ijekavian pronunciation of its constitutional peoples called either Bosnian, Serbian, or Croatian. Both scripts, Latin and Cyrillic, shall be equal." The Constitution of Republika Srpska delivered on 28 February 1992, declared that the official language was Serbian with ijekavian pronunciation written by Cyrillic script. On 21 July 1994, the Government of the B\&H Federation declared Croats and Bosniaks the constitutional peoples and Croatian and Bosnian languages written in Latin script as official languages.

After the war, on 8 July 1996, the President of Republika Srpska delivered a Law on official language and a script establishing Serbian with ekavian pronunciation written with Cyrillic script as the official language. The public in the Republika Srpska reacted, blaming the government for "making us abandon the ijekavian script of Petar Kočić and Branko Ćopić [B\&H writers of ethnic Serb origin, BF] to the Croats and the Muslims." ${ }^{243}$ The Republika Srpska's government motion was not approved. Indeed, all of B\&H remained either ijekavian or ikavian as it always was.

\footnotetext{
${ }_{243}^{24}$ Šipka, M. (1999), Standardni jezik u Bosni i Hercegovini u dokumentima jezičke politike. Open Society Institute: Budapest, p. 25 o.
} 
Post-war B\&H, i.e. the B\&H Federation and the Republika Srpska, circumvented the issue of the name of the language, declaring the languages of the Bosniak people, of the Serb people, and of the Croat people as official languages. ${ }^{244}$ The latest Constitution of Republika Srpska and the Constitution of the B\&H Federation establish Bosniaks, Serbs, and Croats as constitutional peoples, the languages of the Bosniak people, of the Serb people, and of the Croatian peoples as official languages with equal use of Latin and Cyrillic script, equality of all regardless of, inter alia, language, the right to use their own language and script to all in general and in communications with the State, prohibition of discrimination on the basis of, inter alia, language, prohibition of abolition of citizenship on the basis of, inter alia, language, language as one of the vital interests of the constitutional peoples, and the 1992 UN Declaration on the Rights of Persons Belonging to National or Ethnic, Religious and Linguistic Minorities and European Charter for Regional or Minority Languages as instruments for the protection of human rights with the legal effects of constitutional provisions. ${ }^{245}$

Most ICTY cases were adjudicating on crimes committed by Serb(ian)s and/or Croat(ian)s in B\&H against B\&H Muslims. In fact, the ICTY tried a total of 91 defendants for crimes committed in B\&H, 14 in Kosovo, 11 in Croatia, 4 in B\&H and Croatia, and 2 in Macedonia. Out of those 87 defendants tried for crimes committed in $\mathrm{B} \& \mathrm{H}$, joint crimes in $\mathrm{B} \& \mathrm{H}$ and Croatia excluded, 74 committed crimes specifically targeting non-Serbs, including 39 specifically targeting Bosnian Muslims, 10 committed crimes specifically targeting non-Muslims, and 3 committed crimes specifically targeting non-Croats. ${ }^{246}$ Indeed, operationally, the bulk of the ICTY trials were about crimes committed against B\&H Muslims in B\&H, where population speaks the Bosnian language or, rather, does not speak Croatian as spoken in Croatia or Serbian as spoken in Serbia.

\footnotetext{
${ }^{244}$ Although the issue of the name of the official languages in B\&H has been circumvented in the Constitutions of B\&H, FB\&H, and $\mathrm{RS}$, and the entire topic regarding the contemporary languages in B\&H is beyond the scope of this study, several observations on the current state of linguistic affairs are in order. The independence of B\&H also saw the resurgence of Bosnian Muslim nationalism, albeit unorganized and incomprehensive, but as heavy-handed as that of the Serbs and of the Croats. During the war, Bosnian Muslim leaders decided on their own to use the previously discussed old term for all Bosnians, Bosniak, to denote Bosnian Muslims only. In Turkish and French which were major European languages, the first being the language of administration in B\&H for centuries and the second being the major language of European diplomacy until the First World War, the word for modern day Bosnian is "Boşnak" and "bosniaque," respectively, which coincides with the contemporary Bosnian word for Bosnian Muslim: Bošnjak or Bosniak, as translated into English (the translation into French and Turkish remains the same). Here it is worth noting that the terms Bosanac and Bošnjak both derive from the toponym Bosna 'Bosnia' [itself derived from a hydronym of pre/Indo/European origin]. The corresponding adjectives (masculine and plural) are bosanski and bošnjački. During the pre-Yugoslav period, these were synonymous, but in the post-Yugoslav period, they have been differentiated. During the war, some media reported about the B\&H Muslim Army. This B\&H Muslim Army fought against the B\&H Croat Army and the B\&H Serb Army, which were, indeed, homogenous enough to deserve the name. However, the B\&H Army could not have been described as Muslim because people of all ethnicities fought side by side for their homeland, B\&H. In addition, there are many people throughout B\&H and former Yugoslavia from all three ethnic groups with the last names Bošnjak, Bošnjo or Bošnjaković, denoting their national origins. Naturally, this appropriation provoked quite a stir among the B\&H Serbs and B\&H Croats who also considered themselves Bosnian. Therefore, once presenting themselves as the sole protectors of the Bosnian identity, Muslim leaders missed a chance to unite all B\&H citizens under a common Bosnian identity and distanced the others even further away from B\&H. The way it is used now, unfortunately, the term Bosniak describes a member of a religious group. In that vein, some Serbs and some Croats are still very quick to point out that the Bosnian language does not exist at all and that, by extension to the Bosniak identity, there can be only Bosniak language. But that language can be as much Bosniak language or Muslimish as it can be Catholic language or Buddhist language. This is nothing novel as Friedman informs that "what's in a name can be rather what one power bullies others into doing. I had to smile, albeit not happily, at the recent media flap over moving the Gulf of Arabia from the west side of the peninsula (where it is also known as the Red Sea) to the east (also known as the Persian Gulf). The world is actually full of such contested names, from the part of southern Albania called Çamëri, that Greeks insist is Northern Epirus, to the Malay-speakers of southern Thailand that the Thai government calls Muslim Thais. Interestingly enough, the Greek government does something similar to its Turkish-speaking citizens, who are officially Muslim Greeks and whose language in Greece is called Mousoulmaniká Thrákēs, i.e. 'Muslimish of Thrace' (Ellēnikē dialektologia 5[1996-1998]) (Friedman, V.A. (2011), Families, Leagues, and Hybridity: The Past and Future of Slavic and East European Languages (University of Chicago, AATSEEL keynote address). Slavic and East European Journal. Vol 55(1).1-13. 2011.).

${ }^{245}$ Constitution of the FB\&H (1994), Articles 1, 6, 1, 5, 11a, Appendix. Constitution of the Republika Srpska (2005), Articles 1, 7, 34, 10 and 112.

${ }^{246}$ ICTY, Cases.
} 
ICTY trials uncovered a great deal of evidence about the citizens of B\&H being persecuted during the war on $\mathrm{B} \& \mathrm{H}$ only because they were speaking the Bosnian language and displaying their B\&H identity. ${ }^{247}$

A guard came up, and I heard him say that his name was Pop, Popovic, actually, but his nickname was Pop. And [according to a friend] he said, "Well, bon appetit," that sort of thing. And my friend used not a Muslim but a Bosnian word meaning enjoy your meal, "bujrum." And Serbs and Croats know what that means. It means, well, "Have some yourself," sort of thing, in translation, "bujrum." And Pop said to him, "Who are you saying bujrum to, you motherfucker?" And he took him up from the bench, ordered him to stand up against the wall, and with his three fingers he made him stretch out his legs and the beating began. Those of us who were on the pista were ordered to lie down on our stomachs with our heads down, and we of course obeyed. And this went on for about five minutes, this beating, perhaps ten minutes. ${ }^{248}$

There was no evidence in the ICTY's open sources to show killings that resulted from the use of a word from the Croatian or the Serbian language in front of a Bosnian Muslim perpetrator. There were only more examples of killings and persecution of the peoples of $\mathrm{B} \& \mathrm{H}$ because they were expressing their linguistic identity. ${ }^{249}$ Scholars argue that "linguistic identity" may refer to a sense of belonging to a community. ${ }^{25^{\circ}}$ In that sense, the above description of a murder of an innocent man after using a word common to all ethnic groups in $\mathrm{B} \& \mathrm{H}$ was, indeed, senseless on many levels: if the perpetrator did not understand the word bujrum as being part of his own linguistic identity, why else did he get so offended at its use as to commit the murder? The B\&H people's linguistic identity was not the only thing under attack, as violations included attacks against an overall B\&H identity in the form of cultural persecution. A Bosnian survivor of the Serbian concentration camp describes the standard cultural persecution:

That same evening, they called out names one by one, telling us to come out. We stood against the wall below the cell window, with our feet apart, with three fingers leaning against the wall... Three fingers is, I suppose, their salute. Instead of saying "Zdravo" [Hello] as we used to say to each other before, they would point their three fingers, thumb and the two fingers next to it. This was their salute. ${ }^{25^{1}}$

Finally, Serbian religious fundamentalism, based on the non-uniform differences between the peoples, continued to be used as a basis for the persecution and murder of B\&H Muslims:

A. Behind my apartment building in the so-called JNA hall there was a radio station, and there were loudspeakers so that this broadcast could be heard really well. Two things that I remember very vividly and which I can quote is that, "Hodza's voice will not be heard in Foca anymore," and that "circumcised Muslim children will not walk around the town anymore." So these two statements, in addition to the war conditions and so on, is something that I remember quite vividly.

Q. You said “hodza's voice." Could you explain what you meant by that? It may not be clear.

\footnotetext{
${ }^{247}$ ICTY transcripts, Milošević, T. 25607; Vasiljević, T. 3617-3618.

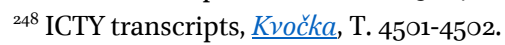

${ }^{249}$ ICTY transcripts, Stakić, T. 15-21; Kvočka, T. 271-272 and T. 1732-1733.

${ }^{250}$ Juergensmeyer, M. and Anheier H. (eds.) (2012), The Encyclopedia of Global Studies. Sage: Thousand Oaks, CA, p. $1080-1084$.

${ }^{251}$ ICTY transcripts, $\underline{\text { Kvočka, T. } 5158 .}$
} 
A. This means that the Muslim -- Islamic religion would not be present there anymore, and also that there wouldn't be any more Muslim children there, because they had mentioned circumcised Muslim children, which means that all those children would be destroyed. ${ }^{252}$

All these attempts to encourage the murder of an entire people serve as an example of systematic and widespread genocide. None have been specifically prosecuted as a crime of atrocity speech or mentioned in any verdicts pronounced by the ICTY.

\subsection{Interim conclusions}

The journey toward linguistic justice based on a top-down examination of the institution of justice, embodied at the UN as the main venue for the prevention of war and protection of human rights, and examination of the situation country, embodied in the former Yugoslavia and $\mathrm{B} \& \mathrm{H}$, as the venue where crimes occurred, is completed. Chapters 2 and 3 describe inherent institutional difficulties in relation to international criminal justice and provide an overview of language and identity-related issues in $\mathrm{B} \& \mathrm{H}$ that had to be tackled by the working institution, the ICTY.

Indeed, language and identity-related issues did contribute to the commission of ethnic crimes in B\&H through a long and comprehensive history of hate campaigns against the citizens of B\&H by their neighbors, the Serbs and the Croats, amounting to a philosophy of hate. On the one hand, this philosophy of hate which led to ethnic crimes has its roots in a comprehensive political, literary, and language campaign by the perpetrators, here the $\operatorname{Serb}(\mathrm{ian}) \mathrm{s}$, and the lack of a consistent, persistent, and unified response to the language and identity-related hate campaign by the peoples of B\&H. On the other hand, this philosophy of hate could not have been dealt with properly because the peoples of B\&H lived in totalitarian societies, be it under the Ottomans, Austro-Hungarians, Karađorđević dynasty, or the Communists, so they did not have any legal or societal tools to address any of the language and identity-related statements stemming from the hate campaign. The hate campaign was allowed to continue undisturbed during the Second Yugoslavia because it was considered an expression of patriotism. The world then was not what it is now, i.e. there was no awareness of the extent of damage that not responding to these issues could cause.

The war against B\&H has shown that B\&H Muslims have been murdered, raped, expelled, and confined to concentration camps purely because they were Muslims: the alleged atavism of the gory Ottoman past and alleged unrepentant renegades from the bosom of Eastern or Western Christianity, depending on the perpetrator. The evidence of language and identity-related crimes was overwhelming, but someone must have decided not to charge anyone for speech atrocity crimes. The ICTY OTP had an opportunity to address language and identity-related issues in almost all of the trials that revolved around B\&H because major works constituting the philosophy of hate did crop up during trials. However, the ICTY OTP did not make any statements on language and identity-related crimes. Instead, the ICTY allowed the evidence to speak for itself. This is problematic because no legal truths have been established on any of these language and identity-related issues for posterity. These legal truths could have been addressed in the verdicts by the judges if the parties had argued them more vigorously. As a consequence, international criminal justice is silent on the language and identity-related issues as the underbelly of the ethnic crimes committed against B\&H and Yugoslavian Muslims. Denialism still reigns supreme in the former Yugoslavia in the aftermath of the ICTY's efforts.

This is how the things stand locally. The next chapter reviews normative language-related rights, obligations, and requirements on the parties involved in international criminal tribunals - from IMT and IMTFE to the present day - and language-related ICTY case law asking whether language-related rights, obligations, and requirements provide for procedural equality between the prosecution and defense, what is the

\footnotetext{
${ }^{252}$ ICTY transcripts, Krnojelac, T. 2737-2738.
} 
role of legal and language professionals when working together in an international criminal context, and what is the role of translation and interpreting at international criminal tribunals. 
Chapter 4: May the legal institution take the stand, please

Chapitre 4 : L'institution judiciaire est priée de venir à la barre

Četvrto poglavlje: Neka pristupi pravna institucija 
The third and the final stop on the first leg of the journey toward linguistic justice at international criminal tribunals examines normative language-related rights, obligations, and requirements on the parties. This leg will start from the IMT and the IMTFE, spanning to the present-day international criminal tribunals and language-related ICTY case law. Since this study endorses the Black's Law Dictionary definition that the party is a person who takes part in legal transactions or proceedings, this examination will encompass: judges, registrar, prosecution, defense, defendants, witnesses, and language professionals. ${ }^{253}$ The purpose of the following examination is to show the position in which international criminal laws put translation, interpreting, and transcription. This examination consists of three parts. The first part describes language-related rights, obligations, and requirements on the judges, registrar, prosecutors, defendants, and defense. The second part examines whether the existing language-related rights, obligations, and requirements provide for procedural equality of arms between Prosecution and Defense at the ICTY. Finally, the third part addresses issues related to legal and language professionals working together, examining their duties toward each other and duties they have toward their clients individually and together. The first examination is conducted to set the type of linguistic justice that must be delivered to the parties in the ICTY and subsequently established tribunals' rules and regulations (statutes, RPEs, etc.). The second examination is conducted to determine whether those rules and regulations worked in practice (practice directions, court decisions and rulings, etc.), and the final examination is conducted to establish how well the legal background to translation and interpreting at the ICTY enabled the proper practical delivery of translation, interpreting, and transcription services. Here, linguistic justice should be understood as the question whether the parties have been communicated with in their own language.

4.1. Due process and language-related rights, obligations, and requirements

Whereas international law deals with the responsibilities of states, criminal law deals with individuals who can be sanctioned and penalized by a State. Therefore, international criminal law deals with the criminal responsibility of individuals. The international criminal law regime, born at the time of the IMT and IMTFE, evolved with the ICTY and subsequently established a number of international criminal tribunals. This body of law is new, not yet uniform, and its courts are not universal. ${ }^{254}$ The IMT closed in 1946, the IMTFE closed in 1948, the ICTY was established in 1993, the ICTR in 1995, the ICC opened its doors in 2002, and various hybrid tribunals followed: SCSL in 2002, ECCC in 2006, and STL in 2009. There are several differences between these international criminal tribunals that have been conditioned by the times in which they were established, establishing authorities, and the state of law at the time of their establishment. Some of these differences had a bearing on language-related rights, obligations, and requirements on the parties during the proceedings.

\footnotetext{
${ }^{253}$ Gardner, B. (2010), The Black's Law Dictionary (ninth edition). West: St. Paul, p. 1232.

${ }^{254}$ Cryer, R., Friman, H., Robinson, D. and Wilmshurst, E. (2013), An introduction to international criminal law and procedure (second edition). Cambridge University Press: New York, p. 3.
} 
Table 2. Major international criminal tribunals

\begin{tabular}{|c|c|c|c|c|c|c|c|c|}
\hline Court & IMT & IMTFE & ICTY & ICTR & ICC & SCSL & STL & ECCC \\
\hline Activity & $\begin{array}{l}\text { 18-10-1945 } \\
\text { Closed after } 1 \text { year }\end{array}$ & $\begin{array}{l}29-04-1946 \\
\text { Closed after } 2.5 \\
\text { years }\end{array}$ & $\begin{array}{l}\text { 17-11-1993 } \\
\text { Residual mecha- } \\
\text { nism }\end{array}$ & $\begin{array}{l}\text { 27-11-1995 } \\
\text { Residual mecha- } \\
\text { nism }\end{array}$ & $\begin{array}{l}\text { 1-07-2002 } \\
\text { Permanent }\end{array}$ & $\begin{array}{l}\text { 1-07-20O2 } \\
\text { Residual mecha- } \\
\text { nism }\end{array}$ & $\begin{array}{l}\text { 1-03-2009 } \\
\text { Operational }\end{array}$ & $\begin{array}{l}\text { 18-o1-2006 } \\
\text { Operational }\end{array}$ \\
\hline $\begin{array}{l}1^{\text {st indict- }} \\
\text { ment }\end{array}$ & 20-10-1945 & 29-04-1946 & 4-11-1994 & 22-11-1995 & 8-07-2005 & 7-03-2003 & $17-01-2011$ & $19-09-2007$ \\
\hline $1^{\text {st }}$ trial & 20-11-1945 & 3-05-1946 & 7-05-1996 & 9-01-1997 & 26-01-2009 & 3-06-2004 & $16-01-2014$ & $30-03-2009$ \\
\hline $\begin{array}{l}1^{\text {st }} \text { judg- } \\
\text { ment }\end{array}$ & $1-10-1946$ & $12-11-1948$ & 29-11-1996 & 2-09-1998 & $14-03-2012$ & 20-06-2007 & 28-09-2015 & $26-07-2010$ \\
\hline Seat & Nuremberg & Tokyo & The Hague & $\begin{array}{l}\text { Arusha and The } \\
\text { Hague }\end{array}$ & The Hague & $\begin{array}{l}\text { Freetown and The } \\
\text { Hague }\end{array}$ & The Hague & Phnom Penh \\
\hline Character & $\begin{array}{l}\text { Ad hoc interna- } \\
\text { tional military tri- } \\
\text { bunal }\end{array}$ & $\begin{array}{l}\text { Ad hoc interna- } \\
\text { tional military tri- } \\
\text { bunal }\end{array}$ & $\begin{array}{l}\text { Ad hoc interna- } \\
\text { tional criminal } \\
\text { tribunal }\end{array}$ & $\begin{array}{l}\text { Ad hoc interna- } \\
\text { tional criminal } \\
\text { tribunal }\end{array}$ & $\begin{array}{l}\text { Permanent inter- } \\
\text { national criminal } \\
\text { tribunal }\end{array}$ & $\begin{array}{l}\text { Ad hoc hybrid tri- } \\
\text { bunal }\end{array}$ & $\begin{array}{l}\text { Ad hoc hybrid tri- } \\
\text { bunal }\end{array}$ & $\begin{array}{l}\text { Ad hoc hybrid tri- } \\
\text { bunal }\end{array}$ \\
\hline $\begin{array}{l}\text { Estab- } \\
\text { lished by }\end{array}$ & Treaty $^{255}$ & $\begin{array}{l}\text { Special Proclama- } \\
\text { tion }^{25^{6}}\end{array}$ & $\begin{array}{l}\text { UN Security } \\
\text { Council Resolu- } \\
\text { tion }^{257}\end{array}$ & $\begin{array}{l}\text { UN Security } \\
\text { Council Resolu- } \\
\text { tion }^{258}\end{array}$ & Rome Statute $^{259}$ & $\begin{array}{l}\text { Agreement: Sierra } \\
\text { Leone and } \mathrm{UN}^{26 \circ}\end{array}$ & $\begin{array}{l}\text { Agreement: Leba- } \\
\text { non and } \mathrm{UN}^{261}\end{array}$ & $\begin{array}{l}\text { Agreement: Cam- } \\
\text { bodia and } \mathrm{UN}^{262}\end{array}$ \\
\hline
\end{tabular}

${ }^{255}$ IMT, Control Council Law No. 10 (1945).

${ }^{256}$ IMTFE, Special proclamation by the Supreme Commander (1946).

${ }^{257} \mathrm{UN}$ Security Council Resolution 827 on the establishment of the ICTY (S/RES/827) (1993).

${ }^{25} 8$ UN Security Council Resolution 955 on the establishment of the ICTR (S/RES/955) (1994).

${ }^{259}$ ICC, Rome Statute (2002).

${ }^{260} \mathrm{UN}$, Agreement between the UN and the government of Sierra Leone (2002).

${ }^{261}$ UN Security Council Resolution 1757 on the establishment of the [STL] (S/RES/1757) (2007).

${ }^{262} \mathrm{UN}$, Agreement between the UN and the Royal Government of Cambodia (2003). 


\begin{tabular}{|c|c|c|c|c|c|c|c|c|}
\hline Court & IMT & IMTFE & ICTY & ICTR & ICC & SCSL & STL & ECCC \\
\hline $\begin{array}{l}\text { Governing } \\
\text { documents }\end{array}$ & $\begin{array}{l}\text { IMT-C }{ }^{263} \\
\text { IMT RoP }{ }^{264}\end{array}$ & $\begin{array}{l}\text { IMTFE-C }{ }^{265} \\
\text { IMTFE RoP }^{266}\end{array}$ & $\begin{array}{l}\text { ICTY-S }{ }^{267} \\
\text { ICTY RPE }^{268}\end{array}$ & $\begin{array}{l}\text { ICTR-S }^{269} \\
\text { ICTR RPE }^{270}\end{array}$ & $\begin{array}{l}\text { Rome Statute } \\
\text { ICC RPE }{ }^{271}\end{array}$ & $\begin{array}{l}\text { SCSL-S }{ }^{272} \\
\text { SCSL RPE }^{273}\end{array}$ & $\begin{array}{l}\text { STL-S } \\
\text { STL RPE } \\
\text { ST5 }\end{array}$ & $\begin{array}{l}\text { ECCC Law }{ }^{276} \\
\text { ECCC IR }^{277}\end{array}$ \\
\hline $\begin{array}{l}\text { Temporal } \\
\text { and terri- } \\
\text { torial juris- } \\
\text { diction }\end{array}$ & $\begin{array}{l}\text { Crimes commit- } \\
\text { ted by the Euro- } \\
\text { pean Axis coun- } \\
\text { tries during the } \\
1939-1945 \text { war }\end{array}$ & $\begin{array}{l}\text { Crimes commit- } \\
\text { ted by the Far } \\
\text { Eastern war crim- } \\
\text { inals during the } \\
\text { 1939-1945 war }\end{array}$ & $\begin{array}{l}\text { Crimes commit- } \\
\text { ted by all sides } \\
\text { since } 1991\end{array}$ & $\begin{array}{l}\text { Crimes commit- } \\
\text { ted during } 1994\end{array}$ & $\begin{array}{l}\text { Crimes commit- } \\
\text { ted since } 1 \text { July } \\
2002\end{array}$ & $\begin{array}{l}\text { Crimes commit- } \\
\text { ted against civil- } \\
\text { ians and UN } \\
\text { peacekeepers } \\
\text { during the 1991- } \\
2002 \text { civil war } \\
\end{array}$ & $\begin{array}{l}\text { Crimes relating to } \\
\text { the attack and as- } \\
\text { sassination of } \\
\text { Prime Minister } \\
\text { Hariri }\end{array}$ & $\begin{array}{l}\text { Crimes commit- } \\
\text { ted by Khmer } \\
\text { Rouge between } \\
1975 \text { and } 1979\end{array}$ \\
\hline $\begin{array}{l}\text { Subject ju- } \\
\text { risdiction }\end{array}$ & $\begin{array}{l}\text { Individuals or or- } \\
\text { ganizations }\end{array}$ & $\begin{array}{l}\text { Individuals or or- } \\
\text { ganizations }\end{array}$ & $\begin{array}{l}\text { All natural per- } \\
\text { sons }\end{array}$ & $\begin{array}{l}\text { All natural per- } \\
\text { sons }\end{array}$ & $\begin{array}{l}\text { All natural per- } \\
\text { sons }\end{array}$ & $\begin{array}{l}\text { All natural per- } \\
\text { sons }\end{array}$ & $\begin{array}{l}\text { All natural per- } \\
\text { sons }\end{array}$ & $\begin{array}{l}\text { All natural per- } \\
\text { sons }\end{array}$ \\
\hline $\begin{array}{l}\text { Types of } \\
\text { crimes }\end{array}$ & $\begin{array}{l}\text { Crimes against } \\
\text { peace, war } \\
\text { crimes, crimes } \\
\text { against humanity. }\end{array}$ & $\begin{array}{l}\text { Crimes against } \\
\text { peace, conven- } \\
\text { tional war crimes, } \\
\text { crimes against } \\
\text { humanity. }\end{array}$ & $\begin{array}{l}\text { War crimes, } \\
\text { crimes against } \\
\text { humanity, geno- } \\
\text { cide }\end{array}$ & $\begin{array}{l}\text { War crimes, } \\
\text { crimes against } \\
\text { humanity, geno- } \\
\text { cide }\end{array}$ & $\begin{array}{l}\text { War crimes, } \\
\text { crimes against } \\
\text { humanity, geno- } \\
\text { cide, aggression }\end{array}$ & $\begin{array}{l}\text { War crimes, } \\
\text { crimes against } \\
\text { humanity }\end{array}$ & $\begin{array}{l}\text { Acts of terrorism } \\
\text { and crimes and } \\
\text { offences against } \\
\text { life and personal } \\
\text { integrity }\end{array}$ & $\begin{array}{l}\text { War crimes, } \\
\text { crimes against } \\
\text { humanity, geno- } \\
\text { cide }\end{array}$ \\
\hline
\end{tabular}

${ }^{263}$ IMT, Charter (1945).

${ }^{264}$ IMT, Rules of Procedure (1945).

${ }^{265}$ IMTFE, Charter (1946).

${ }^{266}$ IMTFE, Rules of Procedure (1946).

${ }^{267}$ ICTY, $\underline{\text { tatute }}$ (2009).

${ }^{268}$ ICTY, Rules of Procedure and Evidence (2015).

${ }^{269}$ ICTR, Statute (2000).

${ }^{270}$ ICTR, Rules of Procedure and Evidence (2000).

${ }^{271}$ ICC, Rules of Procedure and Evidence (2013).

${ }^{272}$ SCSL, Statute (2012).

${ }^{273}$ SCSL, Rules of Procedure and Evidence (2012).

${ }^{274}$ STL, Statute (2016).

${ }^{275}$ STL, Rules of Procedure and Evidence (2017)

${ }^{276}$ ECCC, ECCC Law (2004).

${ }^{277}$ ECCC, Internal Rules (2015). 
The first difference between these international criminal tribunals lies in their character: ad hoc tribunals have been established only for a specific purpose and have a specific temporary and territorial jurisdiction (IMT, IMTFE, ICTY, ICTR, SCSL, STL, ECCC) whereas the ICC is the only permanent international criminal tribunal. The next difference is in their nature: whereas international military tribunals (IMT and IMTFE) are courts of law established to try military personnel and organizations for crimes, international criminal tribunals are courts of law established to try all natural persons accused of war crimes and crimes against humanity (ICTY, ICTR, and ICC) ${ }^{278}$ Since 2017 , the ICC, as the only permanent international criminal court also has jurisdiction over the crime of aggression. ${ }^{279}$ Hybrid tribunals, also called internationalized tribunals, are courts of law whose structure and applicable law consist of both international and national elements (SCSL, STL, and ECCC). ${ }^{280}$ The major differences between international military tribunals and international criminal tribunals are that the international military tribunals are governed by military laws, they are deliberated by a jury, defendants have no say in jury selection, jury verdicts had to be unanimous, the defendants could not plead guilty, and the appeals process was different. The major differences between the international criminal tribunals and hybrid tribunals are related to their funding and jurisdiction. Although all these international criminal tribunals, apart from IMT and IMTFE, were co-established by the UN, it is not the case that the UN entirely funds all of them or, when it does, as Chapter 6 shows in the case of the ICTY, it does not finance every department and it does not do so in full. Another significant difference between these international criminal tribunals lies in the subject jurisdiction of these tribunals: the IMT and IMTFE could try organizations, whereas other tribunals can only try natural persons. The STL is the only modern international criminal tribunal which can try the accused in absentia. As far as individual criminal responsibility is concerned, the most important difference between all these tribunals is that the IMT and IMTFE could impose the death sentence, whereas others cannot. Finally, a residual mechanism tribunal is a type of tribunal set up to perform the remaining functions of the previous standing tribunal.

All the above courts are blended, i.e. they apply certain segments of the Common Law and certain segments of the Civil Law in their work. The Common Law is practiced in countries such as USA, UK, most of Canada, New Zealand, and Australia or, as one scholar has put it: in countries where English is the language of the law. ${ }^{281}$ The Civil Law is practiced in virtually all other countries. There is a substantive and procedural due process practiced before international criminal tribunals. Language-related rights, duties, and obligations on the parties participating in a legal process fall under the procedural due process. According to Bassiouni, procedural due process includes guarantees that ensure that defendants have every reasonable opportunity to make a full and free defense including, inter alia, the right to have all proceedings conducted in or translated into his own language. ${ }^{282}$ In Common Law, the defendant is considered innocent until proven guilty: the truth about the defendant's involvement in the case is established during the trial. The judges listen to the facts and decide together on the issue of the defendant's involvement in the case. The judges do not perform any investigations: investigators do. The judges also do not question the witnesses outside the courtrooms: attorneys do. Attorneys prepare witnesses for their testimony in the court through the assistance of interpreters in a process called "proofing." This means that the first translation and interpreting clients at the international criminal tribunals working under the tenets of Common Law are the investigators and the attorneys. The person at the center of all investigative and lawyerly activities at any court is the defendant. Defendants are the co-first translation and interpreting clients at international criminal tribunals. Not all language professionals encounter defendants, but all their activities revolve around them. Defendants have certain language-related rights, obligations, and requirements during pre-trial procedures, when arrested, when taken

\footnotetext{
${ }^{278}$ McMorran, C. (2003), International War Crimes Tribunals: beyond intractability. Conflict Information Consortium, University of Colorado: Boulder.

${ }^{279}$ ICC Press Release (2017), Assembly activates Court's jurisdiction over crimes of aggression.

${ }^{280}$ Williams, S. (2012), Hybrid and Internationalised Criminal Tribunals. Hart Publishing: London.

${ }^{281}$ Gibbons, J. (2003), Forensic linguistics: an introduction to language in the justice system. Blackwell: Hoboken, p. 5 .

${ }^{282}$ Bassiouni, C. (2011), Crimes against humanity: historical evolution and contemporary application. Cambridge University Press: Cambridge, UK, p. 119 .
} 
to custody, during their initial appearance, throughout, and at the end of the proceedings. However, they cannot determine their own legal position in an appropriate manner without translation and interpreting into their language. So, it is of the utmost importance that defendants can exercise their language rights.

It is natural to take the IMT and IMTFE as the starting point for a discussion about procedural due process: they were the only international criminal tribunals that existed before the ICTY. However, a large time difference of 47 years and fundamental differences between these international criminal tribunals make these institutions virtually impossible to compare. 
Table 3. Due process rights at the IMT, IMTFE, ICTY, ICTR, SCSL, STL and ECCC

\begin{tabular}{|c|c|c|c|c|c|c|c|c|}
\hline Court & IMT & IMTFE & ICTY & ICTR & ICC & SCSL & STL & ECCC \\
\hline $\begin{array}{l}\text { Designation of de- } \\
\text { fendants }\end{array}$ & Defendants & Accused & Suspects, accused & $\begin{array}{l}\text { Suspects, ac- } \\
\text { cused }\end{array}$ & $\begin{array}{l}\text { Accused, persons during } \\
\text { investigation }\end{array}$ & $\begin{array}{l}\text { Suspects, ac- } \\
\text { cused }\end{array}$ & Suspects, accused & $\begin{array}{l}\text { Suspects, } \\
\text { charged per- } \\
\text { sons, accused }\end{array}$ \\
\hline $\begin{array}{l}\text { Liable to death sen- } \\
\text { tence }\end{array}$ & Article 27 & Article 16 & No & No & No & No & No & No \\
\hline $\begin{array}{l}\text { Presumption of inno- } \\
\text { cence }\end{array}$ & $\begin{array}{l}\text { Not men- } \\
\text { tioned }\end{array}$ & $\begin{array}{l}\text { Not men- } \\
\text { tioned }\end{array}$ & Article 21(3) & Article $20(3)$ & Article 66 & Article $17(3)$ & Article 16(3)(a) & Article 35 \\
\hline Trials in absentia & Article 12 & No & No & No & No & No & $\begin{array}{l}\text { Article 22; Section } \\
6 \text {, Rules } 105 \text { bis-109 }\end{array}$ & No \\
\hline Right: fair trial & Article 12 & Article 9 & Article 21 $(2)$ & Article $2 \circ(2)$ & Article $67(1)$ & Article $17(2)$ & Article 16(2) & Article 35 \\
\hline $\begin{array}{c}\text { Right: to be informed } \\
\text { of charges }\end{array}$ & Article $16(a)$ & Article 9(a) & Article $21(4)(a)$ & Article $20(4)(a)$ & Article $67(1)(a)$ & $\begin{array}{l}\text { Article } \\
17(4)(a)\end{array}$ & Article 16(4)(a) & Article $35(a)$ \\
\hline $\begin{array}{l}\text { Right: expeditious } \\
\text { trial and time for } \\
\text { preparation of a de- } \\
\text { fense }\end{array}$ & $\begin{array}{l}\text { Article 18(a), } \\
\text { Article 19; } \\
\text { Rule } 11\end{array}$ & $\begin{array}{l}\text { Article } \\
12(a), \text { Arti- } \\
\text { cle } 13\end{array}$ & Article 21(4)(b) & Article $20(4)(c)$ & Article $67(1)(b)$ & $\begin{array}{l}\text { Article } \\
17(4)(b)\end{array}$ & Article 16(4)(b) & Article $35(d)$ \\
\hline Right: counsel & Article 16(d) & Article 9(c) & Article 21(4)(d) & Article $20(4)(b)$ & Article $67(1)(b)$ & $\begin{array}{l}\text { Article } \\
17(4)(b)\end{array}$ & Article $15(\mathrm{e})$ & Article $35(d)$ \\
\hline $\begin{array}{l}\text { Right: examine wit- } \\
\text { nesses or have them } \\
\text { examined }\end{array}$ & Article $16(\mathrm{e})$ & Article 9(d) & Article 21(4)(e) & Article $20(4)(\mathrm{e})$ & Article $67(1)(e)$ & $\begin{array}{l}\text { Article } \\
17(4)(e)\end{array}$ & Article 16(4)(e) & Article 35(e) \\
\hline Right: remain silent & $\begin{array}{l}\text { Not men- } \\
\text { tioned }\end{array}$ & $\begin{array}{l}\text { Not men- } \\
\text { tioned }\end{array}$ & $\begin{array}{l}\text { Rule } 42(\mathrm{~A})(\mathrm{iii}): \text { Sus- } \\
\text { pect; Rule } 55(\mathrm{E}): \\
\text { Accused. }\end{array}$ & $\begin{array}{l}\text { Rule } 42(A)(\text { iii): } \\
\text { Suspects. }\end{array}$ & $\begin{array}{l}\text { Article } 67(1)(\mathrm{g}) \text { : Accused; } \\
\text { Article } 55(2)(\mathrm{b}) \text { : Person } \\
\text { during investigation }\end{array}$ & $\begin{array}{l}\text { Rule } 42(\mathrm{~A}) \\
\text { (iii): suspect }\end{array}$ & $\begin{array}{l}\text { Rule } 65(A)(\text { iv): Sus- } \\
\text { pect; Rule 1144(B): } \\
\text { Accused. }\end{array}$ & Rule 21(D): all \\
\hline Right: interpreter & $\begin{array}{l}\text { Article 16(a), } \\
\text { 16(c), Article } \\
25\end{array}$ & Article 9(b) & $\begin{array}{l}\text { Article } 21(4)(\mathrm{f}) \\
\text { Rule } 42(\mathrm{~A})(\mathrm{ii})\end{array}$ & $\begin{array}{l}\text { Article } 20(4) \\
\text { (f), Rule } 42(\mathrm{~A}) \\
\text { (ii) }\end{array}$ & $\begin{array}{l}\text { Article 55(1)(c), Article } \\
67(1)(\mathrm{f}) ; \text { Rule } 203(3)(\mathrm{a})\end{array}$ & $\begin{array}{l}\text { Article } 17 \\
\text { (4)(f); Rule } 42 \\
\text { (A) (ii) }\end{array}$ & $\begin{array}{l}\text { Article } 15(\mathrm{~d}) \text {; Arti- } \\
\text { cle } 16(\mathrm{~g}) \\
\text { Rule } 65(\mathrm{~A})(\mathrm{iii})\end{array}$ & $\begin{array}{l}\text { Article 24, Arti- } \\
\text { cle } 35(\mathrm{f})\end{array}$ \\
\hline
\end{tabular}


Due process-related differences between these international criminal tribunals are related to the notion of the defendant. IMT rules and regulations designate defendants as "defendants." IMTFE rules and regulations designate defendants as "accused." IMT and IMTFE do not explicitly mention "suspects." The next international criminal tribunals designated defendants as accused (ICTY, ICTR, ICC, SCSL, STL, ECCC), suspects (ICTY, ICTR, SCSL, STL, ECCC), persons under investigation (ICC), and charged persons (ECCC). The ECCC's designation "charged person" describes a person who is considered to have committed a crime and who has been charged. It could be said that the ICC's designation "persons under investigation" is a modern-age politically correct term constructed to take away the stigma normally associated with the notion of "suspects." All these differences in procedural due process rights between these international criminal tribunals had effect on language-related rights, obligations, and requirements of persons participating in judicial process before international criminal tribunals.

\title{
4.1.1. Pre-ICTY due process language-related rights, obligations, and requirements
}

The IMT Charter (IMT-C) and the Rules of Procedure (IMT RoP) imposed several language-related rights, obligations, and requirements on all parties in the proceedings. The IMT-C established that the official documents and court proceedings shall be held in English, French and Russian, the language of the defendant, and, if it is in the interests of justice and public opinion, in the language of the country where the IMT is sitting without proclaiming any official languages. ${ }^{283}$ In practice, the IMT operated in these three languages only. However, some scholars referred to the other side of efforts to maintain the practicality of the Court while taking the linguistic identity of the testifying witnesses into account.

\begin{abstract}
As Annette Wieviorka notes, the Yiddish-speaking poet, Abraham Sutzkever, the only witness to give testimony specifically on the destruction of European Jewry at IMT, is usually taken as a figure of the elision of victims in Nuremberg. His desire to testify in Yiddish - "I want to speak in Yiddish, any other language is out of the question," he wrote in his diary, was thwarted; no translator was made available, and he gave his account of the mass execution of the Jewish population of Vilnius in halting Russian. ${ }^{284}$
\end{abstract}

This is the first example of an earlier statement that situation countries often seem to be overlooked by international criminal justice authorities when it comes to all the intricacies related to local cultures, customs, languages, etc. The above was not an isolated case: the IMT did not make the language of victims official (Yiddish, Polish, Serbo-Croatian, Sinti, Romani, etc.) and was unable to provide translation or interpreting into/from those languages. According to some sources, 33 witnesses at the IMT testified for the prosecution, 80 witnesses testified for the defense, including 19 of the defendants, and an additional 140 witnesses provided evidence for the defense through written interrogatories. ${ }^{285}$ These "written interrogatories" would be simply called "witness statements" nowadays.

The IMT-C also established that the preliminary examination and trial of the defendant shall be conducted in, or translated into, a language which the defendant understands. ${ }^{286}$ The IMT RoP extended this principle further to German and the language of the document. ${ }^{287}$ The IMT-C established that the defendant has a right to translation of the indictment and accompanying documents into a language which s/he understands. ${ }^{28}$ The IMT RoP extended this further to include the right to a translation of IMT-C, the statement of

\footnotetext{
${ }^{283}$ IMT-C, Article 25 .

${ }^{284}$ Laban Hinton A., La Pointe T., Irvin-Erickson D. (eds.) (2014), Hidden Genocides: Power, Knowledge, Memory. Rutgers University Press: New Brunswick, p. 195 .

${ }^{285}$ Holocaust Education and Archive Research Team, The First Nuremberg Trial.

${ }^{286}$ IMT-C, Article 16(c).

${ }^{287}$ IMT RoP, Rule 9(b).

${ }^{288}$ IMT-C, Article 16(a).
} 
defendants' right to defense, amendments or additions to the indictment, and evidence for the defense. ${ }^{289}$ The IMT RoP established that the General Secretary of the IMT Secretariat should appoint, inter alia, interpreters. ${ }^{290}$ However, IMT RoP also explicitly orders that of all persons participating in the proceedings, only the witnesses are obliged to pledge an oath. ${ }^{291}$ The IMT rules and regulations do not provide the text of the oath. The IMT-C and RoP do not explicitly mention the right to interpreting because the interpreting was "revamped" for the purposes of these trials (see extended discussion below).

The IMTFE Charter (IMTFE-C) and the IMTFE RoP describe the defendant as the "accused" and English and the language of the accused as official languages. ${ }^{22}$ The accused has all the language rights described in the IMT-C and IMT RoP without any significant departures. The only significant difference between the two is procedural in that the Supreme Commander for the Allied Powers appoints, inter alia, interpreters. ${ }^{293}$ The interpreters must pledge an oath and affirmation establishing their obligations to respect the due process recognized by international law before commencing their duties. ${ }^{294}$ The Japanese language has been explicitly mentioned in the context of translation of records, exhibits and documents, and in the context of the forms of oath and affirmation. ${ }^{295}$ The IMTFE set a precedent by obliging interpreters to pledge an oath and affirmation to the accuracy of their interpreting. The difference between an oath and an affirmation is that an oath is widely considered to be a religious pledge whereas an affirmation is secular. Bassiouni reminds us that the 1907 Hague Convention establishing the "laws of humanity" which served as a basis for prosecuting crimes at the IMT and the IMTFE was a Western European exercise which reflected Western European Christian values, as they emerged from the natural law of doctrine and practices of these Christian states, as well as whatever they absorbed from the pre-Christian Greco-Roman civilizations and borrowed from Islamic civilization. So, the distinction the IMTFE made between the oath and an affirmation was no longer Christian-centric. ${ }^{296}$ This was an important contribution by the IMTFE to the fairness of trials, bearing in mind that Japan is a nonChristian country.

Whereas IMT-C, IMT RoP, IMTFE-C, and IMTFE RoP may not be as detailed as the contemporary international criminal tribunals statutes and RPEs, defendants were accorded all the necessary rights to translation and interpreting of records and proceedings into: a language [the defendant] understand[s], a language understood by the accused, the language of the defendant, the language of the accused, the language of any country where the Tribunal is sitting, the language of the document, and a language other than English and Japanese. As far as the mechanics of the language-related work is concerned, the IMT set a precedent by revamping the existing mode of interpreting, consecutive interpreting, into simultaneous interpreting. Consecutive interpreting which was normally used during communication involving a few languages during meetings at the international level was considered too slow for a court of that importance, extent, and language variety. This "speeding up of communication," for lack of a better expression, brought by simultaneous interpreting was in the interest of fair and expeditious trials. ${ }^{297}$ Consecutive interpreting is slow, meaning X speaks, interpreter repeats, Y retorts, interpreter repeats. Imagine a speaker who declares "This 'speeding up of communication" sentence above. It would take such a speaker 20 seconds to utter that sentence. Now imagine that sentence interpreted in consecutive mode into three other languages. That is an additional 6o seconds, assuming fluid and uninterrupted interpreting. This means that even the simplest declarations would take almost a minute and a half to convey, at least. Now imagine any trial being one and-a-half times longer. It is

\footnotetext{
${ }^{289}$ IMT RoP, Rules 2(a), 3 and 4(e).

${ }^{29 \circ}$ IMT RoP, Rule 8.

${ }^{291}$ IMT RoP, Rules 6.

${ }^{292}$ IMTFE-C, Article 9(b).

${ }^{293}$ IMTFE RoP, Rule 3(b)(1).

${ }^{294}$ IMTFE RoP, Rule 8(b).

${ }^{295}$ IMTFE RoP, Rule 6(a) and 8.

${ }^{296}$ Bassiouni, C. (2011), Crimes against humanity: historical evolution and contemporary application. Cambridge University Press: Cambridge, UK, p. xxviii.

${ }^{297}$ IMT RoP, Rule 18(a) and IMTFE RoP, Rule 12(a).
} 
not only that the defendants would suffer, but it would also have an effect on the facts of the case. People speak not because they like the sound of their voice, but because they feel happiness, sadness, fear, anger, surprise, and disgust which they wish to communicate. Lawyers speak because their happiness, sadness, fear, anger, surprise, and disgust needs to motivate the production of a legal effect. And there is only one chance to make a first impression. Simultaneous interpreting is performed in real time where the client is interpreted as s/he speaks. The medium of simultaneous interpreting was a brand new "thing" when it was used at the IMT for the first time and, although wondering whether the use of untrained interpreters had an impact on the fairness of the trial, Gaiba decided that such a discussion is beyond her summarizing that fairness to the defendants during the whole process was given top priority. This is partly because the trials would not have been possible without simultaneous interpreting into four languages and because the IMT Charter ruled that the defendants had the right to a fair trial, which is why all the proceedings had to be translated into a language that the defendants understood. ${ }^{298}$ The fair trial had to be granted to the defendants because they had the right to speak and hear their own language so that there would be no obstacle to the exercise of their rights. Since consecutive interpreting or the reading of pre-translated texts and "simultaneous successive interpreting" would not have been feasible, a new system had to be found that would allow a fair trial to be carried out quickly. That was something that had never been performed before at such a crucial event as the IMT trials. ${ }^{299}$

Both the defendants and interpreters felt that simultaneous interpreting played a key role as one of the requirements for a fair trial. ${ }^{300}$ Gaiba reports that Herman Göring took most advantage of the new system of simultaneous interpreting, although he is reported to have said "This system is very efficient, but it will also shorten my life." So, he learned very quickly how to "play the system" of simultaneous interpreting and turned his examination by the prosecution completely to his advantage. Since he spoke English, Göring did not have to listen to the interpreting to the extent that he depended solely on it. Instead, he used the time during the Prosecutor's discourse to think of the most appropriate answers and to scrutinize translation of evidence being presented, thus avoiding all factual and linguistic pitfalls and turning the tables on the Prosecution. No matter how counter-productive for the actual realm of justice this might be, that is exactly what prosecutors and defense who speak several languages that are used in international criminal tribunals actually do as well. Another accused sentenced to death, Otto Ohlendorff, the Head of Intelligence and Security inside Nazi Germany, wrote the interpreters a letter to thank them for giving him a chance to understand and be understood in the court. ${ }^{301}$

As the fields of international criminal law and international human rights developed after 1946, so did the language-related rights, obligations, and requirements on parties in the proceedings held before international criminal tribunals. As the nature of international criminal law is oriented toward the criminal responsibility of an individual, these rights are individual-centric. The UDHR and the International Covenant on Civil and Political Rights (ICCPR) provide a legal basis for assurance of the right to a fair trial to defendants which is the father right to the use of interpreter. The UDHR from 1948 set forth the following rights of all humanity:

Everyone is entitled to all the rights and freedoms set forth in this Declaration, without distinction of any kind, such as race, colour, sex, language, religion, political or other opinion, national or social origin, property, birth

\footnotetext{
${ }^{298}$ Gaiba, F. (1998), The origins of simultaneous interpreting: the Nuremberg trial. University of Ottawa Press: Ottawa, p. 20-28.

${ }^{299}$ Ibid, p. 33-35.

${ }^{300}$ Ibid, p. 159.

${ }^{301}$ Ibid, p. 110-112.
} 
or other status. Furthermore, no distinction shall be made on the basis of the political, jurisdictional or international status of the country or territory to which a person belongs, whether it be independent, trust, nonself-governing or under any other limitation of sovereignty..$^{302}$

The UDHR is very important because it abolished discrimination, at least nominally, and enabled the expansion of procedural due process recognized by international law, which is an essential principle for all dealings with systems of justice at the national and international level. The ICCPR further elaborated on the concept of procedural due process recognized by international law. ${ }^{303} \mathrm{As}$ far as the language-related rights, obligations, and requirements are concerned, the ICCPR limited the rights of the States Parties to the Covenant in the times of emergency in that they cannot take measures derogating from their obligations which are inconsistent with their other obligations under international law involving discrimination solely on the ground of race, color, sex, language, religion, or social origin. ${ }^{304}$ In addition, the ICCPR forbids discrimination on the basis of language, inter alia, against children, all persons appearing before the law, and ethnic, religious, or linguistic minorities. ${ }^{305}$ The ICCPR expanded on the rights of defendants before courts:

3. In the determination of any criminal charge against him, everyone shall be entitled to the following minimum guarantees, in full equality:

(a) To be informed promptly and in detail in a language which he understands of the nature and cause of the charge against him;

$[\cdots]$

(f) To have the free assistance of an interpreter if he cannot understand or speak the language used in court. ${ }^{306}$

This is the first time in history that international law acknowledged defendants' language and guaranteed defendants the right to an interpreter. This may also be seen as a tacit acknowledgment that the language of a judicial institution is a language of power and that assuring that both the defendant and the representatives of the judicial institution communicate in the same language naturally or through an interpreter establishes an equal footing.

4.1.2. Post-ICTY due process language-related rights, obligations, and requirements

As far as language-related rights, obligations, and requirements in the international criminal tribunals are concerned, the two main governing documents establishing those rights, the UDHR and the ICCPR, give the defendant tried under international criminal jurisdiction the right not to be discriminated against on the basis of language and the right to interpreting. The ICTY, ICTR, ICC, SCSL, STL, and ECCC rules and regulations also imposed certain other language-related obligations and requirements on parties to the proceedings.

Table 4. ICTY, ICTR, SCSL, STL and ECCC language-related rights and obligations

\footnotetext{
${ }^{302}$ UN, UDHR (1948), Article 2.

${ }^{303} \mathrm{UN}, \underline{\text { ICCPR }}(1966)$.

${ }^{304}$ Ibid, Article 4.

${ }^{305}$ Ibid, Articles 24, 26 and 27.

${ }^{306} \mathrm{Ibid}$, Article 14(3)(a) and 14(3)(f).
} 


\begin{tabular}{|c|c|c|c|c|c|}
\hline & ICTY & ICTR & SCSL & STL & ECCC \\
\hline $\begin{array}{l}\text { Lan- } \\
\text { guages }\end{array}$ & $\begin{array}{l}\text { Working lan- } \\
\text { guages: English and } \\
\text { French }\end{array}$ & $\begin{array}{l}\text { Working lan- } \\
\text { guages: English } \\
\text { and French }\end{array}$ & $\begin{array}{l}\text { Working lan- } \\
\text { guages: English }\end{array}$ & $\begin{array}{l}\text { Official and work- } \\
\text { ing languages: Eng- } \\
\text { lish, French and } \\
\text { Arabic }\end{array}$ & $\begin{array}{l}\text { Official working } \\
\text { languages: } \\
\text { Khmer, English } \\
\text { and French }\end{array}$ \\
\hline $\begin{array}{c}\text { Regis- } \\
\text { trar }\end{array}$ & Rule 3(E) & Rule $3(\mathrm{E})$ & Rule $3(\mathrm{D})$ & Not explicit & Article 31 \\
\hline Judges & Not explicit & Not explicit & Not explicit & Article 14 & Not explicit \\
\hline $\begin{array}{l}\text { Prose- } \\
\text { cutors }\end{array}$ & $\begin{array}{l}\text { Rule 66(A)(i); Rule } \\
66(\mathrm{~A})(\mathrm{ii})\end{array}$ & Rule $47(\mathrm{G})$ & Not explicit & Rule $110(\mathrm{~A})$ & Not explicit \\
\hline $\begin{array}{c}\text { De- } \\
\text { fense }\end{array}$ & $\begin{array}{l}\text { Rule } 3(\mathrm{D}) ; \text { Rule } \\
\text { 44(A)(ii); Rule } \\
\text { 44(B) }\end{array}$ & $\begin{array}{l}\text { Rule } 3(C) \text {, Rule } \\
45(A)\end{array}$ & Not explicit & Rule 59(D) & Rule $11(\mathrm{~B})$ \\
\hline $\begin{array}{l}\text { De- } \\
\text { fend- } \\
\text { ants }\end{array}$ & $\begin{array}{l}\text { Suspect: } \\
\text { Article 18(3); Rule } \\
\text { 42(A); Rule } \\
\text { 42(A)(ii); Rule 43(i) } \\
\text { Accused: } \\
\text { Article 21(4)(a); Ar- } \\
\text { ticle 21(4)(f); Rule } \\
\text { 3(B); Rule 55(C); } \\
\text { Rule 55(D); Rule } \\
\text { 55(E); Rule } \\
\text { 59bis(B); Rule } \\
\text { 59bis(C); Rule } \\
\text { 62(A)(ii); Rule } \\
\text { 68ter(D) }\end{array}$ & $\begin{array}{l}\text { Suspect: } \\
\text { Article 17(3); Rule } \\
\text { 42(A), Rule } \\
\text { 42(A)(ii), Rule } \\
\text { 43(i) } \\
\text { Accused: } \\
\text { Article } 20(4)(a) \text {; } \\
\text { Article } 20(4)(a) \text {; } \\
\text { Rule } 3(\text { B), Rule } \\
\text { 55(B)(iii), Rule } \\
\text { 55(C)(iii), Rule } \\
\text { 62(A)(ii), Rule } \\
\text { 108(B) }\end{array}$ & $\begin{array}{l}\text { Suspect: } \\
\text { Rule 3(B); Rule } \\
\text { 42(A); Rule } \\
\text { 42(A)(ii); Rule } \\
\text { 43(i) } \\
\text { Accused: } \\
\text { Article 17(4)(a); } \\
\text { Article 17(4)(f); } \\
\text { Rule 3(B); Rule } \\
52(\mathrm{C}) \text {; Rule } \\
\text { 55(B)(iii); Rule } \\
\text { 55(C)(iii); Rule } \\
\text { 61(ii) } \\
\text { Convicted per- } \\
\text { son: } \\
\text { Rule 3(B) }\end{array}$ & $\begin{array}{l}\text { Suspect: } \\
\text { Article 15(D); Rule } \\
\text { 65(A); Rule } \\
\text { 65(A)(iii); Rule } \\
\text { 66(A)(i) } \\
\text { Accused: } \\
\text { Article 16(4)(A); } \\
\text { Article 16(4)(G); } \\
\text { Rule 1O(C); Rule } \\
\text { 68(K); Rule 79(C); } \\
\text { Rule 79(E); Rule } \\
\text { 79(F); Rule } \\
\text { 98(A)(ii); Rule } \\
\text { 168(C). }\end{array}$ & $\begin{array}{l}\text { Suspect: } \\
\text { Article 24; Rule } \\
\text { 25(A); Rule } 55 \\
\text { Charged person: } \\
\text { Rule 25(A); Rule } \\
55 \\
\text { Accused: } \\
\text { Article 35(a); Ar- } \\
\text { ticle 35(f); Rule } \\
55\end{array}$ \\
\hline $\begin{array}{l}\text { Victims } \\
\text { and } \\
\text { wit- } \\
\text { nesses }\end{array}$ & Not explicit & Not explicit & Not explicit & Not explicit & $\begin{array}{l}\text { Rule 49; Rule } \\
\text { 12bis(D); Rule } 55\end{array}$ \\
\hline $\begin{array}{l}\text { Inter- } \\
\text { preters } \\
\text { and } \\
\text { transla- } \\
\text { tors }\end{array}$ & Rule 76 & Rule 76 & Rule 76 & Rule 46 & Rule 30 \\
\hline
\end{tabular}

All these language-related rights, obligations, and requirements on persons participating in judicial process are first defined in international criminal tribunals statutes and then explained in detail in international criminal tribunal RPEs. They are next examined in turn.

\subsubsection{Languages}

The ICTY, ICTR, and SCSL statutes do not set the official languages of these institutions but they do set working languages.$^{307}$ STL-S sets "official and working languages" whereas ECCC Law sets "official working languages. ${ }^{n 08}$ ECCC is the only international criminal tribunal that made the language of the situation country

${ }^{307}$ ICTY-S, Article 33: English and French; ICTR-S, Article 31: English and French; SCSL-S, Article 24: English.

${ }^{308}$ STL-S, Article 14: English, French, and Arabic, ECCC Law, Article 45: Khmer, English, and French. 
official, figuring the Khmer language into its laws. ECCC Internal Rules (IR) mentions translation into "working languages," but these have nowhere been explicitly mentioned nor that which distinguishes them from "official working languages" used in the rest of the laws. ${ }^{309}$

ICTY RPE explicitly sets English and French as the working languages. ${ }^{310}$ Although mentioned twice in the ICTY RPE, "official languages" have nowhere been clearly set. ${ }^{311}$ ICTY RPE combines "other persons appearing before the Tribunal, other than as counsel" giving those persons the right to use their own language..$^{312}$ ICTR RPE replicates these same rules verbatim. ${ }^{313}$ ICTY RPE also ushers the concept "native language of the suspect or accused" into the field of the international criminal law without any further definition. ${ }^{314}$

SCSL RPE explicitly sets English as the working language, encouraging anyone who does not speak English to seek permission to use his own language..$^{315}$ The authority from whom to seek such permission is not explicitly mentioned.

STL RPE explicitly sets English, French, and Arabic as official languages, gives a Judge or Chamber the right to decide on working languages to be used in the case, and encourages other persons appearing before a Judge or Chamber, other than as counsel, who do not have sufficient knowledge of the official languages, to ask the authorization of the Judge or Chamber to use their own language. ${ }^{316}$

ECCC IR ambiguously establish that "identical versions [of the IR (and amendments)] in Khmer, English, and French" shall enter into force after having been adopted by the Plenary. ${ }^{317}$ The wording "identical versions" suggests that the Khmer, English, and French official documents are considered authentic texts with equal legal authority. However, the notion of authentic texts is a legal fiction. Authentic text is a prevailing text which means that translation of such a text considered authentic has no value but serves merely as a means to understand the gist of things. In practice, one language, here French, is more important than all others. Inspection of several ECCC judgments reveals that they have all been "done in Khmer, English, and French" which confirms that the identical versions of Khmer, English, and French official documents are, indeed, authentic texts, but since there is no disclaimer on which language takes precedence in the case of a dispute between different language versions, it can be taken that these are texts with equal legal authority. ${ }^{318}$

The ICTY, ICTR, and STL RPEs also establish that the RPE text shall be equally authentic where the version which is more consonant with the spirit of the Statute and of the RPE shall prevail in cases of disputes between different language versions. ${ }^{319}$ This section on authentic texts, including a disclaimer, is not present in other rules and regulations under examination.

Obviously, the lawmakers set one, two or three UN languages as the official languages of the legal institution and completely ignored the language of the situation country, except ECCC. Credit should be given to Khmer language policy-makers and lobbyists who succeeded in making Khmer the official language of ECCC. Indeed, the Cambodian government created a precedent by reasserting themselves as an equal partner in an otherwise sea of voiceless actors in the situation country. However, it should be remembered that this victory might only have been possible because the Cambodian government co-finances the work of

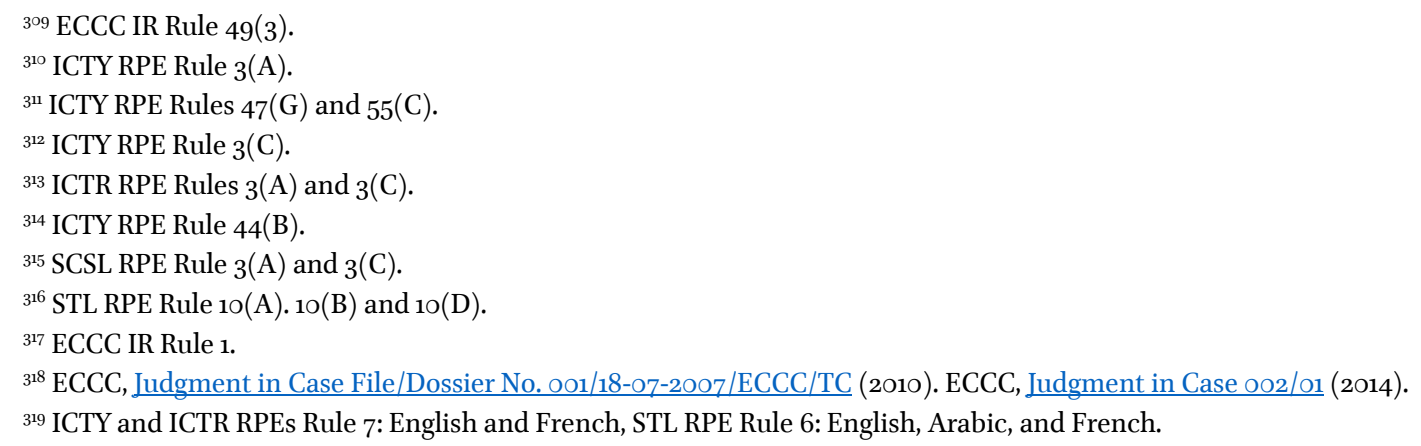


ECCC. Although the same could be said for STL, Arabic is both a language of the situation country, Lebanon, and a UN language..$^{320}$

4.1.2.2. Judges

The ICTY RPE provides a definition of permanent judges and ad litem judges. The SCSL RPE defines a council of judges, a designated judge, and a pre-hearing judge. Other tribunals' RPEs do not provide any definition of judges.

ICTY, ICTR, and SCSL statutes and ECCC Law do not explicitly mention any language-related rights, obligations, and requirements on the judges. STL-S gives the Pre-Trial Judge or a Chamber the right to decide that one or two of the languages may be used as working languages, as appropriate. ${ }^{321}$ In 2011, the STL PreTrial Judge considered that the timely determination of the working language(s) would serve the interests of justice by providing the Prosecutor, the Defense Office, the Defense, the Registrar (notably including the Victims Participation Unit), as well as the victims participating in the proceedings and their representatives, with a desirable degree of clarity and certainty ordering restrictions on English-French translations and giving priority to English-Arabic ones..$^{32}$

Language-related rights, obligations, and requirements placed on ICTY judges are explicit in that the defense counsel who does not speak any of the working languages or the language of the accused may apply to the Presiding Judge of a Chamber for leave to use a language other than the language of the accused. ${ }^{323}$ These aspects are also explicit in the context of the initial appearance of the accused where the Trial Chamber or the Judge shall read or have the indictment read to the accused in a language the accused understands, satisfying himself that the accused understands the indictment. ${ }^{324}$

The section on working languages, official and working languages, and official working languages makes it clear the judges must have proficiency in at least one language set in the rules and regulations. Rules and regulations also provide that "other persons appearing before the [ICTY, ICTR and SCSL], other than as counsel" have the right to use their own language; obviously, this may include judges, as well. The ICTY, ICTR and STL RPEs state that permission to use one's own language is to be sought from the judges, which might be taken to mean that the ICTY, ICTR, and STL judges must speak and understand at least one of the ICTY, ICTR, and STL official or working languages..$^{32}$

The SCSL RPE combines everyone who does not speak English, giving them a right to use their own language. ${ }^{326}$

The ECCC IR obliges Co-Prosecutors or Co-Investigating Judges questioning a suspect or a charged person in the language he understands that the interview is being videoed or audio recorded ${ }^{327}$ They establish that the Co-Investigating Judges and Chambers have the right to use interpreters, which means they may be required to speak and understand only one of the ECCC "working and official languages." ${ }^{328}$ The ECCC IR Rules also address deaf/mute persons obliging the Greffier of the Co-Investigating Judges or the Chambers to

\footnotetext{
${ }^{320}$ ECCC IR Rule 1.

${ }^{321}$ STL-S, Article 14.

${ }^{322}$ STL, Decision on languages in the case of Ayyash et al (2011).

${ }^{323}$ ICTY, ICTR RPE $3(\mathrm{D})$, STL RPE $10(\mathrm{D})$.

${ }^{324}$ ICTY, ICTR RPE 62(A)(ii), SCSL RPE 61(ii), STL RPE 98(A)(ii).

${ }^{325}$ ICTY, ICTR RPE 3 (D) and STL RPE 1O(D).

${ }^{326} \operatorname{SCSL~RPE}_{3}(\mathrm{C})$.

${ }^{327}$ ECCC IR Rule 25(A).

${ }^{328}$ ECCC IR Rule 3 .
} 
write down the questions and ask the person being questioned to read them, and answer in writing. Also, the Greffier may call on "a person able to properly communicate with the deaf/mute person.."329

The most important prerequisite for the effective functioning of judges in the context of an international criminal tribunal is that judges can communicate with each other during deliberations. Gaiba reports that IMT judges spoke their own languages throughout (English, French, Russian), but had their own interpreters assisting them when they wanted to communicate with each other inside and outside the courtroom and during deliberations on sentencing. These interpreters would move in with the judges and could not communicate with the rest of the world during deliberations on sentencing. Gaiba also reports that interpreting for judges was more difficult than interpreting in the courtroom because it was impossible to impose the same discipline on the judges as on the speakers in the courtroom. ${ }^{33^{\circ}}$ In practice, although first language speakers of different languages (Maltese, Dutch, Turkish, Chinese, English, French, etc.), ICTY judges functioned in French and/or English and there has never been a case where they used any other language but these two in their official capacity. ICTY, ICTR, SCSL, and STL staff report that there was no need for interpreters to be involved in communication between the judges as most of them were fully functional English language speakers. ECCC staff report there were no "major problems" with non-Anglophone and non-Francophone judges.

There were a total of 78 judges who adjudicated crimes at the ICTY: 43 permanent judges and $35 \mathrm{ad}$ litem judges. Out of 43 permanent judges: 1 judge worked at the ICTY for 1 year, 6 judges for 2 years, 8 judges for 3 years, 9 judges for 4 years, 4 judges for 5 years, 2 judges for 6 years, 4 judges for 7 years, 4 judges for 8 years, one judge for 9 years, one judge for 12 years, one judge for 13 years, one judge for 14 years, and one judge for 17 years. Out of 35 ad litem judges: 5 judges worked at the ICTY for 1 year, 6 judges for 2 years, 12 judges for 3 years, 3 judges for 4 years, 3 judges for 5 years, 1 judge for 6 years, 3 judges for 7 years, 1 judge for 8 years, and 1 judge for 10 years..$^{311}$ The issue of judges deciding on the languages of defendants and victims is discussed further below.

\subsubsection{Registrar}

The ICTY, ICTR, SCSL, and STL statutes do not refer to any administrative body in charge of translation and interpreting. They do mention that administration and servicing of their institutions is to be done by the Registry, but they do not mention the extent and type of that administration and servicing as far as translation and interpreting are concerned. ECCC Law does not either, but it does establish that the Director of the Office of Administration must be fluent in one of the foreign languages used in the ECCC. ${ }^{3{ }^{2}}$ Since the ECCC Law is originally delivered in the Khmer language, it is understood that these "foreign languages" are English and French.

The ICTY, ICTR, and SCSL RPEs establish that the Registrar shall make all arrangements for translation and interpreting into and from working languages. ${ }^{333}$ The ICTY RPE extends this to documents filed in a language other than one of the working languages of the Tribunal. ${ }^{334}$ The Registrar also must be satisfied that qualified counsel representing a suspect or accused has written and oral proficiency in one of the two working languages of the ICTY but can also waive this requirement at the request of the suspect or accused and where the interests of justice require this. ${ }^{335}$ The ICTY RPE does not define written or oral proficiency and does not

\footnotetext{
${ }^{329}$ ECCC IR Rule 27.

${ }^{33^{\circ}}$ Gaiba, F. (1998), The origins of simultaneous interpreting: the Nuremberg trial. University of Ottawa Press: Ottawa, p. 82-84.

${ }^{3{ }^{1}}$ ICTY, Former judges.

${ }^{332}$ ECCC Law, Article 31.

${ }^{333}$ ICTY RPE Rule 3(E), ICTR RPE Rule 3(D) and SCSL RPE Rule 3(D).

${ }^{334}$ ICTY RPE Rule $3(\mathrm{~F})$.

${ }^{335}$ ICTY RPE Rule 44(A)(ii) and 44(B).
} 
elucidate on means of checking a person's written or oral proficiency in one of the two working languages of the Tribunal.

The obligation on the Registrar from ICTY, ICTR, and SCSL RPEs to make all arrangements for translation and interpreting into and from working languages ${ }^{336}$ has been repeated in specific examples of the indictment, ${ }^{337}$ the execution of arrest warrants, ${ }^{33^{8}}$ and the person or authorities cautioning the accused of his rights when arrested if the accused does not understand either of the official languages of these tribunals and if the language understood by the accused is known to the Registrar. ${ }^{339}$ The ICTY and STL RPEs add that these do not apply if at the time of arrest the accused is served with, or with a translation of, the indictment and the statement of rights of the accused in a language that the accused understands and is able to read. ${ }^{340}$

Furthermore, the SCSL RPE concerning the service of indictment obliges the Registrar to ensure that the indictment is read to the accused by an interpreter and that the accused is provided with a recording of the interpreting in the case that the accused is illiterate, or his language is an oral language. ${ }^{341}$ Other persons appearing before SCSL who might be illiterate or whose language is an oral language are not mentioned in SCSL laws.

The lawmakers did not make a single provision for illiterate persons and ushered two very interesting notions into the realm of international criminal justice that do not exist in linguistics in the terms they used: oral language and written language (SCSL). All languages in the world are oral. These lawmakers should have made provisions for a client whose language is a "non-written language."342 Except for ECCC and SCSL, other international criminal tribunals do not make any provision for illiterate persons. There have been several illiterate persons testifying before the ICTY. However, their illiteracy had no bearing on their testimony. Such a person would sign the statement with a cross or thumb, confirm that he was illiterate before the judges and, like other witnesses, would declare whether his statement was read to him and whether he accepts it as his own. In other words, as long as an illiterate person is read back his statement, the ICTY would be satisfied that they have before them an original and untampered statement.

The lawmakers do not reflect the official position of deaf and mute persons. They should have done that because at the time when they were copy pasting these rules and regulations, they could not have known

\footnotetext{
${ }^{336}$ ICTY RPE Rule $3(\mathrm{E})$ and ICTR and SCSL RPEs Rule $3(\mathrm{D})$.

${ }^{337}$ ICTY RPE Rule $47(\mathrm{G})$, SCSL RPE $5^{2}(\mathrm{C})$, STL RPE 68(K).

${ }^{338}$ ICTY RPE Rule 55(C), ICTR 55(B), SCSL 55(B)(iii), STL RPE 79(C).

339 ICTY RPE Rule 55(E), SCSL RPE 55(C)(iii), STL RPE 79(E).

${ }^{340}$ ICTY RPE Rule 55(F) and STL RPE $79(\mathrm{~F})$.

${ }^{341}$ SCSL RPE Rule $52(\mathrm{C})$.

${ }^{342}$ This point is not at all a matter of sheer pedantry: the ICC is going through what could be described as a linguistic hell because these notions have not been properly covered in the ICC-S or ICC RPE, either. In 2010, the ICC raised an indictment against Abdallah Banda Abakaer Nourain and Saleh Mohammed Jerbo Jamus (these proceedings terminated in 2013) for their alleged involvement in crimes in Darfour. At the onset of trial, the accused stated that they understood no other language but their native language, Zaghawa. However, Zaghawa is not a written language and its vocabulary is limited to no more than 5,ooo words. In order to provide the material to these accused, such material would either first have to be transliterated or read out on audio tapes in Zaghawa. Then it had to be decided how to translate the said material into the ICC official languages from a language that has only 5,00o words and how to translate case-related decisions and deliberations from ICC official languages into a language that has only 5, ooo words. So, due to the poor laws, ICC language services were tasked with the most expensive, time consuming, and ludicrous job: to invent a script. The ICC Language Services management could have proposed that the witness statements in Zagawa should be tape recorded, including interpreting, and then submitted as evidence as such, without any written involvement. Or, the Court could have presented these defendants with facts of their education and career conducted fully in Arabic language. Although discussions on Zagawa are still ongoing, the problem with non-codification does not stop here. Most ethnic dialects appearing before ICC as a language of defendants are either non-written (Lingala, Bété), non-standardized (Sudanese Arabic, Libyian Arabic, Gikuyu, Kiswahili) or a developing language (Ngiti). Similar problems to Zaghawa issue could arise in the case of the languages Lingala and Bété. Problems could also be raised in Kiswahili and Gikuyu because they both rely on incomplete alphabets. And last, but not least, problems could be raised in Sudanese or Libyan Arabic should any supporting document be collected in non-standardized dialects of Arabic. All in all, an additional six to 14 accused could claim incomprehension.
} 
whether there will be any deaf, mute, or illiterate persons testifying. The ECCC did not forget deaf or mute persons and provided that the Greffier may call on "a person able to properly communicate with the deaf/mute person." However, this rule should have stated "sign language interpreter", because that is the functional title of a language professional who communicates with deaf and mute persons.

\subsubsection{Prosecutors}

The ICTY, ICTR, and SCSL statutes and ECCC Law are not explicit about the language-related rights, obligations, and requirements of the Prosecutor. ICTY-S authorizes the Prosecutor to conduct investigations and question suspects, victims and witnesses giving such suspects, victims and witnesses the right to translation and interpretation. ICTR-S replicates the same principles verbatim. ${ }^{343}$

STL-S authorizes the Prosecutor to conduct investigations, to question suspects, victims and witnesses, and entitles suspects to interpretation when questioned by the Prosecutor. ${ }^{344}$ ECCC Law authorizes investigating and co-investigating judges to conduct investigations and question suspects and victims and hear witnesses, entitling such suspects to interpretation during the investigation. ${ }^{345}$ SCSL-S only confers the right on the Prosecutor to conduct investigations. ${ }^{346}$

The ICTY RPE gives suspects certain language-related rights when questioned by the Prosecutor in that the suspect has the right to be informed of his rights in a language he understands and the right to have the free assistance of an interpreter should he not understand or speak the language used for questioning. ${ }^{347}$ This has been replicated verbatim in the ICTR, SCSL, and STL RPEs. ${ }^{348}$ The ICTY RPE also obliges the Prosecutor to inform the suspect in a language the suspect understands that the interview is being videoed or audio recorded.$^{349}$ This requirement has been replicated verbatim in the ICTR and SCSL RPEs and ECCC IR. ${ }^{3{ }^{\circ}}$

The ICTY RPE establishes certain language-related obligations of the Prosecutor toward the defense in that the Prosecutor must make available to the accused in a language he understands: copies of the supporting material which accompanied the indictment when confirmation was sought, all prior statements obtained by the Prosecutor from the accused, copies of the statements of all witnesses whom the Prosecutor intends to call to testify at trial, copies of all transcripts and written statements, and copies of the statements of additional prosecution witnesses, which shall be made available to the defense once a decision is made to call those witnesses. ${ }^{351}$ The STL RPE contains the same language-related obligations for the STL Prosecutor on disclosure. ${ }^{35^{2}}$ However, although the STL Defense is also obliged to disclose similar material, they are not subjected to any language-related, obligations, and requirements in the course of those duties. ${ }^{33}$ The ICTR and SCSL RPEs oblige the Prosecutor and Defense to engage in reciprocal disclosure, but they do not mention any involvement of translators or interpreters in this. ${ }^{354}$ Neither does the ECCC IR, which obliges Co-Prosecutors to disclose all exculpatory materials to Co-Investigative Judges. ${ }^{35}$ All these documents - delivered in the language of the defendant - represent the court sanctioned translation load in these international criminal tribunals.

\footnotetext{
${ }^{343}$ ICTY-S Articles 18(1), 18(2) and 18(3) and ICTR-S Articles 17(1), 17(2) and 17(3).

${ }^{344}$ STL-S Articles 11(1), $11(2)$ and $15(\mathrm{D})$.

345 ECCC Law Articles 23 and 24.

${ }^{346}$ SCSL-S Article $15(2)$.

${ }^{347}$ ICTY RPE Rule $42(\mathrm{~A})$ and $42(\mathrm{~A})(\mathrm{ii})$.

${ }^{348}$ ICTR RPE and SCSL RPE Rules 42 and 42(A)(ii) each, STL RPE Rule 65(A) and Rule 65(A)(iii).

${ }^{349}$ ICTY RPE Rule 43.

${ }^{35^{\circ}}$ ICTR RPE Rule 42(i), SCSL RPE Rules 43(i) and 66(A)(iii) and ECCC IR Rule 25 1(A)).

${ }^{351}$ ICTY RPE Rule 66(A)(i) and 66(A)(ii).

${ }^{352}$ STL RPE Rule 110.

${ }^{353}$ STL RPE Rule 112.

${ }^{354}$ ICTR RPE and SCSL RPE Rules 66 and 67.

${ }^{355}$ ECCC IR Rule 53-4.
} 


\subsubsection{Defense}

The ICTY, ICTR, and SCSL-S recognize the following organs as part of their structure: Chambers (consisting of Trial Chambers and Appeals Chambers), Prosecutor, and Registry (servicing both the Chambers and the Prosecutor). ${ }^{356}$ It needs to be said that, although they do not recognize the Defense as a constituent part of their international criminal tribunals, that did not stop the ICTY, ICTR, and SCSL from explicitly mentioning language-related rights, obligations, and requirements on the defense and imposing the Defense Code of Conduct. ${ }^{357}$ STL-S recognizes Chambers (pre-Trial judge, Trial Chambers, and Appeals Chamber), Prosecutor, Registry, and the Defense as their organs, but does not explicitly mention any language-related rights, obligations, and requirements on Defense. ${ }^{35^{8}}$ The STL imposed a Code of professional conduct for counsels appearing before the [STL] and a separate Code of professional conduct for defense counsel and legal representatives of victims appearing before the $[\mathrm{STL}] .359$

The ICTY RPE states that defense counsels must either have written on oral proficiency in one of the two ICTY working languages, speak the native language of the accused or suspect, or, on application for leave, use a language different from the language of the accused or suspect or the working languages. ${ }^{360}$ Should defense counsel speak only the native language of the accused or suspect, it is required that the counsel or accused undertake to meet all translations and interpreting costs not usually met by the ICTY and undertake not to request any extensions of time as a result of the fact that he does not speak one of the working languages. ${ }^{361}$ Neither ICTY-S nor the ICTY RPE elaborate on "translation and interpretion costs not usually met by the Tribunal," how to establish "the native language of the accused," or provide a definition of "a native language."

The ICTY and STL RPEs provide that the Defense is given a copy of the judgment and the Judges' opinions in the language of the accused or the language in which they were delivered ${ }^{362}$ The STL RPE establishes that the defense counsel must have written and oral proficiency in English or French and that the suspect or the accused have the right to be represented by a counsel who will have "the combined language abilities required for fair and expeditious proceedings," meaning that such a counsel must speak and understand Arabic and/or English and/or French.$^{363}$ ECCC IR imposes arrangements concerning translation on Defense Support Section and the Victims Support Section. ${ }^{34}$

The communication between the defense counsel and a defendant who does not speak his language has not been covered explicitly in any of the rules and regulations under examination. However, EU Directive 2010/64/EU of the European Parliament and of the Council on the right to interpreting and translation in criminal proceedings specifically stipulates that there must be free and adequate linguistic assistance, allowing suspected or accused persons who do not speak or understand the language of the criminal proceedings fully to exercise their right of defense, thus safeguarding the fairness of the proceedings. ${ }^{36}$

\footnotetext{
${ }^{356}$ ICTY-S Article 11, ICTR-S Article 10 and SCSL-S Article 11.

${ }^{357}$ ICTR, Code of professional conduct for defense counsel (1998); SCSL, Code of professional conduct for defense counsel with the right of audience before the [SCSL] (2006).

${ }^{35^{8}}$ STL-S Article 7 .

359 STL, Code of professional conduct for counsels appearing before the [STL] (2011); STL, Code of professional conduct for defence counsel and legal representatives of victims appearing before the [STL] (2012).

${ }^{360}$ ICTY RPE Rule 44(A)(ii), 44(B) and 3(D), ICTR RPE 3(D).

${ }^{361}$ ICTY RPE Rule 44(B).

${ }^{362}$ ICTY RPE Rule 98ter (D) and STL RPE Rule 168(C).

${ }^{363}$ STL RPE Rule $58(\mathrm{~A})$ (ii) and 59 (D).

${ }^{364}$ ECCC IR Rule $11(2)$ (B) and 12 bis $1(\mathrm{D})$.

${ }^{365} \mathrm{EU}$, Official Journal of the European Union L 280/1 (2010), Directive of the European Parliament and of the Council on the right to interpreting and translation in criminal proceedings, Preamble (17).
} 


\subsubsection{Defendants}

Defendants appearing before the ICTY, ICTR, SCSL, STL, and ECCC are called both suspects and accused. Although these are ad hoc tribunals with specific temporal and territorial suspects, none of these statutes, except for the ECCC Law, define the notion of a suspect. When it comes to the language-related or other rights or obligations on the suspects, ICTY-S entitles the suspect to necessary translation into and from a language he speaks and understands when questioned, replicated almost verbatim in ICTR-S. ${ }^{366}$ STL-S gives suspect the right to free assistance of an interpreter if he cannot understand or speak the language used for questioning. ${ }^{367}$ ECCC Law gives a suspect the right to interpretation, as necessary, into and from a language s/he speaks and understands. ${ }^{368}$ SCSL-S is not explicit about any rights of the suspects.

When it comes to the language-related rights, obligations, and requirements on the accused, ICTY-S gives the accused the right to be informed of the nature and the cause of charges against him in the language he understands and the right to interpreter if he cannot understand or speak the language used at the ICTY ${ }^{369}$ These rights are replicated almost verbatim in ICTR, SCSL, and STL-S, and ECCC Law. ${ }^{370}$

The accused have general language-related rights, obligations, and requirements during pre-trial proceedings, in the context of arrest and warrants, at initial appearance, and at publication of a verdict and the judges' opinions as elaborated in the RPEs under examination. The ICTY, ICTR, SCSL, and STL RPEs give the accused the right to use "his or her own language." ${ }^{371}$ The SCSL RPE gives this right to suspects and convicted persons; this is also the only time where SCSL RPE mentions the category of convicted person in the context of language-related rights, obligations, and requirements. ${ }^{372}$

At the pre-trial proceedings, the ICTY, STL, and SCSL RPEs give the accused the right to a translation of the indictment, when confirmed, if the accused does not understand either of the official languages of these tribunals and if the language understood is known to the Registrar, who will serve the indictment and certified copies of the indictment. ${ }^{373}$

When arrested, the ICTY, ICTR, and SCSL RPEs give the accused the right to a translation of the warrant of arrest and a statement of the rights of the accused; $;{ }^{374}$ the STL RPE disclaims practicality. ${ }^{375}$ The accused also has the right to be read the indictment and the statement of the rights of the accused, unless these are already translated as per ICTY and STL RPEs, ${ }^{376}$ or if the accused does not speak and understand English or is illiterate or the language of the accused is an oral language. ${ }^{377}$ The accused also has the right to be cautioned that he has the right to remain silent, and that any statement he makes shall be recorded and may be used in evidence in a language he understands. ${ }^{378}$

When taken into custody, the ICTY RPE gives the accused the right to be informed of charges against him and of the fact that he is being transferred to the Tribunal in a language he understands, including the

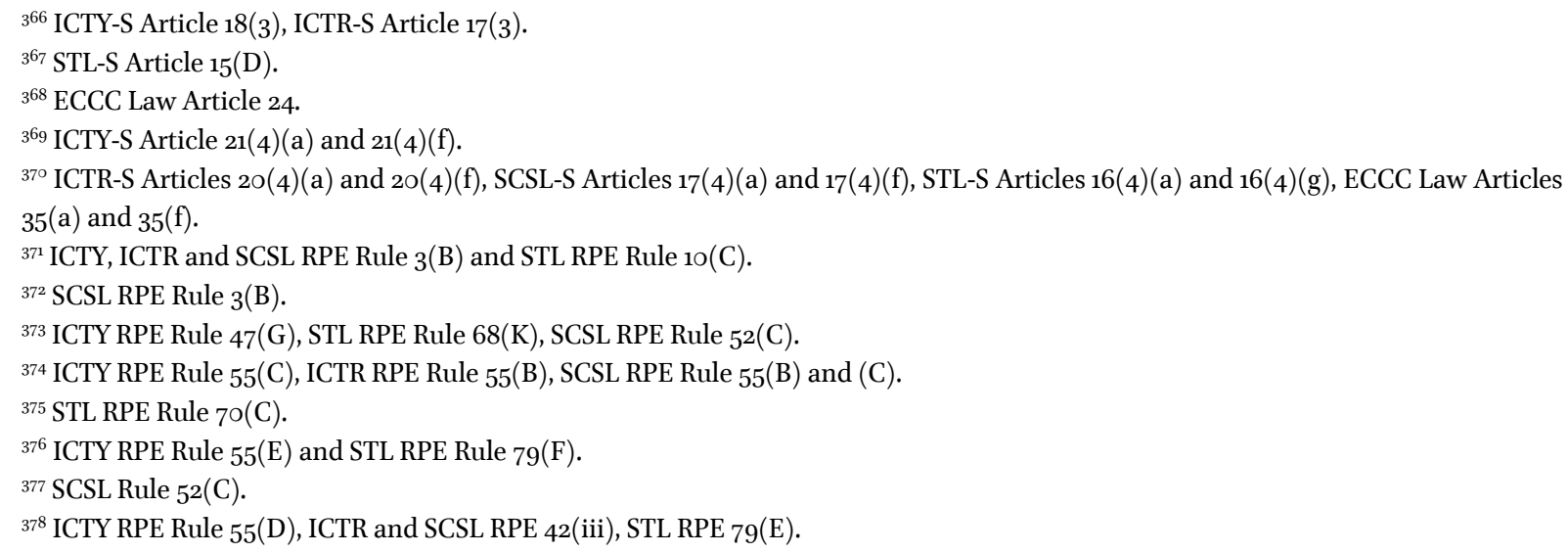


right to be read the indictment and the statement of the rights of the accused in a language he understands and to be cautioned in the language he understands, unless these documents are already translated. ${ }^{379}$

During the initial appearance of the accused, the accused has the right to read or have the indictment read in a language he understands. ${ }^{380}$

At the end of the proceedings, the accused also has the right to a copy of the judgment and of the Judges' opinions in a language which he understands and in the original language..$^{81}$

The lawmakers suffered immensely to define the most basic principles revolving around the language of the defendants, calling it:

\begin{abstract}
his or her own language (ICTY), his own language (ICTR, SCSL, STL), their own language (ICTY, STL), his language (SCSL), language of the accused (ICTY, ICTR), language that the accused understands (ICTY, STL), language understood by the accused (ICTY, ICTR, SCSL, STL), language the suspect understands (ICTY, STL), the native language of the suspect or accused (ICTY), language understood [by the defendant] known to the Registrar (ICTY, ICTR, SCSL), language to be used for questioning (ICTY, ICTR, SCSL, STL), language that he or she understands (ICTY), language he speaks and understands (ICTR, SCSL), language he understands (STL), language understood by him (ICTR, SCSL), language the accused understands and is able to read (ICTY), language he or she fully understands and speaks (ECCC)
\end{abstract}

This issue mostly has to do with the clear absence of editing: a language editor would construct the sentence in such a way as to convey the same principle in an absolutely uniform way throughout. Instead, this lack of editing also resulted in a number of false contingencies due to the immense influence of American legal thinking, in the rules and regulations under examination evident in the following formulas:

language understood [by the defendant] known to the Registrar (ICTY, ICTR, SCSL), language he speaks and understands (ICTR, SCSL), language the accused understands and is able to read (ICTY), language he or she fully understands and speaks (ECCC)

Clearly, lawmakers resorted to a Common Law writing standard. Since Anglo-American legal professionals are deeply skeptical of abstract norms and their legal thinking is inductive, this Anglo-American-centric approach resulted in wordy and lengthy texts and formulas listing seemingly similar notions. ${ }^{382}$ The above examples reflected on problems related to language-related terminology; however, they also reflected on substance: Common Law's prison and jail, aiding and abetting, incitement and instigation, and murder vs killing, to name just a few, vs Civil Law's one word for the concept. The problem here is that an international criminal lawyer has to prove both sides of the phrase although they amount to the same thing both individually and together in the Civil Law legal mind and language.

\title{
4.1.2.7. Victims and witnesses
}

Before getting into discussion about victim's language-related rights, duties, and obligations, a very quick, and definitely non-exhaustive, summary of the victim's overall situation is required, especially addressing types of justice that were supposed to be served to victims by international and local actors. First of all, the maxim of individual criminal responsibility prosecuted at every international criminal tribunal ever since the IMT

\footnotetext{
${ }^{379}$ ICTY RPE Rule $59 b i s(\mathrm{~B})$ and $59 b i s(\mathrm{C})$.

${ }^{380}$ ICTY RPE Rule 62(A)(ii), ICTR RPE Rule 62(ii), SCSL RPE 61(ii)), STL Rule 98(A)(ii).

${ }^{381}$ ICTY RPE Rule 68ter(D), STL RPE Rule 168(C).

${ }^{382}$ Cao, D. (2007), Translating law. Multilingual matters LTD: Bristol, p. 3 .
} 
and IMTFE clearly puts forward a very important truth about international crimes: the crimes "are committed by men, not [by] abstract entities." ${ }^{3{ }^{83}}$ However, there is another very clear part of this statement that seems to be overlooked by every policymaker since the IMT and IMTFE: the crimes are not committed against abstract entities, either, but against specific victims. As to victims' rights, although the above maxim implies certain obligations of the system of international criminal justice, it cannot be said that those obligations have been met by any international criminal tribunal to date, as all the rights remain defendant-centric. It is somewhat natural they should be defendant-centric because s/he is the one on trial, but even when defendants' rights reflect on victims and reciprocity should have been in order, this has not been done. Table 3 on due process rights at the IMT, IMTFE, ICTY, ICTR, SCSL, STL and ECCC provides a good example which shows that defendants have the right to expeditious trial. To a certain extent, this also implies that victims have the right to expeditious justice, but the trials that have been heard before international criminal tribunals have dragged on way too long. It cannot be said that expeditious justice has been served to anyone. ${ }^{384}$ Indeed, the 2017 Amnesty International report on wartime rape survivors in B\&H quotes Bakira Hasečić of the B\&H Women Victims of War Association who said "most survivors will not live long enough to see justice being done." Here, Ms. Hasečić was addressing both the international justice and local justice that is supposed to be served to victims. The local justice was supposed to be served by the B\&H authorities, but in order for victims to receive it, they needed to gain a status of victim. The 2017 Amnesty International report explains:

For many victims of wartime sexual violence, the status of civilian victims of war represents a gateway to a desperately needed monthly allowance and other social benefits, including medical care and social support. Victims can apply for the status under separate, and often considerably different, laws in the Federation of BiH, Republika Srpska or Brčko District.

\section{$[\ldots]$}

This system in which victims' rights and access to services are regulated by entity and cantonal laws in an unharmonised and disconnected way, rather than universally guaranteed by the state, is inherently discriminatory, with the degree of access varying widely and depending on one's place of residence.

\section{$[\ldots]$}

And, finally, after they manage to overcome [...] hurdles [revolving around compensation claims, finding a free legal assistance, and coping with retraumatization], [victims] almost routinely face negative court decisions due to the recent view of $\mathrm{BiH}$ Constitutional Court stating that a statute of limitation should apply to compensation claims directed against the state or the entities. Following such rulings, victims are forced to pay high court fees or face administrative seizure of their assets.

\footnotetext{
${ }^{38_{3}}$ Principles of International Law of the Charter and Judgment of the Nuremberg Tribunal, Formulated by the International Law Commission, Second Session. International Organization, vol. 4, no. 4, 1950, pp. 714-721.

${ }^{384}$ Starting alphabetically and stopping at the tenth case relating to $\mathrm{B} \& \mathrm{H}$, examining the length of proceedings from the initial indictment to the completion of appeals, research has shown that it took: 5 years in Aleksovski (initial indictment issued in 1995, appeals completed in 2000), 8 years in Banović (initial indictment issued in 1995, appeals completed in 2003), 9 years in Blagojević (initial indictment issued in 1998, appeals completed in 2007), 6 years in Jokić (initial indictment issued in 2001, appeals completed in 2007), 9 years in Blaškić (initial indictment issued in 1995, appeals completed in 2004), 12 years in Bralo (initial indictment issued in 1995, appeals completed in 2007), 8 years in Brđanin (initial indictment issued in 1999, appeals completed in 2007), 9 years in Češić (initial indictment issued in 1995, appeals completed in 2004), 3 years in Delić (initial indictment issued in 2001, appeals completed in 2004), 3 years in Deronjić (initial indictment issued in 2002, appeals completed in 2005), etc. ICTY, Cases. Given that it takes only several months to complete a trial in national jurisdictions (UK, Ministry of Justice (2017), Criminal court statistics quarterly, England and Wales, January to March 2017 states that "for cases completing in the Crown Court the average number of days from first listing at the magistrates' court to completion in the Crown Court decreased by 2 days from 196 days in 2015 to 194 days in $2016^{\prime \prime}$ ), given that judges, prosecution and defense practicing before international criminal tribunals have much less on their working plate and much more on their financial, resource, and support plate to motivate them to work harder than their colleagues from national jurisdictions (Starr, S. B. (2009), Ensuring Defense Counsel Competence at International Criminal Tribunals. UCLA J. Int'l L. Foreign Aff. 14, no. 1 (2009): 169-206), this data on the length of trials at ICTY is hard to explain, to say the least.
} 


\section{$[\ldots]$}

Indeed, BiH Constitutional Court's position on the statute of limitations and the inability of the authorities to implement decisions on compensation leave victims without an enforceable right to remedy, which is contrary to international law. ${ }^{385}$

What does this mean in practice? As to international justice, the ICTY did not have any retributive function, meaning it did not provide, arrange, or push for any compensation to victims. For victims, this meant that, on hearing ICTY judgments, victims may declare that justice has been served. And that is about it: the fact that the ICTY may have recognized them as a testifying victim has no bearing on their status in their home country whatsoever.

The ICC came as a pleasant surprise to victims, as one of the reports of the Assembly of States Parties proclaimed that the "Court was created with both a punitive and restorative function, with the Rome Statute giving victims a right to directly participate in proceedings. ${ }^{386}$ However, Garbett argues that it remains unclear whether the ICC's practices are structured with the deliberate aim of meting out restorative justice, or whether mention of this justice approach is used as a broader description of the 'victim-friendly' practices of the Court by its professional staff. In recent years, the relationship between the ICC and restorative justice has become even more ambiguous; the reference to restorative justice has been removed from the 'victims' section of the current version of the website, and there is now no mention of victim participation or reparations being understood to encompass this form of justice. How, then, should we understand the justice approach' of the ICC? Drawing on Bourdieu's conception of the actors and activities of the juridical field, Garbett considers the possible reasons for the exclusion of victims as direct participants. It argues that the seeming subversion of the traditional retributive functions of international criminal justice through the participation of victims does not function in practice. Instead, the ICC retains the retributive focus on authoritative legal actors, and only hears their voices during proceedings. ${ }^{87}$

Chapters 6 and 7 of this study provide more detail on how these voices have been rendered in translation and interpreting at the ICTY. Let us look now at the victim's language-related rights, duties, and obligations as coded in the applicable legislation. When it comes to such rights, obligations, and requirements of victims and witnesses, these are not explicitly mentioned in any of the statutes under examination. The ICTY, ICTR, SCSL, and STL statutes give the Prosecutor the right to question victims and witnesses ${ }^{388}$ and give the accused the right to examine or have the witnesses examined.$^{38}$ ECCC Law gives co-investigating judges the right to question victims and hear witnesses and Co-Prosecutors the right to interrogate the witnesses. ${ }^{390}$

The ICTY, ICTR, STL, SCSL, or ECCC RPEs do not explicitly mention any victims and witnesses' language-related rights, obligations, and requirements, grouping them together with "(any) (other) persons appearing before the Tribunal, other than as counsel." ${ }^{391}$

However, the STL and the ECCC have fully functioning units dedicated to victims and their legal representation. At the STL, the Directive on victims' legal representation (2013) stipulates that the admission

\footnotetext{
${ }^{385}$ Amnesty International (2017), 'WE NEED SUPPORT, NOT PITY' LAST CHANCE FOR JUSTICE FOR BOSNIA'S WARTIME RAPE SURVIVORS. London: Amnesty International Ltd.

${ }^{886}$ Assembly of States Parties, International Criminal Court, Report of the Court on the Implementation in 2013 of the Revised Strategy in Relation to Victims. ICC-ASP/12/41, 11 October 2013.

${ }^{387}$ Garbett, C. (2017), The International Criminal Court and restorative justice: victims, participation and the processes of justice, Restorative Justice, 5:2, 198-220.

${ }^{388}$ ICTY-S Article 18(2), ICTR-S 17(2), SCSL-S, Article 15(2), STL-S Article 11(5).

${ }^{389}$ ICTY-S, Article 21(4)(e), ICTR-S, Article 20(4)(e), SCSL-S, Article 17(4)(e), STL-S, Article 16(4)(e).

${ }^{39 \circ}$ ECCC Law Article 23.

${ }^{391}$ ICTY, ICTR, SCSL RPEs Rule 3(C), STL RPE Rule 1O(D).
} 
panel is responsible for admitting people to the list of victims' counsel. As for applicants whose native language is not English or French, the admission panel may require evidence of English or French proficiency. In considerations for the designation of legal representatives, the Registrar examines whether the candidate has sufficient language capacity to provide effective legal representation to the victims to be represented. In selecting a legal representative to be designated as a lead legal representative, co-legal representative or duty legal representative, the Registrar may consider, inter alia, the candidate's language skills. Facilities, advice and assistance provided by the Victim Participation Unit to designated legal representatives include but are not limited to providing language services and support to victims' legal teams. Language Assistants are included among those who may assist legal representatives in the preparation and presentation of a case before the Tribunal. Chapter 6 provides more information on the institution of Language Assistants. The STL, subject to STL RPE Rule 10, provides translation and interpreting services pursuant to separate applicable procedures. Duties of legal representatives on withdrawal of designation include ensuring all essential work products are legible and available in one of the working languages of the case. ${ }^{392}$ The STL Legal Aid Policy for Victim Participation (2014) stipulates that interpreting and translation services provided by the STL are governed by separate applicable procedures. In addition to those assisting legal representatives set out in §15.1, victims' legal teams may make use of, inter alia, Language Assistants, as approved by the Victim Participation Unit on a case-by-case basis and subject to available budget. ${ }^{393}$ In other words, it seems that Arabic speakers, speakers of the same language as the victims, do not get preferential treatment as legal representatives of the victims appearing before the STL.

The ECCC Victims Support Section takes a more pragmatic view and, among the criteria for inclusion on the list of lawyers, stipulates that foreign lawyers must be fluent in Khmer, French, or English. ${ }^{394}$

\subsection{ICTY case law on language-related rights, obligations, and requirements}

The language and identity-related background to the conflict in the former Yugoslavia and most specifically, $\mathrm{B} \& \mathrm{H}$, is explained in Chapter 3 . Language and identity-related conflicts, which were very common after the Ottomans left B\&H, moved to The Hague with the ICTY defendants and their defenses to support the denial of each other's unique language, identity, and culture by claiming to misunderstand the languages used for interpreting and translation. As expected, perhaps, defendants of Serb origin before the ICTY were the loudest in their claims not to understand the other two versions of the former Serbo-Croatian, Bosnian and Croatian, putting on a constant show about their language, identity, and history. As explained before, in the best traditions of Munchausen's trilemma, their defenses mostly centered around arguments that either the reason to commit crimes was predicated on a series of sub-reasons leading to an infinite regression, or, those reasons were tracked back to arbitrary axiomatic statements, or, the reasons were presented as ultimately circular, i.e. crimes were committed because they were committed.

Although denial of the other's culture, language, and identity is the core of nationalist discourse, the major requirement in all legal processes is fairness to and a presumption of the innocence of the defendant, who can be seen as the most protected person in any trial. Since the court must ensure that the fundamental rights of a defendant in a criminal case are protected throughout that person's trial, practical examples of where the right to translation and interpreting into a language the defendant understands are discussed here more closely in terms of ICTY case law on language-related rights, obligations, and requirements. Paradoxically, most ICTY defendants originate from $\mathrm{B} \& \mathrm{H}$, where they spent most of, if not their entire lives. However, that did not stop B\&H Serbs from trying very hard to switch from their native Bosnian language of ijekavian

\footnotetext{
${ }^{392}$ STL, Directive on victims' legal representation (2013), Articles 12 (A), 12 (C), 19(B)(iv), 19(C)(v), 32 (A)(iii), 33, 35, and 41 (C)(iii).

${ }^{393}$ STL, Legal Aid Policy for Victim Participation (2014), Articles 1.7 and 15.2.a.

${ }^{394}$ ECCC, Legal representation in the Victims Support Section.
} 
pronunciation to Serbian ekavian. ${ }^{395}$ This particularly applies to Messrs. Župljanin, ${ }^{396}$ Mladić, $^{397}$ and Karadžici ${ }^{398}$ whose determination to speak ekavian seems to be associated with their political affiliations and loyalties and can be said to constitute a clear political statement. What brings their linguistic political statement to the realms of absurdist drama is that their speech pattern is a mishmash of the Bosnian language intonation, sentence structure, and expression in both the Bosnian, ijekavian, and the Serbian, ekavian, dialect and that, bizarrely, in the same sentence. In that sense, mixing ekavian and ijekavian or Bosnian ijekavian with Croatian ijekavian should send a message that the Court is dealing with a person with a non-linguistic agenda. It is unfortunate that this point was not explored by the OTP, either. Basically, mixing two ways of pronunciation is as if a person spoke in a mix of US and UK English accent. This is like a speaker of the English langage who prononce all the words of the English langage of origine française and some others with an accent français and English sentence structure. Did you feel the need to read the previous sentence twice and then decide that you got the meaning only from the context? The previous sentence is grammatically correct, you were confused because you simply did not expect such sharp and bizarre switches between the two languages. It would have been interesting to know what you would think of the oratory, intelligence, and coherence of such a speaker in your own language. But, prolonged exposure to such speech begs the question: are these defendants listening to themselves? The defendants have their agenda and they are sticking to it. They are defending themselves and by using the language of the country they consider their mother country, they are fishing for popular acceptance and support. They could be reproached for not being original or for not being consistent, but, in the end, their role is to prove to the Court that their way is the right way. It is rather strange that they are defending themselves against claims of nationalism escalating into ethnic cleansing and genocide by feeding into the nationalist discourse. How did the Court react to these claims of miscomprehension?

In 1995, in anticipation of an issue about the name of the language used and underlying problems of comprehension, the CLSS, the ICTY's language services provider, consulted with two linguistic experts:

\footnotetext{
${ }^{395}$ Apart from making references to Montenegro, whose national language is Montenegrin, in Part I.1. on Script, the Orthography of the Serbian language from 2010 published in the Republic of Serbia makes a series of statements that are not normally expected in books of this type and seem to continue to feed into the nationalist discourse: "In order of importance, the Cyrillic script is the primary and the elementary Serbian script. Since the 197os, the Cyrillic script has been neglected, marginalized, and abandoned, suppressed from the official and public use, and suffered artistic stagnation. In Serbian traditions, the Cyrillic script has an indisputable symbolic function. Therefore, favoring the use of the Cyrillic script in official, public, educational, and cultural activities is justified. The latest cultural, historical, and political development of the Cyrillic script is in primary connection with the existence of almost one century of Serbian-Croatian linguistic community (or 7o years of common state). This led to the production of a rich Serbian heritage written or printed in the Latin script (of course, parts of that heritage date from an earlier period). It also catered to the contemporary exigences of culture, science, and communication, which is dominated by Latin script-based cultures. However, this facilitated the writing of the Serbian language in the Latin script and turned it into our daily practice. Such coexistence of two scripts is rare, although, for our consideration, the only acceptable sequence of learning and use of those scripts would be Cyrillic first and then the Latin script. At any rate, this use cannot be considered detrimental to Serbian culture unless Cyrillic script becomes existentially threatened." [BF translation] In Part II.6. on Ekavian and Ijekavian Pronunciation it is established that the Serbian standard (literary) language has two equal ways of speaking and writing: ekavian and ijekavian. In reference to the discussions on the word aždaja from Chapter 3.3., Part III.15.g. on Sound changes and relationships, Consonant $h$, reads the following: "The sound $h$ is consistently replaced by sound $j$ in following words: aždaja, proja, promaja, jendek (the variants with $h$, such as aždaha, etc., are only pronounced by the Muslims." Pešikan, M., Jerković, J., Pižurica, M. (2010), Pravopis srpskoga jezika (izmenjeno i dopunjeno izdanje). Matica Srpska: Novi Sad.

${ }^{396}$ ICTY transcripts, Župljanin and Stanišić, T. 21-22: zahtjev (request, ijekavian), razriješimo (resolve, ijekavian), rešimo (resolve, ekavian), razrešimo (resolve, ekavian).

${ }^{397}$ ICTY videos, Mladić IA (2011), (ENG), (INT):Ja bih želio (I want, ijekavian), stariji čovek (elderly man, ekavian), mesec dana (one month, ekavian).

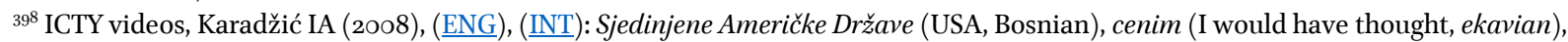
Tužilaštvo (Office of the Prosecutor, Bosnian), etc. It is worth noting that Karadžić was born in Montenegro (Montenegrin, ijekavian) and that he spent most of his life in B\&H either in prison or in high public offices.
} 
Wayles Browne and Morton Benson. ${ }^{399}$ They stated that the varieties of Serbo-Croatian are mutually intelligible to all citizens of the former Yugoslavia, that the differences between Serbian and Croatian are small and that there is no valid reason to justify the refusal of Serbo-Croatian interpreting. ${ }^{400}$ Moreover, when asked for an opinion on the differences between Bosnian, Croatian, and Serbian, Browne stated the following:

Not all speakers from Serbia are aware of all the terminology used in Croatia, and not all speakers from Croatia are aware of all the terminology used in Serbian, so that a conversation about a technical field such as chemistry may require clarification of particular terms. People schooled in $[\mathrm{B} \& \mathrm{H}]$ were exposed to both sets of everyday vocabulary and terminology. Therefore, one should not expect difficulties in understanding when a Bosnian and a person from Croatia or Serbia are speaking. ${ }^{401}$

Therefore, following the assessment of independent experts who repeated some language-related conclusions from Chapter 3 of this study, 23 years before it appeared in the press that people schooled in B\&H were exposed to both sets of everyday vocabulary and terminology, it would be assumed that B\&H language professionals were well represented among ICTY CLSS managerial and staff ranks, as well. Indeed, operationally, 87 defendants tried for crimes committed in B\&H, joint crimes in B\&H and Croatia excluded, 74 committed crimes specifically targeting non-Serbs, including 39 specifically targeting Bosnian Muslims, 10 committed crimes specifically targeting non-Muslims, and 3 committed crimes specifically targeting non-Croats. ${ }^{402}$ In other words, the bulk of ICTY trials were about crimes committed against B\&H Muslims in B\&H, where the population speaks the Bosnian language or, rather, does not speak Croatian as spoken in Croatia or Serbian as spoken in Serbia. In itself, this raises an issue related to language staff: should language staff recruitment at an international criminal tribunal adjudicating on ethnic crimes be based on nationality and ethnicity and preclude language professionals with the ethnicity of the attacking forces from working with victims and witnesses with the ethnicity of the victims? CLSS circumvented all these critical issues by inventing $\mathrm{B} / \mathrm{C} / \mathrm{S}$, a practical abbreviation that stands for Bosnian/Croatian/Serbian or, as they claimed, the language formerly known as Serbo-Croatian. It is just that Serbo-Croatian was just a name, not an actual language which people spoke. Consequently, the invention of $\mathrm{B} / \mathrm{C} / \mathrm{S}$ accounted for a name but did not account for any of the differences in languages remarked on by Browne, did not account for staff-related due diligence at war crimes tribunals adjudicating on ethnic crimes, and did not account for the history of language and identity-related conflicts in the former Yugoslavia.

In 1996, the issue of alleged miscomprehension of language used for translation and interpretation came up as a legal issue for the first time during the testimony of a rather unwilling witness. After having exhausted all of the options not to testify, a witness complained that he did not understand the language used for interpretation. It is only in Mucić where the Trial Chambers actually delivered a decision on the issue when Mucićs defense orally applied for interpretation of the trial proceedings into Croatian for the benefit of the accused, instead of Serbian. However, there were two flaws with this decision. The first flaw is in the wording "the refusal of Serbo-Croatian interpretation" because the issue was not interpretation into SerboCroatian, but into Serbian. The second flaw is that this decision does not mention the citizenship of the defendant $(\mathrm{B} \& \mathrm{H})$ or the Bosnian language: it only decided on differences between Serbian and Croatian. Clearly, given the discussion in Chapter $3, \mathrm{~B} \& \mathrm{H}$, Bosnians and the Bosnian language were again disadvantaged. The

\footnotetext{
${ }^{399}$ Benson was the author of a two-volume definitive Serbo-Croatian-English/English-Serbo-Croatian dictionary (although one of the chief criticisms was its inadequate attention to words of Turkish origin). His chief coworker was a Serbian academic who taught at University of Illinois-Chicago for most of her career. Wayles got his PhD from the University of Zagreb and still teaches at Cornell University. He is arguably the best general linguist with former Serbo-Croatian as his specialty.

${ }^{400}$ ICTY, Order on Zdravko Mucić's oral request for Serbo-Croatian interpreting (1997).

${ }^{401}$ Draženović-Carrieri, M. (2002), B/C/S-A practical approach. Lexicography and Language Policy in South-Slavic Languages after 1989. Verlag Otto Sagner: Munich, p. 51.

${ }^{402}$ ICTY, Cases.
} 
third and the most important flaw is that this decision is very limited: it is unacceptable for someone claiming to be a speaker of Croatian to not understand interpretation by a Serbian interpreter. Therefore, the defense of miscomprehension concerning all other languages and interpretative combinations seemed an excellent one. Naturally, other defendants picked up on that. The Defense in Delalić, a Bosnian Muslim, requested that all transcripts and other documents be provided in Bosnian. They argued that the application is based on the right of an accused to use his own language in order to ensure equal treatment as a party to the proceedings and that the requirement that counsel address the ICTY in one of its working languages presents a restriction on the right of the accused to choose his own counsel. As to the restriction, the Court reiterated that the ICTY does provide a facility for counsel to speak the language of the accused during the proceedings, in addition to the two working languages, concluding there is no restriction on this right. The Prosecution and Chambers agreed that certain documents must be provided in the language of the accused but contended that the both the ICTY-S and the ICTY RPE required all documents to be submitted in the language of the accused. It is noteworthy that this request was not a request to un-recognize or block the use of all other languages, but a legitimate request to the Court to provide the official court transcripts in the language of the accused. The Trial Chamber partially obliged..$^{403}$

In 2000, the parties could not agree on a statement of a deceased witness. ${ }^{404}$ The Prosecution wanted to introduce the statement of a witness taken by an OTP investigator, but since the witness had since died, the Prosecution contended that it was in the interests of justice to admit his statement into evidence. The Trial Chamber first declined, but after hearing further arguments from the parties, the Trial Chamber decided to admit the statement. The Trial Chamber held that Rule $89(\mathrm{C})$ gave it discretion to admit the statement, and that the fact that the statement had not been subjected to cross-examination and was not made under oath were factors that affected the weight to be given to the statement, and not its admissibility. The Trial Chamber noted that, pursuant to the European Court of Human Rights jurisprudence cited by the parties, "it would not be possible to convict the accused on the basis of this statement alone if that evidence was uncorroborated" without violating his fundamental rights. The Defense argued that the statement was erroneous in several respects: the OTP investigator admitted that she did not speak Croatian, the language of the witness, and relied on the interpreter's account of what he was saying. Although witness statements can be taken through an interpreter, this particular statement was unusual as it was not taken in formal circumstances: the witness statement was written in English by the OTP investigator, whose native language is Dutch and was then translated back into Croatian for the witness to sign it. Trial Chambers found that these multiple translations in an informal setting create a much greater potential for inaccuracy than is the case when both the declarant and the witness speak the same language or when the original statement is given in court with a professional, double-checked simultaneous translation. The Appeals Chamber found the statement so lacking in reliability that it should have been excluded as without probative value under Rule $89(\mathrm{C})$.

In 2003, Šešelj surrendered to the ICTY, where he gained the status of a self-representing defendant. Šešelj's sole job, as such, was to defend himself against all allegations made by the Prosecution. Šešelj almost immediately turned against the interpreters during his initial appearance, insisting that the ICTY find an interpreter who can speak the Serbian language well and complained that he did not understand Croatian words that were used in interpreting. Obviously, the naming of the former Serbo-Croatian into neutrally perceived $\mathrm{B} / \mathrm{C} / \mathrm{S}$ did not preclude the accused from actually hearing the language and made them want to be interpreted into their own language. Defendants are free to make claims of misunderstanding which then have to be entertained as per ICTY-S Article 21 on the rights of the accused and ICTY RPE Rule 3 on languages. The ICTY uses established principles to decide the claim, even if the claim lacks a reasonable foundation and no matter how frivolous the defendant's allegations. A reasonable foundation for claiming one does not understand the language is just that: a claim of complete or partial miscomprehension of that language. It is clear the person does not speak the language he claims not to speak, because he does not understand that

${ }^{403}$ ICTY, Decision on Defense application for forwarding the documents in the language of the accused (1996).

${ }^{404}$ ICTY, Decision on appeal regarding statement of a deceased witness (2000). 
language. However, no defendants appearing before ICTY have ever proved that. Šešelj claimed not to have understood the interpreter speaking Croatian, but then provided the Serbian version of disputed words himself (tačka, hotimice, hapšenje for točka, hotimično, uhićenje (point, random, arrest)). ${ }^{405}$ As to translators, Šešelj insisted that "every document, each and every document, must be translated into the Serbian language; otherwise it is unacceptable to this Tribunal. ${ }^{m 06}$ However, except for emphasizing that it is important that he exercises his rights to use his own language during the preparation of his defense, Šešelj never really made any substantive language-related point relevant to his overall argument except for showing his annoyance with the fact that anyone from the area of the former Yugoslavia, apart from Serbs, is entitled to use their own language.

In 2004, realizing that no one was buying his argument, Šešelj took his ICTY-given rights to translation and interpreting into the realm of the bizarre. ICTY RPE Rule 65bis(i) on status conferences calls the parties to organize exchanges between them to ensure expeditious preparation for trial where the OTP, in this case, surrenders to the defense all documents they plan to use to prove their claims in trial. However, Šešelj, a PhD, stated that he did not want the OTP to submit documents in an "electronic form, on diskettes" but rather on paper, because a "document on paper is a basic document." ${ }^{\text {"07 }} \mathrm{He}$ continued asking for documents to be submitted in paper form, stating that submitting documents in electronic form is "the same as if you decided that I had to stand on my head in the courtroom," ${ }^{408}$ exclaiming "I do not use a computer. I do not use this form. I'm never going to use a computer." ${ }^{409}$ After having waited two years to receive disclosure documents, including statements of all protected and open court witnesses on paper, Šešelj bound them all together, manipulated pictures of the judges or prosecutors by giving them horns or other animal-like features, wrote derogatory titles on the cover, called the whole thing a book, and published it in Serbia. ${ }^{410}$

In 2005, the Defense submitted a motion requesting the Trial Chamber not to admit the record of the interview of the accused taken by ОTP investigators and tendered by the Prosecution arguing, inter alia, that the statement has not been taken according to the ICTY RPE Rules: an interpreter was present during the interviews, but the Prosecution did not keep notes of the interview in its records and the interviews were not audio or video recorded. ${ }^{411}$ The Prosecution submitted that the statement was taken with the assistance of a competent UN interpreter, with good knowledge of military terms, who read the statement, as written by the investigator, to the accused before he signed it, and argued that there is no strict requirement to keep records of any notes on the investigator, nor a requirement to keep a list of questions. The Trial Chamber has found that the ICTY RPE Rule 43 on recording interviews of suspects was not applied, the accused had not

\footnotetext{
${ }^{405}$ ICTY transcripts, $\breve{S}$ ešelj, T. 57-59, 76.

${ }^{406}$ ICTY transcripts, $\breve{S}$ ěselj, T. 98-99.

${ }^{407}$ ICTY transcripts, $\underline{S}$ šselj, T. 237.

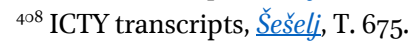

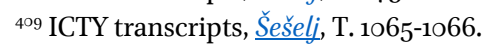

${ }^{410}$ Since his voluntary surrender, Šešelj engaged in a series of attempts to stall the process calling for disqualification of parties to the proceedings, writing books with titles derogatory to the parties, and publishing lists of witnesses containing full particulars and statements of protected witnesses planning to testify against him. Šešelj was accused of contempt of court three times for disclosing confidential information in violation of orders granting protective measures and intentionally disclosing information which identified protected witnesses. As a consequence, brave people who agreed to testify against Šešelj found themselves in mortal danger, especially those who were still living in the territory of the Republic of Serbia which was/is still seething with Šešelj's supporters. Some titles of these books include: "Plucked Turkey from The Hague: Christine Dahl," featuring a plucked turkey with Ms. Dahl's head on the cover (Ms. Dahl was a Senior Trial Attorney in his case), "Bristling Scottish Piece of Shit: Iain Bonomy" (Judge Bonomy was one of the judges on his case), "Wrinkled Kangaroo's Ball: Kevin Parker" (Judge Parker was one of the judges on his case), "South Korean Mite O-Gon Kwon" (Judge Kwon was one of the judges on his case), "Dumbass from Manitoba: Bruce MacFarlane” featuring Mr. MacFarlane with donkey ears on the cover (MacFarlane was a Prosecution's Senior Trial Attorney in his case), "We Resume Plucking Turkeys from The Hague” featuring four plucked turkeys with the heads of Ms. Dahl, Mr. MacFarlane, Ms. Del Ponte and Mr. MacFarlane's unidentified female assistant on the cover. The Court issued verdicts on contempt charges (one finished, two unfinished as of December 2016).

${ }^{41}$ ICTY, Decision on motion for exclusion of statement of accused (2005).
} 
chosen to waive his right to remain silent during trial, and that the admission of the disputed statement would infringe on his right to a fair trial.

In 2007, Šešelj's efforts seemed to have opened avenues for other accused to experiment with, seemingly using same tactics. Tolimir, another self-representing defendant who would routinely bless all in the courtroom at the beginning of each and every trial session, ${ }^{42}$ another $\mathrm{PhD}$, and another Bosnian speaker who mixed the two linguistic variants when speaking, made similar claims to Šešelj's during his initial appearance, asking for all the documents for his review to be provided to him in Cyrillic script and that the written communication with the Court should be conducted in Cyrillic. B\&H born and raised Tolimir provided no coherent argumentation for such a request. He pointed out that "language is a basic characteristic of mankind, which enables complex social life and all aspects of that life" and stressed that "it is with great effort that I would be able to read a document in Serbian but written in a Latin script." Tolimir concluded his plea by saying "Now, there are a lot of people who learned foreign languages when they were young and can no longer use them or write in those languages, especially if they had a passive knowledge of those languages." The Presiding Judge retorted: "I'm taking from your submission that you do, in fact, read and understand the Latin script; however, it is more difficult for you to read in the Latin script than in the Cyrillic script. That's the way I'm going to summarize what you've said on that particular point. But you do read and understand it." ${ }^{\text {"13 }}$ Tolimir's request was dismissed.

In September 2008, Karadžić filed a motion that all materials in his case, including transcripts, should be submitted in Serbian and in Cyrillic script. ${ }^{414}$ The Court informed him that court session transcripts are not available in $\mathrm{B} / \mathrm{C} / \mathrm{S}$, but that the audio tapes of the court sessions could be made available in $\mathrm{B} / \mathrm{C} / \mathrm{S}$ for his perusal. Karadžić appealed, claiming that listening to the audio tapes is unacceptable because the process of listening would be too onerous and would impede with preparation of his defense. He repeated the request and reiterated that he needed all materials, including transcripts, to be delivered to him in the Serbian language and in the Cyrillic script. The Deputy Registrar responded, reminding him that delivery of audio tapes in $\mathrm{B} / \mathrm{C} / \mathrm{S}$ is consistent both with CLSS translation policy and ICTY jurisprudence. The Prosecution responded, reminding him that the request had no support in ICTY-S, ICTY RPE, jurisprudence, or practice, adding that similar requests had been routinely denied by the Court and that the Accused did not provide any reasonable justification for such a request. The Chamber started a discussion on the issue by relating that the Accused stated he does not deny understanding the English language, but that his knowledge of English is insufficient to "understand legal matters." The Chamber noted that there is evidence that the Accused does have broad understanding of English, as he was trained in the USA and has published in English. The Chamber noted that " $\mathrm{B} / \mathrm{C} / \mathrm{S}$ " is the proper qualification of languages used in parts of the former Yugoslavia. As to "all materials," the Chamber reiterated that materials referred to in Rule 66(A), Rule 66(A)(i), and Rule 66(A)(ii), namely disclosure documents, material supporting the indictment and witness statements, including all transcripts disclosed pursuant to Rule 66 should be transcribed into a language the Accused understands, rather than provided to him in audio format. The Court remarked that this decision, however, did not affect documents that are beyond the scope of Rule 66. Moreover, in court, the Accused received real-time audio interpretation and there is no reason that he should receive transcripts on the top of that. The Accused is free to use existing translation and interpretation facilities, can find a counsel who speaks his language, and can be assigned a Language Assistant. As to the Cyrillic script, the Accused only argued a preference, which is insufficient justification for departing from standard practice.

\footnotetext{
${ }^{412}$ ICTY transcripts, Tolimir, T. 4-18.

${ }^{413}$ ICTY transcripts, Tolimir, T. 62-70.

${ }^{414}$ ICTY, Decision on the Accused's request that all materials, including transcripts, be disclosed to him in Serbian and Cyrillic script (2008).
} 
In March 2009, the Prosecution in Karadžić filed a motion seeking a determination that the Accused understands English for the purposes of ICTY-S and ICTY RPE. ${ }^{45}$ The Accused is a self-representing accused, has two legal associates, and one investigator who are paid by the Registry as per standing rules, and several pro bono advisers and interns. In that regard, the Prosecution requested the revision of the Chamber's decision that "all transcripts disclosed pursuant to Rule 66 should be transcribed into a language the Accused understands, rather than provided to him in audio format" arguing it was inconsistent with ICTY case law and "practically infeasible as transcription into $\mathrm{B} / \mathrm{C} / \mathrm{S}$ would require significant expenditure of time and resources." The Accused responded by saying he had no formal training in English, the Prosecution has only managed to show that he resided in the USA more than 30 years ago, and that he conversed in English "from time to time 14 to 17 years ago." Therefore, the Prosecution has not shown that he has a sufficient understanding of English in 2009 and that, from 1996 through 2008, he almost never spoke English. His communication with his associates does not equate to a sufficient understanding of the language for the purposes of his trial. The Accused stated that his associates' draft pleadings and correspondence on his behalf in English is simply evidence of the delegation of tasks within his defense team. The Accused also claimed that he is unfamiliar with English legal terms and, therefore, cannot confidently handle legal matters in English: he has a far better understanding of legal terms in Serbian than in English and that is just common sense. After a lengthy reflection on English-speaking defense team members, the history of the Accused's education, and his use of English in public, the Court found that the Accused "is capable of conversing and understanding the English language, even in the context of a complex criminal trial" as witnessed by his conversations with his legal representatives and his signature on the English documents submitted to the Court. Court granted the motion and notified the Prosecution and the Registry that "English is a language that the Accused understands for the purposes of the Rules and the Statute, and in particular, for the purposes of the Chamber's Decisions of 25 September and 25 November."

In July 2009, the Prosecution sought the admission into evidence of a witness's written statement pursuant to Rule 92quater on unavailable persons because the witness was presumed dead. The Defense objected, claiming that the witness's evidence was never subjected to cross-examination, was not taken under oath, and was therefore not reliable. ${ }^{46}$ The Defense objected to the language in which the witness interview was conducted, the statement recorded, and the witness's ability to speak and understand English. The Trial Chamber found that, while the absence of an interpreter may be a relevant factor, in those circumstances the Chamber was not satisfied that the absence of an interpreter rendered the statement inadmissible. By his signature recorded on each page and the witness acknowledgment, the witness indicated that he speaks and understands English. The Chamber granted the motion and the statement was admitted to evidence.

In November 2009, the Prosecution argued for the reliability of the information given in the witness statement and proposed the following language-related factors that guarantee that reliability: 1) the presence during the interview of duly qualified interpreters appointed by the Registry; 2) the presence of two investigators during the interview; 3 ) the Statement was read back to the witness in the presence of a duly qualified interpreter appointed by the Registry; [... 5) the witness signed the Statement and indicated that it was true and correct to the best of his knowledge and that it had been read over to him in his own language; and 6) the interpreter and the investigators also signed the Statement $[\ldots] .{ }^{417}$ The Trial Chamber confirmed that the statement was made with the assistance of an interpreter duly qualified and approved by the Registry of the Tribunal. Consequently, the Trial Chamber considered that the disputed statement met sufficient indicia of reliability.

\footnotetext{
${ }^{45}$ ICTY, Decision on Prosecution motion seeking determination that the Accused understands English for the purposes of the [ICTYS] and [ICTY-RPE] (2009).

${ }^{416}$ ICTY, Decision on Prosecution's renewed motion for admission of evidence of Antonio Russo pursuant to Rule g2quater (2009).

${ }^{417}$ ICTY, Decision on motion for admission of [witness] testimony pursuant to Rule g2quater (2009).
} 
In 2013 , the defense counsel submitted the view that "translation issues" may have led a doctor to draw incorrect conclusions on the health of the accused. ${ }^{418}$ The Appeals Chamber noted the examination of the accused required interpreting from/into English and $\mathrm{B} / \mathrm{C} / \mathrm{S}$ and that the examining doctor was alert to the associated risks involved, namely that simultaneous interpreting is actually unwanted in an examination situation such as this, as it gives the examining physician insufficient opportunity to evaluate the answers given on questioning. The doctor's report did not indicate any difficulty with interpreting during the twoand-a-half-hour examination. On the contrary, his report contains many detailed and comprehensible quotes from the accused. The Chamber decided that the argument of counsel was based on nothing more than speculation as he failed to substantiate any allegations.

\subsection{Procedural equality of arms between the ICTY Prosecution and Defense}

The equality of arms is one of the principles used to determine whether a trial is fair. However, this principle has not been explicitly incorporated into most international criminal tribunals' statutes or international treaties: the European Convention on Human Rights and Freedoms (ECHR), UDHR, ICCPR, ICTY-S, etc. only suggest the equality of arms under the right to fair trial. ${ }^{419}$ All these provisions under the umbrella of the right to a fair trial require that defendant is informed promptly of the charges against him, has adequate time and facilities to prepare his defense, can access and comment on evidence against him, and has the right to secure the attendance and examination of witnesses on his behalf under the same conditions as witnesses against him. Procedural equality implies that both parties have the same procedural rights before, during and after the trial without any of them being at the disadvantage. Why is procedural equality relevant for languagerelated matters? It is important because, as seen before, it implies translation, interpreting, and transcription: the defendant must not be at a disadvantage if he does not speak the languages of the court.

As to the language of the Court, English and French are languages of both the mother and the working institution, $\mathrm{B} / \mathrm{C} / \mathrm{S}$ is the language of the defendant, and English, French, or $\mathrm{B} / \mathrm{C} / \mathrm{S}$ are the languages of defense counsels. Defense counsels practicing before international criminal tribunals are responsible directly to their client, who may not speak their language and who is free to use his own language according to ICTY rules and regulations. Although there are defendants who are uninterested in their defense, defendants who are interested in the minutest details of their defense, and those who are somewhere in the middle, that is superfluous for discussion of their normative rights. Normatively, in the context of the international criminal tribunals, defendants may have access to all the documents, decisions, orders, etc. used in the determination of their case in their own language. Language-wise, there are defendants who do not speak the official ICTY languages at all, those with rudimentary knowledge of those languages, and those with functional understanding of those languages. Following strict interpretation of ICTY rules and regulations, they all have the right to documents used in trial in their own language. Following ICTY case law, they do not have those rights if, as found in Karadžić, they have been proven to have been professionally functional in English. For all others, should the defendant not be able to communicate with the Court, the Prosecution, and his own Defense in his own language, this would mean his rights to a fair trial are violated. The question that will be discussed in this part of this study is whether the defense counsel, representing the defendant, is at a disadvantage due to a violation of the defendant's language rights and entitlements. In discussing this issue, as far as languagerelated justice is concerned, it should be established whether the finances, resources, facilities, and other material conditions put the Defense at a linguistic disadvantage and constitute procedural inequality with an effect on the fair trial of the accused.

Before exploring this issue, one must consider the "popular" background. The Defense complains that, in practice, there is no equality of arms between the two parties for a host of reasons: The Prosecution

\footnotetext{
${ }^{418}$ ICTY, Public redacted version of 30 November 2012 decision on request to terminate appellate proceedings in relation to Milan Gvero (2013).

${ }^{419}$ ECHR Article 6, UDHR Article 10, ICCPR Article 14, ICTY-S Article 21.
} 
forms part of the Court itself, does not have an a priori stigma of blameworthiness, has more and better resources, has a larger team of investigators, trial attorneys and legal advisers, and a much larger overall support system. The latter refers to various professional associations and civil society organizations lobbying for the Prosecution. Whereas the entire world seems to support the Prosecution, ${ }^{420}$ those associations and organizations supporting Defense are rare and, at times, could be described as denialist, at best. ${ }^{421}$ It is beyond the scope of this study to determine the effects of such discourse on defense efforts. Suffice it to say that the main role of Defense-supporting organizations should revolve around shedding light on the proverbial "other side of the coin." And in that, they are much more successful than the English/French-speaking Court.

The location and motivation of that "other side of the coin" are in the situation country which means that $\mathrm{B} / \mathrm{C} / \mathrm{S}$ speaking defense can get faster to the situation country than the English/French-speaking court officials, who then have to either compete with $\mathrm{B} / \mathrm{C} / \mathrm{S}$ speaking defense to provide novel information or engage in damage control clarifying the defense's ambiguous and other statements. Then, there is also communication between legal professionals, namely those of the Court and those from the region who only speak $\mathrm{B} / \mathrm{C} / \mathrm{S}$. The ICTY Defense Manual acknowledges that one of the major barriers to regional information sharing is linguistic in nature..$^{422}$ While there have been efforts by multiple organizations to translate documents into $\mathrm{B} / \mathrm{C} / \mathrm{S}$, the most relevant jurisprudential and other materials are only published in French and English and untranslated. Ultimately, this is problematic because not many former Yugoslavia counsels understand these two languages sufficiently well for use in legal matters. The Criminal Defense Section (OKO) and its relevant procedural rules were proposed by the Registry of the B\&H Court and adopted by the B\&H Court on 30 June 2005. One solution to the issue of uninformedness that the OKO has proposed is publication and dissemination of a regional magazine on international crimes: the OKO War Crimes Reporter. This magazine is published four times a year in English and B/C/S. It has law reports of decisions from courts in B\&H, Serbia, Montenegro, and Croatia. It is designed to be a regular source of up- to-date case law interpreting war crimes codes in the former Yugoslavia. ${ }^{423}$ In other words, whereas the ICTY informed everybody on the overall ICTY activities through its own Outreach Program mostly in English and French (Chapter 6), the Defense started a targeted information campaign informing the regional public about defense activities in their own language.

As to the facilities at their disposal, the Defense interviewed for the purposes of this study divide their time at the ICTY into: pre-Electronic Disclosure System (EDS) phase and post-EDS phase. The EDS is the system of electronic disclosure of documents which was introduced at the ICTY in 2004. The EDS allows for electronic disclosure of exculpatory and other relevant documents by the Prosecution to the Defense and it removes the reciprocal obligation of disclosure by the Defense to the Prosecution when seeking access to certain classes of material held by the Prosecution. ${ }^{424}$ Defense teams had offices at and outside ICTY; they worked from those offices and, naturally, from home. At the ICTY, the Defense had at their disposal five premises. If there were 161 individuals indicted by ICTY, that also means there were 161 Defense teams in total. One of these premises given to Defense at the ICTY was a room with a computer linked to all databases with relevant evidentiary materials. During the pre-EDS era, the Defense received one computer containing a Judicial Database. This implied that the Defense support staff, hybrid professionals combining the roles of case manager, translator, interpreter, researcher, and legal assistant in one person, would have to go to the room with the computer, when that computer was free, search for documents and, since search results could not be saved electronically, print out all the relevant documents to go through them later manually. Apart from that, the Defense did not have access to the ICTY Intranet and it is only in about 2006 when the Defense received ICTY email addresses. Naturally, this was an immense waste of time and paper, leading to very long working hours because the entire working day revolved around the availability of that one computer. Šljivančanin

\footnotetext{
${ }^{420}$ Human Rights First, The Role of Human Rights NGOs in relation to ICC investigations (2004).

${ }^{421}$ Council for Defense of Radovan Karadžić, Defending Milošević! Defending Serbia!, and Milan Lukić.

${ }^{422}$ ICTY, ADC-ICTY Developed Practices: Manual of International Criminal Defense (2011), UNICRI Publisher, B4.38.

${ }^{423}$ B\&H Court Criminal Defense Section, OKO Reporter.

${ }^{424}$ ICTY 2004 Annual Report (A/59/215) (2004), paras. 22, 25, 29, 36, 26o, 285, 346 and 391.
} 
seems to have been the first trial functioning through the e-court system. According to the ICTY 2004 Annual Report, the height of ICTY activities was in 2004 when three Trial Chambers ran six trials simultaneously and the Appeals Chamber dealt with 17 interlocutory appeals, four appeals from judgment, and one request for review. ${ }^{425}$ All these activities coincided with the EDS teething troubles.

As to the mechanics of their involvement with their client, two defense counsels are usually assigned to each accused at the ICTY: one from the same region as the accused and trained in the Civil Law tradition who speaks the same language as the accused, and an attorney trained in the Common Law system. Authors of the Defense Manual claim that this maximized the team's ability to absorb and function within the mixed legal system at the ICTY and generally obviated the need to employ a translator for meetings with the accused. However, it is unclear whether these two counsels interpreted for each other or whether the Common Law defense counsel spoke B/C/S. At any rate, the Defense Manual states that this distribution of counsels was not required and was not done in every case: there are successful teams comprised of two lawyers from the region and successful teams comprised of two lawyers who are not from the region. Each lead counsel appointed to a case is free to create the kind of legal team which best fits the circumstances of his client's case. ${ }^{426}$ As to the training, Registry provides some limited training for the Defense right before the scheduled beginning of a trial regarding essential technology used in court during the trial and appeal and on administrative issues including, inter alia, the translation of documents. ${ }^{427}$ In preparation for the trial, the Defense must always be in communication with the Prosecution and request that they fulfill their obligation of, inter alia, translation of evidentiary documents. ${ }^{428}$

As to finances, the Registry determines whether an accused is indigent, administers payment to the accused's Defense team and has financial investigators to ensure that the legal aid system functions effectively. The Registry is responsible for ensuring that defense counsels are provided with help and assistance with issues such as resources, translators, and the assignment of defense staff. ${ }^{429} \mathrm{All}$ aspects of representation, except for necessary travel and daily subsistence allowances (DSA), are covered by a lump sum, including interpreting and translation costs. The lump sum includes all interpreting costs and costs of translation of documents other than those documents to be adduced as evidence (translated by the ICTY CLSS and OTP Language Assistants) and other than interpreting and translation costs incurred pursuant to the ICTY-S which may be invoiced separately up to a maximum of $€$, ooo per month. ${ }^{430}$ These provisions are repeated verbatim in the ICTY's Trial Legal Aid Policy for the Defense. ${ }^{431}$ In other words, the defendant and his defense team will not have to settle the costs of translation and interpreting sanctioned by the ICTY-S and ICTY RPE. This leaves out settling payment for translation and interpretion costs related to the Defense evidence. The ICTY-S and ICTY RPE do not contain a single word about Defense evidence, except that the Registrar may admit a counsel who speaks the native language of the suspect or accused, but that such counsel or accused must undertake to meet all translation and interpretion costs not usually met by the Tribunal and must undertake not to request any extensions of time as a result of the fact that he does not speak one of the working languages. Furthermore, such person can be assigned only as co-counsel in accordance with ICTY-S Article 16(D). ${ }^{432}$ In other words, the ICTY imposed restrictions on acceptable languages, accepted a counsel who does not speak those languages but downsized him to the level of co-counsel and charged him, effectively, for translation and interpretion costs.

\footnotetext{
${ }^{425}$ Ibid, paras. 49 and 202.

${ }^{426}$ ICTY, ADC-ICTY Developed Practices: Manual of International Criminal Defense (2011), UNICRI Publisher, B.41.

${ }^{427}$ Ibid, A8.36.

${ }^{428}$ Ibid, D3.49.

${ }^{429}$ Ibid, C. 46 .

${ }^{430}$ ICTY, Defense Counsel: Pre-Trial Legal Aid Policy (2006), paras. 3-4.

${ }^{431}$ ICTY, Defense Counsel: Trial Legal Aid Policy (2009), paras. 3-4.

${ }_{432}$ ICTY, Directive on the assignment of defense counsel (2006), Article 14(C).
} 
How founded were all these provisions in reality? The crimes in the former Yugoslavia happened in the former Yugoslavia. It would not be strange to assume a priori that legal professionals from the former Yugoslavia are in the best position to understand, defend, and prosecute crimes committed in their own backyard. Obviously, the ICTY imposed restrictions on the employment of such legal professionals, requiring them to be professionally functional in English or French and allowing those who can function professionally only in $\mathrm{B} / \mathrm{C} / \mathrm{S}$ to practice at their own linguistic, financial, and time-related detriment. However, the ICTY went above and beyond the mere requirement that local professionals must be professionally functional in English or French: ICTY did not allow them to see any benefit from being fully functional in these, for defense counsels from the former Yugoslavia, completely unimportant languages. In order to be professionally certified and allowed to practice before the ICTY, the ICTY requires members of the Defense team whose native language is not English or French to submit a certificate from a language institute or other evidence of proficiency in English or French. The Registrar may also require such applicants to demonstrate their language ability by means of a language proficiency test. ${ }^{433}$ Language Proficiency Tests are used at the UN System to check the knowledge of UN languages. ${ }^{434}$ This test consists of a written and an oral part: the written part consists of writing a thematic essay followed by a grammar and language use test and the oral test consists of a conversation with the examiner. Once the candidate passes the Language Proficiency Test, he starts receiving a language allowance in addition to his salary ${ }^{435}$ However, the Defense teams who passed this test did not receive a language allowance. Instead, their passing of this exam constituted grounds to allow them to practice before the ICTY. Where is the motivation to brush up on ICTY languages and implement the much talked about UN policies on multilingualism in that? If the Defense must be fluent in English and French, what use is an interpreter? The ICTY put restrictions on proving the knowledge of acceptable languages and avoided paying for multilingualism.

How many defense counsels appearing before the ICTY spoke only the language of their client? According to defense counsels interviewed for the purposes of this study, during the first ten or so years there were teams where defense counsels did not speak French or English at all or where their knowledge of those languages was insufficient for effective communication with the Court or drafting motions. Such Defense teams would overcome this obstacle by engaging a legal assistant who would write, i.e. translate, motions into/from English or French. ICTY 2008 AR reveals that the ICTY Registry adopted a special remuneration scheme for persons assisting indigent self-represented accused and made provisions for the assignment of an investigator, a case manager, and, where necessary, a Language Assistant. ${ }^{46}$ The engagement of Language Assistants for such purposes was closely regulated ${ }^{437}$ Let us put this into context: this means that some segments of the defense, not all, got a right to budgeted language support 15 years into the existence of ICTY, after 48 completed trials, and pending completion of 16 trials. ${ }^{43^{8}}$ Again, the problem here is operational reality: the Defense had to translate their own documents and interpret for their own witnesses all along. Whereas the Prosecution established their own language section and had large teams with strict delineation of jobs, provision of support services for the Defense was somewhat more complicated in that the strict delineation of jobs was largely non-existent: one person often had to do a job of several, such as the proverbial case manager/translator/interpreter/researcher mentioned earlier. Did the ICTY open their purse generously? Finances at the disposal of Defense teams for translation and interpretion costs were scant. A directive on the assignment of the defense counsel (see Appendix I) allows a gross rate of €o.o68 per word for translators with 3 or more years of professional experience and $€$ o.045 per word for translators with o- 3 years of professional experience (see Table 11 for a comparison of rates received by short-term translators and interpreters at the

\footnotetext{
${ }^{433}$ Ibid, Article 15(C)(ii).

${ }^{434} \mathrm{UN}$, Language Proficiency Tests (2016).

$435 \mathrm{UN}$, Administrative Instruction: Language Allowance and Language Incentives (ST/AI/1999/2) (1999).

${ }^{436}$ ICTY 2008 Annual Report (A/63/210) (2008), para 105.

${ }^{437}$ ICTY, Remuneration scheme for persons assisting indigent self-represented accused (2010), Article 15 (d).

${ }^{438}$ ICTY, Completed cases.
} 
UN System). ${ }^{439}$ As to interpretation, whereas CLSS paid the UN approved daily rate for interpreting of about $€ 620$, regardless of the duration of the engagement, the Defense paid an hourly rate of about $€ 35$. The ICTY supported defendants who were indigent to appear fair, but in doing so it indirectly gave freelancers a choice whose request for assistance to respond to, the ICTY's or the Defense team's.

How many translation documents that are not covered in the rules and regulations are we talking about here? There are two groups of documents: trial briefs and other trial documents. Apart from financed translations (ICTY RPE Rules 66(A), 66(A)(i), and 66(A)(ii), namely disclosure documents, material supporting the indictment and witness statements), it is not the case that other documents used in trials were in the language of defendant, here B/C/S, or the language of the Court, i.e. English or French, which means they required translation. Defense members interviewed for the purposes of this study state that there were several large documents, including several videos, in the Srebrenica trial concerning the Dutch Battalion originally submitted in Dutch, for example. Some of those documents were translated by the OTP and some by the CLSS, but only into English. Those which were translated into B/C/S took months to receive. It seems the Netherlands Institute for War Documentation Report of several thousand pages has never been fully translated into $\mathrm{B} / \mathrm{C} / \mathrm{S}$, so the Defense team had to undertake translation of certain parts themselves. Internal UN documents used during trials have also not been routinely translated, such as various UN Protection Forces (UNPROFOR) daily reports, cables, and other internal information, unless they were meant to serve as exhibits. ${ }^{440}$ Finally, in Hadžihasanović and Delić, the Defense received some documents in Italian and Arabic, but did not have any resources for any of these languages and had to turn to the OTP for assistance..$^{411}$ Obviously, since they were not mentioned in the ICTY rules and regulations, translation of documents other than those in English, French, or B/C/S is currently in the limbo.

Three types of briefs, namely pre-trial, final, and appeals brief, which could be defined as summaries of all the facts presented, were also not translated for non-self-representing defendants for their perusal and had to be submitted in English or French. The most important part of the pre-trial period is a pre-trial brief. The pre-trial brief is loosely discussed under ICTY RPE Rule 65ter on the responsibilities of the pre-trial judge. ICTY RPE Rule 65ter (E) defines the types of documents that the Prosecution must serve on the defendant whereas ICTY RPE Rule 65ter (F) defines the type of response the Defense must provide "not later than three weeks before the Pre-Trial Conference." The same goes for the final trial brief mentioned in ICTY RPE Rule 86(B), where it is said that the parties should submit the final brief "not later than five days prior to presenting a closing argument." This means that each and every brief should be translated into the language of the defendant so that he or his defense counsel without knowledge of the official languages of the Court can know what is written in it.

The official ICTY site has a section called Selected Case Documents for each case heard at the ICTY. Appendix 1 contains the full list of pre-trial, final, and appeal briefs. Trial briefs, as found on the official ICTY site under Selected Case Documents, have been submitted in 19 trials: Boškoski \& Tarčulovski (appeal briefs only), Đordević (final and appeal), Erdemović (appeal), Galić (pre-trial), Gotovina et al. (pre-trial, final, and appeal), Hadžić (pre-trial), Haradinaj et al. (pre-trial, appeal), Karadžić (pre-trial, final, appeal), Lukić Milan \& Lukić Sredoje (pre-trial, final, appeal), Milošević, D. (appeal), Mladić (pre-trial), Perišić (appeal), Popović et al. (pre-trial, final, appeal), Prlić et al. (final), Stanišić \& Župljanin (pre-trial, final, appeal), Strugar (pre-trial), Šainović et al. (pre-trial, final, appeal), Šešelj (final) and Tolimir (pre-trial, final, appeal) to a total of 122 documents submitted in English. Only five of these documents have been translated into B/C/S (Šešelj and Tolimir) and two have been translated into French (Šešelj). Obviously, such briefs are not translated for others, but

\footnotetext{
${ }^{439}$ ICTY, Directive on the assignment of defense counsel (undated), Appendix I. According to this Directive, co-counsel is paid a flat rate of around 80 Euro an hour, just like a novice lawyer with up to 9 years of professional experience.

${ }^{440}$ Thirty-seven different countries speaking 21 distinct languages participated in UNPROFOR.

${ }^{441}$ ICTY, Response to urgent defence motion concerning failure of prosecution to comply with Rule 68 (2008).
} 
their defense still has three, i.e. five weeks to review them although most of them exceed well over 11,0oo words.

In response, as, perhaps, could have been expected, the ICTY Selected Case Documents are replete with various Defense requests for extension of time to submit pre-trial/final/appeals brief. Appendix 2 contains the full list of language-related requests, decisions, and orders as found on the official ICTY site under Selected Case Documents. In fact, there are 631 such language-related requests, decisions, and orders to extend the time to file a notice of appeal, to extend the word limit, to extend page limits, to extend the time to file a reply, to correct a transcript, to correct a translation, etc. In total, 67 have been partially granted, 419 granted in full and 145 denied.

Non-translation does not stop at trial briefs: there are also various court orders and decisions which should get translated into English and French, because they are the trial record in the ICTY working languages. However, evidence shows that those documents are seldom translated both from/into ICTY official languages, thus infringing on policies on the parallel existence of bilingual documents or into the language of the defendant when s/he needs them, infringing on the right to translation and "when s/he needs them" due to time constraints. Let us provide some practical examples in Stanišić and Župljanin. ${ }^{42}$ It is hard to say when investigation in this case started, but Case Information Sheet (CIS) is pretty explicit about the following: the initial indictment in Stanišić was issued on 25 February 2005, the operational indictment was filed on 10 September 2009, the initial indictment in Župljanin was issued on 14 March 1999, the operational indictment was filed on 10 September 2009 and the trial of these two began on 14 September 20og. This means that the Prosecution in this case had an advantage of several years over the Defense. This is considered normal: once an international criminal investigation begins it is not the case that the Prosecutor has a suspect right from the outset. However, such a Prosecutor may already begin issuing requests for translation and, if good and prudent, can have all support documents translated by the beginning of the trial either by his own Language Assistants or by the CLSS. On the other hand, the Defense's job has only just begun.

As to trial documents from the above, the table below shows the type and number of documents pending translation into B/C/S or French in Stanišić and Župljanin even after the completion of this Englishspeaking trial. ${ }^{443}$ The table was drawn up by counting and comparing available versions of documents. The next summary table consists of: 7 indictments, 2 Appeals Chamber judgments, 4 trial judgments, 112 Trial Chamber decisions, 47 Trial Chamber orders, 29 Appeals Chamber decisions, 25 Appeals Chamber orders, 1 President's decision, 16 President's orders, 12 Registry decisions, 5 pre-trial briefs, 7 final briefs, 5 appeal briefs, 7 videos, transcripts, 11 press releases, and 1 miscellaneous document to a total of 291 documents produced in English. Since videos, press releases, and transcripts have not been considered, the total of number of documents pending translation under examination came to 273 documents produced in English.

Table 5. Documents pending translation after the completion of the English-speaking trial (Stanišić and Župljanin)

\begin{tabular}{|l|l|l|l|}
\hline Type of document & English & French & B/C/S \\
\hline Indictments & 7 & 2 & 8 \\
\hline $\begin{array}{l}\text { Appeals Chamber judg- } \\
\text { ment }\end{array}$ & 2 & 1 & 1 \\
\hline Trial judgment & 4 & 4 & 4 \\
\hline Trial Chamber decisions & 112 & 9 & 50 \\
\hline Trial Chamber orders & 47 & 1 & 13 \\
\hline $\begin{array}{l}\text { Appeals Chamber deci- } \\
\text { sions }\end{array}$ & 29 & 0 & 2 \\
\hline Appeals Chamber orders & 25 & 0 & 2 \\
\hline
\end{tabular}

${ }^{442}$ ICTY, Stanišić and Župljanin CIS.

${ }^{443}$ ICTY, Stanišić and Župljanin, Selected Documents: English, French, and B/C/S. 


\begin{tabular}{|l|l|l|l|}
\hline Type of document & English & French & B/C/S \\
\hline President's decisions & 1 & 0 & 0 \\
\hline President's orders & 16 & 0 & 4 \\
\hline Registry decisions & 12 & 2 & 4 \\
\hline Pre-trial briefs & 5 & 0 & 0 \\
\hline Final briefs & 7 & 0 & 0 \\
\hline Appeal briefs & 5 & 0 & 0 \\
\hline Miscellaneous & 1 & 0 & 0 \\
\hline Total & 273 & 18 & 88 \\
\hline Missing requiring & 0 & 255 & 185 \\
\hline $\begin{array}{l}\text { Percentage } \\
\text { translation }\end{array}$ & 0 & $93.40 \%$ & $67.66 \%$ \\
\hline
\end{tabular}

Of 273 documents in English 255 have not been translated into French and 185 have not been translated into $\mathrm{B} / \mathrm{C} / \mathrm{S}$. Trial briefs have not been translated into French or B/C/S at all.

The following summary table shows type and number of documents pending translation in Šešelj even after the completion of this French-speaking trial. ${ }^{444}$ The following table has also been made by counting and comparing available versions of documents. However, it has been noticed that although this has been a French-speaking trial, documents submitted in English outnumber those in the French language. The next summary table consists of: 7 indictments, o Appeals Chamber judgments, 5 trial judgments, 231 Trial Chamber decisions, 149 Trial Chamber orders, 16 Appeals Chamber decisions, 2 Appeals Chamber orders, 17 President's decision, 39 President's orders, 19 Registry decisions, o pre-trial briefs, 2 final briefs, o appeal briefs, o Prosecution documents, 1 submissions and requests, 9 videos, transcripts, 24 press releases, and 1 miscellaneous document to a total of 522 documents produced in English. Since videos, press releases, and transcripts have not been considered, total of number of documents pending translation under examination came to 489 documents produced in English.

Table 6. Documents pending translation after the completion of the French-speaking trial ( ̌̌ešelj)

\begin{tabular}{|l|l|l|l|}
\hline Type of document & English & French & B/C/S \\
\hline Indictments & 7 & 4 & 6 \\
\hline $\begin{array}{l}\text { Appeals Chamber judg- } \\
\text { ment }\end{array}$ & 0 & 0 & 0 \\
\hline Trial judgment & 5 & 5 & 5 \\
\hline Trial Chamber decisions & 231 & 248 & 123 \\
\hline Trial Chamber orders & 149 & 111 & 70 \\
\hline $\begin{array}{l}\text { Appeals Chamber deci- } \\
\text { sions }\end{array}$ & 16 & 12 & 7 \\
\hline Appeals Chamber orders & 2 & & \\
\hline President's decisions & 17 & 0 & 2 \\
\hline President's orders & 39 & 29 & 6 \\
\hline Registry decisions & 19 & 22 & 19 \\
\hline Pre-trial briefs & 0 & 18 & 1 \\
\hline Final briefs & 2 & 0 & 0 \\
\hline Appeal briefs & 0 & 1 & 0 \\
\hline Prosecution documents & 0 & 0 & 0 \\
\hline Submissions and requests & 1 & 0 & 24 \\
\hline Miscellaneous & 1 & 0 & 4 \\
\hline Total & 489 & 0 & 0 \\
\hline
\end{tabular}

${ }^{444}$ ICTY, Šešelj, Selected Documents: English, French, and B/C/S. 


\begin{tabular}{|l|l|l|l|}
\hline Type of document & English & French & $\mathrm{B} / \mathrm{C} / \mathrm{S}$ \\
\hline Missing & $\mathrm{O}$ & 39 & 222 \\
\hline $\begin{array}{l}\text { Percentage requiring } \\
\text { translation }\end{array}$ & $\mathrm{O}$ & $7 \cdot 97 \%$ & $45 \cdot 39 \%$ \\
\hline
\end{tabular}

Of 489 documents in English 39 are missing in French and 185 have not been translated into B/C/S. ${ }^{445}$

It is obvious from the above examples that the defendants' right to translation of court documents and the underlying right to information have not been respected.

The defendants do not get any translation for the appeals, including the Defense Appeal, the Prosecutor Appeal, replies, or any other appeal motion, save for some orders and decisions of the Appeals Chambers. On the other hand, the Defense must submit an appeal to judgment several months, even a year, prior to receiving the trial judgment translated into the language of the defendant. Any brief filed with the Appeals Chamber must contain a Book of Authorities "containing a separate compilation setting out clearly all authorities relied upon." All legal authorities, other than authorities of the ICTY and the ICTR must also be provided in "an authorized version of the authority in question, complete with an English or French translation, if the original is not in one of the languages of the International Tribunals." ${ }^{246}$ Any relevant exhibits and documents, when necessary, must also be translated into one of the official languages of the Tribunal. ${ }^{447}$ This means that the Defense must invest their own money to translate parts of the trial judgment and legal authorities for their client so that the defendant can know the overall logic, conclusions, and decisions of the Trial Chambers. This also means that, once the official translation comes out, it is viewed merely as a formality. Finally, it means it is there for the use of professionals from the region, not necessarily the Defense teams. Once the Defense receives a translation of the Trial Judgment into the language of the defendant, they receive an additional extension of time to submit additional grounds for appeal to the Trial Judgment. However, they must argue justifiable and valid reasons why they had to wait until their client reads the Trial Judgment and provides input.

The non-translation of documents is very problematic because it could be understood as a violation of EU Directive 2012/13/EU of the European Parliament and of the Council on the right to information in criminal proceedings, which specifically stipulates that persons accused of having committed a criminal offense should be given all the information on the accusation necessary to enable them to prepare their defense and to safeguard the fairness of the proceedings. Furthermore, this Directive stipulates that such information should be given promptly, and at the latest before their first official interview by the police or another competent authority, and without prejudicing the course of ongoing investigations, etc. to allow for effective exercise of the rights of the defense. ${ }^{448}$

Is there language-related equality of arms between the Prosecution and the Defense? There is formal equality of arms, and to make sure it is there, original decisions get disclaimed ad nauseam, and thus amount to discrimination against the non-English and non-French-speaking counsels. The best example of this is the requirements to be admitted to the list of counsels which stipulates that the counsel

\footnotetext{
${ }_{445}$ Discrepancies in the actual number of documents have to do with the way the Outreach Office filed these documents online. In addition to various double-filings, cutting documents into parts, and misfiling (final briefs have been, indeed, translated into the language of the accused and into French, but the Outreach Office misfiled them under Nalozi pretresnog vijeća (Orders of the Trial Chambers) in the $\mathrm{B} / \mathrm{C} / \mathrm{S}$ site), the Outreach Office seems to have forgotten to file some, as well, hence the uneven number of even the most used documents that had to be translated.

${ }^{446}$ ICTY, ADC-ICTY Developed Practices: Manual of International Criminal Defense (2011), UNICRI Publisher, B1.33.

${ }^{447}$ Ibid, B1.31.

${ }^{448} \mathrm{EU}$, Official Journal of the European Union L 142/3 (2012), Directive of the European Parliament and of the Council on the right to information in criminal proceedings, Preamble (27) and (28).
} 
must have written and oral proficiency in one of the two working languages of the Tribunal;*

*If the Registrar deems it in the interest of justice, he may waive this requirements, as provided in Rule 44 (B) of the Rules and Article $14(\mathrm{C})$ of the Directive. Counsel admitted without the language requirement are only eligible for assignment as co-counsel, pursuant to Article 16 (C)(ii) of the Directive. ${ }^{449}$

In practice, whereas defendants have the right to basic documents in their own language, the above review shows that defense counsels, representing the defendant, are at a disadvantage, due to scant and restrictive finances, resources, facilities, and other material conditions. This puts the ICTY Defense at a clear linguistic disadvantage and creates a procedural inequality, which affects the fair trial of the accused.

4.4. Legal background to the engagement of translators and interpreters at international criminal tribunals

Here, it is important first to examine the legal background to the engagement of translators and interpreters at international criminal tribunals incumbent on legal professionals. This is because such a legal background would define the terms of engagement of language professionals at legal institutions and their professional conduct toward language professionals in legal transactions with their non-legal clients. After that, we will examine language-related rights, duties, and obligations on translators and interpreters as defined in the ICTY and subsequently established tribunals' rules and regulations and the ICTY language professionals' duties and obligations as defined in the Code of Ethics for Interpreters and Translators Employed by the [ICTY] (I\&T Code). In other words, we will examine the legal background to the engagement of translators and interpreters at international criminal tribunals incumbent on language professionals.

Language-related rights, obligations, and requirements of language professionals are not explicit under international criminal tribunals' rules and regulations. In ICTY-S, the involvement of translators is explicitly mentioned in the context of investigation and preparation of indictment in that the suspect has the right to translation from and into language s/he speaks and understands and in the context of the rights of the accused in that the accused has the right to a free assistance of an interpreter if $\mathrm{s} / \mathrm{he}$ cannot understand or speak the language used at the ICTY. ${ }^{450}$ The ICTR and SCSL-S replicate provisions relating to the involvement of translators in the context of investigation and preparation of indictments and the rights of the accused almost verbatim. ${ }^{451}$ SCSL-S, STL-S and ECCC Law do not mention the involvement of translators at all. However, the STL mentions the involvement of interpreters both in the context of the rights of suspects during investigation and in the context of the rights of the accused in that the suspect/accused has the right to translation/interpretation in the event he cannot understand or speak the language used for questioning or cannot understand or speak the language used in the STL, respectively. ${ }^{452}$ ECCC Law mentions the involvement of interpreters in the context of the rights of the accused if they cannot understand or do not speak the language used in the court. ${ }^{453}$

Language professionals are addressed directly only in one provision: ICTY, ICTR, SCSL, and STL RPEs declare that interpreters and translators must make a solemn declaration before conducting any duties that they will do it "faithfully, independently, impartially and with full respect for the duty of confidentiality." ${ }^{\text {44 }}$ This phrase can be taken to mean legal professionals' expectations from translation and interpreting that they can rely on. ECCC IR obliges "each interpreter to take an oath or affirmation in accordance with his or her religion or beliefs to interpret honestly, confidentially and to the best of his or her ability" establishing that

\footnotetext{
${ }^{449}$ ICTY, Qualification requirements to be admitted to the Rule 45 list.

${ }^{45^{\circ}}$ ICTY-S Article 18(3) and 21(4)(f).

${ }^{451}$ ICTR-S Articles 17(3) and 2o(4)(f). SCSL-S Article 17(4)(f).

${ }^{452}$ STL-S Articles $15(\mathrm{D})$ and $14(4)(\mathrm{G})$.

${ }^{453}$ ECCC Law Article 35(f).

${ }^{454}$ ECCC IR Rule 3 O.
} 
interpreters may not be selected from among ECCC Judges, Co-Prosecutors, Judicial Police, Investigators, parties, or witnesses. ${ }^{455}$ The phraseology "before conducting any duties" (STL RPE says "his duties") makes it sound as if translators and interpreters are supposed to affix some sort of oath or affirmation to every single document they translated or to all official ICTY court transcripts affixed to sessions they interpreted. This is in no way unusual, as language professionals practicing in almost every jurisdiction are obliged to declare a similar oath or affirmation. ${ }^{456}$ However, it seems that this declaration has not been signed by ICTY language professionals.

Although the 2009 OIOS Audit Report established that CLSS has been able to ensure compliance through the provision of translation and interpreting services with the basic minimum guarantees in ICTY-S Article 21 on the rights of the accused, the OIOS Auditors also discovered that CLSS staff were not making the said declaration under ICTY RPE Rule 76 which is to be solemnly made before performing any duties. In response, CLSS stated that all ICTY staff must sign a solemn declaration before taking up their duties, i.e. when signing their employment contract. This declaration, CLSS claimed, includes a reference to UN Staff Regulations and UN Rules which, in turn, require staff to act as foreseen in ICTY RPE Rule 76 . This reasoning is logically flawed, given the nature of language professionals' functions in the court, so as to ensure compliance with ICTY RPE, the OIOS Auditors recommended that translators and interpreters need to make a formal declaration and that the ICTY Administration should ensure that CLSS obtains from its staff signed declarations affirming that they have read and understood the provisions contained in ICTY RPE Rule 76. The ICTY Administration accepted the recommendation and agreed that the signature of a specific statement provides an additional level of awareness of the obligations. This recommendation, made in 2009 or 16 years into the existence of ICTY, remained open pending confirmation that CLSS has commenced obtaining from its staff signed declarations signifying that they have read and understood the provisions contained in ICTY RPE Rule $76 .{ }^{457}$

Signing a declaration or affirmation is very important at any court, but, when it comes to the ICTY, as we have seen before, a declaration or affirmation signed by an interpreter attests to the reliability of the witness statement in the eyes of the Court. The only evidence of interpreters making any declaration or affirmation is in the Interpreter Certification attached to ICTY Witness Statement. In the Interpreter Certification, the interpreter declares to be duly qualified and approved by the ICTY Registry to interpret from source to target language and vice versa, to have been informed by the witness s/he speaks one of those languages, to have orally translated all the statements appearing in the statement in the presence of witness who appeared to have heard and understood his translation acknowledging that the facts and matters set out in statement provided, as translated by the interpreter, are true to the best of his knowledge and recollection and has accordingly signed the statement.

\begin{tabular}{l}
\hline \hline INTERPRETER CERTIFICATION \\
Interpreter, certify that: \\
1. I am duly qualified and approved by The Registry of the international criminal tribunal for \\
the Prosecution of Persons Responsible for Serious Violations of International Law Committed \\
in the Territory of the Former Yugoslavia since 1991 to interpret from the \\
guage into the language into the English language and from the English lan- \\
2. I have been informed by_language. \\
the
\end{tabular}

\footnotetext{
${ }^{455}$ ICTY RPE, ICTR RPE, SCSL RPE Rule 76 and STL Rule 46.

${ }^{456}$ US Courts, Linguistic services, Oaths, Rules and Ethics.

${ }^{457}$ UN, OIOS Internal Audit Division, Audit of Language Services at ICTY (2009), paras. 11-12.
} 
3. I have orally translated the above statement from the English language to the language in the presence of who appeared to have

heard and understood my translation of this Statement.

4. L__ has acknowledged that the facts and matters set out in his / her State-

ment, as translated by me, are true to the best of his / her knowledge and recollection and has accordingly signed his / her signature where indicated.

Dated:

Signed:

However, this Interpreter Certification might be a legal fiction. This is because there were three different categories of interpreters who made these statements: CLSS interpreters representing the official ICTY language services working under the auspices of the Registry, Language Assistants representing the parties' semiofficial language service working under the auspices of the OTP or the Defense (see Chapter 6 for an extended discussion of this), and field interpreters who have been declaratively qualified and approved by the Registrar to conduct these duties. In other words, not all categories of interpreters who took witness statements have actually been "duly qualified and approved" by the ICTY Registry to interpret. The Registry merely declared to have duly qualified and approved them, but they could not have duly qualified and approved OTP Language Assistants, for example, because OTP Language Assistants did not fall organizationally under the Registry. This could be seen as the first result of a poor institutional arrangements regarding Language Assistants (see Chapter 6 for an extended discussion of this).

Another problem in this Interpreter Certification lies in the wording "as translated by me." This interpreter interpreted the conversation, the investigator wrote it down as he heard it in interpretation, but the witness confirmed it by signature only after it was back-translated from English as written down by the investigator by the same interpreter who interpreted at the meeting, and, finally, by a different translator who translated it back into B/C/S in The Hague, after which the witness signed it as his own. Waters succinctly summarizes the situation regarding the interpreting of witness statements at the ICTY (the actual names of people involved have been redacted from the original version).

[The witness] actually gave two statements. The first was given on [date], and mainly concerned the events leading to Izbica. It was taken by an Albanian interpreter, [name, ICTY field interpreter], who translated it orally into English for a Frenchman, [name, ICTY investigator], who wrote it down in English. The interpreter then orally interpreted this back to [the witness] in Albanian, who declared orally that it was accurate. This English statement from [investigator]-not a transcript of actual Albanian utterance-was then translated into standard Albanian, a largely Tosk dialect, by the interpreters of the ICTY. [The witness] does not speak standard Albanian, but a north-east Geg dialect; the final Albanian version-actually based on the official English version-could not possibly have been spoken by [the witness].458

Linguistically, it must be noted that the Tosk-based Albanian literary standard is as different from the northeastern Geg of Kosovo as (Standard) Italian from Catalan. Mutual intelligibility is possible on basic matters and in the context of good will, but under different political circumstances, these would have been different languages. Procedurally, participation of at least two different language professionals and certification signed by only one of them is what the OIOS Auditors were talking about: whereas the original interpreter certified the interpretation of a witness statement as his own, the translator who translated it did not make a declaration under ICTY RPE Rule 76 to say it was his own translation nor a reviser who revised it to attest that it was double-checked before submitted for signature by the witness and offered as evidence. Skeptics interpreted this to mean that there were inherent untruths contained in witness statements. Academics questioned the

\footnotetext{
${ }^{45^{8}}$ Waters, T.W. (ed.) (2013), The Milosevic Trial: An Autopsy. Oxford University Press: Oxford, UK, p. 243.
} 
reliability of double-translated statements. The judges thought the whole thing was so bullet-proof that they included interpreters "duly qualified and approved" by ICTY Registry to interpret in the criteria of witness statement reliability.

In reality, the whole process was poorly planned by the OTP. The bulk of witness statements were taken between 1993 and 1999 when former Yugoslavia was recovering from the war and most victims and witnesses were living in poor conditions. Instead of bringing a tape recorder and tape-recording victim and witness statements and subsequently transcribing them or making their client sit down and write their own statement as they would in their national jurisdictions, investigators took witness statement in person, at witness' homes, in English or French, to save time, finances, and get ahead of various resource issues (electricity, space, etc.). The OTP must have realized this as time went on, but only tape-recorded suspect interviews from the beginning. Section 4.2. discusses the underlying ICTY case law governing the tape recording of suspect interviews and notetaking.

Legal professionals delivered the I\&T Code in 1999. Legal professionals focused on their priorities, reasoning that the I\&T Code was delivered because translators and interpreters should maintain high standards of conduct as employees of ICTY as their very functions require them to act faithfully, independently, impartially, and with full respect for the duty of confidentiality, noting their obligations regarding confidentiality do not cease after their engagements at the ICTY as they could be held accountable for any breach of such confidentiality, including, but not limited to, referral to their respective national or international professional associations. ${ }^{459}$ The I\&T Code is meant to provide for standards of conduct applicable to:

interpreters on a fixed-term contract who interpret in simultaneous mode the proceedings held in the Tribunal's courtrooms,

interpreters on a short-term contract or SSA during field-assignments outside the Tribunal headquarters in The Hague or outside the Tribunal courtrooms,

interpreters on a short-term contract who reinforce the Tribunal's interpreting teams and interpret in simultaneous mode the proceedings held in the Tribunal's courtrooms, and

translators on a fixed-term contract who translate in writing the documents referred to CLSS, and translators on a short-term contract who translate in writing, at home, documents meant to be used by the Tribunal. ${ }^{460}$

The I\&T Code contains rules on professional conduct (standards of conduct, professional integrity and dignity, reliability), general obligations such as confidentiality (general obligations, information sharing, lawyerclient privilege, continuation of obligations), impartiality, proficiency (competence: level of expertise), accuracy (truth and completeness, uncertainties in transmission and comprehension, clear transmission), and duties toward the profession (professional development: upgrading and professional solidarity).

The I\&T Code begins well by describing its general purpose and application, stating that translators and interpreters, in addition to being bound by the I\&T Code, shall also be bound by UN Staff Rules and Regulations and all its administrative instructions. ${ }^{461}$ Unfortunately, the I\&T Code then goes on to summarize the existing standing obligations of all UN staff stemming from UN Staff Rules and Regulations, ${ }^{462}$ instead of naming them clearly the first time it mentions them, thus making the Code unduly long and creating confusion similar to that regarding the declaration under ICTY RPE Rule 76 making it unclear whether the UN rules or I\&T Code take precedence when it comes to language professionals' professional conduct. At any rate,

\footnotetext{
${ }^{459}$ ICTY, The Code of Ethics for Interpreters and Translators Employed by the Tribunal (1999), Preamble.

${ }^{460}$ Ibid, Article 1.1.

${ }^{461}$ Ibid, Article 3.3.

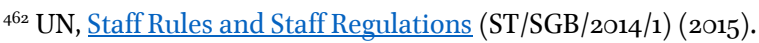


entire Article 4 of the I\&T Code could have been referenced to Rule 1.2.(a) and 1.2.(b) on core values, Article 5.1. to Rule 1.2.(f), 1.2. (g), and 1.2.(m) on general rights and obligations, Article 5.2. to Rule 1.2.(l) thru (p), Article 5.4. to Regulation 1.2.(b), entire Article 7.1. to Rule 1.2.(s) thru (v) on outside employment and activities, Article 7.4 to Regulation 1.2.(i) on general rights and obligations, and Article 8.1. and Article 8.3 to Regulation 1.2.(b), 1.2.(f) and 1.2.(m) and Rule 1.2.(q).

This is the first Code of Ethics on language professionals practicing before an international criminal tribunal, so it is a work in progress. The problem is that it has not been amended since 1999 due to lessons learned or ICTY case law. Another problem is that, although declaring that reliable translation and interpretion has been rendered faithfully, independently, impartially, and with full respect for the duty of confidentiality, the I\&T Code is replete with uncertainties of legal professionals regarding the process of translation and interpreting and translators and interpreters. The I\&T Code spells out the importance of impartiality, stating that interpreters should strive for professional detachment at all times ${ }^{463}$ Unfortunately, this very important prerequisite does not stand alone. It only makes a second part of a provision where the I\&T Code prescribes interpreters' need to act in professional manner toward in-court clients. There has very little in common with the standard professionalism clause and prescription for professional detachment. The provision on professional detachment should have been the core provision of the entire I\&T Code and the one with which the I\&T Code should have begun because it would have set the tone of translators' and interpreters' obligations in a legal context when engaged in an institution adjudicating on ethnic crimes. In turn, this would have allowed the drafters of the I\&T Code to introduce and define translation and interpreting in a legal context as the one revolving around the core concept of all legal work: operational data.

Legal professionals' uncertainties continue when they forbid translators and interpreters to exercise power or influence over their listeners or readers. ${ }^{464}$ The "power and influence" here refers to interpreters and translators as mediators. Who makes interpreters and translators mediate? The ICTY lawmakers or the ICTY Administration: whoever the author of duties and responsibilities incumbent on language professionals. The research conducted so far has shown that Language Assistants' have to mediate as part of their job description in the part where it says that OTP Language Assistants

review $[. .$.$] and summariz [\mathrm{e}]$ material in $\mathrm{B} / \mathrm{C} / \mathrm{S}$ relating to specific cases in support of trials and appeals [and] [s]upport[...] OTP trial teams by reviewing and, in consultation with trial team members, selecting relevant evidentiary materials in $\mathrm{B} / \mathrm{C} / \mathrm{S} .{ }^{465}$

Chapter 6 discusses further whether CLSS translators and revisers like to mediate. Obviously, OTP Language Assistants interpret for the OTP and Defense Language Assistants for the Defense. This affects their neutrality because their loyalty is to the OTP or the Defense. However, such an approach to language professionals puts them in between their clients, which is the last place where they should be as language professionals. In practical terms, this provision needs rewording to unequivocally forbid mediation and state that "Interpreters shall not enter into contact with clients save to clarify utterance" or "Translators shall refrain from explaining the text." This provision would regulate a natural need of any human being to fill in an empty communication slot as it restricts language professionals to performing language-related business only. Language professionals, who are non-legal professionals, cannot explain any parts of operational information to anyone. At the same time, this provision would reinforce the power of legal professionals.

\footnotetext{
${ }^{463}$ ICTY, The Code of Ethics for Interpreters and Translators Employed by the Tribunal (1999), Article 4.2.

${ }^{464}$ Ibid, Article 5.3.

${ }^{465}$ UN vacancies, ICTY G-5 Language Assistant.
} 
Awkward attempts at control by legal professionals resume when the I\&T Code suggests that interpreters should not report late to work and need to inform their supervisors if they will be late, ${ }^{466}$ when it suggests that interpreters should only accept assignments that they are competent to perform, when it advises that, if in the course of interpreting they realize the task is beyond them, translators and interpreters should offer to withdraw from the assignment, that they should prepare for any assignment beforehand, should rectify promptly any mistakes they make in translation and interpreting, ask for repetition, rephrasing or explanation of anything unclear, and should make sure their speech is clearly heard ${ }^{467}$ Similar provisions are contained in the International Association of Conference Interpreters (AIIC) Codes of Conduct applying to freelance interpreters but this is because, again, they are self-employed freelance interpreters who might be interpreting at a book event one day and at the signing of a nuclear deal the next. These provisions make it abundantly clear that the I\&T Code is just a compilation from several existing codes of ethics of translators and interpreters, just like the international criminal tribunals' statutes and RPEs. The profession of translation and interpreting is a self-regulating profession: once professional translators and professional interpreters with a degree in translation and interpreting are employed, all these provisions go without saying. So, in addition to recruiting staff with professional degrees, the subjects of the I\&T Code should have been adequately tested and trained by the ICTY to work in a legal context. Once professionally educated staff are adequately tested, recruited, and trained by the ICTY to work in a legal context there would be no need for this warning. As it is, it sounds like the I\&T Code is accepting that people might have been picked off the street to translate and interpret at the war crimes tribunal.

Confusion continues when the I\&T Code stipulates that interpreters, when working in the courtrooms, should inform the Judges of any doubt arising from a possible lexical lacuna in the source or target language. ${ }^{468}$ Notwithstanding the inaccurate term "doubt", which should have been replaced with "professionally informed opinion," this request is unreasonable both because of the courtroom dynamics and ICTY rules and regulations on languages. As to the courtroom dynamics, a $\mathrm{B} / \mathrm{C} / \mathrm{S}$ speaking witness is taken through evidence by the Prosecution who must examine the witness in English or French after which the witness is cross-examined by the Defense. Remember that, Defense teams normally have one B/C/S speaking counsel and one English or French-speaking counsel, which means that any Defense team can examine the witness in a language they can both understand. Accordingly, the Defense team has the most power over $\mathrm{B} / \mathrm{C} / \mathrm{S}$ speaking victims and witnesses. Since they also share a common culture and history with B/C/S speaking victims and witnesses, defense counsels originating from the area of former Yugoslavia are in a superior position to the Prosecution and the Judges because they can make cultural, societal, and historical references that only the two of them fully understand. After the Defense, the Prosecution gets to clarify with the witness whatever the Defense tried to refute, including the wording and specific language that may have been used. Finally, the Judges may also examine the witness in English and French. Judges do not speak the language of the witness. Accordingly, they do not have the same linguistic power over him as they would over witnesses who speak their language. It could be argued that the judges are the weakest link in this language chain. Former ICTY judge Wald (1999-2001) agrees with this assessment. Given that the ICTY judges do not speak B/C/S, Judge Wald stated that "our [defendants' and witness's] demeanor evaluation [was] based on looks and body language alone. ${ }^{m 69}$ Just like the English and French-speaking Prosecution, the judges cannot resort to their ordinary oratory skills and techniques as they would with a witness speaking their own language and expect the same effects. Only the Defense will, almost, always make a linguistic impact on the witness. A good, knowledgeable, well-read, and astute lawyer can engage any witness on as many linguistic fronts as he pleases and will almost always win.

\footnotetext{
${ }^{466}$ ICTY, The Code of Ethics for Interpreters and Translators Employed by the Tribunal (1999), Article 6.1.

${ }^{467} \mathrm{Ibid}$, Articles 9.1(a). 9.1(b). 9.2, 10.2(a). 10.2(b) and 10.3.

${ }^{468}$ Ibid, Article 6.

${ }^{469}$ Wald, P. (2002), Dealing with witnesses in war crimes trials: lessons from the Yugoslav Tribunal. Yale Human Rights and Development Law Journal, 5: 217-239, p. 237.
} 
In that exchange between the speakers of the same language, some things are bound to be untranslatable. For example, a colleague shared a story about a Defense lawyer, who, just like any examining lawyer, began his examination of a Prosecution lady witness by "Ms. so-and-so..." (Gospođo). However, she answered with a cynical and mocking tone of voice, persistently referring to "Mr. so-and-so..." (Gospodine). All B/C/S language staff roared with laughter at this story. Why is this story so funny? In the former Yugoslavia you did not have categories of Mr. and Ms. and when people addressed you as Mr. and Ms. before the war, you knew they were openly and unabashedly mocking you. Mr. and Ms. were considered elitist markings of an unfair society doomed to extinction by citizens of a country where everyone was a comrade (drug or drugarica). This lady witness thought the Defense lawyer was mocking her, hence her tone of voice and her attitude. However, the Defense lawyer was merely adjusting his polite address form to the new political realities. Should the interpreters have stopped the proceedings and explained the situation? No. Any live conversation is unpredictable both in content and in form and one must examine to what end would interpreters voice their doubt: there was no damage done and an explanation of all such interruptions, stemming from the sheer untranslatability of a culture, would take too much time and encroach on expeditious trials. Did this exchange encroach on operational information? No, it did not. Finally, where to draw the line? Interpreters are not Statler and Waldorf. The process of interpreting is conducted at the level of words, sentences, and the culture, history, and personality of a speaker while understanding that interpreting is merely repeating what a person has said in a foreign language, not a chance to make a cultural commentary. Given the above, the provisions of the I\&T Code seem immature.

As to the "lexical lacuna," it suggests that the judges might question the witness on the legal merits of his testimony, which they do not do. They engage the witness on the facts. Karpova and Kartashkova remind us that the traditional definition of lexical lacuna refers to an absence of a word in one language and its presence in the other. However, when a lexeme in one language may not have a corresponding word, it may have a corresponding fixed word phrase or a paraphrase in the other. In those cases, those are not lexical lacunae, but different structural types of structural objects in different languages, which is why it is important to determine whether the word combination is fixed or not. ${ }^{470}$ Language professionals do this automatically, relying on the interpreter's understanding of correspondence and equivalence, which is a part of their academic training. In other words, interpreters will substitute fixed phrases in language A with those in language $\mathrm{B}$ because that is the correct distribution of correspondence and equivalence between these two phrases. However, it would be wrong to interpret "I find you esthetically unappealing, intellectually unchallenging, and sexually uninteresting" as "You are ugly, stupid, and not sexy at all" because it is not functional: interpreters would be concluding for the listener. Finally, individually, and together, $\mathrm{B} / \mathrm{C} / \mathrm{S}$ is not a language that lacks major concepts, especially in the legal sphere. Indeed, B/C/S lacked certain legal terminology owing to the wars and the switch in political systems, but that is a matter for the ICTY CLSS B/C/S translation unit who were asked to research the issue and provide adequate glossaries to interpreters through the institution of a terminologist. ${ }^{471}$ Lacunae in communication always exist due to differences in life experiences, level of education, etc., especially when conducted through translation and interpreting.

\footnotetext{
${ }^{470}$ Karpova, O. and Kartashkova F. (eds) (2009), Lexicography and terminology: a worldwide outlook. Cambridge Scholars Publishers: Newcastle upon Tyne, UK, p. 66-67.

${ }^{471}$ Since they did not have a dedicated post of terminologist in the English, French, or the B/C/S Translation Sections, the ICTY CLSS resorted to the creation of highly illogical and politically incorrect neologisms. The subpar translation or narodi i narodnost $i$ is discussed in Chapter 3. But, even the most basic and the most widely used terms were erroneously translated. The OTP administrative and legal hierarchy is: Prosecutor, Senior Trial Attorney, Trial Attorney, Legal Advisor, and Legal Intern. Two examples of legal register in the situational context in the form of titles that are ICTY-specific, namely, Senior Trial Attorney and Legal Advisor follow.
}

Senior Trial Attorney is a term used by the ICTY to describe a senior lawyer who tries a case under the UN jurisdiction. The following terms are used to describe a legal professional: lawyer, counsel, advocate, attorney, solicitor, barrister, and counsellor. Choices for translation in the Common Law countries: lawyer and attorney, or formally, Attorney at Law (USA); solicitors and barristers (UK, Canada, Australia, and several other); fused legal profession, lawyers are licensed and can practice both as a barrister and solicitor (Malaysia, Singapore, Canada, excluding the province of Quebec, and some states in Australia). Sources of confusion in the Common 
Instead, the ICTY could have taken a page from the IMT's book. The IMT had a system of monitoring and verification of simultaneous interpreting performed by the Interpretation Monitor and the members of the Third Interpreting Team when they were on their "day off." Gaiba shares the information that the IMT was aware of the shortcomings of simultaneous interpreting even before the trials had begun, but that it was impossible for the speakers to check the accuracy of interpreting. In such highly critical proceedings, defendants and speakers in general would need to be sure that translations of their testimony were accurate. ${ }^{42} \mathrm{In}$ terpreters were working two days and resting up the third. Later in the trial, this arrangement was changed so that day off meant off court, but not at rest: interpreters spent the third day checking the transcripts of their translation against the verbatim recording. Since it was discovered that the interpreting system needed someone to supervise its smooth functioning, the IMT invented the role of an Interpretation Monitor, who was not chosen among interpreters because they completely devoted their attention to translating. The Interpretation Monitor was an army officer chosen from the Translation Division. The Interpretation Monitor was present at all times in court to supervise interpreters and facilitate their tasks by reminding the IMT to speak at the proper pace by manning the "yellow light" letting the speakers know they need to slow down and the "red light" which would require interruption of proceedings. ${ }^{473}$ The Interpretation Monitor sat between the English desk and the Marshal of the Court (the military court version of the Registrar) and was assigned a team of interpreters to supervise. It arises from Gaiba's discussions of the qualities of the Interpretation Monitor that this person could be partly described as a "linguistic project manager" in today's terms. The ICTY had no red or yellow lights or systems of checks and balances to ensure the accuracy of interpreting, as it was incumbent on parties to determine this on their own (Chapter 4.3).

As to whether CLSS interpreters could have checked the accuracy of interpreting, the 2009 OIOS Audit Report established that:

\footnotetext{
Law countries: the USA does not make a distinction between barristers and solicitors and all USA lawyers who pass the bar examination may argue in the courts of the state in which they are admitted. Choices for translation in the Civil Law countries: a person who possesses a degree in law is called a "lawyer" and they can practice law as employees hired by law firms or other legal entities. Sources of confusion in the Civil Law countries: such a person may not be the same as an "attorney" in the USA or a "solicitor" in the UK. In Germany, there is one legal profession of Rechtsanwalt (lawyer). In France, there are avocats, notaires, and conseils juridiques. Spain has a division that generally corresponds to the division in UK between barristers and solicitors. Procuradores represent the interests of a litigant in court, while abogados is the general term for other lawyers. Legal Advisor is a term used by the ICTY to describe a nonsenior lawyer who advises his senior trying the case under the UN jurisdiction. In England, the Commonwealth, and former colonies, barristers are divided into senior counsel and junior counsel; senior counsels are sometimes given the title Queen's Counsel. The Queen's Counsel is a barrister appointed to the British crown and when the sovereign is a woman. In the USA all lawyers who pass the bar examination may argue in the courts of the state in which they are admitted, although some state appellate courts require attorneys to obtain a separate certificate of admission to plead and practice in the appellate court.
}

As Cao points out, in Continental European countries, which includes the former Yugoslavia, different kinds of lawyers perform different functions. In the absence of a professional terminologist, the translation of the above terms was left to virtually anyone in the ICTY CLSS and had to have a blessing of CLSS revisers. The legal system of the former Yugoslavia, also an ICTY audience, knows the following legal-administrative hierarchy: Prosecutor, Legal Adviser, and Legal Intern. The translation of the above institutional terms into B/C/S has been misleading. Since the term Viši Sudski Zastupnik (Senior Trial Attorney) does not exist in the legal system of the former Yugoslavia, the clients were always confused as of "who is in charge," because the B/C/S translation of this term implied that there is someone higher in the prosecutorial hierarchy, but lower than the Prosecutor (Viši means higher). Although the legal system of the former Yugoslavia knows a Pravni Savjetnik, such a person is more a glorified secretary, than someone just below Trial Attorneys, as Legal Advisors are at the ICTY. This issue of non-equivalent translation of the main legal terms into B/C/S by the CLSS is unclear, because the media in the former Yugoslavia always dubbed Mr. Bremmertz, for example, as Glavni Tužilac (Chief Prosecutor) and Mr. Tieger, for example, as Tužilac (Prosecutor) which fully correspond both to their institutional and legal functions. Let us add to this confused CLSS translation another one: the term "Office of the Prosecutor" has an equivalent translation in B/C/S, Tužilaštvo, but the CLSS opted for the literal translation, Kancelarija Tužitelja, which corresponds more to the "Immediate Office of the Prosecutor." The latter was in use until the ICTY's legal peers from the former Yugoslavia complained that they did not know with whom they were communicating.

${ }^{472}$ Gaiba, F. (1998), The origins of simultaneous interpreting: the Nuremberg trial. University of Ottawa Press: Ottawa, p. 38.

${ }^{473}$ Ibid, p. 77 . 
ICTY staff interpreters attended office for interpreting work for around 19 hours a week as opposed to the usual workweek of 37.5 hours. In addition, they worked on interpreting duties for 4 days a week and did not come to office on the fifth day without applying for leave. ${ }^{474}$

Clearly, CLSS interpreters could have checked the accuracy of their interpreting. Since they were not used for those purposes, their absence for half a day every day and no-show on Fridays was an incredible waste of inhouse resources. This waste resulted in incredible doubling and tripling of jobs (see Chapter 6 for an extended discussion of this). As to the Interpretation Monitor, s/he should have been in place from the very beginning, both to monitor exchange by manning the lights, to assign interpreters to check their interpreting on the fifth day and the second half of their working day, or to assign them to interpret for witnesses during preparation for court testimony in the proofing. This would eliminate the need for otherwise unqualified and legally unregulated Language Assistants to interpret for clients. Most importantly, since none of them worked at the international war crimes tribunal before getting a job with the ICTY, by interpreting for witnesses before their testimony, court interpreters would establish contact with them, learn their speech pattern, and, consequently, learn how to avoid or deal with linguistic traps. Those who were not Bosnian language speakers could have learned some new words, since most witnesses were from B\&H (see Chapter 7 for an extended discussion of this). Overall, court interpreters would start improving their overall performance, listening to themselves, learning from their mistakes, and they would not be in position to interpret for someone they have never met before.

Faithfulness and accuracy, which are standard translation and interpreting notions, are also discussed in the I\&T Code. In those discussions, it is clear that legal professionals had little idea about what translation and interpreting entail. For example, the I\&T Code stipulates that translators and interpreters shall convey with the greatest fidelity and accuracy, and with complete neutrality, the wording used by those they interpret or translate, ${ }^{475}$ shall convey the whole message, including vulgar or derogatory remarks, insults, and any non-verbal clue, such as the tone of voice and emotions of the speaker, ${ }^{476}$ and, if patent mistakes or untruths are spoken or written, interpreters and translators shall convey these accurately as presented. ${ }^{477}$ It is unclear how neutrality entails fidelity and accuracy, how productive it is conveying the tone of voice and emotions of the speaker through the headphones, and how interpreters and translators are qualified to spot patent mistakes or untruths. These provisions put too many unregulated obligations on translators and interpreters which should have been within the ambit of their readers and listeners. ICTY trial attorneys who have informally seen this study stated that they preferred reading the transcripts in front of them to listening to the actual voices of interpreters. ICTY judges seem to have preferred the same. For example, one of the intercepts admitted to evidence in Krstić was a conversation in which, when asked what to do with the prisoners, Krstić bluntly responded "Kill them all." That recording was played in the courtroom in the original language with only a transcript of that conversation given to the parties to the proceedings to guide them through because it was important for the Trial Chambers to hear Krstićs tone of voice for themselves. ${ }^{48}$

THE INTERPRETER: Do the interpreters interpret? Because we don't have the transcript.

MR. HARMON: No, it's not necessary to interpret. This is only to listen to the volume of the speakers. So it's just to listen to the original.

\footnotetext{
${ }^{474} \mathrm{UN}$, OIOS Internal Audit Division, Audit of Language Services at ICTY (2009), p. 5.

${ }^{475}$ ICTY, The Code of Ethics for Interpreters and Translators Employed by the Tribunal (1999), Article 10.1.(a).

${ }^{476}$ Ibid, Article 10.1.(b).

477 Ibid, Article 10.1.(d).

${ }_{478}$ ICTY transcripts, Krstić, T. 8720-8721; ICTY transcripts, Krstić, T. 8812.
} 
The I\&T Code soon starts contradicting itself: while instructing interpreters and translators to convey with the greatest fidelity and accuracy, and with complete neutrality, the wording used by the persons they interpret or translate, ${ }^{479}$ it also states that interpreters and translators shall not embellish, omit, or edit anything. ${ }^{400}$ When it comes to embellishing, readers are invited to remember the Milošević-Judge May dynamics with the microphone. ${ }^{41}$ Judge May would turn Miloševićs microphone off whenever Milošević started using court as a stage for political rallies, according to those who supported Judge May, or whenever Milošević said anything contrary to Judge May's liking, according to those who did not support Judge May. Milošević was interpreted into English by a particularly dramatic interpreter. Once, Judge May warned Milošević against doing something and asked, "Did we understand each other, now?" Milošević replied "Yes, Your Honor, we did understand each other" in his normal Garfield-like tone of voice. However, this interpreter rendered it with a particularly dramatic and sarcastic tone of voice to which Judge May reacted by saying "Okay, that's it" and turned Milošević's microphone off. In other words, this overly dramatic interpreter got so worked up that she encouraged Judge May to turn off Milošević's microphone. While it is completely normal to "get in the zone" when working like this interpreter did, how can legal professionals know whether interpreters or translators embellish? They cannot know because what interpreters say and the way in which they said it is the only information legal professionals receive. Should the parties in the courtroom rely only on a transcript without audio, as they often do, that only complicates the matter more. Semantic fields are for language professionals what laws are for legal professional. Semantic fields are based on the representation of meaning, taking into account ambiguity, hyponymy, and synonymy. The way words differ from each other in translation lies in their hierarchy: a thing is non-specific and covers a wider semantic field than furniture which, in turn, covers a wider semantic field than a stool, which is specific. ${ }^{482}$ As to interpreting, tone of voice is for interpreters what semantic fields are for translators: I love you uttered as a whisper differs from I love you!!! uttered as a scream which differs from I LOOOVE YOU uttered as a sarcastic remark. The sentence "I did not say I owned her money" can have seven different meanings depending on what word is emphasized. The tone of voice matters in interpreting. Here, judges could not have relied on $\mathrm{B} / \mathrm{C} / \mathrm{S}$ speaking defense counsels to alert them to possible embellishment once it encroaches on the intended meaning because such counsels listen to the proceedings for other reasons which do not necessarily include scrutinizing what was interpreted against the original at the same time. Besides, as a party with an interest, they will only comment on substance when it suits them, not as a general rule. Obviously, this is another reason why the Interpretation Monitor should have been reintroduced.

Finally, the provision against omitting or editing "anything" is very unfortunate here, because interpreting is all about omitting and editing. If a language professional cannot embellish, omit, or edit, but must convey what has been said with the greatest fidelity and accuracy and neutrality, what exactly is it suggested that the language professional should do? Obviously, legal professionals did not suggest anything practical. Later on, we will see how they contradict themselves (see Chapter 4, Section 4.5 for an extended discussion of this). Translation and interpreting is intended to facilitate communication in the least obstructive way. Anyone setting rules on translation and interpreting must suggest something concrete, palpable, and practical that can actually be applied in everyday work. Everything else is intruding on someone else's expertise and knowledge. This provision should have focused on "operational data", starting and finishing with the premise that no parts of operational data can be lost through communication with the assistance of interpreter in any way. Unfortunately, operational information is not addressed by the I\&T Code in any way.

Notwithstanding provisions of I\&T Code Article 9.1.(a), Article 9.1.(b), Article 9.2, Article 10.2.(a), Article 10.2.(b), and Article 10.3. discussed earlier, legal professionals very clearly and unambiguously distanced

\footnotetext{
${ }^{479}$ ICTY, The Code of Ethics for Interpreters and Translators Employed by the Tribunal (1999), Article 10.(a).

${ }^{480}$ Ibid, Article 10.(c).

${ }^{481}$ The New York Times, Milosevic to face charges covering 3 wars in Balkans (2001).

${ }^{482}$ Simon-Vandenbergen A.M. and Aijmer, K. (2007), The Semantic Field of Modal Certainty: A Corpus-based Study of English Adverbs. Mouton de Gruyter: Berlin, p. 11.
} 
themselves from any training of ICTY language professionals, stating that translators and interpreters shall maintain and continually improve their interpreting and translating skills, and increase their knowledge of court proceedings and technical vocabulary that might be encountered during the performance of their duties, ${ }^{483}$ also stating that it is incumbent on interpreters and translators to support and encourage the professional development of their colleagues, ${ }^{484}$ and, most worryingly of all, that interpreters and translators should provide their colleagues, whenever possible, with any specialized knowledge they acquire which may be useful to the exercise of their duties. ${ }^{485}$ This is worrying because the I\&T Code drafters seem to support the "deaf leading the blind" when it comes to translation and interpreting in a legal context (see Chapter 6 for an extended discussion of this). Did the reader learn anything new about translation and interpretation from the last few passages? So would a translator or an interpreter from a similar size elaborate on legal science delivered to them by legal professionals.

In the Decision to deliver the I\&T Code, the Registrar correctly stated that interpreters and translators employed by the ICTY are hired under different terms and conditions and, as part of their functions, undertake various tasks within the three constituent parts of the ICTY ${ }^{486}$ Unfortunately, the I\&T Code fails to encompass all categories of translators and interpreters working at the ICTY, i.e. Language Assistants and field interpreters, and all the tasks they perform. Instead of providing different ornate definitions of language professionals from the Preamble, the I\&T Code could have very simply and very clearly referred to ICTY staff translators and interpreters, freelance translators and interpreters, field translators and interpreters, and Language Assistants. This failure to encompass different categories of language professionals translating and interpreting at the ICTY is very worrying.

Language professionals are privy to many confidential information and should be bound by specific standards of conduct with the emphasis on safeguarding such confidentiality. Sometimes they are explicitly told that documents on which they are working are confidential, but they are rarely informed for which side: the UN or the submitter. Most ICTY language professionals work on documents and information considered sensitive, classified, or secret in their countries of origin which, in the international criminal tribunal adjudicating on ethnic crimes, should also govern the choice of translator or interpreter in contact with confidential information. But, a professional is a professional, so why this concern? Remember that the ICTY was established to adjudicate on ethnic crimes. So the selection of interpreters in terms of their ethnicity, citizenship, or nationality should be de rigueur at international criminal tribunals adjudicating on ethnic crimes. The research conducted so far has established that the ICTY rules and regulations did not safeguard against language professionals of the attacking ethnicity freely engaging with victims and witnesses of the attacked ethnicity at all levels of the investigative and judicial process. Everyone seems to be dancing around that issue in the legal analysis presented so far. Finally, let us reverse the initial question by asking: why would a national of a formerly belligerent country have access to information deemed sensitive in the country of his former victim at an international criminal tribunal? A country, here B\&H, trusted the supranational organization, here UN, with sensitive, classified, and secret information. The UN could have at least refrained from giving access to that information to nationals of formerly belligerent countries, in this case Serbia and Croatia. Those nationals given access to such information are in possession of sensitive, classified, and secret information relating to $\mathrm{B} \& \mathrm{H}$. They are free to apply for any job in their countries of origin, including those jobs where their knowledge of sensitive, classified, and secret information relating to B\&H would be very useful. The fact they are employed by the UN does not in any way, shape, or form take away from their natural human biases. The $\mathrm{UN}$ and the ICTY should have had legislation in place to prevent them from having access to such information in the first place. Was any damage done?

\footnotetext{
${ }^{483}$ ICTY, The Code of Ethics for Interpreters and Translators Employed by the Tribunal (1999), p. 2.

${ }^{484}$ Ibid, Article 11.1.

${ }^{485}$ Ibid, Article 11.2(a).

${ }^{486}$ Ibid, Article 11.2(b).
} 
The UN bases its overall approach to classifying information entrusted to or originating from the UN on the understanding that the work of the UN should be open and transparent, except insofar as the nature of information concerned is deemed confidential. In that sense, the Secretary-General's bulletin on Information Sensitivity, Classification and Handling classifies sensitive documents as follows:

1.2 Information deemed sensitive shall include the following:

(a) Documents created by the [UN], received from or sent to third parties, under an expectation of confidentiality;

(b) Documents whose disclosure is likely to endanger the safety or security of any individual, violate his or her rights or invade his or her privacy;

(c) Documents whose disclosure is likely to endanger the security of Member States or prejudice the security or proper conduct of any operation or activity of the [UN], including any of its peacekeeping operations;

(d) Documents covered by legal privilege or related to internal investigations; (e) Internal inter-office or intraoffice documents, including draft documents, if disclosure would undermine the Organization's free and independent decision-making process;

(f) Documents containing commercial information, if disclosure would harm either the financial interests of the [UN] or those of other parties involved;

(g) Other kinds of information, which because of their content or the circumstances of their creation or communication must be deemed confidential. ${ }^{487}$

This document also authorizes the originator or the UN recipient to decide whether the information is sensitive, to clearly mark documents, and authorize the heads of departments or offices to make sure certain standards are fulfilled when handling sensitive information. ${ }^{488}$ In addition:

The above minimum standards are without prejudice to the authority of heads of departments or offices to put in place stricter controls over the handling of classified information so long as such controls are consistent with the present bulletin. ${ }^{489}$

In other words, there was no institutional impediment to international criminal tribunals making their own internal rules and regulations governing marking and handling of classified and sensitive information in that the heads of departments and offices could decide that their staff should sign certain confidentiality undertakings. This has been confirmed by the ICTY Human Resources Unit (email on file):

Human Resources Section requires the oath of office (declaration) signed on induction. The rest, for example, confidentiality documents would have been internally done by the unit. This information would not be in your file but kept by the unit.

The Oath of Office is a general document which is signed by all members of the Secretariat.

\footnotetext{
${ }^{487} \mathrm{UN}$, Information sensitivity, classification and handling (ST/SGB/2007/6) (2007), para. 1.2.

${ }^{488} \mathrm{Ibid}$, Sections 3 to 5 .

${ }^{489} \mathrm{Ibid}$, para. 5.3.
} 
I solemnly swear (undertake, affirm, promise) to exercise in all loyalty, discretion and conscience the functions entrusted to me as an international civil servant of the United Nations, to discharge these functions and regulate my conduct with the interests of the United Nations only in view, and not to seek or accept instructions in regard to the performance of my duties from any Government or other authority external to the Organisation. ${ }^{490}$

ICTY OTP, ICTY Detention Unit (UNDU), and Victims and Witnesses Unit (VWU) management contacted for purposes of this study could not confirm that their language staff also signed a separate confidentiality undertaking about their communications with the detainees, victims, and witnesses after signing an Oath of Office at the signing of contract, just like all other ICTY staff. This is potentially damaging.

4.5. Legal background to translation and interpreting at international criminal tribunals

It is important to examine the legal background to engaging translators and interpreters at international criminal tribunals because this would define the terms of engagement of language professionals at legal institution and their professional conduct toward language professionals during their work with clients. Those requiring assistance from language professionals in international criminal tribunals include judges, defense and prosecution counsels, defendants, and victims and witnesses. The Chambers, Registry and OTP are the constituent organs of the ICTY, but Defense is not. Prosecutors, Defense and translators and interpreters practicing and appearing before the ICTY are bound by professional code of ethics which will now be analyzed.

The 1985 UN Basic Principles on the Independence of the Judiciary deals with the independence of the judiciary, freedom of expression and association, qualifications, selection and training, conditions of service and tenure, professional secrecy and immunity, and discipline, suspension and removal of judges. ${ }^{491}$ The 1985 UN Basic Principles do not mention translators and interpreters or any underlying duties and responsibilities of judges toward them. The ICTY did not have any codes of conduct for judges, but the UN Mechanism for International Criminal Tribunals (MICT), successor to the ICTY and the ICTR, does. ${ }^{492}$ The MICT Code also does not mention translators and interpreters nor any underlying duties and responsibilities of judges toward them.

The 1999 ICTY Standards of Professional Conduct for Prosecution Counsel establishes that the duties and responsibilities of the Prosecutor differ from, and are broader than, those of the defense counsel, and that the members of the OTP can be regarded as permanent officers of the Court. ${ }^{493}$ In that regard, the UN's 1990 Guidelines on the Role of Prosecutors and the International Prosecutors Association's Code for Prosecutors should serve as the ICTY Prosecutors' points of reference. The ICTY Standards serve as an international benchmark for the conduct of individual prosecutors and of prosecution services, setting the standards of professional conduct for all prosecutors and their basic duties and responsibilities in the area of: professional conduct, independence, impartiality, role in criminal proceedings, cooperation, and empowerment. The ICTY Standards do not mention translators and interpreters or any underlying duties and responsibilities of Prosecutors toward them. The 199 o UN Guidelines set qualifications, selection and training, status and conditions of service, freedom of expression and association, role in criminal proceedings, discretionary functions, alternatives to prosecution, relations with other government agencies or institutions, disciplinary proceedings, and Prosecutors' observance of the Guidelines. ${ }^{494}$ The UN Guidelines also do not mention translators and interpreters or any underlying duties and responsibilities of Prosecutors toward them. The "International Prosecutors Association's Code for Prosecutors" refers to a non-existent document. Rather, ICTY nicknamed

\footnotetext{
${ }^{490} \mathrm{UN}$, Staff Rules and Staff Regulations (ST/SGB/2014/1) (2015), Regulation 1.1.(b).

${ }^{491} \mathrm{UN}$, Basic Principles on the Independence of the Judiciary (1985).

${ }^{492}$ ICTY, Code of Professional Conduct for the Judges of the Mechanism (2015).

${ }^{493}$ ICTY, Standard of Professional Conduct for Prosecution Counsel (1999).

${ }^{494}$ UN, Guidelines on the Role of Prosecutors (1990).
} 
International Prosecutors Association's Standards of Professional Responsibility and Statement of the Essential Duties and Rights of Prosecutors developed by the International Prosecutors Association in $1999 .{ }^{495}$

The 2006 ICTY Code of Professional Conduct for Counsel Appearing Before the International Tribunal deals with general provisions, obligations of counsel and disciplinary regime. ${ }^{496}$ It does not mention translators and interpreters or any underlying duties and responsibilities of defense counsels toward them.

The 2004 UN Human Rights Standards and Practice for the Police: Expanded Pocket Book on Human Rights for the Police is designed to be a readily accessible and portable reference for police officers. ${ }^{497}$ This 2004 UN Guide is organized into major human rights topics of concern to the police (investigations, arrest, detention, and the use of force) and summarizes relevant international human rights standards and provides practice and recommendations for applying those standards. The 2004 UN Guide does not mention translators at all. It mentions interpreters in one single sentence in the context of arrests saying: "Where necessary, an interpreter shall be provided during interrogation." ${ }^{498}$

Investigators who worked at the ICTY until about 2004 interviewed for the purposes of this study claim that the ICTY never had any official Investigations Guidelines. One ICTY investigator stated that investigation guidelines were "made up as we went along. I know that I generally learned from making mistakes" (email on file). ICTY investigators who started working after 2004 stated that there were Investigation Guidelines, but they were internal procedures (email on file). Both set of investigators stated that they received training to work with translators and interpreters from Institute for International Criminal Investigations (IICI). The IICI is an independent, not-for-profit, non-governmental international organization constituted to provide criminal justice and human rights professionals with training in the techniques and knowledge necessary to impartially investigate and adjudicate egregious human rights violations, war crimes, crimes against humanity, and genocide, and to quickly deploy multi-disciplinary teams to investigate such violations or crimes. ${ }^{499}$

In other words, there were no rules and regulations on the parties defining professional boundaries between legal and language professionals and their professional conduct when engaged with the parties individually or together. Although legal professionals are bound by a professional code of ethics, this has nothing to say about the parties' engagement with language professionals. Finally, should a party want to learn about working with interpreters, they were referred to an external organization.

ICTY case law has several decisions on professional boundaries between legal and language professionals and their professional conduct when engaged with the parties individually, which will be examined next.

In 1997, the Defense filed a motion about an alleged omission or incompleteness in the record of proceedings of an interpreted interview claiming that the interpreter was a witness or potential witness as to whether there was in fact such an omission or gap and as to what in fact occurred at that time. ${ }^{500}$ This Defense motion was mainly based on ICTY RPE Rule 54, stating that a Judge or a Trial Chamber may issue such orders, summonses, subpoenas, warrants, and transfer orders as may be necessary which, obviously, includes language staff. When considering the issue, the Trial Chamber defined an interpreter as "one who interprets from either an official or unofficial language of the International Tribunal into the official languages of the International Tribunal and vice versa in judicial proceedings or proceedings related thereto." As to the status and

\footnotetext{
${ }^{495}$ International Prosecutors Association, Standards of Professional Responsibility and Statement of the Essential Duties and Rights of Prosecutors (1999).

${ }^{496}$ ICTY, Code of Professional Conduct for Counsel Appearing Before the International Tribunal (2009).

${ }^{497}$ UN, Human Rights Standards and Practice for the Police: Expanded Pocket Book on Human Rights for the Police (2004), p. iii.

${ }^{498}$ Ibid, p. 15 .

${ }^{499} \underline{\text { Institute for International Criminal Investigations. }}$

${ }^{500}$ ICTY, Decision on the motion ex parte by the defence of Zdravko Mucić concerning the issue of subpoena to an interpreter (1997).
} 
duty of interpreters, the Trial Chamber clarified that the interpreter is not one of the parties to the proceedings, but an officer of the ICTY, and when providing interpreting before the Trial Chamber, an officer of the Trial Chamber. As such, the interpreter has the status of an impartial third party in furtherance of the administration of justice. The Trial Chamber also pointed out that an interpreter is in a unique position as his or her services are available to both parties. Although relied on to constitute the record of all proceedings, an interpreter is not responsible for its authentication and is not required to keep a record of the proceedings $\mathrm{s} / \mathrm{he}$ interprets or translates. The function of the interpreter is merely to pass on to the Trial Chamber, for the benefit of the parties or to the parties directly, whatever is said during the proceedings. $S /$ he is merely the means through which the parties and the Trial Chamber are made to understand each other and to follow the proceedings. In determining this issue, the Trial Chamber tested whether there was a legal duty on the interpreter to make a record of the interpreting between the parties; whether there is any other way of obtaining the evidence sought other than through the testimony of the interpreter; and whether the determination of the issue should depend entirely on the evidence to be given by the interpreter. The Trial Chamber decided that judicial functionaries such as clerks or registrars of courts should be protected from matters arising from their official duties. The Trial Chamber stated that interpreters make a declaration under ICTY RPE Rule 76 to ensure the maintenance of the position of impartiality owed to the parties, which is an essential prerequisite of the interpreter's function and emphasizes the independence of the interpreter from either party in the proceedings and the confidentiality of the subject matter interpreted. The Trial Chamber also decided that it is undesirable, invidious, and not to be encouraged to compel an interpreter into the arena of conflict on behalf of either party to the proceedings for the determination of an issue arising from such proceedings: an interpreter cannot be relied on to testify on the fleeting words of his/her interpretation in the proceedings between the parties. It is also an important consideration in the administration of justice to insulate the interpreter or other functionaries of the ICTY from constant apprehension of the possibility of being personally involved in the arena of conflict, on either side, in respect of matters arising from the discharge of their duties. On both these grounds, the interests of justice frowns on any of the parties being able to call an interpreter as a witness.

In September 1997, the Defense argued, inter alia, that evidence obtained from the accused or having belonged to him had been excluded, claiming that the statements of the accused were taken under improper conditions in that at the outset, the interpreter was instructed "not to interpret every single word especially when we are talking about background matters. ${ }^{n{ }^{501}}$ As a result, the Defense claimed that the accused was not informed of each word which was part of the questions being asked and the statement does not contain each word of his answer. The Prosecution argued that the interpreting of the interview was complete and correct. The defense counsel, who speaks both English and Bosnian, was present throughout the interviews and could have raised objections about inaccurate translations there and then. The interview was recorded in full and thus any questions or issues disputed can be resolved by a review of the question and answer in the accused's language, i.e. the issue ought to have been raised before. The Trial Chamber denied the motion for exclusion. Since these two decisions preceded the 1999 I\&T Code, it is completely unclear why some of these conclusions on the roles of language professionals, and their limitations, were not included in it.

In 1999, the Prosecution submitted a motion on a "sensitive issue of whether an employee of the International Committee of the Red Cross (ICRC) may be called as a witness" ..$^{02}$ The Prosecution described the witness as an eye-witness who, as a former ICRC interpreter, accompanied ICRC staff on visits to places of detention and during exchanges of civilians supervised by the ICRC. This witness contacted the OTP, was interviewed about facts that came to his knowledge by virtue of his employment and was willing to give evidence before ICTY. The Prosecution wished to call the witness, stating that his testimony was important to prove the guilt of the accused. However, although concurring on the facts, the parties could not agree on the

\footnotetext{
${ }^{501}$ ICTY, Decision on motion of Esad Landžo pursuant to Rule 73 (1997).

${ }^{502}$ ICTY, Ex parte confidential: Decision on the Prosecution motion under Rule 73 for a ruling concerning the testimony of a witness (1999).
} 
consequences that flow from the ICRC's status as an international legal personality and its mandate as conferred on it by the international community. The Trial Chambers decided that evidence from the former ICRC employee should not be given due to confidentiality interests barring the Trial Chamber from admitting the information, and a difference in the tasks, functions, and mandates of these organizations: the ICRC's activities are "preventive," while the ICTY is empowered to prosecute breaches of international humanitarian law once they have occurred.

In 2002, the Prosecution sought to introduce in evidence a newspaper article written by a journalist (1) who conducted the interview with the accused through the interpreting services of a second journalist. ${ }^{503}$ The accused responded that the second journalist had been hostile to him and that what was written in journalist 1's article did not correspond to his words. The Prosecution argued further that the position between the two journalists was effectively no different from "an investigator seeing a witness and taking a statement through an interpreter," and that this was a matter that should depend on the weight of the journalist 1's article and his testimony, rather than on their admissibility. Moreover, the Prosecution reminded the court that "statements made through interpreters are routinely admitted by the Trial Chamber without requiring the interpreter to testify." However, journalist 1 made the entire issue about himself, claiming: "I am willing to speak with [ICTY] investigators but I hesitate as a journalist to testify before the court. I would prefer that my statement and article stand for themselves. However, if that were not possible I would be willing to testify that the quotes accredited to [the accused] are true and accurate." The Trial Chamber dismissed the motion.

In 2004, the Defense submitted a motion that the Prosecution should cease proofing witnesses with immediate effect, or allow representative of the Defense to be present during proofing or that the Defense should be provided with a video or audio recording of proofing sessions..$^{504}$ The Trial Chamber described proofing as "a meeting held between a party to the proceedings and a witness, usually shortly before the witness is to testify in court, the purpose of which is to prepare and familiarize the witness with courtroom procedures and to review the witness's evidence." Proofing was accepted as standard practice at the ICTY although it had not been legally regulated in ICTY-S or ICTY RPE. It seems that it was simply understood that the witness proofing would be done by the parties, the defense and prosecution alike, because "it is a widespread practice in jurisdictions where there is an adversary procedure." The Defense's substantive criticism of the proofing was that it provided the Prosecution with a chance to "coach" the witness. In other words, the Defense claims that the Prosecution used the proofing to instruct the witness on what and how to say what has been asked of them. Jordash proposes that

the interviewing process, combined with the witness being able to refresh his or her memory through reading the statement(s) in their own language [...] will assist a true process of recollection, rather than one engendered through rehearsal and practice..$^{505}$

The Trial Chamber concluded that proofing is beneficial to witnesses coping with the stress and cultural differences. Trial Chamber noted as particularly relevant the cultural differences encountered by most witnesses when brought to The Hague and required to give a detailed account of stressful events, which occurred a long time ago, in a formal setting, and doing so in response to structured precise questions, translated into a different language. Such factors also demand time in preparing a witness to cope adequately with the stress of these proceedings. These matters, in the Chamber's view, are properly in the realm of proofing, and are not to be left to the different form of support provided by the VWU. The above decision of the Trial Chamber

\footnotetext{
${ }^{503}$ ICTY, Decision on motion to set aside confidential subpoena to give evidence (2002).

${ }^{504}$ ICTY, Decision on the Defense motion on Prosecution practice of "proofing" witnesses (2004).

${ }^{505}$ Jordash, W. (2009), The Practice of 'Witness Proofing' in International Criminal Tribunals: Why the International Criminal Court Should Prohibit the Practice. Leiden Journal of International Law, 22, p. 501-523.
} 
seems to be the first of its kind in the history of interpreting because, effectively, this decision puts the witness's wellbeing into the hands of interpreters working during the proofing. Here, the traditional roles of interpreters are extended to include the role of mental helpers.

The following decision, which has already been referred to, completely contradicts certain parts of the I\&T Code on omitting and editing discussed earlier. In July 2008, Šešelj made a number of submissions relating to the quality of interpreting..$^{506}$ This prompted the Trial Chambers to clarify that interpreting, unlike translation, deals with fleeting messages in real time where synthesizing and editing are not only legitimate interpreting techniques, but make interpreting possible. The Trial Chambers offered the view that the quality and precision of interpreting depend on the intelligibility of the speaker, the speed of the delivery and the practice of pauses between questions and answers and can also greatly reduce the quality and legibility of the transcript. The Trial Chambers also reflected that interpreting into French is liaison interpreting (meaning that what has been said in $\mathrm{B} / \mathrm{C} / \mathrm{S}$ is first interpreted into English and then from English into French) which multiplies all the difficulties and increases the risk of errors. The Trial Chambers reminded the court that official verification of the transcript is always at the disposal of the parties. The Trial Chambers rejected all Šešelj's other claims that interpreting errors were intentional, interpreters unprofessional and ignorant of the substance. The Trial Chambers referred Šešelj to the CLSS for all further issues on translation and interpreting.

The following decision again shows just how important it is that every language professional is "legally present" and accountable for his or her work. In 2013, the Prosecution submitted a motion to admit into evidence three ICTY witness statements of Witness RM-o12 under ICTY RPE Rule 92quater on unavailable persons alleging that Witness RM-o12 is unavailable because his mental condition renders him objectively unable to testify due to the diagnosis of Alzheimer's disease.$^{507}$ The Defense objected, stating it considers the evidence in the statements to be unreliable submitting, inter alia, that none of the statements were taken under oath or subjected to cross-examination, but instead only taken through interpreters. The Chamber noted that, with regard to the reliability of the statements, they were neither given under oath nor have been subjected to cross-examination, but they were signed by Witness RM-o12 with an accompanying acknowledgment that they were true to the best of his recollection, taken with the assistance of a duly qualified interpreter approved by the ICTY Registry.

\subsection{Interim conclusions}

This Chapter discusses the position in which international criminal tribunals have put translation and interpreting. It shows that IMT and IMTFE legal professionals revamped the existing mode of interpreting to ensure fair and expeditious trials by inventing simultaneous interpreting and moving away from a Christiancentric approach to oath and affirmation. ICCPR and UDHR principles gave defendants the right to use their own language once the Second World War was over and the world started approaching a different legal paradigm. However, some 40 to 50 years after all these efforts, lawmakers at the next international criminal tribunals established in the 199os simply cut-and-pasted these provisions into their statutes and RPEs. They did not expand them to all parties in proceedings before the modern-day international criminal tribunals and have completely forgotten about certain categories of people, such as the deaf, the mute, and the illiterate. The non-participation of professional linguists in drafting the rules and regulations under examination is overwhelming as the authors seem to refer to the same linguistic concepts over and over again.

The most serious problem in the above analysis is that the international criminal tribunals' language rules and regulations are defendant-centric and that, although victims and witnesses are also entitled to using their language, nobody regulated the situation where the language rights given to defendants might trump the language rights given to victims and witnesses. This is most worrisome in cases of ethnic conflict where

\footnotetext{
${ }^{506}$ ICTY, Decision on defendant's motions concerning the quality of interpreting (2008).

${ }^{507}$ ICTY, Decision on Prosecution Rule g2quater motion (2013).
} 
the belligerents often deny the other's identity and language. Although the full effect of an approach in which a defendant can legally continue to deny the existence of the Bosnian language is examined in the next chapters, it suffices to summarize here that the ICTY case law on languages has established that language and identity-related conflicts that were common after the Ottomans left B\&H moved to The Hague, with ICTY defendants further supporting the denial of other's unique language, identity, and culture by claims of misunderstanding of languages used for interpreting and translation. The ICTY did not make official Bosnian, Croatian, or Serbian language, languages used by their clients, namely defense, defendants, victims and witnesses. Instead, they bulked it into one and called it "B/C/S," despite the findings of experts who did not discover any overlap between these three separate languages. Moreover, experts very clearly established that only the peoples of $\mathrm{B} \& \mathrm{H}$ were exposed to the Croatian and Serbian languages, implying that whereas speakers from B\&H will understand speakers from Croatia and Serbia, it is not the case those speakers will always understand each other or speakers from B\&H. The ICTY's practical approach to languages in the former Yugoslavia under the garb of $\mathrm{B} / \mathrm{C} / \mathrm{S}$ did not preclude anyone from hearing the actual language used in interpreting and reading the actual language used in translation. Some were less successful in voicing their dissatisfaction with this approach than others. Šešelj, for example, went out of his way to misuse the language-related rights, among other facets available to him through the mechanism of international justice, with only one purpose: to stall and sidetrack the main trial against him in any way he could. All other similar attempts by defendants and their defense counsel were stopped as the standard practice at the ICTY was designed to suit the Court: defendants were allowed translation of basic documents (ICTY RPE Rules 66(A), 66(A)(i), 66(A)(ii) and transcripts pursuant to ICTY RPE Rule 66) to be delivered to them in $\mathrm{B} / \mathrm{C} / \mathrm{S}$ and in the Latin script. Those transcripts that were not transcribed in $\mathrm{B} / \mathrm{C} / \mathrm{S}$ were given in an audio or video form for the defense/defendants' perusal.

Legal professionals' duties toward language professionals have not been regulated in any UN, ICTY, or international codes of conduct. Should a party want to learn about working with interpreters, they were referred to an external organization. As far as the ICTY is concerned, legal professionals tried compensating by promulgating a particularly restrictive and contradictive I\&T Code in 1999, which, although subsequently almost entirely refuted by ICTY case law drawing on the practice of translation and interpreting, has never been amended. The ICTY contributed to the field of translation and interpreting in the legal context with the following novelties: proofing interpreters are responsible for the witness's wellbeing (they might perform the role of mental helpers), and the fact that witness statements are taken with the assistance of a duly qualified interpreter approved by the ICTY Registry adds to their reliability. But, lawmakers did not include all categories of language professionals practicing translation and interpreting before the ICTY, leaving an empty slot in place of confidentiality clauses. This is alarming because lawmakers allowed language professionals with the attacking ethnicity unimpeded access to persons, documents, and information belonging to the attacked ethnicity. They also left an empty communication slot when an interpreter is introduced to clients: except for notifying the suspect that he has the right to the free assistance of interpreter, nothing else is said about interpreters at the interview or about transcribers transcribing the interview.

Procedural equality of arms in the sphere of language is almost non-existent: the Defense took matters into their own hands to tackle the lack of information about ICTY cases in $\mathrm{B} / \mathrm{C} / \mathrm{S}$ and gave themselves a voice by publishing what could be dubbed as a Defense Gazette to inform the local audiences of their activities; physical facilities provided by the ICTY to the Defense were insufficient; the ICTY imposed restrictions on acceptable languages, gave audience to a counsel who did not speak those languages, but downsized such a legal professional to the level of co-counsel; the ICTY imposed examinations on non-English or non-Frenchspeaking defense counsels to prove the knowledge of acceptable languages and avoided paying for multilingualism; the ICTY divided indigent defendants, offering unattractive translation and interpreting fees to language professionals who might have otherwise been interested in freelancing for Defense that are much lower than official ICTY interpreting and translation rates; translation of documents other than those in English, 
French, or B/C/S are in limbo. The Defense must literally depend on the kindness of the Prosecution to provide adequate translation of documents in those languages.

ICTY President Meron stated that the ICTY-S was "drafted quickly," but added that the ICTY judges have been entrusted with the authority to write their own RPE. In itself, this

has largely proven a success. Admittedly, there have been many revisions. But the large number of revisions to the $[\mathrm{RPE}]$ reflects one of the main advantages of having judges to do the rule-writing: the ability to quickly take into account lessons learned from concrete experiences in the courtroom..$^{508}$

ICTY RPE and ICTY-S have been amended $5^{2}$ and 9 times by 2017 , respectively. None of the issues explained in this Chapter were ever addressed and are as they appeared the first time the ICTY RPE was written.

That is how the things stand as far as the legal institution is concerned. The next leg of the journey, starting with the next chapter, examines those who interpret, translate, and transcribe justice delivered by international criminal tribunals: language professionals. This part of the journey will also be conducted topto-bottom, beginning with an examination of UN language professionals with the aim of understanding what the position is in which language professionals find themselves.

${ }^{508}$ Meron, T. (2011), The Making of International Criminal Justice, A View from the Bench: Selected Speeches. Oxford University Press: Oxford, UK, p. 116. 
Chapter 5: May UN language professionals take the stand, please

Chapitre 5 : Les linguistes professionnels de l'ONU sont priés de venir à la barre

Peto poglavlje: Neka pristupe profesionalni prevodioci UN-a 
The first leg of the journey has been completed. In examining linguistic justice at the ICTY, this study reviewed the institution of justice, the historical development of the language and identity-related context that contributed to the conflict in the situation country, and the language-related rights, obligations, and requirements on the parties involved in international criminal tribunals with the emphasis on procedural equality of arms between the Prosecution and the Defense, and the nominal relationship between legal and language professionals. This examination was conducted to identify external influences on the conduct of UN language professionals, i.e. in what position do international rules and regulations and international lawyers put language professionals. The next leg of the journey starts with examining those who interpret, translate, edit, and transcribe justice as delivered by international criminal tribunals: UN language professionals. I will now explain the internal influences on the conduct of UN language professionals. This leg of the journey will also be conducted top-down, beginning with a general examination of UN language professionals. Only matters affecting ICTY language services will be touched on and these services will be explained in more detail in Chapters 6 and 7. Who are UN language professionals? How have they been recruited? What are UN rules governing mechanisms to test language professionals to recruitment to their positions? What are UN language professionals' responsibilities, competencies, education, and work experience before they start working for the UN? Who do they turn to for guidance? How well do they keep up with developments in technology?

5.1. UN staff categories, rules and regulations, and partnerships affecting language professionals

UN Staff Rules, ${ }^{509}$ UN Staff Rules and Staff Regulations, ${ }^{510}$ and the UN Charter are the three main documents governing UN staff service, duties, obligations, privileges, etc. There are several types of UN staff: regular and temporary staff, as well as locally hired and internationally hired staff. There are also several types of contracts that UN staff sign: permanent or continuing, fixed-term, and temporary contracts. ${ }^{511}$ Finally, there are three main categories of staff at the UN:

- Professional and Higher Categories (P-level category): ranked between P-1 and P-5, and Principal Officer and Director category, and Under-Secretary-General and Assistant Secretary-General (the latter two form a category of their own because staff on these levels are either career UN staff or political appointees),

- Field Service Category (FS-level category): ranked between FS-1 and FS-7, and

- General Service and related Categories (GS-level category): ranked between GS-1 and GS-7 comprising Language Teacher Category, National Professional Officer Category, Trades and Crafts Category, Public Information Assistant Category, and Security Category.

These categories differ from each other in the type of work staff perform, the manner of recruitment, the level of education, remuneration, and rights and obligations..$^{512}$

The International Civil Service Commission (ICSC) is an independent expert body established by the UN General Assembly with a mandate to regulate and coordinate the conditions of service of staff in the UN System, while promoting and maintaining high standards in the international civil service. ${ }^{513}$ Since all posts in the P-level categories are filled by internationally recruited staff, whether or not the applicant is a resident of a duty station, internationally recruited staff are paid according to the so-called Noblemaire principle whereby staff remuneration is set by reference to the highest paying national civil servant. Since some organizations in the UN System placed certain jobs in the P-level category while others, sometimes within the same

\footnotetext{
${ }^{509}$ UN, Staff Regulations (ST/SGB/2014/2) (2014).

${ }^{{ }^{10}} \mathrm{UN}$, Staff Rules and Staff Regulations (ST/SGB/2014/1) (2015).

${ }^{511} \mathrm{UN}$, Policies for Obtaining the Services of Individuals on Behalf of the Organization (ST/SGB/177) (1982).

${ }^{{ }^{12}}$ UN, Details of UN Salaries, Hazard Pay, Rental Subsidy, Mobility and Hardship Scheme, and other Allowances, Benefits.

${ }^{513}$ UN, ICSC-S and ICSC RPE (1987), Articles 9 to 18.
} 
duty station, placed the same jobs within the GS-level category, the ICSC recognized the importance of developing a methodology for distinguishing between P-level category and GS-level category work..$^{514}$ The ICSC defined work performed by the P-level category staff as "analytical, evaluative, conceptual, interpretive and/or creative and thus requir[ing] the application of the basic principles of an organized body of theoretical knowledge, such as a field of science, learning or specialized discipline." The work performed by the GS-level category staff has been described as "contribut[ing] to the execution of the programs of the organization through work that is procedural, operational and technical. ${ }^{515}$ The ICSC also passed self-explanatory Standards of Conduct for the International Civil Service (2013) affecting all civil servants..$^{516}$

As to the language professionals, the ICSC issued a series of standards affecting various job profiles, including Standards for Translators and Revisers (1981), which set out the following duties and responsibilities of translators and revisers:

5. Jobs in the field of work covered by these grade level standards include those who translate written or recorded material from two or more languages into another, producing a version which is, in meaning, style and effectiveness, equivalent of the original language version by:

(a) studying text and converting it into other languages, using most appropriate vocabulary and commonly accepted equivalents of professional, scientific or technical terms, and ensuring that original meaning is retained;

(b) acquiring information about professional, scientific and technical subject matter covered, consulting specialists and reference works, technical dictionaries and other appropriate sources as necessary and ensuring that terminology and nuances are correctly rendered, and that translation is structurally, grammatically and idiomatically correct;

(c) verifying accuracy of citations;

(d) spotting manifest or possible errors in original text and informing editor and author when appropriate; and

(e) comparing translation of text with original, verifying accuracy and completeness of translated version and suitability of vocabulary and terminology used.

6. In addition to performing the foregoing functions, translators and revisers may specialize in a particular type of subject matter; may establish terminology; may engage in self-revision or in revision or editing of other texts; may supervise and train other translators or revisers; may test applicants' skills and aptitudes for translation work; may check conformity of translations with other language editions; and may draft, revise and edit précis of meetings, summary records and texts for publication. ${ }^{517}$

In theory, these standards are supposed to be adhered to by all UN System entities. In practice, they are adapted to the individual needs of each entity.

The ICSC did not issue any similar standards of conduct for interpreters. ${ }^{518}$ The profession of interpreting was recognized as a profession in its own right and formalized for the first time during the UN General

\footnotetext{
${ }^{514}$ Alexovičková, I. (2012), From hiring to firing: a comparative study on selected legal safeguards for the independence and impartiality of international civil servants serving in the United Nations Secretariat and in the European Commission. Wolf Legal Publishers: Nijmegen, p. 55 .

${ }^{515} \mathrm{UN}$, ICSC Compendium (1980).

${ }^{516} \mathrm{UN}$, ICSC Standards of Conduct for the International Civil Service (2013).

${ }^{517} \mathrm{UN}$, ICSC Standards for Translators and Revisers (1981).

${ }^{518}$ There are two other general documents governing translators and interpreters worldwide. Since it is not clear how they directly impact the work of UN language professionals, they will be footnoted. The first is the Translator's Charter (1994) by the International Federation of Translators' (FIT). FIT's Translator's Charter sets the general obligations, rights and economic and social position of the
} 
Assembly session held on 15 November 1947, when simultaneous interpreting was adopted for permanent service at the UN by General Assembly Resolution 152 (II) "to be used alternatively or in conjunction with consecutive interpreting as the nature of debates may require. ${ }^{n 19}$ Consecutive interpreting is also widely used at the UN. The UN has not issued any similar resolution recognizing or formalizing translation. The UN has not issued any similar resolution on translators or interpreters..$^{20}$

The UN uses freelance translators and interpreter so widely that some reports consulted for the purposes of this study mention that some offices outsource a minimum of $25 \%$ or a maximum of their entire workload to them. Most UN freelancers hail from international professional associations for translators and interpreters that are recognized as partners by the UN: AITC and AIIC. AITC was founded in 1962 mainly to standardize the working conditions and terms of employment of short-term language staff employed by international organizations, particularly those belonging to the UN System, whereas AIIC was founded in 1953 to serve interpreters and the conference industry, to promote professional excellence and good working conditions, and to represent the interests of all interpreters. Currently, AITC has about 450 members with 11 different mother tongues and 44 working languages in addition to the mother tongue. AIIC has more than 3,00o members from over 100 countries who interpret into 58 different languages. Bosnian, Croatian, Serbian, Montenegrin, and Serbo-Croatian language translators and interpreters are represented both in the AITC and AIIC (2017 data). AITC's activities are regulated by the AITC Constitution ${ }^{52}$ and all AITC members are bound by the AITC Professional Code of Conduct ${ }^{522}$ whereas AITC freelancers must adhere to the AITC Guidelines on External Translation guaranteeing users professionalism and quality when dealing with AITC members. ${ }^{523}$ All AIIC members must comply with the AIIC Code of Professional Ethics ${ }^{524}$ and Professional Standards..$^{52}$ Neither AITC nor AIIC offer further job-related training, but they regularly update their members on job-related training possibilities at institutes and universities focusing on translation, précis-writing, ${ }^{526}$ editing, or interpreting. The membership criteria for three AITC membership categories stipulate between 100 and 300 days of professional experience for candidate members and over 300 days of professional experience for active members. A day's worth of professional experience is understood to be either a day of work in-house under a

translator, translators' societies and unions, and a relationship between the national organizations and the FIT. It defines a translation product as the sole responsibility of the translator, stipulating that a translator has a right to refuse to give to a text an interpretation of which he does not approve, or which would be contrary to the obligations of his profession, requires fidelity in translation and defines faithful translation. The FIT Charter requires a translator to have a sound knowledge of the language from which s/he translates in that s/he should be a master of the language into which s/he translates, should have a broad general knowledge and know sufficiently well the subject matter of the translation, refraining from undertaking a translation in a field beyond his or her competence. As far as the relationship with the original author(s) is concerned, the translator shall respect the legitimate interests of the user by treating as a professional secret any information which may come into his possession as a result of the translation entrusted to him because he is a secondary author (FIT, Translator's Charter (1963-1994), Sections 1.2 to 1.11). The second general document governing translators and interpreters worldwide is UNESCO's Recommendation on the Legal Protection of Translators and Translations and the Practical Means to improve the Status of Translators (1976) which does not significantly depart from the FIT Charter. UNESCO's Recommendation defines the general legal position of translators, with measures designed to ensure the practical application of protection afforded to translators under international conventions and in national laws relating to copyright, social and fiscal situation of translators, and training and the working conditions of translators, including translators in developing countries (UNESCO Recommendation on the Legal Protection of Translators and Translations and the Practical Means to improve the Status of Translators (1976).

${ }^{19}$ UN, UN General Assembly Resolution 152(II) on simultaneous interpreting (1947), para 1.

${ }^{520}$ In 2009, AIIC launched a project called Resolution on interpreters in war and conflict zones. Reminding that translators and interpreters are not specifically protected by international legislation and that they fall through the cracks in the Geneva Conventions where, unlike journalists, translators and interpreters are not covered by a separate resolution, the petitioners are calling for a change in legislation proposing that a UN Resolution would be a first step toward ensuring the protection of translators and interpreters under international law mandating member states to prosecute crimes perpetrated against translators and interpreters.

${ }^{5^{21}}$ AITC, AITC Constitution.

${ }^{522}$ AITC, Professional Code of Conduct.

${ }^{523}$ AITC, Guidelines on External Translation.

${ }^{524}$ AIIC, Code of Professional Ethics.

${ }^{525}$ AIIC, Professional Standards.

${ }^{526}$ Précis-writing is a written exercise where only the main points of the delegate's speech, for example, are conveyed. 
contract with an international organization or at an international conference, or 1,650 words of translation work for an international organization or an international conference paid according to the volume of work done. In other words, AITC membership is open to anyone who can provide a certificate of production, for a lack of a better word, on translation, précis-writing, or editing activities in any international organization.

However, joining the ranks of AIIC seems to be more exclusive. For example, for a candidate to apply for membership, s/he needs: at least 15 o days of work overall, at least three sponsors, including two from the region. These sponsors must have listened to him or her work at a meeting no more than three years prior to the date of signing an application; must have signed his or her application form no more than three years prior to the date at which an application is received; must be active members of AIIC with five years of seniority in the languages they are sponsoring and cover at least one language pair. This administrative ceremonialism is problematic because introducing the concept of "sponsorship" with a host of restrictive disclaimers and without clear written rules and regulations with clear definition of responsibilities and duration of that sponsorship cannot be said to guarantee enriching the existing ranks with qualified members in practice. Indeed, closer inspection of the AIIC membership list reveals 132 instances where one interpreter is the only one registered in that one language combination and 62 instances where two interpreters are the only ones registered in that one language combination. This suggests a certain immaculate conception of new members: if a potential candidate needs a sponsor, who sponsored these 132 interpreters who are the only registered interpreters in that one language combination? Obviously, these 132 have not been subjected to any of the above membership requirements. This obvious lack of any serious systems to vet AIIC potential members also strongly suggests a trend of a tit-for-tat sponsoring: the AIIC membership list shows 62 interpreters who are the only two registered interpreters in that one language combination. One can assume they must have sponsored each other. Finally, the world is getting smaller, but of 280 locations from which AIIC interpreters hail, 116 interpreters are the only AIIC interpreters in those locations. Should any potential candidates want to travel and reside in that location for the purposes of being listened to by a sponsor, this creates a priori a geographical and time/opportunity organizational impasse to admission, according to the existing AIIC membership criteria. ${ }^{527}$ These 310 cracks among AIIC members should make the UN question the trust they have in the reliability of the provision of their services.

Finally, the UN recognizes the International Annual Meeting on Language Arrangements, Documentation and Publications (IAMLADP) as a partner. IAMLADP was created in 1967 and could be seen as a UNoriented lobbyist organization consisting of 80 managers of member international organizations employing conference and language service providers brought together to share knowledge and experiences and discuss subjects of common interest. The overall objective of IAMLADP is to enhance the efficiency, quality, and costeffectiveness of conference, language, and publishing services UN System-wide and within each participating organization.$^{52}$ Created in June 1987 at the UN Office at Geneva, the Joint Inter-Agency Meeting on Computer-Assisted Translation and Terminology, renamed in April 2006 International Annual Meeting on Computer-Assisted Translation and Terminology (JIAMCATT) could be seen as an IAMLADP task force which provides its partners with a forum for debate, exchange of expertise, and cooperation in the fields of computer-assisted terminology and translation, interpreting, and documentation retrieval that is working to establish a proprietary terminology and information repository common to all participating organizations. To this end, JIAMCATT intends to enhance exchanges among languages services of international organizations and national bodies to promote the pooling of the partners' terminology resources to make them accessible in an electronic form. JIAMCATT membership includes partners from most international organizations, as well as from various national institutions active in the field of terminology and translation. ${ }^{52}$ The ICTY is a member organization of both IAMLADP and JIAMCATT.

\footnotetext{
${ }^{527}$ AIIC, List of members by location.

${ }^{528}$ IAMLADP.

${ }^{529}$ JIAMCATT.
} 
5.2. Mechanisms governing UN language professionals' entry examinations

UN DGACM recognizes the following groups of language professionals: translators, interpreters, editors, verbatim reporters, terminologists (P-level category), and reference assistants, copy preparers, and proofreaders (GS-level category). The UN DGACM translators' and revisers' hierarchy is as follows: Associate Translator (P2), Translator (P-3), Reviser/Self-revising translator (P-4), Senior Reviser (P-5), and Chief of Service (D-1). In non-headquarters duty stations, Senior Reviser may be the same as Chief of Section, as D-1 posts might not exist at that level. These language professionals' generic job profiles are not that different from those of their peers outside the UN.

UN DGACM language professionals are recruited through semi-regular Language Competitive Examinations (LCEs) which are mostly held in the main UN DGACM-serviced centers: Addis Ababa, Bangkok, Beirut, Geneva, Nairobi, New York, Santiago, and Vienna. In order for a candidate to apply for a job in UN DGACM, that candidate must have three UN languages. The recruitment or placement of candidates successful in LCE for posts requiring special language skills, i.e. translators, interpreters, editors, and interpreters, is governed by several documents of which the last was amended in 2012, ${ }^{53^{\circ}}$ including special conditions for such recruitment (last amended in 2003). ${ }^{531}$ The general requirements to apply for LCEs announced on all calls to applicants are not that strict. All that is needed is that a candidate:

$[\ldots]$ hold $[\mathrm{s}]$ at least a three-year first-level degree or an equivalent qualification from a university or institution of equivalent status in which [name of candidate's main language from the six UN official languages] is the language of instruction or hold a university degree from a recognized school..$^{532}$

Alongside the EU, the UN is the largest organization in the world that employs language staff. UN and intercultural communication through the assistance of translators and interpreters are inseparable. However, right at the onset, the UN administration paints an image of language professionals that could be interpreted to mean language professionals are people who work in UN only until they get a better job elsewhere in the UN System as embodied in the following disclaimer present at all sites promoting LCEs:

Successful candidates are expected to serve a minimum of five years in language posts before they can apply for another type of post with the [UN].

Moreover, attempts at empowerment of potential candidates to LCE come across as self-complimentary, patronizing, and condescending:

There are thousands of language professionals in the world, but only the best can make it to the top. Consider becoming one!

\footnotetext{
${ }^{530} \mathrm{UN}$, Competitive examinations for recruitment and placement in posts requiring specific language skills in the professional category (ST/AI/1998/7) (1998). UN, Competitive examinations for recruitment and placement in posts requiring specific language skills in the professional category (ST/AI/1998/7/Amend.1) (2012).

${ }^{531} \mathrm{UN}$, Special conditions for recruitment or placement of candidates successful in a competitive examination for posts requiring special language skills (ST/AI/200o/1) (2000). UN, Special conditions for recruitment or placement of candidates successful in a competitive examination for posts requiring special language skills (ST/AI/2003/1) (2003).

${ }^{532}$ In addition to semi-regular examinations for language professionals working into UN main languages, every now and then the UN requires language professionals working into German.
} 
In the late 2016, the above banner was supplemented with this one:

Use your language skills for a better world - join the UN language services.

Both still feature on the UN LCE site as a banner, but on different pages.

Footnotes below refer to a description and an assessment method used for the 2015 LCE for English Copy Preparer/Proofreader/Production Editor, ${ }^{533}$ the 2015 LCE for English Translator/Précis-writer, ${ }^{534}$ and for the 2015 LCE for English Interpreters. ${ }^{535}$ In short, when applying, candidates are required to write a short motivational letter. Should the candidates' background and short motivational letter satisfy the selection panel, the candidate is first invited for the written examination and, should s/he pass the written examination, the candidate is invited for an interview. Should the candidate pass the interview, which also includes a short $a$ la vista translation, ${ }^{536} \mathrm{~s} /$ he is put on a roster of eligible language professionals, and, eventually, offered a job in one of the UN DGACM-serviced centers. Among the three stages to recruitment through LCE, there are no costs involved when writing a motivational letter, but candidates have to bear their own costs when traveling and staying at the testing location for the written examination. The UN covers the costs of the third phase (travel, accommodation, and DSA).

The UN System's Joint Inspection Unit (JIU) is an independent, UN system-wide, investigation and inspection organization with the broadest powers of investigation in all matters that have a bearing on the efficiency of the services and the proper use of funds..$^{537}$ The LCEs have not received much attention in the JIU oeuvre, save for two reports in 1995 and 2011, respectively. The 1995 JIU Inspection Report, the first of its kind to refer to LCEs, addressed certain aspects of LCE efforts up to that year, summarizing the recruitment of language professionals (carried out through national language examinations), which were announced in those Member States where the language of examination is the principal language. The number of language staff recruited was estimated to be between 80 and 90 , but, because of the current freeze on recruitment, the Secretariat started using more freelancers, which lead to the quality of the conference services deteriorating in certain areas. The general consensus among the permanent members of the UN Security Council was that the LCE should be kept as it delivers relatively satisfactory work, but the LCE was criticized for not being costeffective and for not yielding good-quality candidates. Some Program Managers complained about the inadequate performance of many staff recruited through the LCE, whereas others acted as if conversion from a probationary into a permanent appointment were automatic. JIU Inspectors could not understand why some of the successful candidates with a relevant academic background were only "recommended," while some others with an inadequate academic background to the post were "highly" recommended. They also remarked that interviews held within the LCE framework focused much more on personal attributes than on job-related issues..$^{58}$

In order to examine whether anything has changed, monitoring LCE data for the purposes of this study that started in 2013 has shown that LCEs are organized every year, but not for every job profile in every language. Rather, LCEs are held as needed, depending on the status of rosters of successful candidates and the projected staffing needs of the service or section in question. Examinations are staggered so that those that are most urgent are held earlier. Vacancies arising from anticipated retirements are advertised at least

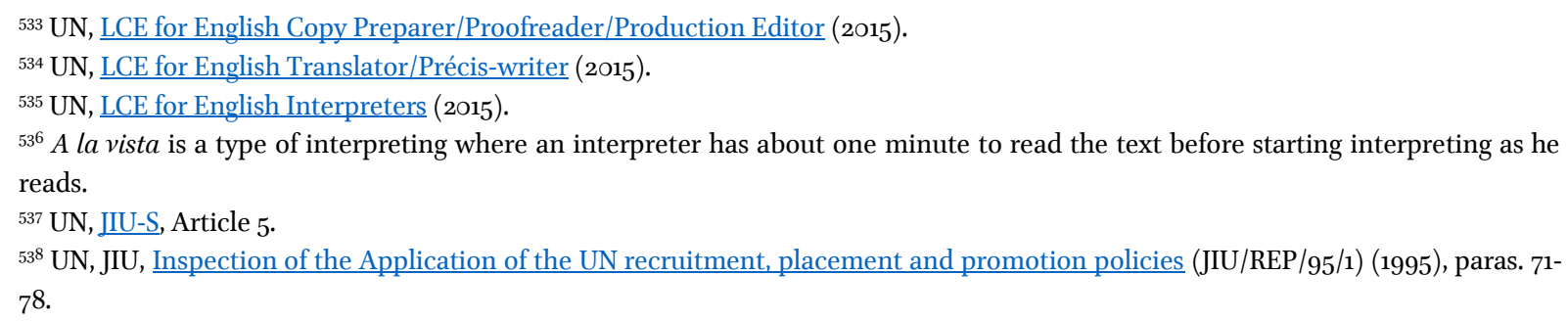


six months in advance in order to ensure the timely completion of the selection process and a smooth succession. ${ }^{539}$ Rostered candidates have the right to refuse a post twice before they are removed from the roster. As to their on-the-job training and induction, staff initially selected for language posts located away from headquarters normally spend the first six months of their appointment in the appropriate service at headquarters for training purposes. ${ }^{540}$ Nominally, the UN broke away with the tradition of holding LCEs in the "principal language" countries and it no longer imposes any requirements vis-à-vis nationality, gender, or the geographic location of candidates applying. In that regard, the LCE schedule is widely advertised through the language careers portal, universities in the memorandum of understanding network, newspapers and, increasingly, social media. ${ }^{54}$ In her welcome note to UN Language Careers site, the Assistant Secretary-General for UN DGACM stated that:

[T]o date, successful candidates include not only applicants who were trained in the language professions (translation, interpreting, linguistics, etc.), but also applicants from a variety of other fields, such as journalism, law, economics and even engineering and medicine..$^{542}$

Indeed, out of 16 language professionals interviewed for a "Meet UN language professional" segment at UN Language Careers site, some had no background in languages, some had a peripheral background in languages (general linguistics or literature) and, with the exception of a professionally educated translator or two, the only UN language professionals with job-related diplomas were found to be interpreters. Three UN language professionals interviewed for this segment had absolutely no prior working experience, six had earlier UN and international organizations-related experience, and others had been working in the private sector. This working experience did not necessarily include hands-on experience in the job profile for which they were hired by the UN after passing the LCE. Staff who were recruited in the 197os say they got a job after being trained through the UN Language Training Program for translators and/or interpreters. This language training seems to have been popular in the 1970 and 1980 s but is no longer offered. ${ }^{543}$

It is worrisome that LCE sites do not contain any clear admission or LCE pass/fail criteria. Also that all duty stations are invited to participate in the organization of LCEs, including selection, marking of test papers, and interviewing candidates. This suggests that there will be no custodians of the LCE's institutional memory. ${ }^{544}$ It is also worrisome that LCE Board of Examiners does not release individual results and does not provide any feedback on performance. ${ }^{545} \mathrm{LCE}$ candidates do have access to past uncorrected exams used to test the candidates and are advised to consult UN documents and UN Editorial Manuals when preparing for examinations ${ }^{546}$ Indeed, the Internet is filled with various UN documents, but only in their final version, not prior to interventions by language professionals. Consequently, this UN approach to the preparation of UN LCE candidates is not helpful.

Indeed, the $2011 \mathrm{JIU}$ Report recommended that the legislative bodies of the organizations of the UN System should dispense with targeted training of candidates for language examinations. ${ }^{547}$ However, this has

\footnotetext{
${ }^{539} \mathrm{UN}$, Pattern of Conferences (A/70/122) (2015), para. 52.

${ }^{5{ }^{\circ} \mathrm{UN}} \mathrm{U}$ Special conditions for recruitment or placement of candidates successful in a competitive examination for posts requiring special language skills (ST/AI/200o/1) (2000), para. 2.3.

${ }_{541} \mathrm{UN}$, Pattern of Conferences (A/70/122) (2015), para. $5^{2}$.

${ }^{542}$ UN, Language Careers, Message from the Assistant Secretary-General DGACM.

${ }^{543}$ UN, Language Careers, Meet a UN language professional.

${ }^{544} \mathrm{UN}$, Pattern of Conferences (A/70/122) (2015), paras. 23 and 28.

545 UN, Language Careers, $\underline{\text { Message about recruitment. }}$

${ }^{546}$ As UN Editorial manual for English and UN Editorial manual for French are available online, it is unclear whether editorial manuals for other official UN languages exist at all or whether they are just not public documents.

${ }^{547} \mathrm{UN}, \mathrm{JIU}$, Multilingualism in the UN System organizations: status of implementation (JIU/REP/2011/4) (2011), p. 33.
} 
not materialized yet..$^{58}$ The 2011 JIU Report addressed certain recent aspects of LCE efforts ten years after it has been agreed, establishing that the main challenges faced by the existing interpreting and translation services include, inter alia, the shortage of professional language staff because many will retire in the near future, the problem of succession planning, and the related issue of roster management of successful LCE candidates. ${ }^{549}$ The common issue underlying all these problems is insufficient awareness among training institutions and professional communities of the very high standards set by the UN in order to meet the demands of its Member States and ensure the highest quality language services. These have, however, been proactively addressed by UN DGACM and IAMLADP through their outreach efforts. Nevertheless, the LCE roster did not provide enough successful candidates to replace retired language staff.

The UN Language Careers does provide a profile of the LCE Training and Outreach Officer, but it is entirely unclear from the online presentation what and whom this Officer trains. Moreover, the key conclusions and speeches of training and outreach efforts seem to have very little to do with language work in an institutional context. ${ }^{550}$ The LCE Training and Outreach activities include increasing LCE visibility, helping candidates better prepare for LCE, and trying to figure out cooperation between different unnamed bodies or organizations and UN staff through visits. ${ }^{551}$ All these efforts led to several conferences on the issue of LCE, but conference reports paid way too much attention to luncheons and self-promotion to offer any genuine contribution to the issue of training for LCE. ${ }^{52}$ However, one obvious problem here is that these outreach efforts through conferences - to widen the pool of candidates - were and are being held in countries that already dominate the structure of UN language professionals both in terms of country representation and language as at 2017 (out of 870 staff):

- three conferences in China (131 UN staff already), Russia (131 UN staff already) and UK (68 UN staff already),

- two conferences in France (116 UN staff already) and Egypt (34 UN staff already), and

- one conference each in Spain (97 UN staff already), Switzerland (14 UN staff already), Belgium (14 UN staff already), Argentina (11 UN staff already), Belarus (4 UN staff already), USA (61 UN staff already), Lebanon (25 UN staff already), and Syria (10 UN staff already). ${ }^{.53}$

Nevertheless, the 2016 Pattern of Conferences report welcomed the existing memoranda of understanding between UN and 22 universities as a way to strengthen the training of language professionals in order to improve the recruitment of qualified language staff, and requested that the UN Secretary-General should continue to assess the appropriate number of memoranda of understanding in order to fulfill the needs of the Organization. ${ }^{554}$ In practice, should LCE Training and Outreach activities continue reaching out to these countries, the UN language professionals structure will be completely taken over by candidates from the above countries. By extension, UN DGACM will be making a very clear political statement about what nationalities they want in their ranks because the citizens of the UN Security Council permanent member countries have a clear priority.

\footnotetext{
${ }^{548}$ Comparing UN language services with those of its younger sister, EU, merits a whole different study. However, it must be at least remarked that EU language staff recruitment efforts, including practical training for the recruitment exams, are fully online and much more concise, lucid, and up-to-the-point as shown in these two sites targeting potential interpreters and potential translators. In addition, as to institutional memory and developments, EU language staff are also provided single online access to publications on translation, interpreting, and linguistic issues. Although dealing with less languages, UN efforts on these issues fade in comparison. ${ }^{549} \mathrm{UN}, \mathrm{JIU}$, Multilingualism in the UN System organizations: status of implementation (JIU/REP/2O11/4) (2011), p. iii.

${ }^{55^{\circ}} \mathrm{UN}$, Language careers, Meet the Training and Outreach Officer.

${ }_{551} \mathrm{UN}$, Language careers, LCE Outreach.

${ }^{552} \mathrm{UN}$, Language careers, LCE MoU Conferences.

${ }^{553} \mathrm{UN}$, Composition of the Secretariat: staff demographics (A/72/123) (2017), p. 103-122.

${ }_{554} \mathrm{UN}$, Pattern of Conferences (A/RES/70/9) (2015), para. 111 .
} 
Indeed, when one looks at the UN staff demographics reports, one cannot shake off the feeling that the recruitment of UN language professionals presents an accurate reflection of the UN Security Council permanent member countries' balance of powers discussed in Chapter 2 because most language staff come from UN Security Council permanent member countries. There is an obvious imbalance among the UN language staff where citizens of the UN Security Council permanent member countries have very clearly taken over. As at 31 December 2016, the UN had a population of 39,651 staff from 187 UN Member States. A total of 19,897 staff were working in non-field operations and 19,754 in field operations. A total of 12,849 staff was in P-level and higher categories, 3,894 in FS-level category, and 22,908 in GS-level and related categories. ${ }^{555}$ There was a total of 870 staff in the $\mathrm{P}$-level and higher categories in posts with special language requirements between 30 June 2015 and 30 June 2016. Practice has shown that working staff includes categories P-1, P-2, and P-3. The P1 category is rarely used at UN DGACM and new recruits, with or without previous working experience, are employed at P-2 level whereas staff at P-3 level have either been with the UN for at least two years and have been already promoted internally or they had considerable working experience elsewhere. Categories $\mathrm{P}-4$ and $\mathrm{P}-5$ include revisers and managers, either chiefs of sections or departments. The following table is a summary of UN staff demographics reports on language professionals between 2013 and 2017.

Table 7. Citizens of UN Security Council permanent member countries in UN DGACM between 2013 and 2017

\begin{tabular}{|l|l|l|l|l|l|}
\hline $\begin{array}{l}\text { Security Council } \\
\text { (SC) country }\end{array}$ & $\mathbf{2 0 1 3}$ & $\mathbf{2 0 1 4 ^ { 5 5 6 }}$ & $\mathbf{2 0 1 5}$ & $\mathbf{2 0 1 6 ^ { 5 5 7 }}$ & $\mathbf{2 0 1 7 ^ { 5 5 ^ { 8 } }}$ \\
\hline China & 137 & 137 & 138 & 132 & 131 \\
\hline France & 117 & 121 & 120 & 115 & 116 \\
\hline Russia & 128 & 126 & 128 & 131 & 131 \\
\hline United Kingdom & 62 & 68 & 66 & 67 & 68 \\
\hline United States & 75 & 69 & 68 & 61 & 61 \\
\hline $\begin{array}{l}\text { Total SC vs. total } \\
\text { staff }\end{array}$ & $513 / 889$ & $521 / 887$ & $520 / 879$ & $506 / 861$ & $507 / 870$ \\
\hline $\begin{array}{l}\text { Percentage SC } \\
\text { staff }\end{array}$ & $57 \cdot 71 \%$ & $58 / 74 \%$ & $59.16 \%$ & $58.77 \%$ & $58.28 \%$ \\
\hline
\end{tabular}

The following table is a summary of the $2017 \mathrm{UN}$ staff demographics report on language professionals who are citizens of UN Security Council permanent member countries at P-1 to P-5 language positions as at 31 December 2016.559

Table 8. Citizens of UN Security Council permanent member countries at P-1 to P-5 language positions in UN DGACM as at ${ }_{31}$ December 2016

\begin{tabular}{|l|l|l|l|l|l|}
\hline SC country & P-1 & P-2 & P-3 & P-4 & P-5 \\
\hline China & - & 3 & 46 & 55 & 27 \\
\hline France & - & 7 & 41 & 47 & 21 \\
\hline Russia & - & 6 & 43 & 53 & 29 \\
\hline United Kingdom & - & 3 & 23 & 30 & 12 \\
\hline United States & - & 2 & 21 & 24 & 14 \\
\hline $\begin{array}{l}\text { Total SC vs. total } \\
\text { staff }\end{array}$ & $-/-$ & $21 / 26$ & $174 / 314$ & $209 / 354$ & $103 / 176$ \\
\hline $\begin{array}{l}\text { Percentage SC } \\
\text { staff }\end{array}$ & - & $80.77 \%$ & $55.41 \%$ & $59.04 \%$ & $58.5^{2} \%$ \\
\hline
\end{tabular}

\footnotetext{
$555 \mathrm{UN}$, Composition of the Secretariat: staff demographics (A/72/123) (2017), p. 10.

${ }^{556} \mathrm{UN}$, Composition of the Secretariat: staff demographics (A/69/292) (2014), p. 110-129.

${ }^{557} \mathrm{UN}$, Composition of the Secretariat: staff demographics $(\mathrm{A} / 71 / 360)$ (2016), p. 109-128.

${ }_{55}^{8} \mathrm{UN}$, Composition of the Secretariat: staff demographics (A/72/123) (2017), p. 103-122.

${ }^{559}$ Ibid.
} 
It is obvious from the above table that the citizens of the UN Security Council permanent member countries dominate the structure of UN working staff by, at least, $55.41 \%(\mathrm{P}-3)$ to, at most, $80.77 \%(\mathrm{P}-2)$, and that they are represented by close to $6 \circ \%$ at managerial positions at $\mathrm{P}-4$ and $\mathrm{P}-5$ levels. The $2013-2017$ comparison of the citizens of UN Security Council permanent member countries staff on language professionals' posts has shown the citizens of these five countries dominate citizens of other countries represented in the ranks of UN DGACM language staff by between $57-59 \%$. This is alarming on many levels and seriously questions the sincerity of UN rules and regulations which apply to language staff purporting there are no nationality or geographical requirements to their recruitment as these numbers clearly show that nationality does play a role in the recruitment of language professionals. Also, since P-2 staff from UN Security Council permanent member countries dominate the structure of UN language staff, this means they will continue dominating the management in the years ahead, as well.

One reason for such a situation is that the LCEs have not taken full advantage of digital opportunities until recently. Since the turn of the century, any written exam could be taken securely online, and any interview could be conducted securely using interviewing software and online platforms. The UN has a presence in almost all the countries in the world and LCEs and related interviews could be performed online from the candidate's home or, should the candidate not have a reliable online service, from one of UN offices in his home country, to offer just two solutions. The 2016 UN Secretary-General's Report on conferences took note of the newly established computer-based testing for translators, which improved test validity, whereas remote testing increased the candidate pool by making it unnecessary for candidates to travel to test centers. ${ }^{56}$ Breaking with a long tradition of pen-and-paper tests, both remote and computer-based testing were piloted in LCEs for English translators/précis-writers and for English editors held in July 2015. The feedback from the candidates and the language services involved was very positive. Specifically, the new method reduced the time spent by senior revisers at the grading stage. The resulting roster of 19 candidates for staff posts in the English Translation Service and 20 in the Editing Section included three nationals of African and Caribbean Member States. LCE for English translators/précis-writers also identified 23 second-tier candidates for temporary work and traineeships. Although these encouraging results could have paved the way for the pilot of a fully remote competitive examination in 2016, as the 2016 LCE for Spanish translators was completely conducted online ${ }^{561}$ the 2016 LCE for Russian verbatim reporters ${ }^{562}$ and the 2016 LCE for Arabic translators ${ }^{563}$ were still entirely paper-based. However, this was a huge leap forward for UN LCE: for the first time in their history they are starting to offer fair access, flexibility, they are keeping up with the times, and showing that they are open to truly widening the pool of candidates.

But, are they really? The UN boasted of recruiting Africans and Caribbeans in the above report, which was replicated by several other reports encountered during research for this study. This boasting was so prominent, I simply had to check the numbers. Mentioning specific regions in reports does bring otherwise implicit messages explicitly home in the minds of readers. The UN mentioned Africa and the Caribbean because they wanted the reader to know they are employing black people. Thankfully, there was a way to find out whether UN really did start employing Africans and Caribbeans. The 2016 UN Secretary-General Report lists 69 candidates from African States who participated in the LCE, namely from Cameroon, Democratic Republic of the Congo, Egypt, Kenya, Morocco, and Senegal, stating that three of them passed. ${ }^{56}$ But, there were several factors that seemed incongruous in that statement. Namely, Egypt and Morocco are Arab States, a separate category in other UN reports, and there are 31 and 33 language staff, respectively from these countries at the UN already. And none of these is a Caribbean country. Also, despite best efforts, not one single translation and interpreting school leading to a degree could be found in Congo or Senegal. The 2016 UN Staff Demographics

\footnotetext{
${ }^{560} \mathrm{UN}$, Pattern of conferences, (A/71/116) (2016), para. 49.

${ }^{561} \mathrm{UN}$, LCE for Spanish translators (2016).

${ }^{562}$ UN, LCE for Russian verbatim reporters (2016).

${ }_{56} 6_{3} \mathrm{UN}$, LCE for Arabic translators (2016).

${ }^{564} \mathrm{UN}$, Pattern of conferences, (A/71/116) (2016), para. 63
} 
report makes it easy to follow the changes in staff in P-1 to P-5 language professionals positions between 30 June 2015 and 30 June 2016, so it was possible to find out whether Africans were employed.$^{55} \mathrm{~A}$ comparison of the numbers of staff in 2015 and 2016 in these countries was done to establish that: Cameroon had no change in the number of staff, Congo had no staff at all, there were three new staff from Egypt in 2016, in Kenya and Morocco there was no change in the number of staff, and Senegal had one member staff less in 2016. According to this data, these three "Africans and Caribbeans" could have only come from Egypt. So, it is fair to say that the 2015 Internet-based LCE did not at all contribute to increasing numbers from African and Caribbean States. On the contrary, it only reconfirmed Egypt's position as the Arab State dominating the pool of Arabic language staff. Online LCEs may have increased the candidates pool, but the UN ran ahead of itself claiming, between the lines, that LCEs also contributed to equal regional and racial distribution, hence African and Caribbean. In reality, as shown above, the UN merely referred to a well-known minority, the Africans and Caribbeans, while actual jobs went to a well-established majority. It seems the UN thought nobody would check the numbers. One should not take UN information for granted and should, indeed, check their numbers. Mentioning these candidates from these African and Caribbean Member States in this and several other $\mathrm{UN}$ reports with a very specific intention to suggest color in the otherwise white, yellow, and brown ranks of UN language professionals amounts to deceit. The only good thing here is that, since these Africans and Caribbeans took these exams online, they did not have to spend any money on traveling.

\subsection{The responsibilities of UN language professionals}

Various translation and interpreting blogs describe the job of a UN language professional as dreamy, prestigious, exciting, and important. Clearly, language professionals external to the UN have created a narrative that rests on their own priorities and their own perceptions of what it is like to get a job and to work as a UN language professional. However, for the most part, these narratives focus on the remuneration of UN language professionals and potential travel worldwide. The actual status of UN language professionals needs to be considered when examining UN language professionals' responsibilities, competencies, education, and work experience required as defined in vacancies for UN language professionals' posts.

The core problems with the image of UN language professionals and the misrepresentation of the actual staff demographics working in the UN System as language professionals are exacerbated by the fact that there is a clear distinction between applying to work in UN DGACM and applying to work in non-UN DGACM-serviced UN System entities. The problem here is that non-UN DGACM-serviced UN System entities do not have a single unified examination or recruitment office for any job profile they employ. Rather, should a language professional wish to "get a job with the UN," such a candidate can either try to get into the UN System by passing one of the semi-regular LCEs and getting a job in UN DGACM-related language posts or s/he needs to apply directly to the individual UN entity whenever there is an open vacancy for language professionals. ${ }^{56}$ Consequently, there is a lack of coordination and uniformity in the approach to language professionals where UN language professionals working in the non-UN DGACM-serviced UN System entities are in limbo because their final clients, who are non-language professionals, interview, recruit, and supervise them. This is a very serious problem.

\footnotetext{
${ }^{565}$ Ibid, p. 109-128.

${ }^{566}$ Most vacancies appearing in this study have been taken from the official site of the UNjobs Association. This is because it has been noticed that links to UN vacancies mostly expire from the main recruitment pages of respective organizations that posted them. As the UNJobs Facebook group moderator explained: "Beginning in 2000, UNjobs Association pioneered the aggregation of vacancy announcements from multiple UN System organizations. It is a social enterprise and a labor of love, providing a livelihood for four persons in Switzerland and Bhutan. The UNjobs team cares deeply about the mission of the organizations it supports and collaborates closely with many of them to produce a comprehensive resource for the use of job seekers, Human Resources and Communications professionals and all those concerned with the work of the international development and relief community" (UNJobs Facebook group moderator, personal communication from 11 March 2016).
} 
First of all, such a lack of coordination and uniformity in the approach to language professionals between the UN DGACM-serviced and non-UN DGACM-serviced UN System entities creates unclear authorities in recruitment. The non-UN DGACM UN System entities established for the purposes of responding to emergencies may or may not have been originally created by the UN. Although these are autonomous organizations, sometimes language professionals recruited to non-UN DGACM-serviced UN System entities fall under UN DGACM rules of employment and vice versa. ${ }^{567}$ It is obvious from Chapter 1, Figure 1 detailing UN System entities that ICJ, for example, falls under the Secretariat in a category of its own. However, judging by ICJ vacancies, it seems that language professionals recruited into ICJ do not fall under regular UN DGACM rules of recruitment as vacancies to ICJ posts do not state "must have passed the UN Competitive Examination for [job profile]". Indeed, ICJ vacancies do not make any mention of any testing methods for language professionals positions. ${ }^{58}$ ICJ works only in two languages, English and French, and has absolutely no reservations mentioning the fact they are looking for mother tongue French or English language professionals in the vacancy title. This approach could be said to be illegal according to UN rules and regulations on language professionals. ${ }^{59}$ The ICJ argues that the fact that the Court operates in two, rather than six official languages

\footnotetext{
${ }^{567}$ Such was the case in the recruitment of an interpreter for the UN International Independent Investigation Commission (IIIC), prequel to the STL, an UN agency that is not supported by UN DGACM. However, notice that the vacancy says that the candidate must have passed "the UN competitive examination for interpreters" or the LCE (UN vacancies, IIIC P-4 interpreter (Arabic/English)). It is not entirely clear why this happened: UN IIIC was established in April 2005 by UN Security Council Resolution 1595 to investigate the 14 February 2005 assassination of Rafik Hariri, the former Prime Minister of Lebanon. It is plausible to assume that, given the urgency and the sensitivity of the matter, either the charge for recruitment was reverted to UN DGACM or the recruitment panel wished to recruit someone from the said roster of UN DGACM interpreters. However, the post in question was a very senior post of a limited duration requiring an incumbent to perform some managerial duties, as well. If so, advertising to manager posts should require uninterrupted service in managing activities. The second is a vacancy for a post of editor in the World Meteorological Organization (WMO), which, again, is not supported by the UN DGACM. Here, notice that the job vacancy also says, "having passed the UN Competitive Examination for translators/editors is considered an asset" (UN vacancies, WMO P-4 Editor/Translator (English)). The WMO was established in 1950 and is an independent UN System entity. Here, the recruitment drive from the above example makes no sense at all. The WMO recruiter for editor/translator seeks someone who passed the LCE for "translators/editors" which are two different exams testing two different skills. It remains unclear why would the independent WMO with its own staff rules and regulations give preference to candidates who have passed an examination organized and implemented by a different agency.

${ }^{568}$ UN Vacancies, ICJ P-4 Translator/Reviser (French); UN Vacancies, ICJ P-2 Proofreader/Copy-preparer (French); UN Vacancies, ICJ $\underline{\mathrm{P}-4}$ Translator/Reviser (English); UN Vacancies, ICJ P-4 Translator/Reviser (English).

${ }^{569}$ As a digression from the main topic, it must be observed that ICJ is not alone here as non-UN DGACM-serviced UN System entities are also seen institutionalizing discrimination on the basis of language as they often advertise for "mother tongue," "native," or candidates with "language of mother tongue proficiency" (UN vacancies, ICAO P-4 Language Officer/Reviser (Spanish); $\underline{\text { IAEA P-3/P-4 Trans- }}$ lator/Reviser (French).
}

First and foremost, this requirement is not founded in language. Working definition of a native speaker defines such a person as "a person who has spoken a certain language since early childhood" (McArthur, T. (ed.) (1992), The Oxford companion to the English language. OUP: Oxford, UK). Davies (Davies, A. (1995), Proficiency or the native speaker: what are we trying to achieve in ELT? Principle and practice in applied linguistics. OUP: Oxford, UK) and Cook (Cook, V. (1999), Going beyond the Native Speaker in Language Teaching. TESOL Quarterly, 33, 2, 185-209) deconstructed this native ability to speak a language into attributes such as: subconscious knowledge of rules, intuitive grasp of meanings, ability to communicate within social settings, range of language skills, creativity of language use, identification with a language community, the ability to produce fluent discourse, and knowing differences between their own speech and that of the standard form of the language. Cook reminds us that, until the 199os it was tacitly assumed that the only owners of a language were its native speakers, but that such a categorization is a highly idealized abstraction because native speakers of any language vary from each other in many aspects of grammar, pronunciation, and vocabulary for dialectal, social, and regional reasons.

Normatively, such qualification of language in work place is in violation of all internal UN laws on recruitment and non-discrimination, namely: the UN Charter and its spirit because the purposes of the UN are promoting and encouraging respect for human rights and for fundamental freedoms for all without distinction as to race, sex, language, or religion (UN, Charter (1945), Article 1(3)); UN Staff Rules and Regulations which command staff members to uphold and respect the dignity and worth of the human person proscribing they shall not discriminate against any individual or group of individuals or otherwise abuse the power and authority vested in them (UN, Staff Rules and Staff Regulations (ST/SGB/2014/1) (2015), Regulation 1.2.(a)); and, finally, they go against UDHR which entitles everyone to all the rights and freedoms without distinction of any kind, such as race, color, sex, language, religion, political or other opinion, national or social origin, property, birth or other status (UN, UDHR (1948), Article 2). 
results in great savings as compared with other UN's organs. However, this could be freely described as an "ostrich approach" to the translation, interpreting, and transcription workload. This is because the ICJ is in

Also, such qualification of language in work place is in violation of most international regulations governing the profession of translators, interpreters, and editors, namely: the ICSC Standards for Translators and Revisers which emphasize knowledge, not mother tongue or a tribe, defining language knowledge as a thorough knowledge of the target language (UN, ICSC Standards for Translators and Revisers (1981), p. 4, etc.); the ICSC Standards for Editors, which define language knowledge as a perfect command of the primary working language (UN, ICSC Standards for Editors (199o), p. 9, etc.); and the Translator's Charter, which does not in any way mention any of the disputable language qualifications mentioned above. UNESCO's Recommendation does recommend that a translator should, as far as possible, translate into his or her own mother tongue or into a language of which s/he has a mastery equal to that of the mother tongue with a view to improving the quality of translations. Unfortunately, neither the "mother tongue" or "a language of which [translator] has a mastery equal to that of his [...] mother tongue" have been clearly defined. As to the practice, recruiters know whether one's mother is a speaker of the language advertised because applications to language posts are not language professionalsspecific, but generic applications that applicants fill regardless of job profile for which they are applying where both UN DGACM and non-UN DGACM applications literally ask: What is your mother/native language?

The OIOS conducted investigations into possible discrimination due to nationality, race, sex, religion and language in recruitment, promotion and placement. On the one hand, the OIOS found shortcomings in the consistency, completeness, and accessibility of data that is essential for this type of review. On the other hand, the OIOS seems not to have conducted any analysis pertaining to the staff recruited to P-level positions. Annex II of the OIOS Report contains samples of vacancies for GS-level posts for which English or French is required as the mother tongue. Such a requirement was usually found for positions in the linguistic units. If applied sensu stricto, the requirement could prove discriminatory against all those who cannot claim to have these languages as their mother tongue, but who have been well educated in the languages concerned, either by choice or as a result of their country being former colonies. With changing lifestyles, in some other cases, a "mother tongue" should be more aptly called a "father tongue". Whatever the initial rationale behind the requirement of a mother tongue as proof of assumed fluency, it is very questionable today and serious consideration should be given to replacing it wherever applicable by the expression "main language of education". Some vacancies do already use that terminology, and this should be reflected accordingly in the recommendation contained in paragraph 101 of the report by the OIOS whereby it is proposed that executive offices undertake a project to verify and input to IMIS data on the mother tongue of their staff. UN, Possible discrimination due to nationality, race, sex, religion and language in recruitment, promotion and placement (A/56/956/Add.1)(2002), para 21.

Alexovičková addressed the practical application of principles of geographical distribution and the principle of merit in her study establishing that the conflict between the two is that preference is given to candidates with the 'right' nationality which completely ignores the candidate's merits. As to the UN System, the paramount consideration in the employment of staff is to secure the highest standards of efficiency, competence and integrity (UN, Charter (1945), Article 101(3)) where due regard shall be paid to the importance of recruiting staff on as wide a geographical basis as possible (UN, Staff Rules and Staff Regulations (ST/SGB/2014/1) (2015), Regulation 4.2). This means that the first set of criteria has paramount importance in staff selection, whereas the importance of recruiting staff on as wide a geographical basis as possible may only be taken into account as a secondary consideration. This has been successfully argued and won by serving staff at UN administrative tribunals several times. Alexovičková also discussed cases where individual Member States often tried to influence UN Secretary-General in decisions regarding the recruitment process for the sake of securing their own political interests (Alexovičková, I. (2012), From hiring to firing: a comparative study on selected legal safeguards for the independence and impartiality of international civil servants serving in the United Nations Secretariat and in the European Commission. Wolf Legal Publishers: Nijmegen, p. 103-108 and 177-178).

Unfortunately, applicants to language professionals' positions cannot complain about suspected discrimination based on language. The Administrative Tribunal of the International Labor Organization (AT ILO) and UN Dispute Tribunal (UNDT) only receive applications from serving or former staff members of the organizations which have recognized the jurisdiction of the Tribunal, as well as external collaborators and contractors, if the terms of their contract provide for this (AT ILO-S and RPE, Article II(4)) and from any current or former staff member or any person making claims in the name of an incapacitated or deceased UN staff member, including of the UN Secretariat or separately administered UN funds and programs (UNDT-S and RPE, Article 3.1).

Finally, the "mother tongue," as used here, is euphemism for the "mother country," meaning USA, UK, France, Russia, China, and Spain. The UN 2016 Staff Demographics report very clearly shows that "mother tongue" is not just any old Arabic, any old Chinese, any old English, any old French, any old Russian, and any old Spanish, but those languages as spoken in UN Security Council permanent member countries. For example, in 2016, 68 UK and 61 USA language staff in the UN DGACM overwhelmingly outnumbered 23, 6, and 3 Canadian, Irish, and Australian staff, respectively. 
charge of resolving disputes between those countries that may not have English or French as an official language. Indeed, in cases when supporting documents are submitted in languages other than those two languages, the ICJ claims they will be translated insofar as resources permit.

Some 3,351 pages of documentary annexes have been submitted to the Court. There is simply not the staff or funds to do the work of translating all of the pages not already available in both languages. Using the traditional means of freelance translation of written pleadings submitted by parties before the Court, the confidential nature of which require them to be translated within the premises of the Court, the estimated costs are of the order of $\$ 530$,ooo. That sum exceeds the balance available to the Court for translation for the 1996-1997 biennium..$^{50}$

A thorough review of ICJ ARs still does not make it clear what happens to such documents and who translates them.

Another contribution to the above findings that international tribunals may be left to their own devices to deal with translation, interpreting, and transcription by the UN DGACM is the fact that the ICTY was established by the UN, it falls organizationally under Subsidiary Organs of the UN Security Council, but it does not fall under the regular UN DGACM rules of recruitment. Although it is entirely unclear why or how this could have happened, the repercussions of this approach to language-related work conducted at the ICTY are explained in the following chapter in terms of recruitment, training, and working output.

Second, a lack of coordination and uniformity in the approach to language professionals between the UN DGACM-serviced and non-UN DGACM-serviced UN System entities leads to an increase in hybrid positions advertised by the non-UN DGACM-serviced UN System entities. These hybrid positions comprise a host of language-related duties whereby incumbents are expected to provide 3-in-1 language services, i.e. translation, interpreting, and editing. ${ }^{571}$ In other words: the responsibilities of UN language professionals, save for those working in UN DGACM, are not strictly delineated and they must translate, interpret, or edit. Although this begs the question of the 3-in-1 incumbents' education and training, it could even be tolerated because, after all, these professionals are conducting language-related responsibilities, and, should they be professionally educated translators or interpreters, they would have come out of college with the basic understanding and skills needed to perform these language-related functions.

However, some vacancies advertised by the non-UN DGACM-serviced UN System entities, besides the 3-in-1 language-related duties, increasingly request incumbents to language professionals' posts to perform other non-language-related duties, called (3-in-1)+ duties for the purposes of this study. These (3-in-1)+ vacancies to language posts abound throughout non-DGACM-serviced UN System entities..$^{52}$ On inspection

${ }^{570} \mathrm{UN}$, Report of the International Court of Justice 1996-1997 (A/51/4), paras. 188-192.

${ }^{571}$ For example, language professionals working in the Organization for the Prohibition of Chemical Weapons (OPCW) are given the title of "Linguist" and translate, interpret, and edit (UN vacancies, OPCW P-3 Linguist (Chinese)). The following UNDP's English and Arabic "Translation/interpreting specialist" is supposed to translate, interpret, manage translation team, perform research, take care of procurement and administration "following a long period of dictatorship [in] Libya" under UNDP (UN vacancies, UNDP P-3 Interpreter/Translation Specialist). ICRC "Translators/interpreters" are required to interpret and to translate. Both sets of professionals normally hold different academic degrees, but the ICRC does not have any other term for such positions (ICRC (grade not defied), Senior Arabic Translator/Reviser). A colleague shared the fact that the Pacific Community in Noumea, New Caledonia, has four interpreter/translator posts. Basically, these are interpreters who translate when they are not on interpreting assignments (UN vacancies, Secretariat of the Pacific Community Interpreter/Translator).

${ }^{572} \mathrm{UN}$ vacancies, IMF Editor (External relations officer) is a vacancy for an editor where the recruiter is looking for a production manager, editor, and software programmer with six to 12 years of experience; UN vacancies, AFRO/WHO Interpreters (English, French, Portuguese) is a vacancy for unspecified number of "someones" to provide translation, editing and interpreting, but those "someones" would be preferred if they were members of AIIC which represents interpreters only; UNOPS IICA-2 Bilingual Communications Consultant/Translator (English and Somali) should have a "Bachelor's degree in Business Administration, or other relevant Social Science. MA in Business Administration, or other relevant Social Science fields is an advantage" and is supposed to produce 
of vacancies in the preceding footnote it becomes clear that the authority to hire language professional has been borrowed, almost hijacked: non-language professionals are taking charge of interviewing, recruiting, and supervising language professionals. Obviously, the problem here is that non-language professionals are misinformed about the limitations of language professional's responsibilities and want them to provide (3in-1)+ service comprising both language and non-language-related duties. As to the (3-in-1)+ hybridization it cannot be overlooked that educational requirements noted in the vacancy notices listed above cover only languages, which means that non-language professionals expect them to perform all these other duties $e x$ nihilo. It is also important to note that most of these vacancies have been advertised in conflict and postconflict areas. It is plausible to assume these language professionals would normally think twice before accepting these (3-in-1)+ positions if they knew they would have to deal with non-language professionals as their immediate supervisors and if they knew they would be engaged in non-language-related work. Most worrying, all these hybrid positions are normally advertised at P-level, but they are offered to applicants from countries devastated by conflict at GS and other equivalent levels. Consequently, the local candidate will be paid at least two times less than a colleague from the seat of the organization concerned, will have many more duties and responsibilities than his colleague, will not be entitled to any benefits normally offered to internationally recruited professionals, and will be left at the whim of non-language professionals. It has been shown previously that two other UN recruitment options could have been used to provide for fair recruitment applicants from countries devastated by conflict: National Professional Officer ${ }^{573}$ and FS-category. ${ }^{574}$ In practice, due to this approach, the non-UN DGACM-serviced UN System entities are seen over-saving on the account

\footnotetext{
"well-articulated French language editorial set of guidelines, revised web content on the event pages, media centre and related subsites, crisp public French language public information products, including content for advertorials, campaigns, media kits and visibility items, well written French subtitling on ECA multimedia content, well written French language media kits and coordination of francophone oriented Communication Section events, clearly articulated responses to francophone media inquiries on a variety of themes including flagship publications and ECA events and related products"; UNDP SB-3 trilingual Administrative/Financial Associate (English, Russian and Georgian) is not only supposed to "assist with relevant administrative tasks such as recruitment of shortterm experts/consultants, including drafting recruitment reports, evaluations as well as logistics, procurement, etc." and "facilitate travel arrangements," but also "act as an interpreter/translator on matters relating to project activities from English, Russian and into Georgian and vice versa when required"; UNOPS LICA-11 Written Translator, Proofreader and Interpreter (English, Spanish, Portuguese) should be a member of the AIIC, association of interpreters, or is a sworn or public translator; UNICEF P-3 Editor (French) who should "revise and edit French texts and publications for print, Web and other digital output; plan and manage the provision of French translation services (Eng-Fre and Fre-Eng); supervise and guide translators, translation agencies, revisers and proofreaders, ensuring compliance with UN/UNICEF terminology, style and language norms; contribute to conceptualizing and developing information and advocacy materials such as brochures, booklets, press kits, reports and online content in English, Spanish and French; prepare, collect and disseminate terminological materials and internal instructions on editorial matters and work procedures, develop, administer and evaluate translation tests" and needs to have an "advanced university degree in a relevant field."

${ }^{573}$ UN, National Professional Officer.

${ }^{574} \mathrm{UN}$, Field Service category.
} 
of the (3-in-1)+ language staff and misusing local potentials. ${ }^{575}$ Current recruitment practice makes it virtually impossible to offer fair recruitment conditions to local candidates. ${ }^{576}$

The only thing that should be added here is that the (3-in-1)+ approach to language professionals is damaging to the reputation of professional translators, professional interpreters, professional editors whose jobs, in the extension of the above UN-wide attitude toward language professionals, seems to be seen by UN clients as something anyone can do, sometimes even for free. ${ }^{577}$

\subsection{Competencies required of UN language professionals}

The responsibilities of UN language professionals are not alone in being incongruent or non-language professional-specific. The 1998 UN Secretary-General Kofi Annan's reforms (discussed in Chapter 2) gave UN managers and their deputies greater, almost infinite, powers, and conditioned the UN System staff to work according to the set of core values and competencies. These UN values were defined to include: respect for diversity, professionalism, and diversity. The UN core competencies were defined to include: creativity, a commitment to continuous learning, accountability, client orientation and professionalism, planning and organizing, teamwork, communication, and awareness of technology. UN managerial competencies were de-

\footnotetext{
${ }^{575}$ UN vacancies, UNHCR SB-2 Receptionist/Translator in the UNHCR Regional Representative's office in Kyiv, Ukraine, is a trilingual English, Russian, and Ukrainian translator and receptionist who delivers "high-quality written translation into English, Ukrainian or Russian," interprets, and take notes during meetings and must "[a]ct as a switchboard operator, answer incoming calls, provide general information, transfer calls to concerned officer." UN vacancies, UNOPS LICA-g Liaison Officer/Translator is a trilingual English, Arabic, and Kurdish speaking liaison officer/translator working in Iraq who is supposed to translate, interpret, and act like a liaison officer on a local level salary offered by UNOPS. UN vacancies, UNDP SC-g Translator/Interpreter/Proofreader in combination English, Russian, and Uzbek will be working with UNDP on local salary. UN vacancies, UNHCR GL-4 Registration Assistant (English and Thai) is also expected "to act as an interpreter and translator from Thai to English or English to Thai when needed"; WHO G-4 Secretary (English, Russian, Ukrainian) also "provides rough translation or synopsis of incoming mail" and "acts as informal interpreter/translator when required"; UNDP SC-9 Legal Translator (English and Somali) is also expected to provide consecutive and simultaneous interpreting, "organize training for Project Staff and partners on legislative and constitutional issues" and should have a "Master's Degree or equivalent in law, foreign languages or any related field," but "a first level university degree in law, foreign languages or any related field with 2 additional years of relevant experience may be accepted in lieu of the advanced university degree"; $\underline{\text { UN Women }}$ SB-4 UN Joint Programme for Gender Equality Project Assistant also "acts as an interpreter/translator on matters relating to UNJP activities from English, Russian and into Georgian language and vice versa when required”; UN Women SC-g Senior Translator-Interpreter (English, Dari, Pashto) with "Bachelor's degree in English language, literature, journalism, Law, or any other gender-related field with at least 5 years of experience; Master's with 3 years' experience preferred" pointing out that "training or prior experience in translation will be highly considered".

${ }^{576}$ The 2011 JIU Report addressed certain recent aspects of language use in field activities, stating that local languages' needs and knowledge should duly be taken into account in delivering activities in the field and in preparing related materials recommending executive heads of the UN System organizations delivering work in the field in the area of humanitarian affairs, peacekeeping, peacebuilding, and development activities, among others, should ensure that due attention is given to delivering their activities and related materials in all official or working languages, taking account of the local language(s) of the beneficiaries (p. 43). Moreover, defining effective implementation of multilingualism, this 2011 JIU Report emphasizes shared responsibilities when setting up partnerships to ensure the availability of high-quality professional language staff between all stakeholders where each one of them have a role to play (para. 69). In addition, the 2011 JIU Report stated that language requirements should be much stricter for internationally recruited staff who should have a good command of at least two working languages, if not from the outset of their career, then during their career development and within a reasonable timeframe (para. 152). Finally, the 2011 JIU Report allotted responsibilities to Member States, as well, recommending that Member States should more actively promote and support effective implementation of multilingualism by using the tools at their disposal through their legislative power and their budgetary support, instead of being sometimes passive observers of the loss of language diversity (para. 192). UN, JIU, Multilingualism in the UN System organizations: status of implementation (JIU/REP/2011/4) (2011).

${ }^{577}$ UN Volunteers in an organization with a self-explanatory job that is looking for volunteers abroad, in one's own country, and online. These volunteers can also help in translation, interpreting, and writing and editing. Upon closer inspection of these volunteer opportunities in translation, interpreting, editing, and writing, it has been discovered they are mostly operational documents, such as institutions' reports, communication materials, guidebooks, rules and regulations, etc. Although volunteering is requested mostly for translation into non-UN DGACM languages (Punjabi, Urdu, Lendo, Dzongkha, etc.), volunteers are also sought for UN DGACM languages.
} 
fined to include: vision, building trust, judgment/decision-making, empowering others, leadership, and managing performance.$^{578}$ Obviously, the first problem here is the lack of concrete mechanisms and requirements for trade-related growth and keeping up to date because the competencies required of UN language professionals are not language profession-specific. Instead, these competencies are generic for all UN staff members, largely non-committal, and worded in a non-binding way. The best example of the should-would-could mentality governing these UN competencies is described in the core competency related to new technology:

Keeps abreast of available technology; understands applicability and limitation of technology to the work of the office; actively seeks to apply technology to appropriate tasks; shows willingness to learn new technology.

This is a perfect example of the damaging effect of UN verbosity. Every professional has to keep up with the contemporary developments of his trade: he cannot exist solely in the now, but must think in increments of tomorrow, in one year, in five years, and in ten years. Once upon a time it was considered that only amazing managers can think ahead, but nowadays, that is expected from everyone, staff and managers alike. Incorporating advances in technology are at the heart of that planning for the future.

Core concepts of technological advancement for translators revolve around computer-assisted translation (CAT) and machine translation (MT) tools. CAT tools are widely used by contemporary professional translators. These consist of tools for the alignment of language pairs, concordancing of search terms, and term extraction. Translation memory tools allow the creation of databases of previous translations which are then used to indicate matches with items in the text on which the translator is working. This speeds up the work and facilitates consistency in the translation of a given term in different texts by different translators. MT tools generate automatic translations. These are largely used for assimilation, i.e. comprehension. The most famous MT tools include free online translators such as Bing translator, Google Translate, and Systran. MT tools are increasingly used for dissemination where the European Commission, for example, uses raw material to provide a draft first translation of documents which are then post-edited by a human translator or editor. ${ }^{579}$ Although not as numerous, technology tools for interpreters do exist and could be used to save costs and reduce effort, as well. ${ }^{50}$

So what is the right way to define technological competency in an organization such as UN? When it comes to concrete competency such as technological competency and the way forward for translators and editors who cannot afford to be frozen in time, the issue must move beyond mere awareness into concrete action obliging the staff member, here a UN language professional, to attend a course and pass exams on CAT tools or MT tools, for example. On the part of the managers, this would entail organizing such courses which should be a fairly straightforward process because there are two educational institutions working directly under the auspices of the UN. Current courses offered by the UN Staff College are broken down into categories of change and innovation, communication and advocacy, leadership, management, safety and security, sustainable development, and sustaining peace. They do not offer a single course for language professionals. ${ }^{51}$ UN University non-degree courses, ranging from training programs in fisheries and geothermal exploration in Iceland, to intensive courses on climate change and human security in Japan do not offer any courses for

\footnotetext{
${ }^{578} \mathrm{UN}$, UN competencies for the future.

${ }^{579}$ Munday, J. (2016), Introducing translation studies: theories and applications (fourth edition). Routledge: London and New York, p. 289 .

${ }^{580}$ Hernani Costa, H., Corpas Pastor, G., Durán Muñoz, I. (2014). Technology-assisted interpreting. Multilingual. Translation Technology Core Focus, pgs. 27-33.

${ }^{581}$ UN, UN Staff College courses.
} 
language professionals, either. ${ }^{5^{82}}$ Obviously, UN managers and UN education-related entities are not helpful..$^{83}$ However, department-wide use of such translation technology would streamline the entire translation process from referencing via provision of pre-translated texts to formatting of a translation, saving the organization massive amounts of money and time. Any other approach would perpetuate the "dinosaurization" of language staff. ${ }^{54}$

\subsection{The education and previous working experience of UN language professionals}

Educational requirement seems to be the most imprecise of all requirements for the recruitment of UN language professionals. This requirement is partly addressed in the example of the 3 -in-1 and (3-in-1)+ hybridization of recruitment to language posts. It has been established that the educational requirements noted in the vacancy notices cover only languages. Both UN DGACM and non-UN DGACM-serviced UN System entities mostly require a first-level degree from a university or institution of equivalent status, but there is an emerging trend, mostly among non-UN DGACM-serviced UN System entities to require a "university degree in translation, languages, social sciences, literature, or in a subject area relevant to [agency name]," notwithstanding the hybridization of professions. Obviously, wanting to hire a translator and requiring any of the five different language or language-related degrees is wrong. However, it is also wrong to want to hire a translator and require a university degree relevant to the field of work of the hiring agency. Complicating the issue of

\footnotetext{
${ }^{582}$ UN, UN University non-degree courses.

${ }^{{ }^{8} 3}$ The UN is not communicating on these issues with outside companies and organizations, either, although there is a documented rise in the entire industry that provides support to language professionals. eCPD Webinars, for example, is one of the companies that offers a number of online training courses and online webinars to help translators, interpreters, and other language professionals develop their careers, but also to run their businesses efficiently and profitably. This company has been accredited by the CPD Standards Office in the UK, in partnership with the Chartered Institute of Linguists, and has also received accreditation from The Netherlands Bureau Wbtv. The eCPD Webinars offers specialized online training courses for in-depth study and more general on-line webinars for all levels of language professionals. The courses they currently have on offer are held in most UN official languages, including German, Dutch and some others. The most presentations and courses are non-language specific, and, as such, can be joined by linguists who work in any language combination. Topics cover technology (industrial technology, IT, science), the law (both translation techniques and substantive subject-matter designed specifically for legal translators), interpreting, medical translation, style and techniques, research tools, editing and copywriting, and more. The company has a substantial library of videos and consistently arranges new presentations and courses throughout the year.

${ }^{58}$ However, in order not to finish this part of the review on an entirely grim note, some updates are in order about the eLUNA, the computer-assisted and machine translation platform that has been developed in-house, within existing resources at the initiative and with the active participation of the UN's own translation staff (UN, Pattern of conferences, $\left(\mathrm{A} /{ }_{71} / 116\right)$ (2016), para. 6). It is very important to mention here that eLUNA did not come from the language staff's management, UN Staff College, or UN University; it came from UN language professionals alone. UN language professionals alone started to usher the UN towards a fully electronic workflow and, in that, there are some indications that they used their own funds. In 2015, four duty stations started implementation and training on two document planning and processing systems, and the four interacting gText applications: eLUNA, the computer-assisted translation tool, Tapta4UN, the statistical machine translation tool, Document Storage, the repository of bilingual parallel texts, and eRef, the automated referencing tool. Together, these applications increase efficiency by expediting the provision of reference materials with which translators work and automating terminology, which contributed to a sharp rise in productivity in 2015 at the three duty stations that handled $97 \%$ of the UN DGACM's translation workload that year. As a web-based tool, eLUNA can be used by translators working remotely, making it possible for contractual staff to also benefit from its time-saving and consistency-enhancing features. In return, UN DGACM will be able to increase the outsourcing of translation work while preserving quality. A new eLUNA interface for editing was designed in 2015 and then developed and piloted in 2016 so that editing can be fully integrated into the electronic workflow. One obstacle limiting the cost-saving potential of eLUNA is the large number of Member State communications that are received in PDF rather than Microsoft Word format, regardless of submission guidelines. The additional workload created by the need to convert documents to an appropriate format has a significant impact on the productivity of the language staff involved: 3,75 o staff hours were spent in 2015 converting at least 15,000 PDF pages to appropriate readable, searchable and manipulable formats, not as 'dead' files. (UN, Pattern of conferences, (A/71/116) (2016), paras. 44-47). Although the UN blames UN Member States for submitting dead files, most UN documents cited in this study are dead PDF files or picture documents posted by the UN administration that do not allow any cut-and-paste or in-document search as only their titles are left in searchable form. The research described in Chapter 6 relies heavily on ICTY annual reports. All those reports are searchable as found on the ICTY site. However, since the ICTY is not a permanent UN organization, it has been decided to link ICTY annual reports as they appear in the UN official document system. When I was checking my links in the final stages of this study, I found that all these previously in-document searchable, cut-andpastable ICTY annual reports have all been converted to dead PDF files.
} 
education further is an emerging trend of "essential" educational requirements and "desirable" educational requirements, also mostly stated by non-UN DGACM-serviced UN System entities.

Essential: A bachelor's degree in translation, linguistics, modern languages, or a related field from an accredited university.

Desirable: A Master's degree in translation, public health, or related field would be an asset. ${ }^{55}$

The trending clash between the "essential" and "desirable" educational requirements is damaging both to language professionals and non-language professionals when submitting their applications. It is damaging to language professionals because the call openly discourages anyone with a BA in translation, etc. from competing for this post. Am I good enough? Furthermore, a language professional with such a BA will probably feel devalued for having to compete with someone with a degree in "linguistics, modern languages, or a related field" for the post of translator. Getting a university degree in those subjects does not entail extensive training in general, specialized, or CAT-related and terminological issues in the way that getting a degree in translation does. Finally, on seeing that a degree in "public health or a related field" is desirable, knowing that UN organizations can have the pick of the best candidates worldwide, such a candidate might give up competing altogether. This trend is also damaging to health professionals. It is openly taking them away from the path their profession has followed up to that point and diverting them to an untraveled path of a profession requiring a different, if not diametrically opposite degree. It looks like the UN is tacitly telling non-language professionals that, if they have not been successful in their own professional domain, they should take some time off and translate while thinking what to do next professionally.

What is the right way to formulate educational requirements for such a position? The UN must move away from should-would-could requirements to actual deeds: if you need a translator, ask for a degree in translation, if you need an interpreter, ask for a degree in interpreting, etc. The EU does that routinely. Are these degrees widely available? Currently, there are 17 universities offering formal, mostly post-graduate, degrees in legal translation and/or interpreting both in classically and via distance learning. These are located in parts of Europe (Croatia, Denmark, France, Italy, Latvia, Poland, Russia, Spain, Switzerland), Asia (Hong Kong) and North America (Canada).$^{56}$ Moreover, there seem to be 190 schools for translation, interpreting or translation studies offering degrees in these fields worldwide: Argentina (22), Spain (19), USA (17), UK (15), Canada (12), Italy (11), Germany (10), Netherlands (8), Belgium (7), five in China, Finland, France, Poland, South Korea, Taiwan, and Turkey, Austria (3), two in Brazil, Israel, New Zealand, Portugal, South Africa, and Switzerland, and one in Australia, Belarus, Chile, Czech Republic, Denmark, Egypt, Greece, Hungary, Ireland, Japan, Jordan, Lebanon, Morocco, Norway, Pakistan, Romania, Sweden, Ukraine, and Uruguay ${ }^{587}$ This site provides information about 144 schools offering a Master's degree in translation or interpreting..$^{58}$ These three sources, of many that are available online, very clearly show that the supposed lack of professionally educated candidates for translation and interpreting positions in UN is not supported by the data.

Joining the list of incongruous requirements for a language position in UN is the requirement related to the earlier working experience. UN DGACM does not require candidates to have any previous working experience to apply to LCE. However, it does state that selected candidates are normally offered an initial two-year fixed-term appointment at the P-2 level. On satisfactory completion of the six-month probationary

\footnotetext{
${ }^{88}$ UN vacancies, Pan American Health Organization P-3 Translator (English).

${ }^{586}$ Juliette Scott is a legal translator and a blogger on legal translation who obtained this information from the relevant university websites and through direct correspondence.

${ }^{587}$ Betranslated.com, Translation schools.

${ }^{588}$ Mastersportal.eu.
} 
period common to all UN staff and the two-year trial period specific to language professionals, their appointment will be extended, and they may be promoted to the P-3 level, as they routinely are. Some other non-UN DGACM-serviced entities state that a first level university degree in combination with two additional years of qualifying experience is accepted in lieu of the advanced university degree for P-2 or entry positions, such as the ICC for the position of P-2 Associate Translator from this footnote. ${ }^{59}$ This is worrying because the main requirement stipulates possession of an advanced university degree, which means that work experience-wise, the ICC translator candidate with a first level university degree must have a minimum four years of professional experience as a translator and/or interpreter. If such a language professional was employed by the UN, he would already have been at P-3 level. Why would any such candidates apply for an entry-level position when they are on the way to being promoted after four years of service? That makes their need to apply for an entry position elsewhere moot. The trend of requiring an advanced university degree for beginner positions has not been observed in any other non-UN DGACM agencies.

There is also a trend of expecting too much in a different way. An ICJ vacancy from the following footnote for the P-3 Head of the Text Processing and Reproduction Division requires both at least five years of proofreading experience, preferably within the UN System and a proven ability to manage a department. ${ }^{590}$ Being a P-3 and having five years of proofreading experience in the context of UN is reasonable, as it describes someone who has probably just got promoted from P-2. However, an "ability to manage" is a nonsensical expression, giving the recruiting panel too much leeway when selecting an adequate candidate due to the sheer ambiguity of the expression, whereas a "proven ability to manage a department" is nonsensical in UN administration. The ICJ is a principal organ of the UN. The UN is a highly administrative and bureaucratic organization. The ICJ falls under the jurisdiction of UN DGACM, but a P-3 language professional is precluded from having managerial experiences because $\mathrm{s} / \mathrm{he}$ might have just been promoted from an entry-level position or might have just started training for more a senior position. There is no way such a person could have been managing a department and, if they had, there is no way management would issue a certificate stating that such a person managed a department but, given his or her title of Translator at P-3 level, would probably say that it was an ad hoc duty if s/he asked for such a certificate. This vacancy is either announced with a view to saving costs, i.e. they should have advertised it at P-4 level, where it would be reasonable that the candidate has had "proven ability" to manage a department in the form of a certificate on managing duties or functional title, or it has been written with a specific candidate in mind. Given the evidence on recruitment in the UN advanced so far, the latter suggestion is not far-fetched.

\subsection{UN language professionals: translation and interpreting output standards}

So, what are the expectations of a UN language professional in terms of production? It can be deduced from the following reports that the UN Secretariat recognizes pre-session, session, and UN agencies parliamentary documents as those with translation priority. Low priority is given to non-session/parliamentary documents which are routinely translated in-house during off-peak times, and to publications, which are mostly outsourced to freelancers. The UN Secretariat also minimizes the use of non-local translators, whereas general use of freelancers is resorted to mostly in peak periods and for certain documents only. Freelancers delivering camera-ready output are preferred. The UN-wide daily translation output seems to be a work in progress throughout UN existence. Mathematical calculations of translation output from a 1989 report on conference services suggest that UN translators in Vienna produced a minimum of 955 and a maximum of 1,543 words per day. It also suggests that external services were used only to compensate for unfilled vacancies. ${ }^{591}$ The UN BoA Report from 1994 established that increasing productivity in translation was an ongoing objective. Although this report does not provide any statistics, it does establish that contractual services are mostly used for publications, non-urgent parliamentary documents, and are limited by the nature and the urgency of the

\footnotetext{
${ }^{589}$ ICC P-2 Associate Translator (Linguist) (Arabic).

${ }^{59^{\circ}}$ UN vacancies, ICJ P-3 Head of the Text Processing and Reproduction Division.

${ }^{591} \mathrm{UN}$, Conference Service at Vienna (A/C.5/44/24) (1989), paras. 14-15.
} 
documents. In order for that drive to be effective for the Organization, translation contractors had to deliver output that was error-free and ready for publication, i.e. they had to be proficient and experienced translators, familiar with UN terminology, whose work required no further revision. ${ }^{592}$ And, in all this, there was not a single word about training, guidance, follow-up, etc. for language professionals.

The following report reveals that, due to high workloads, translators and editors often work beyond the normal working day and on weekends when necessary, but that this does not incur overtime expenditures. It should be pointed out no UN staff employed in P-level positions are paid overtime and that these working arrangements, meaning being available $24 / 7$, are standard throughout the UN System. A report shows that a higher proportion of translation is carried out on a self-revision basis by senior translators and revisers, which has increased output per staff member, but the gains achieved in productivity are somewhat offset by losses in quality control. ${ }^{593}$ It has been recommended the administration starts demand-based forecasting to get a more accurate indication of the actual workload expected ${ }^{594}$ Using established methodology, this report finally gives some output based on statistics covering the period from 1992 to 1994:

- Daily average number of pages of revised translation per staff member: 4.6 (6o\% of the work is done on a selfrevision basis);

- Time spent on non-translation activities: 18\%;

- Productivity of translators doing self-revision: 5.25 pages a day (as compared to the workload standard of 4.25);

- Translators doing translation only, subject to subsequent revision: 5.4 pages a day (as compared to the workload standard of 5 pages);

- Revisers: 15.2 pages a day (as compared with the workload standard of 15 pages). 595

The focus of the next few reports was on the quality of translation. In 1998, it had been warned that outsourcing of translation could adversely affect the quality and it was recommended that former UN translators should be used as contractors. It was also recommended that sometimes the poor quality of translation could be addressed through greater personal accountability of translators and revisers. ${ }^{596} \mathrm{Next}$, it was acknowledged that, even though translation was a creative process and the judgment as to what constituted a good translation was inherently subjective, there had been documented cases of inaccurate translations in which the sense of the original text had been distorted. It was recommended to make every effort to improve the situation through training and more effective quality control systems. ${ }^{57}$ At the start of the new millennium, reports started putting more emphasis on the introduction of new technology in translation services. Those translation technologies which were introduced enabled only a modest increase in productivity because translators needed to be trained in the new technological applications. Translators and revisers, including contractual translators, received direct access to electronic terminology and reference databases. It was estimated that $15 \%$ of translation output would be suitable for computer-assisted translation. ${ }^{598}$ The use of facilities, such as teleconferencing and remote interpreting and translation, together with other forms of electronic communication and data transmission, was encouraged. ${ }^{599}$ As far as contractual costs are concerned, non-local temporary assistance was the most expensive, followed by costs for established posts and local temporary assistance, with the least expensive being contractual services. ${ }^{600}$ It was also established that freelance translators

\footnotetext{
${ }_{592} \mathrm{UN}$, Implementation of the recommendations of the Board of Auditors (A/49/348) (1994), paras. 50-52.

${ }^{593} \mathrm{UN}$, Report of the Secretary-General (A/49/531) (1994), paras. 18-19.

${ }^{594}$ Ibid, para. 35 .

${ }^{595} \mathrm{UN}$, Report of the Secretary-General (A/AC.172/162) (1995), paras. 22-25.

${ }^{596} \mathrm{UN}$, Report of the Committee on Conferences (A/52/32/Rev.1) (1998), paras. 114-116.

${ }^{597} \mathrm{UN}$, Report of the Committee on Conferences for 1999 (A/54/32) (1999), para. 110.

${ }^{598} \mathrm{UN}$, First report on the proposed programme budget for the biennium 2000-2001 (A/54/7) (1999), para. 76 .

${ }^{599}$ Ibid, para. 96

${ }^{600}$ Ibid, para. I.45.
} 
are much more expensive than staff in established positions due to the many additional costs their engagement incurs. ${ }^{601}$ The following new and current workload standards were approved by the UN General Assembly in 1999:

- 1,65 o words for translation subject to revision,

- 1,815 words for self-revised translation,

- 3,960 words for revision. ${ }^{602}$

The length of documents for translation and editing were also being reduced: 2o-page limit (9,0oo words) was given for documents originating in the Secretariat and translators started being engaged to draft summary records. ${ }^{603}$ The 2004 Report on the Reform of UN DGACM was about reviewing the workload standards. It reaffirmed that the workload standards constituted a rather crude, one-dimensional measure of performance which focused exclusively on quantitative output of individual staff members. ${ }^{604}$

As to interpreting, in 1999 the UN General Assembly approved standards, bearing mind that the workload standard for interpreters had been set in the 197os as a partial arrangement. The standard assignment is no longer than three hours at a stretch, but seven three-hour segments per week with at least twohour break between the segments. Other activities of interpreters include preparing glossaries, reading background documents, and assisting in preparing examinations for recruiting new interpreters. Time performing these tasks was not tracked. ${ }^{605}$

\subsection{Interim conclusions}

Prior to examining overall UN language professionals, this study examined the institution of justice, embodied in the $\mathrm{UN}$, the local context, embodied in $\mathrm{B} \& \mathrm{H}$, and the legal institution, embodied in the rules and regulations governing the work of ICTY and subsequently established international criminal tribunals. The purpose was to examine external influences on the conduct of UN language professionals. This chapter sheds light on the situation in which language professionals find themselves within the existing rules and regulations, as it pertains to their work and resources.

The general image of UN language professionals is one of employees who do a type of job anyone can do, and they are by and large taken for granted, especially those who are not working in the UN DGACMsupported UN System entities. It is clear that the UN is not communicating with itself on the issue of language professionals. This might be because, while UN language partners, such as AITC and AIIC, cater to the interests of their clients rather than the Organization, UN language professionals-oriented brain trusts, such as IAMLADP and JIAMCATT, became debating clubs with little effect on the actual work being delivered, and the UN cannot be said to have communicated their actual needs and deadlines to them. The potential of both of these groups of partners is underestimated and unmanaged. In addition, UN language professionals also seem to be largely unmanaged, as well: most rules and regulations relating to the work and status of UN language professionals are outdated and do not account for status, position, training, accountability, or the output of language professionals in the digital age.

The LCEs held until 2017 were impractical (paper-based), cumbersome (no training, no practice materials, no access to performance results and feedback), and elitist (costs for traveling to some of the most expensive cities which host UN headquarters can be met only by some). The LCEs remain a work in progress (they are still not completely offered online, authorities do not publish clear fail/pass criteria, selection and marking of test papers is being decentralized, implying the loss of institutional memory, and there are no

\footnotetext{
${ }^{601}$ Ibid, para. III.7.

${ }^{602} \mathrm{UN}$, Improving the performance of the DGACM (A/57/289) (2002), Appendix I.4.

${ }^{603}$ Ibid, paras. 57-62.

${ }^{604} \mathrm{UN}$, Reform of the DGACM (A/59/172) (2004), para. 49 .

${ }^{605} \mathrm{UN}$, Improving the performance of the DGACM (A/57/289) (2002), Appendix I.3.
} 
clear guidelines for candidates). As to candidates recruited through LCEs, UN Security Council permanent member countries very clearly dominate the pool of UN DGACM language professionals. The UN DGACM training and outreach efforts to present LCEs are held in UN Security Council permanent member countries, which means that the whole concept of a United Nations will no longer make sense. UN DGACM is aware of this as it is seen to be misrepresenting the actual staff demographics data in their reports.

There is a clear distinction between applying to work at the UN DGACM and applying to work in non-UN DGACM-serviced UN System entities, but, whereas the responsibilities of UN language professionals working under UN DGACM revolve around actual translation, interpreting, and editing, the responsibilities of UN language professionals working in non-UN DGACM-serviced UN System entities are different. As to the latter, there is an unclear lead between UN DGACM and non-UN DGACM-serviced UN System entities when people are recruited to language positions. We have seen an increase in hybrid positions comprising either a host of language-related duties (3-in-1 translator, interpreter, and editor) or a host of language-related and other non-language duties (3-in-1+) in the conflict-affected areas advertised by the non-UN DGACM-serviced UN System entities. There is also an unwillingness to employ local language professionals from conflict areas in P-level category positions despite existing recruitment mechanisms, over-saving on costs and over-hybridization of their responsibilities under the garb of brain drain, as well as cases of institutionalized discrimination on the basis of language across the UN System.

The competencies required of UN language professionals are not profession-centric which has a damaging effect on technological advancement. Technology-wise, until UN language professionals have taken matters into their own hands, ushering the translation workflow into the electronic age, they are still lagging 17 years behind contemporary translation and interpreting trends. Educational requirements to apply to language-related posts in UN DGACM and non-UN DGACM-serviced UN System entities are the least appreciated. These are extremely important when employing professionals and need to become professioncentric, streamlined, and take a full account of the fact that there are numerous universities offering degrees in general and specialized translation and interpreting, both at the BA and the MA level. The UN should seriously consider whether they want to continue buying whatever the AIIC, AITC, IAMLADP, and JIAMCATT have been selling them so far, and start recruiting professionally educated translators and interpreters. In reality, the UN can take a worldwide pick of professionally educated candidates with a degree in translation and interpreting and knowledge of the contemporary technological advances in the field of translation and interpreting, requiring only training on substance matter, but it seems the UN has yet to fully grasp that.

The above situation could be said to be the main reason why UN System-wide translation and interpreting output standards seem still to be a work in progress: several internal audit reports very clearly point to the fact that UN managers are hiring according to personal preference. There are no UN publications or reports that address output standards related to the use of translation and interpreting-related and similar technology.

This top-down examination of UN language professionals resumes by examining ICTY language professionals in the next chapter. 
Chapter 6: May ICTY language professionals take the stand, please

Chapitre 6 : Les linguistes professionnels du TPIY sont priés de venir à la barre Šesto poglavlje: Neka pristupe profesionalni prevodioci MKSJ 
In examining linguistic justice at the ICTY, this study reviews the institution of justice, the historical development of the language and identity-related context that contributed to the conflict in the situation country, and the language-related rights, obligations, and requirements on the parties involved in international criminal tribunals with the emphasis on procedural equality of arms between ICTY Prosecution and Defense, and nominal relationship between legal and language professionals. This examination has been conducted to set external influences on the conduct of UN language professionals, i.e. in what position international rules and regulations and international lawyers put language professionals. The next leg of the journey started with the previous chapter examining those who interpret, translate, edit, and transcribe justice delivered by international criminal tribunals: UN language professionals. This examination explained general internal influences on the conduct of UN language professionals, i.e. in what position UN language professionals find themselves. Here, this study will continue examining what language professionals working at international criminal tribunals did with themselves by turning directly to ICTY language professionals, namely translators, interpreters, court reporters, and Language Assistants. These were working in seven different units tasked with certain aspects of language-related work identified in the ICTY Annual Reports (AR) between 1994 and 2016. These units co-existed along the main ICTY language service provider, the CLSS. Throughout this chapter, we will learn who ICTY language professionals are, how they have been recruited, how much they produced, how well they cooperated with the parties, and how much institutional support they received. In addition to relying on ICTY ARs, for reasons explained in Chapter 1, examinations conducted for the purposes of this Chapter will also consider reports of the only two agencies in the UN System that are authorized to conduct audits and financial reviews of UN System entities: UN OIOS and UN BoA.

\subsection{The Bassiouni Commission}

UN Security Council Resolution 780 (1992) requested the UN Secretary-General to establish, as a matter of urgency, an impartial Commission of Experts and provide him with its conclusions on the evidence of grave breaches of Geneva Conventions and other violations of international humanitarian law committed in the territory of the former Yugoslavia. ${ }^{606}$ Cherif Bassiouni was appointed as Chairman and Special Rapporteur on the Gathering and Analysis of Facts. The Bassiouni Commission, as it was known, was the first to start collecting testimonial evidence about atrocities in the former Yugoslavia by taking statements from victims and witnesses in B\&H and Croatia. This evidence was collected by an interdisciplinary team that was in charge of gathering and analyzing facts, on-site investigations and issues of law, Prijedor Project (Manjača, Keraterm, and Omarska concentration camps), the destruction of cultural property, and legal aspects of sexual assault. It could be said that the investigations performed by the Bassiouni Commission were centered around crimes that were already imprinted on the collective memory of the human race: concentration camps, destruction of cultural heritage, and arbitrary executions of civilians. The conclusions of the Bassiouni Commission were that serious crimes were being committed in $\mathrm{B} \& \mathrm{H}$ and Croatia. ${ }^{607}$ The findings of the Commission made it possible to establish the ICTY and to conduct further investigations into criminal acts committed in the territory of the former Yugoslavia. Consequently, the key goals and priorities set by the Bassiouni Commission were: searching for documents immediately after and/or during the conflict, countering parties that refused to cooperate, and combating impunity.

Language professionals were an important part of this process. How was their selection made given that the Bassiouni Commission was established by the UN and B/C/S was not (and is not) a UN official language? Unfortunately, although legal professionals who participated in the work of the Commission were supported by interpreters, Bassiouni does not acknowledge language professionals in the Commission Report or in any of his subsequent writings. Consequently, it is unclear where they came from and whether they had any other tasks but translation and interpreting. Although acknowledging the fact that Bassiouni does not

\footnotetext{
${ }^{606} \mathrm{UN}$, Security Council Resolution 780 Establishing a Commission of Experts to Examine and Analyze Information Submitted Pursuant to Resolution 771 (S/RES/780) (1992), para. 2.

${ }^{607} \mathrm{UN}$, Final report of Commission of Experts established pursuant to the UN Security Council Resolution 771 (S/1994/673) (1994).
} 
explicitly mention language professionals in his report, Elias-Bursać, a former ICTY CLSS reviser who now identifies herself as an independent scholar and literary translator, conducted research into examples of the implicit involvement of interpreters in the Bassiouni Commission, examining the wording of the report in attempt to establish the obvious: the Bassiouni Commission relied on interpreters. Elias-Bursać also shared some personal communication with Bassiouni, but, except for sharing the fact that 11 interpreters were engaged in the work of the Commission in 32 field missions, it seems that Bassiouni himself did not know where these interpreters came from and how they ended up interpreting for the Commission. Bassiouni described these 11 people to Elias-Bursać as "UN interpreters and translators [who] applied UN standards. ${ }^{n 08}$ However, the first problem with this description is that this sounds like these 11 language professionals from/into English and $\mathrm{B} / \mathrm{C} / \mathrm{S}$ were readily available on the UN market. Whereas the UN has six official languages, namely Arabic, Chinese, English, French, Russian, and Spanish, the ICTY is the first international criminal tribunal since the IMT and IMTFE. So there could not have been any UN standards for translation and interpreting at international criminal tribunals when the ICTY was established. IMT scholars concerned with translation and interpreting do not explicitly mention any standards, stopping short from saying that these jobs were learned as staff went along, but if there were any standards, they were almost 5 o years old. In Chapter 5 it is explained that there were UN, rather ICSC Standards for translation and editing, but that these standards were geared toward the translation of, essentially, parliamentary, non-parliamentary documents, and publications, and not at all toward interpreting in the context of international criminal tribunals that were engaged in investigations. Moreover, staff engaged in peacekeeping missions active in the former Yugoslavia at the time of the Bassiouni Commission were not staff at the Secretariat, but mission staff, so these language professionals employed by the Bassiouni Commission could not have been considered "UN translators" for any administrative purposes. Finally, there were no UN-organized examinations of translators and interpreters between $\mathrm{B} / \mathrm{C} / \mathrm{S}$ and any other UN official languages. Language examinations for peacekeeping missions held in the region were aimed at recruiting staff working in the military, not the investigative context: "pretending" to be a military has nothing to do with "pretending" to be an investigator for an interpreter, as these are two completely different contexts and concepts. Consequently, there could have not been a pool of B/C/S interpreters and translators ready to apply "UN standards" at the level of peacekeeping missions. Just as it does now, the UN then only catered to UN languages in terms of language professionals and working standards. Conversely, peacekeeping missions at the time only catered to military and humanitarian contexts. Criminal investigations are not close to any. Non-language professionals hire language professionals, expecting them to provide (3-in-1)+ services ex nihilo (see Chapter 5). This approach seems to have been replicated at the ICTY as well. $\mathrm{B} / \mathrm{C} / \mathrm{S}$ entered the UN arena of languages when the ICTY was established. Although it participated in the work of international criminal tribunals, the UN was not linguistically ready to entertain any other languages in UN entities but translation, interpreting, and court reporting between UN languages in terms of subject matter, resources, staff, or training. It was these 11 language professionals who set the standards for interpreting in international criminal tribunals, not the UN or the ICSC.

Who were these interpreters and how well did they set those standards? It seems that the UN peacekeeping mission in the former Yugoslavia, UNPROFOR, provided interpreters and Bassiouni took them without asking any questions. He does not provide any further detail about the interpreters' overall education, training, and the support they might have received from UN DGACM or UNPROFOR while engaged. If these interpreters were taken from the existing UNPROFOR language staff, it is worth remembering they would have all been deployed at the GS-level as Language Assistants, i.e. they did not necessarily need to have a university diploma. Dubious institutional arrangements and educational requirements aside, were they, at least, independent in their work? Bassiouni does not address that point, but he does briefly refer to a relationship between these 11 interpreters and the investigators they were supporting, conveying to Elias-Bursać that, under his chairmanship, discussions between 22 legal professionals and 11 interpreters involved "how the

\footnotetext{
${ }^{608}$ Elias-Bursać, E. (2015), Translating evidence and interpreting testimony at a war crimes tribunal. Palgrave Macmillan: London, p.
} 19-2o. 
translators would address linguistic variants between the three ethnic groups." ${ }^{609}$ This approach to language professionals seems to suggest two things. First, 22 legal professionals of the Bassiouni Commission spoke $\mathrm{B} / \mathrm{C} / \mathrm{S}$ so proficiently that they could discuss linguistic variants between the languages spoken by the three ethnic groups on equal footing with their interpreters. Bassiouni explicitly states that the discussions with interpreters went along the lines "how the translators would address" problems in interpreting, not along the lines of "avenues translators might explore when deciding how to approach" certain problems in interpreting. Consequently, these legal professionals had a major say in how something would be translated. Since the Commission investigated ethnic conflict and since it had already acknowledged linguistic variants between the languages spoken by the three enemy ethnic groups, did the UN DGACM, UNPROFOR, or anyone select Bassiouni Commission interpreters based on their ethnicity? Acknowledging "linguistic variants between the languages spoken by the three ethnic groups" would constitute a clear procedural and moral violation, if no provisions have been taken by the Commission to refrain from engaging the members of an "attacking ethnicity" to interpret for a client with a "victim/witness ethnicity."

This is a very important point because interpreting is a very personal process, and even more so in the context of investigations. Mulayim et al. explain that interpreters working in the investigative process are:

essentially bound by the legal relationship between the parties. This pre-existing relationship between the parties [along the lines of investigator-subject, in this case], therefore, draws the boundaries within which an interpreter is able to move. It is essential for an interpreter to respect the pre-existing relationship between the clients and not engage in any activity that may interfere with this relationship. Ways in which an interpreter can interfere with a pre-existing professional-client relationship may include: giving advice or information, explaining information, giving any instruction that is not part of the transfer process, taking control of the interview in any other way, providing their own opinion, or even diagnosis, unjustified omission or addition of information, distorting meaning, and allowing personal opinion or views to affect their interpreting. ${ }^{610}$

These 11 interpreters were not confined to offices but engaged in the field with investigators and clients. They were creating a pre-existing relationship between investigators and subjects. Once subjects were identified, language professionals engaged them in a very sensitive pas de trois, both when it came to speaking to the Bassiouni Commission and then to "opening up" during the interviews.

However, in all that, the communication between legal professionals and victims/witnesses is indirect. Mulayim and Lei consider that professional trust plays a significant role in influencing the views of society about a particular profession. They define professional trust as a commitment to those who benefit from the professional service so that they can rely on decisions and opinions provided by a professional and they will not be exploited or taken advantage of. According to these authors, personal trust is the foundation of professional trust, but once that trust is broken, it is extremely difficult to re-establish. Professional trust, once achieved, results in respectful regard, which reflects how highly beneficiaries of a professional service and the broader public value and respect the services, opinions, and judgment afforded by the professional. ${ }^{61}$ It follows that, when investigating an ethnic conflict, professional trust and a successful relationship with victims/witnesses are essential, so one should care about the ethnicity of interpreters. This is because the subjects' personal trust in interpreters is a foundation of the relationship between the subjects and investigators. Conversely, interpreters are of paramount importance because they are creating the relationship between the subjects and investigators. Since communication through a third party is not a natural medium of communication, it is assumed that these interpreters had to rely on their people skills and human instincts when

\footnotetext{
${ }^{6 \circ 9}$ Ibid, p. 20.

${ }^{610}$ Mulayim, S., Lai, M. and Norma, C. (2015), Police Investigative Interviews and Interpreting: Context, Challenges, and Strategies. CRC Press, Taylor \& Francis Group: Boca Raton, p. 16.

${ }^{611}$ Mulayim, S. and Lai, M. (2016), Ethics for police translators and interpreters. CRC Press, Taylor \& Francis Group: Boca Raton, p. 29.
} 
persuading victims and witnesses to speak to the Bassiouni Commission. Nelson Mandela's "If you talk to a man in a language he understands, that goes to his head. If you talk to him in his [own] language, that goes to his heart," fully describes what went on during the back and forth between these language professionals and their $\mathrm{B} / \mathrm{C} / \mathrm{S}$ speaking clients. ${ }^{612}$ At the same time, if they were unhappy about the ethnic background of their interpreter, the clients could have simply spread the word about his ethnicity among their community, thus preempting any attempt at communication through such interpreters. Selecting interpreters based on their ethnicity would have greatly helped in all such efforts. Unfortunately, Elias-Bursać seems to have forgotten to ask Bassiouni about the ethnicity of these 11 "UN interpreters applying UN standards" interpreting for victims and witnesses of ethnic crimes and whether these 11 spoke the linguistic variant of the victims for whom they were interpreting.

As described in Chapter 3, although there were attempts to create sharp linguistic boundaries, they have never corresponded to the political boundaries in the former Yugoslavia throughout its history and, although mutual intelligibility naturally decreases, there are no sharp divisions. ${ }^{6{ }^{63}}$ This means that, in terms of dialectology, ethnic Serbs, Croats, and Muslims speak territorial, not ethnic, dialects. One can say whether a person is from Serbia, Croatia, or B\&H, but one cannot say whether one is speaking with an ethnic Serb, ethnic Croat, or an ethnic Bosniak. Also, one cannot establish the ethnicity of a $\mathrm{B} / \mathrm{C} / \mathrm{S}$ speaker by the way they speak, no matter how proficient they are in $\mathrm{B} / \mathrm{C} / \mathrm{S}$, and that includes the members of the Bassiouni Commission. Should a B/C/S speaking individual have an ethnically unmarked Slavic name, it is also impossible to detect their ethnicity. ${ }^{614}$ As far as $\mathrm{B} \& \mathrm{H}$ is concerned, the Bassiouni Commission investigations were about Prijedor and concentration camps in the surrounding area (Serb perpetrators) and sexual assaults (Serb and Croat perpetrators): what was done to make sure that none of these 11 language professionals were put in a situation where their clients might perceive them as a member of attacking ethnicity because of their linguistic variant? $\mathrm{B} \& \mathrm{H}$ victims would have known they were speaking to someone outside $\mathrm{B} \& \mathrm{H}$ and, since they were victims of Serb(ian) and Croat(ian) crimes, they would have naturally perceived such speakers as members of the attacking ethnicity. A professional is a professional, so why ask such a question? Because it would have been very interesting to know how the Bassiouni Commission would have reacted if a victim/witness spat at the interpreter they perceived as members of attacking ethnicity. Investigations of the conflict in B\&H were investigations of ethnic conflict where people were killed, tortured, and raped only and exclusively because they were Muslims. Should a client have heard a linguistic variant of the attacking ethnicity, in the best-case scenario, that might have re-traumatized him. In the worst-case scenario, good/bad selection of language professionals could make or break the whole investigation and cause a breakdown in personal trust. In such a shocking scenario, victim/witness could have spat at the interpreter. Such an interpreter would not have been used again, because the investigator needs a witness, not an interpreter who he could, virtually, find anywhere, and such a person would have been left jobless for no fault of his own. It often seems to be forgotten that victims do not have to put aside their anger at their aggressor, their despair that they have lost all human dignity, all worldly possessions, or members of the family only because they are being interviewed by staff of

\footnotetext{
${ }^{612}$ Mapping Ignorance, Mandela was right: the foreign language effect (2014).

${ }^{613}$ Alexander, R. (2013), Language and identity: the faith of Serbo-Croatian. Entangled histories of the Balkans, Vol. 1: National ideologies and language policies. Koninklijke Brill NV: Leiden, p. 345 .

${ }^{614}$ Contemporary nationalists often insist on the purity of ethnic identity that has been kept alive and nourished, despite all obstacles, Communism being the greatest of all those obstacles. However, any ethnic group from the former Communist, "ethnicity-free" Yugoslavia of comrades could discuss nationality and ethnicity-related matters only in the safe privacy of their homes, not as a matter of public debate. Remember that "Yugoslav" was the mot du jour in Yugoslavia at that time, not Serb, Croat, Muslim, etc. Conversely, names in the former Yugoslavia cannot be described as strictly ethnic. In that regard, most of the former Yugoslavs genuinely liked to think of themselves as Yugoslavs, rather than as Serbs, Croats, Bosnians, etc. and went out of their way to invent people's names (narodna imena). These were neither Biblical nor Quranic, but had their origin in the rich Slavic lore (Zlatan, Vesna, Dunja, etc.), in the newly founded Yugoslav identity (Dunavka, after the river Danube (Dunav), Jugoslav (Southern Slav), Slobodan or Slobodanka (Freedom), etc.), and even to hail the newfound prosperity (Traktorka named after the fact that the family was overwhelmed with joy for possessing a tractor or Savica named after the first radio produced in post-Second World War Yugoslavia).
} 
the international criminal tribunal. Victims do not owe that favor to anyone. This should have been acknowledged by the staff of the international criminal tribunals where victims should most definitely not have been put in situation where they would have to continue to be cautious about their emotions or physical surroundings in the presence of an entity who shares the ethnicity of their former attacker. Selecting language professionals based on their ethnicity would avoid such situations arising.

Inquiries into the backgrounds of these 11 language professionals have revealed that they were all from Croatia, including some ethnic Serbs, and that none of them were from B\&H or Bosniaks. Then these interpreters from Croatia speaking a Croatian "linguistic variant" went to interpret for Bosniak victims/witnesses in Herzegovina where Croat(ian)s were clearly an attacking ethnicity. It might be argued that these 11 language professionals came from Croatia because only the parts of Croatia bordering with B\&H and Serbia were occupied by the Serbs, i.e. UN headquarters in Zagreb was not under siege like the UN headquarters in Sarajevo. So, it could be taken that this decision was practical: the Bassiouni Commission came to Zagreb, Croatia, took staff UNPROFOR administrators told them were the best and went about their work with no further questions asked. However, in addition to conducting "investigative missions in the territory of the former Yugoslavia" the Commission also performed the bulk of their investigative missions "in other countries that had received refugees from the former Yugoslavia" where they worked mostly with Bosniak victims/witnesses. ${ }^{615}$ Given the huge number of B\&H refugees in the territory of the former Yugoslavia and in other countries that had received refugees from the former Yugoslavia by 1993 and later, one could have examined whether any of these clients or their friends and acquaintances could participate in the work of the Bassiouni Commission if one was a priori concerned about doing something about the ethnicity of language professionals and the acknowledged "linguistic variants." All wars are characterized by an enormous brain drain. Maybe some of that brain drain was waiting both "in the territory of the former Yugoslavia and in other countries that had received refugees from the former Yugoslavia" which the Bassiouni Commission visited.

Bassiouni Commission language professionals should have been allowed to conduct their translation and interpreting duties independently from legal professionals without any interference, except in cases where legal professionals wanted to provide them substantive subject-matter training. According to Mulayim et al., interpreters were creating "pre-existing relationship" between clients. In that sense, interpreting for highly traumatized victims and/or rape victims and participating in persuading a victim/witness to give statement or testify is a very sensitive, mind boggling, and emotionally draining job (see Chapter 7 for an extended discussion of this). Someone should have provided adequate training to these language professionals in terms of substantive subject-matter. However, because of this approach Bassiouni Commission took toward victims/witnesses and language professionals, one may never know how many victims/witnesses had more to say but were uncomfortable in front of a language professional of an attacking ethnicity. After all, the Bassiouni Commission Report says:

Among the 146 [rape] victim-witnesses from $[\mathrm{B} \& \mathrm{H}]$ who were interviewed, 31 were women victims of rape, and two were suspected by the interviewer to have been victims themselves but were unwilling to speak of their own experience. ${ }^{616}$

Why not follow up? Why were they unwilling? What was the ethnicity of those victims? What was the ethnicity of an interpreter? Finally, one may never know just how deeply these 11 language professionals, and all those who followed them, were scarred from conducting these duties because their investigative client did not prepare them to cope with the sheer horror.

\footnotetext{
${ }^{615}$ UN, Final report of Commission of Experts established pursuant to the UN Security Council Resolution 771 (S/1994/673) (1994), paras. 23, 195-209, 239, 241, 252, 257-258.

${ }^{616}$ Ibid, para. 241.
} 
Let it be crystal clear that the author of this study considers that if it weren't for Mr. Bassiouni, personally, there would never be an ICTY. All actual and anecdotal evidence about his personal involvement in establishing the ICTY reveals that he fought tooth and nail for the ICTY to be established. However, it cannot but be concluded that it seems language professionals supporting the Commission were picked at random without any regard as to their ethnicity or nationality and that they were not trained, either on substantive subject-matter or on how to cope with listening to trauma. Their recruitment seems to have been a matter of finding oneself at the right place at the right time and legal professionals seem to have expected they came trained for the job they were conducting in extension of the overall UN approach to language professionals (see Chapter 5). As a trained lawyer, Mr. Bassiouni should have been aware of all the elements that make up a successful investigation of ethnically motivated crimes in which the selection of interpreters based on ethnicity is the most important one.

Between 1993 and 2018, the ICTY, as a whole, delivered the following results: it had indicted 161 individuals ( 90 sentenced, 19 acquitted, 37 proceedings terminated, or indictments withdrawn, 13 individuals referred to countries in the former Yugoslavia for trial, and 2 in retrial before the MICT). All this required the testimony of 4,650 witnesses, 10,800 trial days and 2.5 million pages of transcript ${ }^{6.17} \mathrm{Next}$, this study will turn to an exhaustive examination of the ICTY language services. All ICTY authors, UN auditors, and legal and language scholars reporting on the language-related work at the ICTY failed to notice the existence and veritable separation of at least seven other units in charge of some aspects of language-related work as part of the official, ICTY-wide language service, CLSS, namely: the OTP Language Unit, Rules of the Road language professionals, VWU language professionals, court reporters, UNDU language professionals, Outreach Program language professionals, and Chamber Support Unit language professionals. The underlying reasons for and consequences of this will be discussed next.

\subsection{Transferring cases to domestic jurisdictions: Rules of the Road project}

The Rules of the Road can be seen as a first language service established at the ICTY that was fully independent from the official, ICTY-wide language service, CLSS. This project was set up in 1996 and ran until 2005 . The ICTY handed down its first judgment on 29 November 1996. Although they had only a couple of indictments and ongoing trials and cases, the ICTY "workload" began increasing. The war in the former Yugoslavia was over, practical arrangements for investigations no longer seemed complicated - at least as far as security was concerned - and information on committed crimes kept on coming to The Hague. At that point, it was important to decide which perpetrators were going to be tried by the ICTY and which ones were going to be left to local jurisdictions. During the meeting held in Rome on 18 February 1996,

it was agreed by the parties to the Dayton Accord that persons, other than those already indicted by the Tribunal, may be arrested and detained for serious violations of international humanitarian law only pursuant to a previously issued order, warrant or indictment that has been reviewed and deemed consistent with international legal standards by the Tribunal. It was further agreed that procedures for expeditious decision-making by the Tribunal would be developed and would take effect immediately. The work emanating from the agreement is referred to as the "Rules of the Road" project. ${ }^{618}$

All language-related work in this project was performed by the Rule of the Road's own Language Assistants in charge of making extended summaries of case files submitted for a review (who, what, where, when, why,

\footnotetext{
${ }^{617}$ ICTY, Facts and figures.

${ }^{618}$ Information from this section has been taken from 1996 ICTY AR, para. 80; 1997 ICTY AR, para. 76; 1998 ICTY AR, para. 129; 1999 ICTY AR, para. 181; 2000 ICTY AR, paras. 188-189 and 260; 2001 ICTY AR, para. 242; 2002 ICTY AR, paras. 234-235 and 275; 2003 ICTY AR, para. 253; 2004 ICTY AR, p. 3-5; and 2005 ICTY AR, para. 10.
} 
and how, or the journalistic $5 \mathrm{~W}+\mathrm{H})$. The project relied solely on donations throughout. However, these donations were usually insufficient to clear the backlog of cases submitted for review. In 1999, UK Minister Cook announced a donation to support the project and to fund translation of documents seized by the OTP. The project continued thanks to funding from the donors, producing summary translations and indices of tens of thousands of pages of materials. ${ }^{619}$ The 2001 ICTY AR established that since its commencement, the project received a total of 914 prosecution files from national prosecutors in B\&H, including Republika Srpska, and reviewed close to 1,300 suspects. It has been reported that the project reviewed 190 files involving 1,055 suspects in 2001; 54 files involving 241 suspects in 2002; and 192 files involving 1,134 suspects by the end of 2002 . The Rules of the Road project was incorporated into the B\&H OTP as part of external reforms in 2004. The 2005 ICTY AR reported external reforms in that the Special Chamber for war crimes prosecutions in the new State Court of B\&H was established. This meant that the B\&H also got a court where lower-level perpetrators could be prosecuted and that the project referred suspects to them. Therefore, the ICTY took full charge of all international criminal law- and international humanitarian law-related prosecutions in the territory of the former Yugoslavia, both by prosecuting those that it had already indicted, issuing new indictments, and reviewing national case files from the former Yugoslavia through the Rules of the Road project. Then they moved out of the way for others to do the same.

\subsection{Linguistic independence: UNDU and ICTY VWU}

The UNDU was established in 1994 and it could be seen as a second language service established at the ICTY that was fully independent from the official, ICTY-wide language service, CLSS. The ICTY issued its first indictment on 7 November 1994, but, although the war was still raging in the territory of the former Yugoslavia and there were no detainees, the ICTY had already started making provisions for their accommodation. It was decided that the ICTY shall not tolerate any discrimination on the basis of, inter alia, language ${ }^{620}$ shall provide each detainee with, inter alia, a copy of the rules of detention and any other regulations in his own language and interpreter in cases where the detainee does not speak or understand either of the working languages of the ICTY or those spoken by any of the staff of the UNDU. ${ }^{621}$ Since the 1994 Report establishes that the detainee is entitled to communicate freely and without restraint with his defense counsel, with the assistance of an interpreter where necessary, ${ }^{622}$ this also means that it was planned to provide the UNDU with interpreters. However, they were provided with Language Assistants, the difference between the two types of language professionals being that Language Assistants were tasked with the provision of $\left(3\right.$-in-1)+ services. ${ }^{63}$

The ICTY VWU was established in 1995 and can be seen as a third language service established at the ICTY that was fully independent from the official, ICTY-wide language service, CLSS. It was planned that the VWU would employ its own interpreters to emphasize the impartial nature of its work and its independence from both prosecution and defense. ${ }^{624}$ Witnesses were brought to testify from many countries, mostly from the former Yugoslavia. At first, some were brought to appear in hearings under ICTY RPE Rule 61 on procedure in case of failure to execute a warrant, then to appear in hearings viva voce, and then under ICTY RPE Rule 92bis where their statements would be admitted in lieu of their viva voce testimony. According to the ICTY

\footnotetext{
${ }^{619}$ Summary translation is a mix between a summary and a translation of selected portions of the text, e.g. "In May 2017, the troops of the Army X invaded the area of Y to [summary] because 'it was important to a, b, and c' [direct quote from the text] (para. 1)."

${ }^{620} \mathrm{UN}$, Report of the ICTY (A/49/342) (1994), para. 100.

${ }^{621}$ Ibid, para. 107.

${ }^{622}$ Ibid, para. 109 .

${ }^{623}$ UN vacancies, ICTY G-5 UNDU Language Assistant (Albanian, B/C/S and English); ICTY G-5 UNDU Language Assistant (B/C/S and English).

${ }^{624} \mathrm{UN}$, Report of the ICTY (A/5o/365) (1995), para. 112.
} 
ARs, between 1996 when witnesses first started appearing in hearings and 2016, the ICTY heard a total number of 7,042 witnesses and people supporting them. ${ }^{625}$

Table 9. ICTY witnesses and support persons between 1996 and 2016

\begin{tabular}{|c|c|c|c|c|c|c|c|c|c|c|c|c|c|c|c|c|c|c|c|c|}
\hline$\stackrel{\text { }}{\stackrel{\Xi}{9}}$ & 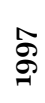 & $\stackrel{\infty}{\stackrel{9}{\odot}}$ & $\underset{Ð}{\stackrel{一}{2}}$ & 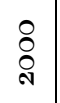 & $\begin{array}{l}\overline{0} \\
\text { ठे }\end{array}$ & $\begin{array}{l}\text { No } \\
\text { ô }\end{array}$ & $\begin{array}{l}\text { O } \\
\stackrel{N}{2}\end{array}$ & $\begin{array}{l}\text { ¿े } \\
\text { Oे }\end{array}$ & $\begin{array}{l}\text { ठ̊ } \\
\text { Oे }\end{array}$ & 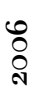 & \begin{tabular}{l}
$\hat{o}$ \\
$\vdots$ \\
\multirow{2}{*}{}
\end{tabular} & $\begin{array}{l}\infty \\
\text { o } \\
\text { Na }\end{array}$ & $\begin{array}{l}\stackrel{8}{8} \\
\vdots\end{array}$ & $\stackrel{0}{0}$ & จิ & స్ & :̊ & 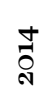 & 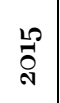 & $\begin{array}{l}0 \\
\text { ते }\end{array}$ \\
\hline$\stackrel{一}{~}$ & $\stackrel{\text { Iิ }}{ }$ & 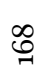 & 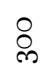 & ஜ̊ & 品 & 郧 & 品 & 苨 & ס̊ & స్ & 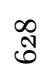 & ల్లి & $\stackrel{N}{N}$ & 范 & $\underset{+}{+}$ & $\stackrel{p}{m}$ & i & 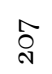 & $\begin{array}{l}\text { D } \\
\text { L }\end{array}$ & \& \\
\hline
\end{tabular}

As to the VWU language staff, although clearly named as "interpreters" by the ICTY AR authors, ${ }^{626}$ research into VWU language professionals' jobs descriptions revealed that they did not have any language-related functional titles, and certainly not that of an interpreter. This is in contradiction to the 1995 ICTY AR statement that the VWU will be manned by its own interpreters. The VWU "interpreters" had the functional titles "Administrative Assistant" or "Witness Assistant" and they had duties to provide language assistance (B/C/S, English, Dutch) for VWU and perform other ad hoc duties as required. ${ }^{627}$ Naturally, these ad hoc duties amounted to a provision of (3-in-1)+ services as Witness Assistants, providing 24-hour live-in support, information, and assistance to their clients. The VWU had been financially and professionally supported by the EU and the Danish Rehabilitation and Research Center for Torture Victims since $1995 .{ }^{628}$

6.4. Servicing the public, the professionals, and posterity: court reporters

ICTY court reporters can be seen as a fourth language service established at the ICTY that was fully independent from the official, ICTY-wide language service, CLSS. The court reporters belong to a category of officers of the court in certain legal traditions or, rather, they are an integral part of courts. However, when the ICTY was established, similarly to other international criminal tribunals, court reporters were unknown in the UN System. The UN recognizes the category of verbatim reporters which are regularly used at standing UN courts (ICJ, UNDT, and AT ILO) and the Secretariat. The difference between the ICTY, and other, court reporters and verbatim reporters in the UN System is that court reporters produce verbatim transcript of court sessions, whereas "[c] ombining the skills of transcription, translation and editing, verbatim reporters ensure the substantive accuracy of all statements, while maintaining a uniformly high standard of style." ${ }^{629}$ In other words, the end product of verbatim reporters' work is not a verbatim transcript, but an extended summary of facts, and they do not use any specialized equipment in the performance of their jobs. Naturally, this does not work for a court where every word uttered needs to be transcribed verbatim. It follows that the ICTY could not have used existing UN sources to find court reporters.

\footnotetext{
${ }^{625}$ Information from this table has been taken from: 1996 ICTY AR (para. 118); 1997 ICTY AR (p. 96); 1998 ICTY AR (para. 154); 1999 ICTY AR (para. 168); 2000 ICTY AR (para. 224); 2001 ICTY AR (para. 234); 2002 ICTY AR (para. 268); 2003 ICTY AR (p. 3); 2004 ICTY AR (para. 351); 2005 ICTY AR (para. 226); 2006 ICTY AR (p. 4); 2007 ICTY AR (para. 106); 2008 ICTY AR (para. 92); 2009 ICTY AR (para. 85); 2010 ICTY AR (para. 91); 2011 ICTY AR (para. 86); 2012 ICTY AR (para. 98); 2013 ICTY AR (para. 78); 2014 ICTY AR (para. 62 ); 2015 ICTY AR (para. 66); and 2016 ICTY AR (para. 64).

${ }^{626} \mathrm{UN}$, Report of the ICTY (A/50/365) (1995), para. 112.

${ }^{627}$ UN vacancies, ICTY G-5 VWU Administrative Assistant (Dutch, B/C/S and English); ICTY G-5 VWU Witness Assistant (Dutch, B/C/S and English).

${ }^{628}$ UN, Report of the ICTY (A/53/219) (1998): http://ow.ly/vUv130946ob, para. 153 .

${ }^{629} \mathrm{UN}$, Verbatim Reporters.
} 
The evolution of court reporting services at the ICTY can be easily followed through ICTY ARs. The ICTY acknowledged from the very beginning that they could not move forward without language professionals, but were struggling with basic terminology relating to language professionals from the onset: they described them as "specialized stenotypists," not as "court reporters" as they are professionally known throughout the industry. ${ }^{60}$ This is not nitpicking, but a rather straightforward indication of legal professionals' awareness of language-related work. ICTY ARs also stated that CLSS was responsible for hiring English and French court reporters who have a duty to prepare transcripts of all sessions in court. ${ }^{61}$ Here, it is unclear why the charge to hire and supervise court reporters was given to translation and interpreting services as, in most jurisdictions, court reporters are hired and supervised directly by the courts. ICTY ARs also state that the work in the courtroom requires the permanent services of court reporters for the ICTY's two working languages: English and French. ${ }^{6{ }^{32}}$ CLSS understood "permanent services of court reporters" not as those stemming from the use of in-house sources as the word "permanent" used in employment context normally suggests, but rather "permanently outsourced." So, the CLSS hired court reporters from outside companies from the very beginning. ICTY Procurement Office would make an Invitation to Tender and select the agency that outsources court reporters on the basis of their passing the court reporter test and, naturally, their price. ICTY staff report that a single agency always won these tenders from the start.

As to them, English language court reporters, in-house contractors of the outsourced company, work in a team of two: one sitting in the actual courtroom and the other one sitting in a nearby office, revising work of his in-courtroom colleague (names, locations, misspellings, etc.). French language court reporters work(ed) off-site. Since they are located in Canada (-6 CET), they are able to respond to deadline to submit cameraready transcript ending at two hours after the court ends the session. Although the author of this study was not in any way privy to information contained in the contract between ICTY and the agency that outsourced court reporters, two things are certain: hiring through an agency is much more expensive than hiring directly, and since the ICTY investigative and prosecutorial workload kept growing and court reporters are recognized professionals who are readily available in the global market both for English and French, the ICTY ought to have hired a few court reporters as in-house staff. However, CLSS did not do any such a thing. That had a bearing on transcripts: if it was hiring outside court reporters, the ICTY should have hired in-house "transcript checkers" to ensure accuracy and completeness in outsourced transcripts. Since there was no Interpretation Monitor, these "transcript checkers" could have also checked the quality of in-court interpreting. ${ }^{63}$ Post-20oo ICTY ARs report that CLSS explored the possibility of finding a more cost-effective method of producing transcripts through off-site reporting. ${ }^{64}$ Notwithstanding those efforts, it is, again, worth remembering that the agency that won the first tender for court reporters in 1994 remained unchanged. CLSS was not alone in their court reporting efforts as ARs report the CLSS Deputy Chief went to the ICTR in order to, inter alia, exchange views on the interpreting and court reporting systems several times. ${ }^{65}$ It is unclear why it did not occur to

\footnotetext{
${ }^{630} \mathrm{UN}$, Report of the ICTY (A/5o/365) (1995), para. 90.

${ }^{63_{1}} \mathrm{UN}$, Report of the ICTY $\left(\mathrm{A} / 5^{1 / 292}\right)$ (1996), para. 134.

${ }^{63^{2}} \mathrm{UN}$, Report of the ICTY (A/52/375) (1997), p. 109.

${ }^{633}$ It seems some subsequently established international criminal tribunals picked up on this. In 2016, ECCC announced a series of vacancies for Language Reviewers in combination French to English and Khmer to English. These have a duty to review transcripts of trial proceedings in the target language against the digital audio recordings in the source language, edit and translate, when necessary, the transcripts to correct substantive errors or omissions detected in the interpreting using the audio recordings in the source language, edit the transcripts to ensure accuracy and consistency in terminology, spelling, grammar and punctuation following the Transcript Unit's guidelines and glossaries, and finalize the transcripts prior to distribution to relevant parties.

${ }^{634} \mathrm{UN}$, Report of the ICTY (A/55/273) (2000), para. 244.

${ }^{6} 35$ Ibid, para. 203
} 
them to hire in-house court reporters, transcript checkers as a check and balance to court reporters' work, or an Interpretation Monitor. ${ }^{636}$

As to ICTY court reporters' substantive tasks, it was clear from the very beginning of their engagement at the ICTY that they were primarily to cater to the Court by creating English and French court transcripts. However, practice has shown a certain curiosity to their engagement which seems to have much to do with the type of contract they signed with CLSS. In the beginning, court reporters were paid by page and then by court session. Obviously, if they were hired on a different type of contract or as in-house staff, the page and hour restriction would not figure in the equation. Court reporters could have been used to shorten the tediously lengthy process of manual transcription of video and audio recordings which are ubiquitous in any investigation or prosecution office, including the ICTY. Instead, English and French court reporters have always been used for the needs of the Court alone and have rarely been used by OTP or Defense for their transcription needs. OTP and the Defense could have used court reporting services almost every day, given numerous interviews with clients conducted in English or French. Also, Chapter 4 has described a legal and practical mess that was created by poor arrangements relating to the mechanics behind taking witness statements where they were written down in English instead of being taped, so court reporters could have been used to transcribed those, as well. But, since the contract court reporters signed with CLSS precluded them from being used for any of these purposes, French and/or English and/or B/C/S and/or Macedonian and/or Albanian Defense and OTP client interview transcripts then had to be made by their respective Language Assistants, a category of (3-in-1)+ services providing staff invented by international criminal tribunals to save on costs.

Most worryingly, there were no attempts made to recruit $\mathrm{B} / \mathrm{C} / \mathrm{S}$ court reporters or create ICTY court transcripts in $\mathrm{B} / \mathrm{C} / \mathrm{S}$ until 2010. This lack of transcripts in $\mathrm{B} / \mathrm{C} / \mathrm{S}$ primarily created problems for non-English and non-French-speaking defense, self-representing, and other defendants as some instances described in Chapter 4 show. The 2009 ICTY Manual on Developed Practices admits that, although B/C/S effectively became a working language in many aspects of the ICTY work, many problems were caused by not having $\mathrm{B} / \mathrm{C} / \mathrm{S}$ as the Tribunal's working language. ${ }^{67}$ By extension, the accused did not have transcripts of proceedings readily available in a language that $\mathrm{s} /$ he could understand and had to actually listen to the audio/visual tapes of the proceedings; the same goes for witnesses who came to testify more than once. Situation country courts, legal professionals, and other interested parties had to do the same. As to the situation country parties, the principles of transparency at any public or international organizations are extremely important. The ICTY had a reputation of being one-sided, biased, unfair, etc. in the situation country which followed them since their inception and this criticism was not only coming from former Yugoslavia audiences. The lack of transcripts, materials, and publications in $\mathrm{B} / \mathrm{C} / \mathrm{S}$ fueled those claims and fed the nationalist discourse currently

\footnotetext{
${ }^{6{ }^{6}}$ Attempts at contacting English and French associations gathering court reporters were futile as none of them answered request for information inquiring whether freelance court reporters would have anything a priori against becoming full time UN staff members. Further inquiries into educational prerequisites to becoming a member of the National Court Reporting Association in the USA, for example, show that one does not have to be a college graduate to become a court reporter. It follows that the UN might have had something against employing court reporters because, as explained before, UN hires staff with university level education on P-level positions. Therefore, the lack of university diploma could be one impediment to recruitment of court reporters in the UN on P-level positions. In that, it is plausible to assume that English and French associations gathering court reporters would not take kindly to their court reporters being employed on GS-level positions because they are, after all, equipped with special skills and knowledge to perform these duties. ICC was established in 2002. However, it is assumed that they also outsourced their court reporters until the 2013 ICC vacancy for P-2 in-house court reporter for English which specifically states that, as far as education is concerned, candidate must have "post-secondary specialised training in court reporting, followed by intensive training in the profession" and "certification as a court reporter by passing a registered professional reporters' examination is essential" without any mention of an actual university diploma. Although it remains unclear why it took ICC 11 years to start hiring court reporters as full-time staff, two things seem likely. The first thing is that ICC is starting to explore a cheaper option to court reporters' engagement as recommended by this study, and, the second, ICC is doing these court reporters a favor by hiring them on P-level posts because they are not in possession of required university education.

${ }^{67}$ UN, ICTY Manual on Developed Practices (2009), para. 83.
} 
thriving in the former Yugoslavia, contributing to a lack of transparency, and perpetuating a popular image of the ICTY as a self-serving institution.

Could ICTY transcripts have been made in $\mathrm{B} / \mathrm{C} / \mathrm{S}$ from the very beginning? Here, this study will first turn to equipment used to transcribe the court proceedings because it is crucial for the use of languages. ${ }^{638}$ There were two options for making transcripts in B/C/S: classical stenography notetaking, followed by transcribing and computer stenography on the stenotype machine, and a computer program for simultaneously recording and transcribing speech. This stenotype machine is regularly used by court reporters in Common Law countries, including at the ICTY. Unfortunately, so far, none of those stenotype machines were adapted for use in $\mathrm{B} / \mathrm{C} / \mathrm{S}$ languages, despite all the best efforts of the local practitioners in the former Yugoslavia. Could the court reporters using the stenotype machine and related computer software be used to make $\mathrm{B} / \mathrm{C} / \mathrm{S}$ transcripts? The answer is: no, such machines and such practitioners do not exist for any of the $\mathrm{B} / \mathrm{C} / \mathrm{S}$ languages. Now, could the manual stenographers be used to record proceedings in $\mathrm{B} / \mathrm{C} / \mathrm{S}$ ? The manual stenographers were working as court reporters throughout the First and the Second Yugoslavia; Yugoslavian Association of Stenographers and Dactylographers was functional between 1945 and 199o, bringing together all professional associations from all the republics, but the collapse of Yugoslavia led to the demise of this Association. ${ }^{6}{ }^{69}$ Could the manual stenographers be used to record proceedings in $\mathrm{B} / \mathrm{C} / \mathrm{S}$ from the very beginning of the ICTY? Yes, they could. Could manual stenographers be used to record proceedings in B/C/S right now (2017)? Yes, they could. However, none of them were used to transcribe ICTY court proceedings in $\mathrm{B} / \mathrm{C} / \mathrm{S}$ then and they are still not used now.

\subsection{Informing the region: the Outreach Program}

The 1997 ICTY AR suggested the establishment of an Outreach Program which could be seen as a fifth language service established at the ICTY that was fully independent from the official, ICTY-wide language service, the CLSS. It anticipated that the Outreach Program, with its related Internet Unit, would enable the ICTY to better inform the people of the former Yugoslavia of its work in the local languages and combat distortion of the ICTY's record. ${ }^{60}$ The Outreach Program falls under the Public Information Services whose activities include, inter alia, translation and distribution of information packets, and systematic translation of all relevant public information materials into $\mathrm{B} / \mathrm{C} / \mathrm{S} .{ }^{641}$ This program has been funded exclusively through voluntary contributions since its inception: the European Commission generously supported the program ${ }^{62}$ This program published and widely distributed all available key and basic ICTY documents in B/C/S and Albanian (all public indictments, judgments, rules of procedure, press releases, leaflets, etc.) in print form and online at the $\mathrm{B} / \mathrm{C} / \mathrm{S}$ section of the ICTY's website. Almost nothing was published in Macedonian or Albanian, including the basic documents, such as the ICTY Statute, RPE, or practice directions. It also established and maintained live audio broadcasting of all public ICTY court sessions on the Internet, which were later available in four languages (English, French, B/C/S and Albanian), two of which came with a complete recording of the hearings (English and B/C/S) ${ }^{643}$ The program has also overseen the production of a series of documentaries in English and $\mathrm{B} / \mathrm{C} / \mathrm{S}$ that provide audiences with an introduction to the work of the Tribunal and the crimes committed in the former Yugoslavia. ${ }^{644}$

\footnotetext{
${ }^{638}$ Ericsson.com, How does stenography work.

${ }^{639}$ Currently, Croatia seems to be the only state emerging after the disintegration of Yugoslavia that keeps up with demands of IT technology in the field of stenography and is a member of the International Federation Intersteno which is a "worldwide community uniting all those using a full range of speed writing methods to quickly produce high quality texts".

${ }^{640} \mathrm{UN}$, Report of the ICTY (A/52/375) (1997), para. 3 .

${ }^{641}$ Ibid, para 152.

${ }^{642} \mathrm{UN}$, Report of the ICTY (A/62/172) (2007), para. 100.

${ }^{643} \mathrm{UN}$, Report of the ICTY (A/57/379) (2002), paras. 255 and 261.

${ }^{644}$ ICTY, Outreach Documentaries.
} 
The motivation and location of crimes are in the situation country and, by speaking the language of the situation country, the $\mathrm{B} / \mathrm{C} / \mathrm{S}$ speaking defense is in a better position to get faster to the situation country than the English/French-speaking court officials. Whatever statements the $\mathrm{B} / \mathrm{C} / \mathrm{S}$ speaking defense makes in the situation country, the Court officials have to either compete with the $\mathrm{B} / \mathrm{C} / \mathrm{S}$ speaking defense to provide novel information or engage in damage control by clarifying the defense's ambiguous statements. The Outreach Program is the most important communicator of the Court's messages to the region. But, in all fairness, nothing could have been found in the Outreach Program's Press Releases or publications that was more than merely informing about the date, time, and subject of the ICTY's work. There was no deeper analysis as to what all this meant for the region and all documents were written in legal language as if the communicators were communicating with their legal peers, not with common people. As far as the Outreach Program language philosophy is concerned, there was no logic from the beginning: the OTP statement on the Judgment of Vojislav Šešelj dated 31 March 2016 was translated into Bosnian ijekavian, Information on the Partially Dissenting Opinion of Judge Lattanzi in Judgment in the case of Vojislav Šešelj from 31 March 2016 was translated into Serbian ekavian, and the OTP statement on the conviction of Radovan Karadžić from 24 March 2016 was translated into Bosnian ijekavian. ${ }^{645}$ This seems to suggest the absence of any language or audience-related standards.

\subsection{Editing and proofreading judicial documents: The Chamber Support Unit}

The 1999 ICTY AR hinted at the existence of yet another unit dedicated to some segments of language-related work at the ICTY: the Chamber Support Unit. Language elements in the ICTY Chamber Support Unit can be seen as a sixth language service established at the ICTY that was fully independent from the official, ICTYwide language service, CLSS. This unit started providing research and drafting assistance, and editorial services in English and French to the judges. They continue with this engagement to date. The 2012 ICTY AR reports that the ICTY President implemented measures to expedite translations of final trial briefs and trial judgments to avoid delays on appeals, instructing both ICTY and ICTR Registrars to assign additional resources in order to halve the projected time needed for translation in four cases.${ }^{66}$ Consequently, Trial Chambers expanded the practice of including translators in the judgment drafting process in order to expedite the translation of trial judgments. ${ }^{67}$ CLSS staff report that this was not a practice, but a one-off instance in which a French translator took part in the judgment drafting process; the identity of this individual could not be established.

The following was written several days after the Trial Chambers delivered verdict in Šešelj on $3^{1}$ March 2016. The Summary Judgment that was supposed to be edited by the Chamber Support Section was riddled with typos and lacking basic proofreading as can be seen in the following examples from the first page only (emphasis added):

The Prosecution also seems to assume that the Serbian military campaign was illegal, thereby making it futile impossible to make any distinction between what may have been a legitimate military campaign and a campaign that may have become criminal, which alone is punishable.

\footnotetext{
${ }^{645}$ ICTY, B/C/S translation of the Statement of the OTP on the Judgement of Vojislav Šešelj (2016); ICTY, B/C/S translation of the Information on the Partially Dissenting Opinion of Judge Lattanzi in Judgement in the case of Vojislav Šešelj (2016); ICTY, B/C/S translation of the Statement of the OTP on the Conviction of Radovan Karadžić (2016).

${ }^{646}$ Here it needs to be reminded that Chapter 4 has shown that out of 122 trial briefs-related documents submitted in the English

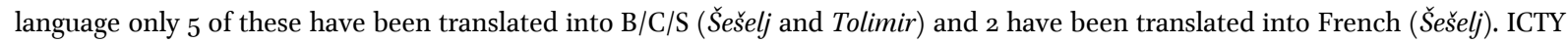
President is referring to these five because they were due to be translated in 2012 when this AR was published.

${ }^{647} \mathrm{UN}$, Report of the ICTY (A/67/214) (2012), para. 8.
} 
Added to this ambiguity are wide-ranging charges which for the Prosecution consist of targeting all the possible $\underline{\text { modes }}$ of criminal conduct provided for under Article 7 (1) of the Statute of the Tribunal, without them necessarily corresponding to the described facts.

For the facts admitted through resulting from the judicial notice under Rule 94 (B) of the Rules, the Chamber recalls that their evidentiary probative value is not binding over the Chamber only rests on a simple presumption $[\ldots]^{648}$

This seems to suggest that this unit does not have ample time for editing and proofreading, or that services provided by the Chambers Legal Support in terms of proofreading and editing are non-existent and/or provided by linguistically incompetent staff. Not a single practice direction analyzed so far mentions this unit or its working methodology in any way. Finally, the above Summary Judgment that is still present on the ICTY site (October 2017) makes it uncertain which copy translators used to produce translation.

At the end of analysis of work of six ICTY language services that were fully independent from the official, ICTY-wide language service, the CLSS, namely, Rules of the Road language professionals, VWU language professionals, UNDU language professionals, court reporters, Outreach Program language professionals, and Chamber Support Unit language professionals, it is obvious their staff provided (3-in-1)+ services, that court reporters' services were poorly planned and underused, and that they were all dependent on donations throughout, except the court reporters. However, it is also obvious that things could have been done differently, as all these categories of language staff have had more experienced colleagues in terms of training and previous working experience in the UN System and other language markets.

UN System staff mobility, which also applies to language staff, presents one of the ways in which the vacant posts may be filled. It comprises a broad range of possible moves, including the change of duty station. The Secretary-General can place staff wherever they are needed. ${ }^{69}$ The idea behind staff mobility is to provide the Secretary-General with the tools needed to ensure proper operation of the UN. However, Alexovičková noticed that voluntary or mandatory mobility is not envisaged in the UN Staff Regulations, UN Staff Rules, or that it is being practiced. ${ }^{65^{\circ}}$ In the 198 os and 1990s, the UN General Assembly adopted a series of resolutions calling for increased mobility of internationally recruited staff, going as far as to state that their mobility presents an "integral part" of their employment regulations. ${ }^{65_{1}}$ All this led the Secretary-General to set out a new mobility policy where mobility was defined as the ability of staff to move within and between functions, departments, occupations, duty stations, and organization of the UN System. ${ }^{65^{2}}$ At the time of her research concluded on 1 August 2011, Alexovičková was in position to provide evolution of UN staff mobility policies up to that time, concluding that since the mandatory mobility policy introduced in the early 2000 but suspended in 2008 has not yet been replaced by a new policy, it is rather difficult to determine how mobility in the UN

\footnotetext{
${ }^{648}$ The ICTY Judgment Summary in Šešelj was continuously checked every week from 31 March 2016 when it became publicly available. These mistakes were still there the last time the text was checked on 31 October 2017.

${ }^{649} \mathrm{UN}$, Staff Rules and Staff Regulations (ST/SGB/2014/1) (2015), Regulation 1.2(c).

${ }^{65^{\circ}}$ Alexovičková, I. (2012), From hiring to firing: a comparative study on selected legal safeguards for the independence and impartiality of international civil servants serving in the United Nations Secretariat and in the European Commission. Wolf Legal Publishers: Nijmegen, p. 452-453.

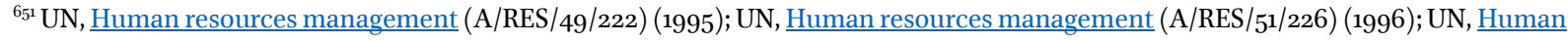
resources management $(\mathrm{A} / \mathrm{RES} / 53 / 221)(1999)$.

${ }^{652} \mathrm{UN}$, Human resources management reform (A/55/253) (2000), Appendix III, para. 11.
} 
Secretariat is supposed to work. ${ }^{63}$ The Administrative Instruction on Managed Reassignment Programme stipulates the following:

\begin{abstract}
Language professionals appointed after passing a competitive examination for posts requiring special language skills, including interpreters, translators/précis-writers, editors, verbatim reporters, proofreaders/copy preparers, revisers, terminologists, text processors, language reference assistants and editorial assistants. [These staff members] will be subject to a special managed reassignment programme, which will be based on the same principles as the programme governed by the present instruction and will apply to language professionals serving at the main duty stations and the regional commissions. ${ }^{654}$
\end{abstract}

This means that, notwithstanding the duration of mobility trends, there has never been any a priori UN impediment to move trained UN DGACM language staff elsewhere. On the contrary, it seems the special program was being established to sort out the details.

In the end, it is worth updating Alexovičková about the UN mobility as examined for the purposes of this study (concluded by 31 October 2017). In 2015, the UN General Assembly adopted a resolution aiming at a more holistic approach to staffing and reemphasized mobility. The new mobility policy affects internationally recruited staff at P-level and FS-level positions and facilitates mobility, which is now defined as integral and a required part of a UN career. ${ }^{655}$ This confirms that there is no impediment to moving trained UN DGACM language professionals elsewhere. In other words, after the obligatory six-month training in UN headquarters in New York City, a successful candidate of the LCE, for example, could have been moved to a position of an editor at the ICTY Chamber Support Unit, or French into English or English into French translators or interpreters could have been moved to a position at the ICTY CLSS, at least. However, none of that was done.

6.7. The UN and ICTY language philosophy vs the CLSS language philosophy

The purpose of language services is to plan and provide the least expensive, the most effective, and the most practical translation, interpreting, and transcription services. The ICTY, as an institution, and CLSS, as its main language services provider, had an overlapping series of internal and external clients. Internal clients included the UN and the parties (judges as a neutral party, and prosecution and defense as parties with an interest). External clients included witnesses, legal professionals from the region who needed the ICTY product and legal lessons learned in order to commence their own legal work, and the public from the region who wanted to see and hear the atrocities of wars fought in the territory of the former Yugoslavia and, hopefully, to start eliminating the causes that led to the situation in the first place, to start gaining critical perspectives on the issues, and to start neutralizing all causes perpetuating the situation in the present. Accordingly, the ICTY language philosophy was supposed to look like this:

- Institution: the UN was to set which languages were going to be used as official and/or working languages,

- Working institution: the ICTY was to determine which languages work best for their purposes,

- Rules and regulations: ICTY lawmakers, informed by practice, were supposed to deliver rules and regulations defining priorities in the use of those languages,

\footnotetext{
${ }^{63}$ Alexovičková, I. (2012), From hiring to firing: a comparative study on selected legal safeguards for the independence and impartiality of international civil servants serving in the United Nations Secretariat and in the European Commission. Wolf Legal Publishers: Nijmegen, p. 466.

${ }^{64} \mathrm{UN}$, Managed Reassignment Programme (ST/AI/2007/2) (2007), Section 2.3.(c).

${ }_{655} \mathrm{UN}$, Mobility framework (A/68/265) (2014).
} 
- $\quad$ Region: the UN and the ICTY were supposed to communicate primarily with the former Yugoslavia, and

- CLSS: as the main language service provider this organization was supposed to deliver all internal decisions enabling smooth operation of translation, interpreting, and transcription.

As far as the UN is concerned, there are six official languages. It is unclear whether the ICTY could pick among those six languages, but they declared English and French ICTY official languages in their rules and regulations. As for the region, operational reality has shown that most cases heard before the ICTY adjudicated on crimes committed against Bosnian Muslims, so the overall language philosophy targeting the region should have been B\&H-centric. However, the history of languages and identities in the former Yugoslavia has shown that Yugoslavian Muslims have been seen as lacking an identity language, or nation - basically an atavistic throwback to a gory Ottoman past (see Chapter 3). As we have seen in Chapter 4, the official position of victims and witnesses regarding language was not determined and ICTY rules and regulations are very defendant-centered, giving defendants a plethora of language-related rights. As for them, although mostly born and raised in $\mathrm{B} \& \mathrm{H}$, defendants claimed to speak Serbian and/or Croatian, because, according to them, B\&H and its language, identity, and history never existed. That premise was at the core of all their entire war effort. The final say on ICTY language philosophy was up to the CLSS because they had a duty to inform.

Draženović-Carrieri quoted below was the first Chief of the CLSS who stayed in that position, to the author's best knowledge, from the establishment of the ICTY until about the end of 1999.

\begin{abstract}
If we were to follow strictly the wording of the [ICTY-S and RPE], all translation, including that of the witness statements, should automatically be done into the language of the accused. However, the real situation in the courtroom makes the choice of the target language somewhat more complex. This became evident with the first trial ever held at the Tribunal, which was against an accused from Bosnia. During his initial appearance, when the accused is called upon to enter a plea of guilty or not guilty on each count of the indictment, he stated that he spoke Serbian. However, he spoke in exactly the same way as most of the witnesses or victims who were bringing charges against him, who were of different ethnic backgrounds. They were all claiming to speak Bosnian and, used, as did the accused, [ijekavian]. The [CLSS] was faced with a dilemma both in interpreting and in translation of how to proceed during the trial. ${ }^{65} 6$
\end{abstract}

Before getting into the legal merits of this statement, examinations have shown several "technical" discrepancies between this official policy and the Realpolitik. First of all, the rule that "simultaneous interpreters speaking the different Bosnian, Croatian, or Serbian variants [take] turns after 30 minutes" has not at all been respected. ${ }^{67}$ Data on the duration of proceedings during the initial appearance of the accused show that interpreters took both longer (3 April 1996, one interpreter for almost one hour) and shorter (all others) turns at interpreting (see Appendices 3-4). The initial appearance of the accused followed a very simple and strict speech topology: the presiding judge introduces him/herself, asks for appearances, satisfies him/herself that the rights of the accused stemming from the ICTY-S and ICTY RPE are respected and, should the accused want, instructs the Registrar to read the indictment. In other words, there is not a lot of interpreting involved, as most of interpreting work amounts to reading. So, it is unclear why interpreters took shorter turns at interpreting.

Second, it seems that very much insisted upon name of the language of the accused had absolutely no place in the Court in practice. The presiding judge would ask the accused to state their full name, date of birth, place of residence, and occupation. He or she would then ask the counsel to introduce themselves and whether the client read or was read the indictment in a language which s/he understands, and, finally whether

\footnotetext{
${ }_{656}^{6}$ Draženović-Carrieri, M. (2002), B/C/S-A practical approach. Lexicography and Language Policy in South-Slavic Languages after 1989. Verlag Otto Sagner: Munich, p. 5o.

${ }^{6}{ }^{6}$ Ibid, p. 51.
} 
$\mathrm{s} /$ he understood the charges. Then the presiding judge would turn to the accused asking whether $\mathrm{s} / \mathrm{he}$ is satisfied with his/her counsel, whether s/he read the indictment in a language which he understands, and whether s/he understood the charges. The presiding judges did not make a single mention of Bosnian, Croatian, Serbian, Serbo-Croatian, Croato-Serbian, Serbo-Croatian, Croato-Serbian, or B/C/S, only "a language which [you] understand." Only the counsel of Mr. Došen stated that his client has, indeed, read and understood the indictment submitted to him in the Serbian language. Mr. Došen made his initial appearance on 8 November 1999 and the presiding judge was referring to the indictment in case IT-95-8-PT, Sikirica et al., dated 24 August 1999. On inspection, it was established that this indictment had been translated into Bosnian. ${ }^{658}$

Third of all, it seems that the authorities responsible for language philosophy automatically assumed from the start that defendants would declare their ethnic language as their own, i.e. the Serbs would claim Serbian, the Croats would claim Croatian, the Muslims would claim Bosnian. Nobody explored a citizenshipbased approach, i.e. if someone was born in $\mathrm{B} \& \mathrm{H}$, why not automatically assume Bosnian as their language?

And, finally, overall, it seems all these issues with language were issues because it was planned that the interpreting for the accused would be interpreter-centric.

Moving to the legal merits, in the following section, this study examines (at the level of the ICTY): whether linguistic justice was served in communication with defendants, as co-internal clients, in a combination of English, French, and B/C/S; whether linguistic justice was served in communication with the region as co-external clients, in a combination of English, French, and B/C/S; and whether linguistic justice was served in communication with witnesses as external clients, in a combination of English, French and B/C/S. Here, linguistic justice should be taken to mean whether these audiences were addressed in languages which they understand.

The purpose of the first examination is to establish whether linguistic justice was served at the level of the ICTY to defendants, as co-internal clients, in a combination of English, French, and B/C/S. Appendix 3 Ethnicity of the accused $v$ s languages of interpreters contains information extracted from the available videos on the ICTY YouTube channel but limited to the initial appearances of the accused. The ethnicity of the accused is recorded as appearing on the CIS, and the language of the interpreters was recorded as heard. This examination shows that there were 81 recorded initial appearances at which 83 individuals entered a plea between 1996 and 2011, namely: 43 Bosnian Serbs, 16 Serbian Serbs, 14 Bosnian Croats, 6 Bosnian Muslims, 4 Croatian Serbs, and 3 Croatian Croats.

From Appendix 3: 43 Bosnian Serbs were provided with interpreting by:

- 1 one-interpreter team speaking Bosnian,

- 6 one-interpreter teams speaking Croatian,

- 9 one-interpreter teams speaking Serbian,

- 9 two-interpreter teams speaking Croatian and Serbian,

- 8 two-interpreter teams speaking Croatian,

- 6 two-interpreter teams speaking Bosnian and Serbian,

- 3 two-interpreter teams speaking Serbian, and

- 1 two-interpreter teams speaking Bosnian and Croatian.

In dialectal terms this means that these 43 Bosnian Serbs speaking ijekavian were provided with interpreting by:

- 16 one- or two-interpreter teams providing interpreting into ijekavian only,

- 15 one- or two-interpreter teams providing interpreting into ijekavian and ekavian, and

${ }^{658} \mathrm{ICTY}$, Amended Indictment in Sikirica et al: English and B/C/S. 
- 12 one- or two-interpreter teams providing interpreting into ekavian only.

From Appendix 3: 16 Serbian Serbs were provided with interpreting by:

- 5 one-interpreter teams speaking Serbian,

- 5 one-interpreter teams speaking Croatian,

- 6 two-interpreter teams speaking Croatian and Serbian,

- 1 two-interpreter teams speaking Bosnian and Croatian, and

- 1 two-interpreter teams speaking Serbian.

In dialectal terms this means that these 16 Serbian Serbs speaking ekavian were provided were interpreting by:

- 6 one- or two-interpreter teams providing interpreting into ijekavian only,

- 6 one- or two-interpreter teams providing interpreting into ijekavian and ekavian, and

- 6 one- or two-interpreter teams providing interpreting into ekavian only.

From Appendix 3: 14 Bosnian Croats were provided with interpreting by:

- 1 one-interpreter teams speaking Croatian,

- 1 one-interpreter teams speaking Bosnian,

- 5 two-interpreter teams speaking Croatian and Serbian,

- 1 two-interpreter teams speaking Bosnian and Serbian, and

- 1 two-interpreter teams speaking Croatian.

In dialectal terms this means that these 14 Bosnian Croats speaking ijekavian were provided with interpreting by:

- 6 one- or two-interpreter teams providing interpreting into ijekavian and ekavian, and

- 3 one- or two-interpreter teams providing interpreting into ijekavian only.

From Appendix 3: 6 Bosnian Muslims were provided with interpreting by:

- 2 one-interpreter teams speaking Bosnian,

- 1 one-interpreter teams speaking Croatian, and

- 1 two-interpreter teams speaking Bosnian and Serbian.

In dialectal terms this means that these 6 Bosnian Muslims speaking ijekavian were provided with interpreting by:

- 3 one- or two-interpreter teams providing interpreting into ijekavian only, and

- 1 one- or two-interpreter teams providing interpreting into ijekavian and ekavian.

From Appendix 3: 4 Croatian Serbs were provided with interpreting by:

- 3 one-interpreter teams speaking Croatian, and

- 2 one-interpreter teams speaking Serbian.

In dialectal terms this means that these 4 Croatian Serbs speaking ïekavian were provided with interpreting by:

- 3 one- or two-interpreter teams providing interpreting into ijekavian only, and

- 2 one- or two-interpreter teams providing interpreting into ekavian only. 
From Appendix 3: 3 Croatian Croats were provided with interpreting by:

- 1 two-interpreter teams speaking Bosnian and Croatian, and

- 1 two-interpreter teams speaking Croatian and Serbian.

In dialectal terms this means that these ${ }_{3}$ Croatian Croats speaking ijekavian were provided with interpreting by:

- 1 one- or two-interpreter teams providing interpreting into ijekavian only, and

- 1 one- or two-interpreter teams providing interpreting into ijekavian and ekavian.

Was linguistic justice served on these 43 Bosnian Serbs, 16 Serbian Serbs, 14 Bosnian Croats, 6 Bosnian Muslims, 4 Croatian Serbs, and 3 Croatian Croats?

Those defendants who originate from $\mathrm{B} \& \mathrm{H}$ were served linguistic justice only in those instances where they were provided with interpreting to/from Bosnian. However, out of $5^{6}$ one- or two-interpreter teams, Bosnian language interpreters figure in 4/56 instances alone and 9/56 instances together with Croatian or Serbian interpreters; Bosnian language and Bosnian interpreters are completely missing in the other oneor two-interpreter teams $(43 / 56)$.

Those defendants who originate from Serbia were served linguistic justice only in those instances where they were provided with interpreting to/from Serbian. However, out of 18 one- or two-interpreter teams, Serbian language interpreters figure in $6 / 18$ instances alone and 6/18 instances together with Croatian or Bosnian interpreters; Serbian language and Serbian interpreters are completely missing in other $6 / 18$ oneor two-interpreter teams.

Those defendants who originate from Croatia were served linguistic justice only in those instances where they were provided with interpreting to/from Croatian. However, out of 7 one- or two-interpreter teams, Croatian language interpreters figure in $3 / 7$ instances alone and $2 / 7$ instances together with Serbian or Bosnian interpreters; Croatian language and Croatian interpreters are missing in the other one- or twointerpreter teams $(2 / 7)$.

Alexander, who serves as a theoretical basis for most of the former Yugoslavia language-related claims throughout this study, writes that dialectally, on a popular level, ekavian or ijekavian speech became strongly associated with national, ethnic, and political identity during the nineteenth-century and that it has continued to be associated as such to this day. ${ }^{659}$ The ICTY adjudicated on ethnic crimes which were motivated by language and identity-related hate campaigns. However, out of $5^{6}$ one- or two-interpreter teams working on the initial appearances of defendants from $\mathrm{B} \& \mathrm{H}$, ijekavian figures in 22/56 instances alone, in 19/56 instances ekavian and ijekavian were used together, and in 15/56 instances ekavian was used alone. In all those 34/56 instances where ekavian appears alone or together with Croatian ijekavian. CLSS, and by extension the ICTY, has made a strong national, ethnic, and political identity statement against B\&H and the peoples of $\mathrm{B} \& \mathrm{H}$, thus feeding into the prevailing nationalist discourse.

But there is more: Bosnian ijekavian is different from Croatian ijekavian. Bosnian ijekavian featured in the initial appearances of 8/43 Bosnian Serbs, 2/14 Bosnian Croats, 3/6 Bosnian Muslims (a total of 13 times), excluding twice where it was used in interpreting for defendants originating from Serbia and Croatia, where it was clearly out of place. In all of those $5^{\circ} / 63$ instances where non-Bosnian ijekavian appears, CLSS, and by extension the ICTY, has made a strong national, ethnic, and political identity statement against B\&H and the peoples of $\mathrm{B} \& \mathrm{H}$, thus feeding into the nationalist discourse. This is especially true in the initial appearances

\footnotetext{
${ }_{659}$ Alexander, R. (2013), Language and identity: the faith of Serbo-Croatian. Entangled histories of the Balkans, Vol. 1: National ideolo-
} gies and language policies. Koninklijke Brill NV: Leiden, p. 349. 
of Bosnian Croats who appeared as perpetrators against the peoples of $\mathrm{B} \& \mathrm{H}$. The same goes for Croatia and Croatian peoples in $3 / 7$ cases where ekavian figures in the interpreting combination. The same goes for Serbia and Serbian peoples in 12/18 cases where ekavian does not figure in the interpreting combination.

According to the ICTY website, the ICTY mandate:

is to bring to justice those responsible for serious violations of international humanitarian law committed in the former Yugoslavia since 1991 and thus contribute to the restoration and maintenance of peace in the region. ${ }^{66}$

Next, we will see whether the ICTY contributed to the restoration and maintenance of peace in the region by delivering justice to the countries in the region in terms of the appropriate linguistic variant. The purpose of this examination is to establish whether linguistic justice was served at the level of the ICTY in communication with the region as co-external clients, in a combination of English, French and B/C/S. Appendix 4 Language of interpreters $v$ s location of crimes and ethnicity of victims contains information extracted from the available videos on the ICTY YouTube channel, but limited to the reading of the 49 trial judgments (TJ), 41 appeals judgments (AJ), 6 sentencing judgments (SJ), 1 sentencing appeal (SA) and 1 revised judgment (RJ) delivered between 1997 and 2016. The ethnicity of the accused, the location of crimes and the ethnicity of victims is recorded as appearing on the CIS, and the language of the interpreters was recorded as heard.

As a location of crimes, $\mathrm{B} \& \mathrm{H}$ figures in 82 instances (twice together with Croatia, and once together with Croatia and Serbia). Bosnian Serbs were identified as perpetrators in $55 / 82$ instances. Serbian ekavian as a language of interpreting features in 47/55 instances. Bosnian Croats were identified as perpetrators in 15/82 instances. Croatian ijekavian as a language of interpreting features in 15/15 instances. Bosnian Muslims were identified as perpetrators in 8 instances. The Bosnian language as one of languages of interpreting features in $3 / 8$ instances, Croatian in $6 / 8$ instances, and Serbian in $6 / 8$ of such instances. Out of 82 instances where B\&H features as the location of crime, Bosnian ijekavian as a language of interpreting features in 17/82 instances and in only $1 / 82$ cases alone.

As a location of crimes, Croatia figures in 15 instances (twice together with $\mathrm{B} \& \mathrm{H}$, and once together with B\&H and Serbia). Croatian Serbs were identified as perpetrators in $11 / 15$ instances. Serbian ekavian as a language of interpreting features in 10/11 instances. Croatian Croats were identified as perpetrators in 2/11 instances. Serbian ekavian as a language of interpreting features in $2 / 2$. Out of 15 instances where Croatia features as the location of a crime, Croatian ijekavian as a language of interpreting features in 14/15 and 1/15 alone (it does not figure in the one where $\mathrm{B} \& \mathrm{H}$ is a co-location of crimes).

As a location of crimes, Serbia, including Kosovo, figures in 4 instances (once together with and Croatia). Serbian ekavian as a language of interpreting features in 4/4, Croatian ijekavian in 3/4 such instances, and Bosnian ijekavian in 2/4 such instances. Serbian ekavian features alone in 1/4 cases.

Were B\&H audiences, as co-external clients, in a combination of English, French and B/C/S served linguistic justice by the ICTY? Out of 82 instances where B\&H features as the location of a crime, Bosnian ijekavian as a language of interpreting features in $17 / 82$ instances and $1 / 82$ alone. Consequently, $\mathrm{B} \& \mathrm{H}$ audiences were served linguistic justice in only that one instance because in all other instances verdicts were read out in the language of the aggressor. Finally, since the Bosnian language was heard by B\&H audiences in 17/82 instances concerning $\mathrm{B} \& \mathrm{H}$, tremendous linguistic injustice was done to $\mathrm{B} \& \mathrm{H}$ audiences. In all of those $65 / 82$ instances where the language of the former aggressor, Serbian ekavian and Croatian ijekavian, was used, CLSS,

${ }^{660}$ ICTY, Mandate and crimes under ICTY jurisdiction. 
and by extension the ICTY, has made a strong national, ethnic, and political identity statement against B\&H and the peoples of $\mathrm{B} \& \mathrm{H}$.

Were Croatian audiences, as co-external clients, in a combination of English and French and B/C/S served linguistic justice by the ICTY? Out of 15 instances where Croatia features as the location of a crime, Croatian ijekavian as a language of interpreting features in 14. Consequently, Croatian audiences were served linguistic justice in only that one instance. Finally, since the Croatian language was heard by Croatian audiences in 14/15 instances concerning Croatia, there was no serious linguistic injustice done to these audiences. However, in all those 10/15 instances where the language of the former aggressor, Serbian ekavian, was used, CLSS, and by extension the ICTY, made a strong national, ethnic, and political identity statement against Croatia and Croatian peoples.

Were Serbian audiences, as co-external clients, in a combination of English, French and B/C/S served linguistic justice by the ICTY? Out of 4 instances where Serbia, including Kosovo, features as the location of a crime, Serbian ekavian as a language of interpreting features in all 4 cases, out of which it only features alone in one case. Consequently, Serbian audiences were served linguistic justice in only that one instance. Finally, since the Serbian language was heard by Serbian audiences in all 4 instances concerning Serbia, including Kosovo, there was no serious linguistic injustice done to these audiences as Croatian or B\&H perpetrators did not commit any crimes in the territory of Serbia, including Kosovo.

So far, the Bosnian ijekavian language featured as part of one- or two-interpreter teams providing interpreting for 174 public proceedings ( 81 initial appearances and 93 judgments) in 45 instances where 63/81 featured initial appearances of $\mathrm{B} \& \mathrm{H}$ nationals and 82/93 judgments featured $\mathrm{B} \& \mathrm{H}$ as a location of crimes. One and the same woman from B\&H who spoke the Bosnian language appeared as an interpreter in 43/45 cases.

But, there was a priori knowledge on the part of CLSS managers that victims and witnesses' language also had to be taken into consideration when translating and interpreting. Draženović-Carrieri claims the following.

\begin{abstract}
Interpreters who were working with witnesses had to be handpicked not only as to their professional skills, but also with regard to their ethnic background and the language they spoke. In general, fact witnesses require special care during the trial and it is provided to them by the [ICTY'S VWU]. Those who are specially fragile might be upset to hear a language they identify with the aggressor. Therefore, the wrong assignment of an interpreter could easily cause suspicion or mistrust or could even result in witnesses refusing to testify. Given the sensitivity of the matter, it was decided to avoid risking such extreme reactions from witnesses who, back in 1995, could become very emotional or suspicious when hearing Serbian [ekavian]. The choice opted was to man the " $\mathrm{B} / \mathrm{C} / \mathrm{S}$ " interpreting booth during the Prosecution case with interpreters who spoke either Croatian or Bosnian, i.e. [ijekavian]. ${ }^{601}$
\end{abstract}

Although singling out Serbian ekavian, Draženović-Carrieri has forgotten to mention Croatian ijekavian. This forgetfulness is somewhat strange as most of the ICTY trials during her tenure tried Croat(ian) perpetrators on $\mathrm{B} \& \mathrm{H}$ soil and $\mathrm{B} \& \mathrm{H}$ victims and witnesses testifying against them would have felt equally uncomfortable hearing the Croatian language. Let us keep that in mind during the next explanation.

The ICTY did not make transcripts into $\mathrm{B} / \mathrm{C} / \mathrm{S}$ because $\mathrm{B} / \mathrm{C} / \mathrm{S}$ is neither an official UN language nor an ICTY working language. However, in 2008 a team of experts, led by the OSCE's Office for Democratic In-

\footnotetext{
${ }^{661}$ Draženović-Carrieri, M. (2002), B/C/S-A practical approach. Lexicography and Language Policy in South-Slavic Languages after 1989. Verlag Otto Sagner: Munich, p. 5 o.
} 
stitutions and Human Rights in conjunction with the ICTY and the UN Interregional Crime and Justice Research Institute carried out a needs assessment among the judiciaries in the former Yugoslavia in order to transfer the wealth of knowledge from the ICTY and build the capacity of local judiciaries before the ICTY completes its mandate. In 2009, these findings were published in a report entitled "Final Report: Supporting the Transition Process: Lessons Learned and Best Practices in Knowledge Transfer." ${ }^{n 62}$ One of the key findings in relation to the needs of local judiciaries in order to efficiently process the war crimes on the local level was a lack of ICTY court transcripts available in local languages. The three organizations jointly started an 18month long "War Crimes Justice Project" in order to address those needs. In July 2010, the ICTY began creating verbatim transcripts of ICTY court proceedings in $\mathrm{B} / \mathrm{C} / \mathrm{S}$ from $\mathrm{B} / \mathrm{C} / \mathrm{S}$ audio recordings of ICTY court proceedings. The ICTY engaged a team of 20 transcribers, who transcribed a total of over 60 ,ooo pages in $\mathrm{B} / \mathrm{C} / \mathrm{S}$ in those 18 months. ${ }^{663}$ The transcription project mainly addressed the most pressing needs of the local judiciaries in terms of assisting their ongoing trials and investigations within the available funding, time, and resource restraints. Unfortunately, on the project's completion in December 2011, the transcription project was discontinued due to a lack of additional funding. Currently, it is not clear whether the project would be continued (2017). These transcripts were made only in $\mathrm{B} / \mathrm{C} / \mathrm{S}$, not in Albanian or Macedonian, the languages of some defendants and some audiences in the situation country. The B/C/S transcripts of some, though not all, court sessions were made in trials: Blagojević and Jokić, Brđanin, Erdemović, Halilović, Karadžić, Krajišnik, Krstić, Lukić, Nikolić, Popović, Stanišić and Župljanin, Tolimir, and Vasiljević (B\&H as a situation country), Martić (Croatia as a situation country), Đorđević and Šainović (Kosovo as a situation country), and Perišić and Milošević (the influence of the Serbian political and military leadership over Serb rebels and Serb(ian) insurgents in B\&H, Croatia and Kosovo).

According to the ICTY website, one of ICTY achievements included giving victims a voice.

The Tribunal has provided thousands of victims the opportunity to be heard and to speak about their suffering. Many of them displayed exceptional courage in recalling their harrowing experiences. The Tribunal preserves their testimonies in court transcripts and video recordings. ${ }^{664}$

The Tribunal's courtrooms have heard hundreds of victims tell what are often painful and tragic stories about what they saw and experienced. People of all walks of life -farmers, doctors, housewives, local politicians, mechanics, students, school children and many others- were victims of horrific crimes. Many of them were victims simply because they were of a different ethnicity from their attackers. ${ }^{665}$

Indeed, there was a priori knowledge on the part of ICTY management that victims and witnesses' language also had to be taken into consideration when translating and interpreting. The 1994 ICTY AR acknowledges throughout that the judges are very much aware that there may be considerable reluctance on the part of witnesses to appear before the Tribunal to testify because the principal witness against the perpetrator of a crime will be the victim, ${ }^{666}$ that the crimes involving the civilian population were committed on, inter alia, ethnic grounds, and that the judges have never allowed themselves to lose sight of the fact that victims and

\footnotetext{
${ }^{662}$ OSCE, Supporting the Transition Process: Lessons Learned and Best Practices in Knowledge Transfer (2009).

${ }^{663}$ Unfortunately, these production indicators are not helpful at all. However, even in the form that they are given, it can be deduced that $\mathrm{B} / \mathrm{C} / \mathrm{S}$ transcribers produced 166 pages a month or 8.3 pages a day. Although, as mentioned before, the UN does not have any standards for transcription, typically, transcribers production is measured in minutes of recorded material, not in the number of pages produced. In other words: how many minutes of recorded material they can transcribe, not how many pages they can produce. This is because the number of words appearing on a page is unpredictable: one single page may have a series of "Uh-huh" or it may have full text from top to bottom, in addition to transcribing tags identifying speakers and the proceedings. According to the MTStars and WAHM forum discussions among professional transcribers, the industry accepted minimum is $15-20$ minutes of audio per one hour of work or 6o-120 minutes of original material a day.

${ }^{664}$ ICTY, Achievements.

${ }^{665}$ ICTY, Voice of the victims.

${ }^{666} \mathrm{UN}$, Report of the ICTY (A/49/342) (1994), para. 79 .
} 
witnesses have rights worthy of protection. ${ }^{667}$ In other words, the judges clearly stated that the UN languages and defendant-centric approach to language services alone are inappropriate for the context of an international criminal tribunal adjudicating on ethnic crimes.

However, practical implementation of this awareness seems not to have taken any of that into account. Appendix 5 The ethnicity of testifying victims and witnesses vs languages of interpreters contains information extracted from available transcripts in B/C/S from the ICTY homepage in trials that concerned B\&H only. Not all existing transcripts have been analyzed: analysis stopped at the $41^{\text {st }}$ witness from $\mathrm{B} \& \mathrm{H}$; witnesses who were not from the former Yugoslavia were not considered. The ethnicity of the accused, the location of crimes, and the ethnicity of victims is recorded as appearing on the CIS, the ethnicity of the testifying witness is recorded as stated by that person, and the language used by interpreters was recorded as appearing in the transcripts. In examining languages of interpreters in the transcripts, the major concern was the fact that the analysis was made without relying on the audio recording in which the author of this study could even recognize some of the interpreters' voices. The main question was: what if this person interpreting was actually a Bosnian language interpreter preferring a Croatian variant? This is because, owing to the wars, the politics of the standard Bosnian language started preferring the Croatian variant, meaning instead of opšti people are encouraged to say opći, and so on. However, whereas Croatian speaker must say opći and Serbian speaker must say opšti, both opći and opšti are correct in the Bosnian language and Bosnian speaker can choose which overlapping ijekavian vocabulary to use. Thankfully, the Bosnian language is a language separate from both Serbian and Croatian, so Croatian speaking interpreters were identified by specific vocabulary a Bosnian speaker would never use, such as: vjerojatno vs vjerovatno, satnik vs kapetan, bojnik vs major, tajnik vs sekretar, točka vs tačka, etc. None of this was an issue with Serbian-speaking interpreters because the main feature of Serbian language is ekavian pronunciation to which Serbian-speaking interpreters stuck throughout. The purpose of the third examination was to establish whether linguistic justice was served at the level of communication with witnesses as external clients, in a combination of English, French and B/C/S. This examination has established that 41 one- or two-interpreter teams provided with interpreting either into Serbian ekavian in 19/41 instances (1/41 alone) or Croatian ijekavian in all 40/41 instances (23/41 alone). Bosnian ijekavian was found in $\mathrm{o} / 41$ transcripts using the above criteria.

Finally, in addition to awareness among the CLSS management and ICTY management about linguistic variants, there was a priori knowledge on the part of interpreters that victims and witnesses' language also had to be taken into consideration during the recruitment of translators and interpreters. Croatian interpreters interviewed for the purposes of this study stated that there was an unofficial policy in the CLSS to speak "the old version" of the Croatian language. They were unable to define the "old version" of the Croatian language except to say it corresponded to language in which words readily associated with the Croatian language (names of months, for example) would be replaced with corresponding terms in the Bosnian language. The very fact that Croatian speaking interpreters deviated from the standard Croatian language using Bosnian language terminology (denoted by an asterisk in Appendices 3-5) shows that they were aware of their public and acutely aware of the fact they were interpreting into the language of aggressor. These interpreters also pointed out that implementation of such an unofficial policy depended on an individual interpreter and that there were some who stuck to the unadjusted version of the Croatian language throughout. CLSS Croatian language interpreters, at least, realized that language is a political statement and unofficially worked to minimize the effects of such a political statement made by the ICTY as an institution.

The first Chief of the CLSS, Draženović-Carrieri, ethnic Croat, stayed in that position, to the author's best knowledge, between 1 January 1994 and 31 December 1999. Draženović-Carrieri stated that interpreters were handpicked to work with victims and witnesses based on their ethnicity. ${ }^{668}$ Let us examine interpreting

\footnotetext{
${ }^{667}$ Ibid, para. 81.

${ }^{668}$ Draženović-Carrieri, M. (2002), B/C/S-A practical approach. Lexicography and Language Policy in South-Slavic Languages after 1989. Verlag Otto Sagner: Munich, p. 5o.
} 
for victims and witnesses during the witness statement taking process under Draženović-Carrieri's management. ICTY court records were searched for witness statements between 1 January 1994 and 31 December 1999; the results yielded 54 different witness statements. Obviously, not all the witness statements had yet been fed into the online ICTY Court Records system at the time of this search (2017). The research showed that Draženović-Carrieri might have got carried away with such absolute statements: examination of her statement that interpreters were handpicked as to their ethnicity cannot be proven or disproven because the witness statement form does not contain a field where the interpreter could explicitly enter his or her ethnicity; only witnesses declared their ethnicity (see the Witness Statement form in Chapter 4). Therefore, these interpreters were assigned to interpret for witnesses on the discretion of the assigning authority. As far as interpreters assisting during the witness statement taking process are concerned, Interpreter Certification obliges them to state the languages from/into which they are qualified to interpret by the ICTY and the language the witness informed them s/he can speak and understand (see Chapter 4 for Interpreter Certification on the Witness Statement). Most interpreters put the language a witness can speak and understand as a language for which they were qualified to interpret from/into by the ICTY. As a result, several interpreters declared that they were qualified for both Bosnian and Serbo-Croatian (ERN oo300299 and ERN oo30o314) and for both Bosnian and Croatian (ERN oo336795 and ERN oo391643). There are also several witness statements on which witnesses entered their language as Bosnian, but interpreters certified that they interpreted their statement into and from Croatian (ERN oo31149o, ERN o0325377, ERN o0325427, ERN o0337976, ERN o0337927, ERN oo337894). This is in direct violation of Draženović-Carrieri's promises and the witnesses' right to the use of their own language under ICTY RPE Rule $3(C)$.

The above examination only establishes that interpreters were assigned to interpret for witnesses at the discretion of the assigning authority, i.e. CLSS management. It does not establish that the interpreting was victim and witness-centric as claimed. It does establish that interpreters did not enter their own language on the witness statement form at all: interpreters would routinely agree that they interpreted from/into whatever language the witness entered he spoke and understood therefore creating the appearance of being victim and witness-centric. The same trend could be observed during the second Chief of CLSS, ethnic Serb, who stayed in that position, to the best of author's knowledge, between 1 January 2000 and 30 June 2007, and the third Chief of CLSS, an ethnic Serb, who assumed that position, to the best of author's knowledge, on 1 July 2007 and is the current Chief of CLSS. This lady has been a Deputy Chief CLSS under the first and the second Chief of CLSS since $1993 .{ }^{669}$

\subsection{ICTY CLSS language professionals}

Until about 2000 when CLSS management changed, the organization of CLSS was rather logical despite the fact that translation, interpreting, and transcription load just kept on growing because of the increased investigations and single and multi-accused trials. Field investigations involved language professionals who were mostly local to the area of investigations, and every in-house investigation team was assigned two CLSS language professionals and two Language Assistants. This allowed for prompt communication between all the parties and a strict separation of duties between different categories of language professionals: one group was working on court-related documents (CLSS translators, interpreters, and court reporters) and the other group on investigation-related documents (Language Assistants). Both groups equally helped with interpreting for in-house witnesses and promptly responded to clients' needs. Field interpreters were hired and worked mostly in B\&H and Croatia, where CLSS chiefs organized regular small-scale exams. Those CLSS language professionals who were not assigned to investigation teams worked in a pool and either "picked up" after the

\footnotetext{
${ }^{669}$ Whereas Chapter 5 mostly discussed the UN's reluctance to employ local language professionals on P-level positions, here it becomes obvious the chiefs of CLSS were also "local" to the region of former Yugoslavia: one ethnic Croat and the others ethnic Serbs. This is not a contradiction in previously established recruitment policies and practices. Although they might be originally from the region of the former Yugoslavia, these individuals are citizens of other countries: France, the USA, and, author is guessing, Belgium; they did not get those jobs as citizens of Croatia and Serbia, respectively. Not a single holder of a passport of any of the countries that emerged after the disintegration of Yugoslavia ever held any managerial position in the ICTY CLSS.
} 
team language professionals or responded to the translation and interpreting needs of other ICTY clients. OTP did not have a pool of Language Assistants; they were all assigned to teams. Although UN OIOS carried out a review of the ICTY in 1996 and 1997, a team of UN OIOS Auditors and investigators conducted a comprehensive review of ICTY for the first time in 1999. The UN OIOS concluded that an effective working relationship and spirit of cooperation existed between the three ICTY organs (OTP, Registry, and the Chambers) and that ICTY operational areas were generally managed in an efficient and effective manner. The OIOS 1999 Report pointed out that some key administrative and financial areas needed to improve, including, inter alia, personnel recruitment. The UN OIOS recommended, inter alia, consistent application of placement and promotional policies for vacant positions. Problems were revealed in relation to allowing promotions without meeting the necessary seniority requirements, but also in recruiting interpreters and translators because of both the high standards required and the competition for qualified staff. ${ }^{670}$

However, all this changed once the CLSS management changed in/around 20oo. The UN SecretaryGeneral Annan's 1998 Reforms, a veritable mot dujour at the UN today (2017), have a major flaw: they give too much power to individuals at all levels of management and provide only their direct subordinates as checks and balances to their conduct. Effectively, these reforms reduce the overall team effort to a core team effort. Members of that team are picked and chosen by the manager, here the Chief of CLSS, or a person from the core team assigned by the Chief, here hiring manager. Scholars have also observed that the UN Secretariat put more responsibility for staff selection in the hands of specific hiring managers rather than the advisory bodies that had existed in the past. ${ }^{61}$ However, even under controlled conditions, such as those applying to the UN DGACM, UN recruitment methods have been criticized as inadequate and irrational, slow, and cumbersome (see Chapter 5). To imagine the effects of such recruitment practices in uncontrolled conditions, such as ICTY CLSS, let us examine the professional profile of ICTY language professionals, recruitment methods, and the ensuing working atmosphere and relationships created by one specific hiring manager, namely the CLSS Chief during the second management period (2000-2007).

\subsubsection{ICTY CLSS language professionals: recruitment}

Soon after the second Chief of CLSS assumed that position, she organized a mission to Budapest to interview candidates for translator and interpreter positions at the ICTY, specifically from Serbia. The reason Budapest, Hungary, was chosen as a testing location is that the then-Milošević regime did not allow an ICTY presence in the territory of Serbia. The candidates from Serbia who were tested and interviewed in Budapest reached that location at their own cost. Successful candidates were first employed at GS-level category positions in ICTY OTP. All such candidates, excluding one known Hungarian hybrid, were ethnic Serbs and there were no fewer than 30 of them. Soon after the successful candidates arrived in The Hague, the Chief of CLSS organized a translation exam from English into B/C/S. Naturally, this examination was open to all new and old staff, but it seems the purpose of this exam was so that the Serb staff from Budapest who did not pass the P-level examination could transition from GS-level to P-level positions. Many candidates of all ethnicities from all regions of the former Yugoslavia, both old and new staff, actually passed the examination. However, only ethnic Serbs were offered P-level positions in the CLSS. It became obvious later that some of them had prior family and/or personal and/or romantic connections to the CLSS management. Other Budapest hires of Serb ethnicity who were left at GS-level positions eventually found their way into the CLSS through three more exams organized in about 2005, 2006, and 2007 for English language translators; the ethnic structure of new recruits remained unchanged. All examinations organized by CLSS were largely unmonitored and candidates had full access to the Internet during the examination. CLSS never organized an examination for $\mathrm{B} / \mathrm{C} / \mathrm{S}$ translators again. CLSS also never organized a similar mass examination for candidates from $\mathrm{B} \& \mathrm{H}$ and/or Croatia in $\mathrm{B} \& \mathrm{H}$

\footnotetext{
${ }^{670} \mathrm{UN}$, OIOS Report on the audit and investigation of the ICTY (A/54/120) (1999), paras. 17-18.

${ }^{671}$ Alexovičková, I. (2012), From hiring to firing: a comparative study on selected legal safeguards for the independence and impartiality of international civil servants serving in the United Nations Secretariat and in the European Commission. Wolf Legal Publishers: Nijmegen, p. 235 .
} 
and/or Croatia or elsewhere into English or B/C/S. Between 2000 and now, all the heads of sections at the ICTY CLSS have been ethnic Serbs, all their deputies were ethnic Serbs, all English and French revisers have been or are married to ethnic Serbs, and most B/C/S revisers were ethnic Serbs. One Bosnian Muslim reviser magically disappeared after pointing out the overwhelming number of Croatians in CLSS during the first management period. One Croatian translator magically disappeared after pointing to the overwhelming number of Serbs in CLSS during the second management period. Since 1996 there have been a total of eight Bosnian Muslims working as P-level translators and interpreters in CLSS anywhere between one to five years or longer than 10 years (names on file). There were four more Muslims at P-level positions in CLSS, but they have not been taken into consideration for the following reasons: two were Muslims from Croatia and from Serbia, respectively, one was from mixed marriage Muslim/Serb, and one was a Dutch Muslim. There were three more Bosnians at P-level positions in the CLSS, but they have not been taken into consideration because they are Bosnian Serbs. The CLSS has had anywhere between 60 and 170 language staff since 1993. This information may sound shocking, but the issue here is not whether one specific ethnicity should have been in the majority at the ICTY CLSS. The issue here is whether their recruitment was fair and whether the dominance of Serb staff in the ranks of ICTY CLSS and OTP Language Assistants affected recruitment practices the quality of translation, interpreting, and transcription product, the rights of victims and fair trials.

As to the core team and recruitment, Elias-Bursać had this to say about how she got a job of a reviser at the ICTY:

I received a call from the ICTY early one June morning in 1998 from a fellow translator who had recently taken a job in CLSS, inviting me to come and try my hand at revising for six weeks that summer. If the revising suited me and I suited the English Translation Unit, we could discuss a longer stay. ${ }^{672}$

The arrangement suited both Elias-Bursać and the English Translation Unit and she stayed at the ICTY, on and off, until 2010. However, according to her LinkedIN account, Elias-Bursać has a BA in Russian Literature and Language from Macalester College (1970-1974), an MA in Comparative Literature from the University of Zagreb (1984-1988), and a PhD in Philology from the University of Zagreb (1992-1999) with a dissertation in the comparative/contrastive linguistic and stylistic analysis of selected poetry. Prior to accepting a job with the ICTY, between September 1979 and November 1990 (11 years 3 months), Elias-Bursać worked as a Coordinator of the Zagreb Fall Program, which is a study-abroad program at Zagreb University, Croatia, and between July 1994 and June 2005 (11 years) she worked as a Preceptor in the Slavic Department at Harvard University, where she taught first-year $\mathrm{B} / \mathrm{C} / \mathrm{S}$ and one-on-one reading classes for intermediate and advanced students. ${ }^{673}$ Obviously, such an education and working experience makes her a novice translator, at best. However, at the ICTY, Elias-Bursać did not work as a translator whose work would be subjected to revision by more experienced colleagues in the field, but as an English language reviser in charge of revision of translations from $\mathrm{B} / \mathrm{C} / \mathrm{S}$ into English: the final check and balance to all translational efforts. ${ }^{674}$ This is not the only ex nihilo recruitment by CLSS core managers. According to his LinkedIN profile, Phillip Hepburn, author of another paper that will be discussed here, graduated with a BSc (Econ.) in International History from the London School of Economic and Political Science in 1981 and became a Doctor of Philosophy specializing in Yugoslav history in 1984. Prior to joining the ICTY in 1998, Hepburn worked as a Political and Trade Officer in the Australian Embassy for 8 years and 2 months. Hepburn worked at the ICTY CLSS English Translation Unit as a translator/reviser for 4 years and 3 months before becoming Head of the English Translation Unit a position in which he stayed for 7 years and 7 months before going back to the position of translator/reviser. ${ }^{675}$ In her

\footnotetext{
${ }^{672}$ Elias-Bursać, E. (2015), Translating evidence and interpreting testimony at a war crimes tribunal. Palgrave Macmillan: London, p. 31.

${ }^{673}$ LinkedIN, Ellen Elias-Bursać.

${ }^{674} \mathrm{UN}$ vacancies, ICTY P-4 Translator/Reviser (English).

${ }^{675}$ LinkedIN, Phillip Hepburn.
} 
description of how she got the job, except for a phone call from an anonymous colleague, Elias-Bursać made no mention of the assessment method or required competencies to qualify her as a reviser of translations in a legal context at the time of her recruitment to this position.

As to the operational reality and substantive subject-matter, the war in the former Yugoslavia was never fought in the territory of Serbia proper: the borders between the countries that once formed Yugoslavia were closed, people could not travel freely for work, and from 1990 onwards Serbia was notorious for arbitrarily allowing and then forbidding the presence of international organizations in its territory. Consequently, it is unclear where language professionals recruited from Serbia would have gained their previous working experience "in the context of the UN or an international organization" as requested for most ICTY vacancies. ${ }^{676}$ With that in mind, apart from very serious ethnicity-related concerns, the full of extent of which is, hopefully, obvious from Appendices 3-5, the CLSS management has done an amazingly poor job in recruiting translators and interpreters who have had experience in translation and interpreting during conflict, namely those from $\mathrm{B} \& \mathrm{H}$ and Croatia where the war was actually fought, where all the peacekeeping and humanitarian agencies were actually deployed, and from where most victims and witnesses of the war against B\&H and Croatia originate.

Notwithstanding open examinations, although most staff with previous UN and international experience worked at the ICTY from the beginning, they were not granted the transition from GS-level to P-level positions and newcomers, veritable outsiders, were recruited. Doing so, the CLSS management deprived themselves a great deal of UN institutional knowledge from the region and created tension between the two types of staff. Elias-Bursać resumes commenting on the relationship between the two:

Unlike the interpreters and translators from the early years, the new hires were, generally, seasoned translators and interpreters, but they had less experience working in the war zone. They were not hired locally, as the earlier translators and interpreters had largely been, which meant that the new staff had more generous salaries and better benefits than did the staff from the early years. It is not difficult to imagine that there was a certain clash of cultures in the process: the staff who had been there since the beginning and had seen the worst of the war felt that the newcomers were privileged, with their higher salaries, yet inexperienced in matters of war, while the incoming staff felt superior in their mastery of the languages they worked in but saw the staff who had been there since the early years as canny insiders. These differences softened over time. ${ }^{677}$

The relationship, however, did not soften over time. The relationship between the two was further exacerbated by constant inquiries from OTP Language Assistants about B\&H and Croatia linguistic, cultural, and regional concepts, including outside the war context, that they did not understand because they were either from Serbia or foreigners to the region mostly educated in Serbia or working there at local colleges as assistants. The Serbs took over from the Croats in CLSS management, revisers, and staff majority with the change in management in 200o. However, their inability to cater to clients had serious repercussions on work as they gradually stopped translating witness statements, stopped interpreting for witnesses during proofing, and stopped working for the OTP in general. Naturally, since staff from Serbia took over with the change of management, the existing staff was scandalized both because of one-sidedness in the ethnicity of the new translators and interpreters and because CLSS management gave jobs to people whose output had to be constantly double-checked because they had no working experience in conflict, post-conflict, or international criminal tribunals. Consequently, this had an effect on quality because these candidates without any previous UN experience, in addition to having been trained, had also to be taught UN-speak and the entire indoctrinationfree background to the conflict. Most newly recruited staff had limited experience (translation of literary texts

\footnotetext{
${ }^{676} \mathrm{UN}$ vacancies, ICTY P-2 Associate Translator (B/C/S); ICTY P-3 Translator (B/C/S).

${ }^{677}$ Elias-Bursać, E. (2015), Translating evidence and interpreting testimony at a war crimes tribunal. Palgrave Macmillan: London, p. 27 .
} 
or texts for publications). The reader will understand that translating Shakespeare is not comparable with translating the law. Even without engaging in an in-depth discussion of the differences between the two types of texts for translation, it is safe to say that translating law requires painstaking precision to the point that translation delivered in a legal context must read like a translation and a translator cannot trick the reader into thinking that $\mathrm{s} / \mathrm{he}$ is reading the original like one would when translating a literary piece, for example. So, new translators had to be taught extreme discipline to leave the operational information intact. The new interpreters were no different either. Parties will normally furnish in-court interpreters with original and translated versions of documents they plan to use during the examination of witnesses. In one such instance, although furnished with an original and a translation, an in-court interpreter decided to substitute the existing translation with her own, translating the time-specific "hitherto" with time ambiguous "outgoing." The prosecution rightfully complained. After all, all this in-court interpreter had to do was read from the existing translation. And for that, she needed discipline ${ }^{678}$ Finally, since most verdicts clearly name the Serb perpetrator as the major attacker and instigator of attacks in the former Yugoslavia, this experience must have been extremely heartbreaking to these Serb staff who never stopped volunteering that they never knew about any events described in evidence they were working on. Unfortunately, they voiced those feelings even when nobody asked them, making it hard for staff directly affected by the war against B\&H and Croatia to move on with their lives or, at the end, to believe their claims: how can you not know? The victims were absolutely scandalized that their former aggressors interpreted for them or translated their documents. A few voiced their objections, without any response from CLSS or ICTY management, in particular from the Registrar. Staff who did were fired: CLSS reviser who was a professor from B\&H, a CLSS interpreter who was a legal dictionary maker from Croatia, and a CLSS translator from Croatia. All of them were also much better qualified than the existing management.

\subsubsection{ICTY CLSS language professionals: training}

The "UN criteria and standards" shows up like a buzzword again and again until the last annual, financial, and audit report analyzed for the purposes of this study. They make it sound like the criteria for recruitment of language professionals were set, as if there were set standards for translation and interpreting, and as if language professionals were afforded comprehensive training in subject matter and translation and interpreting in the legal context once taking up their duties in The Hague or in the field. If such criteria and standards existed at all at the ICTY, they would constitute the first set of criteria and standards for any type of translation and interpreting at an international criminal tribunal in the history of the world. Consequently, it is surprising that such criteria and standards were never published and/or presented during a conference and/or praised in any UN reports at the time or since and/or mentioned in any way by any other legal or investigating body or organization working with the assistance of language professionals or otherwise. Exhaustive five-year long research into the existence of such standards yielded no results. The ICTY Manual on Established Practice dances around the issue of criteria and standards, as well, without ever actually mentioning these criteria and standards or taking credit for their establishment, development, or publication, either. ${ }^{679}$ In part where it discusses translation and interpreting, the ICTY Manual can be described as a series of buzzwords, at best. In it, CLSS recommended certain measures to overcome challenges, but the way these have been worded cannot be said to constitute established practices or that they are appropriate for a manual on developed practices, as such. Indeed, they are but a series of recommendations for a next should-would-could language service at the next should-would-could international criminal tribunal. CLSS did not address the manner in which they overcame or coped with any of the established challenges they acknowledged. The fact that they claim that "only certain documents need to be translated into the language of the accused" is a distortion of the obligations of the OTP (see ICTY RPE Rule 66 which very clearly defines types of documents that have to be provided to the accused in their own language). The fact that the ICTY put their foot down on responsibility for trans-

\footnotetext{
${ }^{678}$ ICTY transcripts, Krstić, T. 6910.

${ }^{679}$ ICTY, Manual on Developed Practices (2009), para. 83.
} 
lation remaining with the CLSS suggests ICTY's acceptance of the CLSS's inability to self-regulate. It also suggests deep client dissatisfaction with their work. Although it is a manual on established practices, the rest of it relating to translation and interpreting discusses obligations on the parties vis-à-vis translation and interpreting matters as if investigative, prosecutorial, and appeals process can be predicted, also addressing matters that the CLSS should do. What they should do includes, according to the Manual, unfortunately, training on almost every aspect of their engagement with legal professionals, and translation and interpreting in the legal context 16 years into their existence. ${ }^{680}$

The problem here is that "criteria and standards" is not a mere buzzword or a platitude that one throws around, but an operational premise: it is a guideline for how something needs to be done in a specific context, supported by examples from practice, and reasoned by lessons learned. The organization simply must have it in the form of a document both for future in-house use and to assist future organizations. However, the main owners of the CLSS working methods, the ICTY revisers, have never understood legal professionals' process of arriving, accepting, and saving the facts. Here, Hepburn, the former ICTY CLSS English Translation Unit Chief and reviser, relates another worrying aspect of the CLSS revisers' job:

\begin{abstract}
The search for terminological consistency nevertheless remains an endless task, especially given the duration and interconnectedness of proceedings. Since documents translated in one case may be used again many years later in another case, translators can rarely afford the luxury of making a fresh start and must align their terminology with what has been used in the past. When new information comes to light that suggests that the existing translation of a term is inadequate (for example, when translators finally discover the real meaning of a term which they have previously translated literally), the database is updated, and translators are informed. If this results in discrepancies between new translations and translations of other documents that were done previously, it may become necessary to revise the old translations as they come up in the new trial. ${ }^{681}$
\end{abstract}

This is worrying for several reasons. First of all, this is yet another proof of an absolute lack of any on-the-job training in the CLSS. This issue is discussed at length in every chapter of this study. Secondly, it seems that the CLSS revisers left their translators alone until they "finally discovered" an appropriate translation all on their own. Obviously, this is wrong because it hints at the non-existence of any collaborative effort, a priori knowledge of the trade, or understanding of the junior-senior system of patronage present in all organizations. And, finally, revising "old translations as they come up in the new trial" should send chills down the back of anyone working in the legal fora. Adjudicated facts of any trial are adjudicated facts: legal professionals are done with those facts in that trial and they have surrendered them to the realm of case law. If legal professionals want to change anything in adjudicated facts, then they declare a mistrial, issue an apology to everyone, or the governmental system collapses. Here, it seems Hepburn suggests that CLSS translators or revisers went back and revised "old translations" to fit new cases. Did the legal professionals know about that?

Exhaustive research of the official ICTY site and the Court Records revealed a series of documents where parties made motions at resubmission of wrong or corrected translations due to the mistakes in filing, ${ }^{682}$ where parties spotted a translation error, ${ }^{683}$ or where parties requested submission of full instead of

\footnotetext{
${ }^{680}$ Ibid, p. 183-186.

${ }^{681}$ Hepburn, P. (2012), The Translation of Evidence at the ICTY: A Groundbreaking Institution. Translation and Interpreting Studies, 7(1):54-71, p. 66 .

${ }_{682}$ ICTY, Order RE exhibits 6D202 (2008); ICTY, Order RE exhibits 6D132 and 6D1496 (2008); ICTY, Second order on exhibits P2885, 1D279, 1D671, 4D3, 4D95, 4D106, and 5D272 (2008); ICTY, Registrar's Certificate on Technical Error in Translation (2001), and many others.

${ }^{68_{3}}$ ICTY, Decision on Prosecution request for extension of time to submit corrected translation of exhibit P942 (2007); ICTY, Order RE exhibit P1999 (2007); ICTY, Order RE exhibits P2166 and P1506 (2008), and many others.
} 
partial translation on the record, ${ }^{684}$ etc. Further research has shown that motions accepting revised translations were granted in cases where translation was replaced with the revised version because the previous versions were in draft format, where parties argued for different terminology, because the existing translation contained errors or omissions, where parties wanted the viva voce interpreting to be replaced by an official translation of the testifying witness' utterances, or most of the above. All these interventions by the parties are entirely normal. What is not normal is going back and revising translations once they were used to arrive at adjudicated facts. Documents used at arriving to adjudicated facts simply cannot be revised post factum. There was not a single document saying, "At the insistence of the CLSS, parties submitted the following new and revised translation of an earlier accepted term." As shown before, CLSS did not have any official Interpretation Monitor or transcript checker and this could have been done only arbitrarily. What is worrying is that there is no way of knowing whether revision of "old translations as they come up in the new trial" by the CLSS staff or revisers has indeed happened as claimed, to what extent, and whether it was done for any ulterior motives. At this point, it is unclear whether those documents have not yet been stored at the official ICTY site and the Court Records, which are in no way perfect or fully updated with documents and information (2017), or whether the incorporation of revised "old translations as they come up in the new trial" is in any way legalized for the purposes of the ICTY. The latter seems unlikely.

The following excerpt from a book on investigating sexual violence authored by ICTY staff describes ICTY CLSS training efforts.

Virtually all victims of sexual violence before the ICTY have required the presence of interpreters fluent in [...] (B/C/S) or Albanian for interviews. These interpreters have been primarily women, close in age to many of the female sexual violence victims interviewed. Having participated in scores of interviews with sexual violence victims, these dedicated OTP staff members have provided particularly poignant insights regarding the need for more preparation of interpreters, investigators, and prosecutors who interviewed these victims. The absence of preparation in the early days of the OTP's operation was largely a reflection of the fact that nobody had previous experience with these types of cases or knew what to expect. Now, however, the situation is different and the pressing need to provide more training and support for interpreters and others involved in interviews of conflict-related sexual violence victims is clear, entirely feasible, and a crucial insight for the future.

None of the interpreters interviewed by the PSV Working Group received any training before participating in interviews with sexual violence victims. They struggled when the investigators or lawyers used technical terminology for sexual acts that the victims did not understand - such as 'penetration' or 'fellatio' - or were vulgar when translated into the witness's language. The terms used by investigators also did not correspond with slang terms used by witnesses. The ICTR faced similar issues and has stressed the importance of acquiring knowledge regarding 'the language the victim may use to describe sexual acts, sexual violence, and genitalia' prior to interviews.

Interpreters were also not adequately prepared for dealing with traumatized victims. Some did not know that the witness would be talking about sexual violence, and the interpreter was sometimes the first person the victim had spoken to about the crimes. One interpreter interviewed in 1998 after three years of interviewing missions explained: I really resent the lack of guidance at the beginning. When they start crying, what do you do? Hug them? I didn't know what to say and you can't say anything without telling the investigator what is going on. We had to learn on our feet.

Maintaining distance from the trauma experienced by witnesses can be particularly difficult for interpreters. Their role is to communicate what the witness is expressing, which can become charged with the witness's

${ }^{684}$ ICTY, Decision on matters relating to certain documents and transcripts (2014), and many others including the above. 
emotions. Interpreters should be briefed about these effects beforehand and learn mechanisms to handle the negative effects. ${ }^{68}$

Although revealing major problems due to a lack of training, the pedantic and shallow description requires commenting on the gender and age of interpreters assigned to work with rape victims. It is not entirely true that interpreters have been assigned because of gender and because of closeness to the age of victims - the author has worked with many men and women victims of rape and they have all been much older than the author; the same practice was observed with other interpreters. It is not entirely true that interpreters struggled with "technical terminology" used during interviews with rape victims, but, because the victims were much older and because they were from different backgrounds they did not understand clinical expressions, such as "Did he rape you vaginally/orally/anally?" This is the reason why these would be interpreted into "Did he approach you from the front/mouth/back?" The biggest failure at training is that the ICTY and CLSS management did not realize that interpreters did not have to know how to work with victims by virtue of their education. Legal professionals had to be trained to know how to do it and, in cooperation with legal professionals, CLSS could have and should have provided appropriate training on these matters. Since that never happened, interpreters walked on eggs around each other, waiting for an auspicious moment where someone would break down to listen for the triggers between the sobs and learn how to work with victims at least without breaking down during the actual interview. As someone who has interpreted for hundreds of rape victims, concentration camp inmates, survivors, the author must remark that assigning people to perform work for which they are not qualified, prepared, or trained is the cruelest thing anyone could ever do to anyone, but that was the modus operandi of the ICTY and CLSS toward language staff.

Chapter 4 provides contemporary data on a specialized school for translators and interpreters leading to a degree. However, none of those schools existed in the former Yugoslavia before 1992 when the wars started. A very few staff who did have a degree in translation or interpreting obtained them abroad. Given the fact that the former Yugoslavia was governed by the socialist system and that the countries that were created after the collapse of the former Yugoslavia became countries in transition, regular courses on, at least, the basics of continental or international criminal law should have been taught. ${ }^{686}$ The ICTY organized various types of in-house training courses for legal professionals in the field of advocacy, international humanitarian law, and to prepare them to conduct their duties, but it seems these training courses did not include language professionals. Although CLSS claims in their online presentation to have been staffed with "highly qualified and certified court interpreters and translators specializing in legal translation" that is, for the reasons advanced before, more than stretching it. Institutional translators in the former Yugoslavia worked mostly in domestic companies that were doing business with foreign companies and could be classified as technical

\footnotetext{
${ }^{685}$ Brammertz, S. and Jarvis M. (eds.) (2016), Prosecuting Conflict-Related Sexual Violence. Oxford University Press: Oxford, UK, p. 101.

${ }^{686}$ Although ICTY Recruitment and Training Office was established in 1993 with the establishment of the ICTY, it is completely unclear from the data how much staff training this office has actually provided or when they actually started providing training. At any rate, none of this stopped them from internally evolving: the "training" component of this Office had a Career Development Unit which transitioned into Career Transition Unit. Again, it is hard to establish when these sections started with career development and career transitioning activities because they are scarcely mentioned in ICTY ARs under examination and, if at all, then in passing. The ICTY trainings were twofold: those targeting the region and those targeting ICTY staff, specifically legal professionals. As far as those trainings targeting the region are concerned, 2012 ICTY AR exclaimed that a total of 14,00o people in the former Yugoslavia have been trained through seminars, workshops, and training (2012 ICTY AR, para. 91). As to the ICTY staff, both categories provided and received training both by in-house and by external resources. The first, and the only time anything substantial has been said about any of these trainings was in the 2002 ICTY AR where it has been stated that the in-house training courses which cover the history of the conflict, the warring factions, violations covered by the ICTY-S, individual criminal responsibility, and practice before the ICTY have been developed by the international legal advisers and given twice a year (2002 ICTY AR, para. 237). ICTY staff training numbers are reported as following: almost 30 staff (2001 ICTY AR, para. 274), over 400 (2002 ICTY AR, para. 316), 350 (2003 ICTY AR, para. 335), 568 (2004 ICTY AR, para. 383), more than 9oo (2005 ICTY AR, para. 247), more than goo (2006 ICTY AR, para. 110), 1,100 (2007 ICTY AR, para. 117) and 950 (2008 ICTY AR, para. 115). After 2008, information about the training abruptly stops. No ICTY ARs under examination ever mentioned any training relating to languages, translation, interpreting, or transcribing.
} 
translators, at best. ${ }^{687}$ Moreover, no ICTY vacancies to the position of translators and interpreters ever mentioned the requirement of court certification. This renders the claim about CLSS language professionals working at P-level positions as court certified moot and makes it clear they have been considered court certified only because they worked for the court; it is declarative pedantry, not a reality. CLSS staff report that CLSS management organized only one translation training session for $\mathrm{B} / \mathrm{C} / \mathrm{S}$ and English translators and three for English and French translators from its establishment in 1993 until today (2017). This was further confirmed in Elias-Bursać's survey of CLSS language professionals:

When asked about further training, a Most of survey participants indicated that they had not received any further training while employed $(56.5 \%){ }^{688}$

The way this information is presented may be misleading. As soon as the ICTY Completion Strategy was announced in about 2004, the ICTY started organizing all sorts of cross-training activities: language staff could be cross-trained in whatever ICTY section offered training. For example, a colleague who normally worked as a language professional in UNDU requested and received cross-training in procurement, another one in administration, etc. So, it is not the case that $43.5 \%$ respondents to Elias-Bursać survey of CLSS language professionals received training in translation and interpreting: these respondents received some training within the overall ICTY cross-training drive aimed at making the soon-to-be-separated staff more competitive on the open market. There were some CLSS translators who cross-trained to become interpreters. That cross-training was open to CLSS staff only. Although many participated, thus being away from the office, only one successfully transitioned and was later used as a conference interpreter. Field interpreters interviewed for the purposes of this study were adamant that they never received any training and that the only communication they ever had with CLSS was when CLSS administrative staff would contact them for booking. A few field interpreters were confused when CLSS was mentioned, stating that they did not know what CLSS was, as they were under the impression that investigators were in charge of field interpreters because they were the ones who called to book them and brought them their contracts to sign. As to the actual training needs, EliasBursać's survey clearly shows that CLSS language professionals have not had much experience in translation and interpreting, knowledge of the substantive subject-matter, or the region prior to taking up their duties at the ICTY. ${ }^{689}$

I am so glad I worked in the CLSS as it enabled me to develop my skills-while I was there I started to do interpreting and I was involved in testing and recruitment which all stood me in good stead for my next job.

The progress made over two years of service at the ICTY as an in-house interpreter, and as freelance thereafter. The initial lack of knowledge in the very beginning turned into an in-depth knowledge of the region and its recent history.

What I preferred in that experience were the people: not only did I find quite a few friends from university, whom I had not seen for twenty years, but I also met new friends, many of whom will stay on for life. ${ }^{690}$

The initial challenge was to understand the roots and the dynamics of the conflict (not being from the former Yugoslavia) and to embrace new legal concepts (having had no previous experiences in criminal law).

\footnotetext{
${ }^{687}$ ICTY, Translation and interpreting.

${ }^{688}$ Elias-Bursać, E. (2015), Translating evidence and interpreting testimony at a war crimes tribunal. Palgrave Macmillan: London, p. 271.

${ }^{689}$ Ibid, p. 262-271.

${ }^{690}$ Ibid, p. 37-38.
} 
Fighting for the idea that international and anglosaxon [sic] legal terms which do not exist in ex-Yugoslav legal system have to be given new names in $\mathrm{B} / \mathrm{C} / \mathrm{S}$ instead of being reduced to the nearest existing terms. ${ }^{61}$

Given the scarcity of training on substantive subject-matter in CLSS confirmed by many sources, the above "development of skills" could be taken to mean that individuals were assigned by CLSS management to random tasks - from interpreting to testing and recruitment - without any prior training or any documented experience in any of those tasks. It is unclear how good they were in any of those tasks as beginners. It is equally unclear how fair this trial-and-error approach to testing and recruitment was for the actual candidates who were obviously "practiced on" by someone without prior experience in interpreting or testing and recruitment. CLSS claimed to be conducting competitive examinations in The Hague and abroad in almost every ICTY AR under examination during the second CLSS management period between 2000 and 2007. Obviously, the reason why these exams yielded no satisfactory number of candidates was not because they were competitive but because they were made by the same people who claim to have been at the ICTY CLSS to develop their skills. Activities relating to the testing and recruitment of language professionals into ICTY CLSS have been left to CLSS management, who surrounded themselves with inexperienced people. That affected their internal functioning and external client satisfaction. Internally, the first respondent to Elias-Bursać's survey of CLSS language professionals almost verbatim stated that recruitment to positions in CLSS was a process of trial and error. Externally, there was a lot of in-house criticism of CLSS management regarding the way they made these exams, because it could hardly be said that these were exams preparing language professionals for any form of legal environment. Most of these exams were excerpts from biographies of famous people or from Serbian surrealist literature of the 1980s and early 199os. They had absolutely nothing to do with language professionals working in a legal context. After the failed staff started contacting internal UN criminal justice authorities en masse, complaining about the sheer inappropriate character of the translation exams, CLSS took all criticism on board and the new exams started incorporating excerpts from local laws. Knowing all this, it is hard to trust the work delivered by the 614 people CLSS put on the roster and all others they hired based on these exams.

Although CLSS language professionals recruited during the second management period had no previous knowledge of the substantive subject-matter or the region and they were recruited after passing nonsensical exams, it is entirely possible that their knowledge of the substantive subject-matter amounted to solid knowledge of the facts. However, one respondent pointed out that it took him ten years. Why would it take anyone ten years to gain in-depth knowledge of the substance matter or the region even as newcomers to the business?

The physical separation of CLSS from the Tribunal's main seat means that translators are working in isolation from the events to which their translation material pertains.

It's a pity there is no real contact with other services that were in the Main building [the seat of the OTP and courtrooms]. The hierarchy is also quite untouchable. ${ }^{692}$

Respondents claim to have been isolated from the rest of the organization: instead of immersing them in work, embedding them in teams with the parties, CLSS management completely isolated them from the whole process. Yet ICTY and CLSS administration were housed in a separate building which was an easy walk from the main ICTY building and the French translation unit was located at Scheveningen, which was a tenminute car ride away.

\footnotetext{
${ }^{691}$ Ibid, p. 40.

${ }^{692}$ Ibid, p. 44.
} 
It seems from the above first set of comments that CLSS was a collection of long lost friends and colleagues. The question whether they all came together because they got the same phone call as Elias-Bursać seems to have been answered: employing people in managerial positions in CLSS without any relevant education, working experience, or on-the-job training has been a trend. Searches were made into other CLSS revisers and section heads, leading to the shocking discovery that for most of them working at the ICTY was the first working experience in their lives. Despite that, they climbed through the ranks pretty quickly and some of them became revisers or heads in less than five years. All this was in violation of the previously discussed 1999 OIOS Report and its findings about the need for consistent application of placement and promotional policies for vacant positions and the need to stop allowing promotions without meeting the necessary seniority requirements. ${ }^{693}$ However, since none of these CLSS managers and staff have written anything about their engagement at the ICTY, there is no point presenting their professional profiles here. The motivation for conducting that research was curiosity and the findings are presented just as they are: a curiosity. Normally, staff do come and go, some are good, and some are bad, some are appointed on merit and some not at all, and some are trainable, while some are not. Inappropriately recruited staff could be easily ignored, but the main problem here is that revisers are the main movers and shakers in any translation department. Revisers do not just appear out of nowhere. Revisers must have attained a certain level of education, must have had previous hands-on working experience, must have had in-depth institutional knowledge, and must have had been in the institution for a certain period of time before being recruited to those positions. An AITC colleague, a retired reviser, interviewed for the purposes of this study said he became a reviser after 23 years of service in a single UN agency. He laughed at 614 freelancers being on the CLSS roster (email on file). Most importantly, this CLSS word-of-mouth recruitment method that replaced the 'being at the right place at the right time' recruitment method practiced during the first management period had a major flaw: whereas it could be true that good professionals know other good professionals, once those good professionals start recommending others from a particular country and with a particular ethnicity, that amounts to brazen and rampant discrimination. Right under the nose of legal professionals practicing before an international criminal tribunal that was established to adjudicate on ethnically motivated crimes.

Finally, despite the lack of previous experience and substantive subject-matter, dubious recruitment practices, and the "deaf leading the blind" process in translation and interpreting, how was the overall atmosphere in the CLSS? Elias-Bursać calls the following comments respondents made on the most challenging aspects of their work "administrative matters."

I could cope with war criminals, war victims - them I could understand. Stupid and insensitive management I could not.

Surviving in the culture of the CLSS.

Politics and manipulation on a higher level, ... favouritism (in the unit), lack of consistency.

Dealing with people's vanities.

Managerial incompetence all across the ICTY. ${ }^{694}$

Incompetence and unsuitability for a job will out: no matter how hard the incompetent and the unsuited try, their incompetence and unsuitability will show. Here, CLSS staff described CLSS management as the ABC of ineptitude. It is regretful they did not do that publicly and when all this was happening but let us assume that this was all expected: there is bound to be some Monday morning quarterbacking by the watercooler in any

\footnotetext{
${ }^{693} \mathrm{UN}$, OIOS Report on the audit and investigation of the ICTY (A/54/120) (1999), paras. 17-18.

${ }^{694}$ Elias-Bursać, E. (2015), Translating evidence and interpreting testimony at a war crimes tribunal. Palgrave Macmillan: London, p. 42-43.
} 
organization and there is bound to be some confusion in any new institution. The last war crimes tribunal closed doors 40 years ago, so employment of experienced people was impossible, and it is human nature to put material benefits before moral objections. But, CLSS staff were set for failure from the start because their management were a failure. And CLSS management were a failure because not planning for staff recruitment and concerns taking languages and linguistic variants into account, as well as staff training is planning to fail.

Having said all this, was CLSS staff only dissatisfied with CLSS management? Elias-Bursać introduces the following comments, calling them "criticism of the Tribunal's mission":

Dissatisfaction with many ICTY judgments.

Trying to persuade my peers that none of it mattered one jot, that the tribunal was deeply biased.

At times (I stress not all of time, but at certain times, particularly around 2005 onwards), I actually felt ashamed to work there, such was my discomfort with some of the judgments in later cases. ${ }^{695}$

The judgments from 2005 onwards included the acquittals of suspected war criminals in cases of alleged crimes against the Serbs in Croatia (Gotovina et al), the Serbs in B\&H (Delić, Halilović, Orić), and the Serbs in Kosovo (Haradinaj et al). The Serb staff at the ICTY seems to have been in a permanent state of angry spasm over these acquittals. They also seemed confident enough in their position that they had no reservations committing their complaints to a paper planned for publication so candidly. The above excerpts confirm that. Some would see the above comments as a matter of institutional allegiance: how can a translator voice an informed opinion about judgments? These could also be interpreted as instances of harassment: how could staff feel free to go around the office persuading colleagues that "none of it mattered one jot"? How could management have allowed that? Also, if "the tribunal was indeed deeply biased" and if one "actually felt ashamed to work there," why not quit and move on? It needs to be said that none of these people took a moral stand: there is no evidence that they quit over this. So, it seems plausible to ask: was there an ulterior motive behind staying at the ICTY? $?^{696}$

\footnotetext{
${ }^{695}$ Ibid, p. 43.

${ }^{696}$ Since these comments touch upon the core reasons behind the establishment of ICTY, insisting on reciprocity in punishment and pointing at institutional disloyalty amounting to denialism, the author of this study asked a colleague investigator who is presently working in an investigation unit setup in a system of internal UN justice to unofficially comment on the above statements: "One must consider those type of comments as personal opinion unless they are backed with facts and/or examples to show as evidence. In the UN System all around the world, I would guess, that a large percentage of its personnel have become disillusioned, frustrated and even discouraged in relation to the UN's effectiveness, efficiency and overall achievements over the last several decades. Yes[,] many of these comments may appear to be counterproductive to the UN in general and probably even more in specific missions and units. In my experience in the UN, I have seen some offices to be quite dysfunctional in terms of its inter-personal relationships and working environments which often leads to low productivity, stress-related incidences and high attrition. This goes a long way in damaging the organizations reputation and the moral of its employees. Some of it relates to abuse of authority by senior personnel and managers, low pay scale for national staff in comparison to the high pay scale of the internationals and as well the country context (war torn, poverty, disaster stricken etc.). As an investigator conducting oversight investigations (some related to harassment and abuse of authority) it is important in my opinion to take into considerations the moral of the office's personnel, especially when I hear comments such as those you describe from the book. I think they should be a cause for worry especially among senior managers and it is their duty to make every effort to rectify the problems resulting in these negative comments. However, I can't see how those type of comments are grounds for dismissal unless, an employee goes public in an attempt to damage the UN's reputation. There are rules about giving public opinions. But in order to prove some type of wrongdoing by that someone who makes such comments, it will be a difficult task in my opinion. Hearing comments with negative tones often occurs when our personnel feel that they have been shortchanged, either with career advancement, salary increases or disciplinary issues. The UN has in place several systems for receiving complaints related to the topic of this discussion. Ethics, Ombudsman and HR offices are now trained to deal with these issues. In addition[,] freedom of speech is one of the human rights that the UN fights to uphold, however, there may be contractual issues which prevent staff from speaking openly like this about their experiences, if they are specifically related to their work. Usually, I think ICTY lawyers should have a look at the book before it goes out. (I know people [sic] like ["]American Sniper["] had to be cleared by the
} 
Finally, how did all this reflect on relationships between former Yugoslavs with different ethnicities now working together to reveal the underlying causes of the conflict. The overall take of CLSS managers on the wars in the former Yugoslavia was that everyone was guilty and that everyone was a victim. CLSS managers, headed by Elias-Bursać, brought to The Hague the poster child of the now dead brotherhood and unity in former Yugoslavia in the aftermath of its 'murder' by the Serbs and the Croats, Svetlana Broz, to give a speech to the ICTY staff. ${ }^{67}$ Broz is Tito's granddaughter and she wrote a book entitled "Good people in evil times," translated by Elias-Bursać. This is a collection of stories about people who helped their neighbors, regardless of ethnicity, during the war in the former Yugoslavia. Broz blames all the leaders of the nationalist parties for the crimes committed. ${ }^{698}$ However, instead of pointing fingers at abstract entities, the ICTY trials have unambiguously shown that there was one very clearly distinguishable victim in B\&H: Bosnian Muslims. A colleague shared the following story:

I was fresh out of college when I started working in the CLSS as a support staff employed on GS-level. Although I was a support staff mainly working on administrative matters, my functional title was Language Assistant, so they tested me for that position. During the interview, I was asked about my education. I was very proud of my academic achievements. B\&H is a typical European country in that some students spend years in college whereas I completed my studies in four. As soon as I said I had a university degree in the Bosnian language, the panel members burst laughing. When they came to, they asked me to define that language. They also asked if I could read and write Cyrillic and, if so, where did I learn it. I said I learned it in the second grade of the elementary school, because B\&H educational system uses both Latin and Cyrillic script. They all got very serious when I said that. They told me I couldn't have learned it in school and concluded for me that I must have learned it by myself. I was commended for my initiative. The rest of the interview consisted of them, practically, continuing to laugh at me whenever the topic of Bosnian language came up. I felt very strange.

As soon as I arrived in the office, the judgment in Delić was read out. I was in the office with colleagues from Serbia. I was very excited to watch my first verdict in real time. The whole office stopped work and followed the reading of the verdict on the Intranet. As soon as the judge declared Delić not guilty, chaos started: colleagues from Serbia started cussing and cursing, screaming even. They all stood up and either left or started pacing up and down the office. Some of them were looking at me saying "How could this have happened? This is bullshit. Is there anyone in this Tribunal guiltier than him?" as if expecting an answer from me. The whole situation was very dramatic. I did not know who Delić was. I did not know what Delić could have done in B\&H to affect them who were from Serbia so much. Later I learned he was tried for relinquishing his command control to mujahedeen in B\&H with repercussions on all in B\&H. I felt highly uncomfortable. I was the last who left the office that evening. I went to Scheveningen that night and just walked on the beach wondering what I have got myself into. I stayed with the CLSS for about four months. I left as soon as I got a chance (email on file).

So far, a review of CLSS management has shown the following: examinations and recruitment catered to a specific ethnicity and resulted in reunions of friends, lovers, college, and other colleagues; there was no substantive subject-matter training; CLSS was isolated from the rest of ICTY; CLSS staff had a poor regard for management, and CLSS catered to pre-war bigoted views of B\&H and Muslims. Fine. None of this matter because, after all, everything comes down to money. So, as a section entirely funded by the UN, what about the CLSS budget?

\footnotetext{
military before allowing the movie to go out because he had a special contract). Generally, the UN doesn't care about disenfranchised staff shooting their mouths off - it's usually from the lower ranks, and is gossip and banter, unsupported by facts. Remember the so called female whistle blower who made the movie about Bosnia. [T] his was very questionable. From my perspective, the comments you suggest are not surprising and personally I would not react to them all that much unless I was officially investigating an issue in an office affecting staff morale[.]" (email on file).

${ }^{697}$ Petejan, S. (undated), Interview with Svetlana Broz.

${ }_{998}$ Broz, S. (2008) (excerpts), Good people in times of Evil (Ellen Elias-Bursac, translator).
} 


\subsubsection{ICTY CLSS language professionals: staff retention}

In the 2000 ICTY AR, CLSS addressed their continual inability to find any translators or interpreters, stating that the available language professionals were unwilling to work in The Hague. The same wording appeared in the 2001 and 2002 ICTY ARs, whereas the problems related to the recruitment of qualified language professionals was the Leitmotiv of all subsequent ICTY ARs. However, there are several problems with this excuse. In 2000, The Hague had been the undisputed capital of international justice for about 100 years. Moreover, The Hague is the capital of a country that has been ranked among the first five countries of the world regarding human development since the inception of the UNDP Human Development Report in 1990. ${ }^{699}$ It is unclear why CLSS management found it hard to recruit anyone in the capital of international justice situated in a highly-developed country. Let us explore the underlying reasons for these recruitment-related problems in an example of French language staff who CLSS claimed were nowhere to be found.

As shown in Chapter ${ }_{5}$, AIIC and AITC are recognized as partners by the UN and they have 917 and 214 members with French as the language of translation/interpreting into, respectively (October 2017). French language professionals can, theoretically, work anywhere in the UN System, providing they pass the UN DGACM or other UN System entities' entrance exams, and they are widely available because French is a UN language. ICTY CLSS would hire mostly young and inexperienced French language professionals, who they would then train to work in the context of an international criminal tribunal for about one year, just like all other staff. Once that year passed, CLSS would lose these French language professionals to other UN System entities. CLSS management reports that they had about ten core French language professionals who had been with them since the beginning and that about 20 other staff changed every two years or so (2017 data). After this two-year limit, staff would leave as soon as they could mostly because ICTY is not a permanent organization. It is human nature to strive for certainty, so those motivations are more than understandable. But, it is highly illogical these other organizations would take CLSS's staff, as CLSS claimed: if you take staff who were trained to work in an international criminal tribunal and you are not working in that context, as is the case with almost all other UN System entities, you will have to retrain them anyway. There were no other international criminal tribunals which could have "stolen" French staff from CLSS until 2002 when the ICC was established, and 2006 and 2007 when the ECCC and STL were established, respectively. The ICC did, indeed, come as a pleasant surprise to ICTY language professionals and almost everyone with ICC language combinations hoped to get a job at the ICC mostly because it is a permanent organization. However, it is the author's personal observation that the ICC has always been reluctant to take on ICTY staff. Fewer than ten former ICTY language, legal, and support staff colleagues work at the ICC and most them got those jobs after the change in ICC overall management in 2012. Most of them were hired at a lower grade than that at which they worked at the ICTY. Moreover, a number of investigators left ICTY in about 2004 to work with UNDP Food for Oil Program to the chagrin of the ICTY management because they were left without almost any investigators. Following the less than glorious closure of the UNDP Food for Oil Program and the renewed availability of these investigators in the international criminal law market, ICTY management made a point of never employing any of those investigators again. Finally, I have also been privy to a discussion during a meeting when ICTY OTP manager publicly warned a manager from a different The Hague-based international criminal tribunal about taking ICTY staff without his consent. One explanation is that French language professionals have been using ICTY as a springboard to steadier or permanent employment in other UN System entities, leaving ICTY without core staff. If so, that requires clear communication between UN agencies about recruitment issues. If French language professionals wanted to leave, the ICTY could not have provided them with additional incentives to stay like a "normal" company would, due to various UN promotion restrictions, which means they could lose them forever.

\footnotetext{
${ }^{699}$ UNDP, Human Development Report, The Netherlands.
} 
However, there is more to permanently losing trained staff. CLSS could always retain them on their list of permanent freelancers. This seems to be CLSS practice as is confirmed by one of the respondents to Elias-Bursać's survey. ${ }^{700}$

Table 10. Short-term, SSA and consultants and individual contractors' agreements between 2000 and 2007

\begin{tabular}{|l|l|l|l|}
\hline Year & \multicolumn{1}{|c|}{$\begin{array}{c}\text { Short-term appointments } \\
\text { court reporters and confer- } \\
\text { ence interpreters) }\end{array}$} & $\begin{array}{c}\text { SSAs (field interpreters, expert } \\
\text { witnesses, exhumations pro- } \\
\text { ject, Witness Assistants) }\end{array}$ & \multicolumn{1}{|c|}{$\begin{array}{c}\text { Consultants and individual } \\
\text { contractors }\end{array}$} \\
\hline 2000 & 260 & 770 & n/a \\
\hline 2001 & 323 & 869 & n/a \\
\hline 2002 & 497 & 676 & n/a \\
\hline 2003 & n/a & n/a & 693 \\
\hline 2004 & n/a & n/a & 320 \\
\hline 2005 & n/a & n/a & 185 \\
\hline 2006 & n/a & n/a & 185 \\
\hline 2007 & n/a & n/a & 150 \\
\hline
\end{tabular}

So, how financially sound were these efforts at staff retention? There were 4,928 short-term appointments (court reporters and conference interpreters), SSAs (field interpreters, expert witnesses, exhumations project, Witness Assistants) and consultants' and individual contractors' agreements issued by the ICTY for language professionals. However, hiring staff under these arrangements is much more expensive than engaging permanent in-house staff because remuneration of temporary staff includes various social security-related components and living and travel costs, as well. The UN 1982 Administrative Instruction on Temporary staff and individual contractors sets out that temporary staff shall be used for less than a year and for a maximum of six consecutive months, it approves special contractual arrangements for language professionals, and establishes they will be paid at an agreed daily, weekly or monthly rate of payment, or on the basis of a lump sum payment or other agreed rate representing the value of the services provided to the organization. ${ }^{701}$ The following table cross-references regular salaries of UN staff (internal language professionals ${ }^{702}$ with temporary externally hired translators ${ }^{703}$ and interpreters. ${ }^{704}$

Table 11. UN-wide annual, monthly, and daily remuneration of internal and external language professionals

\begin{tabular}{|l|l|l|l|}
\hline \multicolumn{1}{|c|}{$\begin{array}{c}\text { Internal language profession- } \\
\text { als }\end{array}$} & \multicolumn{1}{|c|}{ External translators } & \multicolumn{1}{|c|}{ External interpreters } \\
\hline $\begin{array}{l}\text { P-1/I-1 } \\
\text { core }\end{array}$ & $38,056+13,357$ & $309 \cdot 4+311$ DSA for each day & $420+311$ DSA for each day \\
\hline Annual & 51,413 & n/a & n/a \\
\hline Monthly & $4,284 \cdot 41$ & $13,028.4$ & 15,351 \\
\hline Daily & 204 & 620.4 & 731 \\
\hline $\begin{array}{l}\text { P-2/I-2 } \\
\text { core }\end{array}$ & $47,803+16,778$ & $390.8+311$ DSA for each day & $630+311$ DSA for each day \\
\hline Annual & 64,581 & n/a & n/a \\
\hline Monthly & $5,381.75$ & $14,773.8$ & 19,761 \\
\hline Daily & 256 & 701.8 & 941 \\
\hline P-3 core & $57,379+20,140$ & $471.4+311$ DSA for each day & n/a \\
\hline Annual & 77,519 & n/a & n/a \\
\hline
\end{tabular}

${ }^{700}$ This data has been taken from ICTY 2000 AR (para. 242); ICTY 2001 AR (para. 274); ICTY 2002 AR (para. 316); ICTY 2003 AR (para. 335); ICTY 2004 AR (para. 338); ICTY 2005 AR (para. 247); ICTY 2006 AR (para. 10o); and ICTY 2007 AR (para. 117).

${ }^{701} \mathrm{UN}$, Administrative Instruction on Temporary staff and individual contractors (ST/AI/295) (1982), paras. 6-15.

${ }^{702} \mathrm{UN}, \underline{\text { Salaries in the professional and higher categories. }}$

${ }^{703} \mathrm{UN}, \underline{\text { Salaries for short-term translators. }}$

${ }^{704} \mathrm{UN}$, Salaries for short-term conference interpreters. 


\begin{tabular}{|l|l|l|l|}
\hline & \multicolumn{1}{|c|}{$\begin{array}{c}\text { Internal language profession- } \\
\text { als }\end{array}$} & \multicolumn{1}{|c|}{ External translators } & \multicolumn{1}{|c|}{ External interpreters } \\
\hline Monthly & $6,459 \cdot 91$ & $16,430.4$ & n/a \\
\hline Daily & 307 & 782.4 & n/a \\
\hline P-4 core & $69,032+24,230$ & $568.5+311$ DSA for each day & n/a \\
\hline Annual & 93,262 & n/a & n/a \\
\hline Monthly & $7,771.83$ & $18,469 \cdot 5$ & n/a \\
\hline Daily & 370 & $879 \cdot 5$ & n/a \\
\hline P-5 core & $82,586+28,987$ & $681.7+311$ DSA for each day & n/a \\
\hline Annual & 111,573 & n/a & n/a \\
\hline Monthly & $9,297 \cdot 75$ & $20,846.7$ & n/a \\
\hline Daily & 442 & 992.7 & n/a \\
\hline
\end{tabular}

In other words, CLSS overpaid external translators and interpreters, who were making double, triple, and almost four times what in-house translators and interpreters were making. In return, CLSS could have hired almost three and, in some instances, almost four in-house language professionals, for the price of one external language professional.

CLSS had to cope with ICTY proclaiming French as an official language. This proclamation seems to have been supported by the ICTY lawmakers. In 200o ICTY AR, ICTY President Claude Jorda (1999-2003) remarked the following:

I can only regret that French, as an official language of the [UN] and a working language of the Tribunal, is under-represented, in particular with regard to internal communications. ${ }^{705}$

Spending money to translate internal communications represents an unnecessary waste of ICTY budget. The ICTY President clearly understood all those internal communications delivered to him in English. A UN BoA Financial report and audited financial statements 2004-2005 also pointed out disparities in bilingual documents at the ICTY in that nine decisions or judgments were available in English only and that at the end of 2003, only $75 \%$ of documents in English had been translated into French. That figure had dropped to only $69 \%$ by the end of 2005. A UN BoA 2004-2005 Report recommended that ICTY should ensure parity between the two working languages. ICTY pointed out that it had redeployed its resources with the aim of recruiting more French-speaking staff. ${ }^{706}$ French is an official language of the ICTY alongside English, so everything that exists in English must be translated into French and vice versa. However, ushering French into the ICTY linguistic equation was divorced from operational reality from the very beginning of this institution. There have been English-speaking trials and French-speaking trials at the ICTY, meaning Chambers included speakers of both languages. The translation of all court materials and interpreting into these two languages had to be made and could be described as justified. Chapter 4, Tables 5 and 6 showed the end results of those efforts. However, there have also been single UN language trials at the ICTY, mostly English-speaking trials, where the translation of all court materials and interpreting into both English and French cannot be said to be justified from a financial point of view. Elias-Bursać shares the following:

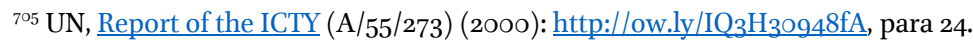

${ }^{706}$ UN, UN BoA Financial report and audited financial statements for biennium 2004-2005 ended 31 December 2005 (A/61/5/Add.12) (2006), paras. 46-48.
} 
After two or three years of translating everything into English and French, Chambers decided that this was too costly. CLSS and the judges agreed that documentary evidence would be translated only into English, even though the trials with a French chamber would still be run in French. ${ }^{707}$

Unfortunately, Elias-Bursać does not provide any reference for this, so it is unclear whether this decision was on paper, a result of private meetings, or just hearsay. Also, the Presiding Judge made the statement in the sixth year of the ICTY's existence, not "two or three years after" which means that "everything" was translated into English and French for at least six years. Elias-Bursać resumes:

\begin{abstract}
English and French are not on an equal footing, however, at the ICTY. Unlike at the ICTR, where most of the trials are conducted in French, most of the ICTY trials have been conducted in English. The only exceptions have been seven trials and two appeals (the trials: Erdemović, Blaškić, Aleksovksi [sic], Jelišić [sic], Hadžihasanović \& Kubura, Šešelj, Prlić et al, the appeals Kunarac et al. and Krnojelac) out of a total of 107 proceedings: 41 trials, 40 appeals, and 26 judgments for sentencing and appeals of sentencing. As this disparity would suggest, there are many resulting inequities. I regret to say that my study only perpetuates the imbalance by focusing largely on an Anglo-Saxon perspective of the court. ${ }^{708}$
\end{abstract}

Unfortunately, Elias-Bursać must be reproached again for doing too many favors in her study, a lack of selfregulation, and a lack of self-reflection: discussion about English and French at the ICTY does not revolve around perpetuating some chimerical imbalance due to this, that, or the other disparity and inequity, but is a matter of operational reality that is complicated by an obvious faire semblant approach to official languages. The question of the French language was a simple one: should it have been an official language, at all? Since French is an official language of the ICTY, all documentary evidence from trials and appeals above had to be translated into French eventually if tendered as evidence, because once they became an exhibit, they were an integral part of those proceedings. The faire semblant approach to official languages could even be said to be fine. The French-speaking ICTY staff cannot possibly be reproached for exercising their rights to all documents in the French language. The problem is that this approach is not cost-free. The problem is that at $\$ 81$ a 3oo-words page of translation, as detailed later, this approach is exorbitantly expensive. The problem is that anyone should urge anyone else to spend additional money on internal communication at all because most internal memos say, "Please note the venue for X has been changed from location A to location B" anyway. The problem is that English language is a contemporary lingua franca and the language used for most case law.

ICTY and, by extension CLSS, might not have been included in this search for French staff by the corporate UN, at all. All further evidence points to unsound financial practices in the CLSS. The 2013 ICTY AR reports that the Office of Document Management (ODM) received 140,114 pages of translation requests, 10,324 pages of which were identified as duplicate pages, resulting in savings of approximately $\$ 836,224 .{ }^{709}$ These numbers allow for mathematical calculations of translation costs yielding a rate of $\$ 8$ o.99 per page or a rate of $\$$ O.26 per word. The 2015 ICTY AR reports that the ODM received 69,731 pages of translation requests, of which 16,231 were identified as duplicate pages, resulting in a saving of approximately $\$ 1,313,253 .{ }^{710}$ These numbers allow for mathematical calculations of translation costs yielding a rate of $\$ 80.91$ per page or a rate of \$o.26 per word. CLSS staff point out that freelancers are regularly used to translate verdicts. The problem here is that these rates are much higher than those offered by all other international organizations based in

\footnotetext{
${ }^{707}$ Elias-Bursać, E. (2015), Translating evidence and interpreting testimony at a war crimes tribunal. Palgrave Macmillan: London, p. 25 .

${ }^{708}$ Ibid, p. 61.

${ }^{709} \mathrm{UN}$, Report of the ICTY (A/68/255) (2013), para. 76.

${ }^{710} \mathrm{UN}$, Report of the ICTY (A/70/226) (2015), para. 96.
} 
The Hague. The AITC contractual rates for 2013 obtained either from the language divisions of the organizations concerned or from freelance translators they contract give the following rates for other organizations based in The Hague:

Table 12. AITC 2013 contractual rates

\begin{tabular}{|c|c|}
\hline Organization & Rates \\
\hline ICC & 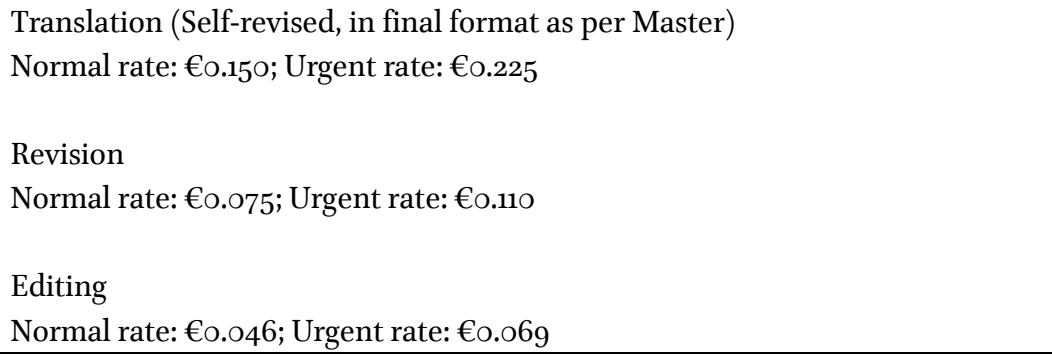 \\
\hline OPCW & $\begin{array}{l}€_{15} \text { o per } 1,000 \text { words or } € \text { o.15 per word } \\
+40 \% \text { for urgent work or } € \text { o.21 per word }\end{array}$ \\
\hline ICJ & $\begin{array}{l}\$ 185 / 195 / 205 \text { per } 1,000 \text { words or } \$ 0.185 / 0.195 / 0.205 \text { per word } \\
+\$ 35 \text { for electronic version of typed text i.e. basic remuneration is } 185 / 195 / 205 \\
+35=\$ 220 / 230 / 240 \text { or } \$ \text { o.22/0.23/o.24 per word }\end{array}$ \\
\hline
\end{tabular}

It is obvious from the above table that, by offering $\$ 0.26$ a word, ICTY paid their freelancers more than all international organizations based in The Hague. However, unlike the standard UN rates for translators and interpreters analyzed before, freelance rates should have been under stricter budgetary control. CLSS staff report that out of 614 rostered freelance translators, CLSS was using only 20 almost from the beginning of their work. This is a very lucrative deal for those 20. Fine. But, CLSS staff also reported that most of these 20 reside in the area of former Yugoslavia: should they have translated 5.5 pages a day they would have made $\$ 9$,oog a month. For comparison, the 2013 salary of the President of Serbia was 150,00o Serbian Dinar or about $€_{1,215}{ }^{711}$ the 2015 salary of the President of Croatia was around $€_{5,100,{ }^{712}}$ and the 2014 salary of the President of B\&H was around 5,600 Bosnian Mark $a$ or around $€ 2,300 .{ }^{713}$ The salaries of the presidents of these countries are given as an example of the highest paid civil servants in the country. Obviously, CLSS freelancers from the former Yugoslavia were paid much more than the highest paid civil servants in their countries. But, UN and UN partners are aware of the fact money must be spent prudently, which is the reason why they signed a contract on these issues both with AITC ${ }^{714}$ and AIIC. ${ }^{75}$ Accordingly, AITC ${ }^{716}$ and AIIC ${ }^{717}$ have strict rules on professional domicile address. Should freelance translators or interpreters engaged by ICTY be paid one single and uniform rate regardless of their reported domicile address, in addition to unsound financial management, ICTY CLSS would be in infraction of agreements between the UN and AIIC and AITC.

Consequently, discussion relating to the French language professionals and freelancer rates may not be a discussion about stealing of staff which, when proven, is taken as a serious issue, but a mere question of why would any freelancer want an in-house job with ICTY CLSS when, it seems, CLSS' inability to self-regulate provided them with more than lucrative income? CLSS was on a regular budget. However, since no other ICTY sections requiring language services could count on CLSS, they would apply and receive various donations to retain their Language Assistants and to, finally, decide to establish completely separate language services to be used for operational purposes only. The CLSS had to do something with all that extra money.

\footnotetext{
${ }^{711}$ Telegraf, Povišica: Nikolićeva nova plata 150.000 dinara (2013).

${ }^{712}$ Novi Magazin, Plata Kolinde Grabar Kitarović 5.100 eura (2015).

${ }^{713}$ Naše vijesti, Sit političar gladnog radnika ne razumije. Mjesečna plaća 5.000 KM (2015).

${ }^{714}$ AITC, $\underline{\text { CEB/AITC Agreement. }}$

${ }^{715}$ AIIC, CEB/AIIC Agreement.

${ }^{716}$ AITC Guidelines on External Translation, para. II.3.

${ }^{717}$ AIIC, Frequently Asked Questions.
} 
Instead of centralizing and taking charge of all the different language units or using UN mobility policies or other UN internal policies to their advantage, they decided to spend their time looking for qualified language professionals, organizing translation and interpreting exams in The Hague and abroad and overpaying external staff. Fine. So what was their translation and interpreting output?

6.8.4. ICTY CLSS language professionals: translation and interpreting output

The CLSS production of 75,000 standard UN pages was first mentioned in the 2004 ICTY AR and repeated in the 2005 ICTY AR, never to be mentioned again until the end of the second management period. This seems to be subpar, bearing in mind a number of internal and external staff at CLSS' disposal, also documented in the ICTY ARs, and bearing in mind technological advancement in the field of translation and interpreting. As to their workload, CLSS had to translate court documents where priority was given to translation into English and French, documents parties planned to use in court which were translated both by the CLSS and OTP Language Assistants, and operational documents of the parties which were translated by OTP/Defense Language Assistants. Trial Chambers in Šešelj reflected on the fact that interpreting into French is a liaison interpreting (i.e. what was said in $\mathrm{B} / \mathrm{C} / \mathrm{S}$ is first interpreted into English and then from English into French) which multiplies difficulties and increases the risk of errors. ${ }^{718}$ It is uncertain whether this was the same for translation from French into B/C/S. In short: CLSS language professionals only had to worry about translating courtrelated documents. The following examination was made after a member of the CLSS translation support staff interviewed for the purposes of this study told the author:

Salary and benefits aside, what I could not believe is that you bring [external translator] to CLSS, give [that external translator] 20,000 Euro a month, [that external translator] barely translates 5 pages by the end of the month and then you bring [that same external translator] again in a couple of months.

Since this has been confirmed by four different people interviewed for the purposes of this study, it has been decided to explore the underlying causes of this shocking statement. Whereas an investigator truly does not know how many leads he will find when he goes on to work, and whereas an analyst truly does know how many documents he will go through by the end of the day, translation production is measurable. UN translation exams have around 500 words which must be translated in 2 hours. ${ }^{79}$ This means that UN conveys their expectations regarding production from the very beginning: "slow producers" are not welcome here. A UN month has 21 days, a year has 12 months, the UN allows 30 days of annual leave, 10 days of uncertified sick leave, and 10 days of official holidays annually. All the following calculations have been performed using the formula considered to deliver the minimum translation:

$$
\mathrm{N}^{*}(5 \cdot 5 *((12 * 21)-50))=1,111
$$

where $\mathrm{N}$ is a number of translators, 5.5 a daily output in translation in pages, 12 a number of months in a year, 21 a number of working days in a month, and 50 a number of total maximum annual leave allowed by UN. This formula allows calculation of the absolute minimum of annual production by an $\mathrm{N}$ translator who took all allowed leave at 1,111 pages.

The median production is calculated using the formula:

$$
\mathrm{N}^{*}\left(5 \cdot 5^{*}((12 * 21)-30)\right)=1,221
$$

\footnotetext{
${ }^{718}$ ICTY, Decision on defendant's motions concerning the quality of interpreting (2008).

${ }^{719}$ UN, LCEs: sample examinations.
} 
where $\mathrm{N}$ is a number of translators, 5.5 a daily output in translation in pages, 12 a number of months in a year, 21 a number of working days in a month, and 30 a number of total annual leave allowed by UN.

Finally, the maximum production is calculated using the formula:

$$
\mathrm{N}^{*}\left(5 \cdot 5^{*}((12 * 21)-10)\right)=1,376
$$

where $\mathrm{N}$ is a number of translators, 5.5 a daily output in translation in pages, 12 a number of months in a year, 21 a number of working days in a month, and 10 a number of total annual holidays allowed by UN. According to this formula, one translator should be able to produce between 1,111 and 1,376 pages annually.

Elias-Bursać claims CLSS had a total of 6o-80 (1997-2004) and 150-170 (2005-2013) in-house staff and, according to the ICTY ARs, they also had 614 external staff to help them. ${ }^{720}$ The 614 external staff have been taken into account in the calculations because there must have been a reason why the time out the office, travel expenses, hotel expenses, and DSA reimbursements were approved by the ICTY Procurement on the orders of the ICTY Deputy Registrar who were charge of Human Resources and CLSS until CLSS found the $614^{\text {th }}$ external staff. Elias-Bursać claims that the output for the average English Translation Unit translator working on evidence was five to seven pages of finished translation per day, or roughly a thousand pages per year, whereas a reviser might revise between 4,000 and 5 ,ooo pages per year. ${ }^{721}$ However, these numbers are too approximate and must be calculated properly. The following is a calculation of the annual production of $\mathrm{N}$ number of translators as reported by Elias-Bursać:

Table 13. CLSS production vs. minimum, median and maximum output

\begin{tabular}{|l|l|l|l|l|}
\hline N & CLSS & MIN & MED & MAX \\
\hline 60 & 69,960 & $66,66 \circ$ & 73,260 & 79,860 \\
\hline 80 & 93,280 & 88,880 & 97,680 & 106,480 \\
\hline 150 & 174,900 & 166,650 & 183,150 & 199,650 \\
\hline 170 & 198,220 & 188,870 & 270,570 & 226,270 \\
\hline 614 & n/a & 682,154 & 749,694 & 817,234 \\
\hline
\end{tabular}

Obviously, in all these instances, CLSS staff only succeeded in exceeding the bare minimum, even according to the particularly liberal calculations presented here, but never even reached the recommended medium. It is also worth remembering that the daily output of 5.5 pages in translation presents a symbolic minimum of the minimum recommendation and, in that sense, the fact that not all staff could have consistently exceeded 5.5 pages a day regardless of the type of texts, although completely expected given the discussions above, is still somewhat depressing.

These findings have been substantiated by the UN OIOS Internal Audit Division, which conducted an audit of ICTY language services again in May 2009. The 2009 OIOS Report established that CLSS had 65 translators on its rolls (excluding revisers) which, given that the standard UN output is about 5.5 pages, would yield an expected yearly output at some 78,65 o pages. However, the output for in-house CLSS translators has ranged from 58,115 to 64,565 , indicating a shortfall of between $18-26 \%{ }^{722}$ The 2009 OIOS Report reconfirmed that the standard UN output for translators is 1,650 words per day (5.5 pages at 300 words per page) subject to revision, 1,815 words per day (6 pages) for self-revised translations, and 3,960 words (13 pages) per day for revisers (see Chapter 5). The 2009 OIOS Report included the following translation output by the CLSS:

\footnotetext{
${ }^{720}$ Elias-Bursać, E. (2015), Translating evidence and interpreting testimony at a war crimes tribunal. Palgrave Macmillan: London, p. 25 .

${ }^{721}$ Ibid, p. 113 .

${ }^{722} \mathrm{UN}$, OIOS Internal Audit Division, Audit of Language Services at ICTY (2009), para. 26.
} 
- 71,950 pages in 2004 (7,385 external staff),

- $\quad 76,193$ in $2005(17,376$ external staff),

- $\quad 71,730$ in 2006 (13,615 external staff), and

- 74,254 in $2007(14,175$ external staff).

Obviously, the authors of the 2004 ICTY AR who reported annual CLSS translation output at 75,000 must have misread the memo CLSS sent them as their contribution to the ICTY ARs. And then they must have misread the numbers CLSS sent them as their contribution to the 2005 ICTY AR again. Using the above formula showed that $\mathrm{N}=65$ should be able to produce a minimum of 72,215 pages annually, median 79,365 pages annually, and maximum 86,515 pages annually, which means that they did not meet even the bare minimum in 2004 and 2006, they got close to median in 2005, and barely went above the minimum in 2007.

The 2009 OIOS Report proposed measures designed to improve the situation. CLSS responded, proposing reduced norms, but OIOS Auditors concluded that even with the reduced norms suggested by CLSS for the English and French translation units, the average productivity would still be below UN norms. OIOS Auditors tracked the production of 16 translators in the English Translation Unit and established that only two translators achieved the required productivity norm during three years of tracking. ${ }^{723}$ The OIOS Auditors concluded that the output levels for translators in the English Translation Unit were sub-optimal and that they needed to become more efficient. ${ }^{724}$ OIOS Auditors tracked the production of 10 translators in the French translation unit and established that productivity levels were below UN standards because only four translators achieved an annual output of more than 1,0oo pages; the French revisers also did not meet their targets. ${ }^{725}$ The OIOS Auditors concluded that the output levels for translators in the French translation unit were suboptimal and that they need to improve their efficiency. ${ }^{726}$ The output for the $\mathrm{B} / \mathrm{C} / \mathrm{S}$ translation unit for the past three years for 11 selected translators and revisers showed that the average output per staff member was far higher: two translators have exceptionally high output of 13.3 and 8.6 pages per day and the $\mathrm{B} / \mathrm{C} / \mathrm{S}$ revisers met their targets. CLSS responded by saying this is because those people were assigned easy documents to translate.$^{727}$ All in all, the OIOS 2009 Report established that between January 2004 and June 2008, ICTY spent $\$ 70.8$ million on salaries and allowances for CLSS staff and \$19 million on outsourced services including external interpreting, translation, and court reporting. ${ }^{728}$

The level of the CLSS management's lack of awareness of its resources and surroundings could be best seen in the following description of CLSS by the CLSS Chief of Conference Interpreting Section and Acting Chief of CLSS in 2009, Marijana Nikolić:

Who are the Tribunal's translators and interpreters? They are professionals working at the same administrative level as lawyers or investigators; all have a university degree, most of them in linguistics or modern languages, and several or more years of related work experience. The revisers are native speakers of the target language. All are hard-nosed practitioners and have worked assiduously to earn the professional respect they now enjoy from judges, prosecution and defence counsel, and from numerous other users of their services. ${ }^{729}$

Nikolić continues in a separate interview:

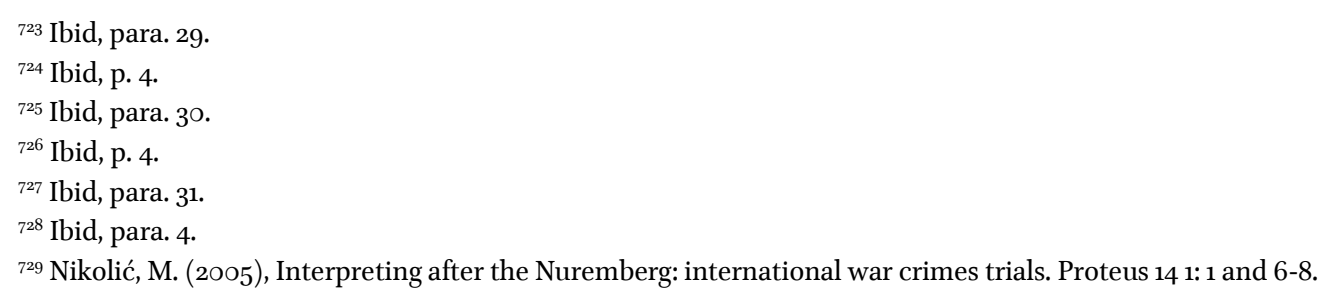


For me as the Head Interpreter, the greatest challenge was to raise our clients' awareness about the nature of conference interpreting and, in the event of a language dispute, to defend the interpreter's legitimate choice of words and expressions without succumbing to the pressures of an adversarial courtroom..$^{7{ }^{\circ}}$

In addition to the above statistics, the 2009 UN OIOS Report clearly established the lack of "systematic feedback mechanisms to gage client satisfaction." Given that this report was addressed, inter alia, to Nikolić, a CLSS manager, the above claims are very clearly divorced from all reality. Why make an issue of this? Because this self-promotion coupled with established facts unequivocally establishes the CLSS management's total obliviousness to their clients, their output, and to what went wrong in the office.

CLSS' interpreting production was mentioned for the first time in the 2008 ICTY AR as comprising 85 ,ooo interpreter days. The number of interpreter days is calculated on the basis of one interpreter being equal to one day. For example, if there are trials five days a week for which seven interpreters are hired to man three interpreting booths for one hearing lasting from o9:0o to 14:00, that one week of engagement of seven staff equals 35 interpreter days $(7 \times 5)$. If the court met in both sessions throughout a week (o9:0o to 14:00 and 14:00 to 19:00) and if seven interpreters were assigned to each session, CLSS would have registered 70 interpreters' days. At that rate, 8,500 conference interpreter days would mean interpreters worked 121.42 days in a given year. It is worth remembering that the UN working year has 252 working days, which means that the CLSS interpreters did not work for even half a year. This finding was also substantiated in the 2009 UN OIOS audit of language services at the ICTY. This report stated that the standard UN workload norms for interpreting are seven sessions of three hours or 21 hours per week, with a two-hour break between sessions. Interpreters use the remaining hours to prepare for assignments. The 2009 OIOS Report established that CLSS interpreters provided interpreting for four court sessions per week and were undertaking interpreting work on average between 16 to 19 hours, which nearly matches the norms, based on the sample taken for testing. However, OIOS Auditors also reviewed entry and exit times for CLSS interpreters for the month of September 2008 and determined that interpreters usually leave the office once they complete their shift and do not come back for the rest of the day. Most interpreters attended the office for an average of 20 to 22 hours per week, compared to the standard 37/2-hour work week in the ICTY. Moreover, they worked four days a week: they did not come to the office on the fifth day and did not apply for leave for this day. For the month of September 2008, the OIOS Auditors calculated that interpreters were absent from office for around 143 days a year, even though they were paid a salary of approximately $\$ 60,000$ for these days. The auditors concluded that, on an annual basis, the same trend of absence would imply an expenditure of around $\$ 720$,ooo on interpreters' salaries for days when they were not in the office. ${ }^{73^{1}}$

Finally, several ICTY ARs claim that CLSS language professionals assisted in field interpreting of interviews by investigation teams and witness-proofing sessions by legal professionals prior to testimony and interviews with suspects. By this time, the ICTY had liaison and field offices in Zagreb, Sarajevo, Banja Luka, Priština, and Belgrade. All these offices were manned by Language Assistants and only one of them, the Sarajevo office, had a CLSS language professional as well. It is unclear why CLSS language professionals would go to interview clients in the first place because, as it is clear from the ARs examined, they were barely coping with the work they already had on their plate. The clients could have been interviewed either by the existing staff in the field offices (Belgrade, Zagreb, Sarajevo, and Banja Luka) or by field interpreters. This makes even more sense because both staff categories are paid at the local level and their engagement would have saved the organization significant costs, in addition to all these other savings identified by the OIOS Auditors. ${ }^{73^{2}}$ However, many CLSS language professionals, translators and interpreters alike, did go out on missions. Given

\footnotetext{
${ }^{73^{\circ}}$ Pavetić, J. (2012), Interview with Greiss lecturer Marijana Nikolić. SlavFile: Newsletter of the Slavic Languages Division. 21 (4): 6-7, 9 .

${ }^{731}$ Ibid, paras. 37-39.

${ }^{732}$ UN, Travel Allowance.
} 
their existing workload, this use of CLSS language professionals is unreasonable and, given the costs of CLSS language professionals, it represents additional expenditure. Finally, given their isolation from the rest of the organization, it is unclear how effective CLSS language professionals would be both vis-à-vis a pas de deux with suspects, victims, witnesses, insiders, investigation, and the prosecution facts-wise, since some of them already voiced dissatisfaction about being away from the prosecutorial and investigatory action. On the other hand, it is only natural that CLSS language professionals would be motivated to go on missions because this provided them with an opportunity to make money on top of their regular earnings. As a rule, CLSS language professionals would not assist during the witness-proofing sessions, which are normally done prior to the victims or witness testimony (see Chapter 4 for an extended discussion of the mechanics of proofing). Witnessproofing is done in The Hague, and it included working weekends and after 17:30, so CLSS language professionals probably had no financial or other interest in assisting with witness proofing. For comparison: witnesses were interviewed by an OTP investigator, lawyer, or analyst who were also P-level staff and who were also not paid overtime if they stay after 17:30 or if they came in during the weekends. So, it seems plausible to ask why CLSS language professionals couldn't have done the same? If any CLSS staff participated in witness proofing, those would be Language Assistants who were normally charged with administrative duties. This means that CLSS also kept staff who were working as support staff and, when needed, as consecutive interpreters in a legal context. It is easy to understand why they would be motivated to come in on the weekends because they were paid at GS-level and entitled to overtime. It would not at all be an exaggeration to say that $95 \%$ of all witness proofing was conducted by OTP Language Assistants and that CLSS support staff were used only when the existing OTP Language Assistant staff were used to full capacity. Coming in over the weekends or staying overtime was a case of “Don't discuss, just do it” for OTP Language Assistants until the first time the ICTY was unable to pay overtime in about 2002. Almost all OTP Language Assistants had more than 100 hours of overtime and Administration tried to make a deal: instead of money, they offered compensatory time off. In the end, the ICTY Administration did not deliver either: they paid out moneys up to 40 hours of overtime and declared all other hours as compensatory time off, which must be used within three months. Naturally, many Language Assistants simply could not take time off to use their compensatory time off in the prescribed period of time because the only safe time to take time off was (and is) during the two two-week court recesses. Later policy regarding overtime was to pay out up to 20 hours of overtime and to give the rest in compensatory time off to be used up within three months. After that, coming in over the weekends or staying overtime was a case of "We understand, but come in anyway" for OTP Language Assistants.

Why is this important? It's important because we are talking about money and this is money from the UN Member States and from donations; it belonged to someone who decided to give it to CLSS to get a job done. This money could have been spent better if CLSS had achieved a reasonable workload and used UN resources to maximize production. Translation is measurable as shown above. The expected workload is also measurable as communicated by the parties CLSS was servicing. It is not always predictable, but minimum and maximum workloads should be clear to all sides. Staff allocation can also be planned. The resources at the disposal of CLSS staff could have been used in a smart and productive way.

Finally, there is much more to translation than translating from scratch: language professionals also use CAT tools and programs (see Chapter 5). Some CLSS management claim that the leading CAT tool, SDL Trados started to be used from 2006 but only in a combination of English and French, while some CLSS language professionals mention that in 2009 only a few translators working in English and French used SDL Trados, and other CLSS Referencing Unit administrative staff claim that the use of SDL Trados was in infancy when they started aligning legal documents, creating bilingual and trilingual parallel texts, checking the quality of aligned documents, and updating the Referencing Unit's reference corpora and Trados legal translation memory in all relevant language combinations in 2014. The author of this study is inclined to believe the administrative staff because should the CLSS have had functioning CAT tool that they were using since 2004 as the 2004 ICTY AR claims, any CAT tool would have done all referencing normally performed by Reference Assistants on its own, provide it as pre-translated, already revised and formatted text, and there would have 
been no need to engage a department full of staff to do that. In addition, the annual production rate would have been much higher than mere 75,0oo pages which was falsely reported in two ARs.

CAT tools are used because they save time, increase productivity, and preserve original formatting. Where the texts are repetitive, they can save considerable time and considerably increase productivity. How much time and productivity are we talking about here? Ms. Fotini Vallianatou is a freelance translator with a degree in translation from the Ionian University, Greece, and more than 20 years of experience translating from English and French into Greek. Her translation specialty includes medical and technical texts. ${ }^{733}$ Since both of these text types fall into the category of specialized translation, just like legal translation, it has been decided to take Vallianatou's data as indicative of translation in a legal context. Vallianatou tracked her translation using two commercial CAT tools, Trados and DejaVu, a customized CAT tool created by one of her clients for the internal needs of their company, and from- scratch translation. During the period between June 2003 and December 2004, Vallianatou received 175 jobs with a total word count of 468,878 words. These fulfilled her tracking criteria: it had to be translation (meaning no summaries, partial translations, transcreation, etc.), no "minimum-charge" jobs subject to a flat rate, and no "paid-by-the-hour" jobs because some of these jobs do not record the number of words translated. The use of CAT tools (and translation times) was successfully tracked in 90 of these jobs, with a total word count of 359,105 words ( $76 \%$ of Vallianatou's total word load for this period) and a total translation time of 544.85 hours.

Table 14. Vallianatou production with CAT tools

\begin{tabular}{|l|l|l|l|}
\hline CAT tool & No. of projects & Total word count & Total time \\
\hline Trados & 36 & 158,940 & 192.8 \\
\hline DejaVu & 25 & 42,525 & 74.35 \\
\hline Custom CAT tool & 26 & 155,023 & 271.2 \\
\hline No CAT tool & 3 & 2,617 & 6.5 \\
\hline Totals & 89 & 359,105 & 544.85 \\
\hline
\end{tabular}

In short, 17 months of tracking revealed a translation output of 359,105 words or 1,197.01 UN pages (one page 300 words) during 544.85 hours of work or 68.10 standard 8-hour days (3.24 standard UN 21-working days' months or 3 months and 8 days). If the CLSS has, indeed, used the CAT tools in their work and if 54.11 translators who are assumed to have had annual output of 75,00o pages had the same production during the same 3.24 standard UN 21-working days' months, they would have produced 64,770.21 pages during the first quarter of the year or more than 194,310.93 pages annually. And 194,310.93 is 2.59 times more than 75,00o. CLSS language professionals claim SDL Trados has, indeed, been sold to the CLSS in 2004. Since then, the B/C/S, English and French translation staff have been trained on how to use SDL Trados twice, once in 2004 and again in 2007. Buying a product, being trained on using a product, and insisting on not using that product is simply squandering money.

Indeed, problems with translation, proper staff allocation, and insufficient savings due to non-use of CAT tools were recurring problem for CLSS. The ICTY 2012 AR reported that the ICTY President focused on problems that might impact the efficiency of proceedings, such as, inter alia, delays in translations. In that vein, measures were taken to reform ICTY's procedures to maximize efficiency, and, in particular, to implement measures to ensure that the pace of translations would not unduly delay proceedings in that additional resources were assigned to Prlić et al, Tolimir, and Šešelj to reduce previously forecast translation times by $50 \% .{ }^{734}$ The ICTY 2014 AR reported that the ICTY President focused his efforts on completing the judicial work expeditiously, while maintaining high standards of procedural justice, including expedited translations of trial judgments by actively managing the translation process. The CLSS delivered the English translation of the French trial judgment issued in the Prlić et al. case at the beginning of June 2014 and that only 13 months

${ }^{733}$ Vallianatou, F. (2005), CAT Tools and Productivity: Tracking Words and Hours. Translation Journal: Vol. 9, No. 4.

${ }^{734} \mathrm{UN}$, Report of the ICTY (A/67/214) (2012), para. 4. 
after the date of the original judgment. ${ }^{735}$ The ICTY 2015 AR reported that in September 2014, CLSS delivered the $\mathrm{B} / \mathrm{C} / \mathrm{S}$ translation of the French Trial Judgment issued in Prlić et al. and that only 16 months after the date of the original judgment. ${ }^{736}$ In short, CLSS took 13 months (2014 AR) and 16 months (2015 AR) to complete the translation of the Prlić et al. judgment into English and B/C/S, respectively, and that after the ICTY President took control of the situation to reduce forecast times by $50 \%$. Now, it should be extremely embarrassing for every professional if the main client took the reins, as the ICTY President did to the CLSS. But, in order to wrap up all this talk of savings and expediting, let us remember that the original French version of Prlić et al. judgment had approximately 1.3 million words or 4,26o [UN] pages and that Ms. Vallianatou translated 359,105 words or 1,197.01 UN pages (one page 300 words) during 544.85 hours of work or 68.10 standard 8-hour days (3.24 standard UN 21-working days' months). Using CAT tools, Ms. Vallianatou would have translated this judgment alone in 242 working days or slightly over 11.5 months. If Ms. Vallianatou was employed at the P-2 level, her annual salary would be $\$ 81,153$ gross. The CLSS spent $\$ 351$, ooo for translation of Prlic et al. judgment alone. If the CLSS had used the CAT tools they bought, trained for, and claimed to have been using, they would have delivered this translation in less than a year in both versions and would have made savings of $\$ 269,847$ on this judgment alone. If it had been revised by a P-4 reviser who makes $\$ 93,262$ annually (see Table 11), the savings would come to $\$ 176,585$. However, legal professionals waiting for the Prlić et al. judgment were adamant about several things: they spent too much time staring blankly at the ICTY Registry when they told them that translation of the Prlic et al. judgment into English had priority. By the time the translation of this judgment arrived, they alone had translated significant portions of it to their clients into $\mathrm{B} / \mathrm{C} / \mathrm{S}$, and, finally, they received this judgment in summer 2015. i.e. a date that is two years after the date of the alleged filing of this judgment as found on the ICTY website and a year after the date reported by ICTY ARs as delivered.

\subsection{OTP Language Assistants}

In addition to CLSS, Rules of the Road language professionals, VWU language professionals, UNDU language professionals, court reporters, Outreach Program language professionals, and Chamber Support Unit language professionals, the OTP Language Unit forms the seventh language-related unit that is completely separate from CLSS and completely dependent on donations. ICTY ARs and ICTY manuals of established practices do not mention the Language Assistants who manned the OTP Language Unit. The UN OIOS Internal Audit Division 2009 audit of ICTY language services stated that the OTP Language Unit forms part of the Information, Evidence and Linguistic Section, which consisted of about 62 staff paid at GS-level and where some 35-40 staff were deployed for translation purposes in 2009. As to the origins of this Unit, OTP has stated that this Language Unit was set up to meet an extremely tight deadline imposed by the Trial Chamber in the Krajišnik pre-trial proceedings, which left it with no alternative but to engage a team of translators. Krajišnik's initial appearance was in 2000, so it is fair to assume this Unit was set up then. ${ }^{737}$ This coincided with the beginning of the second management period in the CLSS. The OTP Language Unit was initially conceived as a temporary measure, but once the urgent work was completed, OTP continued to maintain the Unit because of the advantages it offered. OTP stated that without the resources of this Unit, if they had to wait for translations from CLSS, the trials would come to a complete halt as the CLSS was busy with the defense phase of two multi-accused cases. ${ }^{73^{8}}$ Indeed, at the time of this audit, OTP emphasized that CLSS still worked mainly for the Defense, citing the Registry, which noted that in 2007 and 2008 , CLSS worked mostly for Defense: $75 \%$ in 2007 and $80 \%$ in $2008 .{ }^{739}$ The OIOS Auditors noted that OTP's Language Unit lacked credible workload norms, performance indicators, and the staffing requirements projected in the budget documents were not based on a sound justification. The 2006-2007 and 2008-2009 budget submission notes that the estimated number of pages requiring translation/transcription was expected to be 320,000 and staff requirements were projected

\footnotetext{
${ }^{735} \mathrm{UN}$, Report of the ICTY (A/69/225) (2014), para. 4.

${ }^{736} \mathrm{UN}$, Report of the ICTY $(\mathrm{A} / 7 \mathrm{O} / 226)$ (2015), para. 72.

${ }^{737}$ ICTY, Krajišnik CIS.

${ }^{738} \mathrm{UN}$, OIOS Internal Audit Division, Audit of Language Services at ICTY (2009), para. 43.

${ }^{739}$ Ibid, para. 3 .
} 
based on a rate of 16 pages per person and 220 days per year. The auditors assessed that the yearly output of the OTP Language Unit ranged from 10,00o to 26 ,0oo pages per year. Considering that these GTA staffing projections were based on 16 pages per day, the output of the language staff should typically yield some 140,800 pages per year. The OIOS Auditors concluded that either the staffing projections were incorrect, or the norm needed to be revised, reminding readers that the standard UN output for translators is about 5.5 pages per day and therefore a OTP Language Unit norm, nearly three times the standard UN norm, requires reconsideration. ${ }^{740}$ The auditors recommended that OTP should review the existing workload norms, noted that the maintaining the OTP Language Unit, with limited links to CLSS, represents a duplication of resources, and may not represent efficient allocation of resources. Considering that CLSS and the OTP Language Unit essentially perform the same kind of work, there is a need for coordination between the two language service providers. Given that CLSS is the official language services provider to the ICTY, the OIOS Auditors remarked that the OTP Language Unit needed to consult with CLSS about administering, monitoring, and quality control within the OTP. ${ }^{71}$ Moreover, since translators at the ICTY range from GS-5 to P-4, the auditors said it was necessary to define and categorize the kinds of translation required and match these with the level of translator skill to ensure the most cost-effective use of translation resources. The auditors recommended that the ICTY Administration and OTP should undertake a formal review to assess the justification to maintain separate language service resources within OTP. OTP did not accept this recommendation, stating that it did not believe a formal review was warranted at this early stage: the amount of work that was being submitted together with the liaison/coordination between OTP Language Unit and CLSS made it abundantly clear that both language service resources were required, reiterating that OTP depends on an instantly available and highly flexible service of Language Assistants where, by contrast, in many cases, CLSS cannot accommodate OTP's most immediate needs for assistance at short notice. Unlike CLSS translators, OTP Language Assistants are also involved in numerous other projects such as processing intercepts, quality control of document coding, redaction of witness statements, reviewing video material, and other tasks. The OIOS Auditors replied they were unable to accept the assertion that it was too early for a formal review: the OTP's Language Unit had existed for a decade, though it was initially conceived of only as a temporary measure and the continuation of existing arrangements that are duplicative needed to be reviewed..$^{72}$ The OIOS 2009 Audit Report very nicely summarized the history of OTP Language Assistants and all their trial and tribulations in a pretty candid and open way: whereas the CLSS was underproducing, OTP Language Assistants were overproducing. However, except for summarizing the facts, the auditors did not engage or address the magnitude of problems and injustices behind the engagement of Language Assistants, namely the legality of the use of Language Assistants, existing resources, and document management.

6.9.1. The legality of the use of Language Assistants

Language Assistants were not subject to any codes of ethics, codes of conduct, and left legally unregulated in performance of their tasks (see Chapter 4 for an extended discussion of this). OTP Language Assistants summarize documents, search and select evidence, transcribe, translate and interpret mainly between $\mathrm{B} / \mathrm{C} / \mathrm{S}$ and English, but also other languages such as Dutch, French, Spanish, Italian, and Arabic. They were recruited on the basis of exams organized by CLSS (until about 2000) or OTP (after about 2000) which consisted of the following: one a la vista translation of text into English, one written summary of text written in English, consecutive interpreting roleplay lasting five minutes, and an interview in English. All these were much more relevant than CLSS exams because they tested the candidates' ability to speak and understand both languages, but also to think analytically and fast. Language Assistants are supervised by non-language professionals, mostly OTP team leaders who assign work through translation coordinators or administrative assistants. Translations delivered by OTP Language Assistants are checked by what could be described as revisers: a group of randomly picked staff who performed quality assurance and quality control of translated material.

\footnotetext{
${ }^{740}$ Ibid, paras. 44-45.

${ }^{741}$ Ibid, para. 47.

${ }^{742}$ Ibid, paras. 48-50.
} 
OTP never organized any language-related training for Language Assistants. Even though, Language Assistants could not have kept a closer contact with legal professionals: they are constantly made aware of directions in which the trial case is going, legal points that will be established, and "linguistic traps" along the route of establishing the truth about a particular trial case. Last, but not the least, they personally meet and interpret for almost all witnesses, victims, accused, and insiders through professional contacts. OTP Language Assistants are not an isolated part of the system left to their own devices or unsupervised in terms of their work direction: they are mostly treated as equal members of OTP. However, this supervision has not been clarified as virtually everyone could assign them work, from making summaries via reviewing evidence to interpreting and it all depended on skillful organization on the part of the investigations team leader.

In addition to all problems pointed out by OIOS Auditors, the UN does not recognize the category of Language Assistants as part of any of the existing three main categories of UN staff. ${ }^{73}$ The 2009 OIOS Auditors established that ICTY language professionals are paid at between the GS-4 and P-4 level. ${ }^{744}$ ICSC Standards were announced to eliminate situations in which some organizations placed certain jobs in the P-level category while other organizations, sometimes within the same duty station, placed the same jobs within the GSlevel category. ${ }^{74}$ This means that the engagement of Language Assistants directly violates the core reasons for ICSC Standards: to eliminate differences in payment. Nevertheless, Language Assistants are used in the UN System by all the international tribunals (ICTY, ICTR, ICC, STL, ECCC), OPCW ${ }^{746}$ OSCE, UN field missions (UN Assistance Mission for Iraq, UN Assistance Mission for Afghanistan), and unforeseen crisis missions. ${ }^{74}$ OSCE is the only permanent organization which regularly uses Language Assistants. OSCE explains their engagement of Language Assistants as follows:

OSCE missions provide interpreting services to overcome communication difficulties. For this purpose missions will recruit a number of interpreters from the local population. However, since certified professional interpreters are not always available, missions must often rely on individuals who lack training in interpreting skills although proficient in the English language: the so-called Language Assistants. ${ }^{748}$

According to OSCE arrangements, all ICTY vacancies for Language Assistant posts show that they are paid at the local, GS level and that all such vacancies require a candidate with secondary education. However, as shown above, Language Assistants normally perform jobs that would be expected from candidates with a university education. Some vacancies to the post of Language Assistant announce that "candidates with some post-secondary education training in translation and interpreting preferred," which means that they will employ someone with university degree. Effectively, this perpetuates a violation of ICSC Standards. However, this is done with the consent of the incumbent to the post. Those incumbents have to sign the following waiver form, which is used by the ICTY:

\footnotetext{
${ }^{743}$ UN, Details of UN Salaries, Hazard Pay, Rental Subsidy, Mobility and Hardship Scheme, and other Allowances, Benefits.

${ }^{744} \mathrm{UN}$, OIOS Internal Audit Division, Audit of Language Services at ICTY (2009), paras. 48-49.

${ }^{745}$ Alexovičková, I. (2012), From hiring to firing: a comparative study on selected legal safeguards for the independence and impartiality of international civil servants serving in the United Nations Secretariat and in the European Commission. Wolf Legal Publishers: Nijmegen, p. 55 .

${ }^{746}$ UN vacancies, ICTY G-5 Language Assistant (English and B/C/S); ICTR FS-4 Language Assistant (English, French and Kinyarwanda);

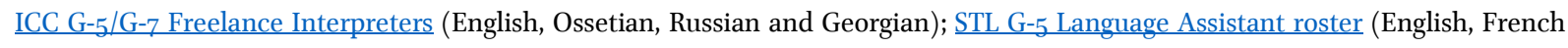
and Arabic); UNAKRT (ECCC) G-7 Language Assistant (English and Khmer); OPCW G-5 Language Assistant (English).

${ }^{747}$ UN vacancies, OSCE G-5 Language Assistant roster (English, Ukrainian and Russian); UN Assistance Mission for Iraq GL-5 Language Assistant (English and Arabic); UN Assistance Mission for Afghanistan (grade not defined) Political Affairs/Language Assistant (English, Dari and Pashto); UNOPS G-5 Language Assistant/Translator (English and Nepali).

${ }^{748}$ OSCE, Handbooks for fieldwork: Working with or as an interpreter (undated).
} 
Figure 2. Waiver form for applicants to GS-level posts with graduate degree

I, the undersigned, have decided to apply for a post in the General Service category and to accept an offer of appointment at that level, even though have a post graduate degree. I have been advised and understand that:

- My educational background does not give rise to any special entitlements in the United Nations nor will it facilitate a move to the Professional level in future;

- Movement from the General Service to the Professional category requires passing a competitive examination. Under current rules, I may become eligible to take the $G$ to $P$ examination after five years of become eligible to take the $G$ to $P$ examination after five years of
service. I understand that this is a highly competitive examination which is open to all other eligible General Service staff members and that the number of $P-2$ posts available each year to successful candidates is very small.

- I also understand that the National Competitive Recruitment Examination is open only to General Service staff members who are nationals of the countries where the examination is offered and who meet the other conditions specified in the information circular announcing the examination.

I have read the above clarifications and understand that they will be part of my terms of employment by the United Nations. 
Obviously, all these organizations employ investigators and want to make sure their investigators have language support while on mission and in the seat. The UN administration uses Language Assistants to their advantage: they have created an army of people who will provide the (3-in-1)+ services comprising a host of language and non-language-related duties. However, this is unacceptable.

As explained in Chapter 4, staff working as language support needs to be legally recognized in terms of their obligations and legal presence, including those regarding confidentiality: whereas CLSS staff were not signing them, ICTY Language Assistants completely fell through the legal cracks in terms of confidentiality. Also, as pointed out in Chapter 5 , Language Assistants are a perfect example of provision of the (3-in-1)+ service in an international criminal context. This conclusion stems from interviews conducted with Language Assistants from all the above organizations, revealing that Language Assistants are used for the entire language-related workload delivered in the non-official UN languages in those organizations, including translation, interpreting, transcription, summaries, etc. A colleague shared the following (email on file):

I remember being exhausted, disillusioned and not having anyone to complain about it. First, I worked in shifts for about a year or two. Then, once we switched to regular working times, various "trial crisis" ensued and we had to stay overtime as a rule. I made summaries, I made transcripts, I translated, I reviewed evidence, I interpreted. I hated reviewing evidence. Why were they giving me to do something I manifestly hated and did not know how to do? I didn't know what to search for! When I look at the document, I look at it for its language and I will remember it because of the typo, because of the sentence structure, because of a word I didn't encounter in a long time, I will definitely not remember it because of legal details. Legal side of it was Spanish villages to me. I feared what would happen if one day a lawyer came and told me I missed an important document. What could I say? From about 2005 onwards, I started getting a grip over the situation: although "trial crises" came and went, I simply decided to say I was too busy to come over the weekend or stay after 17:30 hrs. There was nothing in it for me as a person or a professional. I found it hard to accept I had a college degree, performed jobs normally paid at a P-level and was paid as a support staff. I could receive overtime for up to 20 hours or leave time with three-month expiration date I never managed to use. Besides, since I was overworked, it all blended into a long wordy document or a long sad sentence in my mind, and I was no longer able to see or hear any nuance. I tried getting a job with the CLSS, but could not have passed that wretched exam for the life of me. This was highly illogical for me: I translated much more complicated texts that had nothing to do with the proper name for the whatever was on the top of marching boots of Montenegrin army troops I incorrectly translated into fustanella because what do I care about Montenegrin soldiers from the $19^{\text {th }}$ century and the chachki on the top of their marching boots at a war crimes tribunal? As soon as we were allowed to take study leave, I started working on myself: I enrolled in Master's program at the local university in Holland. "I am sorry, but I already made plans" became my work mantra whenever asked to stay overtime or come over the weekend. I made a point to translate at least seven pages a day and did not care at all about anyone's opinion whether I was a team player or not. "Team player," I learned, was a phrase legal professionals used when wanting to encourage an obviously overworked and exhausted Language Assistant to go on just a little bit more until the end of the project before she collapses. And I was tired of collapsing. None of that had to be such an ordeal, such an existentialism spasm, such a hard thing to do. When Croatia entered EU, I was one of the first to pass their translation exam. I did it in first sitting.

The non-language professionals are obviously misinformed about the limitations of language professional's responsibilities and want them to provide (3-in-1)+ service comprising language and non-language-related duties. On the other hand, once assuming their duties, once being confronted with a situation where they have to perform the (3-in-1)+ service comprising language and non-language-related duties, Language Assistants are precluded from suing the Organization because they signed the form shown above. None of this seems to matter because, after all, everything comes down to money: since the difference in salaries between P-level and GS-level staff is large, the cost-savings made by the use of Language Assistants were enormous. 


\subsubsection{Language Assistants and existing professional resources}

OTP Language Assistants are classified between GS-3 and GS-6 levels and are divided into several different groups without any precise delineation of their duties: they are data-entry clerks cum summarizers (G-3), research assistants cum evidence reviewers (G-4), "proper" Language Assistants cum translators, interpreters, and transcribers (G-5), and coordinators (G-6). They worked either as team Language Assistants or in the pool of Language Assistants.

Team Language Assistants are supposed to follow legal professionals from the beginning of their investigations, including going on missions to seize documents, unless CLSS staff "volunteered," of course. There, they would serve as interpreters providing a la vista translation of documents for legal professionals to decide which documents to take. The seized documents would be fully examined once reaching ICTY because there would be only time to skim through them in the field. In general, once a document or an artifact is seized and transported to ICTY, it is immediately forwarded to the ICTY Evidence Unit where it gets an ERN. Copies of such documents are then given back to the head in the chain of custody (a legal professional) who forwards them to a different team of Language Assistants called IFFers or indexers. IFFers read the document and enter basic information about it in a specially designed database known as the IFF database (later renamed MIF /Mini Index Form/). Legal professionals use IFF and MIF to start their in-house in-depth search for documentary evidence. ${ }^{79}$ Once a document proves to be relevant for a particular trial, in order to support the work of Trial Teams, Language Assistants cum research assistants working in OTP Information Support Unit and OTP Trial Support Unit search through the documents using a program called ZyFind which contains scanned copies of all documentary evidence. ${ }^{750}$ After that, documents are exported to relevant folders, renamed, and linked to the Excel sheets using specialized tools developed by Information Support Unit and Trial Support Unit. Finally, these documents are forwarded to Trial Teams, who make a final decision about what to translate. Once documentary evidence is in the possession of the Trial Teams, legal professionals start

\footnotetext{
${ }^{749}$ ICTY, IFF Form.

${ }^{75^{\circ}}$ In addition to ZyFind, there are also databases used by both Language Assistants and other legal professionals, such as Jigsaw, Ringtail, and CaseMap. ZyFind allows OTP Information Support Unit and OTP Trial Support Unit Language Assistants to perform detailed searches and reviews of individual documents and specific document collections that relate to certain events, places, or persons involved on request by the Trial Teams. After receiving the search request from OTP Trial Teams, the OTP Information Support Unit and Trial Support Unit Language Assistants prepare the search criteria. These consist of a combination of names, functional titles, ranks, or any other relevant information regarding the persons, places, or events which are then used to search ZyFind indexes for the relevant documents. Since all documents appearing in the Zy Index are full-text indexed, creation of search criteria enables searches for any word or combination of words in ZyFind databases. ZyFind provides a unique feature called "Hit Highlighting" that helps clerks spot the information they are searching immediately. For example, when searching for term "Milošević" in ZyFind, the search criteria should be entered in a way to cover all B/C/S nominal endings of a proper name: Milošević, Miloševiću, Miloševića, Miloševićem, Miloševićevo, etc. However, all this is something that the ZyFind cannot understand because of the use of diacritics (̌s, ć, č, ž, etc.). Instead, the following parameters are used: miio?evi* or miLo?evi* or mLio?evi* or mLLo?evi* or miios?evi* or miLos?evi* or mLios?evi* or mLLos?evi* where the question mark replaces one letter and asterisk replaces all endings and combinations. If searching for a person and a location, the function called "Within" is used. For example, if searching for Milošević in Gazimestan in 1989 , all these parameters and variants of Milošević's name in combination with function called "W/5" are used to mean that words "1989" or "Gazimestan" should be located five places around the name: (miio?evi* or miLo?evi* or mLio?evi* or mLLo?evi* or miios?evi* or miLos?evi* or mLios?evi* or mLLos?evi*) w/5 (gazimesta* or gazLmesta* or "1989"). The use of the capital letter "L" in the middle of a name is determined by the fact that documents fed into the ZyFind are typed with different fonts, so the program cannot always know which letter is written. The small letter "l" resembles the capital letter "I" which is why every "l" and "i" is written as a combination of "I" and "L" in both forms. Since the ZyFind also has appropriate tools which enable searching through the documents written in Cyrillic, the same goes for Cyrillic B (Б), Ć (T) and Đ (Ђ). In this way, search results include any document which could possibly mention the name and/or last name of the subject in relation to a particular event, location, or a year. Once basic search results are produced, they are further narrowed down to particular events, years, functional positions, and everything else that helps the person who requested documents to receive appropriate documents. In addition, a separate Excel sheet is created for every search. Once the relevant hits in the document are found, Language Assistants who are performing searches and reviews enter the page numbers corresponding to the pages where hits were found and all other relevant information to save time and avoid future effort. This all might sound very complicated and unnecessary today, but, on the one hand, most documentary evidence was searched from scanned copies, and, on the other, the technological advances of today are not what they were in 1993 or throughout the war on B\&H between 1992 and 1995 from which the bulk of this documentary evidence originates.
} 
further refining it for the needs of the case to which they are assigned. In this they are helped by the team Language Assistants, who select exculpatory and inculpatory evidence. Once relevant documents were selected for translation, they were either given to team Language Assistants or CLSS for translation, depending who was free.

The first time OTP Language Assistants were mentioned was in the 2002-2003 UN BoA Report, which established that to allow defense counsel to select the documentation falling under ICTY rules and regulations on disclosure of exculpatory and other material, the OTP opted for the scanning of documents and for web-based e-disclosure, which was launched late 2003. As a consequence, all documentation available at OTP, regardless of its relevance, had to be translated. Since 2002, OTP Language Assistants translated prosecution material at a preliminary stage to ascertain whether the material would be required for the Court proceedings. If the material was deemed to be required, the Tribunal requested that this already translated prosecution material be translated again before being used in Court. The second translation was provided by certified translators of the CLSS. ${ }^{751}$ During the 2002 plenary sessions, the ICTY Registrar set up a committee to examine translation requests on the basis of the urgency of the request and the capacity of the services in question. ${ }^{752}$ A UN BoA 2002-2003 Report found that OTP Language Assistants translate material before ascertaining whether it will be used in court or not. This is a perfect example of a lack of communication between in-house professionals and poor UN use of existing resources: why would anyone translate something in full before deciding to use it?

The primary responsibility for selecting and analyzing documentary evidence lies with Military, Intelligence, and Research Analysts. However, since it seems these ICTY ARs and the UN BoA Report have been hinting at the poor performance of Military, Intelligence, and Research Analysts, classified between P-2 and $\mathrm{P}-4$, this is the perfect time to say something about them. It seems that the requirement for language professionals to engage in non-strictly language professional affairs was inherited by IMT:

\begin{abstract}
Most interpreters [at the IMT] had additional duties. Between sessions they were assigned to other departments, like investigation, translation, transcript correction... the idea that they would do nothing was not established. Sometimes, interpreters would work for the prosecution as investigators. They were sent to countries in Europe to obtain affidavits from potential witnesses and their agreement to testify personally in court. ${ }^{753}$
\end{abstract}

Once documents reach them, Trial Teams would ask their team Language Assistants to select documents for evidence, which means that Language Assistants would start acting like investigators or Military, Intelligence, and Research Analysts. However, the latter group of professionals should have taken a lead in this process themselves. It has been reasoned that Language Assistants were involved in these matters because most documents waiting to be selected for evidence are in $\mathrm{B} / \mathrm{C} / \mathrm{S}$ and there is a lack of sufficient language capacity in OTP to go through all of them. As we have seen in Chapter 5 , the unwillingness to employ local professionals is a recurrent problem in the $\mathrm{UN}$, stemming from the fact that they are repeatedly trying to sort out problems in the situation country by refraining from engaging local professionals with the necessary language proficiency. Here, it is unclear how anyone, but Military, Intelligence, and Research Analysts, could analyze documents for intelligence at any institution, especially at an international criminal tribunal because so much depends on the proper selection of evidence and analysis thereof. At first sight, this is a serious issue that has to do with the integrity and self-regulation of all participants in the legal process. International organizations should employ military, intelligence, and research analysts who speak the language of the situation country.

\footnotetext{
${ }^{751} \mathrm{UN}$, UN BoA Financial report and audited financial statements for biennium 2002-2003 ended 31 December 2003 (A/59/5/Add.12)

(2004), paras. 50-51.

${ }^{752} \mathrm{UN}$, Report of the ICTY (A/57/379) (2002), para. 37 .

${ }^{753}$ Gaiba, F. (1998), The origins of simultaneous interpreting: the Nuremberg trial. University of Ottawa Press: Ottawa, p. 39.
} 
Managers should not continue allowing outsiders to analyze documents, merely because those outsiders understand the language of the document. It seems that this behavior was institutionally supported. The footnote below contains Language Assistants' generic job description, which clearly states that they are in charge of:

reviewing and summarizing material in $\mathrm{B} / \mathrm{C} / \mathrm{S}$ relating to specific cases in support of pre-trial investigations and ongoing trials, and

supporting OTP trial teams by reviewing and, in consultation with trial team members, selecting relevant evidentiary materials in $\mathrm{B} / \mathrm{C} / \mathrm{S} .{ }^{754}$

This footnote shows that engaging amateurs in professional fields seems to be an institutional requirement: the education requirement for a candidate who will be evaluating evidence is a high school diploma. Language Assistants cannot review documents alone or in consultation because they are not professional Military, Intelligence, and/or Research Analysts. Likewise, Language Assistants cannot select relevant evidentiary materials because they are not lawyers. No job vacancies for the post of Language Assistant mention any educational requirements in legal or analytical field, only language, if that at all. Truth to be told: vacancies stipulate being in possession of a high school diploma only, the fact that OTP had many Language Assistants with language-related diplomas was fortuitous. As a result, it looks as if the Language Assistants' job description was not reviewed by anyone who understands the difference between highly trained Military, Intelligence, and Research Analysts and everyone else. It is unlikely that Language Assistants would even have a natural flair for these jobs because their expertise is language, not analyzing or the practice of law. All the ICTY needed to do to ensure good delivery of all these services was to employ appropriate professionals with knowledge of $\mathrm{B} / \mathrm{C} / \mathrm{S}$.

But this didn't happen. The following ICTY vacancies for Criminal Analyst, ${ }^{755}$ Military Analyst, ${ }^{756}$ and Investigator ${ }^{757}$ clearly state that applicants should have a working knowledge of $\mathrm{B} / \mathrm{C} / \mathrm{S}$. But these vacancies for Legal Officer, ${ }^{75^{8}}$ Trial Attorney, ${ }^{759}$ and Senior Trial Attorney ${ }^{760}$ do not make any mention of B/C/S. So, this is another example of how poorly the UN uses its internal resources and how poorly it enforces its own policies. This supercilious ICTY approach to OTP language staff is clearly wrong and legal professional-centric. It revolves around the needs of legal professionals commanding language professionals to conduct important legal duties for which they are absolutely unqualified. This approach is indicative of an institution that clearly ignores the local context and considers that speaking a local language qualifies a speaker to meddle in every aspect of the associated culture. The fact that a Language Assistant speaks $\mathrm{B} / \mathrm{C} / \mathrm{S}$ does not qualify him to perform the job of an analyst and reviewer of evidence to be used in a criminal context. This approach paints a picture of legal professionals who want to get through documents no matter what, including surrendering them to an unqualified group of people. This failure to plan properly constitutes a serious lack of due diligence: if several groups of people, namely Military, Intelligence, and Research Analysts, were already charged with the task of selecting, reviewing, and analyzing evidence, why involve another group? These were not random individuals, but three different fully staffed organizational units of Military, Intelligence, and Research Analysts with at least two of them from each unit assigned to a particular trial team. Language Assis-

\footnotetext{
${ }^{754}$ UN vacancies, ICTY G-5 Language Assistant.

${ }^{755}$ This 2015 Intelligence Analyst (Criminal) does and this 2012 Intelligence Analyst (Criminal) vacancy does not require candidates to have a working knowledge of the $\mathrm{B} / \mathrm{C} / \mathrm{S}$.

${ }^{756}$ This 2010 Intelligence Analyst (Military) vacancy does require candidates to have a working knowledge of the B/C/S.

${ }^{757} \mathrm{UN}$ vacancies, 2010 vacancy for Investigator.

${ }^{75}{ }^{8} \mathrm{UN}$ vacancies, 2010 vacancy for Legal Officer.

${ }^{759} \mathrm{UN}$ vacancies, 2010 vacancy for Trial Attorney.

${ }^{760}$ UN vacancies, 2015 vacancy for Senior Trial Attorney.
} 
tants cannot provide an adequate check and balance to substantive subject-matter work performed by Military, Intelligence, and Research Analysts and lawyers. The relationship between the analysts/investigators and Language Assistants should have been limited to tasking Language Assistants to make summaries of documents along strict criteria defined by legal professionals, as that is why they hired Military, Intelligence, and Research Analysts in the first place. Language Assistants should not have been given documents to review for evidence under any circumstances. How much unimportant evidence has been selected by Language Assistants in the past 23 years of ICTY? Obviously so much that it has led to a crisis that has been consistently mentioned since the 2000 ICTY AR. And, most importantly, how much important evidence did Language Assistants simply not know whether to include, despite their best efforts?

\subsubsection{Language Assistants and document management}

Operationally, the work at the ICTY was characterized by an abundance of documents for translation since the beginning of the second management period in CLSS. It has been reasoned that this is because of multiaccused trials. However, those trials did not start during the second management period; they took place from the onset. The ICTY President established that there was a need to reduce the number of motions filed and the length of documents and, to that effect, a direction on the length of briefs and motions was signed by the President of the Tribunal on 19 January 2001. ${ }^{761}$ However, this direction only affected court materials which are, as a rule, delivered in English and French; the problem with trial documents did not go away. Judges made the first pick, as expected, and imposed a strict word count on the documents they had to deal with. However, this decision did not in any way address OTP and Defense documentary evidence in $\mathrm{B} / \mathrm{C} / \mathrm{S}$ which required translation. The parties seem to have been left to their own devices to deal with those documents. As explained above, the parties dealt with it by overtasking: the defense monopolized CLSS and the OTP started overusing their Language Assistants. Naturally, the proper resolution of problems posed by an abundance of documents for translation would have been by streamlining and centralizing the various translation and interpreting units to form a single language unit and taking full advantage of $\mathrm{B} / \mathrm{C} / \mathrm{S}$ speaking legal professionals.

As far as translation of trial-related documents is concerned, a 2000-2001 UN BoA Report established that as at 14 January 2002, the CLSS English Translation Unit had a backlog of 13,161 pages and that, as a rule, they resorted to extending deadlines which, in turn, may have affected the cost of the ICTY. The CLSS justified postponing deadlines, claiming difficulties in recruiting high-level translators due to competencies not being readily available on the market, which necessitated CLSS resorting to high-cost, short-term and freelance contracts. ${ }^{72}$ Milošević was arrested on 1 April 2001, transferred to the ICTY on 29 June 2001, and his trial started on 12 February 2002. The arrival of Milošević proved both to the world that the ICTY was a serious player and was about to decisively end impunity. However, at the ICTY, disbelief and chaos ensued. The ICTY realized that, in addition to an abundance of duplicates, they had numerous evidentiary documents that needed to be translated. The 2000-2001 UN BoA Report confirmed that, as far as operational needs were concerned, the number of pages translated per case was more than 18 ,ooo pages, but that no more than $5-10 \%$ of the translated materials were said to be referred to during the proceedings, which meant that $90-95 \%$ of the documents were of little or no use, and the cost of translating them a waste. The UN BoA recommended that the ICTY re-examine its translation policy and facilities with a view to reallocating priorities and being far more selective, choosing documents that are likely to be of use to the Court. The UN BoA commended the ICTY for having undertaken a review of the staffing allocation for translation and for establishing a database and a document control system to monitor translation workflows and costs. ${ }^{763}$ All this sounds like being caught in a devil's merry-go-round: on the one hand there are abundant documents waiting for translation,

\footnotetext{
${ }^{761} \mathrm{UN}$, Report of the ICTY $\left(\mathrm{A} / 5^{6 / 352}\right)$ (2001), para. 59 .

${ }^{762} \mathrm{UN}, \underline{\mathrm{UN} B O A}$ Financial report and audited financial statements for biennium 2000-2001 ended 31 December 2001 (A/57/5/Add.12)

(2000), paras. 74-75.

${ }^{763}$ Ibid, paras. 76-77.
} 
duplicate documents, and no working system of document management, and, on the other, the UN BoA suggests that CLSS should become far more selective in choosing documents that are likely to be of use to the Court. How could CLSS know which documents will be of use to the Court? The parties know that. How can a CLSS, non-legal professional, teach legal professionals which documents are likely to be of use to the Court, and, finally, who services who, CLSS the court and the parties or the other way around? The document flow to the ICTY starts from the region: Language Assistants and legal professionals go on a mission, seize a collection of documents, skim through it, return to the seat, and surrender the seized material to analysts, who further narrow down the documents to be used in the case and present their findings to the trial attorneys who make the final selection of documents for translation. CLSS is at the end of chain. The UN BoA should have made this recommendation to the analysts, who could make an informed decision on the issue. Perhaps, the analysts could have established a precedent and suggested that the ICTY employ their colleagues from the region, who would have had the necessary language skills. It is unclear whether CLSS clients reacted to this recommendation, but, from a legal point of view, the said UN BoA recommendation almost sounds illegal because it seems to be openly inviting CLSS to make important legal decisions, thus meddling in the work of the Court and the parties.

It is equally unclear why the UN BoA commended CLSS for establishment of the document control system. First of all, at that point, the ICTY had been in operation for eight years, and CLSS should have established a document control system years ago. The ICTY 1998 AR confirmed that a large backlog of documentary evidence and donations had been received from the government of the Netherlands to reduce the backlog. ${ }^{74}$ Were OTP and CLSS not communicating before Milošević was arrested? The Milošević and "all eyes of the world" environment in which the ICTY started working revealed a very serious flaw in the ICTY system of communication, but instead of calling up the responsible language and legal management to deal with the translation backlog that persisted despite having numerous internal and external budgetary resources and despite the fact that CLSS seems to have been spending its budget on worldwide travel, the UN is officially commending CLSS for starting to use a document control system established three years ago. The UN must have very clear policies to challenge non-producers instead of commending them for work that should have been done much earlier.

The 2002-2003 UN BoA Report established that the Tribunal created a Documents Control Unit in 2003 and that this unit became operational in 2004. According to this report, CLSS defined the required levels of translator skills in order to ensure the most cost-effective use of translation resources and also ensure that translations of the same material are not made more than once at the same level, even if the same material is requested by different parties. Nevertheless, duplicate translations, first preliminary and then "official," remained a cost factor. UN BoA Auditors encouraged the Tribunal in its action to further reduce the need for costly official translations. ${ }^{76}$ The findings of this report about duplicate translations require some additional explanation. The ODM was established in 2004 to streamline the translation workflow. This unit is a first port of entry for any document due for translation by CLSS and a unit that is a go-between the OTP and the Defense when it comes to translation. Prior to the establishment of the ODM, all work related to translation requests was done by CLSS, the Defense, and the OTP administration separately. The OTP, Chambers, Registry, or Defense translation requester accesses the Translation Tracking System and the request for translation involving English, B/C/S, Macedonian, or Albanian reaches the ODM. ODM staff check the accuracy of the translation request according to the following parameters: type of document, language combination, legibility of original, volume, duplicates, and priority. After checking, the ODM either rejects or approves the request. Once approved, translation requests appear in the CLSS's Translation Tracking System in-tray. If a translation request does not contain necessary information, if information is inaccurate, if the original document is illegible or if the quality of the best copy available is too poor or incomplete, CLSS will reject the request with a comment

\footnotetext{
${ }^{764} \mathrm{UN}$, Report of the ICTY (A/53/219) (1998), paras. 125-127.

${ }^{765} \mathrm{UN}$, UN BoA Financial report and audited financial statements for biennium 2002-2003 ended 31 December 2003 (A/59/5/Add.12) (2004), paras. 52-53.
} 
specifying the problem. The ODM will then reject the item and arrange for the translation requester to resubmit the request with the correct information in the form of an attachment. Translation requesters are notified via email when the ODM rejects their request. Here, it should not be forgotten that the ODM handles translation requests from two opposite sides: the OTP and the Defense. In cases of duplicate translations, the identity of the original translation requester is hidden. For example, should the Defense request a document that has already been translated for OTP purposes, the ODM shall request CLSS to make it seem like the document had been translated for the Defense. This serves as a confidentiality safety guard. ${ }^{766}$ But, the ODM checks for duplicates only in relation to OTP and Defense translation requests into English, B/C/S, Macedonian, or Albanian. Documents in French are not checked which doesn't make sense as French is one of official ICTY languages. OTP Language Assistants still check their own documents submitted by the OTP.

\subsection{Interim conclusions}

Chapter 6 focuses on ICTY language professionals' recruitment, training, staff retention, translation and interpreting output, and internal organization. CLSS, the official ICTY language service, was vested with authority over all these administrative matters. Operationally, CLSS was supposed to provide language services to all parties to the proceedings, creating a language philosophy that would fulfill the requirements of $\mathrm{UN}$ and ICTY rules and regulations. Since CLSS management and staff were domestic to the situation country, it was understood they would handle the local linguistic context professionally, just as any independent institution would. Accordingly, ICTY CLSS language professionals' performance in the delivery of linguistic justice is examined here at the level of: corporate UN (internal client, English and French), ICTY (co-internal client, English, French and B/C/S), defendants (co-internal client, English, French and B/C/S), witnesses (external clients, English, French and B/C/S), legal professionals from the region (co-external clients, English, French and $\mathrm{B} / \mathrm{C} / \mathrm{S}$ ), and the region as a whole (co-external clients, English, French and $\mathrm{B} / \mathrm{C} / \mathrm{S}$ ).

Corporate UN imposed English and French as official languages and translation and interpreting from/into those languages as a priority. The enforcer, CLSS, engaged in proactive recruitment activities and started traveling around the world searching for qualified and competent staff willing to work in The Hague, claiming they were facing severe competition from other international organizations. In order to retain staff, CLSS offered the highest rates of all The Hague-based international organizations but might have violated AIIC and AITC rules on domicile. The whole matter of staff retention might have revolved around CLSS's

\footnotetext{
${ }^{766}$ The document flow in the OTP Language Unit starts after a Language Assistant receives a translation request through a Case Manager, Team Secretary, Translation Coordinator, or a legal professional whereupon an OTP Language Assistant or administrative assistant searches for duplicates. If they do not find any, they translate the document and send it back to the requester. The document flow in CLSS administrative support unit starts after the ODM staff complete their work on finding duplicate documents and duplicate translations. CLSS translation coordinators receive translation requests electronically and then assign them to translators according to expertise or availability. CLSS administrative staff report that although "everybody translates everything," most of their language professionals had a non-linguistic background: among the many historians on their staff, there was also a dentist who was considered an authority on all medical documents, including autopsies, whereas all male staff from the former Yugoslavia were considered to be an authority on military documents because they completed their mandatory military training in the former Yugoslavia. There were no educated lawyers on the CLSS staff. As far as expertise is concerned, CLSS administrative staff report having sent documents for translation to staff who "proved to know how to translate it without major revision." In addition to all the translation units, CLSS also has a Referencing Unit, which works on referencing various types of documents (mostly legal documents, transcripts, witness statements, and military documents), so that they do not have to be translated again. Translators know the text might already be translated if it contains quotes or footnotes specifically referencing other texts. For example, when translating a judgment, Referencing Unit staff provide CLSS translators with all quotes and footnotes referencing other judgments or legal texts before they start with the actual translation of the judgment. If it happens that the text references third, non-legal texts, Referencing Unit staff perform various Google searches to find appropriate originals. In addition, Referencing Unit staff also provide CAT tools, namely the SDL Trados. Once a document is translated, and once all references to previously translated material are incorporated, the translated document is printed and sent for revision. After revision, which is usually done off hard-copy, the translator has the opportunity to accept or refuse changes proposed by the revisers; $\mathrm{s} /$ he sends the final translation back to the administrative staff who send it back to the requester. Some CLSS translators argue that CLSS revisers could have made much more effort revising documents electronically to save time and effort. When pressed by deadlines, CLSS support staff would input the changes to the translation from revisers, instead of translators. Unfortunately, that defeated the didactic purpose of revision and burdened administrative staff with additional duties.
} 
inability to self-regulate, as they regularly overpaid their freelancers. Notwithstanding all the money CLSS spent on external resources, translation and interpreting output remained subpar.

CLSS outsourced court reporting services but did not establish any checks and balances for court reporting transcripts (in the form of transcript reviewers). Despite the fact they could have engaged court reporters from the region, CLSS court reporter transcripts were done only in French and English, thus depriving all $\mathrm{B} / \mathrm{C} / \mathrm{S}$ speaking clients of transcripts which exacerbated existing criticism of the ICTY. The contract CLSS managers signed with the company outsourcing English and French court reporters did not cover English and French transcripts of interviews conducted by the parties. These transcripts, including transcripts into $\mathrm{B} / \mathrm{C} / \mathrm{S}$, were made by the parties' Language Assistants.

Although it was understood by the ICTY, the judges, CLSS management, and staff that victims and witnesses' language also had to be taken into consideration when translating and interpreting, there was no ethnicity-based selection of language professionals. Consequently, language professionals of the attacking ethnicity were allowed to freely engage with victims and witnesses from the region in all stages of the investigative and judicial process. Although the ICTY, the judges, CLSS management, and staff knew that victims and witnesses' language had to be taken into consideration when translating and interpreting, there was no shift from defendant-centric to victims-and-witnesses-centric rules and regulations, despite all the amendments to ICTY rules and regulations.

As to the recruitment of ICTY language professionals, things turned from bad to worse with the change in CLSS management around 2000. At this time, CLSS recruitment could be described as word-ofmouth: examinations and recruitment were catering to candidates from Serbia, resulting in reunions of friends, lovers, college, and other colleagues who had no hands-on experience in war-related, humanitarian context-related, investigations-related or law-related translation. The only claim of CLSS revisers was that they were "native speakers" and there were no further efforts to provide substantive subject-matter training to CLSS staff once they were selected as translators and interpreters. CLSS was totally isolated from the rest of the ICTY and CLSS staff had poor regard for management, while management was catering to pre-war bigoted views of $\mathrm{B} \& \mathrm{H}$ and Muslims, spreading the theory that all were equally guilty and all were equally victims in the former Yugoslavia. This amounted to ethnic discrimination of non-Serb(ian) staff.

CLSS gradually stopped translating witness statements, stopped interpreting for witnesses during proofing, stopped working for OTP in general, and started catering almost exclusively to the Defense since the second Chief of CLSS took over. However, CLSS staff were always ready and willing to go on missions, because it brought in extra income. The OIOS Auditors found that CLSS in-house translators had a shortfall of between 18-26\%, especially in English and French translation units, where production was sub-optimal. The only reason why the $\mathrm{B} / \mathrm{C} / \mathrm{S}$ translation unit met its quota was because they had two staff who regularly produced more than 10 pages per day. CLSS management said that was because those two were assigned easy documents to translate.

As to CLSS interpreters, the OIOS Auditors found that most interpreters attended the office four days a week and worked an average of 20 to 22 hours per week, compared to the standard 37.5 hours. The auditors calculated that interpreters were absent from the office around 143 days, though they were paid a salary of approximately $\$ 6$ o,ooo for these days. They established that, on an annual basis, the same trend would imply expenditures of around $\$ 720$,ooo on interpreters' salary for days they were not in the office.

Operationally, during the second management period, the provision of ICTY language services became highly decentralized and overly segmented: almost every section had its own translation and interpreting unit and CLSS surrendered work they did not want to do to seven other units dedicated to some segments of language-related work at the ICTY: the OTP Language Unit took care of translation of trial-related documents and interpreting for witnesses, VWU language professionals provided community interpreting services 
for witnesses, UNDU language professionals provided community interpreting for detainees, Outreach Program language professionals translated their own publications and ICTY Internet page-related material, Rules of the Road language professionals made summaries of documents relating to transferring cases, and Chamber Support Unit language professionals provided editing services of court-related material. Although CLSS had a separate budget, maintaining all these other language units depended solely on donations throughout their existence.

The OTP needed urgent translations and found people to provide (3-in-1)+ service comprising language as well as non-language-related duties. The OTP kept and expanded the pool of Language Assistants and formalized them into a unit separate from CLSS to be used by the OTP for translation, interpreting, processing of intercepts, quality control of document coding, redaction of witness statements, reviewing of video material, and other needs. The OTP imposed translation norms on this group of people that were three times higher than UN standards without any coordination with CLSS. OTP managers defended their choices and the OIOS Auditors did not press any further. Given the terms of their engagement, the establishment of the OTP Language Unit directly violated the core reasons for the promulgation of ICSC Standards. The most worrying implication of the (3-in-1)+ service was that legal professionals requested Language Assistants to meddle with legal work. They surrendered batches of documents to OTP Language Assistants to select and analyze despite the fact that the primary responsibility for selecting and analyzing documentary evidence lies with Military, Intelligence, and Research Analysts.

Delivery of linguistic justice by ICTY CLSS at the level of defendants in a combination of English, French, and $\mathrm{B} / \mathrm{C} / \mathrm{S}$ is examined here according to the languages and dialects of defendants and of interpreters during initial appearances, the reading of judgments, the situation country, and the testimony of witnesses from $\mathrm{B} \& \mathrm{H}$, showing that CLSS, and by extension the ICTY, has made a strong national, ethnic, and political identity statement against $\mathrm{B} \& \mathrm{H}$ and the peoples of $\mathrm{B} \& \mathrm{H}$ at the level of interpreting for defendants who originate from $\mathrm{B} \& \mathrm{H}$, wherever $\mathrm{B} \& \mathrm{H}$ features as the location of a crime at the reading of indictments or verdicts, and at the level of interpreting for court witnesses from B\&H. The Bosnian ijekavian language featured as part of one- or two-interpreter teams providing interpreting in 45/174 public proceedings: one and the same woman appears as the Bosnian language interpreter in $43 / 45$ cases.

In the next - and last - stop on the journey toward linguistic truth, we examine the medium of translation and interpreting and its quality. 
Chapter 7: May translation and interpreting take the stand, please

Chapitre 7 : La traduction et l'interprétation sont priées de venir à la barre

Sedmo poglavlje: Neka pristupe i pismeno i usmeno prevođenje 
We have reached the final stop on our journey toward linguistic justice. In this chapter we examine translation and interpreting at international criminal tribunals in practice. Mulayim and Lei report that interpreters working in a legal context have been described in many different ways: as a phonograph, a transmission belt, a bilingual transmitter; an electric transformer; a conduit of communication; a cipher, a medium of communication, a language machine, a black box, a cultural mediator, a piece of gum on the bottom of a shoe ignored for all practical purposes, but almost impossible to remove. ${ }^{767}$ The OTP lawyers called CLSS, "the CLSS world", referring to the fact that they are isolated institution with rules of their own and little in common with the rest of the ICTY as is clearly described in previous chapters. ${ }^{768}$ The OTP investigators would normally come cover and request a translator to "type this in Serbo-Croatian" referring to a document they wanted translated and thus showing their knowledge and sensibilities about what translation involves. The following examination will show how well international rules and regulations and international lawyers and UN language professionals find themselves contributed to the proper delivery of translation and interpreting in practice. This chapter describes the nature of the relationship between language and legal professionals, professional boundaries, and the image they present to their clients, including their individual and joint production. How well does the legal background to the engagement between legal and language professionals at international criminal tribunals enable a productive relationship? What is the task of a legal professional when engaged with interpreters and translators? What is the task of a language professional in criminal proceedings? To what extent is it necessary for a language professional to be qualified as both a translator and a criminal lawyer? In what ways do language professionals participate in establishing legal truths? How can you know whether something went wrong in translation and interpreting at international criminal tribunals?

\subsection{Translation in a legal context}

The following section of this study presents a unique contribution to the field of legal translation and interpreting, addressing trends in translation at the ICTY. For full impact and to reiterate what has already been established, perhaps it would be the best to start this section with a joke. "How many translators does it take to change a lightbulb? It depends on the context." This joke accurately pinpoints the very essence of translation and interpreting: both revolve around the context. In that sense, the following basic, even patronizing, albeit necessary Q\&A must be asked from the onset. Who is the translator changing the lightbulb here? A professional independent from the parties with an interest. In what context does such a translator change the proverbial lightbulb? In the context of international criminal tribunal adjudicating on ethnic crimes. Who is supposed to benefit from the light produced by the translator changing the lightbulb? The judges.

As to the language professionals' independence, all translation performed at the ICTY falls into the category of institutional translation. When working as a language professional in the context of international criminal law, one works with all sides involved, judges, the prosecution, the defense, defendants, and victims and witnesses, directly or indirectly working on inculpatory or exculpatory evidence. Each of these sides has their vision of truth which they deliver in documents or orally that needs to be reflected in translation and interpreting. In other words, blind justice includes the truth as appraised by the translators, as well. However, whereas language professionals, by the virtue of their profession, reflect what has been written or said as is, legal professionals, by the virtue of their profession, reflect what is lacking from what has been written or said in a form or content. The job of translators working at the international criminal tribunal is not to please anyone. Their client is the one who is paying them, the UN, and their mission and vision is the mission and vision the UN has of the international criminal tribunals, not of the parties who hired him. So, what is translation in a legal context?

\footnotetext{
${ }^{767}$ Mulayim, S. and Lai, M. (2016). Ethics for police translators and interpreters. CRC Press, Taylor \& Francis Group: Boca Raton, p. $3^{2 .}$

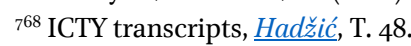


It must be made clear what distinguishes translation in a legal context from legal translation. Cao recognizes three types of documents for legal translation, namely:

Legal translation for normative purpose (equally authentic legal texts in bilingual and multilingual jurisdictions of domestic laws and international legal instruments and other laws),

Legal translation for informative purpose (translation of statutes, court decisions, scholarly works and other types of legal documents if the translation is intended to provide information to the target readers), and

Legal translation for general legal or judicial purpose (legal documents such as statements of claims or pleadings, contracts and agreements, and ordinary texts such as business or personal correspondence, records and certificates, witness statements and expert reports, among many others). ${ }^{769}$

However, Cao also mentions a fourth type of document that requires legal translation: ordinary texts originating from the situation country whose translation is commissioned by a party with an interest. Those ordinary texts are not written in legal language by legal professionals, but by lay people and are thus a type of legal translation that is often left out in the discussion and classification of documents for legal translation, although they serve as the actual basis for determining whether a certain international or national law has been violated. ${ }^{770}$ Since the parties use these documents as evidence to prove their claims, these documents are the main focus of translation activities at international criminal tribunals. ${ }^{77}$

The oldest translation discussion boils down to a debate about word-for-word or sense-for-sense translation, which is fueled by the falsehood of claiming the untranslatability and incomprehensibility of the original culture. Current theories on translation, which are discussed in more detail below, require the text to have the same effect on the reader as it had on the producer. In other words, the job of a contemporary literary translator is to trick the reader into thinking that he is reading a piece originally delivered in his own language. Likewise, the delivery of translation and interpreting in a legal context has always revolved around the issue of equivalence, but in a different way. Nida argues that translation denotes two types of equivalence: formal and dynamic equivalence. Formal equivalence focuses on the message, both in form and content, and should match the original in translation as closely as possible. Should no formal equivalence be achieved, such translation is considered inaccurate or incorrect. Dynamic equivalence is concerned with the equivalent effect of the message: translation should have the same effect on the reader of translation as on reader of the original. In order for it to have the same effect, such translation has to feel natural to the one reading it and should be adjusted to the grammar, lexicon, cultural referencing, and so on, so that readers, effectively, think they are reading material originally written in their own language. Nida prescribes four following basic requirements of a translation: it has to make sense, it has to convey the spirit and manner of the original, it has to have a natural and easy form of expression, and it has to produce a similar response. Nida reminds us that the traditional notions of content and form can conflict, which is sometimes not easily solvable, suggesting

\footnotetext{
${ }^{769}$ Cao, D. (2007), Translating law. Multilingual matters LTD: Bristol, p. 10-12.

${ }^{770}$ Ibid, p. 12.

${ }^{771}$ Whereas OTP Language Assistants selected and translated documents, it is hard to say what the CLSS language professionals were translating because of all the picking and choosing explained in Chapter 6. In the beginning, CLSS language professionals were translating everything, but then, as the management changed, they started rejecting witness statements, reports, and other evidentiary which were then translated by Language Assistants. This has been discussed in detail elsewhere in this study. Let us say here, for the sake of argument, that CLSS language professionals were mostly seen translating legal texts for informative purposes and some texts for general legal or judicial purpose when they had time. There are volumes written about legal translation of the first three types of documents that Cao classifies. This study will not make any attempts at commenting on discussions that have already been explored by so many. The focus here will be on language professionals and what they have to focus on in order to deliver translationtranslation translation in a legal context.
} 
that correspondence in meaning must have priority over correspondence in style should one want to achieve an equivalent effect. Nida is the creator of the receptor-based or reader-based style of translation. ${ }^{772}$

In response to Nida, other general translation theorists questioned putting too much emphasis on the word level, asking about methods used to measure the "equivalent effect." Legal translation theorist, Šarčević, has no problem admitting that legal translation revolves around the production of an equivalent legal effect, but criticizes general translation theorists for misleading statements and a failure to recognize the proper communicative function of legal texts. Šarčević agrees that translation in a legal context is a receiver-oriented exercise, emphasizes preserving the letter of the law, sets the whole text as the basic unit of translation, and suggests that such a translation must take legal considerations into account. ${ }^{773}$ In other words, Šarčević is stressing the paramount importance of operational information contained in text that is subject to the scrutiny of legal professionals. It follows that translation in a legal context must be receiveroriented. ${ }^{774}$ Receivers of translations include: the translation requester and posterity. These receivers scrutinize translations with different purposes. The scrutiny of translation is specially complicated when delivering translation output to a party with an interest. Once cleared by the only neutral party in the process, the judges, such a translation is considered to be a contribution to establishing legal truth. The completeness of legal truth is contingent on the degree to which translation is narrative-free. Should a receiver of a translation reject translation, s/he must name reasons that are based in language. A party with an interest is bound to, at least, nudge a translation into the direction of its argument. Should language staff complain about the influence of the parties to the judges directly, that would create a precedent. It follows that, due to their obligations to legal truth, language staff working in a legal context should never officially be subordinated to any parties with an interest, but only to their peers or to the same authority as their legal clients. That fulfills the first condition for delivering an impartial translation: in order to deliver impartial translations, language professionals must be organizationally independent from the parties.

The main focus of legal professionals' activities consists of examination of (translations of) documents planned to be used in their argumentation before the Court. Here, it is important to point out that legal professionals are also the people of language. The language of the document is their main tool when they advance arguments stemming from the document they are presenting to the Court. The language of the ICTY rules and regulations is the main tool at their disposal as they go about arguing because it tells them what they can and what they cannot do while proving or disproving certain allegations arising from a document. In that, the prosecution concentrates on the onus probandi and the defense on reasonable doubt. However, there are legal professionals who, for a variety of reasons, want to use translators as cultural, historical, and overall source-culture explainers. Since this study will be published in the Netherlands, let us assume the legal professional reader of this study just got a job at an international criminal tribunal adjudicating on crimes committed in one of the former colonies of the Netherlands. How can such a legal professional prepare himself for that task? Such a professional should read a book on the history of that country written by a local person to get an overview of the conflict from the local point of view. Since the Netherlands once colonized the situation country, such a professional should also read a book on history of that country written by a colonial authority at the time of colonialism and another one by a former colonial authority after the situation country gained independence to get an overview of the conflict from the colonial point of view at the time of colonization and after independence. Such a legal professional should also read two more books: a personal perspective of a colonized individual and the personal perspective of a colonizer to get an overview of both sides of the conflict or what each gained and lost from this colonization. The reading list may also include a book authored by an external authority with no interest, if available. After arriving in the country, such a legal

\footnotetext{
${ }^{772}$ Munday, J. (2016), Introducing translation studies: theories and applications (fourth edition). London \& New York: Routledge, p. 62-70.

${ }^{773}$ Šarčević, S. (1997), New approach to legal translation. Kluwer Law International: The Hague, p. 5.

774 Šarčević, S. (2000), Legal Translation and Translation Theory: a Receiver-oriented Approach. Legal Translation: History, Theory/ies, Practice.
} 
professional should watch a video prepared by the institution outlining the situation in the country that led to the conflict. S/he should also watch a second video on the prosecution and defense points of view of the source of conflict. Only then would such a legal professional be prepared to start working: with a good grasp of the history of the conflict from several sources, a good grasp of the institution's point of view, and a good grasp of the views of both sides. Any legal professional who would like to gain all that from a translator assigned to him during investigations is clearly at a loss. Why is this so? Everybody needs help every now and then. A legal professional must make a distinction between communicating with peers on an equal footing and communicating with people who have the potential to influence him: where to draw the line between the translators' quick fix of legal professionals' lack of knowledge and translators taking over the reading of the document? How can you reconcile language professionals' interpreting of the facts with legal professionals' operational needs? Finally, where are the checks and balances that ensure that this quick fix is provided as a one-off? Why are these checks and balances necessary? To eliminate the indifference on the part of legal professionals, who would rather somebody else does a job for them which can lead to problems in the courtroom. This is the second condition for delivering an impartial translation: it needs to be very clear that language professionals are not performing the job of legal professionals.

\subsubsection{The situational context}

As to the context, there are several things one must keep in mind during translation and interpreting in a legal context. The first is that work at any institution is performed in a specific context. Linguistic acts take place in a context and texts are created in a context, not in a vacuum. ${ }^{775}$ Working in the context of an international criminal tribunal amidst ongoing investigations means that new knowledge about the case under investigation is gained every day and everyone that participates in the translation process, including translators and interpreters, constantly has to catch up. Unfortunately, CLSS language professionals have been completely isolated from the rest of the ICTY, whereas Language Assistants have been too firmly embedded in the OTP and the Defense is composed of hybrid professionals tasked with everything relating to documents delivered in $\mathrm{B} / \mathrm{C} / \mathrm{S}$ to the point that the latter could be said to be exploiting them. Any institution is a collective being, the work performed is the result of a group effort and one cannot simply offer a creative approach without consultation with other members of the team and without regard to the main requirement of international criminal law: the legal truth. This truth is best gauged by examining the situational context, which entails an examination of the time and the type of text production.

The second thing one must keep in mind is the examination of the linguistic context within the culture producer. While trying to arrive at the truth during translation in a legal context, it cannot be forgotten that text cannot exist outside of context. The context is everything that surrounds the word, or the phrase being translated and, together with the text, it creates context. Translators working in a legal context must diligently research the background of the text in order to understand its linguistic and situational context and recreate it in their translation. This means that, for the purposes of translation in an international criminal tribunal context, both linguistic and situational contexts have to be fully grasped to arrive at the truth. Once that truth is reached and presented in the form of a translation, should the parties with an interest have any complaints, they should present them to the only party in a process without any interest: the judges.

Good knowledge of the situational context is very important for translators working in international criminal tribunals because they need to have a full grasp of the immediate contextual influences on communication. In that regard, translators must fully understand the setting (institution, home, detention camp, etc.), activity (briefing, discussion, order, etc.), and environment (materials, number of people, temperature, etc.) in which a translation takes place. For example, an ICTY colleague once stated that the reviser returned a translation correcting the translation of the word "trolleybus" as "tram" with the explanation that trolleybuses were discontinued during the war and that only trams were used in that stretch of land described in

\footnotetext{
${ }^{775}$ Bassnett, S. and Trivedi, H. (eds.) (1999), Post-colonial translation: theory and practice. Routledge: London and New York, p. 2.
} 
the actual document. However, unlike the reviser, this translator was a resident of Sarajevo from where the document originated, and the action described in the document included an area where trolleybuses were still functional, despite the ongoing war activities, whereas trams could not have been possibly used on a stretch of three stops running through the frontlines. ${ }^{776}$

\subsubsection{Type of text production}

Inevitably, discussion about the situational context entails the time and the type of text under examination. As shown before, translation in a legal context is a hybrid translation, also involving non-legal texts. When examining ordinary texts that are not written in legal language by legal professionals, but by a layperson, it must be acknowledged that lay people communicate in a way familiar to lay people and professionals communicate in a way familiar to the professionals. Here is where the use of Language for Special Purposes (LSP) comes into use. The use of LSP means that professionals such as doctors, the military, lawyers, etc. have their own way of "naming names." The understanding of a text written in an LSP depends on familiarity with the terminology and knowledge of the specialist domain. All legal translations are specialized or technical translations, and such translations are characterized by the use of an LSP. On the other hand, the Language for Legal Purposes (LLP), for example, is the way in which the legal professionals express themselves when communicating with their peers. ${ }^{777}$ Let us examine a couple of examples from the ICTY in a combination of French and English where the LSP belongs to the domain of military science. The UNPROFOR French Battalion was in charge of the humanitarian and military situation in/around Sarajevo between 1992 and 1995. Sarajevo suffered immensely from snipers. ${ }^{778}$ However, the sides could not agree on anything about the snipers, including whether they existed at all.

Table 15. LSP vs. non-LSP

\begin{tabular}{|l|l|l|}
\hline \multicolumn{1}{|c|}{ Original } & \multicolumn{1}{c|}{ non-LSP } & \multicolumn{1}{c|}{ LSP } \\
\hline armes cachés & hidden weapons & concealed weapons \\
\hline belligérances & belligerences & warring factions \\
\hline ravitaillement & supply & re-supply \\
\hline position de tir & sniping position & sniper hide \\
\hline snipeurs, snippers & snipers & tirs-embusqués \\
\hline
\end{tabular}

The translation process is a progressive, physical production of a translated text in a context in which that production takes place.$^{79}$ Here, the translation process took advantage of the institutional knowledge of the facts: ravitaillement is normally rendered as "supply," but since the city of Sarajevo was under siege, ravitaillement became "re-supply" because UNPROFOR and humanitarian agencies were trying to re-supply the city to its normal, pre-war potentials. Also, position de tir is normally rendered as "sniping position," but snipers in Sarajevo, and elsewhere, were always hidden, so the position de tir became a "sniper hide." Also, tirs-embusqués are normally an integral part of any army, but both sides in the conflict claimed that they had no snipers among their troops, which is the reason why all these instances were translated under the umbrella term "snipers" so as to not to take sides. Denoting the incongruence, the French originals sometimes went even further using the Anglicized snippers, snipeurs and anti-sniping which normally do not exist in French. All sides in the conflict, together with UNPROFOR, would actually go and "search" for those "snipers" every now and then.

\footnotetext{
${ }^{77^{6}}$ Skyscrapercity.com, The history of public transport in Sarajevo.

777 There is a worldwide attempt to simplify legal language and to make it more understandable to a layperson. This discussion does not address any milestones reached in those attempts.

${ }_{778}$ BBC, Sarajevo 1992-1995: looking back after 20 years (2012).

${ }^{779}$ Cao, D. (2002), Legal Terminological Issues in Translation. Translating Law. Multilingual Matters LTD: Bristol, p. 55.
} 


\subsubsection{Time of text production}

Legal language, which is a specialist language, often must be used in such a way as to produce painstaking precision, so it must be translated as such, as well. The Serb minority proclaimed the "Republic of the Serb People of B\&H" (Republika srpskog naroda Bosne i Hercegovine) on 9January 1992 in the municipalities where Bosnian Serbs constituted a majority according to the ${ }_{1991}$ B\&H Census and proclaimed it a part of Yugoslavia. Ideologically, the Serbs were against the separation of the former Yugoslav republics into independent countries. At the very beginning of the war against $\mathrm{B} \& \mathrm{H}$, it was suspected that all the political, and, later, military actions, came from Serbia. When B\&H became recognized as an independent country on 1 March 1992, the Bosnian Serbs did not want to be seen as separatists by the international community. Conversely, Serbia did not want to be seen as aiding and abetting what, officially, as far as the international community and $\mathrm{B} \& \mathrm{H}$ were concerned, became rebels. In order to clarify that they were not rebels, but people convinced they were defending their constitutional rights, Bosnian Serbs changed the name of their rebel area into Republika Srpska (The Republic of the Serbs). In translation, this term is left in the original to signify the passage of time from open Serbian influences on Bosnian Serb politics and actions to the official cutting off of ties with them. However, the OTP labored under the conviction that Serbian Serbs never really cut their ties with Bosnian Serbs. Therefore, it was important to distinguish between Serbs from Serbia and Serbs from B\&H in translation. This was especially important in those cases where it could be understood from the documents that certain Serbian officials from Serbia were aiding and abetting the Serbs from B\&H. The English language did not help at all; it prescribes "Serbian" as adjective of a noun "Serb," but also names "Serbians" as citizens of the Republic of Serbia. The original language did not help either: some Serbs from Serbia think the use of a term Srbijanci (Serbians) to denote citizens of Serbia is derogatory and prefer using the term Srbi (Serbs) to denote all Serbs regardless of where they lived. Their thinking is motivated directly by the SANU Memorandum, in which the authors referred to non-Serb tendencies to divide the Serbs declaring:

There is an increase in influence by those external to the Provinces, and in Vojvodina itself, who spread misinformation only to divide the Serb peoples into 'Serbians' and the Serbs living across the rivers. ${ }^{780}$

Clearly, nationalistic discourse considered all Serbs everywhere as Serbs without distinction and without regard to the toponym Serbia since Vuk (see Chapter 3 for an extended discussion of this). The translation question was: how should one name the Serbs living in B\&H? In the above example, if it was up to language, all those "Serbs" from both sides would be grouped under the common noun and adjective "Serbians/Serbian," and the lawyers simply would not know which ones surrounding Sarajevo were Bosnian Serbs (legitimate military actions) and which ones came from Serbia (foreign interference). However, they needed to know, understand, and show the difference to prove that there was aiding and abetting. ${ }^{78}$ So, it is not at all by accident that, due to ambiguity of the language, legal professionals concentrating on aiding and abetting asked witnesses giving evidence in court clarifying questions, such as: "By 'Serbian command' do you mean the Romanija Corps command [one of the Bosnian Serb Army corps, BF]?" or "Did you visit all the Serbian positions? When? How regularly? Did you notice whether all the positions were linked to the command post by wired communications? Was that command the Romanija Corps command?" ${ }^{782}$ Obviously, legal professionals have their own "checks and balances" to make sure they "get it" just right and these questions were just one visible instance of those "checks and balances."

\footnotetext{
${ }^{780}$ Various authors (1986), Draft Memorandum of the Serbian Academy of Arts and Sciences. Serbian Academy of Arts and Sciences.

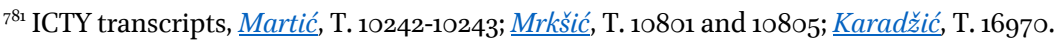

${ }^{782}$ This play on "Serb" and "Serbian" is most obvious in the following transcript from Karadžić trial session from 26 January 2011: note how the Prosecution keeps on using the term "Bosnian Serb" and how Karadžić uses the term "Serbian," T. 10763-10764.
} 


\subsubsection{The linguistic context}

Having clarified the situational context, it may seem easy to go ahead and look into the linguistic context. However, Baker, a general translation theorist concerned with equivalence, states that there is no one-to-one relationship between a word and a meaning and that it is the morphemes that are the minimal formal elements that give meaning to a word. ${ }^{783}$ Indeed, when translating, one immediately notices that languages do not overlap. The choice of a suitable equivalent in a given context depends on a wide variety of strictly linguistic or extralinguistic factors. Although there are no absolute guidelines for dealing with the various types of non-equivalence which exist among languages, it is possible to suggest strategies which may be used to deal with non-equivalence in some contexts. ${ }^{784}$ Common problems of non-equivalence at the word level include: culture-specific concepts, a source-language concept is not lexicalized in the target language, a sourcelanguage word is semantically complex, the source and target languages make different distinctions in meaning, the target language lacks a superordinate, the target language lacks a specific term (hyponym), differences in physical or interpersonal perspective, differences in expressive meaning, differences in form, differences in the frequency and purpose of using specific forms, and use of loan words in the source text. ${ }^{785}$ Strategies used by professional translators include: translation by a more general word (superordinate), translation by a more neutral/less expressive word, translation by cultural substitution, translation using a loan word or loan word plus explanation, translation by paraphrase using a related word, translation by paraphrase using unrelated words, translation by omission and translation by illustration. ${ }^{78}$ Šarčević, a legal translation theorist, defines legal translation as an act of communication within the mechanism of the law. ${ }^{78}$ This communication is conducted between text producers and text receivers. Text producers are those who authenticate the text in the manner prescribed by the law for that particular instrument. ${ }^{78}$ Text receivers are a bit more difficult to describe as they may include both addressees of legal texts on whom an obligation is imposed or on whom a right, privilege, or power is conferred, and a broader group of addressees, including not only the legal subjects named in the text, but also anyone affected by a piece of legislation. ${ }^{789}$ De Groot and Van Laer, legal translation commentators, point out that any given language can have as many legal languages as there are systems using that language as a legal language. ${ }^{70}$ De Groot and Van Laer further point that, because of the system-specificity of legal terms, full equivalence only occurs where the source language and the target language relate to the same legal system, but also, subsidiary solutions must be sought if no acceptable equivalents can be discovered in the legal system of the target language ${ }^{791}$ Translation of certain terms and all underlying issues in the context of international criminal tribunals is not as straightforward and entails a certain translation evolution as facts become known: every word matters, especially those that contain operational information. The following review argues that the word is the minimal unit of meaning in translation in a legal context and that such a translation needs to revolve around properly conveying the operational information. This is the reason why language professionals must not interpret the text.

Translators are supposed to be the most attentive and the most careful readers of any text submitted for translation by the virtue of their profession. This does not mean that they are solely responsible for the text because the quality of a translation is contingent on the quality of the original. As far as international criminal tribunals are concerned, problems abound, even in translation of visible and highly used documents.

\footnotetext{
${ }^{783}$ Baker, M. (2011), In Other Words: A Coursebook on Translation (second edition), Routledge: London and New York, p. 10.

${ }^{78}$ Ibid, p. 15 .

${ }^{785}$ Ibid, p. 18-23.

${ }^{786}$ Ibid, p. 23-44.

${ }^{787}$ Šarčević, S. (1997), New approach to legal translation. Kluwer Law International: The Hague, p. 55.

${ }^{788}$ Ibid, p. 56.

${ }^{789}$ Ibid, p. $5^{8}$.

${ }^{790}$ De Groot, G.R. and Laer, C.J.P. van. (2006), The Dubious Quality of Legal Dictionaries. International Journal of Legal Information: Vol. 34: Iss. 1, Article 6, p. 66.

${ }^{791}$ Ibid, p. 68.
} 
Some examples have been provided already. Bassiouni mentions that overwhelming problems with translation and interpreting at the ECCC are due to the fact that this institution has three working languages, which plagues even the translation of statutory documents. ${ }^{792}$ Bassiouni also mentioned an error that had been spotted in the translation into French of the ICTR-S, Article 3, and that this error had an effect on appeal judgments in several cases heard before the ICTR. The phrase "widespread or systematic", which appears in the ICTR-S, Article 3, which is meant to denote two disjunctive elements, meaning "either or," was translated into French as a coordinating disjunction "and" (et) ${ }^{793}$ This ECCC 2008 Order on the translation rights and obligations of the parties seems to suggest in more ways than one that problems with translation and interpreting at the ECCC are ubiquitous, both because parties do not cooperate on translation issues and because the translation services are overwhelmed with work as they are inadequately staffed. ${ }^{794}$ In their exploration of translation issues at the Special Panels of the Dili District (SPDD), Klip and Sluiter observed a lack of appropriate translation coupled with the illiteracy of both defendants and witnesses. Since there were no qualified translators and interpreters at SPDD, language professionals were appointed to positions of court certified translators and interpreters in a random fashion and without due regard to any on-the-job training. The quality of interpreting was determined by availability, not by objective standards. As a rule, all statements had to be translated twice to reach all the participants. This was more than troubling because, despite the fact that the official languages of SPDD were English, Bahasa Indonesia, Tetun, and Portuguese, the country has 17 other languages and dialects which were used by defendants, victims, and witnesses. ${ }^{795}$ Back at the ICTY, the Appeals Chamber in Nikolić agreed with both parties that the Trial Chamber relied significantly on a false translation of remarks made by the defense counsel during his closing argument, when he said that "around 7,00o men were killed" which was translated as "only 7 ,ooo persons were killed in this campaign." The Appeals Chamber concluded that the Trial Chamber's expression of shock at this statement shows that the translation error had a negative influence on the determination of Nikolić's sentence. So, what did all these legal professionals comment on? They expressed dissatisfaction with language professionals' lack of attention to operational information.

\subsubsection{Glossing}

ICTY language professionals assumed a key role when it came to interpreting of documents for translation. Language professionals had at their disposal several "disclaimers", enabling them both to flag incongruent information and to protect themselves should they be incorrect in their interpretations. These tags cum interpretations were put in distinct forward slash brackets to distinguish them from brackets ordinarily used in documents. Unfortunately, this role interpreting extended into realms that are traditionally left to legal professionals to decide. Elias-Bursać explains:

\footnotetext{
The judges made it clear to the language unit administrators that there was to be no footnoting of translations. In fact the Code of Ethics expressly forbids it: 'Interpreters and translators shall not embellish, omit or edit anything from their assigned work' (Code of Ethics Article 10c). The bench felt strongly that the attorneys, not the translators, were the ones who should be exploring hidden meaning or cultural references. Over time the language units worked out a compromise in this regard. ${ }^{796}$
}

\footnotetext{
${ }^{792}$ Bassiouni, C. (2011), Crimes against humanity: historical evolution and contemporary application, Cambridge University Press: Cambridge, UK, p. 258-261.

${ }^{793}$ Ibid, p. 196.

${ }^{794}$ ECCC, Order on translation rights and obligations of the parties (2008).

${ }^{795}$ Klip, A. and Sluiter, G. (eds.) (2008), Annotated leading cases of international criminal tribunals, Volume XIII, Timor Leste, The Special Panels for serious crimes 2001-2003. Intersentia: Cambridge, UK, p. 23-25.

${ }^{796}$ Elias-Bursać, E. (2015), Translating evidence and interpreting testimony at a war crimes tribunal. Palgrave Macmillan: London, p. 140.
} 
Before moving to the legal merits of the above statement, it must be remarked that forbidding footnoting is normally expressed as "There shall be no footnoting in translations," whereas embellishing, omitting, or editing from translation and interpreting is an entirely different matter. The compromise "the language unit" worked out was to mark '/as printed/' or '/as written/' where a source text was ambiguous, unclear, or erroneous in a way that must be noted in the translation; to avoid using '/sic/' for this same purpose because '/sic/' was perceived as mildly derisive in tone; simple errors in a source text were corrected with no special notation, i.e., if a place name, such as 'Sarajevo', was spelled incorrectly, this error would be corrected and the correction would not be marked as such; in errors of substance when the translator knew with certainty what the correction should be, s/he would present the word in slashes in the translation; if relatively, but not $100 \%$, certain that a correction was warranted, the translator annotated the correction as '/?.../', suggesting that this is a well-founded guess but not a certainty; an illegible word or passage was annotated as precisely as possible, as '/illegible word/', '/three illegible words/', '/illegible paragraph/', etc.; handwritten comments on the margins of an otherwise typewritten text were noted on the translation, and the slashes encompass the entire handwritten annotation '/handwritten .../'; if an unknown word appeared in a text, it was glossed as '/word unknown/'; by the same token, if an abbreviation was unfamiliar to the translator and revisers, it was glossed with '/expansion unknown/' or '/abbreviation unknown/'; if the abbreviation was known to the translator, it was glossed with its expansion the first time it appears in the text; the only abbreviations that were not expanded are BH for Bosnia and Herzegovina and the common English-language abbreviations. ${ }^{797}$ Obviously, this entire process amounted to editing: why not leave everything as in original, typos included? Why decide on a matter that is within the legal ambit? Elias-Bursać also claims that CLSS decided:

to leave [ethnic slurs] in the original when interpreting testimony and to annotate them as derogatory in translations of evidence has both structured how the language services have gone about their business, and spurred related discussions in the trials themselves, informed appeals, and resulted in a request from the bench to change one of the conventions used by the language services. ${ }^{798}$

Before assessing the merits of the above statement, it needs to be said that whoever the authors of the I\&T Code decided these were to be left in the original, not CLSS. CLSS, however, stretched the whole concept of leaving ethnic slurs in the original, deciding to employ tags denoting derogatory meanings: balija /derogatory for Muslim/, šiptar /derogatory for Albanian/, škija /derogatory for Serb/. It has been explained that this must be done because it was in line with I\&T Code, Article 10(c) on accuracy. Again, this tagging was never in line with the I\&T Code because it does not say anything about tagging. On the contrary, the I\&T Code explicitly says: "Interpreters and translators shall not embellish, omit, or edit anything from their assigned work." Moreover, as we have seen before, it warns translators and interpreters against exercising the power described in Article 5(3) on professional integrity and dignity: "Interpreters and translators shall not exercise power or influence over their listeners or readers." Interpreting facts the way the CLSS has done here for legal professionals is the book example of exercising power.

Here, it is obvious the CLSS translators, neutral from the parties, have self-appointed themselves as the explainers of cultural truth. If explainers of cultural truth, why not put: Ustaša /derogatory for some Croats/ and Četnik/derogatory for some Serbs/? Ustašas and Četniks were Croatian and Serbian pro-Nazi supporters, but it is definitely not the case that all Croatians and all Serbians supported them. In the context of the wars in the former Yugoslavia, Ustašas and Četniks were terms used by the sides to the conflict to describe Croat(ian)s and Serb(ian)s as a propaganda tool. However, during the war against B\&H, there were, in fact, real perpetrators who really did call themselves Ustašas and Četniks and this CLSS tagging made them, virtually, invisible. But, surely this is an important issue which needed the attention of legal professionals? Legal

\footnotetext{
${ }^{797}$ Ibid, p. 141-142.
}

${ }^{798}$ Ibid, p. 143 . 
professionals who are not aware of these issues are inadequate. The parties will complain only and exclusively if an issue does not serve their interests. The parties will rarely complain if an issue is wrong but benefits both of them. One of explanations behind the selectiveness here is that the parties felt the need to spoon-feed information to the judges, thereby taking advantage of translators cum cultural explainers who, obviously, thought they were simply doing their job. Unfortunately, these translators cum cultural explainers ran ahead of themselves. Elias-Bursać is convinced that the tagging was appropriate, and even beneficial for the court.

Had CLSS not pursued the policy of leaving ethnic slurs in the original and glossing them as derogatory, the judges would not have had the evidence they needed to draw these conclusions. Hence translation policy directly shaped the legal thinking. ${ }^{799}$

However, whoever has dabbled in the history of the former Yugoslavia must have heard of this term and must have concluded that it is used in a derogatory sense. "Bad" words and cultural stereotypes are often learned first in any language. The selectiveness used by legal professionals is also reflected in selectiveness by language professionals.

Next, Elias-Bursać goes on to engage in discussions about the term šiptar, which is used as derogatory for Albanians, mostly by the Serbs. It is a deliberate mispronunciation of the name Albanians call themselves: people of the land of eagles. Elias-Bursać provides the origins of the word in both Albanian and Serbian, stating that the word became en vogue during the repressive regime of the communist leader Ranković in Kosovo (196os), stating that the use of term was officially abolished in the post-Ranković era, that former Yugoslavian dictionaries reflected official state policies of hate, and that the word returned to use during the Milošević era (1990s). ${ }^{800}$ Elias-Bursać provided information stemming from conversations with her colleague Serbs at the ICTY, some of who told her that the use of term šiptar was completely unacceptable. She quoted Serbian liberals and an American liberal philosopher who unambiguously stated that the intention behind the use of a word matters more than the semantic meaning of that word. She also quoted numerous Albanian and nonAlbanian witnesses who testified at the ICTY as to their disgust at the use of the word, and stops the discussion at seven eights of a page quoting one single Albanian witness who said it was not his personal experience that the word was derogatory when used by his non-ethnically described friends. Elias-Bursać then explained that

\footnotetext{
${ }^{799}$ Ibid, p. 149 .

${ }^{8 \circ 0}$ The theory about the "people of the land of the eagles" belongs to the realms of folk etymology and is the one believed by Albanians. However, in terms of actual historical linguistics the name Shqiptar comes from the verb shqipo(n)j (understand) and adverb shqip (clearly, understandably), whence fol shqip! meaning "speak clearly," as well as "speak Albanian!" The former meaning actually precedes the latter historically. The word derives from an ancient borrowing from Latin excipio (understand). Thus, etymologically Shqiptar is someone who speaks clearly/understandably, i.e. one's own language. The name was not used by Albanian speakers until after the Ottoman invasion, which is why the Albanian speakers of Italy and Greece call their language arbërshe and arbërisht, respectively, and did not know the term Shqiptar until later contact with Albanians of Albania. These forms are from the root Alban(as in Albania) with $l / r$ confusion in the first syllable and Tosk rhotacism in the second (Geg Arbën). The simplification of the initial consonant cluster and stress retraction in South Slavic šiptar are not "deliberate" from a historical point of view but simply the result of historical phonological changes. As to the use of the word, it should be remembered that in the Second Yugoslavia, Šiptar was promoted as an identity separate from Albanac (Albanian) used for Albanians of Albania. The idea was to get Kosovars and other Albanian speakers in Yugoslavia to not identify with the Albanians of Albania. Šiptarski jezik (šiptar language) was promoted as a separate language, and in fact it continued the pre-Second World War Elbasan Geg Albanian standard while Albania switched to a Korça Tosk based standard. The decision by Kosovar and other Yugoslav Albanians in 1968 to adopt the standard of Albania was in direct resistance to this attempt, and it is in connection with that resistance that the term became specifically derogatory rather than merely colloquial. Historically, the word šiptar was an ordinary colloquial term. What happened during the 196os is that it became derogatory, and that was really after the fall of Ranković in 1966. The statement that former Yugoslavian dictionaries reflected official state policies is a later interpreting. The state published textbooks for Serbs in Kosovo entitled "Učimo šiptarski" (Let's learn the šiptar language). It is certainly true that Ranković's rule in Kosovo was hateful and repressive, but the motivation behind the promotion of šiptar language was not necessarily hatred but an attempt to separate the identity of Yugoslav Albanians, one which they resisted. While it is fair to say that in the context of the 199os the word šiptar is derogatory, the description given here is a projection of the present back onto the past.
} 
because the defense counsel in Milutinović complained about tagging the word šiptar as derogatory and because the Prosecution counsel did not complain, Chambers asked CLSS to revisit the tagging of this word as derogatory.

Ultimately the decision was to drop the word 'derogatory' from the gloss. When a Serbian-speaking witness uses the word in a remark in the courtroom now it is still interpreted by the booth in its source-language form as šiptar. But when it appears in a document translated after 2006 it is given as šiptar /Albanian/. This compromise was chosen to guarantee that the nature of the word as a potentially offensive speech marker would not be lost by rendering it neutrally as 'Kosovo Albanian.' Yet in doing so, the staff of CLSS conceded that insistence on the use of the epithet 'derogatory' in every translated document was giving rise to continuing objections from defence counsel and defence witnesses, and that these objections were obstructing the work of the courtroom to a degree that was counter-productive to the goals of the institution. ${ }^{801}$

Essentially, discussions of the word šiptar are similar, if not 100\% same, to discussions about the word nigger. Although this equivalence could be made in the 199os, in the 196os, the value of šiptar was more like "Negro," to which nigger is, of course, etymologically related. That is, Negro was a term that is now perceived as racist, and euphemisms are required. Just as one knows perfectly well all about the intentions of the user of the word nigger in an American context, one also knows all about the intentions of the user of the word siptar in a Serbian context without anyone having to explain anything to the listener. Naturally, the issue is not whether or not white people should use the word nigger or whether or not the Serbs should use the word siptar: the use of such words speaks volumes about their intentions. In reality, the use of such words is no longer a matter of academic discussion, but a matter that is almost becoming a legal liability. It would have been interesting if Elias-Bursać had attempted a similar academic discussion about the pros and cons of using the word nigger in her home country, the USA. It would have been very interesting to know what would have happened if she used the following tag: "nigger/Black person/." Or, if she went out of her way to make a compromise to guarantee that "the nature of the word nigger as a potentially offensive speech marker would not be lost" by rendering it neutrally as "American Black person" as she advocated for the word šiptar in the previous quote. ${ }^{802}$

\footnotetext{
${ }^{801}$ Elias-Bursać, E. (2015), Translating evidence and interpreting testimony at a war crimes tribunal. Palgrave Macmillan: London, p. 160 .
}

${ }^{802}$ The Kosovo Albanian public and diaspora continue to be a weak target for revisionists. It is the responsibility of the government of the Republic of Kosovo to protect its citizens against slurs. However, eliminating slurs is a two-way street and the authorities of the Republic of Kosovo do not have any legal authority over the citizens of the Republic of Serbia where this term is widely used. The first attempts at eliminating the use of word šiptar had to come from the Republic of Serbia. The Republic of Serbia Press Council's Press Complaints Commission was established in September 2011. In 2014, Praksis and 14 other NGOs filed a complaint to the Press Council against Telegraf.rs and daily "Informer" which published a series of articles calling the Albanian soccer supporters šiptars on the eve of the Serbia-Albania soccer game on 14 October 2015, and against "Informer" which published an article entitled "Spider šiptar caught" on 20 October 2015. Telegraf.rs rebutted that the use of word šiptar was etymological, not derogatory. Informer rebutted that the complaint was unjustified, because Albanians call themselves šiptar, which is why the word cannot have a derogatory meaning. In 2015, Youth Initiative for Human Rights filed a complaint to the Press Council against a daily "Informer" which published an article entitled "Four šiptars beat a Serb in Austria to death" (p. 11) featured on the front page as "Crime in Austria: šiptars lynched a Serb" on 18 February 2015. Youth Initiative for Human Rights claimed that the use of word šiptar in the Serbian language is unfoundedly based on the similar use of the same word in the Albanian language. They alerted that, unlike the word Albanian, the word siptar is used by the media and the public in Serbia as derogatory and offensive. They also pointed out that the words Shqiptar as used in the Albanian language and the word šiptar as used in the Serbian language do not have the same connotation, are pronounced and accented differently, concluding that the daily "Informer" must have used this word as a derogatory term to insult Albanians. The "Informer" rebutted that the word šiptar is used by the Albanians to describe themselves, which is why it cannot have derogatory meaning (Udruženje novinara Srbije, Neosnovana upotreba reči "Šiptar" (2015)). In both cases, the Press Council has found that these publications constituted a violation of the Code of Journalists, Article IV.4 on journalists' responsibilities commanding that journalist must oppose all those who violate human rights or promote any kind of discrimination, hate speech, and incitement to violence, and Article V.4 on journalists' vigilance, commanding that a journalist must be aware of the danger of discrimination being spread by media and must do everything to avoid discrimination based, inter alia, on race, gender, age, sexual orientation, language, religion, political, or other opinion, national, or social affiliation. In both cases, the Press Council's Press Complaints Commission publicly reprimanded 
And, finally, if she was attempting to shape legal thinking, Elias-Bursać seems to have missed something, because the entire evolution of the word as it appears in her book was not communicated to the judges.

As far as legal professionals are concerned, they do not need language professionals to teach them how to spot derogatory words, as those derogatory words should clearly jump out at them from the texts they are examining. Indeed, legal professionals who do not know the language will not know the implications and that is exactly why they need to be provided with untainted translation and interpreting, not spoon-fed biased ones. Here, legal professionals obviously bought what CLSS was selling, but the question remains how can any legal professional not know the intention behind the use of expressions normally associated with the term šiptar, how can any legal professional not see this particular word jump out of the text, how can a legal professional allow a non-legal professional to define operational reality? But, in the context of an international criminal tribunal adjudicating on ethnic crimes, non-recognition of these words as ethnic slurs amounts to calling the American South slavery "a peculiar institution of the South" well into the twenty-first century and asking language professionals to confirm this use of language. If a legal professional needs someone to flag the use of the word siptar as derogatory, that is a poor state of affairs. The Serbs called their victims siptars because it was easier to kill a well-known and vilified concept, rather than a person with hopes, dreams, family, mortgages, and that, in itself, is a definition of cowardice. If a legal professional does not know how to argue that the use of word siptar is derogatory, s/he needs to find another profession where his or her shortcomings cannot harm the future of entire nations.

\title{
7.1.2.2. Negotiation of meaning
}

The following examples will show what happens when translators allow themselves to get caught in disputes between the parties with an interest and resort to interpreting of a term for translation that is not based in language, but on the party's expectation of the meaning. Does this imply the parties bully translators into making their preferred translation? They simply usher them in between the term and the judges and let the nature take its course. Elias-Bursać mentions "negotiation of meaning" on which she seems to base entire portions of her study dealing with the practice of translation and interpreting. ${ }^{803}$ Elias-Bursać never really defines negotiation of meaning, but she does explain the process as she understood it:

\begin{abstract}
When the attorneys, judges, witness, interpreters, and translators debate the meaning of a term or phrase in translated evidence or interpreted testimony, they follow a process which the ICTY has refined over time. Such a dispute usually arises when a witness is being examined about a translated document and one of the parties disputes the way that the English Translation Unit translated a word in the document. The judges first ask the interpreters to interpret the passage again, so that if the translation is erroneous, the error can be corrected immediately in court. If this does not resolve the dispute, the bench consults on the matter with CLSS and then decides, having examined all the input, which of the proffered translations of the word they will find credible in the judgment. If the accused contends that the case has been unjustifiably prejudiced by the translation the judges chose, he or she may raise this as a ground for appeal, and once the appeals chamber considers the matter, the meaning of the contested term is settled by the appeals judgment, at least for that case. ${ }^{804}$
\end{abstract}

This explanation of "negotiation of meaning" is loaded in more ways than one, and, as such, it merits full clarification. It seems to refer to a somewhat exaggerated concept of the central role of a translator and an interpreter in the legal process. Scholars observed that those in power can use translators in more ways than

the Portal and the Daily for violation of the Code of Journalists and ordered them to publish the Press Council's Press Complaints Commission decision in their next issue.

${ }^{803}$ Elias-Bursać, E. (2015), Translating evidence and interpreting testimony at a war crimes tribunal. Palgrave Macmillan: London, p. $178,194,195,203$.

${ }^{804}$ Ibid, p. 9 . 
one, and that translators are related to those in power by more than their translations. These interrelationships often depend on how translators integrate into existing power structures and the extent to which they are able to exploit contradictions within those structures. ${ }^{805}$ Discussions in Chapter 4 show that there were plenty of contradictions in the existing ICTY rules and regulations on the engagement of translators and interpreters. The witness statements are recorded in English or French, the official languages of the ICTY, and are never recorded in $\mathrm{B} / \mathrm{C} / \mathrm{S}$, which is not an official language of the ICTY. The bulk of witness statements were taken between 1993 and 1999. B\&H was recovering from the war, most victims and witnesses were living in poor conditions and, instead of bringing a tape recorder and recording victim and witness statements or making their client sit down and write their own statements as they would in their national jurisdictions, investigators took witness statement in person, at witness' homes, in English or French, to save time, finances, and get ahead of various resource issues (electricity, space, etc.), as explained earlier. These statements were highly focused: if $X$ was in the concentration camp, the testimony of $X$ would revolve around the camp command, camp conditions, physical, and emotional impact on the X, X's eye-witnessing abuse, and other such issues. Once those witnesses came to testify, their statements would be waiting for them back-translated into $\mathrm{B} / \mathrm{C} / \mathrm{S}$ so that they could refresh their memory before testifying. The witness signs the statement translated into his or her language and the acknowledgment on the original version in English or French. In proofing, witnesses are asked to clarify or comment on the $\mathrm{B} / \mathrm{C} / \mathrm{S}$ back-translation of their statement or facts provided previously, should they have testified before. Any such changes would be recorded and presented to the Court as a Witness Statement Supplement. This was a routine process that did not involve any ceremony ${ }^{806}$ According to what Elias-Bursać stated: the witness starts presenting evidence, translation of his or her statement is disputed, the judges interrupt the session and ask the interpreters to reinterpret the passage containing the disputed statement. If the parties agree on the re-interpretation, the problem is solved. If the parties do not agree, the judges consult CLSS who elaborate on the meaning of the word and the judges base their trial judgment on that elaboration. Should the parties still disagree, they can take the issue to an appeal. Obviously, Elias-Bursać's understanding of the process and the roles of parties in the courtroom is so skewed that it could be disregarded as a blunder. Translators and interpreters do not normally second-guess each other, especially not in the court. It is taken for granted that a professional who does not have the luxury of time, dictionaries, reference materials or senior colleagues, and whose main purpose is to keep the communication flowing, namely the court interpreter, cannot decide on something so important as the full meaning of a word on the spot. The role and the authority of a courtroom interpreter is best explained in the following court decision:

With respect to the Motion, the Registry acknowledges that errors in simultaneous interpreting are not uncommon as interpreters have to make omissions deliberately in order to be able to instantly convey the message in a targeted language. It also notes that the Accused was informed of this, during the trial management meeting on 19 October 2009. He was also informed that some of the things that are not acceptable in translation—such as paraphrasing, synthesising, and editing — are not only acceptable in simultaneous interpreting but are tools that make interpreting possible. Thus, according to CLSS, the parties should have no expectation of having a translation level of accuracy in interpreting. The Registry also notes that it too has reviewed the transcript of the same day of [contested] testimony and found that the accuracy rate is "extremely high", namely 98.4 per cent, which by far exceeds the required rate of accuracy of 75 per cent in the courts in the United States. The Registry also submits that the Accused is aware that he can seek, on the spot, a corrigendum of any identified interpreting error or, alternatively, submit a request for verification of accuracy after the fact. The Registry notes that the Accused fails to justify why he and/or his defence team cannot raise any errors

\footnotetext{
${ }^{805}$ Delisle, J. and Woodsworth, J. (eds.) (2012), Translators through history. John Benjamins Publishing Company: Amsterdam, p. 147. ${ }^{806}$ Most footnotes from this Amalgamated Statement, meaning compilation of statements this witness has given to the ICTY and his previous court testimonies, clarify the location of that previously provided evidence. Notice footnotes $18,50,58,78,122,126$, and 137 correcting data previously provided mostly with a view to correct spelling, and footnotes $25,27,92,123$, 139, and 144 clarifying data previously provided. Also, notice that the witness signed only the Witness Acknowledgment on the, now, original statement in English, inserted in his language.
} 
contemporaneously during the hearing, as they occur, given that he has at least three $\mathrm{B} / \mathrm{C} / \mathrm{S}$ speakers on his team. $^{807}$

The quote above makes it crystal clear the judges do not make any decisions on the spot, especially on something that troubles one of the parties. The judges are there to instruct the parties on what is the proper - and the improper - way to raise the issue of translation and interpreting and this is best explained in the following exchange between the Judge and the Accused in Šešelj:

JUDGE ANTONETTI: [Interpretation] [...] Yesterday, as you know, at some point in time we had a problem which related to a translation issue. The Trial Chamber asked to have a report on the matter. The report was sent by the head of CLSS. It turns out that after having read and heard the audiotape in $\mathrm{B} / \mathrm{C} / \mathrm{S}$, the interpreter in the language of the accused did say, on page 17237, line 9 to 12, "Blagojevic and Seselj's men." The interpreter, therefore, did say "Seselj's men" in the language of the accused and not "Mr. Seselj." You must have misheard, Mr. Seselj. Maybe there was some interference in your microphone, but the interpreter did interpret the words of the Prosecutor correctly. This is what I wish to clarify. That said --

THE ACCUSED: [Interpretation] And what about checking the verse, the song?

JUDGE ANTONETTI: [Interpretation] This is ongoing. ${ }^{808}$

Elias-Bursać's description of the role of the judges in translation and interpreting (see above) is completely unexpected as she provides many examples in her own study of judges instructing the parties and the clients on the proper and improper way of dealing with translation and interpreting, i.e. slow-down requests, error correction, etc. $^{809}$

In support of "negotiation of meaning," Elias-Bursać discusses a number of terms in B/C/S of which the following are addressed here: komandant and komandir, ${ }^{810}$ rukovodenje $i$ komandovanje, ${ }^{811}$ and stacionar ${ }^{812}$

The conflict between the terms komandant and komandir is in that a komandant commands large units (a battalion, brigade, division, corps) and a komandir commands basic units (a squad, platoon, company). In English komandir would be equivalent to commandant and komandant to commander. Elias-Bursać reasons that, since the word "commandant" is used in various ways by national militaries (in some countries "commandant" is a military or police rank, in others the head of a military training establishment, and in yet others the head of a prison or prison camp), that variety of uses led CLSS to prefer the word "commander" to refer to all those who issue commands, no matter how many men they are in charge of. Since the titles $k o$ mandant and komandir were often paired in military documents, CLSS English Translation Unit settled on translating the two titles as: "commander/komandant/" and "commander /komandir/" in order to preserve the contrast. This distinction, according to Elias-Bursać worked for written documents, but was difficult to convey from the booth. Obviously, because there was no translation involved: both words were left in the original language, regardless to their definitions.

\footnotetext{
${ }^{807}$ ICTY, Decision on [Karadžić's] motion for revision of trial transcripts (2013), para. 8.

${ }^{808}$ ICTY transcripts, $\breve{S}$ ešelj, T. 17269-17270.

${ }^{809}$ Elias-Bursać, E. (2015), Translating evidence and interpreting testimony at a war crimes tribunal. Palgrave Macmillan: London, p. 121-140.

${ }^{810}$ Ibid, p. 205-208.

${ }^{81}$ Ibid, p. 208-214.

${ }^{812}$ Ibid, p. 217-221.
} 
The origins of this problem could be found in CLSS's early attempts to consolidate army ranks because, as Elias-Bursać puts it:

Each of the different fighting forces used a slightly different system of ranks and each of these was slightly different than the English, American, French, and other militaries our staff is familiar with, which has provided the terminologists with constant challenges. ${ }^{813}$

First of all, CLSS did not have a designated terminologist then or now and it is the revisers who were in charge of terminology, i.e. Elias-Bursać and Hepburn, and their colleagues. If there were such a person, given the discussions in Chapter 6, it is safe to assume that, given all earlier discussions on CLSS staff selection, this would be a randomly picked person who was the loudest in these discussions, not a professionally educated terminologist with the actual functional title "Terminologist." Second, even if a B\&H Army Captain were equivalent to a US Army First Lieutenant, or vice versa, what bearing does that have on crimes that the B\&H Army Captain might have committed wearing a uniform of a B\&H Army officer? Third, what bearing would the consolidation of those ranks have under non-US Army and non-NATO jurisdiction, namely under an international criminal court trying individuals under the Geneva Conventions that recognizes officers and nonofficers? It is these "constant challenges," to use Elias-Bursać wording, that CLSS faced, which speaks volumes about the CLSS's knowledge of the substantive subject-matter and their flair for translation in a legal context. This has been explained as follows:

\begin{abstract}
An example of a terminological dispute tinged by bias is the discussion of how to translate the phrase predsjednik vlada [sic]. This is the term usually used for 'prime minister', but its literal translation is 'president of the government'. Translators in the English Translation Unit found it difficult to use the term 'prime minister' for the self-styled leaders of tiny wartime entities who placed this title under their signature. Indeed, one finds in Tribunal documents use of the composite term 'Prime Minister/President of the government' as a way to qualify the term. [...] After struggling with the thought that through their translation they were somehow conferring on someone the status of prime minister, the revisers and translators finally agreed that the courtroom was where this should be debated rather than in the translation units. ${ }^{814}$
\end{abstract}

The above makes it clear that CLSS staff engaged in discussions of the merits. Suppose the author of this study signed a document as a predsjednikvlade and he were tried at the international war crimes tribunal for command responsibility. In that case, if a translator in charge of translating that document has difficulty translating the author's signature predsjednik vlade as prime minister as the dictionary suggests, such a translator is NOT safeguarding against bias, such a translator IS diminishing the author's command responsibility; such a translator is NOT alerting to the author's self-styling, such a translator IS denying the existence of a para-state under the author's administration, describing it as one of a number of "tiny wartime entities." The author of this study is suspected of committing acts charged by the ICTY-S because of the virtue of his position, i.e. predsjednikvlade, and the status that entails, i.e. command responsibility. Letting the courtroom discuss this translator's inability to open a dictionary and substitute one readily available term for another makes such a translator a denialist. Letting the courtroom discuss this makes such a translator a concealer of evidence.

Going back to the discussion at hand: English, the language translated into, had two ready and distinguishable terms, commandant and commander, one denoting a higher commander and the other a lowerlevel commander, just as in the B/C/S original. However, CLSS decided to translate both terms as "com-

\footnotetext{
${ }^{813}$ Ibid, p. 116.

${ }^{814}$ Ibid, p. 116.
} 
mander" because they "preferred it." This preference enabled for blurring or the loss of the distinction between the two terms. Naturally, the defense picked up on that. To illustrate the use of this term, Elias-Bursać provides examples from Tadić and Kvočka. Both of these individuals were alleged to have been the komandir of concentration camps. The English language word "commandant," according to what Elias-Bursać has just explained, covers heads of "military training establishment $[\mathrm{s}]$, prison[s] or prison camp[s]" which is yet another reason why the term should have been properly translated as "commandant." However, Kvočka was referred to in the trial judgment variously as "shift leader" (komandir smjene in original), "shift commander" (komandir smjene in original), "guard shift commander" (komandir smjene in original), and "guard shift leader" (komandir smjene in original). Elias-Bursać concludes:

[D]espite what would seem to be a concession to the defence in the trial judgment regarding the preferred title, apparently Kvočka used this translation issue as one of the grounds for his appeal, protesting the use of the term 'shift leader' and preferring the wording 'in front of the shift'. ${ }^{815}$

First of all, this finger-pointing needs to be clarified. The judges cannot "make concessions in the trial judgment" ex nihilo; they also have to base it on something. Here, the judges based it on what was clearly a wrong translation provided by the CLSS under the garb that it was difficult to convey the difference between the two terms. The Defense figured that if they had got away with it once, why not try again, and offered a third option for translation. It is unclear where negotiation of meaning took place in all of the above discussions on the part of translators, as this sounds more like a request to show understanding for professional incompetence. Did Tadić and Kvočka have extraordinarily attentive defense counsels? They had people who ushered language professionals between them and the court and let nature take its course. Abusing language for prosecution/defense purposes is highly unoriginal; it amounts to lawyering for undesirables. Language professionals should have been aware of that. This whole case of translating two distinguishable terms by a third unrelated and generic term confirms the lack of professionally educated translators or translators with previous experience in a legal context in CLSS on top of all the other examples in previous discussions. As a consequence, the translation case in point clearly sounds like an uninformed translation caused by blatant translation dilettantism, to say the least. Were the judges aware of this? Elias-Bursać continues:

The appeals judgment upheld the decision of the trial chamber and understood [Kvočka] to be the 'shift leader'. Hence Kvočka's attorney successfully steered the chamber away from use of the term 'commander' as the translation of komandir, but did not succeed in evading the word 'leader' (shift leader). ${ }^{816}$

The judges obviously figured out that there was something missing and resorted to interpreting the term with the superordinate, comprising all those who command in general: the leader. Elias-Bursać makes it sound as if the problem was resolved for all times and all contexts, but does not say when exactly this translation was made official. Exhaustive search of ICTY Court Records archives shows a single document where "commander /komandant/" and "commander /komandir/" appears and that was in $2008{ }^{817}$ The Tadić appeal was completed in 2001 and the Kvočka appeal was completed in 2005.

Next, Elias-Bursać discusses the military term rukovođenje $i$ komandovanje translated as "command and control" in a couplet because it is a well-known, widely used, and standard military term without significant deviations in all infantry, artillery, air force, armored units, or navy units. Translation theory describes

\footnotetext{
${ }^{815}$ Ibid, p. 207.

${ }^{816}$ Ibid, p. 207 .

${ }^{817}$ ICTY, The Prosecutor vs. Popović et al, Notice of disclosure of an expert witness report pursuant to Rule 94bis (2008), paras. 4.6.6. and 12.
} 
expressions such as "command and control" as fixed expressions because they show transparency of meaning and have no flexibility in patterning. Fixed expressions are frozen patterns of language which allow little or no variation in form and, in the case of idioms, often carry meanings which cannot be deduced from their individual components. Unless consciously making a joke or attempting a play on words, a speaker or writer cannot normally do any of the following with an idiom: change the order of the words in it, delete a word from it, add a word to it, replace a word with another or change its grammatical structure. As their name suggests, fixed expressions, such as "command and control," allow little or no variation. ${ }^{818}$ Elias-Bursać begins the discussion of this fixed phrase by breaking it into two parts, completely disregarding the other side of the fixed expression rukovođenje i komandovanje, namely komandovanje. Elias-Bursać argues that the word rukovođenje has two distinctive meanings at the root of which is the word ruka (hand), making the meaning of the word closely associated with the term handling. In linguistic and translation terms, this is akin to saying that the ambiguity of the phrase it's raining cats and dogs is structural and that it amounts to a difference between two families of animals, namely felines and canines, making it impossible to know which rained more. If etymology was an issue, it is curious that the second root of the word has been omitted, too: vod- or "lead" or "convey," which, in this context means "lead by hand." It is unclear why any language professional would even engage in such a discussion. But, they did. The Defense in Halilović argued that, when used alone, the term rukovođenje should be translated as management. However, Halilović was not a manager of an enterprise, but a military leader who was accused of relinquishing control over his units to complete imposters: foreign Mujahedin fighters. The Defense asked CLSS to verbalize what Halilović was doing to his troops and whether, when the original implied rukovodenje, he was managing, directing or, as the translation of this fixed expression already suggested, controlling them. According to Elias-Bursać, CLSS issued a memorandum on the translation of the term rukovodenje, citing two general dictionaries on the meaning of the individual word, one military dictionary on the meaning of the expression rukovodenje borbenim dejstvima (directing combat operations), and military documents used in trial. ${ }^{819}$ In other words, by their inability to self-regulate, on top of violating the tenets of the profession of translation by citing general dictionaries for the translation of a military term, CLSS violated the basic tenets of translation of a fixed expression by trying to deduce the meaning of the whole phrase by its individual component and by providing a dictionary version of a completely different expression to explain the disputed one.

In its judgment, Trial Chambers dedicated two footnotes to this discussion. What did the they do? They invited witnesses to explain the meaning to them, of course. They acknowledged that one witness testified that the five functions of the concept of "command and control" are planning, organization, command, coordination, and control. Trial Chambers acknowledged that the witness stated that "control" (rukovođenje) is more akin to direction or management than command where it means the control of personnel and certain services, for instance by giving guidelines. Trial Chambers thus acknowledged that the witness stated that "control" does not imply issuing orders, but that "command," on the other hand, implies all the said five elements and means the issuing of tasks to subordinate units. Trial Chambers also acknowledged CLSS's verification of the term. The disputed line in an order signed by Halilović reads "review of the combat readiness of the commands and units in the field, and control of combat operations" (sagledavanje b/g komandi ijedinica konkretno na terenu, i rukovođenje $b / d$ ). The Trial Chamber noted that it was provided with two different translations of the $\mathrm{B} / \mathrm{C} / \mathrm{S}$ word "rukovođenje" appearing in one and the same sentence. One translation read "directing combat operations" while the other translation read "control of combat operations." The translation of the exhibit was subsequently verified, and the correct translation was admitted into evidence as Ex. 146, together with an explanation of the translation. The Trial Chambers also noted that another witness testified as to the meaning of the $\mathrm{B} / \mathrm{C} / \mathrm{S}$ word "rukovođenje," which was then interpreted as "directing." In light

\footnotetext{
${ }^{818}$ Baker, M. (2011), In Other Words: A Coursebook on Translation (second edition), Routledge: London and New York, p. 67.

${ }^{819}$ This Verification Memorandum cannot be found in the open source searches but seems to have been reproduced in full in EliasBursać p. 210.
} 
of the verification of the translation, Trial Chambers decided not to rely on the part of the testimony of that witness in which he explained the term "rukovođenje."

The story does not end here. When the term was tabled in Tolimir, the Prosecution put their foot down right at the onset:

MR. McCLOSKEY: Yes, I don't want to bring up the old dispute, but CLSS has translated "komandovanje" and "rukovodjenje" as "command" and "control," and the term "kontrola" also is "control," not as "direction" as Mr. Gajic would prefer it. And so as long as we understand that, I think we can go ahead, but that - that's the situation, the old debate which we obviously won't resolve here. ${ }^{821}$

The testifying witness was asked by the Chambers to define rukovodenje and he did. However, this did not put an end to the story of rukovođenje, either. Elias-Bursać tells us that, prior to the beginning of Mladić, the parties agreed on a glossary of commonly used terms for expedience. This glossary was named a Lexicon,

the defence approved of it and CLSS went over it as well[, but s]etting a definition in stone in this manner, however, does limit the options the interpreters are able to draw on; hence, as with komandant and komandir, resorting to the source-language word is sometimes the only way for interpreters to be clear, even in the case of this word, which is not as understandable to people who do not speak Bosnian, Croatian, or Serbian as komandant or komandir are. ${ }^{822}$

In other words, CLSS took the Trial Chambers on a wild goose chase in several cases where this term cropped up as "an issue", allowing that commanding may mean commanding, but that controlling may mean something else. Trial Chambers obviously realized the full meaning of the phrase on its own, which they did by examining the context in which the phrase occurs, just as any novice translator would. Traditionally, the question that needs answering is: what did they need translators for if they were left to their own devices to figure out the meaning at the end of the day? Let us break with tradition and ask: what do they not need translators for? Very simply put: they do not need translators exhibiting their own confusions beyond the point of a whisper to their own supervisors and they do not need translators stalling the legal process. Did Halilović have an excellent defense counsel? Halilović had people who engaged and confused CLSS to the point that CLSS lost sight of the fact that the commander "commands and controls" in the B\&H Army, the US Army, the UK Army, and in fact in every other army by the virtue of his position. But that which is, perhaps, the most damaging in this entire matter is that the CLSS and their subpar translation left room for posterity to wonder who did control the Mujahedin if Halilović was the commander but was busy "managing" instead of "controlling"? Thankfully, the Prosecution in Tolimir was coherent enough to not allow further stretching of a maxim under the garb of the untranslatability of culture.

Obviously, CLSS did not take part in "negotiation of the term." Thankfully, the judges were aware of CLSS's shortcomings and uninvited creation of narratives. The last term considered here that Elias-Bursać discusses is the term stacionar. The word stacionar was found on a training map showing the layout of buildings at a site used by the Croatian Army in 1993 to practice shooting. It came up in Gotovina et al, the veritable spasm of all Serb(ian) and Croat(ian) war efforts to eradicate one another in Croatia. CLSS translated the term stacionar as a medical station.

\footnotetext{
${ }^{820}$ ICTY, Judgment in $\underline{\text { Halilović (2005), F. } 257 \text { and } 634 .}$

${ }^{821}$ ICTY transcripts, Tolimir, T. 18547-18548.

${ }^{822}$ Elias-Bursać, E. (2015), Translating evidence and interpreting testimony at a war crimes tribunal. Palgrave Macmillan: London, p. 213 .
} 
Nevertheless, we in CLSS could not be certain that stacionar could only refer to a medical station. Dictionaries often fail to cover every nuance of word. Those who had served in the military within the translation unit said that in colloquial military usage stacionar could possibly refer to temporary accommodation for soldiers. After much discussion, however, the revisers, who had been asked to respond to the chamber on this question, decided we had no choice. The map was describing military targets. If there was even the slightest chance that one of these targets was, indeed, a medical station, something we in the ETU could not know for a certainty, the translation unit was obliged to refer to it as such. If there was any likelihood that the Croatian Army was training soldiers to target this sort of civilian facility we could not ignore that. Should the defence feel that the issue was important enough for them to find a way to prove otherwise based on testimony or other documentary evidence, they were free to pursue that. So we held firm. This example of negotiating meaning is important as a way of highlighting the different approaches to terminology that a language professional and a legal professional are, by the nature of their jobs, bound to have. This dispute did not have a tidy resolution. Instead of defining the term clearly for the trial, the parties, after submitting motions on their views on the term, backed away from it. And while the staff in CLSS felt that our response was the right one, we were still not able to ascertain what the word stacionar meant on that target map. ${ }^{823}$

Two men proven innocent on appeal spent several years in prison until CLSS clarified all the nuances in this and many other translations they delivered in Gotovina et al. Elias-Bursać concludes the section of her study dealing with the negotiation of meaning by saying that:

If I revised over 30,ooo pages of translations of war crimes evidence and encountered no bias, that would have to suggest that bias can be set aside, overcome, and suppressed to a degree that allows one to work professionally, even on a subject as contentious and wrenching as a war. ${ }^{824}$

However, the translation of the term stacionar and all those other examples proves otherwise. CLSS could have translated the term as /?medical station/ thereby expressly allowing a possibility of a different meaning or could have translated it as /?repository/ thereby responding to the contextual ambiguity of an original phrase with the contextual ambiguity of a translated phrase. CLSS translation did not have to suggest from the onset that the Croatian Army might have practiced shooting on the wounded. A biased translation of this term is surely something to be ashamed of and it did not go unnoticed. This term was so erroneously translated that CLSS and their translations seem to have become a standing joke among their clients. After losing time on a different unimportant issue in Gotovina, the Presiding Judge had this to say:

JUDGE ORIE: A lot of stacionars on it, isn't it, Mr. Misetic $?^{825}$

But, Elias-Bursać had no problem quoting this judge in her study, concluding that the CLSS is simply still not sure whether the facility in question was a medical station or not.

Coining a term like "negotiation of meaning" seems to suggest some decision-making power in negotiations of legal truth contained in a translation. But, there were no translators involved in any "negotiations of meaning" in the above examples: the parties with an interest laid the bait and CLSS went for it. Moreover, the third example shows that CLSS voluntarily put itself between the parties and the judge, in contradiction of the I\&T Code, and not only made a dangerous faux pas, but stuck with it. It follows from EliasBursać's examples that there is no "negotiation of meaning" between attorneys, judges, witness, interpreters, and translators, but clear instances where the Defense, whom Elias-Bursać dubs the owners of $B / C / S$, found

\footnotetext{
${ }^{823}$ Ibid, p. 221.

${ }^{824}$ Ibid, p. 251.

${ }^{825}$ ICTY transcripts, Gotovina, T. 16981.
} 
a hole in CLSS' professionalism, experience, and knowledge, pulling the CLSS into their struggles with the Prosecution and succeeding in doing so, leaving CLSS baffled and confused, unable to explain itself. Years after, Elias-Bursać writes a book where she does not present CLSS as duped by parties' shenanigans or as a section that overstepped its powers by engaging in the active creation of narratives, but as a section legitimately involved in the "negotiation of meaning" where seasoned lawyers led them off the usual translation and interpreting path, saying that they followed because these seasoned lawyers merely wanted input from a translator.

However, none of these issues were naïve, minor, or victimless. These issues had to do with who killed, who raped, who tortured, who put people in concentration camps, who relinquished control over his own army to a band of murderers, and who stayed in prison for no reason. CLSS's translation opened space for alternative narratives in most of the above cases. It is completely plausible to assume that even the most cautious of liberals will one day look at these terms as explained in Elias-Bursaćs book and ask: if Kvočka was merely a shift leader and, at the same time, the highest authority in the concentration camp, who was the concentration camp commander, because nobody else was sentenced specifically for running this concentration camp? So, did these camps really exist? If Halilović was merely managing the troops and, at the same time, he was the highest authority in command, who was commanding them, what role did the Mujahedin play, who commanded them, what happened to them, and are they still in B\&H at the ready to "defend" Islam? If the Croatian Army practiced shooting by targeting medical stations, doesn't that preclude them from respecting the Geneva Conventions? Aren't they a priori guilty, and isn't the whole ICTY biased for letting them go? All these existentialist spasms, posed by the CLSS's inability to translate, now echoed in the former Yugoslavia as a failure of the ICTY to be impartial, could have been avoided if CLSS employed revisers who knew what they were doing in the first place.

A language professional is interested in the contextual, linguistic, cultural, and social aspect of the statement. Professionally educated translators and interpreters know that it is not their job to comment on the substance of a case because they are language professionals. Under certain rules, language professionals can comment on substance, if that substance is obviously flawed. They can work on "Master" originals with legal/technical professionals to produce together a typical UN-formatted, UN-worded document, clear all target language ambiguities and conflicting statements, clear all possible duplication of information and data, take care of grammar, style and referencing, etc. In that regard, it can never be sufficiently reiterated that other professionals who require the services of a language professional need to stop viewing language professionals as an expensive nuisance and an unwelcome guest in their area of expertise and start viewing them as co-authors of their texts. However, interventions by language professionals should stop right there. Negotiation of meaning is something parties do between themselves and, should they disagree, that's something that they surrender to the judges to decide. The translator's involvement finishes once s/he submits what s/he considers to be an informed and neutral translation. Once a translator starts contacting legal professional to discuss meaning, that turns into adopting the legal professionals point of view and makes him or her impartiality and vulnerable in terms of neutrality. This is a third condition for delivering translation in a legal context: the delivery must be coherent with the situational and linguistic context and narrative-free without glossing.

\subsubsection{The unwritten}

People manipulate language to change perceptions and they have been doing that since the beginning of language itself. Manipulation of language is, by definition, intentional and, among other things, done to lure the masses into believing a certain concept or buying into a certain product or a philosophy. However, sometimes that manipulation is state sponsored, sinister in nature, and may lead toward a reality similar to that described in George Orwell's "1984," and that's not only at the level of the leadership. 
Intercepts served as key evidence in many OTP cases (the Srebrenica-related trials, Brđanin, Mladić, Karadžić, etc.). Intercepts first appeared during the first Srebrenica-related trial in Krstić. Krstić was indicted by the ICTY for genocide, crimes against humanity, and violations of the laws and customs of the war. ${ }^{826}$ Under genocide, the OTP alleged that between about 11 July 1995 and 1 November 1995, Krstić, intending to destroy a part of the Bosnian Muslim people as a national, ethnical, or religious group: (a) killed members of the group, and (b) caused serious bodily or mental harm to members of the group ${ }^{827}$ The wide-scale and organized killing of Bosnian Muslim men and boys, which occurred in several different locations in and around the Srebrenica enclave, from 11 July 1995 until 18 July 1995, including Potočari, Bratunac, Tišća, Orahovac near Lazete, the "Dam" near Petkovci, Cerska Valley, Pilica School, Branjevo Military Farm, Pilica Cultural Center, and Kozluk. During and after the opportunistic killings and mass executions, which occurred from 11 July until 1 November 1995, the OTP alleged that Krstic failed to investigate or punish any of his subordinates who were responsible for the killings and executions. On the contrary, Krstić and units under his command, participated in an organized and comprehensive effort to conceal and cover up the killings and executions by burying the bodies of the victims in isolated sites scattered over a wide area. When it became apparent that the international community had learned of the killings, the OTP alleged that Krstić, and units under his command, participated in a second attempt to conceal the killings and executions by digging up the bodies from the initial mass graves at the Dam near Petkovci, Orahovac, Branjevo Military Farm, Kozluk, and Glogova, and transferred them to secondary graves. Some of these secondary graves have still not been found ${ }^{828}$ The Bosnian Serb Army (VRS) offensive against Srebrenica, codenamed "Krivaja", started on 11 July 1995 and officially ended on 15 July 1995, but the subsequent organization of the cover-up activities continued well beyond that period of time into the end of the 1990s. As far as the OTP Srebrenica case is concerned, intercepts that are discussed in the subsequent sections of this study should be understood as the records of VRS radio and telephone communications coordinating or discussing the above activities as intercepted by the Army of B\&H Intelligence officers in July and August 1995. These Srebrenica-related intercepts were handed over to the OTP by the B\&H government three years after they were recorded and transcribed by the Army of B\&H intelligence officers and staff.

Intercepting enemy communications is a standard intelligence procedure all over the world. The aim of interception is to discover and monitor the other side's plans in order to plan preemptive or corrective action. Intelligence services use this information for their own purposes and they are, ordinarily, not intended to be shared with third parties. The VRS had secure means of communication, but these were not always functional during the war. In addition, secure dispatches took a long time to code and send, so unsecured lines were sometimes used for expediency and urgency, which is why Army of B\&H was able to intercept them. As soon as the OTP announced, as part of their disclosure obligations, that they planned to use intercepts as evidence, the Defense raised the issue as to whether the intercepts were legally obtained. However, the Trial Chamber was only interested in knowing whether the intercepts were authentic and reliable ${ }^{829} \mathrm{To}$ that end, subsequent authentication of intercepts was designed to establish whether they were genuine. A number of witnesses, former interceptors, testified to the manner in which intercepts were recorded. Intercepted radio communications were monitored from several different locations by Army of B\&H intelligence and security officers. The fact these radio communications were taken from several different locations helped with authentication: there are plenty of examples of intercepts that were not fully intercepted in one location but were fully intercepted in another, including examples where they complemented each other when they were merged. ${ }^{830}$

\footnotetext{
${ }^{826}$ ICTY, Amended Indictment in $\underline{\text { Krstić. }}$

${ }^{827}$ Ibid, para. 21.

${ }^{828}$ Ibid, paras. $24-26$.

${ }^{829}$ ICTY, Judgment in $\underline{\text { Krstić }}$ (2001), paras. 105-118.

${ }^{80}$ Keeping in mind discussions on duplicate documents (see Chapter 6), this could be seen as a good aspect of duplicate documents: although annoying and amounting to an administrative mess, duplicate documents can, indeed, help in an investigative context.
} 
Depending on the location from which the conversations were monitored, interceptors would either manually press the "record" button on recording machines or the machines would start recording conversations once the connection between the interlocutors was established. This was usually once anyone from monitored lines picked up the phone. After the conversation ended, the interceptors would verbatim transcribe the whole conversation into a notebook. The conversation would then be typed on a computer and sent to headquarters. According to these intelligence officers' testimonies, they learned the voices of key players in the intercepts pretty quickly and by the 1995 VRS Srebrenica operation, interceptors were perfectly able to recognize who was talking to whom, because they had been listening to these voices for at least three years. Nevertheless, the interceptors would still not put the names of participants in their records of conversations unless speakers identified themselves clearly. This means that unless Krstić, for example, clearly identified himself, interceptors would mark him as an "X." Making transcripts is a tedious process, but interceptors took time to fully transcribe each conversation verbatim. These intercepted radio communications were primarily monitored and analyzed for the Army of B\&H only. Once intercepted radio communications came into the possession of the OTP, ICTY language professionals, who had the luxury of time and resources, would retranscribe every important conversation for which recordings were available. These were then analyzed by analysts. No large discrepancies were found between the two different versions of transcripts, so there was never a situation in the courtroom where one transcript version had to take precedence over another. The OTP would tender as evidence its transcript of the intercept and attach the Army of B\&H interceptors' transcript for the Trial Chamber, as well.

Intercepts are very interesting from the point of view of translation because they contain spoken discourse. Effective criteria for translation of spoken discourse must take into account the fact that the main purpose of language is communication. All communication is conducted in a context. In that sense, if they wanted to know what was said in the intercepts, translators and analysts needed to be aware of conversational maxims and contextualization cues. Elements that were mostly lost in the translation of intercepts normally include wordplay, "Balkanisms" in the form of marked status categories bre and $b a$ (evidential, reported, dubitative, admirative, witnessed, etc.), ${ }^{831}$ tone (who speaks to whom (informal $t i$ vs. formal $V i$ )), to what end (informal, inferior or order receiving body $t i$ vs. formal, superior order issuing authority $V i$ ), and curse words. As genuine records of everyday conversations that did not need to follow any rules of prescriptive linguistics, intercepts contained a lot of slang, colloquial and regional expressions, were sometimes illegible (if the only record available was handwritten), and sometimes lacked punctuation. This is why intercepts had to be translated word-for-word whenever possible. Language professionals are not evidence analysts, but they are walking a fine line between a language professional and a paralegal assistant when translating intercepts. To this end, as mentioned before, they had at their disposal several "disclaimers", enabling them both to flag a potentially interesting word and to protect themselves should they be incorrect, namely: /as written/: for instances where there was an obvious mistake in the original in terms of flaunting the conversational maxims, /as printed/: for instances where otherwise common terms or notions were misspelled or used in the wrong context, and /?.../ for instances where the meaning was implied. In 1995, when these transcripts were made, information technology was not as advanced as it is today. The interceptors did not have at their disposal all $\mathrm{B} / \mathrm{C} / \mathrm{S}$ letters on their keyboards and this is why they used various substitutions: ss for š, cc for ć, ch for č, zh for $\check{z}$, dj for đ, etc.

The first intercept presented here is a record of conversation between $\mathrm{X}$ and $\operatorname{Trbici}^{8{ }^{82}}$ In translating this intercept, this translator used /as printed/ to protect himself from improper transcription. Given the discussions above about $\mathrm{B} / \mathrm{C} / \mathrm{S}$ letters and punctuation, the proper transcription of this segment should be as follows:

\footnotetext{
${ }^{81}$ Friedman, V.A. (1994), Variation and Grammaticalization in the Development of Balkanisms. Chicago Linguistic Society: Chicago, p. 101-115.

${ }^{83^{2}}$ ICTY, Intercepts, Krstić, Ex. 665a (English) and 665b (B/C/S).
} 


\begin{tabular}{|l|l|}
\hline Original transcript & BF transcript \\
\hline $\begin{array}{l}\mathrm{T}-\text { Pa meni je veoma tessko dochi do njega o tome se } \\
\text { radi al on che sigurno na tome radi znash. }\end{array}$ & $\begin{array}{l}\mathrm{T}-\mathrm{Pa} \text {, meni je veoma teško doći do njega. O tome se } \\
\text { radi. Al' on 'će, sigurno. Na tome radi. Znaš. }\end{array}$ \\
\hline
\end{tabular}

The sense-for-sense translation based on proper transcription of this segment should be as follows:

\begin{tabular}{|l|l|}
\hline Word-for-word translation & Sense-for-sense translation \\
\hline $\begin{array}{l}\text { T - It's very hard for me to reach him, that's the prob- } \\
\text { lem, but he will, for sure, he's working on that, you }\end{array}$ & $\begin{array}{l}\text { T - Well, it's very hard for me to reach him. That's the } \\
\text { problem. But, he will, for sure. He's working on that. You } \\
\text { know. }\end{array}$ \\
\hline
\end{tabular}

There were no translation losses in this segment, only losses in formal transcription.

The translators' use of /?he/ in the following segment of this intercept is governed by the fact that this conversation revolves around a single individual. This individual is absent and currently busy "[finishing] the work he is doing," but, as soon as he finishes, he is supposed to "report /?here/ immediately." X assures T that it is difficult for him to get in touch with the individual that $\mathrm{T}$ needs, but that he will nevertheless convey the message, to which $\mathrm{T}$ retorts:

\begin{tabular}{|l|l|}
\hline Transcription & Translation \\
\hline T - Al odma ko dodje do tebe zovte me odatle. & $\begin{array}{l}\text { T - But, if / ?he/ comes to your place call me immedi- } \\
\text { ately from there. }\end{array}$ \\
\hline
\end{tabular}

This segment is confusing for a translator.

\begin{tabular}{|l|l|}
\hline BF transcription & BF translation \\
\hline T - Al', odma' 'ko dođe do tebe zov'te me odatle. & $\begin{array}{l}\text { T - But, in case he reaches you, call me from there im- } \\
\text { mediately. }\end{array}$ \\
\hline
\end{tabular}

Although he is talking about a single individual throughout the conversation, it seems that T suddenly introduces ko (who, whoever). However, this could not be "it" because the whole conversation revolves around the whereabouts and the arrival of a single person, not "whoever." This might be because this speaker obviously does not fully pronounce his words: al' for ali (but), odma' for odmah (immediately), zov'te for zovite (/you, pl./ call). Therefore, it is quite possible he also did not fully pronounce the word ako (if) and that he shortened it into ' $k o$. This is all the more plausible because the word that preceded " $k o$ " also ended with a vowel: odma'. In this case, the proper rendering of the phrase would be: "But, if /?he/ comes to your place, call me immediately from there," just as this translator has done.

The second translation point is the rendering of the word "goram."

\begin{tabular}{|l|l|}
\hline Transcription & Translation \\
\hline $\mathrm{X}$ - I odma da ide goram. & $\mathrm{X}$ - And have him come /?here/ immediately. \\
\hline
\end{tabular}

It could be argued that the word "goram" used in this intercept is a dialectal version of "gore" (up here). Speakers of the Bosnian language from the region of Podrinje where the events were taking place (right next to the Drina river bordering with Serbia) usually pronounce directions (here, there, up there, up here) adding or subtracting the "m" at the end of the formal version of those words: goram (gore), dolam (dole). Academically, this was attributed to mispronunciation and lack of education for a very long time. However, there were no studies conducted into Bosnian regional colloquialisms which could shed more light on the use of the final $m$ in these words. It could be argued that by adding " $\mathrm{m}$ " to directions, these speakers just wanted to emphasize that this is where they, themselves, actually were: Hajde goram or "Come up here where I am" or "Come here, with me" or even "Come, join me." For example, Ramo Osmanović, one of the men captured by the VRS forces and kept in the Kravica meadow pending his execution called his son Nermin, who was hiding further down in the bushes, to come goram under clear instructions of VRS soldiers who reiterate "goram... kod Srba" (up 
here, at the Serbs'). ${ }^{83}$ In a general translation context, this could very well be translated as "Come join me and the Serbs up here" but, in a translation in a legal context this has been correctly rendered as the basic "/?here/." This translator, obviously a Bosnian speaker, put a question mark to account for all these other possibilities.

In the beginning, when the intercepts had just been received, OTP Intercept Project managers did not know what they were, how they could use them, or, indeed, how to piece them together to tell the OTP the same story they told the Army of B\&H Intelligence Services. In this, the OTP had to rely heavily on investigative knowledge about the context relating to the intercepts. Linguistically, general communication between any interlocutors simultaneously consists of two messages: the explicit message and the metamessage. ${ }^{834}$ The metamessage may refer to how the speaker wants listeners to interpret a message: a listener must not only understand the sentence's meaning, but also the speaker's intent. The VRS soldiers recorded on the intercepts were fully aware that they were not using protected lines and that their conversations might have been monitored. Here, both the translator and the analyst had to refer to the context or make use of contextualization cues. ${ }^{85}$ Contextualization of communication relies heavily on shared knowledge: interlocutors almost always understood each other. The translators understood them relying on contextualization cues. As far as the contextualization cues are concerned, they could be "anything suspicious," as will be shown in the examples below. OTP Language Assistants flagged potential metamessages making use of contextualization cues. This was the first step in linguistic analysis of intercepts and it relied heavily on spotting violations of conversational maxims. Grice proposes four conversational maxims which enable cooperative and effective conversation: the maxim of quantity, the maxim of quality, the maxim of relation, and the maxim of manner. These maxims provide the rules of conversation, but they also alert us to ways in which conversational meaning might be violated (flouted). ${ }^{86}$ The VRS tried to do everything possible to speak in code, they used euphemisms or otherwise covered up their real meaning. In the intercepts that follow, it will become clear how participants in intercepted conversations advised interlocutors that it would be better to send information through protected lines using the teleprinter (an old-fashioned fax machine run on secure lines) or where participants in a conversation advised their interlocutor that they might be being monitored.

According to Grice, the basic rules of the maxim of quantity are: make your contribution as informative as required and do not make your contribution more informative than is required. For example, when asked "How are you," one is not expected to provide a detailed elaboration of one's psychophysical wellbeing. This maxim was violated in the intercepts because the parties knew they were being intercepted and they went out of their way to code their answers. The second intercept presented here is a record of a conversation between $\mathrm{X}$ and Jevđo. ${ }^{87} \mathrm{In}$ this intercept, unidentified participant $\mathrm{X}$ requires " 200 men for intervention, where needed." The contextualization cues used to flag the following conversation were: intervencija (intervention), 200 ljudi (200 men), and linije držati čvrsto (hold [...] lines firmly). The VRS Communications Colonel Jevđević is asking $\mathrm{X}$ whether he needs the men as drivers to which $\mathrm{X}$ retorts "Not as drivers, 200 men are needed, man, Jevđo, you understand, soldiers with weapons." However, Jevđević is persistent about finding out the purpose of an engagement with such a large number of men and asks X "[These men should be r] eady for...?" to which X flouts the maxim further, by using the wordplay "ready," and resumes ordering: "Gather them and when I order 'Start,' you start." Elements that are lost in translation include the wordplay. The proper transcription of this segment would be as follows:

\begin{tabular}{|l|l|}
\hline Original transcript & Proper transcript \\
\hline X:Znači 2oo ljudi da ima. & X: Znači, 2oo ljudi da ima. \\
\hline
\end{tabular}

\footnotetext{
${ }^{83}$ Senad Ahmetovic YouTube Channel.

${ }^{84}$ Bateson, G. (1972), Steps to an ecology of mind: collected essays on anthropology, psychiatry, evolution, and epistemology. John Aronson Inc.: Lanham, MD.

${ }^{835}$ Gumperz, J.J. (1982), Discourse Strategies. Cambridge University Press: New York.

${ }^{836}$ Grice, P. (1989), Studies in the way of words. Harvard University Press: Cambridge, MA.

${ }^{87} \mathrm{ICTY}$, Intercepts, Krstić, Ex. 699a (English) and 699b (B/C/S) as full intercept, Ex. 70oa (English) and 70ob (B/C/S) as partial intercept.
} 
The above transcription was based on the assumption that this speaker also did not pronounce his words fully and that he was merging vowels: spremni' i prikupi' for spremnih i prikupi ih. The sense-for-sense translation based on transcription of this segment would be as follows:

\begin{tabular}{|l|l|}
\hline Word-for-word translation & Sense-for-sense translation \\
\hline X: So, it means 2oo men to be ready. & X: Have 2oo men ready, that's it. \\
J: Ready for? & J: Ready for...? \\
X: To be ready, gather them and when I order “start," & X: Ready. Gather them. When I order "Start," you start. \\
you start. & \\
\hline
\end{tabular}

The overuse of catchphrases, the natural enemy of all language professionals, also posed problems here. The most overused catchphrases are those with a concrete meaning, here: znači (so, it/that means, therefore, ergo) only added to the awkward rendering. X emphasizes that he is annoyed by Jevđević asking for the reason for deploying these men by uttering bre (the vocative particle) which is, contextually, properly rendered as "man." Next, X addresses Colonel Jevđević by his nickname, Jevđo, to emphasize the friendly relationship between the two and, possibly, make Jevđević reflect on what medium of communication he is using to tell him what he wants him to do. After all, he could not have told him "Dude, we might be intercepted, read between the lines, pal!" This theory is supported by the fact that X dubs Colonel Jevđević friendly šefe at the end of conversation which was properly rendered as "chief" and could be understood as "Okay, I got it." However, at the same time, all this informality and friendliness presents a problem when it comes to establishing authority and proving a legal point about command responsibility: which of these two was actually in charge? Although $\mathrm{X}$ does not address Jevđević formally, it is obvious from the tone of this conversation that $\mathrm{X}$ is an authority issuing orders: is it clear, have them ready, gather them, send them, when I order, have we understood each other, etc. $\mathrm{X}$ has later been identified in a different intercept taken from a different location as Krstić through duplicates. In the aftermath of the fall of Srebrenica and at the onset of the genocide, VRS troops required additional men to sweep up the terrain, meaning search for Srebrenica men and boys who were on their way to Tuzla, to capture and kill them. In the above intercept, Krstić issued an order for 200 VRS soldiers to be ready to start searching.

According to Grice, the maxim of manner requires the speaker to be lucid, to avoid obscurity or ambiguity, and be brief, that is, avoid unnecessary prolixity, and be orderly. This maxim was often violated in the intercepts because participants in the conversations were not the most organized or the most competent speakers either naturally or owing to the circumstances of having to speak through unprotected lines or, perhaps, the horrors of what they were actually doing caught up with them. The third intercept presented here is a record of conversation between Krstić, ?, and Milanković. ${ }^{88}$ In the following conversation, Krstić is talking with Colonel Ignat Milanković about Colonel Vidović. First of all, it is unclear where Vidović is, because Milanković stated that Vidović is: here, outside, resting, not sleeping. It also unclear what Vidović did about the task Krstić called to inquire about because Milanković stated that Vidović: just came back, is here but stepped out, he is watching the situation because he is here, and he is watching the situation in general. This is the reason why Krstić emphatically states "It's okay. Alright then. Take care. Greetings." Krstić obviously gathered Vidović was not doing what he was supposed to do and Milanković was covering up for him. Later, Krstić will admit in court that he decided to appoint a commander other than Vidović to coordinate the forces operating on the Bratunac-Konjević Polje-Milići road. He appointed Blagojević, who is currently serving a 15-year sentence.

The basic rule of the maxim of quality is to be truthful; do not say what you believe to be false, and do not say anything for which you lack adequate evidence. For example, when asked "Where is Vidović," one

\footnotetext{
${ }^{8}{ }^{8}$ ICTY, Intercepts, Krstić, Ex. 696a (English) and 6g6b (B/C/S).
} 
is supposed to state the actual location, not turn the conversation into a different direction. Similarly, the basic rule of the maxim of relation is to be relevant. These two maxims are the main reason why the OTP would, sometimes, go on months-long wild goose chases, looking for meaning in a conversation that, in the end, proved to be nonsensical. Participants in the conversation, aware that the enemy might be listening to them, sometimes went out of their way to "code up" or sidetrack the facts as we have seen above. But, sometimes, they just talked nonsense. The main metamessage in any conversation between two army troops communicating over the radio or telephone always concerns military matters. That is why every suspected contextualization cue had to be examined in full. For example, is there a metamessage in a conversation between two officers when one says: "Yeah, the weather today has been like yesterday, except for the fact that I am wearing a second pair of underwear again." Is this officer referring to the actual additional pair of underwear because he is cold or is he saying that his positions have been reinforced due to anticipated attacks? In other words: why would officers discuss underwear? If they are two plain soldiers, regardless of the weather conditions, there might be nothing more to the underwear conversation than underwear. However, if they are two officers, regardless of the weather conditions, that information might be extremely important because of the metamessage: the situation is unchanged (Yeah, the weather today has been like yesterday), but something got reinforced à nouveau (with the exception of the fact I am wearing a second pair of underwear) in the same manner that it had been reinforced the last time a similar situation cropped up (again). During the Srebrenica operation, at the point where the Srebrenica boys and men were being captured, killed, and chased left, right and center, suddenly, the VRS soldiers started talking about "picking berries." It was important to establish whether this was yet another euphemism. Operational intelligence has established the VRS soldiers used the euphemism paket (parcel, i.e. prisoners) who were planned for dostava (distribution, i.e. killing), and was wondering whether brati maline (picking berries) stood for search operations, selective killings, or something else. After strenuous analysis, checking and cross-referencing, which is all available in-house and on open sources, it was established that the VRS soldiers were, indeed, only picking berries: some intercepts were found where the group that was picking berries boasted just how much jam their wives or mothers made and how they wished they had not picked them in the first place because they are now sick of it.

The main point of war propaganda is to present the enemy as less than human and undeserving of moral consideration. This study calls this the philosophy of hate (Chapter 3 ). This is mostly practiced in the context relating to the battle because, unfortunately, it is understood as giving morale to the soldiers: it is easier to kill it than a person with a spouse, children, mortgage, hopes, and dreams. The last intercept presented here is a record of a conversation between Palma Duty Officer (Major Jokić), Badem, $X$, and Y ${ }^{839}$ Once put through, the following conversation was conducted between Major Dragan Jokić, Zvornik Brigade Chief of Engineering, and Colonel Ljubiša Beara, the VRS Main Staff Chief of Security. The relationship between these two interlocutors is not that of equals: Jokić addresses Beara with formal $\mathrm{Vi}$ (you) to signify his military inferiority (Jokić was a Major, Beara a Colonel), and he addresses Beara with šefe (boss) which, in this situation, cannot be understood as a term of endearment, owing to Beara's higher rank, organizational position, and the formal tone of this conversation, or it might imply that Jokić might have been militarily responsible to Beara. In this conversation between the main actors responsible for killing Srebrenica men and boys, it is evident that these human beings who were killed left, right, and center were not at all seen as humans, but as objects: they became an it, a random object, in the mind of their murderers. Srebrenica men and boys who encountered and, probably, engaged the VRS soldiers were called Turci (Turks), whereas the VRS men are called naši (our guys). In other words, it could be said that the VRS soldiers were made to believe they were attacked and killing people from the past, not real people in the present who had nothing to do with their delusions. Once caught, Srebrenica men and boys were called paket (parcel). There were thousands of men and boys who, once tricked into surrendering or caught, got killed en masse. Their murder required enormous

\footnotetext{
${ }^{839}$ ICTY, Intercepts, Krstić, Ex. 364 (English).
} 
logistics in terms of executioners, security, weapons, etc. In this conversation, Jokić makes a slip up, forgetting that he is supposed to use the code name paket (parcel). He says:

There are big problems. Well, with the people, I mean, with the parcel.

The fact that Jokić refers to a group of people as one single inanimate object is evidence of deliberate dehumanization and institutional support for such dehumanization. Jokić was concerned how the mass murder was going to pan out, and once things did not go as planned, because the Srebrenica men and boys started resisting, he called Beara to take the reins. Jokić is aware he might be bothering Beara and says "Number 155 . That's, I mean, the higher house." The number 155 stood in the calling tables for the highest VRS command. Meaning, the highest command ordered Jokić to call Beara. Jokić's slip of the tongue has just confirmed what has been suspected all along: the involvement of the highest VRS hierarchy in the killings as Beara, who he was told to call, was from the seat of the highest VRS command. Then, Jokić understood the importance and implications of what he had said and corrected himself, saying:

Well, I can't tell you on this line /who the number 155 is/, you know. You have it over there, at the signalmen', who that is.

By doing so, he opened many investigative avenues to the OTP, and cracked the case by moving things beyond the boundaries of local hostilities.

These are examples of how, in a legal context, translation and interpreting should be made for investigators, lawyers, and judges. Such translations must be an absolutely perfect balance between what to render word-for-word and what to render sense-for-sense, without losing operational information. Why should legal professionals insist on neutral and literal interpreting and translation and why should that practice be continued? Because the legal profession firmly regulates the relationship between the literal and the interpreted. Since legal professionals can only rely on words in their work, just like interpreters and translators, it is only natural that legal professionals should make sure that what they have heard or read was a literal translation, not its interpretation by a language professional. It is not at all an exaggeration to say that the main preoccupation of most translators is a fear that their clients will not understand their translation. However, those fears often have to do with control and are not justified, because legal professionals have to do their part of the work relating to documents. Let us imagine a legal professional working in a domestic jurisdiction without the involvement of language professionals. Let us now imagine that the legal professional comes across a new legal principle of which he has no previous knowledge. What is the appropriate due diligence such a legal professional must employ in exploring that legal principle? He or she must check the legal dictionary definition of that term which will, hopefully, also provide previous case law on the issue. Legal professionals need to apply the same approach when encountering culture-specific terms. So, what is an untainted and faithful translation in a legal context? It is an independent, unembellished, and neutral translation that takes into account the type and time of the original text production, rendering it into a narrative-free translation that contains all the required operational information.

\subsection{Interpreting in a legal context}

The ICTY was struggling with basic terminology relating to language professionals: they called "court reporters," as they are professionally known, as "specialized steno typists." They said that the correct provision of courtroom services was affected by the fact that the ICTY had to use several languages: English and French as the working languages of the ICTY, and " $[\mathrm{B} / \mathrm{C} / \mathrm{S}]$, which may also be used by victims, witnesses and the accused," which sounds like ICTY managers were surprised by the fact that victims and witnesses may use their 
own language; they were proud to announce that in the course of 1995, the courtroom was equipped with electronic facilities to support "simultaneous translation" during hearings into three languages, with the possibility of adding more languages to the system, if required; and they alerted the court to the idea that if investigators or legal assistants were not familiar with the language, it was important to hire a translator, and so on. So far, we have seen that the providers of language services used this knowledge of translation, interpreting, and transcribing that was at the disposal of legal professionals in many different ways and that they provided language services that were lacking in appropriate staff, appropriate production, appropriate sense of operational reality, appropriate resource allocation, and appropriate anchoring in new technology. Since the performance of language professionals reflects on them, let us see how well legal professionals performed with the assistance of interpreters.

All translation, including translation in a legal context, started from interpreting. Interpreting preceded translation because the sole purpose of interpreting has always been only to achieve immediate communication by answering the questions: who, what, where, when, why, and how? As we have seen, if there were any discrepancies between the original utterance and version as interpreted, the courts of law recognize and examine only original utterance, which must then be translated, not interpreted (Chapter 7.1.2.2). From a legal point of view, this means that the much talked about court interpreting has almost no authority and is just used to keep the communication flowing. However, interpreting is widely used in a legal context where it presents the first point of contact between clients and authorities. Sorbonne ESIT scholars Seleskovitch and Lederer developed a Theory of Sense or Interpretative Theory, which is based on the fact that different languages have different ways of expressing the same thing. ${ }^{8{ }^{80}}$ However, this theory leaves much to be desired and cannot be relied on in an investigative or judicial context which prefers a balance between sense and literal interpreting where, as we have seen in the examples above, literal translation must be applied to operational information. This is because any other interpreting would come close to drawing conclusions from the statements uttered by the speaker. This point is very important in the context of investigation and judicial activities because legal professionals are absolutely uninterested in language professionals' interpretations and conclusions. Again, the concept of interpreting has a very strict meaning in legal science, in which interpreting is allowed under certain conditions only and can be made by certain authorities only. Conclusions about statements are up to the investigator to make, not the interpreter. In other words, legal professionals want interpreters to repeat what the client said. Therefore, interpreting in a legal context must be an absolutely perfect balance between what to interpret word-for-word and what to interpret sense-for-sense. It follows that being interviewed by the police or, here, investigators and lawyers working on ethnically motivated war crimes, has many additional layers to it that have not been traditionally explored by scholars. In that sense, we must discuss interpreting for investigation purposes, interpreting during proofing, and interpreting in the court.

\subsubsection{Pre-existing relationships}

Most people have limited contact with criminal justice authorities and such contacts often take place in a negative context. Therefore, it is not surprising that clients sometimes perceive these authorities as threatening, and contact with them as a traumatic experience, especially when they need to work with the assistance of a third party, i.e. an interpreter. The experience of criminal justice authorities depends on the capacity in which clients appear before them: as a witness, suspect, or informant. This experience also stems from clients'

\footnotetext{
${ }^{840}$ Seleskovitch, D. and Lederer, M. (1993), Interpreter pour Traduire (3e edition). Didier Erudition: Paris.
} 
level of information about these institutions' approach to working with clients. ${ }^{84}$ If legal professionals cannot establish communication with their clients without the assistance of an interpreter, that means that interpreters participate in creating a relationship between legal professionals and their clients. In order for this relationship to be successful, the client must first trust the interpreter, because personal trust in the interpreter is equivalent to trust in the legal professional. By presenting practical examples, Chapter 6 underlined the importance of interpreters being selected according to their ethnicity and linguistic variant when legal professionals work in the context of ethnic conflict. The interpreter must be of the same ethnicity as a victim and the fact that s/he speaks the same linguistic variant should not at all be understood as a platitude or academic nitpicking, but an operational requirement. Legal professionals are approaching clients out of blue. Client have no reason to trust legal professionals. Clients' red flags can only go up should such a legal professional approach them with an interpreter of an attacking ethnicity.

Similarly, legal professionals must refrain from engaging an interpreter of an attacking ethnicity once their client comes to testify. While at the ICTY, the author of this study was called on several times to interpret for witnesses who turned away interpreters from Serbia. In one such case, a witness, a former concentration camp inmate, told the interpreter from Serbia assigned to interpret for him:

I have nothing against you, but I had terrible experience with the Serbs, I don't like you, I don't believe you, and I do not want you interpreting for me.

Do witnesses have the right to decide who will interpret for them? That is not an issue here: the issue is how could the ICTY have got to a situation where testifying witnesses would have to decide who will interpret for them. Here, it is very important to note that this was a testifying witness: he was in The Hague, he was beyond the point of the establishment of a pre-existing relationship. As a witness, he was on the point of building a relationship with ICTY legal professionals to express his experience of the concentration camp in a way that the judges would refer to in their judgment. Should this unfortunate selection of an interpreter who was perceived to be a member of an attacking ethnicity have happened during the creation of a pre-existing relationship, it is fair to assume that all communication with this client would have stopped there and then. Now, he is at the ICTY and about to testify and was provided with a Serb interpreter. However, there was a very interesting person up here who regularly practiced at the ICTY in these cases: when he complained, this witness got a Bosnian Muslim to interpret for him, namely the author of this study. Any witness testifying anywhere in the world is courted by legal professionals: they need him, not vice versa, so it is natural that they gave him what he wanted. As for the witness, he did make sure to ask for my family name, the name of my father, and the location I am originally from in B\&H. I was happy to oblige because the client is king. The above reaction of this witness should have been anticipated. The ICTY had no other choice but to oblige: they presented this

\footnotetext{
${ }^{841}$ During preparations for the Karadžić trial, I was asked to contact the witness identified as providing in his previous statements to the B\&H and the ICTY authorities the fullest and clearest picture of events in the territory of his municipality that preceded its capture by the Bosnian Serbs. This witness lives in Germany, has a wife, and two children. I tried to speak to him several times, unsuccessfully. First, the client's wife claimed that the witness was gone. After the fifth or the sixth contact when she began insulting and begging me to leave her family alone, the witness actually took the phone and began yelling at me in German. I speak Dutch and can understand a little bit of German, so I asked this witnesses in my corrupted German to resume in Bosnian. The witness began claiming to have forgotten Bosnian. A lawyer who spoke German happened by and picked up the phone. When she took over the conversation, the witness began claiming that he speaks German poorly and that he does not understand her. After this impasse, the Prosecution decided to pay this witness a visit in his home with an investigator who speaks German, a Bosnian interpreter, and German authorities. After having been explained the process and protective measures that he can request, the witness reluctantly agreed to testify. When he came to testify, he spoke Bosnian, and explained that he did not know what the whole process entailed, that he did not want to be reminded of that period of his life, apologized for complications caused to the OTP staff, and declared that he wanted to testify without any protective measures. Although this story had a happy end, it cannot be reiterated enough that refusing a court summons constitutes a criminal offense across the world. The first informal approach to such a witness consists of trying to persuade the witness about the importance of his statement, and, if everything falls, the Trial Chamber may issue an official subpoena. Should the witness still refuse to testify, he is indicted for contempt of court and may become subject to a fine and/or imprisonment.
} 
witness with a fait accompli because they did not have any regulations on the ethnicity of interpreters for witnesses, notwithstanding their claims that they handpick interpreters based on their ethnicity (Chapter 6.7). Of course, similar arrangements were also made for in-court interpreting and that one Bosnian woman in-court interpreter was brought in.

The cruelest thing you can do to anyone is ignore him. The ICTY ignored the victim in this witness. The CLSS, and by extension the ICTY, ignored the fact that this interpreter was a Serb and put him in an embarrassing situation. The original interpreter assigned was not assigned as a Serb, the former aggressor, but as the one who was duly qualified and had been approved by the Registry, at least nominally. Obviously, this witnesses' anger was directed at the wrong person. This witness should have directed his anger against the legal professionals: they were at fault, the OTP, and the Registry alike, not the Serb interpreter. It was legal professionals who put this witness in this situation and retraumatized him by not regulating the ethnicity of interpreters according to the rules. It was, by extension, CLSS fault's for engaging in recruitment since the early zooos and forgetting to proactively recruit Bosnian Muslims. It was, by extension, the Registrar's fault for not directing or monitoring the CLSS's recruitment efforts as a supreme authority over the Recruitment Office and CLSS. Finally, it was the OTP legal professionals' fault for not remembering to safeguard against this situation.

But, they are all at fault for even more: their shortcomings compromised the legal truth. Operationally, the question here is what kind of image this witness impresses about himself and his experience? The last thing he, obviously, expected was his former aggressor interpreting for him. However, if such an obviously provoked witness said to the interpreter that he does not like the Serbs without any hesitation, that opens a real possibility that he might verbally attack or start a conversation with the defendant in the courtroom. Moreover, self-representing defendants have the same rights as defense counsels, including the right to meet witnesses prior to their testimony to ask them for clarification of any statements provided to the OTP. Would those self-representing defendants be safe with such a witness? Finally, since he does not like the Serbs, as he stated himself, there is a real possibility that he may lie or exaggerate events during his court testimony. If such a witness does so, would the Trial Chamber believe him or her? The most "complete" witnesses are those who show at the end of the description of their terrible experiences that they are the winners because they have risen above their former aggressor. By not regulating the ethnicity of interpreters, the ICTY complicated the entire process of providing evidence in court, almost precluding witnesses from having a sound mind before undertaking arguably the most important job in their lives: testifying against their aggressor. In other words, let us imagine a Bosnian Muslim lady who came to seek justice in The Hague after being gangraped by Croatian or Serbian soldiers who, as was the practice, kept her in the rape camp until abortion was no longer possible. She took a deep breath before embarking on this immense task, put on her headphones, and heard the Presiding judge addressing her in the language of her rapists. That is the practical result of the ICTY Registry and CLSS' failure to recruit appropriate language professionals.

\subsubsection{Investigations}

During and after the war on $\mathrm{B} \& \mathrm{H}$, all those who were directly affected by the war (refugees and displaced persons, victims, witnesses, their families, and others) provided a series of statements to the local criminal justice authorities and international humanitarian organizations. Should a person have given a statement to the B\&H Ministry of Interior, it is assumed that the Ministry would have used such information for operational purposes in terms of allegations which they would, share with the B\&H Army, as urgency required. Should a person have given a statement to humanitarian organizations, it is assumed that these organizations would have used such information to plan for the future influx of refugees and displaced persons, and humanitarian aid. Humanitarian organizations are independent organizations and are not required to share their information with local criminal justice authorities, except in exceptional cases as regulated by internal rules of procedure of each of these organizations. The ICTY teams, which consisted of investigators, analysts, and interpreters, began taking statements from witnesses in 1993. The ICTY statement template, which is still 
used, contains general background information about the witness, general information about the witness' experiences during the war, with special attention to the incident of interest, and includes interpreter's and witnesses' affidavits (see Chapter 4 for an extended discussion of this) ${ }^{842}$ The statement is given in $\mathrm{B} / \mathrm{C} / \mathrm{S}$, interpreted into and written down in English, and then reinterpreted from English into the language of the witness, who confirms it as his or her own by putting initials and the date on every page. Notwithstanding the discussions in Chapter 4, it needs to be said that the quality checks on these statements were provided both by the interpreter who certifies the veracity of what has been interpreted (Interpreter Certification) and the witness who signs only the $\mathrm{B} / \mathrm{C} / \mathrm{S}$ version of his statement, once it has been back-translated (Witness Acknowledgment). The ICTY investigators taking the statement are available to explain to witnesses their rights, responsibilities, and duties, and answer any other questions their clients might have. ICTY statements have only one purpose: to gather facts about the witness experience. In this regard, it should be pointed out at the onset that the criminal justice authorities, including the ICTY, are in constant contact with people and that nothing that is human is alien to them. This means that it is extremely important that clients tell the truth and are frank during their contacts with the criminal justice authorities. ${ }^{843}$ Taking statements from witnesses is a strictly controlled process. In the interest of investigators, witnesses, and justice, the utmost care is taken not to waste or exceed the time planned, not to overlook the factual topic of the interview, and efforts should be made to reduce the impact of giving statements on witnesses. Normally, interpreters work in pairs and take turns every 20 or so minutes, but consecutive interpreters, who regularly take witness statements, work alone and are normally given a break at the point when the witness breaks down. Since the statement is taken from an individual, it must contain the personal memories of that individual, not groups. The war on B\&H was still ongoing when the ICTY teams began taking statements from witnesses and most witnesses were housed in overpopulated and poor conditions or collective accommodation. The biggest challenge during that engagement was to separate the witnesses from their groups. In other words, the teams needed to find a room where they could work with a witness undisturbed and without third parties who might affect the witness's memory. This was difficult, given the relative distance of collective accommodation from the local police stations and their occupants. Despite this, the ICTY teams made sure no third parties were present in the room while the statement was being recorded. That fact was recorded in a list of all people who were in the room while the statement was being recorded.

So far, research conducted for purposes of this study shows that neither the UN nor the ICTY have any publicly available criteria or standards for employing language professionals. In addition, the research has shown that neither the UN nor the ICTY have any publicly available guidelines for legal professionals working with language professionals. This is because statements from witnesses were not audio or video recorded, so there is no trace of the entire process from start to finish. Investigative work performed by ICTY investigators was no different to that performed by their peers. Interpreters working with investigators actually do accompany them when searching for witnesses and persuading them to speak to the ICTY. It seems that IMT interpreters were also encouraged to actively participate in examining witnesses. The Chief Inter-

\footnotetext{
${ }^{842}$ ICTY, Amalgamated Witness Statement.

${ }^{843}$ One of the elderly witnesses in the Srebrenica case stated that he has forgotten to bring his glasses with him. Without thinking, ICTY staff called in ICTY duty doctor who examined the witness and set an eye prescription, and, then, they went shopping for new glasses together with the witness. The day after the purchase, they all returned to the office where the witness declared with great difficulty that he can "read, but just a little." In the end, it turned out that the witness was completely illiterate and that he "was embarrassed" to say so at the onset. Naturally, ICTY staff were supposed to engage deeper into the theme of this witness's literacy; the error due to the unnecessary loss of time is fully theirs, not at all witnesses. From that point on, the future work with elderly witnesses always included asking them if they wanted interpreters to read back their statements to them if they are "tired from their journey." Naturally, some OTP legal professionals started taking advantage of that. In absence of ready translations of witness statements, they started volunteering the proofing interpreter to testifying witnesses to provide a la vista translation of their statements. In reality, this overtasking has to do with OTP's poor planning and inability to communicate to the CLSS when exactly certain translations must be ready, of course.
} 
preter of the American Prosecution Team, Richard Sonnenfeldt, describes one such occasion in his memoirs. ${ }^{844}$ However, that has never been allowed at the ICTY. It has also never been disallowed. Again, there were no rules and regulations governing the conduct of translators and interpreters at the ICTY.

The following analysis of the demands which should be placed on language professionals and the minimum quality expected from them was provided by Mulayim and Lai, who propose that professional police interpreters or translators should have:

1. Sound understanding of their service to society.

Understand the moral purpose of the profession of translating and interpreting - directly meeting the need for competent and impartial communication by individuals who don't share a language. The moral self-understanding of this commitment underpins their professional practice and ethical decisions.

2. Competence in specialized skills and knowledge.

Convey what is said or written in one language into another precisely, using their linguistic and extralinguistic knowledge and cognitive transfer skills to assist both parties to be 'on the same linguistic footing'.

3. Fidelity to the trust of people who benefit from interpreting/translating.

a. Appreciate the vulnerability of either party who needs assistance arising from an inability to understand at least part of a dialog at any given moment.

b. Appreciate the vulnerability of both parties arising from reliance on what was interpreted/translated.

c. Respect the primary or pre-existing relationship between the parties and avoid any unjustified intervention or boundary violation.

d. Be committed to the trust of both parties and do not allow bias or conflict of interest to influence professional and ethical decisions.

e. Appreciate the vulnerability of parties arising from having to disclose their confidential details to receive professional service and undertake to maintain privacy and confidentiality of information gained during professional practice.

f. Be committed to building professional trust and maintaining respectful regard for the profession of interpreting and translating. ${ }^{845}$

The following examination will be made of the interpretation of a suspect interview because, as stated above, unlike witness statements, suspect interviews have been recorded, transcribed, and the interpreting can be scrutinized from start to finish. ${ }^{846}$ Before turning to the interpreting side of this examination, there are several things that need to be said about the transcript itself. It is unclear whether it was the investigator who uttered lines 1-7 ENG, p. 1, because these have not at all been reflected in the $\mathrm{B} / \mathrm{C} / \mathrm{S}$ transcript. If it was written post factum, there should have been a notation indicating the authorship of these statements. Investigators must state the date, time, and venue of an interview at the beginning of the interview. Then they must introduce themselves and get all others to introduce themselves, explaining that this is because the interview is being audio recorded. When working with suspects, investigators must inform them of their rights. All these provisions are contained in ICTY RPE Rule 43. However, this Rule does not mention interpreters or transcribers.

\footnotetext{
${ }^{844}$ Sonnenfeldt, R. W. (2002), Witness to Nuremberg. Arcade Publishing: New York, p. 23-32.

${ }^{845}$ Mulayim, S. and Lai, M. (2016), Ethics for police translators and interpreters. CRC Press, Taylor \& Francis Group: Boca Raton, p. 133 .

${ }^{846}$ ICTY, Interview between the OTP and Ivan Čermak (1998): $\underline{\text { NNG }}$ and B/C/S.
} 
When they are working through interpreters, as investigators at international war crimes tribunals do, investigators should also mention both the interpreter and the transcriber, alerting the suspect to the rule that he may not communicate with the interpreter and that he must be mindful of the transcriber who needs to be able to hear every word said in order to produce the interview transcript. Normally, after an interpreter has introduced himself, the interviewing parties would say something to the effect "Are you happy with this interpreter?" This is meant to confirm that the client accepts the interpreter. But nobody is happy to be interviewed by legal professionals and nobody can determine whether they are happy with someone they met three seconds ago. The entire process requires a more serious approach to the introduction of interpreters and transcribers during interviews.

As to this ICTY interpreter, unfortunately, she lost control over the interview by the end of the first sentence. Her loss of control is a good example of how the quality of interpreting depends solely on the quality of the original statements. It is important that both the investigator and the interpreter deliver perfectly. Noticing a third person in the room affiliated with the suspect, this investigator blurts out (Line 18, p. 1 ENG):

Investigator: And if you explain your position in this interview?

The above is neither a proper question nor a grammatical sentence. In addition to having to instantaneously figure out how to say what she heard in the target language, as interpreters do, it left the interpreter having to figure out what the speaker wanted to say from the context. The proper way to ask such a question is:

Investigator: In what capacity do you appear in this interview?

Legal professionals have several quirks encroaching on the quality and smooth process of translation and interpreting: we have seen before how they love nicknaming the documents, how they like to innocently ask questions of the gullible, how they nudge the translation in the direction of their argument, and so on. However, if legal professionals, the people whose work relies on precise language do not use precise language, who will? Naturally, the interpreter was confused, but she, nevertheless, conveyed the basic message (Line 8, p. 1 B/C/S, back-translation):

Interpreter: Could you explain the position, the role in this interview?

The fact is that this investigator entirely botched the question he should have asked and confused the interpreter, who was playing the role of an investigator in the target language. The interpreter, because she was confused, added on both to the question and to the answer.

KD: Moja uloga u ovom razgovoru je moja uloga koja je bila sa gospodinom Čermakom za vrijeme ovo koje smo proveli u Kninu kao njegov tajnik i kao časnik za vezu.

Interpreter: My participation in this interview is because of my role as the secretary to Mr. Čermak and the Liaison Officer for the time we spent in Knin.

BF back-translation: My role in this interview corresponds to the role I played with Mr. Čermak during the period of time in question while we were in Knin as his secretary and as a Liaison Officer. 
What is the problem here? This gentleman stated that he was appearing in the interview for the same reasons he was with a suspect in Knin, where he served as Mr. Čermak's secretary and as $a$ Liaison Officer. This interpreter stated that he was here because he was the suspect's secretary and Liaison Officer. There is a significant difference between these two statements: one implies this gentleman might help with the dates or details whereas the other reinforces his image as a co-suspect. "I am here because what you might ask reflects on me," the interpreter said between the lines. What followed is subpar example that seriously encroaches on the accuracy and quality of the interpreting and professional trust in the interpreter. The following table contains a full list of mistakes in terms of accuracy and approach spotted on the first four pages of this interpreting assignment, which is how long it took the parties to introduce themselves. This means it took them between 15 and 20 minutes to get the basic introductions out the way. 
Table 16. Mistakes in interpreting during an interview with a suspect

\begin{tabular}{|c|c|c|c|}
\hline Page/line & English version & Page/line & $\mathrm{B} / \mathrm{C} / \mathrm{S}$ version \\
\hline & Not translated: suspect's aide declared to be his interpreter, as well. & $1 / 15^{-19}$ & Exchange between the suspect and his aide. \\
\hline $1 / 22$ & Investigator introduces the interpreter: And, finally, interpreter so-and-so... & $1 / 21$ & $\begin{array}{l}\text { Interpreter ignores investigator and introduces herself: I am also... } \\
\text { Establishes personal contact on her own. }\end{array}$ \\
\hline \multirow[t]{5}{*}{$1 / 23$} & Investigator states there is nobody else present in the interview room. & $1 / 23$ & Unfinished: And there is nobody else in this, ehm... \\
\hline & & $1 / 24$ & Official name of the document mistranslated: Pravilnik not Pravila. \\
\hline & & $1 / 26$ & Collocation: your rights not the rights you enjoy \\
\hline & & $1 / 26$ & Switches to Serbian ekavian: obavestim vs. obavijestim. \\
\hline & & $1 / 29$ & $\begin{array}{l}\text { Switches to Serbian ekavian: sledeća prava vs. naredna prava or sljedeća } \\
\text { prava. }\end{array}$ \\
\hline $1 / 36-37$ & $\begin{array}{l}\text { Interpreter formalizes suspect's answer, the fact that he addresses her per- } \\
\text { sonally does not read in her interpreting. }\end{array}$ & $1 / 34$ & $\begin{array}{l}\text { Suspect addresses interpreter personally: it would have been the best if we } \\
\text { were to do this through you as an interpreter... } \\
\text { Suspect says he'd like to ask something: not translated. }\end{array}$ \\
\hline $2 / 2$ & Investigator re-asks suspect about his knowledge of English. & & $\begin{array}{l}\text { Stacking: suspect's previous question was not translated, investigator was not } \\
\text { aware of it, he now asks his own question. Interpreter doesn't interpret that } \\
\text { one either. Interpreter obviously has a problem controlling the clients: sus- } \\
\text { pect keeps on talking. }\end{array}$ \\
\hline \multirow[t]{3}{*}{$2 / 4-7$} & $\begin{array}{l}\text { Interpreting for investigator: I would like to ask just one thing /carried on } \\
\text { from previous segment, evidence of no control over clients/. Since you have } \\
\text { everything here with questions about international law on paper, and that } \\
\text { you will be using the questions from this paper, that you allow me to photo- } \\
\text { copy them bit by bit when it's finished, when we're finished? }\end{array}$ & $2 / 1-3$ & $\begin{array}{l}\text { Mistranslation } \\
\text { BF back-translation: I see that you have all the questions and related interna- } \\
\text { tional law issues and all that stuff on that paper in front of you and that you } \\
\text { plan on using it all here: could I please be allowed to copy all that, part by } \\
\text { part, once we're done here? }\end{array}$ \\
\hline & & $2 / 7-8$ & $\begin{array}{l}\text { Suspect addresses interpreter personally, continuation of personal contact } \\
\text { not reflected in interpreting into ENG. }\end{array}$ \\
\hline & & $2 / 10$ & Nonsensical: da ponavljam vs. da ponovim \\
\hline $2 / 18-20$ & Reading out Rule 42. & $2 / 14-16$ & $\begin{array}{l}\text { Awkward and unnecessary interpreting: investigator is reading suspect his } \\
\text { rights. Why wasn't this simply read out from the B/C/S version of the RPE? } \\
\text { Did she prepare for this meeting? }\end{array}$ \\
\hline $2 / 22-27$ & $\begin{array}{l}\text { Consistency: counsel became attorney once interpreted, sufficient means be- } \\
\text { came resources. }\end{array}$ & & \\
\hline $2 / 22-23$ & $\begin{array}{l}\text { Interpreting for the investigator: } \\
\text { I agree to this conversation without any kind of lawyer because I think that I } \\
\text { can answer the questions without a lawyer. }\end{array}$ & $2 / 18-20$ & $\begin{array}{l}\text { Mistranslation } \\
\text { BF back-translation: I consented to this interview today without lawyers be- } \\
\text { cause I think I can answer those questions without lawyers, without counsels. }\end{array}$ \\
\hline
\end{tabular}




\begin{tabular}{|c|c|c|c|}
\hline Page/line & English version & Page/line & $\mathrm{B} / \mathrm{C} / \mathrm{S}$ version \\
\hline $2 / 26-27$ & $\begin{array}{l}\text { Interpreting for the investigator: } \\
\text { Because I think that I'm not guilty of anything. I've got nothing to hide. That's } \\
\text { why I agree to this conversation. }\end{array}$ & $2 / 22-23$ & $\begin{array}{l}\text { Mistranslation } \\
\text { BF back-translation: I consented to this interview because I consider myself } \\
\text { not guilty and have nothing to hide. }\end{array}$ \\
\hline $2 / 34$ & $\begin{array}{l}\text { Interpreting for the investigator: } \\
\text { Yes. }\end{array}$ & $2 / 30$ & $\begin{array}{l}\text { Mistranslation } \\
\text { BF back-translation: I understood all my rights. They are all clear to me. }\end{array}$ \\
\hline $3 / 1-3$ & & $2 / 32-33$ & $\begin{array}{l}\text { Mistranslation } \\
\text { BF back-translation: If you don't want to speak to us then we will immediately } \\
\text { leave the room. But you have the right to remain silent and also to have a } \\
\text { lawyer. }\end{array}$ \\
\hline $3 / 9$ & $\begin{array}{l}\text { Mistranslation } \\
\text { BF back-translation: If I didn't want to talk to you, you wouldn't be here. }\end{array}$ & $3 / 1$ & \\
\hline \multirow[t]{2}{*}{$3 / 5-7$} & $\begin{array}{l}\text { Exchange between the third person and an investigator which was not trans- } \\
\text { lated to the suspect }\end{array}$ & & \\
\hline & & $3 / 3-11$ & $\begin{array}{l}\text { Switches to Serbian ekavian: obaveštavam vs obavještavam; vreme vs vrijeme; } \\
\text { daće vam se vs dati ćemo vam. }\end{array}$ \\
\hline $3 / 11$ & Not translated: I'm reading all through it. & & \\
\hline 3/15 & Mistranslation: break & $3 / 7$ & $\begin{array}{l}\text { Collocation: break not a breather } \\
\text { Also evidence of bias suggesting investigator will bombard the suspect with } \\
\text { questions. }\end{array}$ \\
\hline 3/17 & Not translated: if you may wish. & & \\
\hline \multirow[t]{2}{*}{$3 / 18$} & Mistranslation: our presence not your presence & $3 / 9$ & \\
\hline & & $3 / 11$ & $\begin{array}{l}\text { Interpreter added: } u \text { najskorijem mogućem roku (in the shortest period possi- } \\
\text { ble) and made promises that were never made. }\end{array}$ \\
\hline \multirow[t]{2}{*}{$3 / 22$} & $\begin{array}{l}\text { Interpreter added: afterwards. } \\
\text { Interpreter put pressure on the suspect and denied him of closure: there } \\
\text { something else after we go through all this. }\end{array}$ & & \\
\hline & & 3/16-25 & $\begin{array}{l}\text { Exchange between suspect and a third person not interpreted for the investi- } \\
\text { gator. }\end{array}$ \\
\hline \multirow[t]{2}{*}{$3 / 24-25$} & & & $\begin{array}{l}\text { Mistranslation } \\
\text { BF back-translation: The tape will be sealed because we do not have means } \\
\text { to copy it here, only in The Hague. }\end{array}$ \\
\hline & & $3 / 28$ & $\begin{array}{l}\text { Suspect addresses the interpreter personally, continuation of personal con- } \\
\text { tact not reflected by interpreting into ENG. }\end{array}$ \\
\hline 3/32-33 & Mistranslation & $3 / 32-34$ & \\
\hline
\end{tabular}




\begin{tabular}{|c|c|c|c|}
\hline Page/line & English version & Page/line & $\mathrm{B} / \mathrm{C} / \mathrm{S}$ version \\
\hline & $\begin{array}{l}\text { BF back-translation: No, nothing specific, I'd just like us to start this inter- } \\
\text { view. Let's see what topics he's interested in discussing and what this is all } \\
\text { about. Then we can talk further. }\end{array}$ & & \\
\hline $4 / 1-2$ & & $4 / 2$ & $\begin{array}{l}\text { Mistranslation } \\
\text { BF back-translation: Okay, for now, name. }\end{array}$ \\
\hline $4 / 4$ & Interpreter editing & $4 / 4$ & $\begin{array}{l}\text { BF back-translation: My name is Ivan, my name is Ivan Čermak, the name of } \\
\text { my father is Vlado or Vladimir. }\end{array}$ \\
\hline $4 / 11$ & Not translated, first sentence: Sure, no problem. & $4 / 10$ & \\
\hline $4 / 11-15$ & Interpreter editing & $4 / 10-13$ & $\begin{array}{l}\text { BF back-translation: I was Assistant Minister for Defense of the Republic of } \\
\text { Croatia in charge of logistics between } 1991 \text { and 1993. I was demobilized in May } \\
\text { 1993. Sorry, I had a rank of Colonel General. I was Assistant Minister for De- } \\
\text { fense of the Republic of Croatia between } 1991 \text { and } 1993 \text { with a rank of Colonel } \\
\text { General. I was in charge of logistics. }\end{array}$ \\
\hline $4 / 22-24$ & & $4 / 22-23$ & $\begin{array}{l}\text { Mistranslation } \\
\text { BF back-translation: Commander of the Knin Garrison. }\end{array}$ \\
\hline $4 / 25$ & & $4 / 26$ & Mistranslation: linija poslovanja not sektor (sector). \\
\hline $4 / 28$ & $\begin{array}{l}\text { Mistranslation } \\
\text { BF back-translation: Up until 1993, sorry, 199o, I was involved with engineer- } \\
\text { ing, air conditioners, electronics. }\end{array}$ & $4 / 27-28$ & \\
\hline & Not translated: I had my own office, my own production. & $4 / 28$ & \\
\hline $4 / 29$ & Interpreter added: on my project. & & \\
\hline $4 / 30$ & & $4 / 30-31$ & $\begin{array}{l}\text { Mistranslation } \\
\text { BF back-translation: I entered politics in 199o, I joined HDZ. }\end{array}$ \\
\hline $4 / 30-31$ & & $4 / 31-32$ & $\begin{array}{l}\text { Mistranslation } \\
\text { BF back-translation: I started working with the Ministry of Defense, I started } \\
\text { preparing defense of the country from the Serbian aggressor and so on. }\end{array}$ \\
\hline $4 / 31$ & Omission: from the Serbian aggressor and so on. & $4 / 32$ & \\
\hline $4 / 32$ & Awkward: ... after being Ministry of Economy... & $4 / 32$ & \\
\hline $4 / 32$ & Mistranslation: companies, enterprises. & $4 / 33$ & \\
\hline 3/32-33 & & $4 / 33-34$ & $\begin{array}{l}\text { Mistranslation } \\
\text { BF back-translation: I opened a company, construction company dealing } \\
\text { with engineering, air conditioning and electronics side of business, etc. }\end{array}$ \\
\hline
\end{tabular}


This interpreter's performance on the first four pages reinforces the finding of this study (see Chapter 6) about CLSS's recruitment methods in that she is obviously someone picked off the streets who had no place interpreting during this interview. This interpreter is not a native speaker of $\mathrm{B} / \mathrm{C} / \mathrm{S}$ and cannot be said to have a command of $\mathrm{B} / \mathrm{C} / \mathrm{S}$ or English that is at an acceptable level for interpreting. This is reflected in the series of missed collocations and phraseology in both languages. This interpreter violated Mulayim and Lei's second principle of police interpreters: competence in specialized skills and knowledge. This interview touched on legal science, military science and economy, and this interpreter regularly misinterpreted all the technical terms. The fact she was not a native speaker of $\mathrm{B} / \mathrm{C} / \mathrm{S}$ relates directly to the examination of native speakers in Chapter 5 where it was obvious that some UN entities, if not all, insist on such speakers, probably thinking that the presence of a native speaker automatically equals quality or accuracy. This practical example refutes such beliefs. It also shows that an interpreter will always be a native or a mother tongue speaker of one, but not of both languages. The paradox of insisting on a native speaker is obvious: since it is not the case that both sides got a native speaker as an interpreter, why insist on only one side getting it? Where is the linguistic justice in that? The above examples serve as a practical example of the utter failure of CLSS recruitment efforts.

At the level of linguistic competence in $\mathrm{B} / \mathrm{C} / \mathrm{S}$, this interpreter mixes Serbian and Croatian, does not provide idiomatic interpreting, and, most importantly, she lost most of the operational data. In addition, mixing ekavian and ijekavian when interpreting for a Croatian suspected of being a perpetrator of crimes against the Serb population defies the common sense promised by CLSS managers (Chapter 6). Moreover, it could easily be interpreted as a provocation. Finally, it is a direct violation of Mulayim and Lei's first principle of police interpreters: by mixing ekavian and ijekavian, this interpreter showed that she does not have a sound understanding of her task.

This interpreter also violated Mulayim and Lei's third principle of police interpreters: fidelity to the trust of people who benefit from interpreting/translating. Neither of the clients were provided with adequate interpreting as there were a whole series of unjustified editing, omissions, and adding to the original. In particular, this interpreter cannot be said to be committed to the trust of both parties and she allowed bias or a conflict of interest to influence professional and ethical decisions. Instead of allowing the suspect "a break," she gave him "a breather," and she did not convey to the investigator that the reason behind the suspect's switch from business to Ministry of Defense was so that he can "prepare the country for defense from Serb aggression," which remained untranslated.

All in all, this subpar interpreting showed that this interpreter violated Mulayim and Lei's 4.f. principle of police interpreters as, overall, her output did not show she was committed to building professional trust and maintaining a respectful regard for the profession of interpreting and translating.

As to the interpreter-related rights, the investigator merely informed the suspect that he had the right to free assistance by an interpreter. He also informed the suspect that the interview was being recorded, that it would be transcribed, and that he would receive the transcript in his own language. However, he did not inform the suspects of his interpreter- and transcriber-related obligations. As to the reading of other rights, the question here is: why does it seem like none of them were written on a simple piece of paper either in English or in B/C/S to be read out in English and then in B/C/S? This delivery should have been fluent both in $\mathrm{B} / \mathrm{C} / \mathrm{S}$ and in English, but it is not at all. Reading the rights as they appear in the ICTY RPE should be done each and every time one encounters a suspect as a matter of routine, both by an investigator and by an interpreter. However, this became an issue because an international criminal tribunal sent out an investigator to work in an interview with a suspect who was not aware of it. Where did the international criminal tribunal think they were sending this investigator, who did they think was going to help him in communication, what did they think he was going to do, who did they think he was going to do it with, and who did they think was going to transcribe all that? These are important questions because institutions, all institutions, are very often seen hiding behind their apparent infallibility instead of acknowledging and remedying simple failures. Write 
the rights on a piece of paper and read them out as a matter of routine. Why give defense ammunition for administrative nitpicking? Protect interpreters: the parties cannot address interpreters personally and vice versa, and you need to tell them that. Support the transcribers: tell the parties to speak loudly and clearly because whatever is said during interview will have to be transcribed. Institutions need rules and regulations to account for every foreseeable situation. And all of these were foreseeable. Setting in writing what happens if rules are violated is the only way to improve the performance of staff and the institution.

Why didn't this suspect say something? This is exactly where the flaws in linguistic justice come into play: who would he complain to and how would he word it? The suspect volunteered that $\mathrm{X}$ was his interpreter, thus either voicing his a priori doubts about the quality of interpreting or wanting to have a backup. At any rate, interpreting was a concern for him. The suspect was bound to have noticed an interpreter who was mixing Serbian and Croatian when speaking. Would it help if he corrected her ekavian into ijekavian? Keeping in mind discussions on linguistic variants as a political statement, that correction would have sent two different messages: the interpreter would be tacitly told that she has to step up, but the investigator may have taken this suspect's intervention as unapologetic nationalism. This suspect was bound to have noticed there were things missing in the interpreting. He must have wondered whether all these little things would detract from his overall message. If he wanted to react, he would have had to be very careful how he voiced his concerns. He could not have reminded the court that he had brought his own interpreter, because an investigator is an authority, and authority brings language support. Even if the suspect did say his interpreter was there and could take over the interpreting, the investigator would most probably have told him that the ICTY uses interpreters who are duly qualified and approved by the Registry. We have seen that Šešelj also voiced his concerns, we have seen the response to those concerns, and Šešelj's response to the response to his concerns. It did not end up well for anyone: Šešelj was charged with contempt, whoever was working on his case was publicly humiliated, and witnesses against him faced the threat of having their identity revealed. Why send an interpreter who mixes ekavian and ijekavian to interview a suspect? How was the investigator to know whether his interpreter was mixing ekavian and ijekavian? The investigator trusted his service provider: CLSS management. CLSS management should have known whether this interpreter was mixing ekavian and ijekavian. CLSS management was bound to have heard this interpreter speaking $\mathrm{B} / \mathrm{C} / \mathrm{S}$ and noticed that she mixes ekavian and ijekavian. CLSS management, without any drama, should have taken this interpreter aside and told her very simply "I noticed you mix ekavian and ijekavian when you speak. This is a war crimes tribunal adjudicating on ethnic crimes, so your mixing two dialects is an issue here. Be aware of it and do not do it during professional contacts." It is as simple as that for anyone with any professional and private integrity. But, CLSS management sent her to interpret for the suspect. What if this suspect had the intention of revealing information in exchange for immunity? What if he heard interpreter mixing ekavian and ijekavian and thought to himself "Nah, she is going to tell on me to Serbs and then I will be in trouble with both." Taking witness statements is a very serious process that requires tremendous concentration from everyone involved and where nothing is taken for granted. Setting clear rules applicable to all parties would uncomplicate all these issues. Assigning work to people that they are incapable of performing has the potential to burn bridges toward clients.

\subsubsection{Proofing}

When one of the parties, in this case the OTP, confirms that a certain witness will present evidence, they first inform the witness and then the VWU who make all the practical arrangements for the witness's arrival. The VWU provide the "door to door" service, meaning, they deal with the witness from their home, via travel to The Hague, to bringing and taking them back to/from the ICTY building for the proofing session and then testifying. Or, that is at least what they claim to do. Practice has shown that VWU Witness Assistants would fetch witnesses from their homes and bring them to the local airport; once arriving at Schiphol, they would bring them to their hotel, and were supposed to bring them to the ICTY building for proofing and to testify. The VWU could not be contacted after 16:0o during the week, or on the weekends. In that case, OTP Language 
Assistant would go and fetch witnesses for proofing at their own cost and in their own time, and also had to spend breaks together. ${ }^{847}$

In June 2016, the ICTY VWU published a report entitled "Echoes of Testimonies: A Pilot Study into the long-term impact of bearing witness before the ICTY." This project, which was conducted in cooperation with the Castleberry Peace Institute of the University of North Texas, was designed to examine the impact that testifying before the Tribunal has had on 300 fact witnesses from B\&H, Croatia, Kosovo, and Serbia, including those who experienced severe emotional or physical trauma during the war. Based on the study's findings, the VWU and the authors recommended that international judicial institutions should further develop and standardize support mechanisms to safeguard witnesses' wellbeing. They also called on courts to implement follow-up programs for those who testified and to develop strong relationships with the communities where witnesses live. In relation to translation and interpreting and its impact on witnesses, the report reasons these issues were examined because they have consequences for all stakeholders in the courtroom and implications for how the law is ultimately interpreted. Witnesses recalled that interpreting did not accurately reflect their meaning and that there were language differences between them and the interpreter. Witnesses also expressed concern about the pace of interpreting, the distracting nature of the interpreting process, and auditory issues associated with hearing what was interpreted ${ }^{848}$ Interviewees suggested that better information needed to be provided about what to expect or that the interpreting process had been problematic. ${ }^{849}$ Some witnesses also complained about interpreting difficulties and the accuracy of the interpreting between native speakers and the interpreters. ${ }^{850}$ This could be taken to mean that these 300 witnesses did say that a selection of proofing or in-court interpreters has mostly been wrong as to their language variant, knowledge of the merits of the case, and their nationality.

Once the witness arrives for proofing, s/he reads all the statements previously given to the OTP and other judicial authorities and/or reviews video recordings of earlier testimonies. Naturally, this is time consuming and requires certain logistics, but could have been faster if the ICTY had made transcripts in $B / C / S$. After clearing all ambiguities from those statements, the witness is asked by the legal professionals the same series of questions that $\mathrm{s} /$ he will be asked in the courtroom. This whole process may take several days, depending on how long the witness takes to read statements and/or listen to earlier testimonies prior to the proofing. As part of proofing, the witness is taken to the courtroom where s/he is shown the seating arrangements in the courtroom. Before testifying, witnesses decide on protective measures. The final decision on protective measures is up to the Trial Chambers to whom the witness orally applies before the trial session. The protective measures available when testifying during public court session include: assigning pseudonyms, altering voice modulation, altering images of the face during video recording, and testifying during a closed session of the court (sealed court sessions whose content never comes out in public). Although requesting protection measures is seen as something natural and human, there is always a dilemma that has to do with the nature of truth: if a witness before the Trial Chamber pronounces, often, shocking, and groundbreaking truth, would it not be better if the entire public heard it?

\footnotetext{
${ }^{847}$ Some witnesses get close to interpreters during their stay at the ICTY because they spend smoking or lunch breaks together, but some do not want anyone treating them to cigarettes or paying for their lunch. What should you do if a witness starts insisting, "No, today I'm paying for your lunch"? The ICTY is a court. In legal terms, the innocent act of treating someone with whom you have spent emotional times to a cigarette or paying for their lunch may be rightfully called "giving and taking a bribe." Why leave an interpreter alone with the client? And, if you do leave them alone, why not alert both parties to the dos and dont's?

${ }^{848}$ University of Texas and VWU (2016), Echoes of Testimonies: A Pilot Study into the long-term impact of bearing witness before the ICTY, p. $85^{-86}$.

849 Ibid, p. 113 .

${ }^{80}$ Ibid, p. 120.
} 


\subsubsection{Testifying}

Once in the courtroom, at the onset of engagement with the witness, the Trial Chamber welcomes him or her, introduces all the present in the room, and the entire process of testifying. The Prosecution takes over the witness first (examination in chief), then the Defense (cross-examination); the Prosecution has the right to follow up after the Defense, and, in rare cases, the defendant and the Trial Chamber may also ask questions. If there is a break, court ushers will take a witness to a specially designed waiting room where s/he is not allowed to enter into contact with any one of the parties until after giving testimony. Following this testimony, the witness bids farewell to the OTP's team who worked with him or her. $\mathrm{S} / \mathrm{he}$ is then taken over by the VWU representatives and goes home the following day.

The parties know their evidence which they are presenting in the court, and examples of what happens when the parties think something has not been correctly interpreted during court session have been provided earlier. But, how can a judge know whether something has been wrongly, inadequately, or badly interpreted? Let us look at the example of the following misinterpretation during the initial appearance of Mr. Milošević at the ICTY on 3 July 20o1. The mistakes in interpreting are marked in bold. The interpreter started one second behind the speaker and finished three seconds after him. ${ }^{81}$

${ }^{851}$ ICTY videos, Milošević IA, ENG and INT. ICTY transcripts, Milošević, T. 1-2. The B/C/S transcript of this session is not available publicly and it has been made and provided by the author of this study. 
Table 17. Mistakes in interpreting during the initial appearance of a defendant

\begin{tabular}{|c|c|c|}
\hline Original & Interpreting & BF back-translation \\
\hline $\begin{array}{l}\text { JUDGE MAY: } \\
\text { Mr. Milosevic, I see that you're not represented by coun- } \\
\text { sel today. We understand that this is of your own choice. } \\
\text { You do have the right, of course, to defend yourself. You } \\
\text { also have a right to counsel, and you should consider } \\
\text { carefully whether it's in your own best interests not to be } \\
\text { represented. These proceedings will be long and complex } \\
\text { and you may wish to reconsider the position. In these cir- } \\
\text { cumstances, if you wish to have time to consider } \\
\text { whether you want to have counsel or not, we would be } \\
\text { prepared to give it to you. Now, do you want some time } \\
\text { to consider now whether you wish to be represented? } \\
\text { THE ACCUSED: } \\
\text { I consider this Tribunal a false Tribunal and the indict- } \\
\text { ment a false indictment. It is illegal being not appointed } \\
\text { by the UN General Assembly, so I have no need to ap- } \\
\text { point counsel to illegal organ. }\end{array}$ & $\begin{array}{l}\text { SUDIJA MAY: } \\
\text { Gospodine Miloševiću, vidim da nemate pravnog } \\
\text { zastupnika danas ovde. Koliko smo obavešteni, to je Vaš } \\
\text { vlastiti izbor. Vi, naravno, imate pravo da se sami branite, } \\
\text { ali, takođe imate pravo i na pravnog zastupnika. Mislim } \\
\text { da treba dobro da razmislite da li je u Vašem interesu, } \\
\text { Vašem najboljem interesu da nemate pravnog } \\
\text { zastupnika. Ovaj postupak će biti veoma dug i složen i } \\
\text { možda ćete razmotriti situaciju i promeniti mišljenje. } \\
\text { Ukoliko želite dodatno vreme kako biste razmislili da li } \\
\text { Vam je potreban pravni zastupnik ili ne, mi smo spremni } \\
\text { da Vam omogućimo neko dodatno vreme. Dakle, da li } \\
\text { želite neko dodatno vreme da razmislite sada da li želite } \\
\text { da Vas neko zastupa pravno? } \\
\text { GOSPODIN MILOŠEVIĆ: } \\
\text { Ja smatram ovaj Sud lažnim sudom i smatram da su op- } \\
\text { tužnice lažne. Radi se o protivzakonitoj instituciji koju } \\
\text { Generalna skupština nije osnovala, stoga ja nemam ni- } \\
\text { kakvog razloga da imenujem pravnog zastupnika da me } \\
\text { zastupa pred nezakonitim organom. }\end{array}$ & $\begin{array}{l}\text { JUDGE MAY: } \\
\text { Mr. Milošević, I see you do not have a legal representative } \\
\text { here, today. As far as we have been informed, that is of } \\
\text { your own choice. You, naturally, have the right to self-rep- } \\
\text { resentation, but, you also have the right to legal repre- } \\
\text { sentative. I think you should think well whether it is in } \\
\text { your own interest, your own best interest to not have a le- } \\
\text { gal representative. This procedure shall be very long and } \\
\text { complex and perhaps you will reconsider the situation } \\
\text { and change your opinion. Should you wish additional } \\
\text { time to consider whether you require legal representative } \\
\text { or not, we are ready to provide you some additional time. } \\
\text { So, do you want some additional time now to think } \\
\text { whether you want a person to legally represent you? } \\
\text { MR. MILOŠEVIĆ: } \\
\text { I think this Tribunal is a fake and these accusations a } \\
\text { sham. This is an illegal institution which the General As- } \\
\text { sembly did not establish, so I do not have any reason to } \\
\text { appoint a legal representative to represent me before an } \\
\text { illegal organ. }\end{array}$ \\
\hline
\end{tabular}


Given that interpreters into B/C/S also have a benefit of live transcript of proceedings in English appearing before them to help them with their interpreting (a la vista translation), and that they work four hours a day with one full working day off to prepare, interpreting from this example is inexplicably subpar and exceedingly erroneous.

There were several misinterpretations (right to defend yourself $\rightarrow$ pravo da se sami branite (right to self-representation); [I consider] the indictment a false indictment $\rightarrow$ smatram da su optužnice lažne (I consider these accusations a sham)), including one self-correction (in your own best interests $\rightarrow$ Vašem interesu, Vašem najboljem interesu (your own interest, your own best interest)), I have no need to appoint $\rightarrow$ nemam nikakvog razloga da imenujem (I do not have any reason to appoint), We understand $\rightarrow$ Koliko smo obavešteni (As far as we have been informed), two omissions (Line 24, "in these circumstances" and Page 2, line 5 "UN"), and several additions whereas the whole style of interpreting is awkward (You may wish to reconsider the position $\rightarrow$ možda ćete razmotriti situaciju i promeniti mišljenje (perhaps you will reconsider the situation and change your opinion), if you wish to have time $\rightarrow$ Ukoliko želite dodatno vreme (Should you wish additional time), we would be prepared to give it to you $\rightarrow$ mi smo spremni da Vam omogućimo neko dodatno vreme (we are ready to provide you some additional time), today $\rightarrow$ danas, ovde (here, today)).

Register is a variety of language that a language user considers appropriate to a specific situation. Register depends on field of discourse, tenor of discourse, and mode of discourse.

Within register, the field of discourse refers to what is going on that is relevant to the language user's choice of linguistic terms. ${ }^{82}$ This is an initial appearance of the defendant before the court. This is the venue where the Presiding Judge informs the defendant of his/her rights and where the defendant may enter a plea. Unfortunately, major mistakes in the field of discourse completely distorted the Presiding Judge's take on Milošević's legal rights. Although the Presiding Judge very clearly informed Milošević that he has a right to "a defense," the interpreter informed him that he has a right to "self-representation." Naturally, defendants also have a right to self-representation (ICTY-S, Article 21(d)), but judges do not normally say to them "You can self-represent yourself' the first time they meet them. It is worth asking whether this erroneous interpreting is to blame for the fact that Milošević chose to represent himself, which caused many issues later on for all the parties.

Within register, the mode of discourse abstractly refers to the role that language plays (speech, essay, lecture, etc.) and to its medium of transmission (spoken or written) ${ }^{853}$ Here, after having informed him of his rights, the Presiding Judge informs Milošević that, with those rights in mind, considering he has not legal representation, he can take some time to reconsider his right to defense:

\begin{abstract}
Now (conclusive), do you want some time to consider now whether you wish to be represented?
Dakle, da li želite neko dodatno vreme da razmislite sada da li želite da Vas neko zastupa pravno?

So, do you want some additional time now (temporal) to consider whether you want a person to legally represent you?
\end{abstract}

This interpreter misinterpreted the second "now", which was clearly a catchphrase and was not meant as "take some time now (here in the courtroom) to rethink your position," but "now that I have explained your rights to you, do you want some time to rethink your position." The subpar interpreting gave this client the impression of time pressure. This interpreter not only distorted all the original messages, but she also omitted two important segments of the original speech and misinterpreted "some time" meant in general for "some

\footnotetext{
${ }^{852}$ Baker, M. (2011), In Other Words: A Coursebook on Translation (second edition), Routledge: London and New York, p. 13-14. ${ }^{83}$ Ibid.
} 
additional time" as here in the courtroom now and, despite having the opportunity to correct herself, she stuck with it to the end.

Within register, the tone of a discourse abstractly refers to the relationship between the people who are taking part in the discourse. ${ }^{854}$ Here, the tone of the Presiding Judge was informative, he is informing his client about the proceedings and his related rights. His position is that of a legal, not a moral authority. This interpreter did not distinguish between these two messages and, instead, she mistook it for condescension: "consider carefully" is a standard legal expression which has its legal equivalent in $\mathrm{B} / \mathrm{C} / \mathrm{S}$ (pažljivo razmotriti), but this interpreter said, "you should think well" (dobro razmislite) which is a dreaded B/C/S expression that parents use with their children when they are being naughty. Here, it is also worth mentioning that Serbian liberals hailed the arrest of Milošević whom they blamed for everything wrong with the country, and continue to do so, more specifically because Serbia suffered under UN sanctions (1992-1995) and, in their view, NATO bombings (1999). Interestingly, public opinion rarely blamed Milošević for the atrocities that Serbian and Serb troops committed in Croatia, $\mathrm{B} \& \mathrm{H}$, and Kosovo, and are very careful to avoid the issue altogether to this day or constantly pitching the idea that everyone was equally guilty. Serbian liberals were very happy to see Milošević in The Hague, so this condescending and patronizing choice of words could also be interpreted as an accidental reflection of public opinion on the part of interpreter ("Gotcha!") and is an example of a biased preconception about the client.

The second problem with the tone of discourse is in the designation of Presiding Judge as a speaker. The Presiding Judge speaks on behalf of a Trial Chamber, not in his personal capacity. This interpretation completely disregarded that: insertion "mislim" (I think) makes it seem like the Presiding Judge is offering his own personal opinion regarding the choices this client has vis-à-vis his legal representation. However, the Presiding Judge clearly said, "you should consider/reconsider/take time" without involving himself in his client's choices and making it clear the client should consider/reconsider/take time, not somebody else on his behalf. The way this was interpreted makes it seem like a Presiding Judge is saying: "I see you are here without defense. Sure, you can defend yourself alone. But, if I were you I would take some time to think it over. So, take that time here and now and think it over, okay?" whereas the Presiding Judge said: "I see you are here without defense. You do have a right to defense. This will be a long ride: take time and think that over." This subpar interpretation gave the impression of the Presiding Judge's personal agenda toward this client. It is worth saying that the relationship between these two was never respectful, from this very beginning up until Presiding Judge's demise in 2004.

How could this go unnoticed? How could the defendant be misinformed of his rights in the presence of a judge, prosecution, and defense, media, region, etc., and how could he be bullied into time pressure at the international criminal tribunal during such a high-profile case (or any case, for that matter)? In addition to all that has been established previously in this study regarding ICTY and CLSS recruitment, quality and quantity control, and etc., nobody challenged the interpretation. Who could challenge interpreting? Since his rights were being encroached and violated and he was the one being time pressured in interpreting, Milošević or his defense counsel could have challenged the interpreting. However, Milošević did not do that because he relied on interpreting and the interpreting was completely wrong. How many mistakes are there like this in tens of thousands of court hours? Who knows? Maybe these examples will serve as an invitation to all those willing to do more research on the quality of court interpreting at the ICTY. Again, something like this could not have happened at the IMT because the IMT had a system of monitoring and verification of simultaneous interpreting performed by the Interpretation Monitor and the members of the Third Interpreting Team when on their "day off." May the above serve as another practical example of the utter failure of CLSS recruitment efforts.

\footnotetext{
${ }^{84}$ Ibid.
} 
This study argues throughout for ethnicity-based recruitment of interpreters working at international criminal tribunals in general, especially those that are adjudicating on ethnic crimes. By extension, the study advances the arguments that interpreters from B\&H should interpret for clients from B\&H, and so on. The linguistic and legal background to this argumentation is provided in the earlier chapters of this study. Here, the study will turn to practical example of a non-Bosnian interpreter interpreting a Bosnian language speaking witness into English. Before moving to the analysis of the interpreting merits, several comments must be made on the overall philosophy behind the presentation addressing the following examples. Quoting I\&T Code, Article 10, Accuracy, para. 1 Truth and Completeness, former ICTY interpreter Hajdu argues that it is okay to interpret an obvious slip of tongue "bio sam kindapovan" with "I was kindapped." However, although not reprimanded here for laughing behind her client's backs, such interpreters and such interpreting seem to contradict the overall picture that a witness should have of the Trial Chambers: should such a witness be unable to tell the obvious difference between "kindapped" and "kidnapped," could he be trusted to know the difference between being in remand, being detained, being imprisoned, and being in a concentration camp, and, ultimately, could his experience be accepted as genuine and trustworthy by Trial Chamber that evaluates it. This example is made to say that, whereas it is completely acceptable to pay attention to accuracy, being excessive about it can have legal effects. Being kidnapped, detained, raped, subjected to watching the killing or the rape of one's own children is as traumatic as it gets. Do interpreters really have to make a show about it? Careful reader will have noticed that whenever the ICTY originals were quoted, either in the shape of transcript or a document, they are full of typos and lack editing. The ICTY language staff have worked with many legal professionals who even 20 years after working on the former Yugoslavia have not been able to properly spell or pronounce toponyms or personal names they encountered in their daily work day in and day out. Interpreters spelling or pronouncing those same toponyms the same way legal professionals did would send very unflattering messages about themselves, the legal professionals, and the court. So why pick on a victim?

The witness from the next example is a Bosnian Muslim, and the interpreter is non-Bosnian. Further, Hajdu analyses shifts in the testimony of Witness B-1054 in Milošević about the events in Višegrad. ${ }^{85}$

Table 18. Mistakes in interpreting during the testimony of a witness

\begin{tabular}{|c|c|c|}
\hline Original & As interpreted & BF back-translation \\
\hline $\begin{array}{l}\text { Pa kad smo tuj došli, ćilimi što su bili } \\
\text { prostrti: oni su nečim bili posuti, kao } \\
\text { nekom naftom, gorivom, tako da je... } \\
\text { Tuj smo i našli toga naroda osim nas } \\
\text { što su nas prećerali iz kuće u kuću i } \\
\text { tuj su nas popalili. Među nama je bila } \\
\text { beba od dva dana starosti. Uglavnom } \\
\text { da su djeca vrištala, žene, starci poma- } \\
\text { gali. Ja sam do prozora odma prešla } \\
\text { tako da sam izbacila sina od trinaest i } \\
\text { po godina kroz prozor i da sam i ja za } \\
\text { njim do dva-tri minuta iskočila kroz } \\
\text { prozor. U to me ranio: lijeva ruka li- } \\
\text { jeva noga. Tako da sam u potok otišla i } \\
\text { u kanalizaciju. U toj sam kanalizaciji } \\
\text { ostala tri dana i tri noći. Tuj sam se } \\
\text { ucrvala. }\end{array}$ & $\begin{array}{l}\text { When we reached this Omeragic } \\
\text { house, the carpets had been - } \\
\text { some oil or fuel had been poured } \\
\text { on the carpets. [...] And that is } \\
\text { when they set fire to us. Amongst } \\
\text { us was a two-day-old baby. The } \\
\text { children were screaming. The } \\
\text { women, the old men, were trying } \\
\text { to help. I was right next to the } \\
\text { window, and I threw out my } 13- \\
\text { year-old son out the window, and } \\
\text { then I followed him a couple of } \\
\text { minutes later. Then I was } \\
\text { wounded in my left arm and left } \\
\text { leg. I went into the stream and the } \\
\text { sewage canal where I stayed for } \\
\text { three nights and three days. }\end{array}$ & $\begin{array}{l}\text { When we got there, those carpets } \\
\text { that were spread, they have been } \\
\text { doused with something like oil, } \\
\text { like fuel. This is where we joined } \\
\text { other people they chased from } \\
\text { house to house. This is where they } \\
\text { set fire on us. There was a two } \\
\text { days old baby among us. Basically, } \\
\text { children were screaming, women, } \\
\text { elderly were wailing. I got to the } \\
\text { window and I threw my 13.5 years } \\
\text { old son through the window. I fol- } \\
\text { lowed him jumping through the } \\
\text { window in about two-three } \\
\text { minutes. But, I got wounded: left } \\
\text { arm, left leg. I ended up in the } \\
\text { ditch, in the sewage. I stayed in } \\
\text { that sewage for three days and } \\
\text { three nights. My injuries got in- } \\
\text { fected by maggots. }\end{array}$ \\
\hline
\end{tabular}

${ }^{85}$ Nata Hajdu, The kindapper and the kidnapped: Interpreting at the ICTY (undated). 
The mistakes in interpreting are marked in bold. The interpreter was from Croatia. Although interpreting into English, it is obvious from her delivery that she has not been educated in an English- speaking country ("tu su nas popalili" has been wrongly translated as "that is when they set fire to us" whereas it should be "that is where they set fire on us"). Other mistakes consist of serious additions ("this Omeragic house" was not mentioned in the original at all) and some serious omissions ([in the house where they set fire on us] "we found more people whom they brought in raiding house by house" and "tuj sam se ucrvala" meaning "this is where maggots started coming out my injuries" missing at the end of the discourse). There was a mistake which had to do with misunderstanding the Bosnian original: "Uglavnom da su djeca vrištala, žene, starci pomagali" was interpreted as "The children were screaming. The women, the old men, were trying to help" whereas it should be "The women, the old men, were wailing," "The women, the old men wailed," or "The women, the old men called for help." This mistake in interpreting is not an innocent one as the perpetrators in this case were accused of extermination. Instead, saying that "people were trying to help" suggests that these people had an option to defend themselves. In reality, they were wailing, just like this witness has said, meaning they were lamenting the fact that the Serb perpetrator doused them with petrol, was about to light the match, and burn them and their children alive. Thankfully, other evidence helped the Trial Chamber find that:

(i) Milan Lukić placed an explosive device in the room in which the Koritnik Group was being detained in the Omeragić House;

(ii) accelerant on the floor of the room caught fire; and

(iii) a fire then enveloped the room and the people in it. ${ }^{856}$

The fact that these people were helpless was corroborated by a survivor who testified that "the room was extremely crowded." The Trial Chamber accepted that this witness's "view was unobstructed because the people in the Omeragić House were sitting down" and that this witness's testimony "provided a logical explanation as to how she was able to see Milan Lukić in the doorway with the device." ${ }^{857}$ The fact that interpreters did not know that can only mean they had not used half day off and one full day off to prepare for their assignment. ${ }^{858}$

Again, how many mistakes are there like this in tens of thousands of court hours? Who knows? Again, maybe these examples will prove useful for anyone willing to do more research on the quality of court interpreting at the ICTY. May the above serve as a practical example of the utter failure of CLSS recruitment efforts.

Elias-Bursać reports on two serious interpreting incidents that she noticed at the ICTY calling that "an impressive record" for 10,000 trial days. ${ }^{89}$ One of these "impressive record[s]" for 10,000 trial days is an instance where a court interpreter translating into English, during the court session, on hearing what the client had to say completed her interpreting and then exclaimed into the microphone in a language the client can understand "Jao, što sere!" (Is he bullshitting or what!). Naturally, the client heard her and complained right there in the courtroom. The Trial Chamber called this "an interpreting incident" and confirmed that the CLSS carried out an "inquiry and [provided an] explanation" that an offensive comment has, indeed been made by one of the interpreters "in reaction to a statement made by the witness in a video clip presented as evidence" and that it was inadvertently broadcast. The Trial Chamber concluded that "it does not appear to

\footnotetext{
${ }^{856}$ ICTY, Prosecutor v. Milan Lukić, Sredoje Lukić, Judgment on Appeals (2012), para. 307.

${ }^{87} \mathrm{Ibid}$, para. 297 .

${ }^{85^{8}}$ Not all testifying witnesses had time to comment on the interpreting, but this one in Kupreškić et al was unhappy with the interpreting and "want[ed] the names of the months to be interpreted in a dialect he understands better. Third and fourth month." (T. $7288)$.

${ }_{599}$ Elias-Bursać, E. (2015), Translating evidence and interpreting testimony at a war crimes tribunal. Palgrave Macmillan: London, p. 54 .
} 
the Chamber [that the comment made by an interpreter] arise[s] from any ethnic prejudice or hostility to the Defence, [but that] the comment was entirely inappropriate. Such comments are not acceptable in this Chamber or at the Tribunal." As for the results of the CLSS inquiry, "[ $t]$ he Chamber is satisfied that appropriate action was taken in respect of the interpreter in question in order to prevent future incidents of this nature." The whole thing suggests a certain degree of misplaced generosity, because the Chamber concludes the case by establishing "Furthermore, this interpreter offered to be removed from this case. This interpreter will no longer be assigned to work on the Krajišnik trial. ${ }^{\prime 860} \mathrm{The} \mathrm{B} / \mathrm{C} / \mathrm{S}$ transcript of this session is not available. It should be added that B/C/S transcripts for 22 and 24 March 2006 in the Krajišnik trial, the day before and the day after this incident, are available. ${ }^{861}$

Speaking from hindsight, Elias-Bursać clarifies that the "procedure at the ICTY [...] was to move the interpreter to another case. ${ }^{862}$ However, this is just another proof that the ICTY CLSS checks and balances were lacking as this case could have been disciplined differently, more so because the interpreter in question was a member of CLSS management. The author of this study recalls that this interpreter had been a former Chief of Conference Interpreting Section at the ICTY at a certain point, a person in a managerial position who, due to the virtue of her position, should have known better and should have been disciplined more severely. May the above example serve as the last practical example of the utter failure of CLSS recruitment efforts.

I do not wish to suggest that any of these mistakes were intentional. However, all the little mistakes, all the persistent little mistakes, all the persistent little mistakes on the gist of document/testimony do add up and all the persistent little mistakes on the gist of document/testimony paint an opposite picture of what has been actually stated in the original in pretty unambiguous terms. Whereas we can all makes mistakes, this is too much. It is highly unlikely that a professional would do this. The above evidence shows that much more attention should have been paid to recruiting professionally educated interpreters and translators based on their ethnic and national background. Clearly, the CLSS interpreters found themselves overwhelmed for a variety of reasons. Most of those reasons could have been avoided if they had engaged with witnesses from the time when they arrived in The Hague, i.e. they should have interpreted for them during the proofing instead of working 4 hours a day and resting one full working day without applying for leave. This engagement would take care of these and similar linguistic problems because the interpreters would have had a chance to investigate the witness's use of language. Even if the interpreters were unaware of their inadequacy, in this case, the proofing team of legal professionals could have certainly inquired about the ambiguity in the statement by asking "What do you mean by trying to help: what means did they have to counter the violence?" In addition to arguing for ethnicity- and nationality-based recruitment of interpreters, this study also argues that court interpreters should work with witnesses throughout the process: while taking the witness statement, during proofing, and testifying.

\section{7·3. Interim conclusions}

The previous chapter in this study touched on the nature of the relationship between language and legal professionals, professional boundaries, and the image they reflect on their clients, including their individual and joint product. Indeed, legal translation is very different to translation in a legal context.

The task of a legal professional when engaged with interpreters, translators and transcribers is to introduce them to clients and to make sure no parties overstep professional boundaries during such engagement. ICTY experience has shown that legal professionals require comprehensive training to work together with language professionals.

\footnotetext{
${ }^{860}$ ICTY transcripts, Krajišnik, T. 21867-21868.

${ }^{861}$ ICTY, Krajišnik.

${ }^{862}$ Elias-Bursać, E. (2015), Translating evidence and interpreting testimony at a war crimes tribunal. Palgrave Macmillan: London, p. 54.
} 
The task of language professionals in criminal proceedings is to dedicate themselves to proper translation and interpreting without glossing or negotiating meaning, as they must deliver an untainted and faithful version of events. In that sense, untainted and faithful translation in a legal context is an independent, unembellished, and neutral translation that takes into account the type and time of the original text, rendering it into a narrative-free translation that contains all required operational information.

A language professional does not necessarily have to be qualified as both a translator and a criminal lawyer but must always refrain from interpreting the text. His or her translation must be an absolutely perfect balance between what to render word-for-word and what to render sense-for-sense. Interpreting of utterances must be an absolutely perfect balance between what to interpret word-for-word and what to interpret sense-for-sense. He or she must never lose any operational information and this takes precedent over all other linguistic elements. 
The most damaging phrase in the language is: It's always been done that way.

Grace Hopper 
Chapter 8: May posterity approach the bench, please?

Chapitre 8 : La postérité est priée de se présenter à la barre

Osmo poglavlje: Neka priđu buduća pokoljenja 
This study deals with linguistic justice in the delivery of translation, interpreting, and transcription services at the ICTY. It is a journey toward the linguistic justice that was supposed to be served at international criminal tribunals adjudicating on ethnic crimes. It uses three key terms to approach the topic of the relationship between language and international criminal law: linguistic justice, legal truth, and posterity.

As to the first key term, linguistic justice, Mowbray examined international law and the use of language in education, culture and the media, work, communication with the state, and participation in public life. She concluded that the 'emerging linguistic justice debate' is characterized by competing visions of what constitutes justice, linguistically speaking. ${ }^{863}$ This study expands Mowbray's research into the field of international criminal law, more specifically, international criminal tribunals, examining language policies delivered or adopted by the ICTY to serve linguistic justice, with reflections on other subsequently established international criminal tribunals, and shedding light on normative guidelines which should be followed by international criminal tribunals in order to serve linguistic justice.

The second key term is legal truth, which should be taken to mean the facts about crimes as found by ICTY investigators, argued by ICTY parties to the proceedings, and adjudicated by ICTY judges. Finally, this study is perhaps the first of its kind to consider the local context in all these discussions, which is here represented by the third key term, posterity. Local audiences were the first and the most important audiences for ICTY conduct and they are the first and the most important posterity for the legal truths established by the ICTY. This is because the purpose of the entire legal exercise that was the ICTY was for local audiences to take its legal truths as a starting point for restoring their societies. The ICTY and subsequently established international criminal tribunals should have addressed and communicated first with posterity locally and second with posterity globally.

As to its structure, this study was non-exhaustive because there was not sufficient space to dedicate attention to international criminal tribunals other than the ICTY. Subsequently established international criminal tribunals are mentioned only peripherally and will be the subject of a similar study in the future by the same author. This was a top-down journey because it started with all the relevant sources: mother institution (UN), working institution (ICTY), and the situation country. The mother institution should be taken to mean the UN in its capacity as a supranational organization that was involved in establishing international criminal tribunals. The country concerned (the situation country) is the former Yugoslavia, the venue of wars which were waged on the territory of Slovenia, Croatia, B\&H, Macedonia, and Kosovo between 1991 and 1999.

The first leg of the journey traversed the UN via the situation country to the ICTY rules and regulations that were applicable to the parties in the proceedings (Chambers, OTP, Defense) looking at the realities in the situation country and the institutional arrangements affecting language, translation, and interpreting with a view to examining what is the position in which international criminal legal professionals put language, translation, and interpreting. The second leg traversed UN language services via ICTY language services to translation and interpreting in a legal context, with a view to examining what is the position in which UN language professionals find themselves.

The following section of this study consists of a summary of relevant points and recommendations on the mechanisms of linguistic justice at international criminal tribunals. Most of these recommendations are not limited to the ICTY and can be applied to all international criminal tribunals.

Philosophically, this study was inspired by Pierre Bourdieu's concept that language is more than just a means of communication; it is a mechanism of power. In that sense, this study looked at each participant in the mechanism of power schemes at international criminal tribunals and their contributions to linguistic justice: the UN as the mother institution, the local context as a place where linguistic justice was supposed to be delivered, the ICTY as a drafter of rules and regulations delivering linguistic justice, the parties, as checks

\footnotetext{
${ }^{863}$ Mowbray, J. (2012), Linguistic justice: International Law and Language Policy. Oxford University Press: Oxford, UK, p. 2.
} 
and balances to linguistic justice, and language professionals (translators, interpreters, transcribers) as communicators of linguistic justice.

The main research question asked in this study is:

What are the conditions for the delivery of linguistic justice at international criminal tribunals in a context in which language plays a role in the conflict?

When considering these conditions in the examination of linguistic justice, this study explored whether UN and ICTY language policies, including those adopted by subsequently established international criminal tribunals, addressed posterity from the onset, in what language, and whether such language policies were effective. I first looked at the existing relationships in the UN System in view of its mission, management, powers, and programs (Chapter 2.1), and then at the relationships between the UN System and international criminal tribunals (Chapter 2.2). Overall, the discussion of the UN mission, management, powers, and programs raised a set of problems revolving around the absence of a clear leadership, the flux created by the power of the veto in the hands of the UN Security Council permanent members, and the lack of clear mandates governing the work performed by UN entities (Chapter 2.1). Kofi Annan's 1998 reforms turned the UN into a self-protective bureaucratic machine run by managers appointed by and responsible to other managers (Chapter 2.1.2). These two trends are extremely important in the context of the main research question because they set the stage for examining the conduct of the entire organization. Putting self-protecting leaders or managers in charge is problematic because most countries in the world worked hard throughout their history to either refuse giving power to individuals or to impose solid checks and balances on their conduct. At the level of professional conduct that resonates internationally, this is still problematic, because the UN is not a law unto itself, but an interactive entity with a duty to respond.

While Annan's 1998 reforms enabled transformation in staff recruitment, they did not transform the $\mathrm{UN}$ and the current world order remains predicated on nation states. In that, the UN is in a kind of a double bind because it is supposed to prevent nation states from doing wrong, but, it is made up of nation states, which sometimes assert their sovereignty to override morality (Chapter 2.2). Consequently, on the one hand, this study discovered that the UN is not keen on taking full charge of international criminal justice which, in turn, put the ICC, the first permanent international criminal tribunal, in a league of its own (Chapter 2.2.3). On the other hand, this study discovered a very clear trend in the UN's lack of commitment to international criminal tribunals: the UN did not fully fund these tribunals which, in turn, gave rise to hybrid tribunals. This is a UN-coined euphemism for international criminal tribunals that are funded both by the UN and by the government of the situation country (Chapter 2.2.4).

After reviewing the institutional background, this study turned to language matters to discover that the UN actively supports and promotes six UN official languages, namely Arabic, Chinese, English, French, Russian, and Spanish, through the policies of multilingualism, proclaiming at least one of these as the official language in every UN entity (Chapter 5.3). Indeed, UN proclaimed that the ICTY would have two official languages, English and French (Chapter 4.1.2.1). This arrangement also implied a two-language translation and interpreting combination, French into English, and English into French, which is the least expensive, the most effective, and the most practical combination. However, the more the topic of linguistic justice was explored, the more it became clear that such language arrangements at international criminal tribunals adjudicating on ethnic crimes in a non-English and non-French-speaking country are not a reflection of the operational needs of the working institution, in this case the ICTY, but a reflection of power struggles among the UN Security Council permanent member countries (Chapter 6.8.3). As operational, budgetary, and practical realities were explored further, the viability of such policies was questioned because translation and interpret- 
ing into/from UN official languages is neither free nor cheap, as it is governed by the UN-wide rules and regulations on translation and interpreting set by the ICSC for regular staff or as negotiated with AIIC and AITC for the engagement of freelancers. Indeed, under such requirements, the costs of translating a single page into several languages is exorbitantly high, both at a level of the UN (a six-language combination) and at the level of UN entities (at least a three-language combination) (Chapter 6.8.3). Clearly, such linguistic arrangements are incongruous in international criminal tribunals whose area of criminal responsibility is restricted to the territories of the respective countries where the courts are adjudicating on local, not international conflicts, because they ignore the fact that the communication priority should be the local population.

The most important communication package for international criminal tribunals consists of an official record of trials: translation of evidence and exhibits, court interpreting, and court transcripts (Chapter 6.8.3). It follows that international criminal tribunals should address the situation in a country by making official record of trials in the language of the country concerned, not in two or more UN languages, if they want to provide for the least expensive, the most effective, and the most practical language services. In itself, this should not have cropped up as an issue at all, as it is a matter of common sense: the ICTY is addressing the people of the former Yugoslavia in the aftermath of their ethnic conflict. Those audiences (including all the belligerents involved) need to see the issues clearly, gain critical perspectives on the conflict, and use legal truths established by the ICTY to start rebuilding their country and changing the mentality that led to ethnic conflict. Clearly, in order for the former Yugoslavia to do this, the problem-solver, the ICTY, had to address the former Yugoslavia in the language spoken in the former Yugoslavia. However, right from the outset, the UN insisted that the official record of trials had to be made in the UN's official languages, English and French, and that translation and interpreting into UN official languages had to have a priority over the language spoken in the former Yugoslavia (Chapter 6.8.4).

This study shows that UN policies on multilingualism simply do not work at international criminal tribunals, which very clearly expose as a 'pretend' approach to language services (Chapter 6.7 and Chapter 6.8.3). Generally, UN policies on multilingualism present an extremely damaging UN-wide trend that is completely divorced from linguistic realities because they are devouring the budget and disabling the communication of UN messages to recipients of its services under the garb of alleged linguistic diversity (Chapter 6.8.4). In the context of international criminal tribunals, UN policies on multilingualism are especially damaging because they blur the lines of communication, making it unclear who it is that the UN, the founding organization of international criminal tribunals, is communicating with (Chapter 4.3 and Chapter 6.5). It is imperative that all lines of communication should be crystal clear at all times: if the war crimes tribunal is for the former Yugoslavia, then the UN must communicate with the former Yugoslavia. It is unclear why the French language figured in the ICTY's linguistic equation at all.

International criminal law is inchoate; it is supposed to be blended, but its blending is ongoing and unfinished, as it still incorporates elements of both Common (English-speaking only) and of Civil Law (all other languages). In the interest of fairness to defendants, international criminal tribunals must take positive language-related developments from both legal traditions, but in the interest of language, they must give priority to the language of case law, i.e. English. This study does not endorse the negative aspects of globalism but reiterates the fact of the international dominance of English in the sphere of law. In that way, the court and its language services provider would a priori identify and agree on common terminological and conceptual stumbling blocks between the two legal traditions, including their proper translation; in this the role of the terminologist is of a paramount importance.

It should not be controversial to state that, when it comes to the official languages of international criminal tribunals, the UN must use only English and make official the language of the situation country to provide for the least expensive, the most effective, and the most practical translation, interpreting and transcription combination: English into X and X into English. Having two or more UN official languages for the 
purposes of adequate communication via translation, interpreting, and transcription in the context of international criminal tribunals is not viable, because the language of the situation country must be a priority language. Obviously, the exception to this would be a country where one of the UN languages is an official language of the country. Unfortunately, once formulated, the ICTY official's language policies were never amended and $\mathrm{B} / \mathrm{C} / \mathrm{S}$, the acronym for the languages spoken by the peoples of the former Yugoslavia, never gained equal footing with the ICTY's official languages.

\section{First recommendation}

The official languages of international criminal tribunals must be limited to a minimum to provide for the least expensive, the most effective, and the most practical translation, interpreting and transcription combination: English into the language of the situation country and vice versa. Should the international criminal tribunal adjudicate on crimes that occurred in a bi- or multilingual country, both or all relevant languages must be made official.

When considering the first condition for the effective delivery of linguistic justice at international criminal tribunals, this study looked at the venue of crimes committed and the home for the UN's and the ICTY's subjects (defendants, defense attorneys from the situation country , victims and witnesses, and posterity) to discover the ever-present and lasting history of identity and language-related conflict that led to the commission of ethnic crimes in the former Yugoslavia (Chapter 3). In examining linguistic justice, this study explores whether the ICTY took the philosophy of hate that led to the ethnic cleansing (and genocide) of Yugoslavian Muslims into account. A key question is whether the CLSS considered language-related conflicts and the bearing they had on the provision of language services.

A major characteristic of ethnic conflict is denial of the other's history, identity, and language. The ICTY was established by the UN to adjudicate on ethnic crimes committed in the former Yugoslavia which were mostly perpetrated against Yugoslavian Muslims in B\&H and Kosovo. The official language of the former Yugoslavia was Serbo-Croatian, which speaks volumes about ethnic elites in the former Yugoslavia. For B\&H, in terms of language and identity, once the notions of romantic nationalism became en vogue, some people started identifying as Serb, some as Croat, some as Turk, some as Bosniaks, some as none-of-the-above, and Cyrillic, Latin, Bosančica, and Arebica scripts were all in use in the late Ottoman B\&H at the same time (Chapter 3.3). After the Austro-Hungarian project of 'Bosniakhood' as an overarching principle of nationality in $\mathrm{B} \& \mathrm{H}$ failed under pressure of Serb(ian) and Croat(ian) activists, the name of the language was changed to Serbo-Croatian in 1908 following the annexation of the country and the only peoples of B\&H who identified with being Bosnians were B\&H Muslims (Chapter 3.4). However, Serbo-Croatian never existed as a unitary phenomenon. What existed was distinct variants of one and the same language, which the Serbs called Serbian, and the Croats called Croatian. These linguistic variants - the Eastern or ekavian (Serbian) and the Western or ijekavian (Croatian, B\&H, Montenegro) variant of Serbo-Croatian - were used as a political statement well before the Ottomans left the area when Serbia and Croatia started making direct claims on B\&H by claiming that the Bosnian Catholic and Bosnian Orthodox populations were part of their own corpus with the blessing of the international community. B\&H was in the middle of the conflict between the Serb(ian)s and the Croat(ian)s who propounded the theses that the Slavic-speaking B\&H Muslims had no original identity and were Muslim Serbs or Muslim Croats (Chapters 3.5-3.7). In the aftermath of the conflict, once the UN took over in the 1990s, the UN, as shown above, was not ready for non-UN languages, so the ICTY did not make the language of the country concerned official. By doing that, the ICTY ignored the entire local linguistic context (linguistic variants) and language and identity-related aspects of the conflict (the history of hate propaganda against the Muslims that contributed to ethnic cleansing), by extension (Chapter 3.8). 
In itself, acknowledging the language of the situation country entailed acknowledging the fact that linguistic variants had a bearing on the commission of ethnically motivated crimes and should have been a matter of due diligence toward defendants, victims and witnesses. The language of defendants at the IMT and IMTFE coincided with the official languages or languages in use in those institutions, but the IMT did not make the language of victims official (Yiddish, Polish, Serbo-Croatian, Sinti, Romani, etc.) and was unable to provide translation or interpreting into/from those languages (Chapter 4.1.1). This study has discovered that UN and ICTY lawmakers should have known better about the linguistic treatment of victims and witnesses at the level of overall management, at the level of language services providers, and at the level of investigations teams. The Bassiouni Commission which launched the ICTY, was not only aware of linguistic variants, but its 22 legal professionals instructed translators on how to address linguistic variants between the three ethnic groups (Chapter 6.1). The ICTY judges claimed to be very much aware that there might be considerable reluctance on the part of witnesses to appear to testify because a principal witness against the perpetrator of a crime will be the victim, that the crimes against the civilian population were committed on, inter alia, ethnic grounds, and that the judges never allowed themselves to lose sight of the fact that victims and witnesses have rights worthy of protection (Chapter 6.7). But the judges could not have acted on this observation of their own volition: somebody needed to alert them to the disconnect between the existing rules and regulations and reality, requiring a change in the rules and regulations. The Defense and the OTP were not going to do that as those legal professionals will almost never comment on what naturally fits their side of the legal argument. Indeed, the first witness who appeared claiming he did not understand the language of his former aggressor as it was used in interpreting was told by the Court that such claims are unacceptable and that he was bound to understand it (Chapter 4.2). However, this study has found many reasons to believe that the CLSS, the official ICTY language services provider, could have alerted the court to the relevance of conflict anchored in the language alone, including the disconnect between the existing rules and regulations and the realities of linguistic variants (Chapter 6.7).

The CLSS staff and managers were from the territory of the former Yugoslavia, so they did not really need much explanation what they needed to do: the history of conflict in the former Yugoslavia can be viewed as a history of language use in the former Yugoslavia, so CLSS management must have been aware of the various nuances of ethnic conflict being reflected in the language and identity-related issues underlying the commission of crimes (Chapter 3). And they certainly were. Indeed, this awareness led them to invite two experts, who testified about the mutual intelligibility of linguistic variants in the situation country and the fact that B\&H speakers would understand all differences in these languages better than the Serbs and the Croats because, unlike them, B\&H speakers were exposed to both linguistic variants (Chapter 4.2). Indeed, this awareness led them to acknowledge there was a perceived disconnect between the languages spoken by defendants and those of their victims, which is the reason why they instructed Croatian speaking interpreters to refrain from using vocabulary associated with Croatian when interpreting for victims (Chapter 6.7). However, the CLSS never acted on this knowledge. Some Croatian language interpreters stuck to using exclusive Croatian associated vocabulary and Serbian language interpreters stuck to ekavian throughout their engagement when interpreting for victims of Serbian and of Croatian crimes in B\&H (Appendices 3-5). B\&H born, raised, and educated defendants who claimed to be speaking Croatian or Serbian were merely laughed at, creating a disconnect between their claims and reality. Victims were pitied at every opportunity, but nevertheless assigned interpreters of the attacking ethnicity at the discretion of the assigning authorities in the CLSS during the investigations, proofing, and testifying (Chapter 6.7). Although translation and interpreting in a legal context depends on the trust the interviewee has in his or her interpreter, the CLSS decided not to act on any of the ICTY's observations concerning the victims and their language, thus breaking their trust and presenting them with a fait accompli once they appeared to testify in The Hague. The CLSS hijacked proper provision of language services preemptively, inventing a politically correct abbreviation $\mathrm{B} / \mathrm{C} / \mathrm{S}$ to be used as denoting one and the same language without any acknowledgment of the significance of the relevant linguistic variants (Chapter 6.7). All research points out that $\mathrm{B} / \mathrm{C} / \mathrm{S}$ was invented purely and exclusively to justify the 
overwhelming recruitment of language professionals who were not from $\mathrm{B} \& \mathrm{H}$ and who did not have Bosnian as part of their translation and interpreting combination (Appendices 3-5).

Indeed, this study found evidence of the CLSS's efforts at providing language services. When the Chief of the CLSS was a Croat, most translators and interpreters were Croats too, and when the Chief of the CLSS was a Serb, most translators and interpreters were Serbs. Defendants, victims and the peoples of B\&H have been served linguistic justice only in those instances where they were communicated with in the Bosnian language: in $4 / 56$ instances, in which Bosnian figured alone at the level of interpreting for defendants, in $22 / 56$ instances at the level of language variant, in $1 / 82$ instances at the level of interpreting for the peoples of $\mathrm{B} \& \mathrm{H}$, and in $\mathrm{O} / 41$ transcripts at the level of testifying victims and witnesses (see Appendices 3-5). Consequently, CLSS, and by extension the ICTY, made a strong national, ethnic, and political identity statement against $\mathrm{B} \& \mathrm{H}$ and the peoples of $\mathrm{B} \& \mathrm{H}$, directly feeding into the nationalist discourses that were used to promote the conflict in the first place. As to translation, the CLSS and ICTY lawmakers swept the entire issue of translation into Bosnian under an untraceable rug: interpreters did not enter their own language on the witness statement form and would routinely agree that they interpreted from/into whatever language the witness had stated that $\mathrm{s} /$ he spoke and understood (Chapter 6.7). A total of 78 judges adjudicated crimes at the ICTY for a period of between one and 14 years (Chapter 4.1.2.2). None of them have publicly acknowledged the situation country and the victims were communicated with in the language of their aggressors. There were ample opportunities for CLSS to alert to the disconnect between $\mathrm{B} / \mathrm{C} / \mathrm{S}$ and reality and for ICTY lawmakers to make those differences official between the two as ICTY RPE and ICTY-S were amended $5^{2}$ and 9 times by the end of 2017, respectively (Chapter 4.6).

\section{Second recommendation}

In addition to making official the language of the situation country, the rules and regulations of international criminal tribunals adjudicating on ethnic crimes must also include the different language variants spoken in the situation country when these variants are invested with ethnic and/or political significance because they reflect on the provision of language services to defendants, defense attorneys from the situation country, victims and witnesses, and posterity. Moreover, when the dialect/language of victims differs significantly from the standard language, these differences must be taken into account and accommodated.

When considering the second condition for the proper delivery of linguistic justice at international criminal tribunals, language-related rules and regulations in international criminal tribunals' statutes and RPEs were examined in order to see how they reflect on defendants (Chapter 4). In examining linguistic justice, this study explored whether the ICTY and subsequently established international criminal tribunals delivered or adopted language policies that would ensure the proper delivery of language services to the defendant. Translation and interpreting is one of checks and balances in procedural due process: to make sure a defendant's language-related rights have been respected, $\mathrm{s} / \mathrm{he}$ must be provided with adequate translation and interpreting. Language-related rights, duties, and obligations on the parties participating in a legal process fall under the procedural due process which includes guarantees securing defendants with every reasonable opportunity to make a full and free defense including, inter alia, the right to have all proceedings conducted in or translated into his or her own language. The defendant is the most legal rights-loaded person in any process; those rights include language-related rights (Chapter 4.1). IMT and IMTFE legal professionals revamped the existing mode of interpreting to ensure fair and expeditious trials by inventing simultaneous interpreting and moving away from a Christian-centric approach to oath and affirmation (Chapter 4.1.1). During later developments, ICCPR and UDHR principles gave defendants the right to use "[their] own language" once the Second World War was over and the world started approaching a different legal paradigm where it was tacitly accepted that the language of the institution is the language of power (Chapter 4.1.2). However, some 40 to $5^{\circ}$ 
years after all these efforts, lawmakers of the next international criminal tribunals - established in the 1990s - simply cut-and-pasted these provisions into their statutes and RPEs. Unfortunately, this has had an effect on the rights of defendants at the ICTY: defendants' nominal right to translation and interpreting have not been treated as absolute.

Sticking to the principles of UN policies on multilingualism, ICTY rules and regulations gave precedence to communication in English and French, specifying that the counsel or accused must undertake to meet all translations and interpreting costs not usually met by the Tribunal, and not request any extensions of time as a result of the fact that he does not speak one of the working languages (Chapter 4.1.2.5). This is a rather heavy-handed rule that seems to be ignorant of the fact that the Court needed to be communicated with, the Court could not have communicated with one side only, and that the Court should have made every possible effort to ensure there was cost-free and unrestricted communication with it. Furthermore, ICTY rules and regulations made a clear distinction between defendants' translation-related rights and defendants' interpreting-related rights (Chapter 4.1.2.6). As to translation, instead of being entitled to translation of the entire court records, defendants had the right to translation of OTP disclosure documents, material supporting the indictment, and witness statements (Chapter 4.1.2.6). Defendants did not have the right to translation of trial briefs, various court orders and decisions, the entire appeals process, and documents used against them that had not been submitted in French or English (Chapter 4.3). Although the court records also include court transcripts, these were made in English and French only. Instead of transcripts, the ICTY offered audio or video tapes of the proceedings to the defendants i.e. they both prescribed time limits to respond to motions and provided time-consuming solutions (Chapter 4.2). This study shows that court transcripts could have been made in $\mathrm{B} / \mathrm{C} / \mathrm{S}$ from the very beginning and that the CLSS, who were in charge of making court transcripts, did not have to put the Court in the situation where they had to decide whether to provide transcripts at all or to provide them made-to-order only (Chapter 6.4). As to interpreting, instead of being entitled to interpreting with all parties to the proceedings, ICTY rules and regulations left an empty slot instead of communication between a defendant and his counsel who does not speak his language (Chapter 4.1.2.6). All this is in contradiction to current international rules and regulations on the right to information and communication and on the right to translation and interpreting of and to persons under criminal investigation (Chapter 4.1.2.5).

In practice, since neither the language nor linguistic variants of the situation country were made official, the situation backfired for the Court and for the victims and witnesses, as defendants flaunted their nationalistic and religious fundamentalism, anchored in their convictions of the superiority of their language and identity in the courtroom and in front of their victims. Šešelj immediately spotted the fact that the linguistic variants of the situation country were not official and started to turn it to his advantage. He insisted on being served documents on paper, in translation into the Serbian language, and that he be interpreted into/from Serbian. Indeed, Šešelj insisted on this for three years until he was provided with what he wanted as a part of OTP's disclosure obligations. And then, Šešelj took the statements of all witnesses provided to him in Serbian , bound them together, and published them as a book (Chapter 4.2). This is alarming because it is completely natural that future generations wondering about ethnic conflict in former Yugoslavia anchored in language will read the statement of a B\&H or Croatian victim or witness testifying against Šešelj, for example, see that they are in Serbian and wonder what the whole deal was in the first place when the records clearly show those victims or witnesses spoke Serbian. Šešelj is an extreme case because his intention was only to insult, complicate, stall, and, ultimately, undermine the process from the very beginning. Notwithstanding those efforts, Šešelj's sound and fury did signify nothing because, except for making the ICTY deliver material for a book that he could publish, he did not make any point about the language and linguistic variants that he set out to do. Although Šešelj was born, raised, and educated in B\&H, just like many defendants, together they claim to speak Serbian, which brings this entire discussion into the realm of absurdist drama, indeed, because their sentence structure, word choice, and intonation is clearly Bosnian (Chapter 4.2). 
Legally, however, although everyone is free to name the language they speak any way they want, the use of languages is bound by descriptive and prescriptive rules. In that sense, mixing ekavian and ijekavian or Bosnian ijekavian with Croatian ijekavian at all or in the same sentence, even, should send a message that the Court is dealing with a person with a non-linguistic agenda. It is unfortunate that this point was not explored more vigorously by the OTP. The ICTY lawmakers gave defendants the right to "[their] own language," CLSS invented $\mathrm{B} / \mathrm{C} / \mathrm{S}$, which was definitely not their language, but it did preclude victims and witnesses speaking different linguistic variants from having any language-related rights (Chapter 4.1.2.7). "[Defendants'] own language" in cohorts with the "practical" $\mathrm{B} / \mathrm{C} / \mathrm{S}$ a priori trumped victims and witnesses' rights to language. And their linguistic variant was part of the reason why they were victims in the first place. International criminal tribunals adjudicating on ethnic crimes must make every effort to make sure the language variant of the defendant does not trump that of their victims.

However, there might be a solution. Although unsure what language they speak, almost all the defendants who were on trial were sure they did not do what OTP claims they did. Defendants are, for all intents and purposes of the law, presumed innocent until the end of trial. In cases where the linguistic variant of the defendant trumps that of his victims in trials adjudicating on ethnic crimes, the Court may have an option to propose that the defendant signs a disclaimer of "good will" in which he would allow for the linguistic variant of his victim to take precedence in translation and interpreting over the linguistic variant he claims to be his own. Victims and witnesses had already declared their language in the witness statement form, but this would, at least, make sure their statements were translated into the language that is their own, rather than into the language that is that of the defendant. In that way, both the defendant and the Court will appear as victims-oriented in this linguistic variant-dictated triadic 'marriage' among defendants, victims, and posterity.

\section{Third recommendation}

Defendants' rights to translation and interpreting must be absolute: they need to be provided with the essential documents of the court record in a language they understand.

When considering the third condition to properly delivering linguistic justice at international criminal tribunals, language-related rules and regulations in international criminal tribunals' statutes and RPEs are examined in order to see how they reflect on defense attorneys from the situation country (Chapter 4). In examining linguistic justice, this study explored whether the ICTY and subsequently established international criminal tribunals delivered or adopted language policies that can ensure the proper delivery of language services to the parties to the proceedings. The non-absolute right of defendants to translation and interpreting are derivative of the position of the accused: these non-absolute rights have more bearing on defense counsels who are authorized agents of defendants representing them in the case against them. This is why this study discussed whether the defense counsel, representing the defendant, is at a disadvantage due to violation of defendant's language rights and entitlements. In exploring this issue, examinations were conducted as to whether the finances, resources, facilities, and other material conditions put the Defense at a linguistic disadvantage and constituted procedural inequality with an effect on the fair trial of the accused (Chapter 4.3). Examinations have shown that defense counsels, representing those defendants, were at a constant disadvantage due to unfair practices in the recruitment of defense attorneys from the former Yugoslavia, restrictive finances, and other material conditions at the disposal of the defense in general, as well as non-translation of certain documents for use by defense attorneys from the former Yugoslavia.

The problem of recruiting staff from situation countries is a recurrent and institution-wide problem for the UN. This study shows that the UN recruitment mechanisms in place make it impossible to recruit local staff under the same conditions as their international peers, although there are several recruitment options 
that would fully provide for employment on an equal footing (Chapter 5.1). However, impartiality and neutrality need to be safeguarded, as well. So, although refraining from recruiting staff from situation countries on an equal footing with their internationally recruited peers is understandable, the staff from situation countries with citizenship of foreign countries can still find their way into the UN System as internationally recruited staff and the problem of impartiality and neutrality remains an issue. It is hard to say whether situation country nationals could be as impartial as others, because they have not been put on equal footing with each other or with their internationally recruited peers. The ICTY experience shows what can happen if the representation of nationalities and ethnicities among staff is imbalanced (Chapter 6.8).

The crimes investigated by the ICTY happened in the former Yugoslavia. So it is reasonable to assume a priori that legal professionals from the former Yugoslavia are in the best position to understand, defend, and prosecute crimes committed in their own backyard. Making official the language of the situation country would have made local professionals equal partners in communication with the UN and it would have invited them to participate side by side with their international peers in sorting out the problems for which the ICTY was established. Consequently, local professionals would have participated in shaping the future of their country, would have taken ownership of the ICTY output, and would have finally broken away from being passive observers of their own future. Obviously, the international community did not facilitate this in any way and the mechanism was manipulated by selecting former nationals of the situation country. Moreover, the ICTY went beyond not making the language of the situation country official: they made it much more difficult for local legal professionals to be selected as leading counsels, making it virtually impossible for them to be on an equal footing with their internationally recruited peers.

ICTY defendants could choose from a list of defense counsels, but, in order for local legal professionals to be admitted to the list, they had to prove, inter alia, their knowledge of ICTY languages. Once they proved it by passing appropriate language examinations, the ICTY did not allow them to benefit from being professionally functional in these languages, as defense counsels from the former Yugoslavia did not receive a language allowance, while regular staff did. All this had an effect on the delivery of fair trials. The ICTY proclaimed that local legal professionals who could not prove knowledge of the ICTY official languages could only be assigned as co-counsels. In the same vein, the ICTY proclaimed that local legal professionals who did not have knowledge of ICTY languages must meet all of the non-sanctioned translation and interpretation costs, as detailed above, themselves. Then they provided them with limited finance, leading to translation and interpreting rates that were much lower that the official ICTY rates for translation and interpreting. In terms of physical and digital resources, the ICTY provided just one computer linked to all databases with relevant evidentiary materials to 161 defense teams and started migrating to digital disclosure only in about 2004 (Chapter 4.3). However, the most serious aspect was the problem of non-translation: documents that were not in English, French or B/C/S, documents required for the appeals process, and trial briefs or summaries of all facts presented, were not all translated for non-English and non-French functioning local legal professionals. Notwithstanding restrictions on translation and interpreting in the ICTY rules and regulations, this issue might have also had to do with CLSS's failure to provide language services in all required combinations. Various court orders and decisions that are part of the trial record, which should get translated into English and French because these are the ICTY's working languages, were also not translated, and those that were, were seldom translated both from/into ICTY official languages or into the language of the defendant when s/he needed them, making it impossible for them to respond to court deadlines (see Appendices 1-2).

Procedural equality of arms in terms of language was almost non-existent: defense attorneys were at a linguistic disadvantage and suffered from procedural inequality, which affected the accused receiving a fair trial. The existing mechanisms at the ICTY did not support the due process rights of defendants. But, the Defense had the last word locally, as they took matters into their own hands to tackle the lack of information about ICTY cases in B/C/S and gave themselves a voice by publishing what could be called a Defense Gazette 
to inform local audiences of their activities. The Defense were aware that both the location and the motivation of crimes were in the situation country and started publishing information in the local language and in the way that would be understood by local audiences. So, the B/C/S speaking defense got first and faster to the situation country than the English/French-speaking court officials, who then had to either compete with the $\mathrm{B} / \mathrm{C} / \mathrm{S}$ speaking defense to provide novel information or engage in damage control clarifying the defense's ambiguous statements (Chapter 4.2). The supporters of the accused heard a watered down version of the conclusions of this study, i.e. there was language-related discrimination against defendants and their attorneys at the ICTY. However, in the post-conflict context in which they found themselves, what they heard only contributed to not communicating the core reasons for which the ethnic conflict was justified in the first place: perceived language and identity-related discrimination against the Serb(ian)s and the Croat(ian)s.

\section{Fourth recommendation}

The way the selection procedure of defense attorneys is conducted affects the free choice of defense attorneys. Defense attorneys who do not speak the languages of the court and defense attorneys who do not speak the languages of defendants must be afforded exactly the same translation and interpreting rights as defendants.

The next section, which addresses the relationship between legal professionals and language professionals communicating linguistic justice on behalf of international criminal tribunals, answers the first sub-research question in this study:

Does the fact that language is a tool in conflict require specific standards for the recruitment of language professionals engaged to perform translation, interpreting, and transcription at international criminal tribunals?

The ICTY was the first international criminal tribunal to be established after the IMT and IMTFE closed their doors in 1946 and 1947. However, the UN DGACM, which provided rules, status, and support- to all UN language professionals, did not have any standards for translation, interpreting, or court reporting in the context of international criminal tribunals. There were also no requirements for or recruiting language professionals working in international criminal tribunals adjudicating on ethnic crimes at the time or since (Chapter 5.1). In examining linguistic justice, this study explored whether the CLSS delivered or adopted a series of rules of regulations regarding the conduct of language professionals with their clients. It shows that legal professionals' duties toward language professionals were not regulated in any UN, ICTY, or international rules and regulations or codes of conduct. Indeed, should a party to the proceedings at international criminal tribunals want to learn about working with language professionals, their very voice at such tribunals, they were referred to an outside organization and participation in courses was optional (Chapter 4.5). All CLSS managers who addressed their experiences at the ICTY were absolutely oblivious to the core concepts governing the engagement of legal and language professionals, both in terms of translation, consecutive interpreting, and simultaneous interpreting to the extent that they could not even be said to have been able to define those core concepts. This came dangerously close to facilitating denialism of crimes. This study explained this by arguing that working at the ICTY was their first experience of working at the UN for most language professionals in the CLSS (Chapter 6.8.1). Indeed, CLSS managers referred to "UN standards" but seemed not to have recognized that they were supposed to set standards for translation, interpreting, and transcription at international criminal tribunals. This was a major bottleneck in all CLSS's efforts, because language professionals (translators, interpreters, transcribers) are communicators of linguistic justice: what they translated or interpreted is 
used as exculpatory or inculpatory evidence at international criminal tribunals and what they transcribed is left for posterity. This means that they must be subject to certain rules of conduct in a legal context, certain standards for translation and interpreting in a legal context, and that their legal involvement in the documents and in the interviews needed to be regulated. This study shows that such standards and requirements were necessary first of all in the shape of legal rules regulating the relationship between legal and language professionals as well as that between language professionals and non-legal clients. There should have been standards for recruiting language professionals, and finally for translation and interpreting output.

In search of a fifth condition for properly delivering linguistic justice at international criminal tribunals, this study first looked at the ICTY and international rules and regulations regulating the relationship between legal and language professionals (Chapter 4.4) and that between language professionals engaged in legal transactions or legal professionals and their non-legal clients (Chapter 4.5). The existing language-related rules and regulations provided language professionals with basic guidelines for providing for the least expensive, the most effective, and the most practical translation, interpreting, and transcription services. It was up to language professionals to regulate the resulting relationships. However, it seems they did not do this, because no mutual legal obligations were codified between legal and language professionals or between language professionals engaged in legal transactions or legal professionals and their non-legal clients at international criminal tribunal adjudicating on ethnic crimes.

These mutual legal obligations are very important because the defense and the prosecution are parties with an interest and they try to figure out which language would fit their side of the argument. This directly encroaches on the duties of language professionals. Accordingly, the role and the position of translators and interpreters when engaged with legal professionals from the investigations phase via proofing to testifying needed to be regulated, including the role and position of translators and interpreters in legal transactions between legal professionals and their non-legal clients (Chapter 7). A draft understanding on that role and position was supposed to be provided by the CLSS because they are the official ICTY language service provider and the first language service to operate at an international criminal tribunal after the IMT and IMTFE. But, ICTY legal professionals took a stab at the issue instead: the only documents regulating the relationship between legal and language professionals are the ICTY I\&T Code of Ethics and ICTY language professionalsrelated case law. There are no documents regulating the relationship between language professionals engaged in legal transactions or between legal professionals and their non-legal clients.

The rules and regulations address language professionals directly only in one provision obliging them to make a declaration that they will do their job "faithfully, independently, impartially and with full respect for the duty of confidentiality" before conducting any duties (ICTY RPE Rule 76), but the 2009 OIOS Audit Report established that CLSS staff were not making this declaration, which was drafted 16 years ago. Moreover, this Rule fails to mention all categories of language professionals working at the ICTY, namely, Language Assistants and field interpreters, who should have also been subject to ICTY RPE Rule 76 by virtue of their engagement with the parties to the proceedings in their legal transactions with their non-legal clients (Chapter 4.4). This failure is very worrying, both from a normative and a security-related point of view. Normatively, the failure to include Language Assistants makes ICTY RPE Rule 76 and Interpreter Certification attached to the Witness Statement a legal fiction, as the ICTY Registry merely declared to have duly qualified and approved whoever was interpreting for that witness, although those interpreters could have come from any of the three different categories of ICTY language professionals. Only an actual interpreter at the actual meeting was declaratively qualified and approved by the Registrar to conduct these duties, whereas the translator translating and the reviser revising that same witness statement had not signed any declarations as per ICTY RPE Rule 76. In other words, not all categories of translators and interpreters were bound by ICTY RPE Rule 76 or actually "duly qualified and approved" by ICTY Registry to interpret or translate witness statements. As to security concerns, Language Assistants are not formally recognized in any rules relating to language professionals. Although never formally mentioned as part of the translators' and interpreters' corpus to be, at 
least, formally subject to ICTY RPE Rule 76, most ICTY language professionals actually worked on documents and were in possession of information considered to be sensitive, classified, or secret in their countries of origin. This, in itself, should have also governed the choice of translator or interpreter in contact with confidential information in the international criminal tribunal adjudicating on ethnic crimes, as there is absolutely no need for nationals of former belligerent nations to have access to each other's confidential material. There was no institutional impediment to international criminal tribunals making their own internal rules and regulations governing the marking and handling of classified and sensitive information. The heads of the ICTY departments and offices could decide that their staff should sign certain confidentiality undertakings. However, the ICTY OTP, UNDU, and VWU management, who were contacted for purposes of this study, could not confirm whether their language professionals also signed a separate confidentiality undertaking about their communications with the detainees or victims and witnesses after signing an Oath of Office at the signing of contract, just like all other ICTY staff (Chapter 4.4).

This study also shows that, since international criminal tribunals are relatively new, standing language-related rules and regulations have merely been cut-and-pasted instead of being adapted to the context of the 199os when the ICTY was established and to the context of international criminal tribunal adjudicating on ethnic crimes. Such was the case with the I\&T Code, which also seems to have been cut-and-pasted from several existing codes of ethics for translators and interpreters, but unadjusted to the actual needs and requirements of ICTY language services (Chapter 4.4). Naturally, it was subsequently almost entirely refuted by ICTY case law drawing on the practice of translation and interpreting. This lack of codification of needs and requirements led to a loose (Chapter 7.1.2.1) and non-legal professional oriented provision of language services in a legal context (Chapter 7.1.2.2). ICTY lawmakers completely ignored interpreters during investigations, proofing, and testifying, and did not define the role of translators and interpreters in legal transactions between legal professionals and their non-legal clients. Normatively, except for notifying suspects that they have a right to the free assistance of an interpreter, nothing else is said about interpreters at the interview or when transcribers are transcribing it (Chapters 7.2.1-7.2.4). Practically, this left many questions relating to the involvement of interpreters in legal transactions between legal professionals and their non-legal clients unanswered: who introduces the interpreter, who introduces the transcriber, who reacts to parties' or non-legal clients' shenanigans or discomfort, who regulates breaks during interpreting assignments, who decides on disputed wording, etc. Those are some of the standards and conditions for UN translation and interpreting in the context of international criminal tribunals that everyone talked about, but no one clearly defined. They should have been available for staff in the form of an operational guideline delivered to all parties to the proceedings. The I\&T Code was left untouched since it was delivered in 1999.

\section{Fifth recommendation}

The relationship between legal and language professionals and that between language professionals engaged in legal transactions or legal professionals and their non-legal clients from the investigations phase via proofing to testifying must be firmly regulated and it must be binding on both parties in the form of actual written standards of translation, interpreting, and transcription at international criminal tribunals.

In search of a sixth condition for properly delivering linguistic justice at international criminal tribunals, this study then looked more closely first at the recruitment mechanisms at UN DGACM (Chapter 5.2) and then at the recruitment mechanisms at the ICTY (Chapter 6.8.1). In examining linguistic justice, this study explored whether the CLSS delivered or adopted a series of rules of regulations regarding the recruitment, training, retention, and output of language professionals, first turning to their recruitment. The research has shown that the UN DGACM language staff structure is dominated by citizens of the countries that are permanent 
members of the UN Security Council because there are no geographical, nationality, or ethnicity requirements attached to the recruitment of language staff at the UN (Chapter 5.2). However, this approach is open to discrimination on the basis of skin color, religion, ethnicity, and all other categories that are regularly used as a basis for discrimination as UN entities established to eradicate them will confirm. Although these policies are contrary to the science of language, the principle of merit and education, and most international covenants governing the profession of translation and interpreting, some of which are promulgated by the UN, this discrimination is legal. UN entities freely advertise looking for X UN language as a mother language, UN entities can screen out candidates applying to language posts because applications ask about the candidate's native or mother language, and a candidate has no place complaining about potential discrimination as UN administrative tribunals only accept applications from past and present serving UN staff (Chapter 5.3). This trend of dominance of certain nations over others seems to have been replicated in full at the ICTY. At the ICTY, most attorneys and legal professionals were from the USA and UK because their managers were too, most investigators were from Australia because their managers were too, most interns came from USA Ivy League schools because intern coordinators used to teach there, etc. Finally, when a Croat was a Chief of CLSS, most language professionals were from Croatia, and later when the Serbs took over as the second and the third Chief of CLSS, most language professionals were from Serbia. Obviously, this is a veritable institution-wide problem and it is sustained only because UN Member States do not do anything about it. Consequently, it is the silence of the UN Member States that perpetuates nepotism.

As to the CLSS translators and interpreters, this nationality, and by extension, ethnicity-based recruitment method that was practiced during the second management period at the international criminal tribunal adjudicating on ethnic crimes had a major sinister flaw. Whereas it could be true that good professionals know other good professionals, once they start recommending other good professionals from a particular country and with a particular ethnicity that amounts to brazen and rampant ethnic discrimination, right under the nose of a variety of legal professionals who all got together to adjudicate on ethnically motivated crimes for which language was one of the indices. The CLSS managers have completely forgotten to hire adequate or even minimum numbers of Bosnian-speaking language professionals (Appendices $3-5$ ). This research shows that nobody was looking for Bosnian language speaking translators and interpreters from $\mathrm{B} \& \mathrm{H}$. The Bassiouni Commission came to Zagreb, Croatia, took staff that the UN administration gave them and went about their business taking those Croatian-language speaking ethnic Croats and one ethnic Serb to interpret for victims and witnesses in $\mathrm{B} \& \mathrm{H}$ (Chapter 6.1). So, the UN administration allowed CLSS interpreters speaking the linguistic variant of the attacking ethnicity to interpret for direct and indirect victims. Soon after the second Chief of CLSS assumed that position, she organized a mission to Budapest to interview candidates for translator and interpreter positions at the ICTY, specifically from Serbia. The reason Budapest, Hungary, was chosen as a testing location is that the then Milošević regime did not allow an ICTY presence in the territory of Serbia. The candidates from Serbia who were tested and interviewed in Budapest reached that location at their own peril and cost. Successful Serbian candidates who were interviewed in Budapest were first employed in GS-level category positions in ICTY OTP. All such candidates, excluding one known Hungarian hybrid, were ethnic Serbs, and there were no less than 30 of them. Soon after successful candidates from the Budapest testing location arrived in The Hague, the Chief of CLSS organized a translation exam from English into B/C/S. Naturally, this examination was open to all new and old staff, but it seems the purpose of this exam was so that the Serb staff from Budapest who did not pass the P-level examination could transition from GS-level to P-level positions. Many candidates of all ethnicities from all regions of the former Yugoslavia, both old and new staff, actually passed the examination. However, only ethnic Serbs were offered P-level positions in CLSS. Other Budapest hires with the Serb ethnicity who were left at GS-level positions eventually found their way into the CLSS through three more exams organized in about 2005, 2006, and 2007 for English language translators. The ethnic structure of new recruits remained unchanged. Examinations organized by CLSS were largely unmonitored and candidates had full access to the Internet during examinations. CLSS never again organized examinations for $\mathrm{B} / \mathrm{C} / \mathrm{S}$ translators after that first time in 2000. CLSS never organized a similar mass examination for candidates from $\mathrm{B} \& \mathrm{H}$ and/or Croatia in $\mathrm{B} \& \mathrm{H}$ and/or Croatia or elsewhere into 
English or B/C/S. Between 2000 and now, all the heads of sections at the ICTY CLSS were ethnic Serbs, all their deputies were ethnic Serbs, all English and French revisers have been or are married to ethnic Serbs, and all B/C/S revisers have been ethnic Serbs (Chapter 6.81). As a consequence, there were a total of eight Bosnian Muslims working as P-level translators and interpreters in CLSS anywhere between one to five years or longer than 10 years. There were four more Muslims at P-level positions in CLSS, but they have not been taken into consideration because two were Muslims from Croatia and from Serbia, one was from a mixed Muslim/Serb marriage, and one was a Dutch Muslim. There have been three more Bosnians at P-level positions in CLSS, but they have not been taken into consideration because they are Bosnian Serbs. CLSS had anywhere between 60 and 170 language staff since 1993 .

The issue here is not how or why this has happened: the mother institution paints a very clear image of language professionals who were interrupting their real profession, people who tried to get into another job once being appointed as language professionals, and people who equate being employed by an institution with professional success (Chapter 5.2). It is unsurprising that this approach was replicated in the recruitment of ICTY language professionals. It is unnatural and surprising that nobody noticed the dominance of language professionals from the ranks of the two former attacking ethnicities translating and interpreting for their victims, B\&H Muslims, in an institution that was supposed to be staffed with legal professionals and whose job it was to pay attention to these details because they were working on ethnic crimes.

\section{Sixth recommendation}

The recruitment of language professionals at international criminal tribunals adjudicating on ethnic crimes must be entirely governed by citizenship and ethnicity concerns.

In search of a seventh condition for properly delivering linguistic justice at international criminal tribunals, this study stays with the delivery of the least expensive, the most effective, and the most practical language services, identifies ways in which the provision of those services was misused and is continuing to be misused by international criminal tribunals at the level of staff planning (Chapters 6.7-6.9). In examining linguistic justice after recruitment, this study explored whether the CLSS delivered or adopted a series of rules of regulations regarding the training and output of language professionals. The example of defense attorneys above shows that UN recruitment offices are reluctant to hire local professionals under the same terms as their internationally recruited colleagues. As to language professionals, this research revealed that, unless employed by the UN DGACM, the UN entities impose a host of language-related and non-language-related duties on language professionals in that they must translate, interpret, or edit or, in other words, provide 3-in-1 language services (Chapter 5.3). Although this begs the question as to their education and training, it was tolerated because, after all, these professionals are conducting language-related responsibilities, and, if they were professionally educated translators or interpreters, they should come out of college with a basic understanding and the skills needed to perform all these language-related functions. However, some vacancies advertised by the non-UN DGACM-serviced UN System entities, besides the 3-in-1 language-related duties, increasingly request incumbents to language professionals' posts to perform other non-language-related duties, the (3-in-1)+ duties (Chapter 5.3). Here, the authority to hire language professional has been borrowed: non-language professionals are taking charge of the recruitment of language professionals and then they supervise them. But, there are three problems here: these hybrid positions are normally advertised at a professional level, they are offered at the local level almost exclusively to applicants from countries devastated by conflict, and the educational requirements noted in the vacancy notices only refer to languages (Chapter 5 ). 
This approach was entirely replicated at the ICTY: on top of CLSS (Chapter 6.8), Language Assistants, a category of language professionals invented to improvise on everything that has to do with languages spoken in the situation country, were used to man at least seven units in charge of some segments of languagerelated work at the ICTY, namely: the OTP Language Unit (Chapter 6.9), Rules of the Road language professionals (Chapter 6.2), UNDU and VWU language professionals (Chapter 6.3), court reporters (Chapter 6.4), Outreach Program language professionals (Chapter 6.5), and Chamber Support Unit language professionals (Chapter 6.6). However, this was highly problematic. First of all, since they do not formally exist for all of the UN's intents and purposes, i.e. they are not classified among staff categories, they were not required to sign the above ICTY RPE Rule 76, and were not subject to other confidentiality regulations and language professionals manning these units were completely separate from CLSS in an administrative, financial, and support sense (Chapter 4.4). Second, given the terms of Language Assistants' engagement, the establishment of the OTP Language Unit directly violated the core reasons for the promulgation of ICSC Standards. Since employment of staff in GS-level positions does not require incumbents to be in possession of a university diploma, ICTY Recruitment made sure all Language Assistants with a university diploma signed a form in which they waived their university diploma (Chapter 6.9.1). Third, Language Assistants were, normatively, high school graduates without specialized diplomas, but were hired to translate, interpret, transcribe, process intercepts, perform quality control of document coding, redact witness statements, review video material, and perform other jobs as needed (Chapter 6.9.2). Once starting their duties and confronted with a situation where they had to deliver the (3-in-1)+ service comprising both language and non-language-related duties, Language Assistants have been precluded from suing the Organization because they signed the form. Nobody is making an issue about this because, after all, it always comes down to money: since the difference in salaries between P-level and GS-level staff is large, the cost-savings made by the use of ICTY Language Assistants were enormous. But ICTY CLSS language services were set up to fail from the start because CLSS management clearly failed. Not planning for concerns related to languages and linguistic variants (Chapter 6.7), for staff recruitment (Chapter 6.8.1), for staff training (Chapter 6.8.2), and staff retention (Chapter 6.8.3) is planning to fail.

CLSS failed to inform the ICTY practitioners that there was no operational need for the involvement of Language Assistants, just a need for a thorough reassessment and reappointment of existing UN, internal, and external resources, and turned the situation to their advantage. This study has established that CLSS slowly and gradually stopped translating witness statements, stopped interpreting for witnesses during proofing, and stopped working for the OTP in general. The provision of ICTY language services became highly decentralized and over-segmented where CLSS simply surrendered the work they did not want to do to seven other units dedicated to some segments of language-related work at the ICTY. First, the OTP Language Unit took care of translation of trial-related documents, thus relieving CLSS translators of most of their duties, and they took care of interpreting for witnesses, thus relieving CLSS interpreters of most of those duties, as well. VWU language professionals provided community interpreting services for witnesses, UNDU language professionals provided community interpreting for detainees, Outreach Program language professionals mostly translated their own publications and ICTY Internet page-related materials, Rules of the Road language professionals performed summaries of documents relating to transferring cases, and Chamber Support Unit language professionals provided editing services of court-related material, thus relieving the CLSS from all those duties. All these language units performed all those jobs without any translation or interpreting standards, as explained above, and, most worryingly, without any production indicators. Although CLSS had a separate budget, maintaining all these other language units depended solely on donations throughout their existence (Chapter 6.2-6.6). Still keeping all that unused money on their books, CLSS overpaid external staff: external translators and interpreters were making double, triple, and almost four times what in-house translators and interpreters were making. CLSS could have hired almost three and, in some instances, almost four in-house language professionals, for the price of one external language professional. As to the workload, since all the above language-related work was surrendered to various other units, CLSS only had to take care of court materials. However, they still resorted to postponing court deadlines and changes in court schedules (Chapter 6.8.4). 
It has already been established that it is very important that language professionals perform only language-related jobs, especially if they work at the court because their output does have a legal effect. But, here, the ICTY allowed people trained in language to assess the evidentiary value of statements and documents. The OTP should never have asked Language Assistants to meddle in legal work because they are unqualified to do that. Instead, the OTP should have made clear that all documentary evidence is for Military, Intelligence, and Research Analysts (Chapter 6.9.2). Next, CLSS could arrange that court interpreters work with witnesses from taking their initial witness statement to their testimony or, at least during proofing and testifying. In that way, there would be no need to compromise consistency in the approach to individuals by engaging at least three different interpreters during the process (Chapter 7.2). This study shows that court reporters for French were outsourced and their output taken as is without further scrutiny and that, although available, B/C/S court reporters were never hired (Chapter 6.4). This was a serious failure because it resulted in numerous problems with defendants, their defense attorneys from the region, and victims and witness speakers of $\mathrm{B} / \mathrm{C} / \mathrm{S}$, on top of the impact on the entire legal professionals' corpus and posterity. People from the region were waiting for those transcripts so that they could clearly see the issues related to the belligerents involved, gain critical perspectives, and use the legal truths established by the ICTY to start rebuilding their country and changing the mentality that led to ethnic wars in the first place. As to them, VWU could take full charge of witnesses $24 / 7$, just like they claimed to have done in ICTY ARs, and no one else, such as the OTP, Defense staff or Language Assistants would have to call them, fetch them, or spend any time with them at their own expense (Chapter 6.3). But, it was the CLSS's failure to properly plan and the ICTY's failure to properly use existing resources that resulted in the overuse of Language Assistants.

\section{Seventh recommendation}

The UN, in general, and international criminal tribunals in particular, must start recruiting professionally educated translators and interpreters. It must be made clear that staff recruited to language positions at international criminal tribunals should never perform any other jobs: the use of Language Assistants must disappear from international criminal tribunals.

The history of CLSS tells the story of a language service that was in dire need of training in every single aspect of their work to the point that the CLSS's failures in recruitment and training of their staff posed serious reasons for reconsidering whether language professionals should be managing other language professionals at all. In examining linguistic justice, this study explored the CLSS's translation output. CLSS was seen to be engaging experts and ignoring their recommendations (Chapter 6.7) and running around the world in search of "qualified French staff" (Chapter 6.8). Instead, they could have requested assistance from the UN, which has had 44 years of experience working with interpreters and editors in the English/French combination through UN DGACM policies on staff mobility (Chapter 6.6). Instead, they could have taken advantage of community interpreters and police interpreters who could have been engaged to train the ICTY language professionals on police and/or community interpreting (Chapter 6.8), etc. Instead, CLSS staffed their ranks with unqualified and inexperienced translators and interpreters in the legal sphere or in the context of international criminal tribunals. Not a single publicly available resume of a CLSS language professional is indicative of a person who has had any contact with law or translation and interpreting in a legal context prior to assuming their duties at the ICTY (Chapter 6.8.1). Here, it must be considered whether legal professionals had a duty to provide or to inform ICTY language professionals about opportunities in investigations and legal science-specific training in terms of dealing with rape victims, concentration camp inmates, insiders, defendants, and subsequent coping with trauma. This study shows that legal professionals seem to have expected that language professionals would come prepared to do their job (Chapter 6.8.2). But, if so, why would they instruct "[...] translators [how to] [...] address linguistic variants between the three ethnic groups" (Chapter 6.1)? The answer to this dilemma is very simple and not at all philosophical, despite the flowery language 
used. Working with legal professionals entails being acutely aware of the fact that legal professionals will take care of their own needs first and that they will leave you alone until your failures reflect badly on them. CLSS did not realize that. And CLSS's failures reflected badly on legal professionals. Legal professionals must have informally approached them, but it seems CLSS refused them, and that is why legal professionals referred to them as "the CLSS world" (Chapter 7).

Perhaps the clearest indication of how CLSS management was oblivious to their tasks at hand was the fact that CLSS did not have a post of terminologist. This post was necessary because that translators and interpreters from the former Yugoslavia could, at best, be classified as technical translators. This terminologist would have isolated and consolidated Socialist and Capitalist-driven and Common Law and Civil Law driven terminology from the rules and regulations and the translation process would not entail the creation of so many neologisms in all three directions. Given the scarcity or lack of training on substantive subjectmatter in CLSS (confirmed by many sources), staff seemed to have trained themselves or worked on "development of [their own] skills." However, this study shows that this development meant that individuals were assigned by CLSS management to random tasks, from interpreting to testing and recruitment without any prior training or any documented experience in any of those tasks (Chapter 6.8.2). At the same time, translation and interpreting, as reported by CLSS, as found by OIOS and by the author of this study, could not have been poorer. Remember that CLSS misinformed ICTY ARs authors of their production (Chapter 6.8.4). Remember that UN DGACM reports misinformed the Secretary-General about the staff structure (Chapter 5.2). This is a very interesting development. On the one hand, it means that CLSS was aware of constant production concerns and the UN was aware of constant staff diversity concerns. On the other, it means that UN DGACM management was acutely aware they had problems maintaining diversity, and CLSS management was acutely aware they had problems with translation and interpreting, hence one felt the need to "stretch it" before the corporate UN and ICTY. Together, this brings the issue back to particular UN DGACM and CLSS managers and the devastating effects of the 1999 Annan Reforms.

Obviously, this is not about individuals, but about a botched policy. As to CLSS individual and collective management, they were seen constantly bringing back freelancers who were not producing (Chapter 6.8.4). They were seen constantly overpaying external staff in what seems to be a violation of standing agreements between the UN and AITC and AIIC on reported domicile (Chapter 6.8.3). They were seen constantly being duped by the parties with an interest to the point they seemed to have been genuinely convinced they were doing their job when it was clear that legal professionals ushered them in between the term and the judges and let nature take its course (Chapter 7.1.2.2). They were seen consciously violating the I\&T Code which, although mostly divorced from the realities of translation and interpreting in a legal context, was explicit in certain places (Chapter 7.1.2.1). They were seen leaving their own staff to their own devices until they figured out how to translate something and then, it seems, CLSS management went back and fixed translations of documents used to arrive on adjudicated facts (Chapter 6.8.2). They were seen not to be producing output, in general, resulting in postponed deadlines and changes in court schedules (Chapter 6.8.4). And all this in addition to the fact that they decentralized the provision of language services to the point that they only needed to work on court-related materials. Finally, and most worryingly, they were seen not using the resources they paid and trained for: the latest CAT technologies (Chapter 6.8.4).

There are two types of documents that are regularly translated at the ICTY: those submitted in hard copy and those submitted in soft copy. As to the documents submitted in hard copy, i.e. documents that legal professionals seized in the field, they had to be translated from scratch. Still, their translation was measurable at the minimum, median, and maximum level (Chapter 6.8.4). As to the documents submitted in soft copy, every court document that the CLSS was supposed to translate was submitted in that format. Modern-day translators no longer translate from scratch, especially not in a legal context where material is so repetitive. All those documents could have been fed into the simplest CAT to yield excellent results. But CLSS bought the CAT, trained staff on using it, and then did not use it in their everyday work. 


\section{Eighth recommendation}

Language services at international criminal tribunals are seriously lagging behind in the use of CAT. There is no reason not to fully migrate to using CAT when translating documents submitted in soft copy.

The introduction to the last recommendation will be the shortest, because many of these issues have been touched on already. In examining linguistic justice, this study explored the CLSS's interpreting output. Coupled with all established facts on recruitment, training, and translation, CLSS's dubious interpreting practices, such as not staying in the office between o9:0o and 17:30 like the rest of ICTY staff, not participating in witness proofing, and readiness to go on mission and earn extra income, are not at all surprising, either. In reality, CLSS interpreters lacked supervision. The CLSS Interpreting Chief changed every once in a while, and almost every court interpreter was a Chief of the Interpreting Section for at least for a period of time. Since they lacked supervision, CLSS interpreters were underused and they were assigned to interpret without any consideration of the ethnicity of their clients. Since their clients had no mechanisms to complain without being described as unapologetic nationalists, CLSS interpreters' mistakes were routinely unnoticed if neither party with an interest had an objection. Since they were unsupervised, the quality of their interpreting output was unsupervised, as well. Chapter 8 tells a story of an amazingly poor interpreting performance right in the courtroom.

The ICTY could have taken a page out of the IMT's book and reinstated the institution of Interpretation Monitor to supervise the smooth functioning of the Court by manning the "yellow light", letting speakers know that they need to slow down and the "red light" which would require interruption of proceedings to relieve the stress on interpreters and instill some discipline on clients. Interpretation Monitors could be described as "linguistic project managers" in today's terms and could have assigned CLSS interpreters to interpret for witnesses during proofing. This would have eliminated the need for otherwise unqualified and legally unregulated Language Assistants to interpret at all. Since none of them worked at the international war crimes tribunal before getting a job with ICTY and since they had only one Bosnian woman on their staff, interpreting for witnesses during proofing would be to the benefit of court interpreters as they would establish contact with witnesses, learn their speech pattern, and how to avoid or deal with linguistic traps, including their shoddy knowledge of the Bosnian language. Finally, since nobody checked the quality and completeness of interpreting, an Interpretation Monitor could have assigned CLSS interpreters to double check their own interpreting before court transcripts were distributed to the parties and surrendered to case law. Overall, Interpretation Monitors would help court interpreters to improve their overall performance, listen to themselves, and learn from their mistakes, and they would not be put in a position to interpret for someone they have never met before.

\section{Ninth recommendation}

As a quality check on language professionals' output, international criminal tribunals must reinstate the IMT's institution of appointing an Interpretation Monitor.

So, what are the conditions for the delivery of linguistic justice at international criminal tribunals in a context in which language plays a role in the conflict? The legal and language professionals must work together on drafting rules and regulations that affect their joint output and their contact with their non-legal clients. Provision of any service, including language services, must be planned as the least expensive, the most effective, and the most practical. The language of the situation country must become an official language of the international criminal tribunal, because it allows the provision of translation, interpreting and transcription services to the parties. The essential documents in the court record must be provided to the defendant in the 
language s/he understands, while the language-related rights of his or her defense attorney must mirror his. Language professionals must be organizationally independent from the parties. In order for them to deliver independent translation it needs to be very clear that language professionals do not perform the job of legal professionals: the practice of using Language Assistants must simply disappear from international criminal tribunals. Recruitment of language professionals must be entirely governed by citizenship and ethnicity concerns and the court needs to stop allowing former belligerents to interpret for each other. Finally, translators must fully migrate to using CAT when translating documents submitted in soft copy and international criminal tribunals must appoint Interpretation Monitors as a quality check on interpreters' output.

The following section addresses the effect of ICTY efforts and answers the third and final sub-research question in this study:

Have legal truths established by the ICTY through translation, interpreting, and transcription been properly communicated to posterity?

Yes, ICTY's legal truths have been communicated properly to posterity in the English-speaking world. No, ICTY's legal truths have not been communicated properly to posterity in terms of $\mathrm{B} / \mathrm{C} / \mathrm{S}$ speaking people. Ultimately, the answer is no, as ICTY's legal truths have not been communicated properly. The problem remains: the fact that the ICTY's legal truths have not been properly communicated to $\mathrm{B} / \mathrm{C} / \mathrm{S}$ speakers matters more to them and to stability in the region because the ICTY mandate included bringing perpetrators to justice and contributing to the restoration and maintenance of peace in the region (Chapter 6).

This study contributed to Mowbray's findings in that the use of language and linguistic justice in international criminal law, more specifically at international criminal tribunals and especially those adjudicating on ethnic crimes, is a mere extension of competing visions of what constitutes justice, linguistically speaking, as in public international law. Conclusions and recommendations reached on the first part of the legal background to ICTY language-related effort in relation to the main parties to the proceedings clearly show that international criminal law has not taken a holistic approach to dealing with the issue of language and ignored local languages, local language variants, and local professionals. In response, the ICTY oversimplified and downplayed the role that philosophies of hate, language, and linguistic variants played in connection with the commission of ethnically motivated crimes. Conclusions and recommendations on the second part of the translation and interpreting background to the ICTY clearly show that CLSS was not staffed with professionally educated, professionally experienced, appropriate providers of linguistic justice in terms of citizenship and ethnicity. This led to discrimination in recruitment practices, shoddy translation and interpreting output, non-existent training, and legally unregulated relationships between legal and language professionals and those between language professionals engaged in legal transactions or legal professionals and their non-legal clients.

At the root of these failures is the fact that, due to UN policies on multilingualism, all the money that was spent on communication, translation, interpreting, and transcription into French represents an enormous waste of ICTY's money, which affects the rights of defendants and equality of arms. Next, the ICTY should have engaged with the philosophy of hate and the recurrent theme of Serbia and Croatia settling scores in $\mathrm{B} \& \mathrm{H}$ that led to the conflict in the first place. Moreover, although ICTY judges defined the ICTY as a victim-oriented court, CLSS management allowed CLSS interpreters speaking the linguistic variant of the attacking ethnicity to interpret for direct and indirect victims during the investigations, proofing, and testifying. Even when shown that current language-related rules and regulations were not working, the lawmakers did not move to amend them and brought in a new excuse, instead: practicality. Indeed, it was practical for the Court to provide transcripts in English and French only, it was practical for the Court to invent the concept of $\mathrm{B} / \mathrm{C} / \mathrm{S}$, it was practical for the Court to ignore the entire local linguistic context (linguistic variants) and language and identity-related aspects of the conflict (the history of hate propaganda against the Muslims 
that led to ethnic cleansing). In reality, the Court did not know what to do with the issue of language or language variants because there was no one available to teach them better. Instead, the Court did things the way they have always been done.

The Hague, Manassas, Tuzla, 2013-2017 
VALORIZATION ADDENDUM 
1. Relevance: what is the social and/or economic relevance of your research results in addition to the scientific relevance?

This is the first study to examine an interplay between the language, translation, and interpreting at international criminal tribunals adjudicating on ethnic crimes examining the concept of linguistic justice asking whether the parties to the proceedings have been addressed by international criminal tribunals in a language that they understand. It is an interdisciplinary study that makes conceptual and substantive contributions both to translation and interpretation studies and practice, and to the legal studies and practice.

Conceptual relevance of the present study to both the legal and translation and interpretation studies and practice lies in the fact that the present study is, perhaps, the first of its kind to consider the local context in the delivery of language services and, by extension, the delivery of legal truths. Local audiences were the first and the most important audiences to ICTY conduct and they are the first and the most important posterity to legal truths established because the purpose of the entire legal exercise that was ICTY and subsequently established international criminal tribunals was for local audiences to take their legal truths as a starting point to recovering their societies. Conceptual relevance to the legal studies and practice is in series of arguments to rethink the existing legal rules and regulations incumbent on the parties to the proceedings and resultant relationships when in contact with language professionals alone and when in contact with nonlegal clients through the assistance of language professionals because the current ones are full of lacunae.

Substantially, most topics that have been broached by the present study are entirely under-researched. This includes the impact of 1999 Annan Reforms to the recruitment at the UN, including recruitment of language professionals, the relevance of philosophy of hate that led to perpetration of ethnic crimes anchored in language, the linguistic equality of arms between the parties at international criminal tribunals, the relevance of ethnicity- and nationality-based recruitment of language professionals at international criminal tribunals adjudicating on ethnic crimes, and the relevance of checks and balances on language professionals' tasks, production, and resultant relationship with their legal and non-legal clients. Because these topics are under-researched, some aspects that should have been codified in the rules and regulations for the purposes of ICTY and subsequently established international criminal tribunals have completely fallen through the cracks, namely: non-codification of the languages of the situation countries in the laws, non-prosecution of speech atrocity crimes, non-codification of victims' language-related rights in the context of at international criminal tribunals adjudicating on ethnic crimes, incomplete codification of defendants' language-related rights with effect on proper translation and interpretation, and, last but not the least, improper designation of languagerelated terminology. The relevance of the present study is in detailing these lacunae and providing concrete examples to detail the consequences.

2. Target groups: to who, in addition to the academic community, are your research results of interest and why?

In the first place, the present study addresses both practicing and theoretical legal and language professionals who practice both in the situation countries and in the international criminal tribunals. Since some of the underlying aspects of the present study point that these categories cannot be said to be in healthy, productive, or respectful communication, the present study is unique in almost shouting that they cannot afford to notcommunicate since the lack of that communication bears detrimentally on their working status and on their work product which should be of paramount interest to both.

In addition, research results of the present study should garner immediate action of the courts, rather than ad nauseam academic debates. This is because research results clearly point to a series of undelivered linguistic justices at ICTY and subsequently established international criminal tribunals amply documented throughout the study. Whereas some ICTY and subsequently established international criminal tribunals' practices stem from sloppy lacunae in the rules and regulations pointing to a lack of communication between 
the two types of professionals, some legal practices are in contradiction to the current international rules and regulations on the right to information and communication and on the right to translation and interpretation of and to persons under criminal investigation.

The present study also addresses situation country associations of professional translators and interpreters, academic institutions producing such cadre, and policymakers pointing that they have been completely overpowered by the UN and international criminal tribunals, asking them to reconsider their relationships with the UN and international criminal tribunals, and pointing to the ways how they can make themselves genuinely equal partners in that contact. Here, although the UN should have known better when recruiting language staff from the situation countries by merely enforcing their own internal rules and regulations, ultimately, it is the fault of the situation country agents that UN keeps on recruiting mostly unqualified language staff.

Finally, the present study addresses legal institutions, policymakers, and legal professionals from the situation countries calling them to rethink their position when in contact with the UN pointing to a series of instances where they have made themselves unequal partner, passive recipient of UN rules and regulations and practices, and mindless enforcers of UN policies which, essentially, have very little to do with the actual (set of) problem(s) the UN is trying to sort out in the first place. Here, although the UN should have known better when recruiting legal staff from the situation countries by merely respecting their internal rules and regulations, ultimately, it is the fault of the situation country governments that their resources, working priorities, and operational requirements have not been implemented.

\section{Activities: into which concrete activities will your results be translated and shaped?}

International rules and regulations incumbent on judges, prosecutors, defense attorneys, investigators, defendants, and victims and witnesses that have been clearly named in the present study must be revised to include a proviso on their contact with language professionals. Conversely, international rules and regulations incumbent on language professionals must be revised to include a proviso on their contact with nonlegal clients.

Since there are no international rules and regulations incumbent on language professionals working in international criminal tribunals, those that are institution made must be revised to define translation and interpreting in legal context as a product that simply must front all operational information relevant for the work of legal professionals. Such rules and regulations must be also revised in view of actual tasks, roles, and legal safeguards pertaining to language professionals either as suggested in the presents study or, at least, as those that stem from language professionals' education, working experience, and on-job training.

As to the latter, international and institution-made rules and regulations incumbent on language professionals working in international criminal tribunals must include all categories of language professionals working in the said institutions, must refrain from defining language professionals as anything but a facilitator of communication between legal professionals and their clients, must clearly define all their tasks as revolving around translation, interpretation, and transcription, and must prescribe legal penalties for breaches just like they do for other categories of professionals working at international criminal tribunals.

Since majority of issues broached by the present study has to do with international criminal tribunals' refraining from recruiting professionals from the situation countries, it is suggested the judges panels, investigation, and, by extension, trial teams include one situation country professional for every two internationally recruited professionals. This will facilitate eradication of the institution of Language Assistants who simply cannot be used as is at the international criminal tribunals. In turn, this will save enormous costs that are currently being dispensed on unnecessary translation. 
Finally, although entirely out of scope of the present study, since it has bearing on linguistic delivery of services, it must be pointed that the outreach programs and information departments of international criminal tribunals must learn to address the audiences in the situation countries the way that those audiences understand, preempting and cutting at the root of denialism, not in the way that is institutionally practiced.

4. Innovation: to what degree can your results be called innovative in respect to the existing range of products, services, processes, activities, and commercial activities?

The present study was descriptive and analytical, and, as such, cautionary. During the preparations for this study, topical ideas revolved around technological innovations of how much did ICTY and subsequently established international criminal tribunals add to the current technological innovations in the field of translational and interpretation studies and practices. However, soon, all the research pointed that these institutions were barely coping with work. One thing led to another and, inevitably, the research conducted for the purposes of the present painted a consistent picture of no use of current technological advancements in translational and interpretation practices, of underuse of the existing UN and institutional resources, of lack of communication between the language-services deliverers and language-services recipients, of heavy handedness and immaturity in managerial and practicing approach to languages, translation, interpretation, and transcription, and to resultant shameful absence of any linguistic justice to anyone. All these are amply documented throughout the study, including the ways how they could have been overcome. However, the study has shown that even in the present conditions, some innovations could still be made both by legal and language professionals.

As to legal professionals, the study has recommended some innovative solutions to commonly encountered problems in approach to official languages, linguistic variances of defendants trumping those of their victims, the uncompleted process of consolidation between Civil Law and Common Law terminology, etc. in the last chapter, in addition to measures under point 3 of this Addendum. Since the speech atrocity crimes and underlying philosophy of hate have never been prosecuted by the ICTY, for example, it may be suggested as an innovation that the parties appearing before international criminal tribunals, especially those adjudicating on ethnic crimes, before the beginning of the trial make a habit of submitting to judges an independent brief authored by the interdisciplinary group of academic on the historical development of ethnic aspects conflict, including the philosophy of hate anchored in language, as an introduction to the case. ICTY, for example, did not charge any individual for speech atrocity crimes, authors of all those books mentioned in the study that have motivated the ethnic crimes could not have and should not have possibly be prosecuted, so this measure would, at least, acknowledge the philosophy of hate that motivated the commission of ethnic crimes putting it in a context of continuum, not a vacuum.

As to the language professionals, the study has recommended some innovative solutions to commonly encountered problems in recruitment, selection, production outputs, and checks and balances to the conduct of language professionals approach, etc. throughout the study and in the last chapter, in addition to measures under point 3 of this Addendum.

5. Schedule \& Implementation: how will this/these plan(s) for valorization be shaped? What is the schedule, are there risks involved, what market opportunities are there and what are the costs involved?

It is unfortunate the present thesis is published after the ICTY has been closed and at the time when the functioning international criminal tribunals are wrapping up their activities caught in different stages of completion strategy. In the same time, this is very auspicious because the practice has shown that the UN does not like being motioned or criticized during delivery of services. In that sense, it is believed the UN and other actors might accept the proposals advanced by the present study because the points of contention are moot but could be applied to future international criminal tribunals. 
In that sense, all the recommendations of the present study, including the activities under points 2 and 3 of this Addendum, can be carried out at the initial stages of planning the next ICC-independent international criminal tribunals. Recommendations and activities that might be applicable to the ICC could start at the next meeting of the parties to the Rome Agreement. It could be safely assumed that there are no associated risks as the recommendations and activities are result- and merit-based catering to the least expensive, the most effective, and the most practical delivery of language services to international and situation country clients. Market opportunities are plentiful and untapped. Recommended measures and activities would lead to recruitment of educated professionals which, in turn, would engage in results- and merit-based, service-, and equity-oriented provision of language services guaranteed to cut existing costs immensely by streamlining and redefining the existing processes and activities and pushing the amateurs out the way. 
APPENDICES 
Appendix 1. Full list of pre-trial, final and appeal briefs

\begin{tabular}{|c|c|c|c|}
\hline Trial & Pre-trial, final and appeals brief & $\mathrm{B} / \mathrm{C} / \mathrm{S}$ & FRE \\
\hline Boškoski \& Tarčulovski & $\begin{array}{l}4 \text { Nov } 2008 \\
\text { Prosecution's Appeal Brief }\end{array}$ & - & - \\
\hline Boškoski \& Tarčulovski & $\begin{array}{l}\text { 12 Jan } 2009 \\
\text { Appeal Brief of Johan Tarculovski }\end{array}$ & - & - \\
\hline Đorđević & $\begin{array}{l}\text { 20 Dec } 2011 \\
\text { Public Redacted Final Trial Brief and Corrigendum (Part } 1 \text { ) }\end{array}$ & - & - \\
\hline Đorđević & $\begin{array}{l}20 \text { Dec } 2011 \\
\text { Public Redacted Final Trial Brief and Corrigendum (Part 2) }\end{array}$ & - & - \\
\hline Đorđević & $\begin{array}{l}15 \text { Aug } 2011 \\
\text { Appeal Brief - Redacted Version }\end{array}$ & - & - \\
\hline Erdemović & $\begin{array}{l}7 \text { May } 1997 \\
\text { Erdemović Appeal: Summary of the Briefs Filed by the Parties }\end{array}$ & - & - \\
\hline Galić & $\begin{array}{l}23 \text { Oct } 2001 \\
\text { Prosecution pre-trial brief }\end{array}$ & - & - \\
\hline Gotovina et al & $\begin{array}{l}5 \text { Apr } 2007 \\
\text { Pre-trial brief of General Ante Gotovina }\end{array}$ & - & - \\
\hline Gotovina et al & $\begin{array}{l}5 \text { Apr } 2007 \\
\text { Mladen Markac's pre-trial brief }\end{array}$ & - & - \\
\hline Gotovina et al & $\begin{array}{l}5 \text { Apr } 2007 \\
\text { Pre-trial brief of Ivan Cermak }\end{array}$ & - & - \\
\hline Gotovina et al & $\begin{array}{l}23 \text { Mar } 2007 \\
\text { Prosecution pre-trial brief }\end{array}$ & - & - \\
\hline Gotovina et al & $\begin{array}{l}17 \text { May } 2012 \\
\text { Ante Gotovina's supplemental brief pursuant to the oral order of the Appeals Cham- } \\
\text { ber of } 14 \text { May } 2012\end{array}$ & - & - \\
\hline Gotovina et al & $\begin{array}{l}23 \text { May } 2011 \\
\text { Notice of re-classification and re-filing of defendant Mladen Markac's public redacted } \\
\text { Final Trial Brief }\end{array}$ & - & - \\
\hline Gotovina et al & $\begin{array}{l}13 \text { Sept } 2010 \\
\text { Ivan Čermak's Public Redacted Final Brief }\end{array}$ & - & - \\
\hline Gotovina et al & $\begin{array}{l}2 \text { Aug } 2010 \\
\text { Prosecution's public redacted Final Trial Brief }\end{array}$ & - & - \\
\hline Gotovina et al & $\begin{array}{l}27 \text { Jul } 2010 \\
\text { Gotovina Defence Final Trial Brief }\end{array}$ & - & - \\
\hline Gotovina et al & $\begin{array}{l}\text { 11 Oct } 2011 \\
\text { Mladen Markac's public redacted Appeal Brief }\end{array}$ & - & - \\
\hline Gotovina et al & $\begin{array}{l}5 \text { Oct } 2011 \\
\text { Mladen Markač's public redacted Appeal Brief }\end{array}$ & - & - \\
\hline Gotovina et al & $\begin{array}{l}6 \text { Sept } 2011 \\
\text { Errata to Appellant's Brief of Ante Gotovina }\end{array}$ & - & - \\
\hline Gotovina et al & $\begin{array}{l}2 \text { Aug } 2011 \\
\text { Appellant's Brief of Ante Gotovina (Public Redacted) }\end{array}$ & - & - \\
\hline Hadžić & $\begin{array}{l}\text { 31 Jul } 2012 \\
\text { Defence pre-trial brief }\end{array}$ & - & - \\
\hline Hadžić & $\begin{array}{l}\text { Jul } 2012 \\
\text { Prosecution's redacted pre-trial brief }\end{array}$ & - & - \\
\hline Haradinaj et al & $\begin{array}{l}19 \mathrm{Jul} 2011 \\
\text { Pre-trial brief on behalf of Ramush Haradinaj for the partial retrial }\end{array}$ & - & - \\
\hline Haradinaj et al & $\begin{array}{l}\text { 10 Feb } 2011 \\
\text { Appeal brief on behalf of Ramush Haradinaj on scope of partial retrial }\end{array}$ & - & - \\
\hline Haradinaj et al & $\begin{array}{l}\text { 19 Jul } 2008 \\
\text { Appeal Brief on behalf of Lahi Brahimaj }\end{array}$ & - & - \\
\hline Karadžić & $\begin{array}{l}29 \text { Jun } 2009 \\
\text { Defence pre-trial brief }\end{array}$ & - & - \\
\hline Karadžić & $\begin{array}{l}18 \text { May } 2009 \\
\text { Prosecution's submission pursuant to rule } 65 \text { ter (E)(i)-(iii) }\end{array}$ & - & - \\
\hline Karadžić & 8 Apr 2009 & - & - \\
\hline
\end{tabular}




\begin{tabular}{|c|c|c|c|}
\hline Trial & Pre-trial, final and appeals brief & $\mathrm{B} / \mathrm{C} / \mathrm{S}$ & FRE \\
\hline & Prosecution's submission of interim pre-trial brief & & \\
\hline Karadžić & $\begin{array}{l}10 \text { Oct } 2014 \\
\text { Public Redacted Version of Prosecution Final Trial Brief Appendices A \& D }\end{array}$ & - & - \\
\hline Karadžić & $\begin{array}{l}29 \text { Sept } 2014 \\
\text { Defence Final Trial Brief }\end{array}$ & - & - \\
\hline Karadžić & $\begin{array}{l}\text { 23 Sept } 2014 \\
\text { Public Redacted Version of Prosecution Final Trial Brief with Appendices E \& J }\end{array}$ & - & - \\
\hline Karadžić & $\begin{array}{l}23 \text { Nov } 2012 \\
\text { Defence Respondent's Brief - Rule 98Bis }\end{array}$ & - & - \\
\hline Karadžić & $\begin{array}{l}19 \text { Nov } 2012 \\
\text { Corrigendum to Prosecution rule 98bis Appeal Brief }\end{array}$ & - & - \\
\hline Karadžić & $\begin{array}{l}24 \text { Sept } 2012 \\
\text { Prosecution Rule 98bis Appeal Brief - Redacted version }\end{array}$ & - & - \\
\hline $\begin{array}{l}\text { Lukić Milan \& Lukić } \\
\text { Sredoje }\end{array}$ & $\begin{array}{l}14 \text { Mar } 2008 \\
\text { Prosecution's Pre-Trial Brief Pursuant to Rule } 65 \text { ter (E) (I) }\end{array}$ & - & - \\
\hline $\begin{array}{l}\text { Lukić Milan \& Lukić } \\
\text { Sredoje }\end{array}$ & $\begin{array}{l}15 \text { May } 2009 \\
\text { Corrigendum to prosecution's final trial brief }\end{array}$ & - & - \\
\hline $\begin{array}{l}\text { Lukić Milan \& Lukić } \\
\text { Sredoje }\end{array}$ & $\begin{array}{l}13 \text { May } 2009 \\
\text { Milan Lukić's final trial brief and submissions }\end{array}$ & - & - \\
\hline $\begin{array}{l}\text { Lukić Milan \& Lukić } \\
\text { Sredoje }\end{array}$ & $\begin{array}{l}12 \text { May } 2009 \\
\text { Prosecution Final Trial Brief }\end{array}$ & - & - \\
\hline $\begin{array}{l}\text { Lukić Milan \& Lukić } \\
\text { Sredoje }\end{array}$ & $\begin{array}{l}12 \text { May } 2009 \\
\text { Sredoje Lukić's Defence Final Brief }\end{array}$ & - & - \\
\hline $\begin{array}{l}\text { Lukić Milan \& Lukić } \\
\text { Sredoje }\end{array}$ & $\begin{array}{l}17 \text { Mar } 2010 \\
\text { Redacted Appeal Brief - Milan Lukic }\end{array}$ & - & - \\
\hline $\begin{array}{l}\text { Lukić Milan \& Lukić } \\
\text { Sredoje }\end{array}$ & $\begin{array}{l}2 \text { Nov } 2009 \\
\text { Appeal Brief on behalf of Sredoje Lukic }\end{array}$ & - & - \\
\hline $\begin{array}{l}\text { Lukić Milan \& Lukić } \\
\text { Sredoje }\end{array}$ & $\begin{array}{l}2 \text { Nov } 2009 \\
\text { Prosecution Appeal Brief }\end{array}$ & - & - \\
\hline Milošević, D. & $\begin{array}{l}14 \text { Aug } 2008 \\
\text { Dragomir Milosevic - Defence Appeal Brief }\end{array}$ & - & - \\
\hline Mladić & $\begin{array}{l}24 \text { Feb } 2012 \\
\text { Prosecution Pre-Trial Brief (part 2b) } \\
\end{array}$ & - & - \\
\hline Mladić & $\begin{array}{l}24 \text { Feb } 2012 \\
\text { Prosecution Pre-Trial Brief (part 2a) }\end{array}$ & - & - \\
\hline Mladić & $\begin{array}{l}24 \text { Feb } 2012 \\
\text { Prosecution Pre-Trial Brief (part 3) }\end{array}$ & - & - \\
\hline Mladić & $\begin{array}{l}24 \text { Feb } 2012 \\
\text { Prosecution Pre-Trial Brief (part 1) }\end{array}$ & - & - \\
\hline Perišić & $\begin{array}{l}\text { 10 Apr } 2012 \\
\text { Public redacted version of the Appeal brief of Momčilo Perišić }\end{array}$ & - & - \\
\hline Popović et al & $\begin{array}{l}12 \text { Jul } 2006 \\
\text { Pre-Trial Brief - Milan Gvero }\end{array}$ & - & - \\
\hline Popović et al & $\begin{array}{l}12 \text { Jul } 2006 \\
\text { Pre-Trial Brief - Vinko Pandurević }\end{array}$ & - & - \\
\hline Popović et al & $\begin{array}{l}12 \text { Jul } 2006 \\
\text { Pre-Trial Brief - Drago Nikolić }\end{array}$ & - & - \\
\hline Popović et al & $\begin{array}{l}12 \text { Jul } 2006 \\
\text { Pre-Trial Brief-Vujadin Popović }\end{array}$ & - & - \\
\hline Popović et al & $\begin{array}{l}\text { 30 Jul } 2010 \\
\text { Public redacted version of the Final Trial Brief - Drago Nikolić }\end{array}$ & - & - \\
\hline Popović et al & $\begin{array}{l}\text { 30 Jul } 2010 \\
\text { Final Brief - Milan Gvero }\end{array}$ & - & - \\
\hline Popović et al & $\begin{array}{l}28 \text { Jul } 2010 \\
\text { Defendant, Ljubisa Beara's notice of filing a public redacted version of the Beara Final } \\
\text { Trial Brief }\end{array}$ & - & - \\
\hline Popović et al & $\begin{array}{l}28 \text { Jul } 2010 \\
\text { Public redacted version of Vujadin Popovic's Final Brief }\end{array}$ & - & - \\
\hline
\end{tabular}




\begin{tabular}{|c|c|c|c|}
\hline Trial & Pre-trial, final and appeals brief & $\mathrm{B} / \mathrm{C} / \mathrm{S}$ & FRE \\
\hline Popović et al & $\begin{array}{l}26 \mathrm{Jul} 2 \mathrm{O} 0 \\
\text { Pandurevic notice of filing a public redacted version of the Pandurevic final trial brief }\end{array}$ & - & - \\
\hline Popović et al & $\begin{array}{l}\text { 14 Jul } 2010 \\
\text { Prosecution's notice of filing a public redacted version of the prosecution Final Trial } \\
\text { Brief }\end{array}$ & - & - \\
\hline Popović et al & $\begin{array}{l}23 \text { Apr } 2010 \\
\text { Ljubomir Borovcanin - Public and Corrected Final Trial Brief }\end{array}$ & - & - \\
\hline Popović et al & $\begin{array}{l}\text { 30 Sept } 2009 \\
\text { Second corrigendum to the prosecution Final Trial Brief }\end{array}$ & - & - \\
\hline Popović et al & $\begin{array}{l}1 \text { Sept } 2009 \\
\text { Corrigendum to the prosecution Final Trial Brief }\end{array}$ & - & - \\
\hline Popović et al & $\begin{array}{l}\text { 30 Jul } 2009 \\
\text { Public redacted version of Chap XIV of the prosecution Final Trial Brief }\end{array}$ & - & - \\
\hline Popović et al & $\begin{array}{l}19 \text { Feb } 2013 \\
\text { Public redacted version of Appeal Brief on behalf of Milan Gvero against the trial } \\
\text { judgment of } 10 \text { June } 2010\end{array}$ & - & - \\
\hline Popović et al & $\begin{array}{l}18 \text { Feb } 2013 \\
\text { Prosecution Appeal Brief (Grounds Against Milan Gvero) }\end{array}$ & - & - \\
\hline Popović et al & $\begin{array}{l}3 \text { Aug } 2011 \\
\text { Appellant's brief on behalf of Drago Nikolić }\end{array}$ & - & - \\
\hline Popović et al & $\begin{array}{l}18 \text { Jul } 2011 \\
\text { Public redacted version of brief in reply on behalf of Drago Nikolić }\end{array}$ & - & - \\
\hline Popović et al & $\begin{array}{l}\text { 16 Jun } 2011 \\
\text { Appellant Ljubiša Beara's notice of reclassification and re-filing of the public redacted } \\
\text { version of Appeal Brief }\end{array}$ & - & - \\
\hline Prlić et al & $\begin{array}{l}1 \text { Apr } 2011 \\
\text { Redacted Final Trial Brief }\end{array}$ & - & - \\
\hline Prlić et al & $\begin{array}{l}31 \text { Mar } 2011 \\
\text { Berislav Pušić's Final Brief (Public Redacted Version) }\end{array}$ & - & - \\
\hline Prlić et al & $\begin{array}{l}1 \text { Mar } 2011 \\
\text { Bruno Stojić's redacted final trial brief }\end{array}$ & - & - \\
\hline Prlić et al & $\begin{array}{l}31 \text { Mar } 2011 \\
\text { Slobodan Praljak's Redacted Final Trial Brief }\end{array}$ & - & - \\
\hline Prlić et al & $\begin{array}{l}31 \text { Mar } 2011 \\
\text { Petković defence final brief }\end{array}$ & - & - \\
\hline Prlić et al & $\begin{array}{l}29 \text { Mar } 2011 \\
\text { Jadranko Prlić's Final Brief }\end{array}$ & - & - \\
\hline Prlić et al & $\begin{array}{l}28 \text { Mar } 2011 \\
\text { Valentin Ćorić's Final Trial Brief }\end{array}$ & - & - \\
\hline Stanišić \& Simatović & $\begin{array}{l}2 \text { Apr } 2007 \\
\text { Prosecution Pre-Trial Brief }\end{array}$ & - & - \\
\hline Stanišić \& Simatović & $\begin{array}{l}\text { 18 Jan } 2005 \\
\text { Pre-Trial Brief }\end{array}$ & - & - \\
\hline Stanišić \& Simatović & $\begin{array}{l}19 \mathrm{Jul} 2 \mathrm{OO} 4 \\
\text { Pre-Trial Brief }\end{array}$ & - & - \\
\hline Stanišić \& Simatović & $\begin{array}{l}28 \text { Feb } 2013 \\
\text { Public redacted version of prosecution Final Trial Brief }\end{array}$ & - & - \\
\hline Stanišić \& Simatović & $\begin{array}{l}15 \text { Feb } 2013 \\
\text { Final Trial Brief }\end{array}$ & - & - \\
\hline Stanišić \& Simatović & $\begin{array}{l}11 \text { Feb } 2013 \\
\text { Defence Final Trial Brief }\end{array}$ & - & - \\
\hline Stanišić \& Simatović & $\begin{array}{l}25 \text { Sept } 2013 \\
\text { Prosecution Appeal Brief }\end{array}$ & - & - \\
\hline Stanišić \& Župljanin & $\begin{array}{l}31 \text { Jul } 2009 \\
\text { Supplement to defence pre-trial brief on behalf of Mr. Stojan Zupljanin pursuant to } \\
\text { rule } 65 \operatorname{ter}(\mathrm{F})\end{array}$ & - & - \\
\hline Stanišić \& Župljanin & $\begin{array}{l}\text { 31 Jul } 2009 \\
\text { Supplemental pre-trial brief of the defence of Mićo Stanišić }\end{array}$ & - & - \\
\hline
\end{tabular}




\begin{tabular}{|c|c|c|c|}
\hline Trial & Pre-trial, final and appeals brief & $\mathrm{B} / \mathrm{C} / \mathrm{S}$ & FRE \\
\hline Stanišić \& Župljanin & $\begin{array}{l}29 \text { Jun } 2009 \\
\text { Pre-trial brief of the defence of Mico Stanisic }\end{array}$ & - & - \\
\hline Stanišić \& Župljanin & $\begin{array}{l}\text { 29 Jun } 2009 \\
\text { Defence pre-trial brief on behalf of Mr. Stojan Zupljanin pursuant to rule } 65 \text { ter (f) }\end{array}$ & - & - \\
\hline Stanišić \& Župljanin & $\begin{array}{l}1 \text { Dec } 2006 \\
\text { Prosecutor's Pre-trial brief }\end{array}$ & - & - \\
\hline Stanišić \& Župljanin & $\begin{array}{l}12 \text { Jul } 2012 \\
\text { Prosecution Final Trial Brief - part } 3\end{array}$ & - & - \\
\hline Stanišić \& Župljanin & $\begin{array}{l}12 \text { Jul } 2012 \\
\text { Prosecution Final Trial Brief - part } 1\end{array}$ & - & - \\
\hline Stanišić \& Župljanin & $\begin{array}{l}12 \text { Jul } 2012 \\
\text { Prosecution Final Trial Brief - part } 2\end{array}$ & - & - \\
\hline Stanišić \& Župljanin & $\begin{array}{l}12 \text { Jul } 2012 \\
\text { Prosecution Final Trial Brief - part } 5\end{array}$ & - & - \\
\hline Stanišić \& Župljanin & $\begin{array}{l}12 \text { Jul } 2012 \\
\text { Prosecution Final Trial Brief - part } 4\end{array}$ & - & - \\
\hline Stanišić \& Župljanin & $\begin{array}{l}12 \text { Jul } 2012 \\
\text { Defence Final Trial Brief (Redacted) - Stojan Župljanin }\end{array}$ & - & - \\
\hline Stanišić \& Župljanin & $\begin{array}{l}\text { 2o Apr } 2016 \\
\text { Stojan Župljanin's Appeal Brief }\end{array}$ & - & - \\
\hline Stanišić \& Župljanin & $\begin{array}{l}19 \text { Aug } 2013 \\
\text { Appellant's Brief on Behalf of Mićo Stanišić }\end{array}$ & - & - \\
\hline Stanišić \& Župljanin & $\begin{array}{l}19 \text { Aug } 2013 \\
\text { Prosecution Appeal Brief }\end{array}$ & - & - \\
\hline Strugar & $\begin{array}{l}27 \text { Aug } 2003 \\
\text { Prosecutor's pre-trial brief pursuant to rule } 65 \operatorname{ter}(\mathrm{E})(\mathrm{i})\end{array}$ & - & - \\
\hline Šainović et al & $\begin{array}{l}\text { 28 Jul } 2008 \\
\text { Prosecution Public Redacted Final Trial Brief and Corrigendum }\end{array}$ & - & - \\
\hline Šainović et al & $\begin{array}{l}15 \text { May } 2006 \\
\text { Corrigendum to prosecution's pre-trial brief }\end{array}$ & - & - \\
\hline Šainović et al & $\begin{array}{l}10 \text { May } 2006 \\
\text { Prosecution's pre-trial brief }\end{array}$ & - & - \\
\hline Šainović et al & $\begin{array}{l}29 \text { Jul } 2008 \\
\text { Vladimir Lazarevic's Final Trial Brief }\end{array}$ & - & - \\
\hline Šainović et al & $\begin{array}{l}21 \text { Jul } 2010 \\
\text { Nikola Šainović - Public redacted version of "Defence Brief in reply" }\end{array}$ & - & - \\
\hline Šainović et al & $\begin{array}{l}11 \text { Dec } 2009 \\
\text { General Ojdanić's Amended Appeal Brief }\end{array}$ & - & - \\
\hline Šainović et al & $\begin{array}{l}17 \text { Nov } 2009 \\
\text { Prosecution's consolidated reply brief }\end{array}$ & - & - \\
\hline Šainović et al & $\begin{array}{l}7 \text { Oct } 2009 \\
\text { Sreten Lukic - Appendix D of the Defense Appelant's Brief }\end{array}$ & - & - \\
\hline Šainović et al & $\begin{array}{l}7 \text { Oct } 2009 \\
\text { Sreten Lukic - Defense Appelant's Brief Refiled }\end{array}$ & - & - \\
\hline Šainović et al & $\begin{array}{l}\text { 30 Sept } 2009 \\
\text { General Pavković's submission of his amended Appeal Brief }\end{array}$ & - & - \\
\hline Šainović et al & $\begin{array}{l}23 \text { Sept } 2009 \\
\text { Pavkovic's Appeal Brief-Appendix }\end{array}$ & - & - \\
\hline Šainović et al & $\begin{array}{l}23 \text { Sept } 2009 \\
\text { Ojdanic's Appeal Brief }\end{array}$ & - & - \\
\hline Šainović et al & $\begin{array}{l}23 \text { Sept } 2009 \\
\text { Pavkovic's Appeal Brief }\end{array}$ & - & - \\
\hline Šainović et al & $\begin{array}{l}23 \text { Sept } 2009 \\
\text { Sainovic Defence Appeal Brief }\end{array}$ & - & - \\
\hline Šainović et al & $\begin{array}{l}23 \text { Sept } 2009 \\
\text { Appendix A-Defence Appelant's Brief - Lukic }\end{array}$ & - & - \\
\hline Šainović et al & $\begin{array}{l}24 \text { Aug } 2009 \\
\text { Corrigendum to Prosecution Appeal Brief }\end{array}$ & - & - \\
\hline
\end{tabular}




\begin{tabular}{|l|l|l|l|}
\hline Trial & Pre-trial, final and appeals brief & B/C/S & FRE \\
\hline Šainović et al & $\begin{array}{l}\text { 21 Aug 2009 } \\
\text { Prosecution Appeal Brief }\end{array}$ & - & - \\
\hline Šešelj & $\begin{array}{l}\text { 22 Jun 2012 } \\
\text { Defence Final Brief - part 1 }\end{array}$ & + & + \\
\hline Šešelj & $\begin{array}{l}\text { 22 Jun 2012 } \\
\text { Defence Final Brief - part 2 }\end{array}$ & + & + \\
\hline Šešelj & $\begin{array}{l}\text { 5 Feb 2012 } \\
\text { Prosecution's Closing Brief - part1 }\end{array}$ & - & - \\
\hline Šešelj & $\begin{array}{l}\text { 5 Feb 2012 } \\
\text { Prosecution's Closing Brief - part2 }\end{array}$ & - & - \\
\hline Tolimir & $\begin{array}{l}\text { 30 Sept 2009 } \\
\text { Zdravko Tolimir's submission with a pre-trial brief pursuant to rule 65 ter (f) and no- } \\
\text { tification of the defence of alibi in respect of some charges }\end{array}$ & - & - \\
\hline Tolimir & $\begin{array}{l}\text { 29 Sept 2009 } \\
\text { Prosecution filing of public version of Pre-trial Brief }\end{array}$ & + & - \\
\hline Tolimir & $\begin{array}{l}\text { 28 Nov 2012 } \\
\text { Prosecution Public Redacted Final Trial Brief }\end{array}$ & + & - \\
\hline Tolimir & $\begin{array}{l}\text { 1 Oct 2012 } \\
\text { Defence Final Trial Brief }\end{array}$ & $\begin{array}{l}\text { 28 Feb 2014 } \\
\text { Public Redacted Version of the Consolidated Appeal Brief }\end{array}$ & - \\
\hline Tolimir & & - & - \\
\hline
\end{tabular}


Appendix 2. Language-related requests, decisions, and orders

\begin{tabular}{|c|c|c|}
\hline Trial & Language-related request & $+1-$ \\
\hline Babić & $\begin{array}{l}28 \mathrm{Jul} 2004 \\
\text { Decision on Motion to Extend Time for Filing of Notice of Appeal }\end{array}$ & $+/-$ \\
\hline Banović & $\begin{array}{l}24 \text { Apr } 2002 \\
\text { Order Granting Extension of Time to Respond }\end{array}$ & + \\
\hline Blagojević \& Jokić & $\begin{array}{l}\text { 8 Jan } 2003 \\
\text { Decision on Accused Blagojevic's Request for Extension of Time to File Defence Pre-trial Brief }\end{array}$ & - \\
\hline Blagojević \& Jokić & $\begin{array}{l}17 \text { Jul } 2003 \\
\text { Decision on Independent Counsel's Request for Extension of Time to File Request for Certifica- } \\
\text { tion (Rule 73) }\end{array}$ & + \\
\hline Blagojević \& Jokić & $\begin{array}{l}8 \text { Sept } 2003 \\
\text { Decision on Accused Dragan Jokic's Request for Extension of Time to File Defence Pre-trial } \\
\text { Brief }\end{array}$ & - \\
\hline Blagojević \& Jokić & $\begin{array}{l}27 \text { Mar } 2003 \\
\text { Decision on Accused Jokic's Motion for Extension of Time in which to File a Response to Prose- } \\
\text { cution Rule } 92 \text { bis and Rule } 94 \text { bis Motions }\end{array}$ & - \\
\hline Blagojević \& Jokić & $\begin{array}{l}14 \text { Apr } 2005 \\
\text { Decision on Vidoje Blagojevic's Motion for Extension of Time in Which to File his Notice of Ap- } \\
\text { peal and on Dragan Jokic's Motion for Extension of Time in Which to File his Appeal Brief }\end{array}$ & + \\
\hline Blagojević \& Jokić & $\begin{array}{l}\text { 21 Jul } 2005 \\
\text { Decision on Blagojevic's and Jokic's Motions for Extension of Time to File Their Appeal Brief }\end{array}$ & + \\
\hline Blagojević \& Jokić & $\begin{array}{l}15 \text { Feb } 2005 \\
\text { Decision on Defence Motion for Extension of Time in Which to File the Defence Notice of Ap- } \\
\text { peal }\end{array}$ & $+1-$ \\
\hline Blagojević \& Jokić & $\begin{array}{l}6 \text { Dec } 2005 \\
\text { Decision on Prosecution's Motion to Extend Word Limit of Consolidated Response Brief }\end{array}$ & - \\
\hline Blaškić & $\begin{array}{l}26 \text { Sept } 2000 \\
\text { Decision on the Appellant's Motions for the Production of Material, Suspension or Extension of } \\
\text { the Briefing Schedule, and additional Filings }\end{array}$ & $+1-$ \\
\hline Blaškić & $\begin{array}{l}7 \text { Nov } 2001 \\
\text { Decision on Appellant's Motion to Extend Deadline for Filing Appellant's Brief and Request for } \\
\text { Authorization to Exceed the Page Limit for Appellant's Brief }\end{array}$ & + \\
\hline Blaškić & $\begin{array}{l}\text { 29 Jan } 2002 \\
\text { Decision on Prosecution's Request for an Extension of Time and for Authorisation to Exceed } \\
\text { the Page Limit for its Response to the Appellant's Brief }\end{array}$ & + \\
\hline Blaškić & $\begin{array}{l}16 \text { Oct } 2002 \\
\text { Decision on Appellants Dario Kordic and Mario Cerkez's Supplemental Request for Assistance } \\
\text { in Gaining Access to non-public post Trial Submissions, Appellate Briefs, and Hearing Tran- } \\
\text { scripts filed in The Prosecutor v. Tihomir Blaskic }\end{array}$ & - \\
\hline Blaškić & $\begin{array}{l}24 \text { Nov } 2003 \\
\text { Decision on Appellant's Application for Extension of Page Limits for Supplementary Brief on } \\
\text { Appeal }\end{array}$ & + \\
\hline Boškoski \& Tarčulovski & $\begin{array}{l}23 \text { Apr } 2008 \\
\text { Decision on joint defence motion for extension of word-limit for final trial brief }\end{array}$ & +- \\
\hline Boškoski \& Tarčulovski & $\begin{array}{l}16 \text { Oct } 2008 \\
\text { Decision on johan Tarčulovski's motion for extension of time to file appeal brief }\end{array}$ & - \\
\hline Boškoski \& Tarčulovski & $\begin{array}{l}22 \text { Oct } 2008 \\
\text { Decision on Johan Tarčulovski's second motion for extention of time to file appeal brief }\end{array}$ & + \\
\hline Boškoski \& Tarčulovski & $\begin{array}{l}16 \text { Apr } 2009 \\
\text { Decision on Boškoski defence corrigendum to respondent brief }\end{array}$ & - \\
\hline Boškoski \& Tarčulovski & $\begin{array}{l}16 \text { Apr } 2009 \\
\text { Decision on Tarčulovski's urgent motion for extension of time to file his reply brief }\end{array}$ & - \\
\hline Bralo & $\begin{array}{l}13 \text { Feb } 2007 \\
\text { Decision on Miroslav Bralo's motion for extension of time to file reply brief in relation to his } \\
\text { second supplemental brief }\end{array}$ & + \\
\hline Brđanin & $\begin{array}{l}3 \text { Oct } 2002 \\
\text { Decision on "request for certification to appeal against the decision to separate trials" and on } \\
\text { "motion to extend time-limit for filing brief in support of request for certification to appeal" }\end{array}$ & - \\
\hline
\end{tabular}




\begin{tabular}{|c|c|c|}
\hline Trial & Language-related request & $+/-$ \\
\hline Brđanin & $\begin{array}{l}\text { 30 Mar } 2004 \\
\text { Decision on Prosecution's Request for Variation of Page Limit on Final Brief }\end{array}$ & + \\
\hline Brđanin & $\begin{array}{l}31 \text { Mar } 2004 \\
\text { Further Decision on Variation of Page Limit on Final Brief }\end{array}$ & + \\
\hline Brđanin & $\begin{array}{l}5 \text { May } 2005 \\
\text { Decision on Motion to Extend Date for Filing Appellant's Brief }\end{array}$ & + \\
\hline Brđanin & $\begin{array}{l}22 \text { Jun } 2005 \\
\text { Decision on Appellant's Motion for Extension of Time to File a Consolidated Brief and for En- } \\
\text { largement of Page Limit }\end{array}$ & + \\
\hline Brđanin & $\begin{array}{l}20 \mathrm{Jul} 2005 \\
\text { Decision on Motion for Extension of Time for the Filing of Prosecution Response Brief }\end{array}$ & + \\
\hline Delić & $\begin{array}{l}10 \text { Oct } 2007 \\
\text { Decision on defence motion requesting time to prepare case }\end{array}$ & $+/-$ \\
\hline Delić & $\begin{array}{l}29 \text { Sept } 2005 \\
\text { Decision on Prosecution's Request for Additional Time to Seek Leave to Amend the Indictment }\end{array}$ & + \\
\hline Delić & $\begin{array}{l}\text { 20 Sept } 2006 \\
\text { Decision on the Prosecution motion to exceed word limits imposed by the Practice Direction } \\
\text { On The Length Of Briefs And Motions }\end{array}$ & + \\
\hline Delić & $\begin{array}{l}26 \text { Sept } 1996 \\
\text { Decision on the prosecution motion to exceed word limits imposed by the Practice Direction } \\
\text { On The Length Of Briefs And Motions }\end{array}$ & + \\
\hline Delić & $\begin{array}{l}8 \text { May } 2008 \\
\text { Decision on urgent defence motion to exceed word limit for final trial brief }\end{array}$ & + \\
\hline Deronjić & $\begin{array}{l}\text { 13 Jan } 2004 \\
\text { Decision on Prosecution Motion for Extention of Pages }\end{array}$ & + \\
\hline Deronjić & $\begin{array}{l}16 \text { Sept } 2004 \\
\text { Decision Denying Extension of Time }\end{array}$ & - \\
\hline Deronjić & $\begin{array}{l}28 \text { Sept } 2004 \\
\text { Corrigendum to Decision Denying Extension of Time }\end{array}$ & - \\
\hline Deronjić & $\begin{array}{l}11 \text { May } 2004 \\
\text { Order Granting Extension of Time }\end{array}$ & $+/-$ \\
\hline Đorđević & $\begin{array}{l}16 \text { Mar } 2011 \\
\text { Decision on Vlastimir Dordević's motion for an extension of time to file a notice of appeal }\end{array}$ & + \\
\hline Đorđević & $\begin{array}{l}16 \text { Apr } 2008 \\
\text { Decision on Vlastimir Djordevićs motion for extension of time to file objections pursuant to } \\
\text { rule } 94 \text { bis (b), }\end{array}$ & + \\
\hline Đorđević & $\begin{array}{l}18 \text { Oct } 2012 \\
\text { Order setting a time limit to file any motion seeking a variation of the grounds of appeal follow- } \\
\text { ing translation of the trial udgement into } \mathrm{B} / \mathrm{C} / \mathrm{S} \text { language }\end{array}$ & + \\
\hline Đorđević & $\begin{array}{l}17 \text { Oct } 2008 \\
\text { Order of translation of the prosecution's pre-trial brief }\end{array}$ & + \\
\hline Galić & $\begin{array}{l}16 \text { Mar } 2005 \\
\text { Decision on Request for Extension of Page Limit for the Prosecution's Response to Galic's Third } \\
\text { Rule } 115 \text { Motion }\end{array}$ & - \\
\hline Galić & $\begin{array}{l}21 \text { Feb } 2005 \\
\text { Decision on Prosecution's Requests for Extensions of Time and of Page Limit for the Response }\end{array}$ & - \\
\hline Galić & $\begin{array}{l}7 \text { Feb } 2005 \\
\text { Decision on Prosecution's Request for Extension of Time and for an Order Requiring Official } \\
\text { Translations of Documents Attached to the Defence Third Motion for Additional Evidence }\end{array}$ & + \\
\hline Galić & $\begin{array}{l}17 \text { Sept } 2004 \\
\text { Decision on Defence's Motion to Increase the Page Limit and Extend the Time Limit }\end{array}$ & - \\
\hline Galić & $\begin{array}{l}21 \mathrm{Jul} 2004 \\
\text { Decision on Prosecution's Request for an Extension of Pages }\end{array}$ & - \\
\hline Galić & $\begin{array}{l}28 \text { Jun } 2004 \\
\text { Decision on Prosecution's Request for Extension of Time to File Response to Defence Addi- } \\
\text { tional Evidence Motion of } 18 \text { June } 2004\end{array}$ & + \\
\hline Galić & $\begin{array}{l}2 \text { Sept } 2004 \\
\text { Decision on "Urgent Prosecution Motion for an Order Requiring the Appellant to Re-file his Ap- } \\
\text { peal Brief and Request for Leave to Exceed Word-limit for Motion" }\end{array}$ & $+/-$ \\
\hline
\end{tabular}




\begin{tabular}{|c|c|c|}
\hline Trial & Language-related request & $+/-$ \\
\hline Galić & $\begin{array}{l}19 \text { May } 2004 \\
\text { Decision on Defence's Request for Leave to Exceed Page Limit in Defence's Appellant's Brief }\end{array}$ & - \\
\hline Hadžić & $\begin{array}{l}26 \text { Jun } 2012 \\
\text { Decision on prosecution motion for extension of word limit for pre-trial brief }\end{array}$ & + \\
\hline Hadžić & $\begin{array}{l}25 \text { Sept } 2012 \\
\text { Decision on timing of rule } 92 \text { ter motions for three delayed disclosure witnesses }\end{array}$ & + \\
\hline $\begin{array}{l}\text { Hadžihasanović \& Ku- } \\
\text { bura }\end{array}$ & $\begin{array}{l}11 \text { Sept } 2001 \\
\text { Decision on Request for Extension of Deadline }\end{array}$ & + \\
\hline $\begin{array}{l}\text { Hadžihasanović \& Ku- } \\
\text { bura }\end{array}$ & $\begin{array}{l}2 \text { Oct } 2003 \\
\text { Decision on Prosecution's Application Seeking Authorization to Exceed the Page Limits of the } \\
\text { Pre-trial Brief }\end{array}$ & + \\
\hline $\begin{array}{l}\text { Hadžihasanović \& Ku- } \\
\text { bura }\end{array}$ & $\begin{array}{l}24 \text { Jan } 2002 \\
\text { Order on Extension of Time and Clarification of Filing Issue }\end{array}$ & + \\
\hline $\begin{array}{l}\text { Hadžihasanović \& Ku- } \\
\text { bura }\end{array}$ & $\begin{array}{l}5 \text { Sept } 2003 \\
\text { Decision on Joint Defence Motion for Access to Confidential Supporting Material, Filings, Tran- } \\
\text { scripts and Exhibits in the Rajic Case }\end{array}$ & - \\
\hline $\begin{array}{l}\text { Hadžihasanović \& Ku- } \\
\text { bura }\end{array}$ & $\begin{array}{l}7 \text { Nov } 2003 \\
\text { Decision on Joint Defence Motion by Enver Hadzihasanovic and Amir Kubura for Access to All } \\
\text { Confidential Material, Filings, Transcripts and Exhibits in the Naletilic and Martinovic Case }\end{array}$ & $+/-$ \\
\hline Halilović & $\begin{array}{l}8 \text { Oct } 2003 \\
\text { Decision on Motion for Extension of Pages }\end{array}$ & + \\
\hline Halilović & $\begin{array}{l}23 \text { Mar } 2006 \\
\text { Decision on Motion for Extension of Time to File Respondent's Brief }\end{array}$ & + \\
\hline Halilović & $\begin{array}{l}8 \text { Oct } 2003 \\
\text { Decision on Motion for Extension of Pages }\end{array}$ & + \\
\hline Halilović & $\begin{array}{l}19 \text { Sept } 2005 \\
\text { Decision on Prosecution's Motions to Strike Halilovic's Redacted Final Trial Brief and to Strike } \\
\text { Halilovic's “Defence Final Trial Brief public Redacted Version” }\end{array}$ & - \\
\hline Halilović & $\begin{array}{l}25 \text { May } 2005 \\
\text { Decision on Defence Motion for Disclosure of Circumstances of Translation and Replacing of } \\
\text { Flawed Exhibit and Failure of Prosecution to Give Notice Thereof }\end{array}$ & $+/-$ \\
\hline Haradinaj et al & $\begin{array}{l}2 \text { May } 2005 \\
\text { Order on Extension of Time }\end{array}$ & + \\
\hline Haradinaj et al & $\begin{array}{l}21 \text { Apr } 2005 \\
\text { Further Order on Application for Extension of Time }\end{array}$ & + \\
\hline Haradinaj et al & $\begin{array}{l}14 \text { Apr } 2005 \\
\text { Order on Application for Extension of Time }\end{array}$ & + \\
\hline Haradinaj et al & $\begin{array}{l}5 \text { May } 2005 \\
\text { Decision on Prosecution's Urgent Application for Authorisation to Exceed Page Limit for Re- } \\
\text { sponses }\end{array}$ & + \\
\hline Haradinaj et al & $\begin{array}{l}15 \text { Dec } 2011 \\
\text { Decision on Prosecution's motion relating to English translations of exhibits associated with } \\
\text { Bislim Zyrapi's written evidence }\end{array}$ & $+/-$ \\
\hline Jelisić & $\begin{array}{l}15 \text { Sept } 2000 \\
\text { Decision on Motion requesting Extension of Time }\end{array}$ & + \\
\hline Jokić & $\begin{array}{l}7 \text { May } 2004 \\
\text { Decision Denying Extension of Time }\end{array}$ & - \\
\hline Karadžić & $\begin{array}{l}2 \text { Sept } 2009 \\
\text { Decision on accused's motion for extension of time to respond to rule } 92 \text { bis motion for expert } \\
\text { witnesses and to exclude the reports of Kathryn Barr }\end{array}$ & $+/-$ \\
\hline Karadžić & $\begin{array}{l}\text { 9 Jun } 2009 \\
\text { Decision on accused's motion for extension of time and reclassification: OTP motion concern- } \\
\text { ing member of humanitarian organization }\end{array}$ & - \\
\hline Karadžić & $\begin{array}{l}22 \text { Apr } 2009 \\
\text { Decision on accused motion for extension of time and to exceed word limit: Holbrooke agree- } \\
\text { ment motion }\end{array}$ & $+/-$ \\
\hline Karadžić & $\begin{array}{l}17 \text { Apr } 2009 \\
\text { Decision on motion for extension of time to respond to the second and third motions for judi- } \\
\text { cial notice of adjudicated facts }\end{array}$ & $+/-$ \\
\hline
\end{tabular}




\begin{tabular}{|c|c|c|}
\hline Trial & Language-related request & $+/-$ \\
\hline Karadžić & $\begin{array}{l}27 \text { Mar } 2009 \\
\text { Decision on prosecution's motion for an extension of time to file interim pre-trial brief and to } \\
\text { exceed the word limit }\end{array}$ & + \\
\hline Karadžić & $\begin{array}{l}18 \text { Jun } 2009 \\
\text { Order following on rule } 65 \text { ter meeting and decision on motions for extension of time }\end{array}$ & $+/-$ \\
\hline Karadžić & $\begin{array}{l}27 \text { Jan } 2009 \\
\text { Decision on motion for extension of time }\end{array}$ & $+/-$ \\
\hline Karadžić & $\begin{array}{l}2 \text { Jul } 2010 \\
\text { Decision on accused's motion for additional time to prepare cross-examination of Momčilo } \\
\text { Mandić }\end{array}$ & - \\
\hline Karadžić & $\begin{array}{l}22 \text { Apr } 2009 \\
\text { Decision on accused motion for extension of time and to exceed word limit: Holbrooke agree- } \\
\text { ment motion }\end{array}$ & $+/-$ \\
\hline Karadžić & $\begin{array}{l}15 \text { Apr } 2009 \\
\text { Decision on accused's motion to exceed word limit: access to confidential material in com- } \\
\text { pleted cases }\end{array}$ & + \\
\hline Karadžić & $\begin{array}{l}\text { 30 Mar } 2009 \\
\text { Decision on accused's second motion seeking authorization to exceed word limit }\end{array}$ & + \\
\hline Karadžić & $\begin{array}{l}27 \text { Mar } 2009 \\
\text { Decision on prosecution's motion for an extension of time to file interim pre-trial brief and to } \\
\text { exceed the word limit }\end{array}$ & + \\
\hline Karadžić & $\begin{array}{l}23 \text { Mar } 2009 \\
\text { Decision on accused's motion seeking authorization to exceed the word limit - preliminary mo- } \\
\text { tion on JCE III - Specific intent crimes }\end{array}$ & + \\
\hline Karadžić & $\begin{array}{l}9 \text { Mar } 2009 \\
\text { Decision on accused's motion seeking authorization to exceed the word limit and clarification } \\
\text { of due date for preliminary motions }\end{array}$ & + \\
\hline Karadžić & $\begin{array}{l}17 \text { Feb } 2009 \\
\text { Decision on prosecution motion to exceed the word limit for a motion }\end{array}$ & + \\
\hline Karadžić & $\begin{array}{l}21 \text { Apr } 2009 \\
\text { Order for expedited response to accused's motion for extension of time and to exceed word } \\
\text { limit: Holbrooke agreement motion }\end{array}$ & + \\
\hline Karadžić & $\begin{array}{l}25 \text { Mar } 2009 \\
\text { Order for expedited response to prosecution's motion to exceed the word limit }\end{array}$ & + \\
\hline Karadžić & $\begin{array}{l}25 \text { Mar } 2009 \\
\text { Scheduling order for expedited response to prosecution's motion for an extension of time to file } \\
\text { interim pre-trial brief and to exceed the word limit }\end{array}$ & + \\
\hline Karadžić & $\begin{array}{l}13 \text { Feb } 2009 \\
\text { Scheduling order for expedited response to prosecution motion seeking authorisation to exceed } \\
\text { the word limit for a motion }\end{array}$ & + \\
\hline Karadžić & $\begin{array}{l}\text { 3 Jul } 2013 \\
\text { Decision on the accused's motion for revision of trial transcripts }\end{array}$ & - \\
\hline Karadžić & $\begin{array}{l}18 \text { Jun } 2010 \\
\text { Decision on prosecution's motion and submission pursuant to "Decision on prosecution's } \\
\text { fourth motion for admission of statements and transcripts of evidence in lieu of viva voce testi- } \\
\text { mony pursuant to rule } 92 \text { bis (Sarajevo siege witnesses)" }\end{array}$ & $+/-$ \\
\hline Karadžić & $\begin{array}{l}18 \text { Mar } 2010 \\
\text { Decision on prosecution's second motion for admission of statements and transcripts of evi- } \\
\text { dence in lieu of viva voce Testimony pursuant to rule } 92 \text { bis(witnesses ark municipalities }\end{array}$ & $+/-$ \\
\hline Karadžić & $\begin{array}{l}5 \text { Mar } 2010 \\
\text { Decision on prosecution's fourth motion for admission of statements and transcripts of evi- } \\
\text { dence in lieu of viva voce testimony pursuant to Rule } 92 \text { bis Sarajevo siege witnesses }\end{array}$ & $+/-$ \\
\hline Karadžić & $\begin{array}{l}23 \text { Dec } 2009 \\
\text { Corrigendum on decision on prosecution's seventh motion for admission of transcripts of evi- } \\
\text { dence in lieu of viva voce testimony pursuant to rule } 92 \text { bis: delayed disclosure witnesses }\end{array}$ & + \\
\hline Karadžić & $\begin{array}{l}16 \text { Nov } 2009 \\
\text { Corrigendum to decision on prosecution's first motion for admission of statements and tran- } \\
\text { scripts of evidence in lieu of viva voce testimony pursuant to rule } 92 \text { bis (witnesses for eleven } \\
\text { municipalities) }\end{array}$ & + \\
\hline
\end{tabular}




\begin{tabular}{|c|c|c|}
\hline Trial & Language-related request & $+1-$ \\
\hline Karadžić & $\begin{array}{l}\text { 10 Nov } 2009 \\
\text { Decision on prosecution's first motion for admission of statements and transcripts of evidence } \\
\text { in lieu of jilva voce testimony pursuant to rule } 92 \text { bis witnesses for eleven municipalities) }\end{array}$ & $+/-$ \\
\hline Karadžić & $\begin{array}{l}15 \text { Oct } 2009 \text { Decision on prosecution's third motion for admission of statements and } \\
\text { transcripts of evidence in lieu of wva voce testimony pursuant to rule } 92 \text { bis (witnesses for Sara- } \\
\text { jevo municipality) }\end{array}$ & + \\
\hline Karadžić & $\begin{array}{l}15 \text { Oct } 2009 \text { Decision on prosecution's third motion for admission of statements and } \\
\text { transcripts of evidence in lieu of wva voce testimony pursuant to rule } 92 \text { bis (witnesses for Sara- } \\
\text { jevo municipality) }\end{array}$ & + \\
\hline Karadžić & $\begin{array}{l}25 \text { Sept } 2008 \text { Decision on the accused's request that all materials, including transcripts, } \\
\text { be disclosed to him in Serbian and Cyrillic script }\end{array}$ & $+1-$ \\
\hline Karadžić & $\begin{array}{l}3 \text { Oct } 2014 \\
\text { Order to Redact the Public Transcript and Public Broadcast of a hearing }\end{array}$ & + \\
\hline Karadžić & $\begin{array}{l}1 \text { Oct } 2014 \\
\text { Order to Redact the Public Transcript and Public Broadcast of the Hearing }\end{array}$ & + \\
\hline Karadžić & $\begin{array}{l}17 \text { Dec } 2013 \\
\text { Order to redact the public transcript and the public broadcast of a hearing }\end{array}$ & + \\
\hline Karadžić & $\begin{array}{l}6 \text { Dec } 2013 \\
\text { Order to Redact the Public Transcript and the Public Broadcast of a Hearing of o5/12/2013 }\end{array}$ & + \\
\hline Karadžić & $\begin{array}{l}5 \text { Aug } 2013 \\
\text { Order to redact the public transcript and the public broadcast of a hearing }\end{array}$ & + \\
\hline Karadžić & $\begin{array}{l}7 \text { Feb } 2013 \\
\text { Order to redact the public transcript and the public broadcast of a hearing }\end{array}$ & + \\
\hline Karadžić & $\begin{array}{l}20 \text { Dec } 2012 \\
\text { Order to redact the public transcript and the public broadcast of a hearing }\end{array}$ & + \\
\hline Karadžić & $\begin{array}{l}17 \text { Dec } 2012 \\
\text { Order to redact the public transcript and the public broadcast of a hearing }\end{array}$ & + \\
\hline Karadžić & $\begin{array}{l}6 \text { Dec } 2012 \\
\text { Order to redact the public transcript and the public broadcast of a hearing }\end{array}$ & + \\
\hline Karadžić & $\begin{array}{l}29 \text { Nov } 2012 \\
\text { Order to redact the public transcript and the public broadcast of a hearing }\end{array}$ & + \\
\hline Karadžić & $\begin{array}{l}21 \text { Nov } 2012 \\
\text { Further Order for the Temporary Transfer of a Detained Witness }\end{array}$ & + \\
\hline Karadžić & $\begin{array}{l}3 \text { Sept } 2012 \\
\text { Order to Redact the Public Transcript and the Public Broadcast of a Hearing }\end{array}$ & + \\
\hline Karadžić & $\begin{array}{l}8 \text { May } 2012 \\
\text { Order to Redact the Public Transcript and the Public Broadcast of a Hearing }\end{array}$ & + \\
\hline Karadžić & $\begin{array}{l}24 \text { Nov } 2011 \\
\text { Order to Redact the Public Transcript and the Public Broadcast of a Hearing }\end{array}$ & + \\
\hline Karadžić & $\begin{array}{l}3 \text { Nov } 2011 \\
\text { Order to redact the Public French Transcript. and the public broadcast of a hearing }\end{array}$ & + \\
\hline Karadžić & $\begin{array}{l}28 \text { Oct } 2011 \\
\text { Order to redact the public transcript and the public broadcast of a hearing }\end{array}$ & + \\
\hline Karadžić & $\begin{array}{l}18 \text { Aug } 2011 \\
\text { Order to redact the public transcript and the public broadcast of a hearing }\end{array}$ & + \\
\hline Karadžić & $\begin{array}{l}\text { 30 Jun } 2011 \\
\text { Order to redact the public transcript and the public broadcast of a hearing }\end{array}$ & + \\
\hline Karadžić & $\begin{array}{l}\text { 30 Jun } 2011 \\
\text { Order to redact the public transcript and the public broadcast of a hearing }\end{array}$ & + \\
\hline Karadžić & $\begin{array}{l}14 \text { Mar } 2011 \\
\text { Order to redact the public transcript and the public broadcast of a hearing }\end{array}$ & + \\
\hline Karadžić & $\begin{array}{l}1 \text { Feb } 2011 \\
\text { Order to redact the public transcript and the public broadcast of a hearing }\end{array}$ & + \\
\hline Karadžić & $\begin{array}{l}6 \text { Dec } 2010 \\
\text { Order in relation to exhibits marked for identification pending English translation }\end{array}$ & + \\
\hline Karadžić & $\begin{array}{l}23 \text { Apr } 2010 \\
\text { Order to redact the public transcript and the public broadcast of a hearing }\end{array}$ & + \\
\hline Karadžić & 21 Apr 2010 & + \\
\hline
\end{tabular}




\begin{tabular}{|c|c|c|}
\hline Trial & Language-related request & $+/-$ \\
\hline & Order to redact the public transcript and the public broadcast of a hearing & \\
\hline Karadžić & $\begin{array}{l}16 \text { Feb } 2010 \\
\text { Order to redact the public transcript and the public broadcast of a hearing }\end{array}$ & + \\
\hline Karadžić & $\begin{array}{l}19 \text { Sept } 2014 \\
\text { Decision on Motion to Strike Prosecution Final Brief }\end{array}$ & - \\
\hline Kordić \& Čerkez & $\begin{array}{l}2 \text { Jul } 2001 \\
\text { Decision on Second Motions to extend Time for filing Appellant's Briefs }\end{array}$ & - \\
\hline Kordić \& Čerkez & $\begin{array}{l}9 \text { Jul } 2003 \\
\text { Decision on Application by Cerkez for Extensions of Time and Page Limits }\end{array}$ & + \\
\hline Kordić \& Čerkez & $\begin{array}{l}24 \text { Jun } 2003 \\
\text { Decision on Application by Prosecution for Leave to File Further Response and for Extensions } \\
\text { of Time and Page Limits }\end{array}$ & + \\
\hline Kordić \& Čerkez & $\begin{array}{l}29 \text { May } 2003 \\
\text { Decision on Application by Cerkez for Extensions of Time and Page Limits }\end{array}$ & + \\
\hline Kordić \& Čerkez & $\begin{array}{l}8 \text { May } 2003 \\
\text { Order on Extension of Pages }\end{array}$ & + \\
\hline Kordić \& Čerkez & $\begin{array}{l}16 \text { Oct } 2002 \\
\text { Decision on Appelants Dario Kordic and Mario Cerkez's Supplemental Request for Assistance } \\
\text { in Gaining Access to non-public post Trial Submissions, Appellate briefs, and Hearing Tran- } \\
\text { scripts filed in The Prosecutor v. Tihomir Blaskic }\end{array}$ & - \\
\hline Kordić \& Čerkez & $\begin{array}{l}26 \text { Sept } 2001 \\
\text { Decision Authorising Reply Brief to Exceed the Limit Imposed by the Practice Direction on the } \\
\text { Length of Briefs and Motions }\end{array}$ & + \\
\hline Kordić \& Čerkez & $\begin{array}{l}30 \text { Aug } 2001 \\
\text { Decision authorising Respondent's Brief to exceed the Limit impose by the Practice Direction } \\
\text { on the Length of Briefs and Motions and granting an Extension of Time to file Brief }\end{array}$ & + \\
\hline Kordić \& Čerkez & $\begin{array}{l}29 \text { Aug } 2001 \\
\text { Decision authorising Appellant's Briefs to exceed the Limit imposed by the Practice Direction } \\
\text { on the Length of Briefs and Motions }\end{array}$ & + \\
\hline Kordić \& Čerkez & $\begin{array}{l}11 \text { May } 2001 \\
\text { Decision on Motions to extend Time for filing Appellant's Briefs }\end{array}$ & + \\
\hline Kordić \& Čerkez & $\begin{array}{l}1 \text { Apr } 1999 \\
\text { Order on Motion to Enlarge Time concerning Translations }\end{array}$ & + \\
\hline Kordić \& Čerkez & $\begin{array}{l}\text { 14 Jun } 2000 \\
\text { Order releasing Transcript and granting protective Measures }\end{array}$ & + \\
\hline Kordić \& Čerkez & $\begin{array}{l}16 \text { Oct } 2002 \\
\text { Decision on Appelants Dario Kordic and Mario Cerkez's Supplemental Request for Assistance } \\
\text { in Gaining Access to non-public post Trial Submissions, Appellate briefs, and Hearing Tran- } \\
\text { scripts filed in The Prosecutor v. Tihomir Blaskic }\end{array}$ & - \\
\hline Kordić \& Čerkez & $\begin{array}{l}19 \mathrm{Jul} 2002 \\
\text { Order on Pasko Ljubicic's Motion for Access to Confidential supporting material, transcripts } \\
\text { and Exhibits in the Kordic and Cerkez Case }\end{array}$ & + \\
\hline Kordić \& Čerkez & $\begin{array}{l}\text { 19 Jul } 2002 \\
\text { Order on Pasko Ljubicic's Motion for Access to Confidential supporting material, transcripts } \\
\text { and Exhibits in the Kordic and Cerkez Case }\end{array}$ & + \\
\hline Kordić \& Čerkez & $\begin{array}{l}\text { 4 Apr } 2003 \\
\text { Order on Application by Mario Cerkez to Exceed Page Limit }\end{array}$ & + \\
\hline Kovačević & $\begin{array}{l}14 \text { Nov } 2001 \\
\text { Decision on Prosection's Motion for Variation of length of Pre-trial Brief }\end{array}$ & - \\
\hline Krajišnik & $\begin{array}{l}7 \text { Jan } 2008 \\
\text { Decision on request by Momcilo Krajisnik for extension of time to comply with appeal brief } \\
\text { word limit }\end{array}$ & + \\
\hline Krajišnik & $\begin{array}{l}3 \text { Dec } 2007 \\
\text { Order to comply with appeal brief word limit }\end{array}$ & + \\
\hline Krajišnik & $\begin{array}{l}31 \text { Jul } 2007 \\
\text { Order on amicus curiaes motions regarding word limits and ordering of his appeal brief }\end{array}$ & + \\
\hline Krajišnik & $\begin{array}{l}\text { 1 Feb } 2007 \\
\text { Decision on 'Urgent motion for extension of time for filing notice of appeal pending translation } \\
\text { of the judgment into the language of the convicted person' }\end{array}$ & - \\
\hline
\end{tabular}




\begin{tabular}{|c|c|c|}
\hline Trial & Language-related request & $+/-$ \\
\hline Krajišnik & $\begin{array}{l}18 \mathrm{Jul} 2008 \\
\text { Decision of urgent requests to extend word limits }\end{array}$ & + \\
\hline Krajišnik & $\begin{array}{l}3 \text { Nov } 2008 \\
\text { Order to redact the public transcript and the public broadcast of a hearing }\end{array}$ & + \\
\hline Krajišnik & $\begin{array}{l}27 \text { Jul } 2001 \\
\text { Decision on Prosecution's Motion for Extension of Limit of Length of Pre-Trial Brief }\end{array}$ & + \\
\hline Krnojelac & $\begin{array}{l}16 \text { Sept } 2002 \\
\text { Decision on Request for Extension of Time }\end{array}$ & + \\
\hline Krsitć & $\begin{array}{l}12 \text { May } 2003 \\
\text { Order on Extension of Pages }\end{array}$ & + \\
\hline Krstić & $\begin{array}{l}5 \text { Nov } 2001 \\
\text { Order Granting Extension of Time }\end{array}$ & + \\
\hline Krstić & $\begin{array}{l}17 \text { Dec } 2001 \\
\text { Decision on Application by Appellant to Suspend Briefing Schedule or for Extension of Time }\end{array}$ & - \\
\hline Krstić & $\begin{array}{l}5 \text { Nov } 2001 \\
\text { Order Granting Extension of Time }\end{array}$ & + \\
\hline Kunarac et al & $\begin{array}{l}7 \text { Sept } 2001 \\
\text { Order on Page Limits }\end{array}$ & + \\
\hline Kunarac et al & $\begin{array}{l}10 \text { Jul } 2001 \\
\text { Decision on Joint Request for Authorisation to exceed prescribed Page Limits }\end{array}$ & - \\
\hline Kunarac et al & $\begin{array}{l}7 \text { Sept } 2001 \\
\text { Order on Page Limits }\end{array}$ & + \\
\hline Kunarac et al & $\begin{array}{l}3 \text { Sept } 2001 \\
\text { Decision on Prosecution Request for Extension of time, Notice of filing Respondent briefs over } \\
\text { 10o pages and, if necessary Motion to Exceed page limit of Prosecution's response briefs }\end{array}$ & + \\
\hline Kupreškić et al & $\begin{array}{l}13 \text { Dec } 2000 \\
\text { Order on Motions for Extension of Time }\end{array}$ & + \\
\hline Kupreškić et al & $\begin{array}{l}28 \text { Sept } 2000 \\
\text { Order on Application for Extension Time }\end{array}$ & + \\
\hline Kupreškić et al & $\begin{array}{l}18 \text { Apr } 2000 \\
\text { Order granting Extension of Time and Scheduling Order }\end{array}$ & + \\
\hline Kupreškić et al & $\begin{array}{l}3 \text { Nov } 2003 \\
\text { on Request for Extension of Time }\end{array}$ & + \\
\hline Kupreškić et al & $\begin{array}{l}13 \text { Dec } 2000 \\
\text { Order on Motions for Extension of Time }\end{array}$ & + \\
\hline Kupreškić et al & $\begin{array}{l}27 \text { Jul } 1999 \\
\text { Order for Release of Transcript }\end{array}$ & + \\
\hline Kupreškić et al & $\begin{array}{l}\text { 10 May } 1999 \\
\text { Order (Release of Transcript) }\end{array}$ & + \\
\hline Kvočka et al & $\begin{array}{l}29 \text { Oct } 2002 \\
\text { Order Granting Extension of Time }\end{array}$ & + \\
\hline Kvočka et al & $\begin{array}{l}16 \text { Sept } 2003 \\
\text { Decision Granting Extensions of Time and Page Limits }\end{array}$ & + \\
\hline Kvočka et al & $\begin{array}{l}\text { 19 Jun } 2003 \\
\text { Decision on Application by Prosecution for Extensions of Time and Pages }\end{array}$ & + \\
\hline Kvočka et al & $\begin{array}{l}1 \text { Feb } 2002 \\
\text { Decision on Appellant Request for an Extension of Time }\end{array}$ & + \\
\hline Kvočka et al & $\begin{array}{l}2 \text { May } 2003 \\
\text { Order Granting Extension of Pages }\end{array}$ & + \\
\hline Kvočka et al & $\begin{array}{l}\text { 20 Mar } 2003 \\
\text { Order Granting Extension of Pages }\end{array}$ & + \\
\hline Kvočka et al & $\begin{array}{l}29 \text { Oct } 2002 \\
\text { Order Granting Extension of Time }\end{array}$ & + \\
\hline Kvočka et al & $\begin{array}{l}13 \text { Jun } 2001 \\
\text { Order for Correction of Transcript }\end{array}$ & + \\
\hline Kvočka et al & $\begin{array}{l}15 \text { Oct } 2002 \\
\text { Decision on Zoran Zigic's request to verify accuracy of translation }\end{array}$ & - \\
\hline Kvočka et al & 3 Oct 2002 & + \\
\hline
\end{tabular}




\begin{tabular}{|c|c|c|}
\hline Trial & Language-related request & $+1-$ \\
\hline & Decision on Zoran Zigic's Motion for Translation of Documents Relating to his Appeal & \\
\hline Kvočka et al & $\begin{array}{l}7 \text { Mar } 2002 \\
\text { Decision on Request by Zoran Zigic for Corrigenda of Transcript and Judgment }\end{array}$ & $+1-$ \\
\hline Kvočka et al & $\begin{array}{l}22 \text { Apr } 2002 \\
\text { Decision on Filing of Consolidated Respondent's Brief }\end{array}$ & - \\
\hline Kvočka et al & $\begin{array}{l}22 \text { Mar } 2002 \\
\text { Decision on Appellant Request for Variant of length of Appellant's Brief }\end{array}$ & + \\
\hline Kvočka et al & $\begin{array}{l}\text { 13 Jun } 2001 \\
\text { Order for Correction of Transcript }\end{array}$ & + \\
\hline Limaj et al & $\begin{array}{l}7 \text { May } 2004 \\
\text { Decision on Defence's Applications for Extension of Time to File Pre-trial Briefs and Order for } \\
\text { Filing of Expert Reports and Notice under Rule } 94 \text { bis }\end{array}$ & + \\
\hline Limaj et al & $\begin{array}{l}27 \text { Apr } 2006 \\
\text { Decision on "Motion on Behalf of Haradin Bala to Join 'Defence Application for Further Exten- } \\
\text { sion of Time to File Response to Prosecution Brief on Appeal' Filed on } 25 \text { April 2006" }\end{array}$ & - \\
\hline Limaj et al & $\begin{array}{l}26 \text { Apr } 2006 \\
\text { Decision On Defence Application For Further Extension Of Time To File Response To Prosecu- } \\
\text { tion Brief On Appeal }\end{array}$ & - \\
\hline Limaj et al & $\begin{array}{l}7 \text { Apr } 2005 \\
\text { Decision on Prosecution's Motion for Admission of Transcript Pursuant to Rule 92bis }\end{array}$ & + \\
\hline $\begin{array}{l}\text { Lukić Milan \& Lukić } \\
\text { Sredoje }\end{array}$ & $\begin{array}{l}\text { 3o Oct } 2009 \\
\text { Decision on Milan Lukic's motion seeking extension of time to file appeal brief and motion for } \\
\text { stay of proceedings }\end{array}$ & $+1-$ \\
\hline $\begin{array}{l}\text { Lukić Milan \& Lukić } \\
\text { Sredoje }\end{array}$ & $\begin{array}{l}5 \text { Jun } 2007 \\
\text { Decision on Milan Lukic's motion for leave to file an amended notice of Appeal and for an ex- } \\
\text { tension of time for filing his Appeal brief }\end{array}$ & $+1-$ \\
\hline $\begin{array}{l}\text { Lukić Milan \& Lukić } \\
\text { Sredoje }\end{array}$ & $\begin{array}{l}19 \text { Aug } 2009 \\
\text { Decision on Milan Lukic's urgent motion for enlargement of time to file notice of appeal }\end{array}$ & - \\
\hline $\begin{array}{l}\text { Lukić Milan \& Lukić } \\
\text { Sredoje }\end{array}$ & $\begin{array}{l}26 \text { Jun } 2012 \\
\text { Order for translation }\end{array}$ & + \\
\hline $\begin{array}{l}\text { Lukić Milan \& Lukić } \\
\text { Sredoje }\end{array}$ & $\begin{array}{l}19 \text { May } 2009 \\
\text { Order to redact the public transcript and the public broadcast of a hearing }\end{array}$ & + \\
\hline $\begin{array}{l}\text { Lukić Milan \& Lukić } \\
\text { Sredoje }\end{array}$ & $\begin{array}{l}19 \text { May } 2009 \\
\text { Order to redact the public transcript and the public broadcast of a hearing }\end{array}$ & + \\
\hline $\begin{array}{l}\text { Lukić Milan \& Lukić } \\
\text { Sredoje }\end{array}$ & $\begin{array}{l}19 \text { May } 2009 \\
\text { Order to redact the public transcript and the public broadcast of a hearing }\end{array}$ & + \\
\hline $\begin{array}{l}\text { Lukić Milan \& Lukić } \\
\text { Sredoje }\end{array}$ & $\begin{array}{l}19 \text { May } 2009 \\
\text { Order to redact the public transcript and the public broadcast of a hearing }\end{array}$ & + \\
\hline $\begin{array}{l}\text { Lukić Milan \& Lukić } \\
\text { Sredoje }\end{array}$ & $\begin{array}{l}19 \text { May } 2009 \\
\text { Order to redact the public transcript and the public broadcast of a hearing }\end{array}$ & + \\
\hline $\begin{array}{l}\text { Lukić Milan \& Lukić } \\
\text { Sredoje }\end{array}$ & $\begin{array}{l}2 \text { Feb } 2009 \\
\text { Order to redact the public transcript and the public broadcast of a hearing }\end{array}$ & + \\
\hline $\begin{array}{l}\text { Lukić Milan \& Lukić } \\
\text { Sredoje }\end{array}$ & $\begin{array}{l}23 \text { Jan } 2009 \\
\text { Order to redact the public transcript and the public broadcast of a hearing }\end{array}$ & + \\
\hline $\begin{array}{l}\text { Lukić Milan \& Lukić } \\
\text { Sredoje }\end{array}$ & $\begin{array}{l}22 \text { Jan } 2009 \\
\text { Order to disclose portions of the transcript }\end{array}$ & + \\
\hline $\begin{array}{l}\text { Lukić Milan \& Lukić } \\
\text { Sredoje }\end{array}$ & $\begin{array}{l}16 \text { Jan } 2009 \\
\text { Order to redact the public transcript and the public broadcast of a hearing }\end{array}$ & + \\
\hline $\begin{array}{l}\text { Lukić Milan \& Lukić } \\
\text { Sredoje }\end{array}$ & $\begin{array}{l}12 \text { Nov } 2008 \\
\text { Order to redact the public transcript and the public broadcast of a hearing }\end{array}$ & + \\
\hline $\begin{array}{l}\text { Lukić Milan \& Lukić } \\
\text { Sredoje }\end{array}$ & $\begin{array}{l}12 \text { Nov } 2008 \\
\text { Order to redact the public transcript and the public broadcast of a hearing }\end{array}$ & + \\
\hline $\begin{array}{l}\text { Lukić Milan \& Lukić } \\
\text { Sredoje }\end{array}$ & $\begin{array}{l}2 \text { Oct } 2008 \\
\text { Order to redact the public transcript and the public broadcast of a hearing }\end{array}$ & + \\
\hline $\begin{array}{l}\text { Lukić Milan \& Lukić } \\
\text { Sredoje }\end{array}$ & $\begin{array}{l}5 \text { Sept } 2008 \\
\text { Order to redact the public transcript and the public broadcast of a hearing }\end{array}$ & + \\
\hline $\begin{array}{l}\text { Lukić Milan \& Lukić } \\
\text { Sredoje }\end{array}$ & $\begin{array}{l}25 \text { Aug } 2008 \\
\text { Order to redact the public transcript and the public broadcast of a hearing }\end{array}$ & + \\
\hline
\end{tabular}




\begin{tabular}{|c|c|c|}
\hline Trial & Language-related request & $+1-$ \\
\hline $\begin{array}{l}\text { Lukić Milan \& Lukić } \\
\text { Sredoje }\end{array}$ & $\begin{array}{l}4 \text { Aug } 2011 \\
\text { Further order on disclosure of portions of private/closed session transcripts }\end{array}$ & + \\
\hline $\begin{array}{l}\text { Lukić Milan \& Lukić } \\
\text { Sredoje }\end{array}$ & $\begin{array}{l}3 \text { Dec } 2010 \\
\text { Order regarding the alteration of the status of exhibits consisting of transcripts from other cases }\end{array}$ & + \\
\hline $\begin{array}{l}\text { Lukić Milan \& Lukić } \\
\text { Sredoje }\end{array}$ & $\begin{array}{l}28 \text { Jun } 2008 \\
\text { Order regarding the status of exhibits consisting of transcripts from other cases }\end{array}$ & + \\
\hline Martić & $\begin{array}{l}22 \text { Aug } 2005 \\
\text { Decision on Motion for Extension of Time (Submission No. 100) }\end{array}$ & $+1-$ \\
\hline Martić & $\begin{array}{l}31 \text { Oct } 2007 \\
\text { Decision on Motion for Extension of Time for Filing the Respondent's brief }\end{array}$ & $+1-$ \\
\hline Martić & $\begin{array}{l}21 \text { Sept } 2007 \\
\text { Corrigendum to decision on motion for extension of time and enlargement of word limit }\end{array}$ & + \\
\hline Martić & $\begin{array}{l}5 \text { May } 2004 \\
\text { Decision on Prosecution's Motion for Leave to File Pre-trial Brief of Sixty Pages }\end{array}$ & - \\
\hline Martić & $\begin{array}{l}\text { 13 Jan } 2006 \\
\text { Decision on Prosecution's Motions for Admission of Transcripts Pursuant to Rule } 92 \text { bis (d) and } \\
\text { of Expert Reports Pursuant to Rule } 94 \text { bis }\end{array}$ & + \\
\hline Martić & $\begin{array}{l}26 \text { May } 2004 \\
\text { Further Decision on Motion by the Defence of Milan Martic for Access to Confidential Tran- } \\
\text { scripts and Documents }\end{array}$ & + \\
\hline Martić & $\begin{array}{l}\text { 1 Mar } 2004 \\
\text { Decision on Motion by the Defence of Milan Martic for Access to Confidential Transcripts and } \\
\text { Documents }\end{array}$ & $+1-$ \\
\hline Martić & $\begin{array}{l}25 \text { Feb } 2004 \\
\text { Decision on Motion Filed by the Defence of Milan Martic for Access to Confidential Transcripts } \\
\text { and Documents }\end{array}$ & + \\
\hline Milošević, D. & $\begin{array}{l}11 \text { Aug } 2008 \\
\text { Decision on defence motion for extension of time to file appellate brief and to increase the } \\
\text { word limit }\end{array}$ & - \\
\hline Milošević, D. & $\begin{array}{l}22 \text { Feb } 2007 \\
\text { Decision on admission of written statements, transcripts and associated exhibits pursuant to } \\
\text { rule 92ter }\end{array}$ & + \\
\hline Milošević, D. & $\begin{array}{l}\text { 24 Jul } 2009 \\
\text { Order to redact the public transcript and the public broadcast of a hearing }\end{array}$ & + \\
\hline Milošević, D. & $\begin{array}{l}24 \text { Jul } 2009 \\
\text { Order to redact the public transcript and the public broadcast of a hearing }\end{array}$ & + \\
\hline Milošević, D. & $\begin{array}{l}23 \text { Nov } 2007 \\
\text { Order to redact the public transcript and the public broadcast of a hearing }\end{array}$ & + \\
\hline Milošević, D. & $\begin{array}{l}14 \text { Nov } 2007 \\
\text { Order to redact the public transcript and the public broadcast of a hearing }\end{array}$ & + \\
\hline Milošević, D. & $\begin{array}{l}16 \text { Dec } 2005 \\
\text { Order on Guidelines for Drawing Up the List of Witnesses and Exhibits and Order to Translate } \\
\text { the Witness Statements }\end{array}$ & + \\
\hline Milošević, S. & $\begin{array}{l}14 \text { Feb } 2006 \\
\text { Decision on Assigned Counsel Request for an Extension of Time }\end{array}$ & + \\
\hline Milošević, S. & $\begin{array}{l}17 \text { Apr } 2002 \\
\text { Decision on Prosecution's Motion for Extension of limit of length of Pre-Trial brief }\end{array}$ & + \\
\hline Milošević, S. & $\begin{array}{l}22 \text { Mar } 2004 \\
\text { Order Extending Page Limit for Prosecution Response to the Rule 98bis Motion }\end{array}$ & + \\
\hline Milošević, S. & $\begin{array}{l}\text { 27 Jun } 2003 \\
\text { Order on Amici Curiae's Request for Approval to Identify Relevant Trial Documents in Person } \\
\text { for the Completion of Written Submissions and for Further Extension of Time }\end{array}$ & + \\
\hline Milošević, S. & $\begin{array}{l}28 \text { Jul } 2004 \\
\text { Order on Amici Curiae Motion in Relation to Accused's Disclosure Obligations and Request for } \\
\text { Additional Time }\end{array}$ & + \\
\hline Milošević, S. & $\begin{array}{l}25 \text { Feb } 2004 \\
\text { Order Rescheduling and Setting the Time Available to Present the Defence Case }\end{array}$ & + \\
\hline Milošević, S. & $\begin{array}{l}17 \text { Jan } 2003 \\
\text { Order on Three Requests from the Amici Curiae for Variation of Time Limits }\end{array}$ & + \\
\hline
\end{tabular}




\begin{tabular}{|c|c|c|}
\hline Trial & Language-related request & $+/-$ \\
\hline Milošević, S. & $\begin{array}{l}5 \text { Feb } 2004 \\
\text { Decision on Amici Curiae Request to Exceed the Page Limit }\end{array}$ & + \\
\hline Milošević, S. & $\begin{array}{l}28 \text { Sept } 2004 \\
\text { Order Granting Leave to Exceed the Page Limit for Interlocutory Appeal Against the Trial } \\
\text { Chamber's Decision on Assignment of Defence Counsel }\end{array}$ & + \\
\hline Milošević, S. & $\begin{array}{l}22 \text { Mar } 2004 \\
\text { Order Extending Page Limit for Prosecution Response to the Rule 98bis Motion }\end{array}$ & + \\
\hline Milošević, S. & $\begin{array}{l}28 \text { Sept } 2004 \\
\text { Order Granting Leave to Exceed the Page Limit for Interlocutory Appeal Against the Trial } \\
\text { Chamber's Decision on Assignment of Defence Counsel }\end{array}$ & + \\
\hline Milošević, S. & $\begin{array}{l}11 \text { May } 2004 \\
\text { Decision on Joint Motion of the Defence in Case Prosecutor v. Mrksic, Radic and Slivancanin for } \\
\text { Access to Transcripts and Documents }\end{array}$ & + \\
\hline Milošević, S. & $\begin{array}{l}25 \text { Feb } 2004 \\
\text { Decision on Motion Filed by the Defence of Milan Martic for Access to Confidential Transcripts } \\
\text { and Documents }\end{array}$ & + \\
\hline Milošević, S. & $\begin{array}{l}18 \text { Feb } 2004 \\
\text { Second Decision on Prosecution Motion for Admission of Transcript Pursuant to Rule 92bis (D) } \\
\text { for Witness B-1132 }\end{array}$ & + \\
\hline Milošević, S. & $\begin{array}{l}18 \text { Feb } 2004 \\
\text { Second Decision on Prosecution Motion for Admission of Transcripts Pursuant to Rule } 92 \text { bis } \\
\text { (D) for Witnesses B-1585 and B-1764 }\end{array}$ & + \\
\hline Milošević, S. & $\begin{array}{l}\text { 27 Jan } 2004 \\
\text { Decision on Prosecution Motion for Admission of Transcripts Pursuant to Rule 92bis (D) for } \\
\text { witness B-1132 }\end{array}$ & - \\
\hline Milošević, S. & $\begin{array}{l}22 \text { Jan } 2004 \\
\text { Decision on Prosecution Motion for Admission of Transcripts Pursuant to Rule 92bis (D) for } \\
\text { Witnesses B-1585 and B-1764 }\end{array}$ & - \\
\hline Milošević, S. & $\begin{array}{l}\text { 13 Jan } 2004 \\
\text { Decision on Prosecution Motion for Admission of Transcripts Pursuant to Rule 92bis(D) for } \\
\text { Witnesses B-1032, B-1034, and B-1083 }\end{array}$ & + \\
\hline Milošević, S. & $\begin{array}{l}12 \text { Jan } 2004 \\
\text { Decision on Confidential Prosecution Motion for Admission of a Transcript and Statement Pur- } \\
\text { suant to Rules 92bis (D) and } 89 \text { (F) for Witness B-1805 }\end{array}$ & + \\
\hline Milošević, S. & $\begin{array}{l}\text { 4Jan } 2004 \\
\text { Second Decision on Prosecution Motion for Admission of Transcript Pursuant to Rule 92bis(D) } \\
\text { and Statement Pursuant to Rule } 89 \text { (F) for Witness B-1804 }\end{array}$ & + \\
\hline Milošević, S. & $\begin{array}{l}17 \text { Dec } 2003 \\
\text { Decision on Prosecution Motion for Admission of Transcripts and Portions of a Statement Pur- } \\
\text { suant to Rules 92bis(D) and 89(F) for Witnesses B-1068, B-1021, 1266, 1354, and B-1695 }\end{array}$ & + \\
\hline Milošević, S. & $\begin{array}{l}16 \text { Dec } 2003 \\
\text { Decision on Prosecution Motion for Admission of Transcripts Pursuant to Rule 92bis (D), filed } \\
\text { o3 December } 2003\end{array}$ & + \\
\hline Milošević, S. & $\begin{array}{l}2 \text { Dec } 2003 \\
\text { Decision on Confidential Prosecution Motion for the Admission of Transcripts Pursuant to } \\
\text { 92bis(D) and the Statement of Witness B-1636 Pursuant to Rule } 89(\mathrm{~F})\end{array}$ & + \\
\hline Milošević, S. & $\begin{array}{l}24 \text { Nov } 2003 \\
\text { Decision on Confidential Prosecution Motion for the Admission of Transcripts Pursuant to } \\
\text { 92bis (D) }\end{array}$ & + \\
\hline Milošević, S. & $\begin{array}{l}30 \text { Oct } 2003 \\
\text { Decision on Prosecution's Submission of the Expert Reports of Helge Brunborg Pursuant to Rule } \\
\text { 94bis and Motion for the Admission of Transcripts Pursuant to Rule 92bis(D) }\end{array}$ & $+/-$ \\
\hline Milošević, S. & $\begin{array}{l}20 \text { Oct } 2003 \\
\text { Decision on Defence Motion Filed by the Defence of Franko Simatovic (IT-03-69-PT) for Access } \\
\text { to Transcripts and Documents }\end{array}$ & + \\
\hline Milošević, S. & $\begin{array}{l}12 \text { Sept } 2003 \\
\text { Decision on Prosecution Motions for Admission of the Statement of the Witness Baron van } \\
\text { Lynden Pursuant to Rule 92bis (A) and Transcript of Testimony in Another Trial Pursuant to } \\
\text { Rule 92bis (D) }\end{array}$ & + \\
\hline
\end{tabular}




\begin{tabular}{|c|c|c|}
\hline Trial & Language-related request & $+/-$ \\
\hline Milošević, S. & $\begin{array}{l}4 \text { Sept } 2003 \\
\text { Decision on Confidential Prosecution Motion for the Admission of Transcripts Pursuant to Rule } \\
\text { 92bis }\end{array}$ & + \\
\hline Milošević, S. & $\begin{array}{l}30 \text { Jul } 2003 \\
\text { Decision on Prosecution Motions for the Admission of Statement and Transcripts in lieu of viva } \\
\text { voce Testimony Pursuant to Rules } 54,75 \text { and } 92 \text { bis }\end{array}$ & + \\
\hline Milošević, S. & $\begin{array}{l}\text { 30 Jun } 2003 \\
\text { Decision on Prosecution Motion for the Admission of Transcripts in lieu of Viva Voce Testi- } \\
\text { mony Pursuant to 92bis(D) - Foca Transcripts }\end{array}$ & + \\
\hline Milošević, S. & $\begin{array}{l}27 \text { Mar } 2003 \\
\text { Decision on Prosecution Motion for the Admission of Transcripts in lieu of viva voce Testimony } \\
\text { Pursuant to } 92 \text { bis(D) }\end{array}$ & + \\
\hline Milošević, S. & $\begin{array}{l}\text { 14 Jun } 2002 \\
\text { Decision on Defence Motions for Access to Transcripts and Documents and for Disclosure of Ex } \\
\text { Parte Filing }\end{array}$ & + \\
\hline Milošević, S. & $\begin{array}{l}1 \text { Feb } 2006 \\
\text { Order Lifting Seal on Witness Statement and Changing Status of Transcript }\end{array}$ & + \\
\hline Milošević, S. & $\begin{array}{l}18 \text { Aug } 2005 \\
\text { Order on Assigned Counsel Request for a Trial Chamber Order to Disclose to the Accused Video } \\
\text { and Audio Recordings of Proceedings }\end{array}$ & + \\
\hline Milošević, S. & $\begin{array}{l}30 \text { Jun } 2005 \\
\text { Order Directing Parties to Clarify Their Positions on Admission of Translations of Exhibits Ad- } \\
\text { mitted During Prosecution Case and Decision on Prosecution Motion To Admit Translations of } \\
\text { Documents Concerning Events in Racak }\end{array}$ & + \\
\hline Milošević, S. & $\begin{array}{l}17 \text { Jan } 2003 \\
\text { Order on Prosecution Motion for Admission of the Transcrips of Testimony of Dr. Vesna } \\
\text { Bosanac Pursuant to Rul 92bis (D) }\end{array}$ & + \\
\hline Mladić & $\begin{array}{l}2 \text { Sept } 2016 \\
\text { Decision on Defence motion for an extension of time to tender sentence related information }\end{array}$ & - \\
\hline Mladić & $\begin{array}{l}2 \text { May } 2014 \\
\text { Decision on urgent Defence Motion Seeking to Enlarge Time Due to the Tribunal's Inability to } \\
\text { Provide Necessary Technical Means }\end{array}$ & $+/-$ \\
\hline Mladić & $\begin{array}{l}\text { 22 Jan } 2014 \\
\text { Decision concerning motion to exceed word count and Defence motion pursuant to Rule 15(B) } \\
\text { seeking disqualification of Presiding Judge Aplhons Orie }\end{array}$ & + \\
\hline Mladić & $\begin{array}{l}2 \text { Jan } 2014 \\
\text { Decision concerning motion to exceed word count and Defence motion pursuant to Rule 15(B) } \\
\text { seeking disqualification of Presiding Judge Christoph Flügge }\end{array}$ & - \\
\hline Mladić & $\begin{array}{l}19 \text { Jun } 2013 \\
\text { Decision on prosecution sixth motion to admit written statements and transcripts in lieu of oral } \\
\text { testimony pursuant to rule } 92 \text { bis }\end{array}$ & + \\
\hline Mladić & $\begin{array}{l}29 \text { Aug } 2016 \\
\text { Order to redact the public transcript and the public broadcast of a hearing }\end{array}$ & + \\
\hline Mladić & $\begin{array}{l}16 \text { Dec } 2015 \\
\text { Orders to redact the public transcript and the public broadcast of a hearing }\end{array}$ & + \\
\hline Mladić & $\begin{array}{l}19 \text { Oct } 2015 \\
\text { Orders to redact the public transcript and the public broadcast of a hearing }\end{array}$ & + \\
\hline Mladić & $\begin{array}{l}24 \mathrm{Feb} 2015 \\
\text { Orders to redact the public transcript and the public broadcast of a hearing }\end{array}$ & + \\
\hline Mladić & $\begin{array}{l}16 \text { Feb } 2015 \\
\text { Orders to redact the public transcript and the public broadcast of a hearing }\end{array}$ & + \\
\hline Mladić & $\begin{array}{l}11 \text { Feb } 2015 \\
\text { Orders to redact the public transcript and the public broadcast of a hearing }\end{array}$ & + \\
\hline Mladić & $\begin{array}{l}8 \text { Dec } 2014 \\
\text { Order to redact the public transcript and the public broadcast of a hearing }\end{array}$ & + \\
\hline Mladić & $\begin{array}{l}14 \text { Oct } 2014 \\
\text { Order to redact the public transcript and the public broadcast of a hearing }\end{array}$ & + \\
\hline Mladić & $\begin{array}{l}14 \text { Oct } 2014 \\
\text { Order to redact the public transcript and the public broadcast of a hearing }\end{array}$ & + \\
\hline
\end{tabular}




\begin{tabular}{|c|c|c|}
\hline Trial & Language-related request & $+/-$ \\
\hline Mladić & $\begin{array}{l}\text { 10 Jun } 2014 \\
\text { Order to Redact the Public Transcript and the Public Broadcast of a Hearing }\end{array}$ & + \\
\hline Mladić & $\begin{array}{l}10 \text { Jun } 2014 \\
\text { Order to Redact the Public Transcript and the Public Broadcast of a Hearing }\end{array}$ & + \\
\hline Mladić & $\begin{array}{l}22 \text { Jan } 2014 \\
\text { Order to redact the public transcript and the public broadcast of a hearing [hearing of } \\
29 / 08 / 2013 \text { ] }\end{array}$ & + \\
\hline Mladić & $\begin{array}{l}22 \text { Aug } 2013 \\
\text { Order to redact the public transcript and the public broadcast of a hearing }\end{array}$ & + \\
\hline Mladić & $\begin{array}{l}23 \text { May } 2013 \\
\text { Order to redact the public transcript and the pnblic broadcast of a hearing }\end{array}$ & + \\
\hline Mladić & $\begin{array}{l}25 \text { Apr } 2013 \\
\text { Order to redact the public transcript and the public broadcast of a hearing }\end{array}$ & + \\
\hline Mladić & $\begin{array}{l}\text { 30 Jan } 2013 \\
\text { Order to redact the public transcript and the public broadcast of a hearing }\end{array}$ & + \\
\hline Mladić & $\begin{array}{l}\text { 23 Jan } 2013 \\
\text { Order to redact the public transcript and the public broadcast of a hearing }\end{array}$ & + \\
\hline Mladić & $\begin{array}{l}\text { 21 Jan } 2013 \\
\text { Order to redact the public transcript and the public broadcast of a hearing }\end{array}$ & + \\
\hline Mladić & $\begin{array}{l}6 \text { Nov } 2012 \\
\text { Order to redact the public transcript and the public broadcast of a hearing }\end{array}$ & + \\
\hline Mladić & $\begin{array}{l}5 \text { Nov } 2012 \\
\text { Order to redact the public transcript and the public broadcast of a hearing }\end{array}$ & + \\
\hline Mladić & $\begin{array}{l}11 \text { Oct } 2012 \\
\text { Order to redact the public transcript and the public broadcast of a hearing }\end{array}$ & + \\
\hline Mladić & $\begin{array}{l}\text { 30 Nov } 2016 \\
\text { Decision on Defence Motion to Strike the Prosecution Final Trial Brief }\end{array}$ & $+/-$ \\
\hline Mrkšić et al & $\begin{array}{l}22 \text { Feb } 2007 \\
\text { Decision on Sljivancanin defence motion for variation from word limit }\end{array}$ & $+/-$ \\
\hline Mrkšić et al & $\begin{array}{l}11 \text { May } 2004 \\
\text { Decision on Joint Motion of the Defence in Case Prosecutor v. Mrksic, Radic and Sljivancanin } \\
\text { for Access to Transcripts and Documents }\end{array}$ & + \\
\hline Mrkšić et al & $\begin{array}{l}23 \text { Feb } 2007 \\
\text { Decision on Mrksic defence motion for variation from word limit }\end{array}$ & $+/-$ \\
\hline Mucić et al & $\begin{array}{l}1 \text { Oct } 1996 \\
\text { Order on the Prosecutor's Motion for Delayed Release of Transcripts and Video and Audio } \\
\text { Tapes of Proceedings }\end{array}$ & + \\
\hline Mucić et al & $\begin{array}{l}26 \text { May } 2000 \\
\text { Order relating to Appeal Brief filed on behalf of Zejnil Delalic }\end{array}$ & + \\
\hline Mucić et al & $\begin{array}{l}\text { 1 Sept } 1997 \\
\text { Decision on Zdravko Mucic's Motion for Leave to File an Out-of-Time Application Pursuant to } \\
\text { Rule } 73\end{array}$ & + \\
\hline Naletilić \& Martinović & $\begin{array}{l}21 \text { Nov } 2000 \\
\text { Decision on Motion for an Extension to submit the Pre-trial Brief }\end{array}$ & + \\
\hline Naletilić \& Martinović & $\begin{array}{l}26 \text { Nov } 1999 \\
\text { Order in Respect of the Prosecution Motion to extend the Deadline for Disclosure of Names and } \\
\text { Statements of certain Witnesses }\end{array}$ & + \\
\hline Naletilić \& Martinović & $\begin{array}{l}18 \text { Sept } 2003 \\
\text { Decision on Prosecution's Request for Extension of Page Limits }\end{array}$ & + \\
\hline Naletilić \& Martinović & $\begin{array}{l}12 \text { Sept } 2003 \\
\text { Decision on Motions for Extensions of Time }\end{array}$ & + \\
\hline Naletilić \& Martinović & $\begin{array}{l}18 \text { Aug } 2003 \\
\text { Decision on Martinovic Motion for Extension of Time for Filing the Respondent's Brief and on } \\
\text { Naletilic Motion for Enlargement of Time for Filing Rule }{ }_{115} \text { Motion, Appeals Brief, and Re- } \\
\text { sponse to Prosecutor's Appeal Brief }\end{array}$ & - \\
\hline Naletilić \& Martinović & $\begin{array}{l}\text { 25 Jun } 2003 \\
\text { Decision on Mladen Naletilic's Motions for Extension of Time }\end{array}$ & $+\&+/-$ \\
\hline Naletilić \& Martinović & 3 Oct 2002 & + \\
\hline
\end{tabular}




\begin{tabular}{|c|c|c|}
\hline Trial & Language-related request & $+/-$ \\
\hline & $\begin{array}{l}\text { Decision on the Prosecution Submission of } \mathrm{B} / \mathrm{C} / \mathrm{S} \text { original and } \mathrm{B} / \mathrm{C} / \mathrm{S} \text { Translation of some Exhib- } \\
\text { its }\end{array}$ & \\
\hline Naletilić \& Martinović & $\begin{array}{l}18 \text { Oct } 2001 \\
\text { Decision on Defence's Motion concerning Translation of all Documents }\end{array}$ & + \\
\hline Naletilić \& Martinović & $\begin{array}{l}11 \text { Sept } 2001 \\
\text { Decision on Prosecutor's Motion for Admission of Additional Transcripts and Exhibits from } \\
\text { other ICTY Proceedings }\end{array}$ & + \\
\hline Naletilić \& Martinović & $\begin{array}{l}\text { 9 Jul } 2001 \\
\text { Decision regarding Prosecutor's Notice of intent to offer Transcripts under Rule } 92 \text { bis D }\end{array}$ & + \\
\hline Naletilić \& Martinović & $\begin{array}{l}27 \text { Nov } 2000 \\
\text { Decision on Prosecution Motion for Admission of Transcripts and Exhibits tendered during } \\
\text { Testimony of certain Blaskic and Kordic Witnesses }\end{array}$ & + \\
\hline Naletilić \& Martinović & $\begin{array}{l}7 \text { Nov } 2003 \text { Decision on Joint Defence Motion by Enver Hadzihasanovic and Amir Ku- } \\
\text { bura for Access to All Confidential Material, Filings, Transcripts and Exhibits in the Naletilic } \\
\text { and Martinovic Case }\end{array}$ & $+/-$ \\
\hline Naletilić \& Martinović & $\begin{array}{l}26 \text { Sept } 2002 \\
\text { Decision on the Prosecution Request to Vary Lenght of Final Trial Brief }\end{array}$ & $+/-$ \\
\hline Naletilić \& Martinović & $\begin{array}{l}18 \text { Aug } 2003 \\
\text { Decision on Martinovic Motion for Extension of Time for Filing the Respondent's Brief and on } \\
\text { Naletilic Motion for Enlargement of Time for Filing Rule } 115 \text { Motion, Appeals Brief, and Re- } \\
\text { sponse to Prosecutor's Appeal Brief }\end{array}$ & $+/-$ \\
\hline Nikolić, D. & $\begin{array}{l}25 \text { Mar } 2004 \\
\text { Decision on Motion for Variation of Time limit }\end{array}$ & $+/-$ \\
\hline Nikolić, M. & $\begin{array}{l}3 \text { Feb } 2005 \\
\text { Decision on Prosecution Motion for Extension of Pages }\end{array}$ & + \\
\hline Nikolić, M. & $\begin{array}{l}22 \text { Nov } 2004 \\
\text { Decision on Prosecution's Motion for Extension of Pages }\end{array}$ & + \\
\hline Nikolić, M. & $\begin{array}{l}\text { 11 Jan } 2005 \\
\text { Decision on Prosecution's Motion for Extension of Time }\end{array}$ & + \\
\hline Nikolić, M. & $\begin{array}{l}\text { 20 Oct } 2004 \\
\text { Decision on Prosecution's Motion for Extension of Pages }\end{array}$ & + \\
\hline Nikolić, M. & $\begin{array}{l}13 \text { Apr } 2004 \\
\text { Decision on Second Defence Motion for Variation of Time limits }\end{array}$ & + \\
\hline Nikolić, M. & $\begin{array}{l}22 \text { Jan } 2004 \\
\text { Decision on Motion for Variation of Time limit }\end{array}$ & $+/-$ \\
\hline Nikolić, M. & $\begin{array}{l}\text { 19 Jul } 2005 \\
\text { Decision on Appelant's Request to Withdraw Previous Motions to Revise Appelant's Brief and } \\
\text { to Amend Notice of Appeal }\end{array}$ & + \\
\hline Orić & $\begin{array}{l}11 \text { Jun } 2003 \\
\text { Decision on Confidential Application for Leave to File a Reply and Motion for an Extension on } \\
\text { Time }\end{array}$ & + \\
\hline Orić & $\begin{array}{l}9 \text { Mar } 2006 \\
\text { Order on Defence Motion for Variation of the Word Limit for Final Trial Brief }\end{array}$ & + \\
\hline Orić & $\begin{array}{l}21 \text { Mar } 2006 \\
\text { Decision On Prosecution Motion Seeking Leave To File A corrigendum To Prosecution Final } \\
\text { Brief }\end{array}$ & + \\
\hline Orić & $\begin{array}{l}18 \text { May } 2007 \\
\text { Decision on the Motion to strike APPENDICES A, C, D and E of the Prosecution's appeal brief }\end{array}$ & - \\
\hline Perišić & $\begin{array}{l}24 \text { Sept } 2007 \\
\text { Decision on Defence motion for extension of time }\end{array}$ & + \\
\hline Perišić & $\begin{array}{l}22 \text { Feb } 2007 \\
\text { Order on confidential materials and defence requests for additional time and to exceed word } \\
\text { limit }\end{array}$ & $+/-$ \\
\hline Perišić & $\begin{array}{l}\text { 24 Jul } 2008 \\
\text { Decision on defence request to exceed word limit and addendum to defence objection to prose- } \\
\text { cution's motion for judicial notice of facts and documents relevant to the Zagreb crime base, } \\
\text { with confidential APPENDICES }\end{array}$ & - \\
\hline Perišić & $\begin{array}{l}28 \text { Mar } 2007 \\
\text { Decision on counsel's request to exceed word limit for pre-trial brief }\end{array}$ & + \\
\hline
\end{tabular}




\begin{tabular}{|c|c|c|}
\hline Trial & Language-related request & $+1-$ \\
\hline Perišić & $\begin{array}{l}\text { 30 Jan } 2012 \\
\text { Decision on Momcilo Perisićs motion for leave to exceed the word limit for the appeal brief }\end{array}$ & + \\
\hline Perišić & $\begin{array}{l}27 \text { Sept } 2007 \\
\text { Decision regarding Defense request for B/C/S transcript of the accused's statement }\end{array}$ & + \\
\hline Perišić & $\begin{array}{l}11 \text { Jan } 2013 \\
\text { Order to redact the public transcript and the public broadcast of a hearing }\end{array}$ & + \\
\hline Perišić & $\begin{array}{l}27 \text { Jan } 2010 \\
\text { Order to redact the public transcript and the public broadcast of a hearing }\end{array}$ & + \\
\hline Perišić & $\begin{array}{l}\text { 25 Jan } 2010 \\
\text { Order to redact the public transcript and the public broadcast of a hearing }\end{array}$ & + \\
\hline Perišić & $\begin{array}{l}\text { 3 Jul } 2009 \\
\text { Order to Redact the Public Transcript and the Public Broadcast of a Hearing }\end{array}$ & + \\
\hline Perišić & $\begin{array}{l}6 \text { Mar } 2009 \\
\text { Order to redact the public transcript and the public broadcast of a hearing }\end{array}$ & + \\
\hline Perišić & $\begin{array}{l}21 \text { Jan } 2008 \\
\text { Order to redact the public transcript and the public broadcast of a hearing }\end{array}$ & + \\
\hline Popović et al. & $\begin{array}{l}6 \text { Jan } 2009 \\
\text { Decision on request for extension of time to file a reply }\end{array}$ & + \\
\hline Popović et al & $\begin{array}{l}20 \text { May } 2008 \\
\text { Decision on request for extension of time to file English translation of expert reports }\end{array}$ & + \\
\hline Popović et al & $\begin{array}{l}8 \text { May } 2008 \\
\text { Decision on extension of time to file one expert report and English translations of four expert } \\
\text { reports }\end{array}$ & $+\&+/-$ \\
\hline Popović et al & $\begin{array}{l}11 \text { Apr } 2008 \\
\text { Decision on Popović's request for an extension of time to file a response to the motion to reo- } \\
\text { pen the prosecution case }\end{array}$ & + \\
\hline Popović et al & $\begin{array}{l}1 \text { Apr } 2008 \\
\text { Decision on Popovic request seeking an extension of the deadline for the filing of the part of } \\
\text { English translation of military expert's report }\end{array}$ & + \\
\hline Popović et al & $\begin{array}{l}14 \text { Mar } 2007 \\
\text { Decision on defence motion for extension of time to file a rule } 94 \text { bis notice }\end{array}$ & + \\
\hline Popović et al & $\begin{array}{l}\text { 1 Jun } 2011 \\
\text { Decision on defence requests for extension of time to file motions pursuant to rule } 115\end{array}$ & - \\
\hline Popović et al & $\begin{array}{l}20 \text { Oct } 2010 \\
\text { Decision on motions for extension of time and for permission to exceed word limitations }\end{array}$ & $+/-$ \\
\hline Popović et al & $\begin{array}{l}\text { 18 Jan } 2011 \\
\text { Decision on motion of Radivoje Miletić for permission to further exceed word limitation }\end{array}$ & - \\
\hline Popović et al & $\begin{array}{l}\text { 17 Jan } 2011 \\
\text { Decision on motion of Vujadin Popovic for permission to further exceed word limitation }\end{array}$ & - \\
\hline Popović et al & $\begin{array}{l}\text { 12 Jan } 2011 \\
\text { Decision on motion of Drago Nikolic for permission to further exceed word limitation }\end{array}$ & - \\
\hline Popović et al & $\begin{array}{l}\text { 12 Jan } 2011 \\
\text { Decision on motion of Drago Nikolic for permission to further exceed word limitation }\end{array}$ & + \\
\hline Popović et al & $\begin{array}{l}23 \text { Mar } 2006 \\
\text { Decision on Joint Defence Motion Seeking Certification of the Trial Chamber's Decision on the } \\
\text { Joint Defence Motion Seeking the Trial Chamber to Order the Registrar to Provide the Defence } \\
\text { With B/C/S Transcripts of Proceedings in Two Past Cases Before the International Tribunal }\end{array}$ & - \\
\hline Popović et al & $\begin{array}{l}6 \text { Mar } 2006 \\
\text { Decision on Joint Defence Motion Seeking the Trial Chamber to Order the Registrar to Provide } \\
\text { the Defence with B/C/S Transcripts of Proceedings in Two Past Cases Before the International } \\
\text { Tribunal }\end{array}$ & - \\
\hline Popović et al & $\begin{array}{l}27 \text { Oct } 2011 \\
\text { Order to redact the trial public transcript and the trial public broadcast of a hearing }\end{array}$ & + \\
\hline Popović et al & $\begin{array}{l}21 \text { Oct } 2011 \\
\text { Order to redact the trial public transcript and the trial public broadcast of a hearing }\end{array}$ & + \\
\hline Popović et al & $\begin{array}{l}30 \text { Sept } 2009 \\
\text { Post session order to redact the public transcript and the public broadcast of a hearing }\end{array}$ & + \\
\hline Popović et al & $\begin{array}{l}22 \text { Sept } 2009 \\
\text { Post session order to redact the public transcript and the public broadcast of a hearing }\end{array}$ & + \\
\hline
\end{tabular}




\begin{tabular}{|c|c|c|}
\hline Trial & Language-related request & $+/-$ \\
\hline Popović et al & $\begin{array}{l}8 \text { Sept } 2009 \\
\text { Post session order to redact the public transcript and the public broadcast of a hearing }\end{array}$ & + \\
\hline Popović et al & $\begin{array}{l}25 \text { Mar } 2009 \\
\text { Order to redact the public transcript and the public broadcast of a hearing }\end{array}$ & + \\
\hline Popović et al & $\begin{array}{l}25 \text { Sept } 2008 \\
\text { Order to redact the publilc transcript and the public broadcast of a hearing }\end{array}$ & + \\
\hline Popović et al & $\begin{array}{l}19 \text { Sept } 2008 \\
\text { Order to redact the publilc transcript and the public broadcast of a hearing }\end{array}$ & + \\
\hline Popović et al & $\begin{array}{l}\text { 21 Jul } 2008 \\
\text { Order to redact the public transcript and the public broadcast of a hearing }\end{array}$ & + \\
\hline Popović et al & $\begin{array}{l}\text { 21 Jul } 2008 \\
\text { Order to redact the public transcript and the public broadcast of a hearing }\end{array}$ & + \\
\hline Popović et al & $\begin{array}{l}30 \text { Jan } 2008 \\
\text { Order to redact the public transcript and the public broadcast of a hearing }\end{array}$ & + \\
\hline Popović et al & $\begin{array}{l}18 \mathrm{Jan} 2008 \\
\text { Order to redact the public transcript and the public broadcast of a hearing }\end{array}$ & + \\
\hline Popović et al & $\begin{array}{l}5 \text { Dec } 2007 \\
\text { Order to redact the public transcript and the public broadcast of a hearing }\end{array}$ & + \\
\hline Popović et al & $\begin{array}{l}28 \text { Nov } 2007 \\
\text { Order to redact the public transcript and the public broadcast of a hearing }\end{array}$ & + \\
\hline Popović et al & $\begin{array}{l}\text { 3 Jan } 2012 \\
\text { Order setting a time limit to file any motion seeking variation of the grounds of appeal follow- } \\
\text { ing translation of the trial judgment into } \mathrm{B} / \mathrm{C} / \mathrm{S} \text { language }\end{array}$ & + \\
\hline Popović et al & $\begin{array}{l}21 \text { Oct } 2011 \\
\text { Order to redact the public transcript and the public broadcast of a hearing }\end{array}$ & + \\
\hline Prlić et al & $\begin{array}{l}22 \text { Aug } 2014 \\
\text { Decision on Defence Motions to extend time and/or exceed word limits for Appeal Briefs and } \\
\text { Prosecution motion for extension of time to file respondent's Briefs }\end{array}$ & $+/-$ \\
\hline Prlić et al & $\begin{array}{l}16 \text { Oct } 2012 \\
\text { Decision on the accused Praljak's motion for further extension of time to file motion for review } \\
\text { of Registrar's decision of } 22 \text { August } 2012\end{array}$ & + \\
\hline Prlić et al & $\begin{array}{l}\text { 30 Aug } 2012 \\
\text { Decision on accused Praljak's motion for extension of time to file motion for review of regis- } \\
\text { trar's decision of } 22 \text { August } 2012\end{array}$ & + \\
\hline Prlić et al & $\begin{array}{l}30 \text { Aug } 2012 \\
\text { Decision on accused Praljak's motion for extension of time to file motion for review of regis- } \\
\text { trar's decision of } 22 \text { August } 2012\end{array}$ & + \\
\hline Prlić et al & $\begin{array}{l}8 \text { Oct } 2004 \\
\text { Decision on Stokic's Request for an Extension of Page Limits }\end{array}$ & - \\
\hline Prlić et al & $\begin{array}{l}18 \text { Jan } 2006 \\
\text { Order Granting an Extension of Time }\end{array}$ & + \\
\hline Prlić et al & $\begin{array}{l}9 \text { Apr } 2015 \\
\text { Decision on requests for extension of word limit for respondent's briefs and reply briefs and for } \\
\text { time limit for reply briefs }\end{array}$ & - \\
\hline Prlić et al & $\begin{array}{l}9 \text { Oct } 2014 \\
\text { Decision on Appellant's requests for extension of time and word limits }\end{array}$ & + \\
\hline Prlić et al & $\begin{array}{l}22 \text { Aug } 2013 \\
\text { Decision on Motions for extension of time to file Appeal Briefs and for authorization to exceed } \\
\text { word limit }\end{array}$ & $+/-$ \\
\hline Prlić et al & $\begin{array}{l}\text { 21 Jun } 2013 \\
\text { Decision on motions for an extension of time to file notices of appeal and other relief }\end{array}$ & $+/-$ \\
\hline Prlić et al & $\begin{array}{l}\text { 21 Jun } 2013 \\
\text { Decision on motions for an extension of time to file notices of appeal and other relief }\end{array}$ & $+\&+/-$ \\
\hline Prlić et al & $\begin{array}{l}17 \text { Mar } 2010 \\
\text { Order on request of Praljak defence seeking a stay on the time limit ordered by the chamber for } \\
\text { filing } 20 \text { written statements or transcripts of evidence pursuant to rule 92bis of the rules }\end{array}$ & + \\
\hline Prlić et al & $\begin{array}{l}22 \text { Feb } 2006 \\
\text { Order Granting the Defence Counsel for the Accused Valentin Coric Leave to Exceed the Num- } \\
\text { ber of Words in the Pre-Trial Brief }\end{array}$ & + \\
\hline
\end{tabular}




\begin{tabular}{|c|c|c|}
\hline Trial & Language-related request & $+1-$ \\
\hline Prlić et al & $\begin{array}{l}2 \text { Dec } 2008 \\
\text { Corrigendum to the English translation of Decision on Valentin Ćorić's request for provisional } \\
\text { release }\end{array}$ & + \\
\hline Prlić et al & $\begin{array}{l}17 \text { Jul } 2008 \\
\text { Corrigendum to the English translation of decision on the accused Praljak'smotion for provi- } \\
\text { sional release }\end{array}$ & + \\
\hline Prlić et al & $\begin{array}{l}6 \text { Dec } 2007 \\
\text { Decision on the request of the accused Prlic to obtain a B/C/S transcription of his statement }\end{array}$ & + \\
\hline Prlić et al & $\begin{array}{l}16 \text { Feb } 2011 \\
\text { Order to Redact the Public Transcript and the Public Broadcast of a Hearing }\end{array}$ & + \\
\hline Prlić et al & $\begin{array}{l}17 \text { Mar } 2010 \\
\text { Order on request of Praljak defence seeking a stay on the time limit ordered by the chamber for } \\
\text { filing } 20 \text { written statements or transcripts of evidence pursuant to rule 92bis of the rules }\end{array}$ & + \\
\hline Prlić et al & $\begin{array}{l}2 \text { Mar } 2010 \\
\text { Order to redact the public transcript and the public broadcast of a hearing }\end{array}$ & + \\
\hline Prlić et al & $\begin{array}{l}21 \text { May } 2009 \\
\text { Order to redact the public transcript and the public broadcast of a hearing }\end{array}$ & + \\
\hline Prlić et al & $\begin{array}{l}20 \text { May } 2009 \\
\text { Order to redact the public transcript and the public broadcast of a hearing }\end{array}$ & + \\
\hline Prlić et al & $\begin{array}{l}29 \text { Apr } 2009 \\
\text { Order to redact the public transcript and the public broadcast of a hearing }\end{array}$ & + \\
\hline Prlić et al & $\begin{array}{l}7 \text { Apr } 2009 \\
\text { Order to translate exhibit Po6346 }\end{array}$ & + \\
\hline Prlić et al & $\begin{array}{l}30 \text { Mar } 2009 \\
\text { Order to redact the public transcript and the public broadcast of a hearing }\end{array}$ & + \\
\hline Prlić et al & $\begin{array}{l}19 \text { Mar } 2009 \\
\text { Order to redact the public transcript and the public broadcast of a hearing }\end{array}$ & + \\
\hline Prlić et al & $\begin{array}{l}2 \text { Mar } 2009 \\
\text { Order to redact the public transcript and the public broadcast of a hearing }\end{array}$ & + \\
\hline Prlić et al & $\begin{array}{l}4 \text { Feb } 2009 \\
\text { Order to redact the public transcript and the public broadcast of a hearing }\end{array}$ & + \\
\hline Prlić et al & $\begin{array}{l}28 \text { Jan } 2009 \\
\text { Order to redact the public transcript and the public broadcast of a hearing }\end{array}$ & + \\
\hline Prlić et al & $\begin{array}{l}4 \text { Dec } 2008 \\
\text { Order to upload the French transcripts of witness testimony admitted pursuant to rule } 92 \text { bisof } \\
\text { the rules }\end{array}$ & + \\
\hline Prlić et al & $\begin{array}{l}13 \text { Oct } 2008 \\
\text { Order on Slobodan Praljak's motion regarding the translation of documents }\end{array}$ & + \\
\hline Prlić et al & $\begin{array}{l}16 \text { May } 2008 \\
\text { Order on Slobodan Praljak's motion concerning the translation of documents }\end{array}$ & + \\
\hline Prlić et al & $\begin{array}{l}28 \text { Mar } 2008 \\
\text { Order on motion by Bruno Stojić, Milivoj Petković and Valentin Ćorić concerning translation of } \\
\text { documents, }\end{array}$ & + \\
\hline Prlić et al & $\begin{array}{l}19 \text { Mar } 2008 \\
\text { Order on Slobodan Praljak's motion concerning the translation of documents } \\
14 \text { Feb } 2008\end{array}$ & + \\
\hline Prlić et al & $\begin{array}{l}9 \text { Oct } 2007 \\
\text { Order lifting the confidentiality of passages of transcripts and audio recordings from an exparte } \\
\text { hearing }\end{array}$ & + \\
\hline Prlić et al & $\begin{array}{l}4 \text { Oct } 2007 \\
\text { Order to redact the public transcript and public broadcast of a hearing }\end{array}$ & + \\
\hline Prlić et al & $\begin{array}{l}23 \text { Aug } 2006 \\
\text { Order to Redact Passages from the Transcript and Audiovisual Recordings }\end{array}$ & + \\
\hline Prlić et al & $\begin{array}{l}25 \text { Jan } 2006 \\
\text { Order Clarifying the Order of } 17 \text { January } 2006 \text { for the Translation of Documents }\end{array}$ & + \\
\hline Prlić et al & $\begin{array}{l}17 \text { Jan } 2006 \\
\text { Order for the Translation of Documents }\end{array}$ & + \\
\hline Prlić et al & 30 Nov 2005 & + \\
\hline
\end{tabular}




\begin{tabular}{|c|c|c|}
\hline Trial & Language-related request & $+1-$ \\
\hline & $\begin{array}{l}\text { Order Directing the Registrar to Provide an Accused with a Translation of an Amended Indict- } \\
\text { ment }\end{array}$ & \\
\hline Prlić et al & $\begin{array}{l}11 \text { Mar } 2015 \\
\text { Decision on Prlić's motion to replace translation of exhibits } 4 \text { Doo348 and 3Do3o65 }\end{array}$ & + \\
\hline Prlić et al & $\begin{array}{l}5 \text { Dec } 2008 \\
\text { Decision on Slobodan Praljak's appeal of the trial chamber's } 13 \text { october } 2008 \text { order limiting the } \\
\text { translation of defence evidence }\end{array}$ & - \\
\hline Prlić et al & $\begin{array}{l}4 \text { Sept } 2008 \\
\text { Decision on Slobodan Praljak's appeal against the trial chamber's decision of } 16 \text { may } 2008 \text { on } \\
\text { translation of documents }\end{array}$ & + \\
\hline Prlić et al & $\begin{array}{l}23 \text { Nov } 2007 \\
\text { Decision on appeals against decision admitting transcript of Jadranko Prlic's questioning into } \\
\text { evidence }\end{array}$ & - \\
\hline Prlić et al & $\begin{array}{l}11 \text { Feb } 2016 \\
\text { Order to redact the public transcript and the public broadcast of a hearing }\end{array}$ & + \\
\hline Prlić et al & $\begin{array}{l}4 \text { Feb } 2015 \\
\text { Order for Clarification concerning Translation of Exhibits } 3 \text { Do3o65 and } 4 \text { Doo348 }\end{array}$ & + \\
\hline Rajić & $\begin{array}{l}15 \text { Sept } 2003 \\
\text { Decision on Joint Defence Motion for Access to Confidential Supporting Material, Filings, Tran- } \\
\text { scripts and Exhibits in the Rajic Case }\end{array}$ & $+1-$ \\
\hline Šainović et al & $\begin{array}{l}14 \text { Sept } 2009 \\
\text { Decision on Sreten Lukic's motion to reconsider decision on defence motions for extension of } \\
\text { word limit }\end{array}$ & - \\
\hline Šainović et al & $\begin{array}{l}\text { 10 Jun } 2008 \\
\text { Decision on Lukic defence motion for reconsideration of denial of extension of time and leave } \\
\text { to file replies }\end{array}$ & - \\
\hline Šainović et al & $\begin{array}{l}\text { 4 Jul } 2007 \\
\text { Decision on Prosecution request for extension of time to submit corrected translation of exhibit } \\
\text { P942 }\end{array}$ & + \\
\hline Šainović et al & $\begin{array}{l}\text { 20 Jun } 2007 \\
\text { Decision on Defence motions for extension of time to file reports of expert witnesses }\end{array}$ & + \\
\hline Šainović et al & $\begin{array}{l}22 \text { Jul } 2005 \\
\text { Decision on Prosecution's Request for Extension of Time to File Amended Consolidated Indict- } \\
\text { ment }\end{array}$ & - \\
\hline Šainović et al & $\begin{array}{l}\text { 20 Jan } 2010 \\
\text { Decision on defence requests for extension of time and word limits to file reply briefs }\end{array}$ & $+1-$ \\
\hline Šainović et al & $\begin{array}{l}14 \text { Sept } 2009 \\
\text { Decision on Sreten Lukic's motion to reconsider decision on defence motions for extension of } \\
\text { word limit }\end{array}$ & - \\
\hline Šainović et al & $\begin{array}{l}11 \text { Sept } 2009 \\
\text { Decision on Nikola Sainovic's and Dragoljub Ojdanic's joint motion for extension of word limit }\end{array}$ & + \\
\hline Šainović et al & $\begin{array}{l}8 \text { Sept } 2009 \\
\text { Decision on defence motions for extension of word limit }\end{array}$ & $+1-$ \\
\hline Šainović et al & $\begin{array}{l}23 \text { Mar } 2009 \\
\text { on motions for extension of time to file notices of appeal }\end{array}$ & $+1-$ \\
\hline Šainović et al & $\begin{array}{l}22 \text { Sept } 2010 \\
\text { Decision on the prosecution's motion seeking clarification and an order regarding the timelimit } \\
\text { for the defence to file potential motions to vary grounds of appeal }\end{array}$ & - \\
\hline Šainović et al & $\begin{array}{l}14 \text { Nov } 2007 \\
\text { Order on timing of motions prior to Winter recess and presentation of Lukic Defence case }\end{array}$ & + \\
\hline Šainović et al & $\begin{array}{l}22 \text { May } 2008 \\
\text { Decision on Lukić defence alteration of official translations of witness statements }\end{array}$ & - \\
\hline Šainović et al & $\begin{array}{l}7 \text { Dec } 2007 \\
\text { Decision regarding outstanding translations and admission of Milutinovic Defence exhibits }\end{array}$ & + \\
\hline Šainović et al & $\begin{array}{l}27 \text { Sept } 2007 \\
\text { Decision on Lukic motion to compel registry to provide verbatim transcript of proceedings }\end{array}$ & - \\
\hline Šainović et al & $\begin{array}{l}\text { 4 Jul } 2007 \\
\text { Decision on Prosecution request for extension of time to submit corrected translation of exhibit } \\
\text { P942 }\end{array}$ & + \\
\hline
\end{tabular}




\begin{tabular}{|c|c|c|}
\hline Trial & Language-related request & $+/-$ \\
\hline Šainović et al & $\begin{array}{l}20 \text { Jun } 2008 \\
\text { Order re Sreten Lukic's request to replace the translation of Exhibit } 6 \mathrm{D}_{146 \mathrm{o}}\end{array}$ & + \\
\hline Šainović et al & $\begin{array}{l}6 \text { Feb } 2008 \\
\text { Corrigendum to Order on Lazarevic Defence notice re documents marked for identification } \\
\text { pending translation }\end{array}$ & + \\
\hline Šainović et al & $\begin{array}{l}1 \text { Feb } 2008 \\
\text { Order on Lazarevic Defence notice re documents marked for identification pending translation }\end{array}$ & + \\
\hline Šainović et al & $\begin{array}{l}5 \text { Dec } 2007 \\
\text { Order to redact the public transcript and the public broadcast of a hearing }\end{array}$ & + \\
\hline Šainović et al & $\begin{array}{l}21 \text { Sept } 2007 \\
\text { Order on joint Prosecution and Defence notification regarding translation of exhibits admitted } \\
\text { into evdence by agreement }\end{array}$ & + \\
\hline Šainović et al & $\begin{array}{l}31 \mathrm{Jul} 2007 \\
\text { Order for submissions on joint prosecution and defence notice regarding translation of exhibits } \\
\text { admitted into evidence by agreement }\end{array}$ & + \\
\hline Šainović et al & $\begin{array}{l}21 \text { Jun } 2007 \\
\text { Order rejoint Prosecution and Defence notice regarding translation of exhibits admitted into } \\
\text { evidence by agreement }\end{array}$ & + \\
\hline Šainović et al & $\begin{array}{l}14 \text { Mar } 2007 \\
\text { Order on lukic notice with respect to translations of exhibits } 6 \mathrm{D}_{139} \text { and } 6 \mathrm{D} 140 \text { and request for } \\
\text { their admission into evidence }\end{array}$ & + \\
\hline Šainović et al & $\begin{array}{l}22 \text { Mar } 2011 \\
\text { Decision on Nikola Sainovic's motions for leave to vary his grounds of appeal following the } \\
\text { translation of the trial judgment and for admission of additional evidence on appeal }\end{array}$ & - \\
\hline Šainović et al & $\begin{array}{l}16 \text { Feb } 2010 \\
\text { Decision on Vlastimir Dordevic's motion for access to transcripts, exhibits and documents }\end{array}$ & $+/-$ \\
\hline Šainović et al & $\begin{array}{l}26 \text { Jan } 2010 \\
\text { Decision on Vladimir Lazarevic's motion to present additional evidence and on prosecution's } \\
\text { motion for order requiring translations of excerpts of Appendix E of Lazarevic's rule } 115 \text { motion }\end{array}$ & - \\
\hline Šainović et al & $\begin{array}{l}\text { 16 Jun } 2011 \\
\text { Order on disclosure of portions of private/closed session transcripts }\end{array}$ & + \\
\hline Šainović et al & $\begin{array}{l}5 \text { Apr } 2011 \\
\text { Order regarding the alteration of the status of exhibits consisting of transcripts from another } \\
\text { case }\end{array}$ & + \\
\hline Šainović et al & $\begin{array}{l}29 \text { Sept } 2009 \\
\text { Decision on the prosecution's motion for an order requiring Sreten Lukic to file his appellant's } \\
\text { brief in accordance with the appeals chamber decisions }\end{array}$ & + \\
\hline Šainović et al & $\begin{array}{l}16 \text { Jun } 2011 \\
\text { Order requiring Sreten Lukic to re-file his second motion for leave to vary his notice of Appeal } \\
\text { and Appeal Brief }\end{array}$ & + \\
\hline Šešelj & $\begin{array}{l}1 \text { Feb } 2012 \\
\text { Decision on Prosecution's motion for extension of time and clarification }\end{array}$ & - \\
\hline Šešelj & $\begin{array}{l}22 \text { Aug } 2005 \\
\text { Decision on Motion for Extension of Time (Submission No. 100) }\end{array}$ & $+/-$ \\
\hline Šešelj & $\begin{array}{l}9 \text { Dec } 2004 \\
\text { Decision on the Accused's Submissions Number 6o and 61 for Request for Leave to Reply and } \\
\text { for Extension of Time to Reply }\end{array}$ & - \\
\hline Šešelj & $\begin{array}{l}\text { 30 Nov } 2004 \\
\text { Decision on Extension of Time to File a Response }\end{array}$ & - \\
\hline Šešelj & $\begin{array}{l}27 \text { May } 2010 \\
\text { Order on prosecution motion for extension of time to seek addition of materials belonging to } \\
\text { General Mladic to the } 65 \text { ter list of exhibits }\end{array}$ & + \\
\hline Šešelj & $\begin{array}{l}15 \text { Sept } 2008 \\
\text { Order on the accused's motion to extend the deadline to file his response to the motion to im- } \\
\text { pose counsel (submission) } 396\end{array}$ & + \\
\hline Šešelj & $\begin{array}{l}27 \text { Sept } 2006 \\
\text { Decision on extension of word limits }\end{array}$ & + \\
\hline Šešelj & $\begin{array}{l}4 \text { Feb } 2004 \\
\text { Decision on Prosecution's Request to Exceed the Ten Page Limit for Motions }\end{array}$ & + \\
\hline
\end{tabular}




\begin{tabular}{|c|c|c|}
\hline Trial & Language-related request & $+/-$ \\
\hline Šešelj & $\begin{array}{l}2 \text { Sept } 2003 \\
\text { Decision on Prosecution's Request to Exceed the Ten Page Limit for Motions }\end{array}$ & + \\
\hline Šešelj & $\begin{array}{l}9 \text { Mar } 2012 \\
\text { Order to redact the public transcript and the public broadcast of a hearing }\end{array}$ & + \\
\hline Šešelj & $\begin{array}{l}16 \mathrm{Jan} 2012 \\
\text { Order to redact the public transcript and the public broadcast of a hearing }\end{array}$ & + \\
\hline Šešelj & $\begin{array}{l}5 \text { Oct } 2011 \\
\text { Order to redact the public transcript and the public broadcast of a hearing }\end{array}$ & + \\
\hline Šešelj & $\begin{array}{l}24 \text { Aug } 2011 \\
\text { Order to redact the public transcript and the public broadcast of a hearing }\end{array}$ & + \\
\hline Šešelj & $\begin{array}{l}\text { 4 May } 2011 \\
\text { Order to redact the public transcript and the public broadcast of a hearing }\end{array}$ & + \\
\hline Šešelj & $\begin{array}{l}1 \text { Dec } 2010 \\
\text { Order to redact the public transcript and the public broadcast of a hearing }\end{array}$ & + \\
\hline Šešelj & $\begin{array}{l}\text { 25 Jun } 2010 \\
\text { Order to redact the public transcript and the public broadcast of a hearing }\end{array}$ & + \\
\hline Šešelj & $\begin{array}{l}\text { 14 Jun } 2010 \\
\text { Order to redact the public transcript and the public broadcast of a hearing }\end{array}$ & + \\
\hline Šešelj & $\begin{array}{l}19 \text { Mar } 2010 \\
\text { Order to redact the public transcript and the public broadcast of a hearing }\end{array}$ & + \\
\hline Šešelj & $\begin{array}{l}16 \text { Jun } 2010 \\
\text { Order to redact the public transcript and the public broadcast of a hearing }\end{array}$ & + \\
\hline Šešelj & $\begin{array}{l}4 \text { Feb } 2010 \\
\text { Order to redact the public transcript and the public broadcast of a hearing }\end{array}$ & + \\
\hline Šešelj & $\begin{array}{l}13 \text { Jan } 2010 \\
\text { Order to redact the public transcript and the public broadcast of a hearing }\end{array}$ & + \\
\hline Šešelj & $\begin{array}{l}7 \text { Jul } 2009 \\
\text { Order to redact the public transcript and the public broadcast of a hearing }\end{array}$ & + \\
\hline Šešelj & $\begin{array}{l}\text { 15 Jun } 2009 \\
\text { Order to redact the public transcript and the public broadcast of a hearing }\end{array}$ & + \\
\hline Šešelj & $\begin{array}{l}\text { 8 Jun } 2009 \\
\text { Order to redact the public transcript and the public broadcast of a hearing }\end{array}$ & + \\
\hline Šešelj & $\begin{array}{l}\text { 4Jun } 2009 \\
\text { Order to redact the public transcript and the public broadcast of a hearing }\end{array}$ & + \\
\hline Šešelj & $\begin{array}{l}7 \text { May } 2009 \\
\text { Order to redact the public transcript and the public broadcast of a hearing }\end{array}$ & + \\
\hline Šešelj & $\begin{array}{l}25 \text { Feb } 2009 \\
\text { Order to redact the public transcript and the public broadcast of a hearing }\end{array}$ & + \\
\hline Šešelj & $\begin{array}{l}18 \text { Nov } 2008 \\
\text { Order to redact the public transcript and the public broadcast of a hearing }\end{array}$ & + \\
\hline Šešelj & $\begin{array}{l}22 \text { Oct } 2008 \\
\text { Order to redact the public transcript and the public broadcast of a hearing }\end{array}$ & + \\
\hline Šešelj & $\begin{array}{l}7 \text { Jul } 2008 \\
\text { Order to redact the public transcript and the public broadcast of a hearing }\end{array}$ & + \\
\hline Šešelj & $\begin{array}{l}5 \text { Jun } 2008 \\
\text { Order to redact the public transcript and the public broadcast of a hearing }\end{array}$ & + \\
\hline Šešelj & $\begin{array}{l}16 \text { May } 2008 \\
\text { Order to redact the public transcript and the public broadcast of a hearing }\end{array}$ & + \\
\hline Šešelj & $\begin{array}{l}13 \text { May } 2008 \\
\text { Order to redact the public transcript and the public broadcast of a hearing }\end{array}$ & + \\
\hline Šešelj & $\begin{array}{l}25 \text { Apr } 2008 \\
\text { Order to redact the public transcript and the public broadcast of a hearing }\end{array}$ & + \\
\hline Šešelj & $\begin{array}{l}19 \text { Mar } 2008 \\
\text { Order to redact the public transcript and the public broadcast of a hearing }\end{array}$ & + \\
\hline Šešelj & $\begin{array}{l}19 \mathrm{Feb} 2008 \\
\text { Second order concerning the translation of documents the accused intends to tender as De- } \\
\text { fence evidence }\end{array}$ & + \\
\hline Šešelj & 22 Jan 2008 & + \\
\hline
\end{tabular}




\begin{tabular}{|c|c|c|}
\hline Trial & Language-related request & $+1-$ \\
\hline & Order to redact the public transcript and the public broadcast of a hearing & \\
\hline Šešelj & $\begin{array}{l}10 \text { Dec } 2007 \\
\text { Order to make correction to the transcript }\end{array}$ & + \\
\hline Šešelj & $\begin{array}{l}29 \text { Nov } 2007 \\
\text { Order on the translation of documents to be used by the accused in the cross-examination of } \\
\text { Anthony Oberschall }\end{array}$ & + \\
\hline Šešelj & $\begin{array}{l}27 \text { Nov } 2007 \\
\text { Order concerning the translation of documents the accused intends to tender as Defence evi- } \\
\text { dence }\end{array}$ & + \\
\hline Šešelj & $\begin{array}{l}14 \text { Nov } 2007 \\
\text { Order to redact the public transcript and the public broadcast of a hearing }\end{array}$ & + \\
\hline Šešelj & $\begin{array}{l}13 \text { Nov } 2007 \\
\text { Order to redact the public transcript and the public broadcast of a hearing }\end{array}$ & + \\
\hline Šešelj & $\begin{array}{l}6 \text { Mar } 2003 \\
\text { Order on Translation of Documents }\end{array}$ & + \\
\hline Šešelj & $\begin{array}{l}8 \text { Feb } 2012 \\
\text { Order on final trial brief filed by accused Vojislav Seselj }\end{array}$ & + \\
\hline Šešelj & $\begin{array}{l}26 \text { Jun } 2007 \\
\text { Order regarding the length of Prosecutions pre-trial brief }\end{array}$ & \\
\hline Sikirica et al & $\begin{array}{l}23 \text { May } 2001 \\
\text { Decision on Prosecution's Application to Admit Transcripts under Rule 92bis }\end{array}$ & + \\
\hline Sikirica et al & $\begin{array}{l}13 \text { Nov } 2000 \\
\text { Order releasing Transcript and granting protective Measures }\end{array}$ & + \\
\hline Simić et al & $\begin{array}{l}10 \text { Aug } 2004 \\
\text { Decision on Prosecution's Motion for Extension of Pages }\end{array}$ & - \\
\hline Simić et al & $\begin{array}{l}\text { 19 Jan } 2004 \\
\text { Decision on Motion of Blagoje Simic for Extension of Time to File Appellate Brief and Request } \\
\text { for Expedited Decision }\end{array}$ & + \\
\hline Stakić & $\begin{array}{l}27 \text { May } 2004 \\
\text { Decision on Prosecution's Motions for Extension of Page Limit and to Strike out Documents } \\
\text { from Appellant's Rule } 115 \text { Motion }\end{array}$ & + \\
\hline Stakić & $\begin{array}{l}\text { 12 Jan } 2004 \\
\text { Decision on Prosecution Motion for Extension of Time to File Reply Brief and for Extension of } \\
\text { Pages }\end{array}$ & + \\
\hline Stakić & $\begin{array}{l}19 \text { Dec } 2003 \\
\text { Decision on Second Motion for Extension of Time to File Appellant's Brief }\end{array}$ & + \\
\hline Stakić & $\begin{array}{l}30 \text { Oct } 2003 \\
\text { Decision on Motion for Extension of Time }\end{array}$ & $+1-$ \\
\hline Stakić & $\begin{array}{l}15 \text { Aug } 2003 \\
\text { Decision on Motion for Extension of Time }\end{array}$ & - \\
\hline Stakić & $\begin{array}{l}10 \text { Feb } 2004 \\
\text { Decision on Milomir Stakic's Motion to Enlarge Time for Filing of Copies of Documentary Evi- } \\
\text { dence Attached to his Motion for Admission of Additional Evidence Pursuant to Rule } 115\end{array}$ & $+1-$ \\
\hline Stakić & $\begin{array}{l}\text { 1 May } 2001 \\
\text { Order to the Prosecution to Disclose Transcript of Confirmation Hearing }\end{array}$ & + \\
\hline Stakić & $\begin{array}{l}\text { 15 Jan } 2002 \\
\text { Order on Prosecution's Motion for Reconsideration of prior Motion for Variation of length of } \\
\text { Pre-trial Brief }\end{array}$ & + \\
\hline Stakić & $\begin{array}{l}23 \text { Feb } 2004 \\
\text { Decision on Prosecution's Urgent Motion Regarding Defects in Milomir Stakic's Brief on Appeal }\end{array}$ & + \\
\hline Stanišić \& Simatović & $\begin{array}{l}6 \text { Dec } 2004 \\
\text { Decision on Defence Request for Extension of Page Limit Relating to Defence Pre-trial Brief }\end{array}$ & + \\
\hline Stanišić \& Simatović & $\begin{array}{l}22 \text { Aug } 2005 \\
\text { Decision on Motion for Extension of Time (Submission No. 100) }\end{array}$ & $+1-$ \\
\hline Stanišić \& Simatović & $\begin{array}{l}5 \text { Dec } 2012 \\
\text { Closing and scheduling order and decision on defence requests for word limit extensions for Fi- } \\
\text { nal Trial Briefs }\end{array}$ & + \\
\hline Stanišić \& Simatović & $\begin{array}{l}31 \text { Oct } 2013 \\
\text { Decision on Stanisic's urgent request for extension of word limit }\end{array}$ & $+1-$ \\
\hline
\end{tabular}




\begin{tabular}{|c|c|c|}
\hline Trial & Language-related request & $+/-$ \\
\hline Stanišić \& Simatović & $\begin{array}{l}24 \text { Aug } 2012 \\
\text { Decision on the Parties' Requests for Leave to Exceed Word Limit for Final Trial Briefs }\end{array}$ & $+/-$ \\
\hline Stanišić \& Simatović & $\begin{array}{l}\text { 30 Mar } 2009 \\
\text { Decision on prosecution request for leave to exceed word limit }\end{array}$ & - \\
\hline Stanišić \& Simatović & $\begin{array}{l}15 \text { Jun } 2005 \\
\text { Decision on 1. Defence Motions for Access to Ex Parte Supporting Materials related to the Prose- } \\
\text { cution Motion for Leave to Amend the Amended Indictment and flag = 3; And 2. Request from } \\
\text { the Defence of Stanisic for Leave to File a Response Exceeding the Page Limit to the Prosecu- } \\
\text { tion Motion for Leave to Amend the Amended Indictment }\end{array}$ & + \\
\hline Stanišić \& Simatović & $\begin{array}{l}7 \text { May } 2004 \\
\text { Decision on Prosecution's Motion for Leave to File Pre-trial Brief of Sixty Pages }\end{array}$ & + \\
\hline Stanišić \& Simatović & $\begin{array}{l}23 \text { May } 2012 \\
\text { Decision on Stanišić defence motion for admission of full transcripts of examination of } \\
\text { Tomislav Kovač in the scorpions trial }\end{array}$ & + \\
\hline Stanišić \& Simatović & $\begin{array}{l}15 \text { Dec } 2011 \\
\text { Decision on Stanisic defence motion for admission of transcripts and related exhibits in lieu of } \\
\text { viva voce testimony for two witnesses pursuant to Rule } 92 \text { bis }\end{array}$ & + \\
\hline Stanišić \& Simatović & $\begin{array}{l}20 \text { Oct } 2003 \\
\text { Decision on Defence Motion Filed by the Defence of Franko Simatovic (IT-o3-69-PT) for Access } \\
\text { to Transcripts and Documents }\end{array}$ & + \\
\hline Stanišić \& Simatović & $\begin{array}{l}15 \text { May } 2012 \\
\text { Order to Redact the Public Transcript and the Public Broadcast of a Hearing }\end{array}$ & + \\
\hline Stanišić \& Simatović & $\begin{array}{l}2 \text { Feb } 2012 \\
\text { Order to Redact the Public Transcript and the Public Broadcast of a Hearing }\end{array}$ & + \\
\hline Stanišić \& Simatović & $\begin{array}{l}\text { 26 Jan } 2012 \\
\text { Order to Redact the Public Transcript and the Public Broadcast of a Hearing }\end{array}$ & + \\
\hline Stanišić \& Simatović & $\begin{array}{l}\text { 25 Jan } 2012 \\
\text { Order to Redact the Public Transcript and the Public Broadcast of a Hearing }\end{array}$ & + \\
\hline Stanišić \& Simatović & $\begin{array}{l}14 \text { Dec } 2011 \\
\text { Order to redact the public transcript and the public broadcast of a hearing }\end{array}$ & + \\
\hline Stanišić \& Simatović & $\begin{array}{l}24 \text { Nov } 2011 \\
\text { Order to Redact the Public Transcript and the Public Broadcast of a Hearing }\end{array}$ & + \\
\hline Stanišić \& Simatović & $\begin{array}{l}3 \text { Aug } 2011 \\
\text { Order to Redact the Public Transcript and the Public Broadcast of a Hearing }\end{array}$ & + \\
\hline Stanišić \& Simatović & $\begin{array}{l}\text { 29 Jul } 2011 \\
\text { Order to Redact the Public Transcript and the Public Broadcast of a Hearing }\end{array}$ & + \\
\hline Stanišić \& Simatović & $\begin{array}{l}29 \text { Jul } 2011 \\
\text { Order to Redact the Public Transcript and the Public Broadcast of a Hearing }\end{array}$ & + \\
\hline Stanišić \& Simatović & $\begin{array}{l}22 \text { Jun } 2010 \\
\text { Order to Redact the Public Transcript and the Public Broadcast of a Hearing }\end{array}$ & + \\
\hline Stanišić \& Simatović & $\begin{array}{l}19 \text { May } 2010 \\
\text { Order to Redact the Public Transcript and the Public Broadcast of a Hearing }\end{array}$ & + \\
\hline Stanišić \& Simatović & $\begin{array}{l}26 \text { Feb } 2010 \\
\text { Order to Redact the Public Transcript and the Public Broadcast of a Hearing }\end{array}$ & + \\
\hline Stanišić \& Simatović & $\begin{array}{l}22 \text { Feb } 2010 \\
\text { Order to Redact the Public Transcript and the Public Broadcast of a Hearing }\end{array}$ & + \\
\hline Stanišić \& Simatović & $\begin{array}{l}14 \text { May } 2008 \\
\text { Order to redact the public transcript and the public broadcasting of a hearing, }\end{array}$ & + \\
\hline Stanišić \& Simatović & $\begin{array}{l}4 \text { Feb } 2008 \\
\text { Order regarding translations and disclosure }\end{array}$ & + \\
\hline Stanišić \& Simatović & $\begin{array}{l}\text { 25 Jun } 2015 \\
\text { Decision on Prosecution motion to replace audiovisual files of Witness Milan Babićs testimony } \\
\text { and to lift confidentiality of transcript excerpt }\end{array}$ & + \\
\hline Stanišić \& Župljanin & $\begin{array}{l}11 \text { May } 2012 \\
\text { Decision denying prosecution motion for extension of word limit for final trial brief }\end{array}$ & - \\
\hline Stanišić \& Župljanin & $\begin{array}{l}1 \text { May } 2012 \\
\text { Decision denying Prosecution motion for extension of word limit for final trial brief }\end{array}$ & - \\
\hline Stanišić \& Župljanin & $\begin{array}{l}27 \text { Apr } 2012 \\
\text { Decision denying Stanišić defence motion for extension of word limit for final Trial Brief }\end{array}$ & - \\
\hline
\end{tabular}




\begin{tabular}{|c|c|c|}
\hline Trial & Language-related request & $+/-$ \\
\hline Stanišić \& Župljanin & $\begin{array}{l}25 \text { Apr } 2012 \\
\text { Decision on denying Župljanin defence motion for extension of word limit for Final Brief }\end{array}$ & - \\
\hline Stanišić \& Župljanin & $\begin{array}{l}25 \text { Apr } 2012 \\
\text { Decision granting in part prosecution's motion for extension of time to file the final trial brief } \\
\text { and order on final trial briefs and closing arguments }\end{array}$ & $+/-$ \\
\hline Stanišić \& Župljanin & $\begin{array}{l}7 \text { Apr } 2010 \\
\text { Decision denying the Prosecution motion for an extension of time to request certification to ap- } \\
\text { peal the decision granting in part Prosecution's motions for judicial notice of adjudicated facts } \\
\text { pursuant to rule } 94(\mathrm{~B})\end{array}$ & - \\
\hline Stanišić \& Župljanin & $\begin{array}{l}\text { 31 Mar } 2011 \\
\text { Decision partially granting the defence motions for variation of the time limits set out in the or- } \\
\text { der of } 9 \text { February } 2011\end{array}$ & $+/-$ \\
\hline Stanišić \& Župljanin & $\begin{array}{l}8 \text { Jun } 2010 \\
\text { Decision partially granting prosecution's motions seeking additional time for witnesses to be } \\
\text { called pursuant to rule } 92 \text { ter }\end{array}$ & + \\
\hline Stanišić \& Župljanin & $\begin{array}{l}\text { 21 Jun } 2013 \\
\text { Decision on Mico Stanisic's motion seeking reconsideration of decision on variation of time and } \\
\text { word limits to file appellant's brief }\end{array}$ & - \\
\hline Stanišić \& Župljanin & $\begin{array}{l}\text { 4Jun } 2013 \\
\text { Decision on Mico Stanisic's and Stojan Zupljanin's motions seeking variation of time and word } \\
\text { limits to file appeal briefs }\end{array}$ & $+/-$ \\
\hline Stanišić \& Župljanin & $\begin{array}{l}18 \text { Aug } 2009 \\
\text { Decision on Milan Lukic's urgent motion for enlargement of time to file notice of appeal }\end{array}$ & - \\
\hline Stanišić \& Župljanin & $\begin{array}{l}\text { 13 Jul } 2011 \\
\text { Order to Redact the Public Transcript and the Public Broadcast of a Hearing }\end{array}$ & + \\
\hline Stanišić \& Župljanin & $\begin{array}{l}17 \text { Feb } 2011 \\
\text { Order to Redact the Public Transcript and the Public Broadcast of a Hearing }\end{array}$ & + \\
\hline Stanišić \& Župljanin & $\begin{array}{l}13 \text { Dec } 2010 \\
\text { Order to Redact the Public Transcript and the Public Broadcast of a Hearing }\end{array}$ & + \\
\hline Stanišić \& Župljanin & $\begin{array}{l}26 \text { Nov } 2010 \\
\text { Order to Redact the Public Transcript and the Public Broadcast of a Hearing }\end{array}$ & + \\
\hline Stanišić \& Župljanin & $\begin{array}{l}3 \text { Nov } 2010 \\
\text { Order to Redact the Public Transcript and the Public Broadcast of a Hearing }\end{array}$ & + \\
\hline Stanišić \& Župljanin & $\begin{array}{l}1 \text { Nov } 2010 \\
\text { Order to Redact the Public Transcript and the Public Broadcast of a Hearing }\end{array}$ & + \\
\hline Stanišić \& Župljanin & $\begin{array}{l}28 \text { Oct } 2010 \\
\text { Order to Redact the Public Transcript and the Public Broadcast of a Hearing }\end{array}$ & + \\
\hline Stanišić \& Župljanin & $\begin{array}{l}22 \text { Oct } 2010 \\
\text { Order to Redact the Public Transcript and the Public Broadcast of a Hearing }\end{array}$ & + \\
\hline Stanišić \& Župljanin & $\begin{array}{l}20 \text { Oct } 2010 \\
\text { Order to Redact the Public Transcript and the Public Broadcast of a Hearing }\end{array}$ & + \\
\hline Stanišić \& Župljanin & $\begin{array}{l}\text { 6 Jul } 2010 \\
\text { Order to redact the public transcript and the public broadcast of a hearing }\end{array}$ & + \\
\hline Stanišić \& Župljanin & $\begin{array}{l}29 \text { Jun } 2010 \\
\text { Order requiring the Prosecution to select the relevant portions of the Mladic notebooks and to } \\
\text { provide English translations thereof }\end{array}$ & + \\
\hline Stanišić \& Župljanin & $\begin{array}{l}17 \text { Nov } 2009 \\
\text { Order to Redact the Public Transcript and the Public Broadcast of a Hearing }\end{array}$ & + \\
\hline Stanišić \& Župljanin & $\begin{array}{l}\text { 21 Jun } 2013 \\
\text { Decision on Mico Stanisic's motion seeking reconsideration of decision on variation of time and } \\
\text { word limits to file appellant's brief }\end{array}$ & - \\
\hline Stanišić \& Župljanin & $\begin{array}{l}\text { 4 Jun } 2013 \\
\text { Decision on Mico Stanisic's and Stojan Zupljanin's motions seeking variation of time and word } \\
\text { limits to file appeal briefs }\end{array}$ & $+/-$ \\
\hline Strugar & $\begin{array}{l}9 \text { May } 2005 \\
\text { Decision on Defence Request for Extension of Time }\end{array}$ & $+/-$ \\
\hline Strugar & $\begin{array}{l}1 \text { Mar } 2005 \\
\text { Decision on Request for Extension of Time } \\
\end{array}$ & - \\
\hline Strugar & 13 Jun 2005 & - \\
\hline
\end{tabular}




\begin{tabular}{|c|c|c|}
\hline Trial & Language-related request & $+/-$ \\
\hline & $\begin{array}{l}\text { Decision on "Defence request for variation of time limit to file response to prosecution's appeal } \\
\text { brief" }\end{array}$ & \\
\hline Strugar & $\begin{array}{l}26 \text { May } 2004 \\
\text { Decision on Motion field on behalf of Mr. Miodrag Jokic for Access to Certain Confidential Por- } \\
\text { tions of the Trial Transcript in the Case of the Prosecutor v. Pavle Strugar }\end{array}$ & + \\
\hline Strugar & $\begin{array}{l}3 \text { Oct } 2007 \\
\text { Order for Translation }\end{array}$ & + \\
\hline Strugar & $\begin{array}{l}13 \text { Jun } 2005 \\
\text { Decision on "Defence request for variation of time limit to file response to prosecution's appeal } \\
\text { brief" }\end{array}$ & - \\
\hline Tolimir & $\begin{array}{l}10 \text { Oct } 2012 \\
\text { Decision on the prosecution request for extension of time to file public redacted version of the } \\
\text { prosecution Final Brief }\end{array}$ & $+/-$ \\
\hline Tolimir & $\begin{array}{l}14 \text { May } 2012 \\
\text { Consolidated decision on prosecution's bar table motions and the accused's motion for exten- } \\
\text { sion of time }\end{array}$ & $+/-$ \\
\hline Tolimir & $\begin{array}{l}29 \text { May } 2009 \\
\text { Decision on Tolimir's request for extension of time limit for filing a response to the prosecution } \\
\text { motion under rule 92bis }\end{array}$ & $+/-$ \\
\hline Tolimir & $\begin{array}{l}17 \text { Apr } 2009 \\
\text { Decision on Tolimir's motion for an extension of time to file a response to the prosecution's mo- } \\
\text { tion for judicial notice of adjudicated facts and motion for an order for verification of transla- } \\
\text { tion of the indictment }\end{array}$ & +-1 \\
\hline Tolimir & $\begin{array}{l}20 \text { Feb } 2014 \\
\text { Decision on Tolimir's motion for extension of time for filing amendments to the brief in reply }\end{array}$ & + \\
\hline Tolimir & $\begin{array}{l}17 \text { Jun } 2013 \\
\text { Decision on Tolimir's request for extension of time for filing an appellant's brief }\end{array}$ & + \\
\hline Tolimir & $\begin{array}{l}17 \text { May } 2013 \\
\text { Decision on motion for setting a time limit for filing an appellant's brief and for an extension of } \\
\text { word limit }\end{array}$ & + \\
\hline Tolimir & $\begin{array}{l}24 \text { Apr } 2009 \\
\text { Decision on Tolimir's requests regarding setting time limits for filing responses to prosecution } \\
\text { motions under rules } 92 \text { bis and } 94 \text { bis }\end{array}$ & $+/-$ \\
\hline Tolimir & $\begin{array}{l}\text { 9 Jul } 2013 \\
\text { Decision on Tolimir's request for a time limit to amend his notice of appeal and his Appeal brief }\end{array}$ & $+/-$ \\
\hline Tolimir & $\begin{array}{l}17 \text { May } 2013 \\
\text { Decision on motion for setting a time limit for filing an appellant's brief and for an extension of } \\
\text { word limit }\end{array}$ & $+/-$ \\
\hline Tolimir & $\begin{array}{l}12 \text { Jan } 2012 \\
\text { Decision on prosecution's motion for variation of the word limit for its final trial brief }\end{array}$ & +-1 \\
\hline Tolimir & $\begin{array}{l}27 \text { Aug } 2010 \\
\text { Decision on Zdravko Tolimir's request for transcripts in a language which he understands }\end{array}$ & - \\
\hline Tolimir & $\begin{array}{l}20 \mathrm{Jul} 2007 \\
\text { Decision on submission of Tolimir requesting translation of documents and transcripts }\end{array}$ & $+/-$ \\
\hline Tolimir & $\begin{array}{l}25 \mathrm{Jul} 2011 \\
\text { Order to redact the public transcript and the public broadcast of a hearing }\end{array}$ & + \\
\hline Tolimir & $\begin{array}{l}26 \text { May } 2011 \\
\text { Order to redact the public transcript and the public broadcast of a hearing }\end{array}$ & + \\
\hline Tolimir & $\begin{array}{l}11 \text { Nov } 2010 \\
\text { Order to redact the public transcript and the public broadcast of a hearing }\end{array}$ & + \\
\hline Tolimir & $\begin{array}{l}29 \text { Oct } 2010 \\
\text { Order to redact the public transcript and the public broadcast of a hearing }\end{array}$ & + \\
\hline Tolimir & $\begin{array}{l}14 \text { Sept } 2010 \\
\text { Order to redact the public transcript and the public broadcast of a hearing }\end{array}$ & + \\
\hline Tolimir & $\begin{array}{l}2 \text { Mar } 2009 \\
\text { Order regarding response to request of the prosecution relating to the length of the pre-trial } \\
\text { brief }\end{array}$ & + \\
\hline
\end{tabular}


Appendix 3. Ethnicity of the accused vs. languages of interpreters

\begin{tabular}{|c|c|c|c|}
\hline $\begin{array}{l}\text { Date and duration of pro- } \\
\text { ceedings }\end{array}$ & Accused & Ethnicity of the accused & Interpreters language \\
\hline $\begin{array}{l}\text { 3/04/1996 } \\
5^{\prime} 22^{\prime \prime}\end{array}$ & Tihomir Blaškićn ${ }^{864}$ & Bosnian Croat & Croatian (ijekavian) $)^{865}$ \\
\hline $\begin{array}{l}\text { 4/07/1997 } \\
\text { 24'08" }\end{array}$ & Slavko Dokmanović86 & Croatian Serb & Serbian $(\text { ekavian })^{867}$ \\
\hline $\begin{array}{l}\text { 30/o7/1997 } \\
36^{\prime} 38^{\prime \prime}\end{array}$ & Milan Kovačević ${ }^{868}$ & Bosnian Serb & $\begin{array}{l}\text { Croatian (ijekavian })^{869} \\
\text { Serbian (ekavian) }\end{array}$ \\
\hline $\begin{array}{l}\text { 8/10/1997 } \\
\text { 1hog'23" }\end{array}$ & Dario Kordić $^{870}$ & Bosnian Croat & $\begin{array}{l}\text { Croatian (ijekavian) })^{871} \\
\text { Serbian }(\text { ekavian })\end{array}$ \\
\hline $\begin{array}{l}\text { 8/10/1997 } \\
\text { 1hog'23" }\end{array}$ & Zoran Kupreškić $^{872}$ & Bosnian Croat & $\begin{array}{l}\text { Croatian (ijekavian) })^{873} \\
\text { Serbian }(\text { ekavian })\end{array}$ \\
\hline $\begin{array}{l}\text { 19/12/1997 } \\
22^{\prime} 56^{\prime \prime}\end{array}$ & Anto Furundžija ${ }^{874}$ & Bosnian Croat & $\begin{array}{l}\text { Croatian (ijekavian) } \\
\text { Serbian (ekavian) }\end{array}$ \\
\hline $\begin{array}{l}\text { 26/o1/1998 } \\
\text { 1h34'39" }\end{array}$ & Goran Jelisić $^{876}$ & Bosnian Serb & $\begin{array}{l}\text { Croatian (ijekavian) })^{877} \\
\text { Croatian (ijekavian) }\end{array}$ \\
\hline $\begin{array}{l}\text { 17/02/1998 } \\
\text { 59'22" }\end{array}$ & Miroslav Tadić ${ }^{878}$ & Bosnian Serb & $\begin{array}{l}\text { Croatian (ijekavian) })^{879} \\
\text { Croatian (ijekavian) }\end{array}$ \\
\hline $\begin{array}{l}17 / 02 / 1998 \\
45^{\prime} 15^{\prime \prime}\end{array}$ & Milan Simićc ${ }^{880}$ & Bosnian Serb & $\begin{array}{l}\text { Croatian (ijekavian) })^{881} \\
\text { Croatian (ijekavian) }\end{array}$ \\
\hline $\begin{array}{l}26 / 02 / 1998 \\
35^{\prime} 42^{\prime \prime}\end{array}$ & Simo Zarić & Bosnian Serb & $\begin{array}{l}\text { Croatian (ijekavian) })^{882} \\
\text { Croatian (ijekavian) }\end{array}$ \\
\hline $\begin{array}{l}9 / 03 / 1998 \\
165^{\prime \prime}\end{array}$ & Dragoljub Kunarac ${ }^{883}$ & Bosnian Serb & Serbian $(\text { ekavian })^{884}$ \\
\hline $\begin{array}{l}\text { 30/09/1998 } \\
5^{2} 34^{\prime \prime}\end{array}$ & Stevan Todorović $c^{885}$ & Bosnian Serb & $\begin{array}{l}\text { Croatian (ijekavian) }{ }^{886} \\
\text { Croatian (ijekavian) }\end{array}$ \\
\hline $\begin{array}{l}\text { 14/o6/1999 } \\
155^{\prime \prime}\end{array}$ & Dragan Kolundžija ${ }^{887}$ & Bosnian Serb & $\begin{array}{l}\text { Croatian }{\text { (ijekavian }{ }^{888}} \\
\text { Croatian (ijekavian) }\end{array}$ \\
\hline $\begin{array}{l}12 / 07 / 1999 \\
42^{\prime} 22^{\prime \prime}\end{array}$ & Radoslav Brđanin $^{889}$ & Bosnian Serb & $\begin{array}{l}\text { Serbian }(\text { ekavian })^{890} \\
\text { Croatian (ijekavian) }\end{array}$ \\
\hline
\end{tabular}

${ }^{864}$ ICTY, Blaškić CIS.

${ }^{865}$ ICTY videos, Blaškić IA, Original (FRE) and INT.

${ }^{866}$ ICTY, Dokmanović CIS.

${ }^{867}$ ICTY videos, Dokmanović IA, Original (ENG) and INT.

${ }^{868}$ ICTY, Kovačević CIS.

${ }^{869}$ ICTY videos, Kovačević IA, Original (ENG) and INT.

${ }^{870}$ ICTY, Kordić, Čerkez CIS.

${ }^{871}$ ICTY videos, Kordić, Čerkez IA, Original (FRE) and INT.

${ }^{872}$ ICTY, Kuprešić et al CIS.

${ }^{873}$ ICTY videos, Kuprešić et al IA, Original (FRE)and INT.

${ }^{874}$ ICTY, Furundžija CIS.

${ }^{875}$ ICTY videos, Furundžija IA, Original (ENG) and INT.

${ }^{876}$ ICTY, Jelisić CIS.

${ }_{877}^{8 C T Y}$ videos, Jelisić IA, Original (FRE) and INT.

${ }^{878}$ ICTY, Tadić CIS.

${ }_{879}^{8}$ ICTY videos, Tadić IA, Original (FRE): 1st, 2nd part; INT: 1st, nㅔ part.

${ }^{880}$ ICTY, Simić CIS.

${ }^{881}$ ICTY videos, Simić IA, Original (FRE) and INT.

${ }^{882}$ ICTY videos, Zarić IA, Original (FRE) and INT.

${ }^{883}$ ICTY, Kunarac et al CIS.

${ }^{884}$ ICTY videos, Kunarac et al IA, Original (ENG) and INT.

${ }^{885}$ ICTY, Todorović CIS.

${ }^{886}$ ICTY videos, Todorović IA, Original (ENG): 1st, 2nd part; INT: 1st, 2nd part.

${ }^{887}$ ICTY, Sikirica, Došen CIS.

${ }^{888}$ ICTY videos, Kolundžija IA, Original (ENG) and INT.

${ }^{889}$ ICTY, Brđanin CIS.

${ }^{890}$ ICTY videos, Brđanin IA, Original (ENG) and INT. 


\begin{tabular}{|c|c|c|c|}
\hline $\begin{array}{c}\text { Date and duration of pro- } \\
\text { ceedings }\end{array}$ & Accused & Ethnicity of the accused & Interpreters language \\
\hline $\begin{array}{l}\text { 12/o8/1999 } \\
42^{\prime} 22^{\prime \prime}\end{array}$ & Vinko Martinović $^{891}$ & Bosnian Croat & $\begin{array}{l}\text { Bosnian (ijekavian) } \\
\text { Serbian (ekavian) }\end{array}$ \\
\hline $\begin{array}{l}8 / 11 / 1999 \\
14^{\prime} 46^{\prime \prime}\end{array}$ & Damir Došen & Bosnian Croat & Bosnian $(\text { ijekavian })^{893}$ \\
\hline $\begin{array}{l}\text { 29/12/1999 } \\
\text { 30'31" }\end{array}$ & Stanislav Galić 894 & Bosnian Serb & $\begin{array}{l}\text { Serbian }(\text { ekavian })^{895} \\
\text { Croatian (ijekavian) }\end{array}$ \\
\hline $\begin{array}{l}\text { 28/o1/2000 } \\
10 ' 39 "\end{array}$ & Mitar Vasiljević ${ }^{896}$ & Bosnian Serb & Serbian (ekavian) \\
\hline $\begin{array}{l}10 / 03 / 2000 \\
41^{\prime} 41^{\prime \prime}\end{array}$ & Dragoljub Prcać ${ }^{897}$ & Bosnian Serb & $\begin{array}{l}\text { Croatian (ijekavian) } \\
\text { Serbian (ekavian) }\end{array}$ \\
\hline $\begin{array}{l}24 / 03 / 2000 \\
\text { 1h16'37" }\end{array}$ & Mladen Naletelic ${ }^{898}$ & Bosnian Croat & $\begin{array}{l}\text { Croatian (ijekavian) } \\
\text { Serbian (ekavian) }\end{array}$ \\
\hline $\begin{array}{l}\text { 7/04/2000 } \\
27^{\prime} 24 "\end{array}$ & Momčilo Krajišnik ${ }^{899}$ & Bosnian Serb & $\begin{array}{l}\text { Bosnian (ïekavian) } \\
\text { Serbian (ekavian) }\end{array}$ \\
\hline $\begin{array}{l}\text { 24/04/2000 } \\
\text { o7'31" }\end{array}$ & Dragan Nikolićc9o & Bosnian Serb & Serbian (ekavian) \\
\hline $\begin{array}{l}\text { 7/07/2000 } \\
24^{\prime} 45^{\prime \prime} \\
\end{array}$ & Duško Sikirica $^{901}$ & Bosnian Serb & Serbian (ekavian) \\
\hline $\begin{array}{l}11 / 01 / 2001 \\
18^{\prime} 45^{\prime \prime}\end{array}$ & Biljana Plavšićco2 & Bosnian Serb & Serbian (ekavian) \\
\hline $\begin{array}{l}15 / 03 / 2001 \\
16^{\prime} 50 "\end{array}$ & Blagoje Simićc ${ }^{903}$ & Bosnian Serb & $\begin{array}{l}\text { Serbian (ekavian) } \\
\text { Serbian (ekavian) } \\
\end{array}$ \\
\hline $\begin{array}{l}28 / 03 / 2001 \\
38 \text { 'O2" }\end{array}$ & Milomir Stakićco4 & Bosnian Serb & $\begin{array}{l}\text { Croatian (ijekavian) } \\
\text { Croatian (ijekavian) }\end{array}$ \\
\hline $\begin{array}{l}18 / 04 / 2001 \\
10^{\prime} 06^{\prime \prime}\end{array}$ & Dragan Obrenovićco5 & Bosnian Serb & Croatian (ijekavian) \\
\hline $\begin{array}{l}\text { 3/o7/2001 } \\
\text { o9'25" }\end{array}$ & Slobodan Miloševića ${ }^{906}$ & Serbian Serb & Serbian (ekavian) \\
\hline $\begin{array}{l}\text { 9/08/2001 } \\
21 ' 26 "\end{array}$ & $\begin{array}{l}\text { Enver Hadžihasanović } \\
\text { Mehmed Alagić } \\
\text { Amir Kubura }^{907}\end{array}$ & $\begin{array}{l}\text { Bosnian Muslim } \\
\text { Bosnian Muslim } \\
\text { Bosnian Muslim } \\
\end{array}$ & $\begin{array}{l}\text { Bosnian (ijekavian) } \\
\text { Serbian (ekavian) }\end{array}$ \\
\hline $\begin{array}{l}16 / 08 / 2001 \\
10 \text { '०8" }\end{array}$ & Vidoje Blagojevićc ${ }^{98}$ & Bosnian Serb & Bosnian (ijekavian) \\
\hline $\begin{array}{l}21 / 08 / 2001 \\
09^{\prime} 48^{\prime \prime}\end{array}$ & Dragan Jokićc ${ }^{\circ 9}$ & Bosnian Serb & Serbian (ekavian) \\
\hline $\begin{array}{l}27 / 09 / 2001 \\
116^{\prime \prime}\end{array}$ & Sefer Halilovićc ${ }^{910}$ & Bosnian Muslim & Bosnian (ijekavian) \\
\hline
\end{tabular}

${ }^{891}$ ICTY, Naletilić, Martinović CIS.

${ }^{892}$ ICTY videos, Martinović IA, Original (FRE) and INT.

${ }^{893}$ ICTY videos, Došen IA, Original (ENG) and INT.

${ }^{894}$ ICTY, Galić CIS.

${ }^{895}$ ICTY videos, Galić IA, Original (ENG) and INT.

${ }^{896}$ ICTY videos, Vasiljević IA, Original (ENG) and INT.

${ }^{897}$ ICTY videos, Prcać IA, Original (FRE) and INT.

${ }^{898}$ ICTY videos, Naletelić IA, Original (FRE) and INT.

${ }^{899}$ ICTY videos, Krajišnik IA, Original (ENG) and INT.

${ }^{900}$ ICTY videos, Nikolić IA, Original (ENG) and INT.

${ }^{901}$ ICTY videos, Sikirica IA, Original (ENG) and INT.

${ }^{902}$ ICTY videos, Plavšić IA, Original (ENG) and INT.

${ }_{903}^{\circ}$ ICTY videos, Simić IA, Original (ENG) and INT.

${ }^{904}$ ICTY videos, Stakić IA, Original (FRE) and INT.

${ }^{905}$ ICTY videos, Obrenović IA, Original (ENG) and INT.

${ }^{906}$ ICTY videos, Milošević IA, Original (ENG) and INT.

${ }^{907}$ ICTY videos, Hadžihasanović, Alagić, Kubura IA, Original (ENG) and INT.

${ }_{908}$ ICTY videos, Blagojević IA, Original (ENG) and INT.

${ }^{909}$ ICTY videos, Jokić IA, Original (ENG) and INT.

${ }^{910}$ ICTY videos, Halilović IA, Original (FRE) and INT. 


\begin{tabular}{|c|c|c|c|}
\hline $\begin{array}{l}\text { Date and duration of pro- } \\
\text { ceedings }\end{array}$ & Accused & Ethnicity of the accused & Interpreters language \\
\hline $\begin{array}{l}25 / 10 / 2001 \\
\text { 1ho8' } 37^{\prime \prime}\end{array}$ & Pavle Strugar $^{911}$ & Serbian Serb & $\begin{array}{l}\text { Croatian (ijekavian) } \\
\text { Serbian (ekavian) }\end{array}$ \\
\hline $\begin{array}{l}\text { 29/10/2001 } \\
2 \mathrm{~h} 45^{\prime 22 "}\end{array}$ & Slobodan Miloševićc ${ }^{12}$ & Serbian Serb & $\begin{array}{l}\text { Croatian (ijekavian) } \\
\text { Serbian (ekavian) }\end{array}$ \\
\hline $\begin{array}{l}14 / 11 / 2001 \\
45^{\prime} 40^{\prime \prime} \\
\end{array}$ & Miodrag Jokićs'is & Serbian Serb & $\begin{array}{l}\text { Croatian (ijekavian) } \\
\text { Serbian (ekavian) } \\
\end{array}$ \\
\hline $\begin{array}{l}16 / 11 / 2001 \\
20^{\prime} 50^{\prime \prime}\end{array}$ & $\begin{array}{l}\text { Nenad Banović } \\
\text { Predrag Banović }{ }^{914} \\
\end{array}$ & $\begin{array}{l}\text { Bosnian Serb } \\
\text { Bosnian Serb }\end{array}$ & Croatian (ijekavian) \\
\hline $\begin{array}{l}\text { 11/12/20o1 } \\
2 \text { hoo'25" }\end{array}$ & Slobodan Miloševićc ${ }^{15}$ & Serbian Serb & $\begin{array}{l}\text { Croatian (ijekavian) } \\
\text { Bosnian (ijekavian) }\end{array}$ \\
\hline $\begin{array}{l}\text { 3/04/2002 } \\
\text { 1h16'o7" }\end{array}$ & Momir Nikolićc ${ }^{916}$ & Bosnian Serb & $\begin{array}{l}\text { Croatian (ijekavian) } \\
\text { Serbian (ekavian) }\end{array}$ \\
\hline $\begin{array}{l}\text { 26/04/2002 } \\
10 ' 10 "\end{array}$ & Dragoljub Ojdanićc ${ }^{17}$ & Serbian Serb & Croatian (ïekavian) \\
\hline $\begin{array}{l}\text { 3/05/2002 } \\
10{ }^{\prime} 8^{\prime \prime} \\
\end{array}$ & Nikola Šainovićgi18 & Serbian Serb & Croatian (ijekavian) \\
\hline $\begin{array}{l}16 / 05 / 2002 \\
18^{\prime} 21^{\prime \prime}\end{array}$ & Mile Mrkšić ${ }^{19}$ & Serbian Serb & Croatian (ijekavian) \\
\hline $\begin{array}{l}\text { 21/05/2002 } \\
35 \text { '57" }\end{array}$ & Milan Martićc $c^{92 o}$ & Croatian Serb & Croatian (ijekavian) \\
\hline $\begin{array}{l}\text { 17/06/2002 } \\
26^{\prime} 17^{\prime \prime}\end{array}$ & Darko Mrđa ${ }^{921}$ & Bosnian Serb & Serbian (ekavian) \\
\hline $\begin{array}{l}\text { 20/06/2002 } \\
17^{\prime} 42^{\prime \prime}\end{array}$ & Ranko Češićc ${ }^{22}$ & Bosnian Serb & $\begin{array}{l}\text { Bosnian (ijekavian) } \\
\text { Serbian (ekavian) }\end{array}$ \\
\hline $\begin{array}{l}10 / 07 / 2002 \\
43^{\prime} 5^{\prime \prime}\end{array}$ & Miroslav Deronjićc $c^{93}$ & Bosnian Serb & $\begin{array}{l}\text { Serbian (ekavian) } \\
\text { Serbian (ekavian) }\end{array}$ \\
\hline $\begin{array}{l}\text { 26/o2/2003 } \\
\text { 2h24'54" }\end{array}$ & Vojislav Šešelj ${ }^{924}$ & Bosnian Serb & $\begin{array}{l}\text { Bosnian (ijekavian) } \\
\text { Croatian (ijekavian) }\end{array}$ \\
\hline $\begin{array}{l}\text { 25/03/2003 } \\
\text { 1hoo'5o" }\end{array}$ & Vojislav Šešelj ${ }^{25}$ & Bosnian Serb & $\begin{array}{l}\text { Serbian (ekavian) } \\
\text { Croatian (ijekavian) }\end{array}$ \\
\hline $\begin{array}{l}15 / 04 / 2003 \\
12 ' 42^{\prime \prime} \\
\end{array}$ & Naser Orićc ${ }^{26}$ & Bosnian Muslim & Croatian (ijekavian) \\
\hline $\begin{array}{l}21 / 05 / 2003 \\
41 ' 59 "\end{array}$ & Miroslav Radić ${ }^{927}$ & Serbian Serb & $\begin{array}{l}\text { Serbian (ekavian) } \\
\text { Croatian (ijekavian) }\end{array}$ \\
\hline $\begin{array}{l}\text { 2/06/2003 } \\
11 ' 25 "\end{array}$ & Franko Simatovićc $c^{928}$ & Serbian Serb & Serbian (ekavian) \\
\hline $13 / 06 / 2003$ & Jovica Stanišícic ${ }^{929}$ & Serbian Serb & Serbian (ekavian) \\
\hline
\end{tabular}

${ }^{91}$ ICTY videos, Strugar IA, Original (FRE) and INT.

${ }_{912}$ ICTY videos, Milošević $2^{\text {nd }}$ IA, Original (ENG): 1st, 2nd, 3rd, 4th part; INT: 1st, 2nd, 3rd, 4th part.

${ }^{913}$ ICTY videos, Jokić IA, Original (FRE) and INT.

${ }^{914}$ ICTY videos, Nenad Banović, Predrag Banović IA, Original (FRE) and INT.

${ }_{915}$ ICTY videos, Milošević $3^{\text {rd }}$ IA, Original (ENG): 1st, 2nd, 3rd, 4th part; INT: 1st, 2nd, 3rd, 4th part.

${ }_{916}^{91 C T Y}$ videos, Nikolić IA, Original (ENG) and INT.

${ }^{917}$ ICTY videos, Ojdanić IA, Original (ENG) and INT.

${ }_{918}$ ICTY videos, Šainović IA, Original (ENG) and INT.

${ }_{919}^{19}$ ICTY videos, Mrkšić IA, Original (ENG) and INT.

${ }^{920}$ ICTY videos, Martić IA, Original (ENG) and INT.

${ }^{921}$ ICTY videos, Mrđa IA, Original (ENG) and INT. Note mistake on ICTY site where "IA" video has been mistakenly linked under "TJ" in both language versions.

${ }_{922}^{22}$ ICTY videos, Češić IA, Original (ENG) and INT.

${ }^{923}$ ICTY videos, Deronjić IA, Original (ENG) and INT.

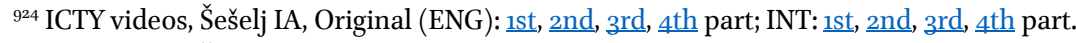

${ }_{925}$ ICTY videos, Šešelj $2^{\text {nd }}$ IA, Original (ENG): 1st, 2nd part; INT: 1st, 2nd part.

${ }^{926}$ ICTY videos, Orić IA, Original (ENG) and INT.

${ }_{927}$ ICTY videos, Radić IA, Original (ENG) and INT.

${ }^{928}$ ICTY videos, Simatović IA, Original (ENG) and INT.

${ }^{929}$ ICTY videos, Stanišić IA, Original (ENG) and INT. 


\begin{tabular}{|c|c|c|c|}
\hline $\begin{array}{c}\text { Date and duration of pro- } \\
\text { ceedings }\end{array}$ & Accused & Ethnicity of the accused & Interpreters language \\
\hline \multicolumn{4}{|l|}{$11^{\prime} 57^{\prime \prime}$} \\
\hline $\begin{array}{l}\text { 3/o7/2003 } \\
13^{\prime} 23^{\prime \prime}\end{array}$ & Veselin Šljivančanin ${ }^{930}$ & Serbian Serb & Croatian (ijekavian) \\
\hline $\begin{array}{l}26 / 11 / 2003 \\
23^{\prime} 06^{\prime \prime}\end{array}$ & Milan Babićc931 & Croatian Serb & Croatian (ijekavian) \\
\hline $\begin{array}{l}12 / 03 / 2004 \\
56^{\prime} 51^{\prime \prime}\end{array}$ & $\begin{array}{l}\text { Ivan Čermak } \\
\text { Mladen Markač }{ }^{932}\end{array}$ & $\begin{array}{l}\text { Croatian Croat } \\
\text { Croatian Croat }\end{array}$ & $\begin{array}{l}\text { Croatian (ijekavian) } \\
\text { Bosnian (ijekavian) }\end{array}$ \\
\hline $\begin{array}{l}\text { 6/04/2004 } \\
\text { 1h21'40" }\end{array}$ & $\begin{array}{l}\text { Jadranko Prlić } \\
\text { Bruno Stojić } \\
\text { Slobodan Praljak } \\
\text { Milivoj Petković } \\
\text { Valentin Čorić } \\
\text { Berislav Pušić933 }\end{array}$ & $\begin{array}{l}\text { Bosnian Croat } \\
\text { Bosnian Croat } \\
\text { Bosnian Croat } \\
\text { Bosnian Croat } \\
\text { Bosnian Croat } \\
\text { Bosnian Croat }\end{array}$ & $\begin{array}{l}\text { Croatian (ijekavian) } \\
\text { Serbian (ekavian) }\end{array}$ \\
\hline $\begin{array}{l}\text { 12/10/2004 } \\
\text { o6'16" }\end{array}$ & Ljubiša Beara ${ }^{934}$ & Bosnian Serb & Serbian (ekavian) \\
\hline $\begin{array}{l}15 / 11 / 2004 \\
31 ' 55^{\prime \prime} \\
\end{array}$ & Miroslav Bralo 935 & Bosnian Croat & $\begin{array}{l}\text { Croatian (ijekavian) } \\
\text { Croatian (ijekavian) }\end{array}$ \\
\hline $\begin{array}{l}/ 12 / 2004 \\
31^{\prime} \circ 8^{\prime \prime} \\
\end{array}$ & Dragomir Miloševićc 936 & Bosnian Serb & $\begin{array}{l}\text { Croatian (ijekavian) } \\
\text { Croatian (ijekavian) }\end{array}$ \\
\hline $\begin{array}{l}\text { 27/01/2005 } \\
\text { O7'O5" }\end{array}$ & Milan Milutinović937 & Serbian Serb & Serbian (ekavian) \\
\hline $\begin{array}{l}\text { 7/02/2005 } \\
51 ' 24 "\end{array}$ & Vladimir Lazarević 938 & Serbian Serb & $\begin{array}{l}\text { Croatian (ijekavian) } \\
\text { Serbian (ekavian) }\end{array}$ \\
\hline $\begin{array}{l}\text { 2/o3/2005 } \\
\text { 1h4o'23" }\end{array}$ & $\begin{array}{l}\text { Radivoje Miletić } \\
\text { Milan Gvero }\end{array}$ & $\begin{array}{l}\text { Bosnian Serb } \\
\text { Bosnian Serb }\end{array}$ & $\begin{array}{l}\text { Serbian (ekavian) } \\
\text { Serbian (ekavian) }\end{array}$ \\
\hline $\begin{array}{l}\text { 3/03/2005 } \\
17^{\prime} 13 "\end{array}$ & Rasim Delićc ${ }^{940}$ & Bosnian Muslim & Bosnian (ijekavian) \\
\hline $\begin{array}{l}\text { 9/03/2005 } \\
\text { 10'07" }\end{array}$ & Momčilo Perišićc 941 & Serbian Serb & Croatian (ijekavian) \\
\hline $\begin{array}{l}\text { 23/03/2005 } \\
\text { o7'08" }\end{array}$ & Drago Nikolić942 & Bosnian Serb & Croatian (ijekavian) \\
\hline $\begin{array}{l}31 / 03 / 2005 \\
28^{\prime} 21^{\prime \prime}\end{array}$ & Vinko Pandurević943 & Bosnian Serb & $\begin{array}{l}\text { Croatian (ijekavian) } \\
\text { Serbian (ekavian) } \\
\end{array}$ \\
\hline $\begin{array}{l}\text { 6/04/2005 } \\
11 ' 30^{\prime \prime}\end{array}$ & Sreten Lukićc94 & Serbian Serb & $\begin{array}{l}\text { Croatian (ijekavian) } \\
\text { Serbian (ekavian) } \\
\end{array}$ \\
\hline $\begin{array}{l}7 / 04 / 2005 \\
56^{\prime} 52^{\prime \prime}\end{array}$ & Ljubomir Borovčanin $^{945}$ & Bosnian Serb & $\begin{array}{l}\text { Croatian (ijekavian) } \\
\text { Serbian (ekavian) }\end{array}$ \\
\hline $\begin{array}{l}\text { 18/04/2005 } \\
12 ' 59 "\end{array}$ & Vujadin Popović' ${ }^{946}$ & Bosnian Serb & Croatian (ijekavian) \\
\hline
\end{tabular}

${ }_{930}$ ICTY videos, Šljivančanin IA, Original (ENG) and INT.

${ }^{931}$ ICTY videos, Babić IA, Original (FRE): $\underline{1 s t}$, nd part; INT: $\underline{1 s t}$, nd part. Note mistake on the ICTY site where "IS" video has been mistakenly linked under "TJ" in B/C/S.

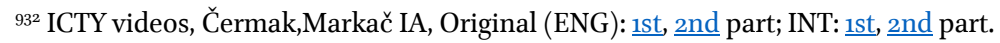

${ }^{933}$ ICTY videos, Prlić, Stojić, Praljak, Petković, Čorić, Pušić IA, Original (ENG): 1st, nd part; INT: 1st, nd part.

${ }_{934}$ ICTY videos, Beara IA, Original (ENG) and INT.

${ }_{935}$ ICTY videos, Bralo IA, Original (FRE) and INT.

${ }^{936}$ ICTY videos, Milošević IA, Original (ENG) and INT.

${ }^{937}$ ICTY videos, Milutinović IA, Original (ENG) and INT.

${ }_{938}^{8}$ ICTY videos, Lazarević IA, Original (ENG) and INT.

${ }_{939}$ ICTY videos, Miletić, Gvero IA, Original (ENG): 1st, 2nd part; INT: 1st, nd part.

${ }^{940}$ ICTY videos, Delić IA, Original (ENG) and INT.

${ }^{941}$ ICTY videos, Perišić IA, Original (ENG) and INT.

${ }_{942}$ ICTY videos, Nikolić IA, Original (ENG) and INT.

${ }^{943}$ ICTY videos, Pandurević IA, Original (FRE) and INT.

${ }^{944}$ ICTY videos, Lukić IA, Original (ENG) and INT.

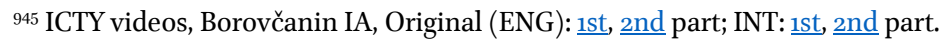

${ }^{946}$ ICTY videos, Popović IA, Original (ENG) and INT. 


\begin{tabular}{|c|c|c|c|}
\hline $\begin{array}{l}\text { Date and duration of pro- } \\
\text { ceedings }\end{array}$ & Accused & Ethnicity of the accused & Interpreters language \\
\hline $\begin{array}{l}28 / 04 / 2005 \\
22 ' 12 "\end{array}$ & Nebojša Pavkovićc ${ }^{947}$ & Serbian Serb & $\begin{array}{l}\text { Serbian (ekavian) } \\
\text { Serbian (ekavian) }\end{array}$ \\
\hline $\begin{array}{l}12 / 12 / 2005 \\
1 h_{33} 35^{\prime \prime}\end{array}$ & Ante Gotovina ${ }^{948}$ & Croatian Croat & $\begin{array}{l}\text { Croatian (ijekavian) } \\
\text { Serbian (ekavian) }\end{array}$ \\
\hline $\begin{array}{l}\text { 13/o2/2006 } \\
\text { o6'55" }\end{array}$ & Sredoje Lukić 949 & Bosnian Serb & Croatian (ijekavian) \\
\hline $\begin{array}{l}31 / 03 / 2006 \\
21 ' 55 "\end{array}$ & Milan Lukić 950 & Bosnian Serb & Serbian (ekavian) \\
\hline $\begin{array}{l}\text { 19/o6/2007 } \\
17^{\prime} \mathrm{O} 2^{\prime \prime}\end{array}$ & Vlastimir Đorđević ${ }^{951}$ & Serbian Serb & Serbian (ekavian) \\
\hline $\begin{array}{l}\text { 3/07/2007 } \\
41^{\prime} 52^{\prime \prime}\end{array}$ & Zdravko Tolimir ${ }^{952}$ & Bosnian Serb & $\begin{array}{l}\text { Serbian (ekavian) } \\
\text { Croatian (ijekavian) }\end{array}$ \\
\hline $\begin{array}{l}\text { 31/o7/2008 } \\
\text { 1ho6'26" }\end{array}$ & Radovan Karadžić953 & Bosnian Serb & $\begin{array}{l}\text { Bosnian (ijekavian) } \\
\text { Serbian (ekavian) }\end{array}$ \\
\hline $\begin{array}{l}29 / 08 / 2008 \\
24 \text { '09" }\end{array}$ & Radovan Karadžićc954 & Bosnian Serb & $\begin{array}{l}\text { Bosnian (ijekavian) } \\
\text { Serbian (ekavian) }\end{array}$ \\
\hline $\begin{array}{l}\text { 20/11/2008 } \\
10 \text { '30" }\end{array}$ & $\begin{array}{l}\text { Mićo Stanišić } \\
\text { Stojan Župljanin }^{955}\end{array}$ & $\begin{array}{l}\text { Bosnian Serb } \\
\text { Bosnian Serb }\end{array}$ & Croatian (ijekavian) \\
\hline $\begin{array}{l}\text { 3/o6/2011 } \\
\text { 1ho2'5o" }\end{array}$ & Ratko Mladić $95^{6}$ & Bosnian Serb & $\begin{array}{l}\text { Bosnian (ijekavian) } \\
\text { Serbian (ekavian) }\end{array}$ \\
\hline $\begin{array}{l}4 / 07 / 2011 \\
48 ' 49 "\end{array}$ & Ratko Mladić957 & Bosnian Serb & $\begin{array}{l}\text { Serbian (ekavian) } \\
\text { Bosnian (ijekavian) }\end{array}$ \\
\hline $\begin{array}{l}\text { 25/o7/2011 } \\
11 ' 21 "\end{array}$ & Goran Hadžić9 $95^{8}$ & Croatian Serb & Serbian (ekavian) \\
\hline $\begin{array}{l}\text { 24/o8/2011 } \\
\text { o8'29" }\end{array}$ & Goran Hadžić959 & Croatian Serb & Croatian (ijekavian) \\
\hline
\end{tabular}

${ }^{947}$ ICTY videos, Pavković IA, Original (ENG) and INT.

${ }_{948}$ ICTY videos, Gotovina IA, Original (ENG): 1st, 2nd part; INT: 1st, 2nd part.

${ }^{949}$ ICTY videos, Lukić IA, Original (ENG) and INT.

${ }^{95^{\circ}}$ ICTY videos, Lukić IA, Original (ENG) and INT.

${ }^{951}$ ICTY videos, Đorđević IA, Original (ENG) and INT.

${ }_{952}^{2}$ ICTY videos, Tolimir IA, Original (ENG) and INT.

${ }_{953}$ ICTY videos, Karadžić IA, Original (ENG): 1st, 2nd part; INT: 1st, nd part.

${ }^{954}$ ICTY videos, Karadžić IA, Original (ENG) and INT.

${ }_{955}$ ICTY videos, Stanišić, Župljanin IA, Original (ENG) and INT.

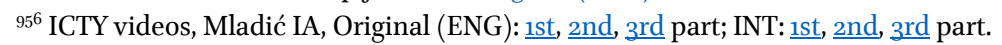

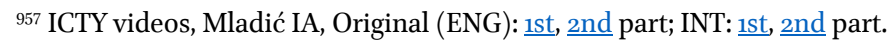

${ }_{958}^{8}$ ICTY videos, Hadžić IA, Original (ENG) and INT.

${ }_{959}$ ICTY videos, Hadžić IA, Original (ENG) and INT. 
Appendix 4. Language of interpreters vs. location of crimes and ethnicity of victims

\begin{tabular}{|c|c|c|c|}
\hline $\begin{array}{l}\text { Date, type and duration of } \\
\text { proceedings }\end{array}$ & Accused and the ethnicity & $\begin{array}{l}\text { Location of crimes and eth- } \\
\text { nicity of victims }\end{array}$ & Interpreters language \\
\hline $\begin{array}{l}\text { 14/o7/1997, TJ } \\
\text { 13"O5' }\end{array}$ & $\begin{array}{l}\text { Tadić96o } \\
\text { Bosnian Serb }\end{array}$ & $\begin{array}{l}\text { B\&H } \\
\text { Bosnian Muslims }\end{array}$ & $\begin{array}{l}\text { Croatian (ijekavian)* } \\
\text { Serbian (ekavian) }\end{array}$ \\
\hline $\begin{array}{l}7 / 10 / 1997, \mathrm{AJ} \\
22 " 50^{\prime}\end{array}$ & $\begin{array}{l}\text { Erdemović }^{961} \\
\text { Bosnian Serb }\end{array}$ & $\begin{array}{l}\text { B\& } \mathrm{H}^{962} \\
\text { Bosnian Muslims }\end{array}$ & $\begin{array}{l}\text { Croatian (ijekavian) } \\
\text { Serbian (ekavian) }\end{array}$ \\
\hline $\begin{array}{l}\text { 7/o5/1999, TJ } \\
32 " 31\end{array}$ & $\begin{array}{l}\text { Aleksovski }^{963} \\
\text { Bosnian Croat }\end{array}$ & $\begin{array}{l}\text { B\&H }{ }^{964} \\
\text { Bosnian Muslims }\end{array}$ & $\begin{array}{l}\text { Croatian (ijekavian) } \\
\text { Croatian (ijekavian) }\end{array}$ \\
\hline $\begin{array}{l}15 / 07 / 1999, \mathrm{AJ} \\
26^{\prime \prime} 6^{\prime}\end{array}$ & $\begin{array}{l}\text { Tadić }{ }^{65} \\
\text { Bosnian Serb }\end{array}$ & $\begin{array}{l}\text { B\&H } \\
\text { Bosnian Muslims }\end{array}$ & $\begin{array}{l}\text { Croatian (ijekavian)* } \\
\text { Croatian (ijekavian)* }\end{array}$ \\
\hline $\begin{array}{l}14 / 12 / 1999, \mathrm{TJ} \\
26 " 35\end{array}$ & $\begin{array}{l}\text { Jelisić }^{966} \\
\text { Bosnian Serb }\end{array}$ & $\begin{array}{l}\text { B\&H } \\
\text { Bosnian Muslims }\end{array}$ & $\begin{array}{l}\text { Croatian (ijekavian) } \\
\text { Serbian (ekavian) }\end{array}$ \\
\hline $\begin{array}{l}\text { 14/12/1999, TJ } \\
57 " 51^{\prime}\end{array}$ & $\begin{array}{l}\text { Delalić et al }{ }^{967} \\
\text { Bosnian Muslims and Croats }\end{array}$ & $\begin{array}{l}\text { B\& }{ }^{968} \\
\text { Bosnian Serbs }\end{array}$ & $\begin{array}{l}\text { Serbian (ekavian) } \\
\text { Croatian (ijekavian) }\end{array}$ \\
\hline $\begin{array}{l}\text { 14/o1/200o, TJ } \\
37^{\prime \prime} 46^{\prime}\end{array}$ & $\begin{array}{l}\text { Kupreškić et al }{ }^{969} \\
\text { Bosnian Croats }\end{array}$ & $\mathrm{B} \& \mathrm{H}^{970}$ & $\begin{array}{l}\text { Croatian (ijekavian)* } \\
\text { Croatian (ijekavian) }\end{array}$ \\
\hline $\begin{array}{l}\text { 3/o3/200o, TJ } \\
\text { 1ho6"15' }\end{array}$ & $\begin{array}{l}\text { Blaškićc }{ }^{91} \\
\text { Bosnian Croat }\end{array}$ & $\mathrm{B} \& \mathrm{H}$ & $\begin{array}{l}\text { Croatian (ijekavian) } \\
\text { Croatian (ijekavian) }\end{array}$ \\
\hline $\begin{array}{l}\text { 24/O3/200o, TJ } \\
28 " 41^{\prime}\end{array}$ & $\begin{array}{l}\text { Aleksovski }^{972} \\
\text { Bosnian Croat }\end{array}$ & $\mathrm{B} \& \mathrm{H}$ & $\begin{array}{l}\text { Serbian (ekavian) } \\
\text { Croatian (ijekavian) }\end{array}$ \\
\hline $\begin{array}{l}\text { 21/o7/200o, AJ } \\
13 " 32\end{array}$ & $\begin{array}{l}\text { Furundžija }{ }^{973} \\
\text { Bosnian Croat }\end{array}$ & $\mathrm{B} \& \mathrm{H}$ & Croatian (ijekavian) \\
\hline $\begin{array}{l}\text { 20/O2/2001, AJ } \\
40 " 58 '\end{array}$ & $\begin{array}{l}\text { Delalić et al }{ }^{974} \\
\text { Bosnian Muslims and Croats }\end{array}$ & $\mathrm{B} \& \mathrm{H}$ & $\begin{array}{l}\text { Serbian (ekavian) } \\
\text { Bosnian (ijekavian) }\end{array}$ \\
\hline $\begin{array}{l}22 / 02 / 2001, \mathrm{TJ} \\
32 " 23\end{array}$ & $\begin{array}{l}\text { Kunarac et al }{ }^{975} \\
\text { Bosnian Serbs }\end{array}$ & $\mathrm{B} \& \mathrm{H}$ & $\begin{array}{l}\text { Bosnian (ijekavian) } \\
\text { Croatian (ijekavian)* }\end{array}$ \\
\hline $\begin{array}{l}\text { 26/O2/2001, TJ } \\
35 " 31^{\prime}\end{array}$ & $\begin{array}{l}\text { Kordić and Čerkez }{ }^{976} \\
\text { Bosnian Croats } \\
\end{array}$ & $\mathrm{B} \& \mathrm{H}$ & $\begin{array}{l}\text { Croatian (ijekavian) } \\
\text { Serbian (ekavian) }\end{array}$ \\
\hline $\begin{array}{l}\text { 5/o7/2001, AJ } \\
23 " 40^{\prime}\end{array}$ & $\begin{array}{l}\text { Jelisić977 } \\
\text { Bosnian Serb }\end{array}$ & $\mathrm{B} \& \mathrm{H}^{978}$ & Croatian (ijekavian) \\
\hline $\begin{array}{l}31 / 07 / 2001, \mathrm{SJ} \\
16^{\prime \prime} \mathrm{O} 2\end{array}$ & $\begin{array}{l}\text { Todorović }{ }^{979} \\
\text { Bosnian Serb }\end{array}$ & $\mathrm{B} \& \mathrm{H}$ & $\begin{array}{l}\text { Serbian (ekavian) } \\
\text { Croatian (ijekavian) }\end{array}$ \\
\hline $\begin{array}{l}\text { 2/08/2001, TJ } \\
\text { 1h26"34' }\end{array}$ & $\begin{array}{l}\text { Krstićc }{ }^{80} \\
\text { Bosnian Serb }\end{array}$ & $\mathrm{B} \& \mathrm{H}^{981}$ & $\begin{array}{l}\text { Croatian (ijekavian)* } \\
\text { Serbian (ekavian) }\end{array}$ \\
\hline
\end{tabular}

${ }^{960}$ ICTY videos, Tadić TJ, Original (ENG) and INT.

${ }^{961}$ ICTY videos, Erdemović AJ, Original (ENG) and INT.

${ }^{962}$ ICTY, Erdemović CIS.

${ }^{963}$ ICTY videos, Aleksovski TJ, Original (FRE) and INT.

${ }^{964}$ ICTY, Aleksovski CIS.

${ }^{965}$ ICTY videos, Tadić AJ, Original (ENG) and INT.

${ }^{966}$ ICTY videos, Jelisić TJ, Original (FRE) and INT.

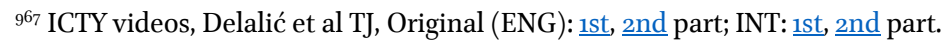

${ }^{968}$ ICTY, Delalić et al CIS.

${ }^{969}$ ICTY videos, Kupreškić et al TJ, Original (ENG) and INT.

${ }_{970}$ ICTY, Kupreškić et al CIS.

${ }_{971}$ ICTY videos, Blaškić TJ, Original (FRE): 1st, 2nd part; INT: 1st, 2nd part.

${ }^{972}$ ICTY videos, Aleksovski AJ, Original (ENG) and INT.

${ }_{973}$ ICTY videos, Furundžija AJ, Original (ENG) and INT.

${ }_{974}$ ICTY videos, Delalić et al AJ, Original (ENG) and INT.

975 ICTY videos, Kunarac et al TJ, Original (ENG) and INT.

${ }^{976}$ ICTY videos, Kordić, Čerkez TJ, Original (ENG) and INT.

${ }_{977}$ ICTY videos, Jelisić AJ, Original (ENG) and INT.

${ }_{978}$ ICTY, Jelisić CIS.

${ }^{979}$ ICTY videos, Stevan Todorović SJ, Original (ENG) and INT.

${ }^{980}$ ICTY videos, Krstić TJ, Original (FRE) and INT.

${ }^{881}$ ICTY, Krstić CIS. 


\begin{tabular}{|c|c|c|c|}
\hline $\begin{array}{c}\text { Date, type and duration of } \\
\text { proceedings }\end{array}$ & Accused and the ethnicity & $\begin{array}{c}\text { Location of crimes and eth- } \\
\text { nicity of victims }\end{array}$ & Interpreters language \\
\hline $\begin{array}{l}23 / 10 / 2001, A J \\
57 " 57\end{array}$ & $\begin{array}{l}\text { Kupreškić et al }{ }^{982} \\
\text { Bosnian Croats }\end{array}$ & $\mathrm{B} \& \mathrm{H}$ & $\begin{array}{l}\text { Bosnian (ijekavian) } \\
\text { Croatian (ijekavian) }\end{array}$ \\
\hline $\begin{array}{l}2 / 11 / 2001, \mathrm{TJ} \\
59^{\prime \prime} 34^{\prime}\end{array}$ & $\begin{array}{l}\text { Kvočka et al }{ }^{9{ }^{83}} \\
\text { Bosnian Serbs } \\
\end{array}$ & $\mathrm{B} \& \mathrm{H}^{984}$ & $\begin{array}{l}\text { Croatian (ijekavian)* } \\
\text { Serbian (ekavian) }\end{array}$ \\
\hline $\begin{array}{l}13 / 11 / 2001, \text { SJ } \\
25 " 28\end{array}$ & $\begin{array}{l}\text { Sikirica et al } \mathrm{l}^{985} \\
\text { Bosnian Serbs }\end{array}$ & $\mathrm{B} \& \mathrm{H}^{986}$ & Croatian (ijekavian)* $^{*}$ \\
\hline $\begin{array}{l}15 / 03 / 2002, \mathrm{TJ} \\
28 ” 04^{\prime}\end{array}$ & $\begin{array}{l}\text { Krnojelac }^{987} \\
\text { Bosnian Serb }\end{array}$ & $\mathrm{B} \& \mathrm{H}^{988}$ & $\begin{array}{l}\text { Croatian (ijekavian) } \\
\text { Serbian (ekavian) }\end{array}$ \\
\hline $\begin{array}{l}\text { 22/06/2002, AJ } \\
43 " 54^{\prime}\end{array}$ & $\begin{array}{l}\text { Kunarac et al }{ }^{989} \\
\text { Bosnian Serbs } \\
\end{array}$ & $\mathrm{B} \& \mathrm{H}$ & $\begin{array}{l}\text { Croatian (ijekavian) } \\
\text { Serbian (ekavian) }\end{array}$ \\
\hline $\begin{array}{l}\text { 17/10/2002, TJ } \\
23 " 066^{\prime}\end{array}$ & $\begin{array}{l}\text { Simić99o } \\
\text { Bosnian Serb }\end{array}$ & $\mathrm{B} \& \mathrm{H}^{991}$ & $\begin{array}{l}\text { Croatian (ijekavian)* } \\
\text { Serbian (ekavian) }\end{array}$ \\
\hline $\begin{array}{l}28 / 11 / 2002, \mathrm{TJ} \\
26 " 13\end{array}$ & $\begin{array}{l}\text { Vasiljević }^{992} \\
\text { Bosnian Serb }\end{array}$ & $\mathrm{B} \& \mathrm{H}^{993}$ & $\begin{array}{l}\text { Serbian (ekavian) } \\
\text { Croatian (ijekavian)* }\end{array}$ \\
\hline $\begin{array}{l}27 / 02 / 2003, \mathrm{TJ} \\
32 " 56^{\prime}\end{array}$ & $\begin{array}{l}\text { Plavšićc94 } \\
\text { Bosnian Serb } \\
\end{array}$ & $\mathrm{B} \& \mathrm{H}^{995}$ & $\begin{array}{l}\text { Serbian (ekavian) } \\
\text { Bosnian (ijekavian) }\end{array}$ \\
\hline $\begin{array}{l}\text { 31/o3/2003, TJ } \\
\text { 1h29"21' }\end{array}$ & $\begin{array}{l}\text { Naletelić and Martinović } 996 \\
\text { Bosnian Croats }\end{array}$ & $\mathrm{B} \& \mathrm{H}^{997}$ & $\begin{array}{l}\text { Croatian (ijekavian) } \\
\text { Bosnian (ijekavian) }\end{array}$ \\
\hline $\begin{array}{l}31 / 07 / 2003, \mathrm{TJ} \\
58^{\prime \prime} 6^{\prime}\end{array}$ & $\begin{array}{l}\text { Stakić }{ }^{99} \\
\text { Bosnian Serb } \\
\end{array}$ & $\mathrm{B} \& \mathrm{H}^{999}$ & $\begin{array}{l}\text { Bosnian (ijekavian) } \\
\text { Serbian (ekavian) }\end{array}$ \\
\hline $\begin{array}{l}17 / 09 / 2003, \mathrm{AJ} \\
\text { 1h12"22' }\end{array}$ & $\begin{array}{l}\text { Krnojelac }^{1000} \\
\text { Bosnian Serb }\end{array}$ & $\mathrm{B} \& \mathrm{H}$ & $\begin{array}{l}\text { Croatian (ijekavian)* } \\
\text { Serbian (ekavian) }\end{array}$ \\
\hline $\begin{array}{l}17 / 10 / 2003, \mathrm{TJ} \\
25 " 28^{\prime}\end{array}$ & $\begin{array}{l}\text { Simić et al }{ }^{1001} \\
\text { Bosnian Serbs }\end{array}$ & $\mathrm{B} \& \mathrm{H}^{1002}$ & $\begin{array}{l}\text { Croatian (ijekavian) } \\
\text { Serbian (ekavian) }\end{array}$ \\
\hline $\begin{array}{l}28 / 10 / 2003, \mathrm{SJ} \\
26 " 47^{\prime}\end{array}$ & $\begin{array}{l}\text { Banovićico3 } \\
\text { Bosnian Serb }\end{array}$ & $\mathrm{B} \& \mathrm{H}^{1004}$ & $\begin{array}{l}\text { Croatian (ijekavian) } \\
\text { Serbian (ekavian) }\end{array}$ \\
\hline $\begin{array}{l}2 / 12 / 2003, \mathrm{TJ} \\
32^{\prime \prime O 5}\end{array}$ & $\begin{array}{l}\text { Nikolićín } \\
\text { Bosnian Serb }\end{array}$ & $\mathrm{B} \& \mathrm{H}^{1006}$ & $\begin{array}{l}\text { Croatian (ijekavian) } \\
\text { Serbian (ekavian) }\end{array}$ \\
\hline $\begin{array}{l}5 / 12 / 2003, \mathrm{TJ} \\
44^{\prime \prime} 36^{\prime}\end{array}$ & $\begin{array}{l}\text { Galić }^{1007} \\
\text { Bosnian Serb }\end{array}$ & $\mathrm{B} \& \mathrm{H}$ & $\begin{array}{l}\text { Serbian (ekavian) } \\
\text { Croatian (ijekavian) }\end{array}$ \\
\hline
\end{tabular}

\footnotetext{
${ }^{982}$ ICTY videos, Kupreškić et al AJ, Original (ENG) and INT.

${ }^{983}$ ICTY videos, Kvočka et al TJ, Original (FRE) and INT.

${ }^{984}$ ICTY, Kvočka et al CIS.

${ }^{985}$ ICTY videos, Sikirica et al SJ, Original (ENG) and INT.

${ }^{986}$ ICTY, Sikirica et al CIS.

${ }^{987}$ ICTY videos, Krnojelac TJ, Original (ENG) and INT.

${ }^{888}$ ICTY, Krnojelac CIS.

${ }^{989}$ ICTY videos, Kunarac et al AJ, Original (FRE) and INT.

${ }^{990}$ ICTY videos, Simić TJ, Original (ENG) and INT.

${ }^{991}$ ICTY, $\underline{\text { Simić CIS. }}$

${ }^{992}$ ICTY videos, Vasiljević TJ, Original (ENG) and INT.

${ }^{993}$ ICTY, Vasiljević CIS.

${ }^{994}$ ICTY videos, Plavšić TJ, Original (ENG) and INT.

${ }^{995}$ ICTY, Plavšić CIS.

${ }_{996}$ ICTY videos, Naletelić, Martinović TJ, Original (ENG): 1st, nd part; INT: 1st, 2nd part.

${ }^{997}$ ICTY, Naletelić, Martinović CIS.

${ }^{998}$ ICTY videos, Stakić TJ, Original (ENG): $\underline{1 s t}$, nd part; INT: $\underline{1 s t}$, 2nd part.

${ }^{999}$ ICTY, Stakić CIS: http://ow.ly/PjCF3ogacjC.

${ }^{1000}$ ICTY videos, Krnojelac AJ, Original (FRE) and INT: 1st, end part.

${ }^{1001}$ ICTY videos, Simić et al TJ, Original (ENG): 1st, nd part; INT: 1st, 2nd part.

${ }^{1002}$ ICTY, Simić et al CIS.

${ }^{1003}$ ICTY videos, Banović SJ, Original (ENG) and INT.

${ }^{1004}$ ICTY, Banović CIS.

${ }^{1005}$ ICTY videos, Nikolić TJ, Original (ENG) and INT.

${ }^{1006}$ ICTY, Nikolić CIS.

${ }^{1007}$ ICTY videos, Galić TJ, Original (ENG) and INT.
} 


\begin{tabular}{|c|c|c|c|}
\hline $\begin{array}{l}\text { Date, type and duration of } \\
\text { proceedings }\end{array}$ & Accused and the ethnicity & $\begin{array}{c}\text { Location of crimes and eth- } \\
\text { nicity of victims }\end{array}$ & Interpreters language \\
\hline $\begin{array}{l}10 / 12 / 2003, \mathrm{TJ} \\
28 " 15\end{array}$ & $\begin{array}{l}\text { Obrenović }^{1008} \\
\text { Bosnian Serb }\end{array}$ & $\mathrm{B} \& \mathrm{H}^{1009}$ & $\begin{array}{l}\text { Serbian (ekavian) } \\
\text { Croatian (ijekavian) }\end{array}$ \\
\hline $\begin{array}{l}\text { 18/12/2003, TJ } \\
46^{\prime \prime} 18^{\prime}\end{array}$ & $\begin{array}{l}\text { Nikolić }^{1010} \\
\text { Bosnian Serb }\end{array}$ & $\mathrm{B} \& \mathrm{H}^{1011}$ & $\begin{array}{l}\text { Croatian (ijekavian) } \\
\text { Serbian (ekavian) }\end{array}$ \\
\hline $\begin{array}{l}\text { 2/O2/2004, AJ } \\
45^{\prime \prime} 49^{\prime}\end{array}$ & $\begin{array}{l}\text { Vasiljevićic12 }^{\prime 12} \\
\text { Bosnian Serb }\end{array}$ & $\mathrm{B} \& \mathrm{H}$ & $\begin{array}{l}\text { Bosnian (ijekavian) } \\
\text { Croatian (ijekavian)* }\end{array}$ \\
\hline $\begin{array}{l}\text { 18/03/2004, TJ } \\
17 " 29 \text { ' }\end{array}$ & $\begin{array}{l}\text { Jokićíli3 } \\
\text { Serbian Serb }\end{array}$ & Croatia $^{1014}$ & $\begin{array}{l}\text { Bosnian (ijekavian)* } \\
\text { Croatian (ijekavian) }\end{array}$ \\
\hline $\begin{array}{l}3 \circ / 03 / 2004, \text { SJ } \\
36 " 32\end{array}$ & $\begin{array}{l}\text { Deronjićio15 } \\
\text { Bosnian Serb }\end{array}$ & $\mathrm{B} \& \mathrm{H}^{1016}$ & $\begin{array}{l}\text { Serbian (ekavian) } \\
\text { Croatian (ijekavian) }\end{array}$ \\
\hline $\begin{array}{l}\text { 31/o3/2004, TJ } \\
22 " 07\end{array}$ & $\begin{array}{l}\text { Mrđa }^{1017} \\
\text { Bosnian Serb }\end{array}$ & $\mathrm{B} \& \mathrm{H}^{1018}$ & $\begin{array}{l}\text { Serbian (ekavian) } \\
\text { Croatian (ijekavian) }\end{array}$ \\
\hline $\begin{array}{l}\text { 19/04/2004, AJ } \\
1 \mathrm{~h} 17^{\prime \prime} 57^{\prime}\end{array}$ & $\begin{array}{l}\text { Krstić }^{1019} \\
\text { Bosnian Serb }\end{array}$ & $\mathrm{B} \& \mathrm{H}$ & $\begin{array}{l}\text { Serbian (ekavian) } \\
\text { Croatian (ijekavian) }\end{array}$ \\
\hline $\begin{array}{l}29 / 06 / 2004, \mathrm{SJ} \\
2 \mathrm{O}^{\prime \prime} 38^{\prime}\end{array}$ & $\begin{array}{l}\text { Babicín } \\
\text { Croatian Serb }\end{array}$ & Croatia $^{1021}$ & $\begin{array}{l}\text { Croatian (ijekavian) } \\
\text { Serbian (ekavian) }\end{array}$ \\
\hline $\begin{array}{l}\text { 29/07/2004, AJ } \\
\text { 1h43"14' }\end{array}$ & $\begin{array}{l}\text { Blaškićí1022 } \\
\text { Bosnian Croat }\end{array}$ & $\mathrm{B} \& \mathrm{H}$ & $\begin{array}{l}\text { Croatian (ijekavian) } \\
\text { Croatian (ijekavian) }\end{array}$ \\
\hline $\begin{array}{l}\text { 1/o9/2004, TJ } \\
1 \mathrm{~h} 37^{\prime \prime 13}\end{array}$ & $\begin{array}{l}\text { Brđanin }^{1023} \\
\text { Bosnian Serb }\end{array}$ & $\mathrm{B} \& \mathrm{H}$ & $\begin{array}{l}\text { Bosnian (ijekavian) } \\
\text { Croatian (ijekavian) }\end{array}$ \\
\hline $\begin{array}{l}\text { 17/12/2004, AJ } \\
\text { 1h12"22' }\end{array}$ & $\begin{array}{l}\text { Kordić and Čerkez }{ }^{1024} \\
\text { Bosnian Croats }\end{array}$ & $\mathrm{B} \& \mathrm{H}$ & $\begin{array}{l}\text { Croatian (ijekavian) } \\
\text { Bosnian (ijekavian) }\end{array}$ \\
\hline $\begin{array}{l}17 / 01 / 2005, \mathrm{TJ} \\
55^{\prime \prime} 47^{\prime}\end{array}$ & $\begin{array}{l}\text { Jokić and Blagojevićic25 } \\
\text { Bosnian Serb }\end{array}$ & $\mathrm{B} \& \mathrm{H}^{1026}$ & $\begin{array}{l}\text { Bosnian (ijekavian) } \\
\text { Croatian (ijekavian) }\end{array}$ \\
\hline $\begin{array}{l}31 / 01 / 2005, \mathrm{TJ} \\
47^{\prime \prime} 14^{\prime}\end{array}$ & $\begin{array}{l}\text { Strugar } \\
\text { Serbian Serb } \\
\end{array}$ & Croatia $^{1028}$ & $\begin{array}{l}\text { Serbian (ekavian) } \\
\text { Croatian (ijekavian) }\end{array}$ \\
\hline $\begin{array}{l}\text { 4/O2/2005, AJ } \\
29^{\prime \prime} 04^{\prime}\end{array}$ & $\begin{array}{l}\text { Nikolicic } \\
\text { Bosnian Serb }\end{array}$ & $\mathrm{B} \& \mathrm{H}$ & $\begin{array}{l}\text { Croatian (ijekavian) } \\
\text { Serbian (ekavian) }\end{array}$ \\
\hline $\begin{array}{l}\text { 28/O2/2005, AJ } \\
1 \mathrm{~h} 28^{\prime \prime} 22^{\prime}\end{array}$ & $\begin{array}{l}\text { Kvočka et al }{ }^{1030} \\
\text { Bosnian Serbs }\end{array}$ & $\mathrm{B} \& \mathrm{H}$ & $\begin{array}{l}\text { Croatian (ijekavian)* } \\
\text { Serbian }(\text { ekavian) }\end{array}$ \\
\hline $\begin{array}{l}\text { 18/o7/2005, SA } \\
30^{\prime \prime} 56^{\prime}\end{array}$ & $\begin{array}{l}\text { Babićn }^{1031} \\
\text { Croatian Serb }\end{array}$ & Croatia & $\begin{array}{l}\text { Bosnian (ijekavian)* } \\
\text { Serbian (ekavian) }\end{array}$ \\
\hline
\end{tabular}

${ }^{1008}$ ICTY videos, Obrenović TJ, Original (ENG) and INT.

${ }^{1009}$ ICTY, Obrenović CIS.

${ }^{1010}$ ICTY videos, Nikolić TJ, Original (ENG) and INT.

${ }^{\text {1on }}$ ICTY, Nikolić CIS.

${ }^{1012}$ ICTY videos, Vasiljević AJ, Original (ENG) and INT.

${ }^{1013}$ ICTY videos, Jokić TJ, Original (ENG) and INT.

${ }^{1014}$ ICTY, Jokić CIS.

${ }^{1015}$ ICTY videos, Deronjić SJ, Original (ENG) and INT.

${ }^{1016}$ ICTY, Deronjić CIS.

${ }^{1017}$ ICTY videos, Mrđa TJ, Original (ENG) and INT. Note mistake on ICTY site where "IA" video has been mistakenly linked under "TJ" in both language versions.

${ }^{1018}$ ICTY, Mrđa CIS.

${ }^{1019}$ ICTY videos, Krstić AJ, Original (ENG) and INT.

${ }^{1020}$ ICTY videos, Babić SJ, Original (ENG) and INT.

${ }^{1021}$ ICTY, Babić CIS.

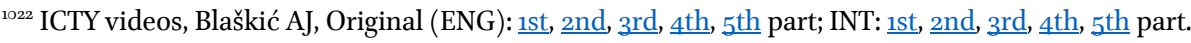

${ }^{1023}$ ICTY videos, Brđanin TJ, Original (ENG): 1st, 2nd, 3rd part; INT: 1st, 2nd, 3rd part.

${ }^{1024}$ ICTY videos, Kordić, Čerkez AJ, Original (ENG): 1st, nd part; INT: 1st, 2nd part.

${ }^{1025}$ ICTY videos, Jokić, Blagojević TJ, Original (ENG): 1st, nd part; INT: 1st, 2nd part.

${ }^{1026}$ ICTY, Jokić, Blagojević CIS.

${ }^{1027}$ ICTY, Strugar TJ, Original (ENG): 1st, 2nd part; INT: 1st, 2nd part.

${ }^{1028}$ ICTY, $\underline{\text { Strugar CIS. }}$.

${ }^{1029}$ ICTY videos, Nikolić AJ, Original (ENG) and INT.

${ }^{1030}$ ICTY videos, Kvočka et al AJ, Original (ENG) and INT.

${ }^{1031}$ ICTY, Babić SA, Original (ENG): 1st, 2nd, 3rd part; INT: 1st, 2nd, 3rd part. 


\begin{tabular}{|c|c|c|c|}
\hline $\begin{array}{l}\text { Date, type and duration of } \\
\text { proceedings }\end{array}$ & Accused and the ethnicity & $\begin{array}{c}\text { Location of crimes and eth- } \\
\text { nicity of victims }\end{array}$ & Interpreters language \\
\hline $\begin{array}{l}20 / 07 / 2005, \mathrm{AJ} \\
23 " 28\end{array}$ & $\begin{array}{l}\text { Deronjićín } \\
\text { Bosnian Serb }\end{array}$ & $\mathrm{B} \& \mathrm{H}$ & $\begin{array}{l}\text { Bosnian (ijekavian) } \\
\text { Serbian (ekavian) }\end{array}$ \\
\hline $\begin{array}{l}16 / 11 / 2005, \mathrm{TJ} \\
46^{\prime \prime} \mathrm{o}^{\prime}\end{array}$ & $\begin{array}{l}\text { Halilović }^{1033} \\
\text { Bosnian Muslim } \\
\end{array}$ & $\mathrm{B} \& \mathrm{H}^{1034}$ & $\begin{array}{l}\text { Croatian (ijekavian) } \\
\text { Bosnian (ijekavian) }\end{array}$ \\
\hline $\begin{array}{l}\text { 7/12/2005, TJ } \\
14 " 15\end{array}$ & $\begin{array}{l}\text { Bralo }^{1035} \\
\text { Bosnian Croat }\end{array}$ & $\mathrm{B} \& \mathrm{H}^{1036}$ & Bosnian (ijekavian) \\
\hline $\begin{array}{l}8 / 03 / 2006, \mathrm{AJ} \\
32 " 45\end{array}$ & $\begin{array}{l}\text { Nikolićílio37 } \\
\text { Bosnian Serb }\end{array}$ & $\mathrm{B} \& \mathrm{H}$ & $\begin{array}{l}\text { Serbian (ekavian) } \\
\text { Bosnian (ijekavian) }\end{array}$ \\
\hline $\begin{array}{l}\text { 22/o3/2006, AJ } \\
55 " \circ 8\end{array}$ & $\begin{array}{l}\text { Stakićio38 } \\
\text { Bosnian Serb }\end{array}$ & $\mathrm{B} \& \mathrm{H}$ & $\begin{array}{l}\text { Croatian (ijekavian)* } \\
\text { Serbian (ekavian) }\end{array}$ \\
\hline $\begin{array}{l}\text { 3/05/2006, AJ } \\
5^{2 " 13}\end{array}$ & $\begin{array}{l}\text { Naletelić and Martinovićín } \\
\text { Bosnian Croats }\end{array}$ & $\mathrm{B} \& \mathrm{H}$ & $\begin{array}{l}\text { Croatian (ijekavian) } \\
\text { Bosnian (ijekavian) }\end{array}$ \\
\hline $\begin{array}{l}8 / 05 / 2006, \mathrm{TJ} \\
21{ }^{\prime \prime} 6^{\prime}\end{array}$ & $\begin{array}{l}\text { Rajićlio40 } \\
\text { Bosnian Croat }\end{array}$ & $\mathrm{B} \& \mathrm{H}^{1041}$ & $\begin{array}{l}\text { Croatian (ijekavian) } \\
\text { Bosnian (ijekavian) }\end{array}$ \\
\hline $\begin{array}{l}\text { 30/o6/2006, TJ } \\
\text { 1h17"56' }\end{array}$ & $\begin{array}{l}\text { Orićílit2 } \\
\text { Bosnian Muslim }\end{array}$ & $\mathrm{B} \& \mathrm{H}^{1043}$ & $\begin{array}{l}\text { Serbian (ekavian) } \\
\text { Bosnian (ijekavian) }\end{array}$ \\
\hline $\begin{array}{l}\text { 27/og/2006, TJ } \\
35^{\prime \prime 13}\end{array}$ & $\begin{array}{l}\text { Krajišnik }{ }^{1044} \\
\text { Bosnian Serbs }\end{array}$ & $\mathrm{B} \& \mathrm{H}^{1045}$ & $\begin{array}{l}\text { Bosnian (ijekavian) } \\
\text { Serbian (ekavian) }\end{array}$ \\
\hline $\begin{array}{l}\text { 28/11/2006, AJ } \\
58^{\prime \prime \prime \prime \prime}\end{array}$ & $\begin{array}{l}\text { Simići } \\
\text { Bosnian Serbs }\end{array}$ & $\mathrm{B} \& \mathrm{H}$ & $\begin{array}{l}\text { Serbian (ekavian) } \\
\text { Croatian (ijekavian)* }\end{array}$ \\
\hline $\begin{array}{l}\text { 30/11/2006, AJ } \\
\text { 1h12" } 2^{\prime}\end{array}$ & $\begin{array}{l}\text { Galić1047 } \\
\text { Bosnian Serb }\end{array}$ & $\mathrm{B} \& \mathrm{H}$ & $\begin{array}{l}\text { Croatian (ijekavian) } \\
\text { Serbian (ekavian) }\end{array}$ \\
\hline $\begin{array}{l}\text { 2/04/2007, AJ } \\
5^{\circ "} 5^{\prime}\end{array}$ & $\begin{array}{l}\text { Bralo }^{1048} \\
\text { Bosnian Croat }\end{array}$ & $\mathrm{B} \& \mathrm{H}$ & $\begin{array}{l}\text { Croatian (ijekavian) } \\
\text { Serbian (ekavian) }\end{array}$ \\
\hline $\begin{array}{l}3 / 04 / 2007, \mathrm{AJ} \\
35 " 53\end{array}$ & $\begin{array}{l}\text { Brđanin }^{1049} \\
\text { Bosnian Serb }\end{array}$ & $\mathrm{B} \& \mathrm{H}$ & $\begin{array}{l}\text { Croatian (ijekavian) } \\
\text { Serbian (ekavian) }\end{array}$ \\
\hline $\begin{array}{l}\text { 3/04/2007, SJ } \\
23^{\prime \prime} 06\end{array}$ & $\begin{array}{l}\text { Češići1050 } \\
\text { Bosnian Serb }\end{array}$ & $\mathrm{B} \& \mathrm{H}^{1051}$ & $\begin{array}{l}\text { Bosnian (ijekavian) } \\
\text { Croatian (ijekavian) }\end{array}$ \\
\hline $\begin{array}{l}4 / 04 / 2007, \mathrm{TJ} \\
21^{\prime \prime} 46^{\prime}\end{array}$ & $\begin{array}{l}\text { Zelenović1052 } \\
\text { Bosnian Serb }\end{array}$ & $\mathrm{B} \& \mathrm{H}^{1053}$ & $\begin{array}{l}\text { Serbian (ekavian) } \\
\text { Croatian (ijekavian)* }\end{array}$ \\
\hline $\begin{array}{l}\text { 9/05/2007, AJ } \\
52^{\prime \prime O 2}\end{array}$ & $\begin{array}{l}\text { Jokić and Blagojevićic54 } \\
\text { Bosnian Serbs }\end{array}$ & $\mathrm{B} \& \mathrm{H}$ & $\begin{array}{l}\text { Serbian (ijekavian) } \\
\text { Croatian (ijekavian) }\end{array}$ \\
\hline
\end{tabular}

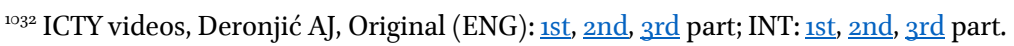

${ }^{1033}$ ICTY videos, Halilović TJ, Original (ENG): 1st, nd part; INT: 1st, nd part.

${ }^{1034}$ ICTY, Halilović CIS.

${ }^{1035}$ ICTY videos, Bralo TJ, Original (ENG) and INT:.

${ }^{1036}$ ICTY, Bralo CIS.

${ }^{1037}$ ICTY videos, Nikolić AJ, Original (ENG) and INT.

${ }^{1038}$ ICTY videos, Stakić AJ, Original (ENG): 1st, nㅔ part; INT: 1st, nㅔ part.

${ }^{1039}$ ICTY videos, Naletelić, Martinović AJ, Original (ENG): 1st, nd part; INT: 1st, nd part.

${ }^{1040}$ ICTY videos, Rajić TJ, Original (ENG) and INT.

${ }^{1041}$ ICTY, Rajić CIS.

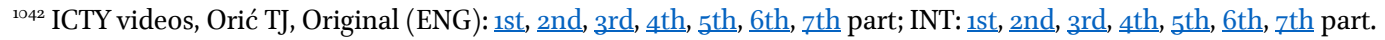

${ }^{1043}$ ICTY, Orić CIS.

${ }^{1044}$ ICTY videos, Krajišnik TJ, Original (ENG): 1st, 2nd part; INT: 1st, 2nd part.

${ }^{1045}$ ICTY, Krajišnik CIS.

${ }^{1046}$ ICTY videos, Simić AJ, Original (FRE): 1st, 2nd part; INT: 1st, 2nd part.

${ }^{1047}$ ICTY videos, Galić AJ, Original (ENG): 1st, 2nd part; INT: 1st, 2nd part.

${ }^{1048}$ ICTY videos, Bralo AJ, Original (FRE): 1st, 2nd part; INT: 1st, 2nd part.

${ }^{1049}$ ICTY videos, Brđanin AJ, Original (ENG) and INT.

${ }^{1050}$ ICTY videos, Ranko Češić SJ, Original (ENG) and INT.

${ }^{1051}$ ICTY, С̌ešić CIS.

${ }^{1052}$ ICTY videos, Zelenović TJ, Original (ENG): 1st, nㅔ part; INT: 1st, nd part.

${ }^{1053}$ ICTY, Zelenović CIS.

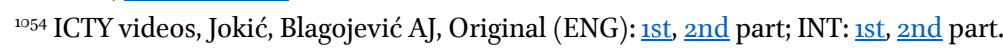




\begin{tabular}{|c|c|c|c|}
\hline $\begin{array}{l}\text { Date, type and duration of } \\
\text { proceedings }\end{array}$ & Accused and the ethnicity & $\begin{array}{c}\text { Location of crimes and eth- } \\
\text { nicity of victims }\end{array}$ & Interpreters language \\
\hline $\begin{array}{l}\text { 12/o6/2007, TJ } \\
1 \mathrm{~h} 17^{\prime \prime O 2}\end{array}$ & $\begin{array}{l}\text { Martić' } \\
\text { Croatian Serb }\end{array}$ & Croatia $^{1056}$ & $\begin{array}{l}\text { Serbian (ekavian) } \\
\text { Croatian (ijekavian) }\end{array}$ \\
\hline $\begin{array}{l}\text { 27/og/20o7, TJ } \\
\text { 1hoo" } 52^{\prime}\end{array}$ & $\begin{array}{l}\text { Mrkšić et al }{ }^{1057} \\
\text { Serbian Serbs }\end{array}$ & Croatia $^{1058}$ & $\begin{array}{l}\text { Croatian (ijekavian) } \\
\text { Serbian (ekavian) }\end{array}$ \\
\hline $\begin{array}{l}16 / 10 / 2007, \mathrm{AJ} \\
26^{\prime \prime} 42^{\prime}\end{array}$ & $\begin{array}{l}\text { Halilović1059 } \\
\text { Bosnian Muslim }\end{array}$ & $\mathrm{B} \& \mathrm{H}$ & $\begin{array}{l}\text { Croatian (ïjkavian) } \\
\text { Croatian (ijekavian) }\end{array}$ \\
\hline $\begin{array}{l}31 / 10 / 2007, \mathrm{AJ} \\
15^{\prime \prime} 36^{\prime}\end{array}$ & $\begin{array}{l}\text { Zelenovićic6o } \\
\text { Bosnian Serb }\end{array}$ & $\mathrm{B} \& \mathrm{H}$ & Croatian (ijekavian)* \\
\hline $\begin{array}{l}12 / 12 / 2007, \mathrm{TJ} \\
25 " \mathrm{OO}\end{array}$ & $\begin{array}{l}\text { Milošević }^{1061} \\
\text { Bosnian Serb }\end{array}$ & $\mathrm{B} \& \mathrm{H}^{1062}$ & $\begin{array}{l}\text { Croatian (ijekavian) } \\
\text { Serbian (ekavian) }\end{array}$ \\
\hline $\begin{array}{l}22 / 04 / 2008, \mathrm{AJ} \\
47^{\prime 21}\end{array}$ & $\begin{array}{l}\text { Hadžihasanović and Ku- } \\
\text { bura }^{1063} \\
\text { Bosnian Muslims }\end{array}$ & $\begin{array}{l}\text { B\&H } \\
\text { Bosnian non-Muslims }\end{array}$ & $\begin{array}{l}\text { Croatian (ijekavian) } \\
\text { Serbian (ekavian) }\end{array}$ \\
\hline $\begin{array}{l}\text { 3/o7/2008, AJ } \\
35 " 08\end{array}$ & $\begin{array}{l}\text { Orić1 }^{164} \\
\text { Bosnian Muslim }\end{array}$ & $\begin{array}{l}\text { B\&H } \\
\text { Bosnian Serbs }\end{array}$ & $\begin{array}{l}\text { Croatian (ijekavian)* } \\
\text { Serbian (ekavian) }\end{array}$ \\
\hline $\begin{array}{l}17 / 07 / 2008, \mathrm{AJ} \\
47^{\prime \prime} \mathbf{1}^{\prime}\end{array}$ & $\begin{array}{l}\text { Strugar }^{1065} \\
\text { Serbian Serb }\end{array}$ & $\begin{array}{l}\text { Croatia } \\
\text { Non-Serbs }\end{array}$ & $\begin{array}{l}\text { Serbian (ekavian) } \\
\text { Croatian (ijekavian) }\end{array}$ \\
\hline $\begin{array}{l}15 / 09 / 2008, \mathrm{TJ} \\
57^{\prime \prime} 58^{\prime}\end{array}$ & $\begin{array}{l}\text { Delićio66 } \\
\text { Bosnian Muslim }\end{array}$ & $\begin{array}{l}\text { B\&H } \mathrm{H}^{1067} \\
\text { Bosnian non-Muslims }\end{array}$ & $\begin{array}{l}\text { Croatian (ijekavian) } \\
\text { Serbian (ekavian) }\end{array}$ \\
\hline $\begin{array}{l}8 / 10 / 2008, \mathrm{AJ} \\
28^{\prime \prime} 46^{\prime}\end{array}$ & $\begin{array}{l}\text { Martić }^{1068} \\
\text { Croatian Serb }\end{array}$ & $\begin{array}{l}\text { Croatia } \\
\text { Croatian Croats }\end{array}$ & $\begin{array}{l}\text { Croatian (ijekavian) } \\
\text { Serbian (ekavian) }\end{array}$ \\
\hline $\begin{array}{l}\text { 26/o2/2009, TJ } \\
\text { 1h28" } 27\end{array}$ & $\begin{array}{l}\text { Šainović et al }{ }^{1069} \\
\text { Serbian Serbs }\end{array}$ & $\begin{array}{l}\text { Kosovo }^{1070} \\
\text { Kosovars }\end{array}$ & $\begin{array}{l}\text { Serbian (ekavian) } \\
\text { Croatian (ijekavian) }\end{array}$ \\
\hline $\begin{array}{l}17 / 03 / 2009, \mathrm{AJ} \\
42^{\prime \prime} 42^{\prime}\end{array}$ & $\begin{array}{l}\text { Krajišnik }^{1071} \\
\text { Bosnian Serb }\end{array}$ & $\begin{array}{l}\text { B\&H } \\
\text { Bosnian Muslims }\end{array}$ & $\begin{array}{l}\text { Croatian (ijekavian)* } \\
\text { Serbian (ekavian) }\end{array}$ \\
\hline $\begin{array}{l}\text { 5/05/2009, AJ } \\
\text { 1h1o"17' }\end{array}$ & $\begin{array}{l}\text { Mrkšić and Šljivančanin }{ }^{1072} \\
\text { Serbian Serbs }\end{array}$ & $\begin{array}{l}\text { Croatia } \\
\text { Croatian Croats }\end{array}$ & $\begin{array}{l}\text { Serbian (ekavian) } \\
\text { Croatian (ijekavian) } \\
\text { Croatian (ijekavian) }\end{array}$ \\
\hline $\begin{array}{l}\text { 20/07/2009, TJ } \\
42 " 33^{\prime}\end{array}$ & $\begin{array}{l}\text { Milan and Sredoje Lukić }{ }^{1073} \\
\text { Bosnian Serbs }\end{array}$ & $\begin{array}{l}\mathrm{B} \& \mathrm{H}^{1074} \\
\text { Bosnian Muslims }\end{array}$ & $\begin{array}{l}\text { Croatian (ijekavian) } \\
\text { Serbian (ekavian) }\end{array}$ \\
\hline $\begin{array}{l}12 / 11 / 2009, \mathrm{AJ} \\
46^{\prime \prime} 38^{\prime}\end{array}$ & $\begin{array}{l}\text { Miloševićín75 } \\
\text { Bosnian Serb }\end{array}$ & $\begin{array}{l}\text { B\&H } \\
\text { Bosnian Muslims }\end{array}$ & $\begin{array}{l}\text { Bosnian (ijekavian) } \\
\text { Serbian (ekavian) }\end{array}$ \\
\hline $\begin{array}{l}\text { 10/o6/2010, TJ } \\
\text { 1h26"12' }\end{array}$ & $\begin{array}{l}\text { Popović et al }{ }^{1076} \\
\text { Bosnian Serbs }\end{array}$ & $\begin{array}{l}\mathrm{B} \& \mathrm{H}^{1077} \\
\text { Bosnian Muslims }\end{array}$ & $\begin{array}{l}\text { Bosnian (ijekavian) } \\
\text { Serbian (ekavian)** }\end{array}$ \\
\hline
\end{tabular}

${ }^{1055}$ ICTY videos, Martić TJ, Original (ENG): $\underline{1 s t}$, 2nd part; INT: $\underline{1 s t}$, 2nd part.

${ }^{1056}$ ICTY, Martić CIS.

${ }^{1057}$ ICTY videos, Mrkšić et al TJ, Original (ENG) and INT.

${ }^{1058}$ ICTY, Mrkšić et al CIS.

${ }^{1059}$ ICTY videos, Halilović AJ, Original (FRE): 1st, nㅔ, zrd part; INT: 1st, nㅔ, 자 part.

${ }^{1060}$ ICTY videos, Zelenović AJ, Original (ENG): 1st, 2nd part; INT: 1st, 2nd part.

${ }^{1061}$ ICTY videos, Milošević TJ, Original (ENG): 1st, 2nd, 3rd part; INT: 1st, 레, 자 part.

${ }^{1062}$ ICTY, Milošević CIS.

${ }^{1063}$ ICTY videos, Hadžihasanović, Kubura AJ, Original (ENG): 1st, nㅔ, 3rd, 4th part; INT: 1st, 2nd, 3rd, 4th part.

${ }^{1064}$ ICTY videos, Orić AJ, Original (ENG) and INT.

${ }^{1065}$ ICTY videos, Strugar AJ, Original (FRE): $\underline{\text { stt, } \text { nd }}$ part; INT: 1st, 2nd part.

${ }^{1066}$ ICTY videos, Delić TJ, Original (ENG): 1st, 2nd, 3rd, 4th, 5th part; INT: 1st, 2nd, 3rd, 4th, 5th part.

${ }^{1067}$ ICTY, Delić CIS.

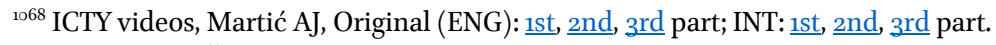

${ }^{1069}$ ICTY videos, Šainović et al TJ, Original (ENG): 1st, nd, 3rd, 4th, 5th, 6th, 7th, 8th part; INT: 1st, 2nd, 3rd, 4th, 5th, $\underline{\text { th }}$, 7th, $\underline{\text { th }}$ part.

${ }^{1070}$ ICTY, Šainović et al CIS.

${ }^{1071}$ ICTY videos, Krajišnik AJ, Original (ENG): 1st, 2nd, 3rd, 4th part; INT: 1st, 2nd, 3rd, 4 th.

${ }^{1072}$ ICTY videos, Mrkšić et al AJ, Original (ENG): 1st, 2nd, 3rd, 4th, 5th, 6th part; INT: 1st, 2nd, 3rd, 4th, 5th, 6th part.

${ }^{1073}$ ICTY videos, Milan Lukić, Sredoje Lukić TJ, Original (ENG): 1st, 2nd, 3rd, 4th part; INT: 1st, 2nd, 3rd, 4th part.

${ }^{1074}$ ICTY, Milan Lukić, Sredoje Lukić, CIS.

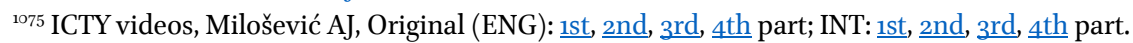

${ }^{1076}$ ICTY videos, Popović et al TJ, Original (ENG): 1st, 2nd, 3rd, 4th, 5th, 6th, 7th, 8th, 9th part; INT: 1st, 2nd, 3rd, 4th, 5 th, $\underline{\text { the }}$, 7 th part.

${ }^{1077}$ ICTY, Popović et al CIS. 


\begin{tabular}{|c|c|c|c|}
\hline $\begin{array}{l}\text { Date, type and duration of } \\
\text { proceedings }\end{array}$ & Accused and the ethnicity & $\begin{array}{c}\text { Location of crimes and eth- } \\
\text { nicity of victims }\end{array}$ & Interpreters language \\
\hline $\begin{array}{l}8 / 12 / 2010, \mathrm{RJ} \\
27 " 52^{\prime}\end{array}$ & $\begin{array}{l}\text { Šljivančanin }^{1078} \\
\text { Serbian Serb }\end{array}$ & $\begin{array}{l}\text { Croatia }^{1079} \\
\text { Croatian Croats }\end{array}$ & $\begin{array}{l}\text { Croatian (ijekavian) } \\
\text { Serbian (ekavian) }\end{array}$ \\
\hline $\begin{array}{l}\text { 23/O2/2011, TJ } \\
50^{\prime \prime} 57^{\prime}\end{array}$ & $\begin{array}{l}\text { Đorđevićc } \\
\text { Serbian Serb } \\
\end{array}$ & $\begin{array}{l}\text { Kosovo }^{1081} \\
\text { Kosovars }\end{array}$ & $\begin{array}{l}\text { Serbian (ekavian) } \\
\text { Bosnian (ijekavian)* }\end{array}$ \\
\hline $\begin{array}{l}6 / 12 / 2011, \mathrm{TJ} \\
32 " 40^{\prime}\end{array}$ & $\begin{array}{l}\text { Perišicico82 } \\
\text { Serbian Serb }\end{array}$ & $\begin{array}{l}\mathrm{B} \& \mathrm{H}^{1083} \\
\text { Bosnian Muslims }\end{array}$ & $\begin{array}{l}\text { Serbian }(\text { ekavian }) \\
\text { Croatian (ijekavian)* }\end{array}$ \\
\hline $\begin{array}{l}\text { 15/O4/2O12, TJ } \\
5 \mathrm{O}^{\prime \prime} 2 \text { ' }\end{array}$ & $\begin{array}{l}\text { Gotovina et al }^{1084} \\
\text { Croatian Croats }\end{array}$ & $\begin{array}{l}\text { Croatia }^{1085} \\
\text { Croatian Serbs } \\
\end{array}$ & $\begin{array}{l}\text { Croatian (ijekavian) } \\
\text { Serbian (ekavian) }\end{array}$ \\
\hline $\begin{array}{l}\text { 16/11/2O12, AJ } \\
37^{\prime \prime} 59^{\prime}\end{array}$ & $\begin{array}{l}\text { Gotovina and Markač }{ }^{1086} \\
\text { Croatian Croats }\end{array}$ & $\begin{array}{l}\text { Croatia } \\
\text { Croatian Serbs }\end{array}$ & $\begin{array}{l}\text { Croatian (ijekavian) } \\
\text { Serbian (ekavian) }\end{array}$ \\
\hline $\begin{array}{l}4 / 12 / 2012, \mathrm{AJ} \\
36 " 44^{\prime}\end{array}$ & $\begin{array}{l}\text { Milan and Sredoje Lukić }{ }^{1087} \\
\text { Bosnian Serbs }\end{array}$ & $\begin{array}{l}\text { B\&H } \\
\text { Bosnian Muslims }\end{array}$ & $\begin{array}{l}\text { Croatian (ijekavian) } \\
\text { Serbian (ekavian) }\end{array}$ \\
\hline $\begin{array}{l}\text { 12/12/2O12, TJ } \\
\text { 1ho3" } 59 \text { ' }\end{array}$ & $\begin{array}{l}\text { Tolimir }^{1088} \\
\text { Bosnian Serb } \\
\end{array}$ & $\begin{array}{l}\text { B\&H }{ }^{1089} \\
\text { Bosnian Muslims }\end{array}$ & $\begin{array}{l}\text { Croatian (ijekavian)* } \\
\text { Serbian }\left(\text { ekavian) }{ }^{*}\right.\end{array}$ \\
\hline $\begin{array}{l}\text { 28/o2/2013, AJ } \\
54 " 18\end{array}$ & $\begin{array}{l}\text { Perišićín } \\
\text { Serbian Serb }\end{array}$ & $\begin{array}{l}\text { B\&H } \\
\text { Bosnian Muslims }\end{array}$ & $\begin{array}{l}\text { Serbian (ekavian) } \\
\text { Croatian (ijekavian) }\end{array}$ \\
\hline $\begin{array}{l}27 / 03 / 2013, \mathrm{TJ} \\
\text { 1ho5" } 58^{\prime}\end{array}$ & $\begin{array}{l}\text { Stanišić and Župljanin }{ }^{1091} \\
\text { Serbian Serbs }\end{array}$ & $\begin{array}{l}\mathrm{B} \& \mathrm{H}^{1092} \\
\text { Non-Serbs }\end{array}$ & $\begin{array}{l}\text { Serbian (ekavian) } \\
\text { Bosnian (ijekavian) }\end{array}$ \\
\hline $\begin{array}{l}\text { 30/05/2013, TJ } \\
45^{\prime \prime O 1 '}\end{array}$ & $\begin{array}{l}\text { Stanišić and Simatovićín } \\
\text { Serbian Serbs }\end{array}$ & $\begin{array}{l}\text { B\&H and Croatia }{ }^{1094} \\
\text { Non-Serbs }\end{array}$ & $\begin{array}{l}\text { Serbian (ekavian) } \\
\text { Croatian (ijekavian) }\end{array}$ \\
\hline $\begin{array}{l}\text { 23/o1/2014, AJ } \\
\text { 1h26" } 37^{\prime}\end{array}$ & $\begin{array}{l}\text { Šainović et al }{ }^{1095} \\
\text { Serbian Serbs }\end{array}$ & $\begin{array}{l}\text { Kosovo } \\
\text { Kosovars }\end{array}$ & $\begin{array}{l}\text { Serbian (ekavian) } \\
\text { Croatian (ijekavian) }\end{array}$ \\
\hline $\begin{array}{l}\text { 27/01/2014, AJ } \\
38 " 18\end{array}$ & $\begin{array}{l}\text { Đorđevićic }^{1096} \\
\text { Serbian Serb }\end{array}$ & $\begin{array}{l}\text { Kosovo } \\
\text { Kosovars }\end{array}$ & $\begin{array}{l}\text { Serbian (ekavian) } \\
\text { Serbian (ekavian) }\end{array}$ \\
\hline $\begin{array}{l}\text { 30/o1/2015, AJ } \\
\text { 2ho4"2o' }\end{array}$ & $\begin{array}{l}\text { Popović et al }{ }^{1097} \\
\text { Bosnian Serbs }\end{array}$ & $\begin{array}{l}\text { B\&H } \\
\text { Bosnian Muslims }\end{array}$ & $\begin{array}{l}\text { Serbian (ekavian) } \\
\text { Croatian (ijekavian) }\end{array}$ \\
\hline $\begin{array}{l}\text { 8/04/2015, AJ } \\
\text { 1h12" } 37^{\prime}\end{array}$ & $\begin{array}{l}\text { Tolimir }{ }^{1098} \\
\text { Bosnian Serb }\end{array}$ & $\begin{array}{l}\text { B\&H } \\
\text { Bosnian Muslims }\end{array}$ & $\begin{array}{l}\text { Bosnian (ijekavian) } \\
\text { Croatian (ijekavian)* }\end{array}$ \\
\hline $\begin{array}{l}15 / 12 / 2015, \mathrm{AJ} \\
31 " 27\end{array}$ & $\begin{array}{l}\text { Stanišić and Simatovićn }{ }^{1099} \\
\text { Serbian Serbs }\end{array}$ & $\begin{array}{l}\text { B\&H and Croatia } \\
\text { Non-Serbs }\end{array}$ & $\begin{array}{l}\text { Bosnian (ijekavian) } \\
\text { Serbian (ekavian) }\end{array}$ \\
\hline $\begin{array}{l}\text { 24/o3/2016, TJ } \\
\text { 1h42" } 47^{\prime}\end{array}$ & $\begin{array}{l}\text { Karadžićíioo } \\
\text { Bosnian Serb }\end{array}$ & $\begin{array}{l}{\mathrm{B} \& \mathrm{H}^{\mathrm{n}}}^{\mathrm{n} 11} \\
\text { Bosnian non-Serbs }\end{array}$ & $\begin{array}{l}\text { Croatian (ijekavian) }{ }^{*} \\
\text { Bosnian (ijekavian) }\end{array}$ \\
\hline
\end{tabular}

${ }^{1078}$ ICTY videos, Šljivančanin RJ, Original (ENG) and INT.

${ }^{1079}$ ICTY, Mrkšić et al CIS.

${ }^{1080}$ ICTY videos, Đorđević TJ, Original (ENG): 1st, nㅔ, 3rd part; INT: 1st, 2nd, 3rd part.

${ }^{1081}$ ICTY, Đorđević CIS.

${ }^{1082}$ ICTY videos, Perišić TJ, Original (ENG) and INT.

${ }^{1083}$ ICTY, Perišić CIS.

${ }^{1084}$ ICTY videos, Gotovina et al TJ, Original (ENG): 1st, nㅔ, 3rd part; INT: 1st, nd , 3rd part.

${ }^{1085}$ ICTY, Gotovina et al CIS.

${ }^{1086}$ ICTY videos, Gotovina et al AJ, Original (ENG) and INT.

${ }^{1087}$ ICTY videos, Milan Lukić, Sredoje Lukić AJ, Original (FRE) and INT.

${ }^{1088}$ ICTY videos, Tolimir TJ, Original (ENG) and INT.

${ }^{1089}$ ICTY, Tolimir CIS.

${ }^{1090}$ ICTY videos, Perišić AJ, Original (ENG) and INT.

${ }^{1091}$ ICTY videos, Stanišić, Župljanin TJ, Original (ENG) and INT.

${ }^{1092}$ ICTY, Stanišić, Župljanin, CIS.

${ }^{1093}$ ICTY videos, Stanišić, Simatović TJ, Original (ENG) and INT.

${ }^{1094}$ ICTY, Stanišić, Simatović CIS.

${ }^{1095}$ ICTY videos, Šainović et al AJ, Original (ENG) and INT.

${ }^{1096}$ ICTY videos, Đorđević AJ, Original (ENG) and INT.

${ }^{1097}$ ICTY videos, Popović et al AJ, Original (ENG): 1st, nd part; INT: 1st, 2nd part).

${ }^{1098}$ ICTY videos, Tolimir AJ, Original (ENG) and INT.

${ }^{1099}$ ICTY videos, Stanišić, Simatović AJ, Original (ENG) and INT.

${ }^{1100}$ ICTY videos, Karadžić TJ, Original (ENG) and INT.

${ }^{1101}$ ICTY, Karadžić CIS. 


\begin{tabular}{|c|c|c|c|}
\hline $\begin{array}{l}\text { Date, type and duration of } \\
\text { proceedings }\end{array}$ & Accused and the ethnicity & $\begin{array}{c}\text { Location of crimes and eth- } \\
\text { nicity of victims }\end{array}$ & Interpreters language \\
\hline $\begin{array}{l}24 / 03 / 2016, \mathrm{TJ} \\
\text { 1h42" } 49^{\prime}\end{array}$ & $\begin{array}{l}\text { Prlić et al }^{1102} \\
\text { Bosnian Croats }\end{array}$ & $\begin{array}{l}\mathrm{B} \& \mathrm{H}^{1103} \\
\text { Bosnian Muslims }\end{array}$ & $\begin{array}{l}\text { Croatian (ijekavian) } \\
\text { Serbian (ekavian) } \\
\text { Croatian (ijekavian) }\end{array}$ \\
\hline $\begin{array}{l}\text { 31/o3/2016, TJ } \\
\text { 1h26" } 88^{\prime}\end{array}$ & $\begin{array}{l}\check{S ̌ s ̌ s e l j}^{1104} \\
\text { Bosnian Serb }\end{array}$ & $\begin{array}{l}\text { Serbia, Croatia, B\&H }{ }^{1105} \\
\text { Non-Serbs }\end{array}$ & $\begin{array}{l}\text { Serbian (ekavian) } \\
\text { Bosnian (ijekavian) } \\
\text { Croatian (ijekavian) }\end{array}$ \\
\hline $\begin{array}{l}\text { 30/06/2016, AJ } \\
54^{\prime \prime} 8^{\prime}\end{array}$ & $\begin{array}{l}\text { Stanišić and Župljanin }{ }^{\mathrm{n} 16} \\
\text { Bosnian Serbs }\end{array}$ & $\begin{array}{l}\text { B\&H } \\
\text { Non-Serbs }\end{array}$ & $\begin{array}{l}\text { Croatian (ijekavian) } \\
\text { Bosnian (ijekavian) }\end{array}$ \\
\hline
\end{tabular}

${ }^{1102}$ ICTY videos, Prlić et al TJ, Original (FRE) and INT.

${ }^{1103}$ ICTY, Prlić et al CIS.

${ }^{1104}$ ICTY videos, Šešelj TJ, Original (FRE) and INT.

${ }^{105}$ ICTY, Šešelj CIS.

${ }^{106}$ ICTY videos, Stanišić, Župljanin AJ, Original (ENG) and INT. 
Appendix 5. Ethnicity of testifying victims and witnesses vs. languages of interpreters

\begin{tabular}{|c|c|c|}
\hline $\begin{array}{c}\text { Date, trial, victims, and perpe- } \\
\text { trators }\end{array}$ & Ethnicity and language of the witness & Interpreter's language \\
\hline $\begin{array}{l}\text { 10/10/1995, Nikolić } \\
\text { Bosnian Serbs perpetrators } \\
\text { Bosnian Muslims victims }\end{array}$ & $\begin{array}{l}\text { Witness Ibro Osmanović } \\
\text { Bosnian Muslim }^{1107} \\
\text { Bosnian (ijekavian) }\end{array}$ & Croatian (ijekavian)* \\
\hline $\begin{array}{l}\text { 10/10/1995, Nikolić } \\
\text { Bosnian Serbs perpetrators } \\
\text { Bosnian Muslims victims }\end{array}$ & $\begin{array}{l}\text { Witness Redžo Čakišić } \\
\text { Bosnian Muslim }^{1108} \\
\text { Bosnian (ijekavian) }\end{array}$ & Croatian (ijekavian)* \\
\hline $\begin{array}{l}\text { 10/10/1995, Nikolić } \\
\text { Bosnian Serbs perpetrators } \\
\text { Bosnian Muslims victims }\end{array}$ & $\begin{array}{l}\text { Witness Amir Berbić } \\
\text { Bosnian Muslim }{ }^{1109} \\
\text { Bosnian (ijekavian) }\end{array}$ & Croatian (ijekavian)* \\
\hline $\begin{array}{l}\text { 10/10/1995, Nikolić } \\
\text { Bosnian Serbs perpetrators } \\
\text { Bosnian Muslims victims }\end{array}$ & $\begin{array}{l}\text { Witness Sead Ambešković } \\
\text { Bosnian Muslim }^{110} \\
\text { Bosnian (ijekavian) }\end{array}$ & Croatian (ijekavian)* \\
\hline $\begin{array}{l}\text { 19/11/1996, Erdemović } \\
\text { Bosnian Serbs perpetrators } \\
\text { Bosnian Muslims victims }\end{array}$ & $\begin{array}{l}\text { Witness Dražen Erdemović } \\
\text { Bosnian Croat }^{111} \\
\text { Bosnian (ijekavian) }\end{array}$ & $\begin{array}{l}\text { Croatian (ijekavian)* } \\
\text { Serbian (ekavian) }\end{array}$ \\
\hline $\begin{array}{l}\text { 20/11/1996, Erdemović } \\
\text { Bosnian Serbs perpetrators } \\
\text { Bosnian Muslims victims }\end{array}$ & $\begin{array}{l}\text { Witness Dražen Erdemović } \\
\text { Bosnian Croat }^{1112} \\
\text { Bosnian (ijekavian) }\end{array}$ & $\begin{array}{l}\text { Croatian (ijekavian)* } \\
\text { Serbian (ekavian) }\end{array}$ \\
\hline $\begin{array}{l}\text { 20/11/1996, Erdemović } \\
\text { Bosnian Serbs perpetrators } \\
\text { Bosnian Muslims victims }\end{array}$ & $\begin{array}{l}\text { Witness X } \\
\text { Bosnian Croat }^{1113} \\
\text { Bosnian (ijekavian) } \\
\end{array}$ & Serbian (ekavian) \\
\hline $\begin{array}{l}\text { 2o/11/1996, Erdemović } \\
\text { Bosnian Serbs perpetrators } \\
\text { Bosnian Muslims victims }\end{array}$ & $\begin{array}{l}\text { Witness Y } \\
\text { Bosnian Croat }^{1114} \\
\text { Bosnian (ijekavian) }\end{array}$ & $\begin{array}{l}\text { Croatian (ijekavian)* } \\
\text { Serbian (ekavian) }\end{array}$ \\
\hline $\begin{array}{l}\text { 14/o4/200o, Krstić } \\
\text { Bosnian Serbs perpetrators } \\
\text { Bosnian Muslims victims }\end{array}$ & $\begin{array}{l}\text { Witness P } \\
\text { Bosnian Muslim }{ }^{115} \\
\text { Bosnian (ijekavian) }\end{array}$ & $\begin{array}{l}\text { Croatian (ijekavian)* } \\
\text { Serbian (ekavian) }\end{array}$ \\
\hline $\begin{array}{l}\text { 14/04/200o, Krstić } \\
\text { Bosnian Serbs perpetrators } \\
\text { Bosnian Muslims victims }\end{array}$ & $\begin{array}{l}\text { Witness Q } \\
\text { Bosnian Muslim¹ } \\
\text { Bosnian (ijekavian) }\end{array}$ & $\begin{array}{l}\text { Serbian (ekavian) } \\
\text { Croatian (ijekavian)* }\end{array}$ \\
\hline $\begin{array}{l}\text { 22/05/200o, Krstić } \\
\text { Bosnian Serbs perpetrators } \\
\text { Bosnian Muslims victims }\end{array}$ & $\begin{array}{l}\text { Dražen Erdemović } \\
\text { Bosnian Croat }^{1117} \\
\text { Bosnian (ijekavian) }\end{array}$ & $\begin{array}{l}\text { Croatian (ijekavian)* } \\
\text { Serbian (ekavian) }\end{array}$ \\
\hline $\begin{array}{l}\text { 18/o4/2001, Vasiljević } \\
\text { Bosnian Serbs perpetrators } \\
\text { Bosnian Muslims victims }\end{array}$ & $\begin{array}{l}\text { Witness Mevsud Poljo } \\
\text { Bosnian Muslim }^{\text {1118 }} \\
\text { Bosnian (ijekavian) }\end{array}$ & Croatian (ijekavian)* \\
\hline $\begin{array}{l}\text { 25/04/2002, Brđanin } \\
\text { Bosnian Serbs perpetrators } \\
\text { Bosnian Muslims victims }\end{array}$ & 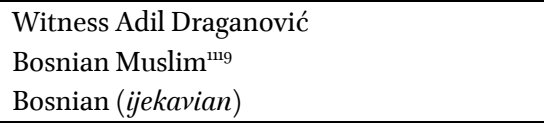 & $\begin{array}{l}\text { Croatian (ijekavian)* } \\
\text { Serbian (ekavian) }\end{array}$ \\
\hline $\begin{array}{l}\text { 26/04/2002, Brdanin } \\
\text { Bosnian Serbs perpetrators }\end{array}$ & $\begin{array}{l}\text { Witness Adil Draganović } \\
\text { Bosnian Muslim }^{1120}\end{array}$ & $\begin{array}{l}\text { Serbian (ekavian) } \\
\text { Croatian (ijekavian)* }\end{array}$ \\
\hline
\end{tabular}

${ }^{1107}$ ICTY transcripts, Nikolić, T. 236-29o.

${ }^{1108}$ Ibid, T. 292-329.

${ }^{1109}$ Ibid, T. 330-361.

${ }^{m o}$ Ibid, T. 362-376.

${ }^{111}$ ICTY transcripts, Erdemović, T. 177-205.

${ }^{112}$ ICTY transcripts, Erdemović, T. 259-310.

${ }^{m 3}$ Ibid, T. 177-245.

${ }^{114}$ Ibid, T. 245-257.

${ }^{115}$ ICTY transcripts, Krstić, T. 2490-3014.

${ }^{116}$ Ibid, T. 3014-3053.

${ }^{117}$ ICTY transcripts, Krstić, T. 3065-3183.

${ }^{118}$ ICTY transcripts, Vasiljević, T. 628-649.

${ }^{119}$ ICTY transcripts, Brđanin, T. 4972-5012.

${ }^{1120}$ ICTY transcripts, Brđanin, T. 5066-512O. 


\begin{tabular}{|c|c|c|}
\hline $\begin{array}{l}\text { Date, trial, victims, and perpe- } \\
\text { trators }\end{array}$ & Ethnicity and language of the witness & Interpreter's language \\
\hline Bosnian Muslims victims & Bosnian (ïjekavian) & \\
\hline $\begin{array}{l}\text { 15/o5/2002, Brdanin } \\
\text { Bosnian Serbs perpetrators } \\
\text { Bosnian Muslims victims } \\
\end{array}$ & $\begin{array}{l}\text { Witness Adil Draganović } \\
\text { Bosnian Muslim }^{121} \\
\text { Bosnian (ijekavian) } \\
\end{array}$ & $\begin{array}{l}\text { Serbian (ekavian) } \\
\text { Croatian (ijekavian)* }\end{array}$ \\
\hline $\begin{array}{l}\text { 21/o1/2003, Krstić } \\
\text { Bosnian Serbs perpetrators } \\
\text { Bosnian Muslims victims } \\
\end{array}$ & $\begin{array}{l}\text { Witness Miroslav Deronjić } \\
\text { Bosnian Serb }^{1122} \\
\text { Bosnian (ijekavian) } \\
\end{array}$ & Croatian (ijekavian)* \\
\hline $\begin{array}{l}\text { 21/o1/2003, Krstić } \\
\text { Bosnian Serbs perpetrators } \\
\text { Bosnian Muslims victims } \\
\end{array}$ & $\begin{array}{l}\text { Witness Dragan Obrenović } \\
\text { Bosnian Serb }{ }^{123} \\
\text { Bosnian (ijekavian) }\end{array}$ & Croatian (ijekavian)* \\
\hline $\begin{array}{l}\text { 21/O1/2003, Krstić } \\
\text { Bosnian Serbs perpetrators } \\
\text { Bosnian Muslims victims }\end{array}$ & $\begin{array}{l}\text { Witness Momir Nikolić } \\
\text { Bosnian Serb }^{124} \\
\text { Bosnian (ijekavian) }\end{array}$ & Croatian (ijekavian)* \\
\hline $\begin{array}{l}\text { 21/o1/2003, Krstić } \\
\text { Bosnian Serbs perpetrators } \\
\text { Bosnian Muslims victims } \\
\end{array}$ & $\begin{array}{l}\text { Witness VG-59 } \\
\text { Bosnian Muslim }{ }^{1125} \\
\text { Bosnian (ijekavian) }\end{array}$ & Croatian (ijekavian)* \\
\hline $\begin{array}{l}\text { 21/o1/2003, Krstić } \\
\text { Bosnian Serbs perpetrators } \\
\text { Bosnian Muslims victims } \\
\end{array}$ & $\begin{array}{l}\text { Witness VG-77 } \\
\text { Bosnian Muslim }^{1126} \\
\text { Bosnian (ijekavian) } \\
\end{array}$ & Croatian (ijekavian)* \\
\hline $\begin{array}{l}\text { 21/o1/2003, Krstić } \\
\text { Bosnian Serbs perpetrators } \\
\text { Bosnian Muslims victims }\end{array}$ & $\begin{array}{l}\text { Witness VG-8o } \\
\text { Bosnian Muslim }^{1127} \\
\text { Bosnian (ijekavian) } \\
\end{array}$ & Croatian (ijekavian)* \\
\hline $\begin{array}{l}\text { 21/o7/2003, Blagojević and Jokić } \\
\text { Bosnian Serbs perpetrators } \\
\text { Bosnian Muslims victims }\end{array}$ & $\begin{array}{l}\text { Witness Mevludin Orić } \\
\text { Bosnian Muslim }^{1128} \\
\text { Bosnian (ijekavian) }\end{array}$ & Croatian (ijekavian)* \\
\hline $\begin{array}{l}\text { 21/07/2003, Blagojević and Jokić } \\
\text { Bosnian Serbs perpetrators } \\
\text { Bosnian Muslims victims }\end{array}$ & $\begin{array}{l}\text { Witness P-111 } \\
\text { Bosnian Muslim }^{1129} \\
\text { Bosnian (ijekavian) } \\
\end{array}$ & Croatian (ijekavian)* \\
\hline $\begin{array}{l}\text { 1/12/2003, Blagojević and Jokić } \\
\text { Bosnian Serbs perpetrators } \\
\text { Bosnian Muslims victims }\end{array}$ & $\begin{array}{l}\text { Witness Cvijetin Ristanović } \\
\text { Bosnian Serb }{ }^{\text {13० }} \\
\text { Bosnian (ijekavian) } \\
\end{array}$ & Croatian (ijekavian)* \\
\hline $\begin{array}{l}\text { 1/12/2003, Blagojević and Jokić } \\
\text { Bosnian Serbs perpetrators } \\
\text { Bosnian Muslims victims }\end{array}$ & $\begin{array}{l}\text { Witness Nenad Đokić } \\
\text { Bosnian Serb }{ }^{\mathrm{n}_{31}} \\
\text { Bosnian (ijekavian) }\end{array}$ & Croatian (ijekavian)* \\
\hline $\begin{array}{l}\text { 9/12/2003, Brđanin } \\
\text { Bosnian Serbs perpetrators } \\
\text { Bosnian Muslims victims } \\
\end{array}$ & $\begin{array}{l}\text { Witness Radosava Džombić } \\
\text { Bosnian Serb }{ }^{1_{32}} \\
\text { Bosnian (ijekavian) } \\
\end{array}$ & $\begin{array}{l}\text { Serbian (ekavian) } \\
\text { Croatian (ijekavian)* }\end{array}$ \\
\hline $\begin{array}{l}\text { 19/o1/2004, Blagojević and Jokić } \\
\text { Bosnian Serbs perpetrators } \\
\text { Bosnian Muslims victims }\end{array}$ & $\begin{array}{l}\text { Witness Miroslav Deronjić } \\
\text { Bosnian Serb }^{\text {133 }_{3}} \\
\text { Bosnian (ijekavian) } \\
\end{array}$ & Croatian (ijekavian)* \\
\hline $\begin{array}{l}\text { 20/01/2004, Blagojević and Jokić } \\
\text { Bosnian Serbs perpetrators } \\
\text { Bosnian Muslims victims }\end{array}$ & $\begin{array}{l}\text { Witness Miroslav Deronjić } \\
\text { Bosnian Serb }{ }^{134} \\
\text { Bosnian (ijekavian) }\end{array}$ & $\begin{array}{l}\text { Croatian (ijekavian)* } \\
\text { Serbian }(\text { ekavian })\end{array}$ \\
\hline
\end{tabular}

${ }^{1121}$ ICTY transcripts, Brđanin, T. 5624-5708.

${ }^{1122}$ ICTY transcripts, Krstić, T. 101-172.

${ }^{1123}$ Ibid, T. 172-177.

${ }^{1124}$ Ibid, T. 177-181.

${ }^{1125}$ Ibid, T. 652-683.

${ }^{1126}$ Ibid, T. 688-720.

${ }^{1127}$ Ibid, T. 724-731.

${ }^{1128}$ ICTY transcripts, Jokić, T. 1336-1378.

${ }^{1129}$ Ibid, T. 1379-1410.

${ }^{1130}$ ICTY transcripts, Jokić, T. 5357-5429.

${ }^{1131}$ Ibid, T. 5430-5442.

${ }^{{ }^{132}}$ ICTY transcripts, Brđanin, T. 23439-23462.

${ }^{1133}$ ICTY transcripts, Jokić, T. 6131-6207.

${ }^{{ }^{134}}$ ICTY transcripts, Jokić, T. 6215-63oo. 


\begin{tabular}{|c|c|c|}
\hline $\begin{array}{l}\text { Date, trial, victims, and perpe- } \\
\text { trators }\end{array}$ & Ethnicity and language of the witness & Interpreter's language \\
\hline $\begin{array}{l}\text { 21/o1/2004, Blagojević and Jokić } \\
\text { Bosnian Serbs perpetrators } \\
\text { Bosnian Muslims victims }\end{array}$ & $\begin{array}{l}\text { Witness Miroslav Deronjić } \\
\text { Bosnian Serb }^{135} \\
\text { Bosnian (ijekavian) } \\
\end{array}$ & $\begin{array}{l}\text { Croatian (ijekavian)* } \\
\text { Serbian }(\text { ekavian })\end{array}$ \\
\hline $\begin{array}{l}\text { 22/01/2004, Blagojević and Jokić } \\
\text { Bosnian Serbs perpetrators } \\
\text { Bosnian Muslims victims }\end{array}$ & $\begin{array}{l}\text { Witness Miroslav Deronjić } \\
\text { Bosnian Serb }{ }^{136} \\
\text { Bosnian (ijekavian) }\end{array}$ & $\begin{array}{l}\text { Croatian (ijekavian)* } \\
\text { Serbian (ekavian) }\end{array}$ \\
\hline $\begin{array}{l}\text { 20/02/2004, Brdanin } \\
\text { Bosnian Serbs perpetrators } \\
\text { Bosnian Muslims victims }\end{array}$ & $\begin{array}{l}\text { Witness Goran Nešković } \\
\text { Bosnian Serb }{ }^{137} \\
\text { Bosnian (ijekavian) }\end{array}$ & $\begin{array}{l}\text { Serbian (ekavian) } \\
\text { Croatian (ijekavian)* }\end{array}$ \\
\hline $\begin{array}{l}\text { 23/02/2004, Brđanin } \\
\text { Bosnian Serbs perpetrators } \\
\text { Bosnian Muslims victims }\end{array}$ & $\begin{array}{l}\text { Witness Goran Nešković } \\
\text { Bosnian Serb }{ }^{113} \\
\text { Bosnian (ijekavian) } \\
\end{array}$ & $\begin{array}{l}\text { Serbian (ekavian) } \\
\text { Croatian (ijekavian)* }\end{array}$ \\
\hline $\begin{array}{l}\text { 8/o6/2004, Blagojević and Jokić } \\
\text { Bosnian Serbs perpetrators } \\
\text { Bosnian Muslims victims }\end{array}$ & $\begin{array}{l}\text { Witness Petar Salapura } \\
\text { Bosnian Serb }{ }^{139} \\
\text { Bosnian (ijekavian) } \\
\end{array}$ & Croatian (ijekavian)* \\
\hline $\begin{array}{l}\text { 9/o6/2004, Blagojević and Jokić } \\
\text { Bosnian Serbs perpetrators } \\
\text { Bosnian Muslims victims }\end{array}$ & $\begin{array}{l}\text { Witness Petar Salapura } \\
\text { Bosnian Serb }^{1140} \\
\text { Bosnian (ijekavian) }\end{array}$ & Croatian (ijekavian)* \\
\hline $\begin{array}{l}\text { 9/o6/2004, Blagojević and Jokić } \\
\text { Bosnian Serbs perpetrators } \\
\text { Bosnian Muslims victims }\end{array}$ & $\begin{array}{l}\text { Witness Dragomir Keserović } \\
\text { Bosnian Serb }{ }^{141} \\
\text { Bosnian (ijekavian) }\end{array}$ & Croatian (ijekavian)* \\
\hline $\begin{array}{l}\text { 19/o7/2004, Blagojević and Jokić } \\
\text { Bosnian Serbs perpetrators } \\
\text { Bosnian Muslims victims }\end{array}$ & $\begin{array}{l}\text { Witness Zoran Radosavljević } \\
\text { Bosnian Serb }{ }^{1142} \\
\text { Bosnian (ijekavian) }\end{array}$ & Croatian (ijekavian)* \\
\hline $\begin{array}{l}\text { 19/07/2004, Blagojević and Jokić } \\
\text { Bosnian Serbs perpetrators } \\
\text { Bosnian Muslims victims }\end{array}$ & $\begin{array}{l}\text { Witness Mirko Rebić } \\
\text { Bosnian Serb }{ }^{143} \\
\text { Bosnian (ijekavian) }\end{array}$ & Croatian (ijekavian)* \\
\hline $\begin{array}{l}\text { 23/05/2005, Halilović } \\
\text { Bosnian Muslims perpetrators } \\
\text { Bosnian Serbs victims }\end{array}$ & $\begin{array}{l}\text { Witness Bakir Alispahić } \\
\text { Bosnian Muslim¹44 } \\
\text { Bosnian (ijekavian) } \\
\end{array}$ & $\begin{array}{l}\text { Serbian (ekavian) } \\
\text { Croatian (ijekavian) }\end{array}$ \\
\hline $\begin{array}{l}\text { 24/05/2005, Halilović } \\
\text { Bosnian Muslims perpetrators } \\
\text { Bosnian Serbs victims }\end{array}$ & $\begin{array}{l}\text { Witness Bakir Alispahić } \\
\text { Bosnian Muslim¹45 } \\
\text { Bosnian (ijekavian) } \\
\end{array}$ & Croatian (ijekavian)* \\
\hline $\begin{array}{l}\text { 26/05/2005, Halilović } \\
\text { Bosnian Muslims perpetrators } \\
\text { Bosnian Serbs victims }\end{array}$ & $\begin{array}{l}\text { Witness Bakir Alispahić } \\
\text { Bosnian Muslim¹46 }^{1146} \text { Bosnian (ijekavian) } \\
\end{array}$ & $\begin{array}{l}\text { Croatian (ijekavian)* } \\
\text { Serbian (ekavian) }\end{array}$ \\
\hline $\begin{array}{l}\text { 27/05/2005, Halilović } \\
\text { Bosnian Muslims perpetrators } \\
\text { Bosnian Serbs victims }\end{array}$ & 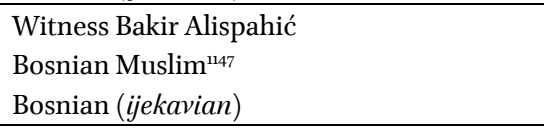 & $\begin{array}{l}\text { Croatian (ijekavian)* } \\
\text { Serbian (ekavian) }\end{array}$ \\
\hline
\end{tabular}

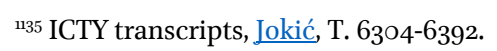

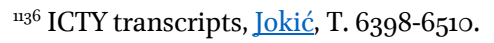

${ }^{1137}$ ICTY transcripts, Brđanin, T. 24846-24932.

${ }^{1138}$ ICTY transcripts, Brđanin, T. 24935-25009.

${ }^{1139}$ ICTY transcripts, Jokić, T. 10486-6223. Note there seems to be a problem with the pagination of this transcript: it starts at p. 10486 and ends at p. 6223 .

${ }^{1140}$ ICTY transcripts, Jokić, T. 10581-10622.

${ }^{1141}$ Ibid, T. 10622-10669.

${ }^{1142}$ ICTY transcripts, Jokić, T. 12O42-12O78.

${ }^{1143}$ Ibid, T. 12079-12103.

${ }^{1144}$ ICTY transcripts, Halilović, T. 8-74.

${ }^{1145}$ ICTY transcripts, Halilović, T. 1-74.

${ }^{1146}$ ICTY transcripts, Halilović, T. 1-76.

${ }^{1147}$ ICTY transcripts, $\underline{\text { Halilović, }}$ T. 1-82. Here, the pagination does not correspond to pagination of the original transcripts court reporters made in the English language. 


\section{BIBLIOGRAPHY}

\section{Books and journal articles}

Academy of Arts and Sciences of B\&H, Yearbooks: $\underline{\text { http://ow.ly/gLca3obZCSD. }}$

Ágoston, G. and Masters, B. (2009), Encyclopedia of the Ottoman Empire. Facts On File, Inc., An imprint of Infobase Publishing, New York.

Alexander, R. (2013), Language and identity: the faith of Serbo-Croatian. Entangled histories of the Balkans, Vol. 1: National ideologies and language policies. Koninklijke Brill NV: Leiden.

Alexovičková, I. (2012), From hiring to firing: a comparative study on selected legal safeguards for the independence and impartiality of international civil servants serving at the UNited Nations Secretariat and in the European Commission. Wolf Legal Publishers: Nijmegen.

Amnesty International (2017), 'WE NEED SUPPORT, NOT PITY’. LAST CHANCE FOR JUSTICE FOR BOSNIA'S WARTIME RAPE SURVIVORS. London: Amnesty International Ltd: https://goo.gl/2T95Mc.

Andrić, I., The bridge on the Drina (Lovett F. Edwards, translator): http://ow.ly/JpNR3o8FYFS.

Arbour, L. (2008), The responsibility to protect as a duty of care in international law and practice. Review of International Studies, 34(3): 445-458.

Assembly of States Parties, International Criminal Court, Report of the Court on the Implementation in 2013 of the Revised Strategy in Relation to Victims. ICC-ASP/12/41, 11 October 2013.

Babić, A. (1946), Istorija naroda Jugoslavije. Svjetlost:, Sarajevo.

Baker, M. (2011), In Other Words: A Coursebook on Translation (second edition), Routledge: London and New York.

Barker, C. and Galasin, A.D. (2011), Cultural studies and discourse analysis. SAGE: London.

Bassiouni, C. (1994), Former Yugoslavia: Investigating Violations of International Humanitarian Law and Establishing an International Criminal Tribunal. Fordham International Law Journal, 18/4, p. 1198-1199.

Bassiouni, C. (2011), Crimes against humanity: historical evolution and contemporary application. Cambridge University Press: Cambridge, UK.

Bassnett, S. and Trivedi, H. (eds.) (1999), Post-colonial translation: theory and practice. Routledge: London and New York.

Bateson, G. (1972), Steps to an ecology of mind: collected essays on anthropology, psychiatry, evolution, and epistemology. John Aronson Inc.: Lanham, MD.

Bertrand, M. (1995), The UN as an organization. A critique of its functioning. European Journal of International Law 6, p. 349-359.

Bertrand, Maurice (1995), The UN as an organization. A critique of its functioning. EJIL (1995), 349-359.

Blažević, R. and Alijagić, A. (2010), Antižidovsko i rasno zakonodavstvo u Fašističkoj Italiji, Nacističkoj Njemačkoj i Ustaškoj NDH. Zbornik Pravnog fakulteta: Zagreb, p. 879-916.

Bougarel, X., Helms E. and Duijzings G. (eds.) (2007), The New Bosnian Mosaic Identities, Memories and Moral Claims in a Post-War Society. Ashgate: Burlington, VT.

Božič, I., Ekmečić, M. and Dedijer, V. (1970), Istorija Jugoslavije. Prosveta: Beograd.

Brammertz, S. and Jarvis M. (eds.) (2016), Prosecuting Conflict-Related Sexual Violence. Oxford University Press: Oxford, UK.

Cao, D. (2002), Legal Terminological Issues in Translation. Translating Law. Multilingual Matters LTD: Bristol.

Cao, D. (2007), Translating law. Multilingual matters LTD: BristolCao, D. (2007), Translating law. Multilingual matters LTD. 
Carrier, P. (2006), Holocaust Monuments and National Memory Cultures in France and Germany Since 1989. Berghahn Books: New York City.

Çelebi, E. (1979), Putopis (Hazim Šabanović, translator). Veselin Masleša:, Sarajevo.

Clark, C. (2009), Kaiser Wilhelm II: A life in power. Taylor and Francis: New York, p. 251.

Cook, V. (1999), Going beyond the Native Speaker in Language Teaching. TESOL Quarterly, 33, 2, 185-209.

Cryer, R., Friman, H., Robinson, D. and Wilmshurst, E. (2013), An introduction to international criminal law and procedure (second edition). Cambridge University Press: New York.

Čulinović, F. (1961), Jugoslavija između dva rata. Jugoslavenska akademija znanosti i umjetnosti: Zagreb.

Dadrian, V. N. and Akçam, T. (2012), Judgment at Istanbul: the Armenian genocide trials. Berghahn Books: New York City.

Davies, A. (1995), Proficiency or the native speaker: what are we trying to achieve in ELT? Principle and practice in applied linguistics. OUP: Oxford, UK.

De Groot, G.R. and Laer, C.J.P. van. (2006), The Dubious Quality of Legal Dictionaries. International Journal of Legal Information: Vol. 34: Iss. 1, Article 6.

Dedijer, V. (1987), Vatikan i Jasenovac: dokumenti. Izdavačka radna organizacija Rad: Beograd.

Delisle, J. and Woodsworth, J. (eds.) (2012), Translators through history., John Benjamins Publishing Company: Amsterdam.

Detrez, R. (2002), Language or nation: what came first? Lexicography and Language Policy in South-Slavic Languages after 1989. Verlag Otto Sagner: Munich.

Draženović-Carrieri, M. (2002), B/C/S-A practical approach. Lexicography and Language Policy in SouthSlavic Languages after 1989. Verlag Otto Sagner: Munich.

Elias-Bursać, E. (2015), Translating evidence and interpreting testimony at a war crimes tribunal: working in a tug-of-war. Palgrave Macmillan: London.

Fichtelberg, A. (2015), Hybrid Tribunals. A Comparative Examination. Springer: New York.

Fine, John V. A. (1985), The Bosnian Church: A new interpreting: A study of the Bosnian Church and its place in state and society from the 13th to the 15th centuries. Boulder: East European quarterly; New York: distributed by Columbia University Press.

Fletcher, R. (1999), Interview: Converting by the sword. Christian History Issue \#63: http://ow.ly/7JeD 30 hgAir. Friedman, V.A. (1994), Variation and Grammaticalization in the Development of Balkanisms. Chicago: Chicago Linguistic Society.

Friedman, V.A. (2011), Families, Leagues, and Hybridity: The Past and Future of Slavic and East European Languages (University of Chicago, AATSEEL keynote address). Slavic and East European Journal. Vol 55(1).1-13. 2011.

Gaiba, F. (1998), The origins of simultaneous interpreting: the Nuremberg trial. University of Ottawa Press: Ottawa.

Garašanin, I. (1844), Načertanije. http://ow.ly/hUNM308FWrJ.

Garbett, C. (2017), The International Criminal Court and restorative justice: victims, participation and the process of justice. Restorative Justice, 5:2, 198-220: https://goo.gl/4v6gRf.

Gardner, B. (2010), The Black's Law Dictionary (ninth edition). West: St. Paul.

Gardner, J. (2016), Misused English words and expressions in EU publications: http://ow.ly/pGHw3oeUFQd.

Gazi Husrev-begova Medresa, Yearbooks: http://ow.ly/ewc23obZCVa.

Gibbons, J. (2003), Forensic linguistics: an introduction to language in the justice system. Blackwell: Hoboken. Grant, J.P. and Barker C.B. (2009), Parry \& Grant encyclopaedic dictionary of international law. Oxford University Press: Oxford, UK.

Grice, P. (1989), Studies in the way of words. Harvard University Press: Cambridge, MA.

Grubić, M. (2013), Makedonska drama između dva rata, Croatica et Slavica Iadertina IX/I, pgs. 315-331.

Gumperz, J. J. (1982), Discourse Strategies. Cambridge University Press: New York.

Hadžijahić, M. (1985), Građa o posljednjim ostacima bosančice u nas. Anali Gazi Husrev-begove biblioteke, Sarajevo. 
Hajdarpašić, E. (2015), Whose Bosnia? Nationalism and political imagination in the Balkans 1840-1914. Cornell University Press: Ithaca and London.

Hepburn, P. (2012), The Translation of Evidence at the ICTY: A Groundbreaking Institution. Translation and Interpreting Studies, 7(1):54-71.

Herder, J.G. (2002), Philosophical Writings (Michael N. Forster, translator). Cambridge University Press: Cambridge, UK.

Hernani Costa, H., Corpas Pastor, G., Durán Muñoz, I. (2014). Technology-assisted interpreting. Multilingual. Translation Technology Core Focus.

Hobsbawm, E. (2002), War and peace in the twentieth-century: http://ow.ly/mTRF308Hocf.

Holbrooke, R. (1999), To End a War. Modern Library Paperbacks.

Holbrooke, Richard (1999), To End a War. Modern Library Paperbacks.

ICTY, ADC-ICTY Developed Practices: Manual of International Criminal Defense (2011), UNICRI Publisher: http://ow.ly/ZSW2308Hhae.

Imamović, M. (2014), Historija države i prava Bosne i Hercegovine. University Press:, Sarajevo.

Imber, C. (2002), The Ottoman Empire, 1300-1650: the structure of power. Palgrave Macmillan: London.

Isaković, A. (2001), Vid bosanskog jezika. Anali Gazi Husrev-begove biblioteke XIX-XX, Sarajevo.

Jaspers, K. (1946), The Significance of the Nurnberg Trials for Germany and the World. 22 Notre Dame Law

15 O, 155 .

Jordash, W. (2009), The Practice of 'Witness Proofing' in International Criminal Tribunals: Why the International Criminal Court Should Prohibit the Practice. Leiden Journal of International Law, 22, pgs. 501-523.

Judah, T. (1997), The Serbs: The Sweet and Rotten Smell of History. Daedalus, 126, p. 23-45.

Juergensmeyer, M. and Anheier H. (eds.) (2012), The Encyclopedia of Global Studies. Sage: Thousand Oaks,

CA.

Kamusella, T. (2009), The Politics of Language and Nationalism in Modern Central Europe. Palgrave Macmillan: London.

Karpova, O. and Kartashkova F. (eds) (20o9), Lexicography and terminology: a worldwide outlook. Cambridge Scholars Publishers: Newcastle on Tyne, UK.

Kasumović, A. (2001), Bosanskohercegovački muslimani i njihov jezik. Anali Gazi Husrev-begove biblioteke XIX-XX, Sarajevo.

Keefer, E. C. (undated), The Nixon Administration and the UN: It's a damned debating society: http://ow.ly/CzAx308EC6T.

Kille, K. J. (2006), The Secretary-General of the United Nations. Palgrave Macmillan: London.

Kissinger, H. (2015), World Order: Reflections on the Character of Nations and the Course of History. Penguin Press: London.

Klaić, V. (1899), Povijest Hrvata. Knjižara Lav Hartmana (Kugli i Deutsch):, Zagreb.

Klip, A. and Sluiter, G. (eds.) (2008), Annotated leading cases of international criminal tribunals, Volume

XIII, Timor Leste, The Special Panels for serious crimes 2001-2003. Intersentia: Cambridge, UK.

Koljanin, D. (2010), U službi 'novog poretka': osnovno školstvo i udžbenici istorije u Srbiji (1941-1944). Istraživanja, br. XXI, 395-415, Novi Sad.

Kulenović, S. (1977), Ponornica (Lost River). Nolit:, Beograd.

Laban Hinton A., La Pointe T., Irvin-Erickson D. (eds.) (2014), Hidden Genocides: Power, Knowledge,

Memory. Rutgers University Press: New Brunswick.

Lunde, L. (2000), Coherence or dissonance in the international institutional framework. ECON, Centre for Economic Analysis: http://ow.ly/o3 $\mathrm{SO}_{3}$ oevMY.

Lunt, H. G. (1974), Old Chruch Slavonic Grammar. The Hague: Mouton.

Mahmood, O.O. (2001), The root causes of the United Nations failure in Somalia. The role of neighboring countries in the Somali crisis. iUniverse: Bloomington, IN, p. 15.

McArthur, T. (ed.) (1992), The Oxford companion to the English language. OUP: Oxford, UK.

McMorran, C. (2003), International War Crimes Tribunals: beyond intractability. Conflict Information Consortium, University of Colorado:, Boulder. 
Meron, T. (2011), The Making of International Criminal Justice, A View from the Bench: Selected Speeches. Oxford University Press: Oxford, UK.

Moerland, C.A.R. (2015), The killing of death: denying the genocide against the Tutsi. Intersentia: Cambridge, UK.

Mowbray, J. (2012), Linguistic justice: International Law and Language Policy. Oxford University Press: Oxford, UK.

Mulayim, S. and Lai, M. (2016), Ethics for police translators and interpreters. CRC Press, Taylor \& Francis Group: Boca Raton.

Mulayim, S., Lai, M. and Norma, C. (2015), Police Investigative Interviews and Interpreting: Context, Challenges, and Strategies. CRC Press, Taylor \& Francis Group: Boca Raton.

Munday, J. (2016), Introducing translation studies: theories and applications (fourth edition). London \& New York: Routledge.

Nata Hajdu, The kindapper and the kidnapped: Interpreting at the ICTY: http://ow.ly/YmmHzoaYyı.

Negalign, L. (2014), The need to reform the UN Security Council. Addis Ababa University: Addis Ababa.

Nikolić, M. (2005), Interpreting after the Nuremberg: international war crimes trials. Proteus 14 1:1 and 6-8.

Okhovat, S. (2012), UN Security Council: its veto power and its reform. Centre for Peace and Conflict Studies: Melbourne.

OSISA, Lessons for Africa from Cambodia's genocide trials (2012): http://ow.ly/osSo308FUJK.

Parolin, G. P. (2009), Citizenship in the Arab world: kin, religion and the nation-state. Amsterdam University Press: Amsterdam.

Pavetić, J. (2012), Interview with Greiss lecturer Marijana Nikolić. SlavFile: Newsletter of the Slavic Languages Division. 21 (4): 6-7, 9 .

Pečo, A. (2001), Muslimanski narodni govori i standardizacija našeg jezika. Anali Gazi Husrev-begove biblioteke XIX-XX, Sarajevo, pg.p. 243-246.

Pešikan, M., Jerković, J., Pižurica, M. (2010), Pravopis srpskoga jezika (izmenjeno i dopunjeno izdanje). Matica Srpska: Novi Sad.

Petrović, Petar II Njegoš, The mountain wreath (James W. Wiles, translator): http://ow.ly/h3RD $308 \mathrm{FVwk}$. Principles of International Law of the Charter and Judgment of the Nuremberg Tribunal, Formulated by the International Law Commission, Second Session. International Organization, vol. 4, no. 4, 1950, pp. 714-721: https://goo.gl/qjKU85.

Recchia, S. and Welsh, J. M. (eds.) (2013), Just and Unjust Military Intervention: European Thinkers from Victoria to Mill. Cambridge University Press: Cambridge, UK.

Republic of B\&H, Institute for Statistics of the Republic of B\&H, Statistical Bulletin 233, The 1991 Census of population, households, dwellings and agricultural lands, Ethnic characteristics of the population, The 1991 results at the level of the Republic and on the municipal level, Sarajevo, October 1993.

Ringmar, E. (2010), Performing international relations: two East Asian alternatives to the Westphalian order. CenPRIS Working Paper No. 125/10.

Rizvić, M. (1995), Bosanski muslimani u Andrićevom svijetu. Ljiljan: Sarajevo.

Rizvić, M. (1996), Bosna i Bošnjaci: jezik i pismo. KDB Preporod: Sarajevo.

Röhl, J. C. G. (2014), Wilhelm II: into the abyss of war and exile, 1900-1941. Cambridge University Press: Cambridge, UK.

Rothe, D. L., Meernik, J. D. and Ingadóttir, T. (eds.) (2013), The Realities of International Criminal Justice. Martinus Nijhoff Publishers: Leiden.

Šarčević, S. (1997), New approach to legal translation., Kluwer Law International: The Hague.

Šarčević, S. (2000), Legal Translation and Translation Theory: a Receiver-oriented Approach. Legal Translation: History, Theory/ies, Practice: $\mathrm{http://ow.ly/5Q8y30glGeo.}$

Seleskovitch, D. and Lederer, M. (1993), Interpreter pour Traduire (3e edition). Paris: Didier Erudition: Paris. Selimović, M. (1976), Sjećanja. Svjetlost:, Sarajevo.

Simon-Vandenbergen A.M. and Aijmer, K. (2007), The Semantic Field of Modal Certainty: A Corpus-based Study of English Adverbs. Mouton de Gruyter: Berlin. 
Šipka, M. (1999), Standardni jezik u Bosni i Hercegovini u dokumentima jezičke politike. Open Society Institute: Budapest.

Skok, P. (1971), Etimologijski rječnik hrvatskoga ili srpskoga jezika. Zagreb: Jugoslovenska akademija znanosti i umjetnosti.

Sonnenfeldt, R. W. (2002), Witness to Nuremberg. Arcade Publishing: New YorkSonnenfeldt, R. W. (2002),

Witness to Nuremberg. New York: Arcade Publishing.

Starr, S. B. (2009), Ensuring Defense Counsel Competence at International Criminal Tribunals. UCLA J. Int'l L. Foreign Aff. 14, no. 1 (2009): 169-206.

Tabeau, E. (ed.) (2009), Conflict in Numbers: Casualties of the 199os Wars in the Former Yugoslavia (19911999). Helsinki Committee for Human Rights in Serbia: Belgrade.

Thakur, R. (2007), The United Nations, Peace and Security. From Collective Security to the Responsibility to Protect. Cambridge University Press: Cambridge, UK.

The Report of the Commission on the Responsibility of the Authors of the War and on Enforcement of Penalties from 29 March 1919, The American Journal of International Law 14.1/2 (1920): 95-154.

Truhelka, Ć. (1889), Bosančica: prilog bosanskoj paleografiji. Glasnik zemaljskog muzeja u Bosni i Hercegovini, Sarajevo.

University of Texas and VWU (2016), Echoes of Testimonies: A Pilot Study into the long-term impact of bearing witness before the ICTY: http://ow.ly/Petc3oaYqF3.

Vallianatou, F. (2005), CAT Tools and Productivity: Tracking Words and Hours. Translation Journal: Vol. 9,

No. 4.

Various authors (1986), Draft Memorandum of the Serbian Academy of Arts and Sciences. Serbian Academy of Arts and Sciences: http://ow.ly/KTKpзo8FXWz.

Various authors (2005), Fenomen 'Krstjani' u Srednjevjekovnoj Bosni i Humu, Institut za istoriju u Sarajevu i Hrvatski institut za povijest, Zagreb.

Vukšić, T. (2005), Papa Pio II i kralj Stjepan Tomaš. Fenomen 'krstjani' u srednjovjekovnoj Bosni i Humu," Institut za istoriju, Sarajevo, and Hrvatski institut za povijest, Zagreb.

Wald, P. (2002), Dealing with witnesses in war crimes trials: lessons from the Yugoslav Tribunal. Yale Human Rights and Development Law Journal, 5: 217-239.

Walling, C. B. (2013), All necessary measures: UN and humanitarian intervention. University of Pennsylvania Press: Philadelphia.

Warah, R. (2016), UNsilenced: Unmasking the United Nations' culture of cover-ups, corruption and impunity. AuthorHouse: UK.

Waters, T.W. (ed.) (2013), The Milosevic Trial: An Autopsy. Oxford University Press: Oxford, UK.

Weiss, T. G. (2012), What's wrong with the United Nations and how to fix it. Polity Press: Cambridge, UK.

Williams, S. (2012), Hybrid and Internationalised Criminal Tribunals. Hart Publishing: London.

Yavnai, E. M. (2014), Military Justice:The U.S. Army War Crimes Trials in Germany. ProQuest LLC: Ann Arbor, MI.

Žeželj, M. (1967), Prošlost u slikama. Školska Knjiga: Zagreb.

Ziabari, K. (2011), The UN Security Council: an organization for injustice. Global Research: http://ow.ly/QRKMzoevMGg.

\section{International treaties and the situation country laws}

Constitution of the FB\&H (1994): http://ow.ly/7lfP308FZ15.

Constitution of the Kingdom of the Serbs, Croats and Slovenes (1921): http://ow.ly/3OSzzoeRy2f.

Constitution of the Republika Srpska (2005): http://ow.ly/HEhQ308FZ3I.

Constitution of the SFRY (1974): http://ow.ly/4Mr6308FXAz.

Convention (II) with Respect to the Laws and Customs of War on Land and its annex: Regulations concerning the Laws and Customs of War on Land (1899): $\underline{\text { http://ow.ly/cdg4308FRHv. }}$ 
Convention (IV) respecting the Laws and Customs of War on Land and its annex: Regulations concerning the Laws and Customs of War on Land (1907): http://ow.ly/gMGA308FRJn.

European Convention on Human Rights and Freedoms (2010): http://ow.ly/7HcH3o8G6hV. International Covenant on Civil and Political Rights (1966): http://ow.ly/cOxy308G5Ex. Joint Ministry of Finance, Decree 168539 (1907), Arhiv Bosne i Hercegovine: Sarajevo. Joint Ministry of Finance, Decree 6687 (1880), Arhiv Bosne i Hercegovine: Sarajevo.

Journal of Laws and Orders for Bosnia and Herzegovina, LI/1918 (1918): The law on official language and script. Niška deklaracija: ratni ciljevi Srbije (1914): http://ow.ly/OEWE3ohgFZO.

Republic of Serbia, Higher Court in Belgrade, Rehabilitation: http://ow.ly/hTFx308FWOF.

Republic of Serbia, Official Gazette of the Republic of Serbia 92/2011 (2011), Law on Rehabilitation: http://ow.ly/HTIczoeSImD.

The Kingdom of the Serbs, the Croats and the Slovenes, Official Gazette LXXXI/2O4 (1929), Orthographic Instructions for all elementary, high and professional schools.

The Kingdom of Yugoslavia, Official Gazette CXIX/289 (1929), The Law on People's Schools.

The Kingdom of Yugoslavia, Official Gazette LXIII/167 (1930), Constitution of the Islamic Religious Community of the Kingdom of Yugoslavia.

The Kingdom of Yugoslavia, Official Gazette LXVI/207 (1931), Constitution of the Kingdom of Yugoslavia.

The Serbian Gazette LXXX/257 (1913), Decision to enact the following provisions of the Constitution of the Kingdom of Serbia of 5 June 1903 in the annexed Old Serbia.

Treaty of Berlin (1878): http://ow.ly/BIrA308FVtx.

Treaty of peace with Turkey signed at Lausanne (1923): http://ow.ly/ik2Y3o8FRXM.

Treaty of peace with Turkey signed at Lausanne: Declaration of amnesty (1923): $\mathrm{http}: / /$ ow.ly/izjq308FRYm.

Treaty of Sèvres (1920): $\underline{\mathrm{http}: / / 0 w . l y / a d D s 308 F R M 5}$.

Treaty of Versailles (1920): http://ow.ly/GrYE308FRKa.

Universal Declaration of Human Rights (1948): http://ow.ly/zIvG308G5Cm.

\section{UN documents}

UN General Assembly Homepage: http://ow.ly/whFW308Ezvg.

UN Peacekeeping Operations, UNPROFOR: https://goo.gl/7tnxiK.

UN Security Council Homepage: http://ow.ly/yVfLzobqJUU.

UN Security Council Resolution 1757 on the establishment of the [STL] (S/RES/1757) (2007): http://ow.ly/lMIA308FTjQ.

UN Security Council Resolution 827 on the establishment of the ICTY (S/RES/827) (1993): http://ow.ly/YZ2m308FTdb.

UN Security Council Resolution 955 on the establishment of the ICTR (S/RES/955) (1994): http://ow.ly/UtJszo8FTg1.

UN Travel Allowance: http://ow.ly/GHBz3og7ZHl.

UN vacancies, AFRO/WHO (grade not defined) Interpreters (English, French, Portuguese): http://ow.ly/eatW30928NS.

UN vacancies, IAEA P-3/P-4 Translator/Reviser (French): http://ow.ly/guTF3ogzbpd.

UN vacancies, ICAO P-4 Language Officer/Reviser (Spanish): http://ow.ly/63q93092biI.

UN vacancies, ICJ P-3 Head of the Text Processing and Reproduction Division: http://ow.ly/Mj6nzogzfjk.

UN vacancies, ICJ P-4 Translator/Reviser (English mother tongue): http://ow.ly/lwjozogzbuy.

UN vacancies, ICJ P-4 Translator/Reviser (English mother tongue): http://ow.ly/zuMozoenUlV.

UN vacancies, ICJ P-4 Translator/Reviser (English mother tongue): http://ow.ly/LlTOzoenUx5.

UN vacancies, ICJ P-4 Translator/Reviser (French mother tongue): http://ow.ly/I3BfzoenTPr.

UN vacancies, ICRC (grade not defined) Senior Arabic Translator/Reviser: http://ow.ly/wDSM30928Dq.

UN vacancies, ICTR FS-4 Language Assistant (English, French and Kinyarwanda):

http://ow.ly/4AoK3og8oDK. 
UN vacancies, ICTY G-5 Language Assistant (English and B/C/S): http://ow.ly/pTK13098oBM.

UN vacancies, ICTY G-5 Language Assistant: http://ow.ly/77FT30981cu.

UN vacancies, ICTY G-5 Language Assistant: http://ow.ly/suRS3oaLovb.

UN vacancies, ICTY G-5 UNDU Language Assistant (Albanian, B/C/S and English):

http://ow.ly/vzJM3oeIQ7a.

UN vacancies, ICTY G-5 UNDU Language Assistant (B/C/S and English): http://ow.ly/Lck73oeIQgl.

UN vacancies, ICTY G-5 VWU Administrative Assistant (Dutch, B/C/S and English): http://ow.ly/SSM530947fN.

UN vacancies, ICTY G-5 VWU Witness Assistant (Dutch, B/C/S and English): $\underline{\text { http://ow.ly/5z1c30947nD. }}$

UN vacancies, ICTY P-2 Associate Translator (B/C/S): http://ow.ly/EBFRzoaxRza.

UN vacancies, ICTY P-2 Intelligence Analyst (Criminal): http://ow.ly/wDg230g810R.

UN vacancies, ICTY P-2 Intelligence Analyst (Criminal): http://ow.ly/ZPV83og81rb.

UN vacancies, ICTY P-3 Intelligence Analyst (Military): http://ow.ly/3fuY3og81sp.

UN vacancies, ICTY P-3 Investigator: http://ow.ly/y25930981tm.

UN vacancies, ICTY P-3 Legal Officer: http://ow.ly/BLjv30g81vc.

UN vacancies, ICTY P-3 Translator (B/C/S): http://ow.ly/iYzG3oaxRm4.

UN vacancies, ICTY P-4 Translator/Reviser (English): http://ow.ly/DTZx3097YAp.

UN vacancies, ICTY P-5 Senior Trial Attorney: http://ow.ly/8B6m30g81yW.

UN vacancies, ICTY P-5 Senior Trial Attorney: http://ow.ly/8B6m3og8iyW.

UN vacancies, IIIC P-4 interpreter (Arabic/English): http://ow.ly/nzcQ230927Qu.

UN vacancies, IMF (grade not defined) Editor (External relations officer): http://ow.ly/4QyT30928Ie.

UN vacancies, OPCW G-5 Language Assistant (English): http://ow.ly/37zJ3098oLp.

UN vacancies, OPCW P-3 Linguist (Chinese): http://ow.ly/Rıfo3og28rj.

UN vacancies, OSCE G-5 Language Assistant roster (English, Ukrainian and Russian): http://ow.ly/ZYZk30980RA.

UN vacancies, Pan American Health Organization P-3 Translator (English): http://ow.ly/VMnG3ogzeQH.

UN vacancies, Secretariat of the Pacific Community (grade not defined) Interpreter/Translator: http://ow.ly/kso73oabnYP.

UN vacancies, STL G-5 Language Assistant roster (English, French and Arabic): http://ow.ly/s5Zk3098oIK.

UN vacancies, UN Assistance Mission for Afghanistan (grade not defined) Political Affairs/Language Assistant

(English, Dari and Pashto): $\underline{\text { http://ow.ly/IJTv3og8oUj. }}$

UN vacancies, UN Assistance Mission for Iraq GL-5 Language Assistant (English and Arabic): http://ow.ly/UOxX3og8oSP.

UN vacancies, UN Women SB-4 UN Joint Programme for Gender Equality Project Assistant (English, Russian and Georgian): $\underline{\text { http://ow.ly/nhoX } 3092 a L h}$.

UN vacancies, UN Women SC-9 Senior Translator-Interpreter (English, Dari, Pashto):

http://ow.ly/Ys383092aPS.

UN vacancies, UNAKRT (ECCC) G-7 Language Assistant (English and Khmer): http://ow.ly/ysjY30980Kg.

UN vacancies, UNAKRT Consultant Language reviewer French to English: http://ow.ly/bRDz30940Qa.

UN vacancies, UNAKRT Consultant Language reviewer French to English: http://ow.ly/b4AX30940UN.

UN vacancies, UNDP P-3 Interpreter/Translation Specialist: http://ow.ly/eL1O30928wj.

UN vacancies, UNDP SB-3 trilingual Administrative/Financial Associate (English, Russian and Georgian):

http://ow.ly/JJJ309295Y.

UN vacancies, UNDP SC-9 Legal Translator (English and Somali): http://ow.ly/OIcN3ogzaFZ.

UN vacancies, UNDP SC-9 Translator/Interpreter/Proofreader: http://ow.ly/TgrBzogzaqa.

UN vacancies, UNHCR GL-4 Registration Assistant (English and Thai): http://ow.ly/7ud73og2axE.

UN vacancies, UNHCR SB-2 Receptionist/Translator: http://ow.ly/d7173092ac1.

UN vacancies, UNICEF P-3 Editor (French): http://ow.ly/3Wtp3ogzggt.

UN vacancies, UNOPS G-5 Language Assistant/Translator (English and Nepali): http://ow.ly/LA7f3og8oWB. 
UN vacancies, UNOPS IICA-2 Bilingual Communications Consultant/Translator (English and Somali): http://ow.ly/5zRm30928Vv.

UN vacancies, UNOPS LICA-11 Written Translator, Proofreader and Interpreter (English, Spanish, Portuguese): http://ow.ly/gJFzzog2gc7.

UN vacancies, UNOPS LICA-9 Liaison Officer/Translator: http://ow.ly/MnYJ3ogzaiu.

UN vacancies, WHO G-4 Secretary (English, Russian, Ukrainian): http://ow.ly/HfMt3ogzaBv.

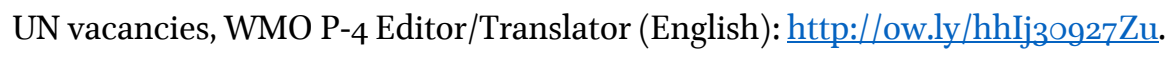

UN Volunteers, Voluntering opportunities: http://ow.ly/z2nA3oeTLZc.

UN, Administrative Instruction on Temporary staff and individual contractors (ST/AI/295) (1982): http://ow.ly/1Hxk3097Z8r.

UN, Administrative Instruction: Language Allowance and Language Incentives (ST/AI/1999/2) (1999): http://ow.ly/6AZl $308 \mathrm{G} 6 \mathrm{tH}$.

UN, Administrative Tribunal of the International Labour Organizations, $-S$ and RPE: http://ow.ly/NrTb3og2dW4.

UN, Agreement between the UN and the government of Sierra Leone (2002): http://ow.ly/oBIR308FTiD.

UN, Agreement between the UN and the Royal Government of Cambodia (2003): http://ow.ly/kGEw3o8FTkG.

UN, Basic Principles on the Independence of the Judiciary (1985): $\underline{\text { http://ow.ly/EAwX } 308 G_{5} b A}$.

UN, Board of Auditors Homepage: http://ow.ly/1Aogzog2fvu.

UN, Charter (1945): http://ow.ly/KXZK3o8rges.

UN, Competitive examinations for recruitment and placement in posts requiring specific language skills in the professional category (ST/AI/1998/7) (1998): http://ow.ly/dzoO30922vp.

UN, Competitive examinations for recruitment and placement in posts requiring specific language skills in the professional category (ST/AI/1998/7/Amend.1) (2012): http://ow.ly/8wZW30922Z7.

UN, Composition of the Secretariat: staff demographics (A/69/292) (2014): http://ow.ly/kf5v3ofcyb7.

UN, Composition of the Secretariat: staff demographics (A/71/36o) (2016): http://ow.ly/fizV309275P.

UN, Composition of the Secretariat: staff demographics (A/72/123) (2017): http://ow.ly/ $/ \mathrm{SP}_{3} \mathrm{O}_{3}$ of $8 \mathrm{YRK}$.

UN, Conference Service at Vienna (A/C.5/44/24) (1989): http://ow.ly/76Xc3097Zhd.

UN, Covenant of the League of Nations: http://ow.ly/8PHT3OhfAiW.

UN, Details of UN Salaries, Hazard Pay, Rental Subsidy, Mobility and Hardship Scheme, and other Allowances, Benefits: http://ow.ly/JVRY $3091 Y Z Y$.

UN, Diplomatic Conference of Plenipotentiaries on the Establishment of the ICC (1998): http://ow.ly/u5a7308FSr5.

UN, Draft Statute for the ICC with commentaries: http://ow.ly/81Iq308FSoZ.

UN, Editorial manual for English: http://ow.ly/uET830926fm.

UN, Editorial manual for French: http://ow.ly/fmGg30926ks.

UN, Field Service category: http://ow.ly/gvHpзogzbTd.

UN, Final report of Commission of Experts established pursuant to the UN Security Council Resolution 771 (S/1994/673) (1994): http://ow.ly/FhNo3og2fFp.

UN, First report on the proposed programme budget for the biennium 200o-2001 (A/54/7) (1999): http://ow.ly/ScMt3og7ZwY.

UN, Guidelines on the Role of Prosecutors (1990): http://ow.ly/goAB308G5gI.

UN, Human resources management (A/RES/49/222) (1995): http://ow.ly/LEfR3og243s.

UN, Human resources management (A/RES/51/226) (1996): http://ow.ly/swizzog248U.

UN, Human resources management (A/RES/53/221) (1999): http://ow.ly/Qozk30924fx.

UN, Human resources management reform (A/55/253) (2000): http://ow.ly/lisk30924kM.

UN, Human Rights Standards and Practice for the Police: Expanded Pocket Book on Human Rights for the Police(2004): http://ow.ly/8vDt3oaUh6J.

UN, Human rights: https://goo.gl/8jjzoc.

UN, ICJ: All cases: $\underline{\text { http://ow.ly/P7m7zoezgcO. }}$ 
UN, ICSC Compendium (1980): http://ow.ly/LgLR30g1Zdx.

UN, ICSC Standards for Editors (1990): http://ow.ly/uQbezogiZzH.

UN, ICSC Standards for Translators and Revisers (1981): http://ow.ly/Pbf43091Zrq.

UN, ICSC Standards of Conduct for the International Civil Service (2013): http://ow.ly/lqXizogiZje.

$\mathrm{UN}$, Implementation of the recommendations of the Board of Auditors (A/49/348) (1994):

http://ow.ly/gtAz3097ZmG.

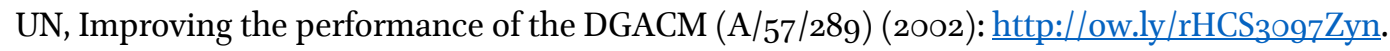

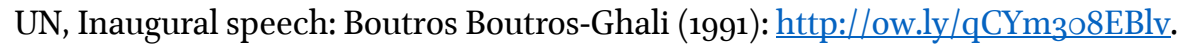

UN, Inaugural speech: Dag Hammarskjöld (1953): http://ow.ly/frUn308L4jB.

UN, Inaugural speech: Javier Perez de Cuellar (1981): http://ow.ly/zQFG308EB8u.

UN, Inaugural speech: Kurt Waldheim (1971): $\underline{\text { http://ow.ly/fOtd3o8L4KC. }}$

UN, Inaugural speech: Trygve Lie (1946): http://ow.ly/jj4S308EAQd.

$\mathrm{UN}$, Information sensitivity, classification and handling (ST/SGB/2007/6) (2007):

http://ow.ly/Wufd308IYmR.

UN, International Annual Meeting on Computer-Assisted Translation and Terminology: http://ow.ly/Zpa73ogzesj.

UN, International Annual Meeting on Language Arrangements, Documentation and Publications: http://ow.ly/mCQn309215q.

UN, International Civil Service Commission Statute and RPE (1987): http://ow.ly/Lngv3og1Z3M.

UN, International Court of Justice,-S: http://ow.ly/Ghxg3ohfEAY.

UN, JIU, Inspection of the Application of the UN recruitment, placement and promotion policies (JIU/REP/95/1) (1995): http://ow.ly/XwGg30921Rb.

UN, JIU, Multilingualism at the UN System organizations: status of implementation (JIU/REP/2011/4) (2011): http://ow.ly/70P330922lu.

UN, Joint Inspection Unit,-S: http://ow.ly/dLKN3og21FI.

UN, Language careers, LCE MoU Conferences: http://ow.ly/NNK930926S7.

UN, Language careers, LCE Outreach: http://ow.ly/432X $30926 \mathrm{Ky}$.

UN, Language careers, Meet a UN language professional: http://ow.ly/O1e630925Xs.

UN, Language careers, Meet the Training and Outreach Officer: $\mathrm{http}: / /$ ow.ly/dhAd $30926 \mathrm{~F} 7$.

UN, Language careers, Message about recruitment: http://ow.ly/zweW30g262k.

UN, Language careers, Message from the Assistant Secretary-General DGACM: http://ow.ly/ZPHozog25OW.

UN, Language careers: http://ow.ly/BsjF30925Kn.

UN, Language Competitive Examinations: http://ow.ly/mDtW3og21lJ.

UN, Language Proficiency Tests (2016): http://ow.ly/Kqhozo8G6qO.

UN, LCE for Arabic translators (2016): http://ow.ly/fPdb30927q9.

UN, LCE for English Copy Preparer/Proofreader/Production Editor (2015): http://ow.ly/PFPr30922Xy.

UN, LCE for English Interpreters (2015): http://ow.ly/QXJ63og23a8.

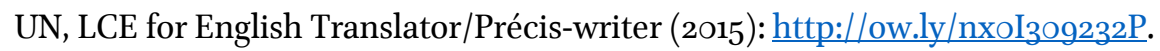

UN, LCE for Russian verbatim reporters (2016): http://ow.ly/3dJezog27iw.

UN, LCE for Spanish translators (2016): http://ow.ly/VOoh3og27vp.

UN, LCE into German: http://ow.ly/bVyX30922So.

UN, LCEs: http://ow.ly/LNck30925Fh.

UN, LCEs: sample examinations: http://ow.ly/KANbzoeRFfs.

UN, Managed Reassignment Programme (ST/AI/2007/2) (2007): http://ow.ly/TxQd30925l3.

UN, Mobility framework (A/68/265) (2014): http://ow.ly/dPpuzog25pc.

UN, National Professional Officer: http://ow.ly/Zoag3ogzaV5.

UN, Office of Internal Oversight Services Homepage: http://ow.ly/Ln2G3og2fr7.

UN, OIOS Audit of Language Services at the ICTY (2009): $\underline{\text { http://ow.ly/VEAR3oaoMbH. }}$

UN, OIOS Report on the audit and investigation of the ICTY (A/54/120) (1999): http://ow.ly/ioMY30949Jb.

UN, Pattern of Conferences (A/70/122) (2015): http://ow.ly/2KOC30925tJ. 
UN, Pattern of Conferences (A/RES/7o/9) (2015): http://ow.ly/HF3D 30926YM.

UN, Pattern of Conferences, (A/71/116) (2016): http://ow.ly/2phJ30927e2.

UN, Policies for Obtaining the Services of Individuals on Behalf of the Organization (ST/SGB/177) (1982):

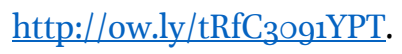

UN, Possible discrimination due to nationality, race, sex, religion and language in recruitment, promotion and placement (A/56/956/Add.1)(2002): http://ow.ly/SIHY3ohiKiL.

UN, Reform of the DGACM (A/59/172) (2004): http://ow.ly/XMOH3097ZDa.

UN, Relationship Agreement between the UN and the ICC (2004): $\underline{\text { http://ow.ly/KTjJ308FSze. }}$

UN, Report of the Committee on Conferences (A/52/32/Rev.1) (1998): http://ow.ly/bD6czog7ZrH.

UN, Report of the Committee on Conferences for 1999 (A/54/32) (1999): http://ow.ly/VC123097ZtD.

UN, Report of the ICTY (A/49/342) (1994): http://ow.ly/hrps30945Lg.

UN, Report of the ICTY (A/5o/365) (1995): http://ow.ly/5TKT30945Xk.

UN, Report of the ICTY (A/51/292) (1996): http://ow.ly/gdcA30946cg.

UN, Report of the ICTY (A/52/375) (1997): http://ow.ly/WNrC30946io.

UN, Report of the ICTY (A/53/219) (1998): http://ow.ly/vUvi30946ob.

UN, Report of the ICTY (A/54/187) (1999): http://ow.ly/sZJL30946wd.

UN, Report of the ICTY (A/55/273) (2000): $\underline{\text { http://ow.ly/IQ } 3 H_{3} 0948 f A}$.

UN, Report of the ICTY (A/56/352) (2001): http://ow.ly/mWwy3097XUq.

UN, Report of the ICTY (A/57/379) (2002): http://ow.ly/ZXnQ30948Xb.

UN, Report of the ICTY (A/58/297) (2003): http://ow.ly/36hh3097Ygo.

UN, Report of the ICTY (A/59/215) (2004): $\underline{\text { http://ow.ly/BWRa3097Yfi. }}$

UN, Report of the ICTY (A/6o/267) (2005): http://ow.ly/z63z3097Yim.

UN, Report of the ICTY (A/61/271) (2006): http://ow.ly/oCfr3097YjK.

UN, Report of the ICTY (A/62/172) (2007): http://ow.ly/Grxb30948Sy.

UN, Report of the ICTY (A/63/210) (2008): http://ow.ly/faeA3098VCZ.

UN, Report of the ICTY (A/64/205) (2009): http://ow.ly/gxot3098VEy.

UN, Report of the ICTY (A/65/205) (2010): http://ow.ly/eSqE3098VG3.

UN, Report of the ICTY (A/66/210) (2011): http://ow.ly/hBJy3098VMo.

UN, Report of the ICTY (A/67/214) (2012): http://ow.ly/4cA330949x1.

UN, Report of the ICTY (A/68/255) (2013): http://ow.ly/cIVO3098VZh.

UN, Report of the ICTY (A/69/225) (2014): http://ow.ly/YhID 3098 WoA.

UN, Report of the ICTY (A/70/226) (2015): http://ow.ly/EkD33098W3M.

UN, Report of the International Court of Justice (A/51/4) (1997): http://ow.ly/KPyG3oenQbA.

UN, Report of the Secretary-General (A/49/531) (1994): http://ow.ly/YFLizog7ZoF.

UN, Report of the Secretary-General (A/AC.172/162) (1995): http://ow.ly/q6sf3og7Zqq.

UN, Salaries for short-term conference interpreters: http://ow.ly/jnjw3obwv5S.

UN, Salaries for short-term translators: http://ow.ly/tGSR 30 bwuZu.

UN, Salaries in the professional and higher categories: http://ow.ly/AGcf3obwuRc.

UN, Secretary-Generals' Bulletin: Building the future (ST/SGB/1998/6) (1998): http://ow.ly/pSbF3o8Hgmk.

UN, Security Council Resolution 780 Establishing a Commission of Experts to Examine and Analyze Information Submitted Pursuant to Resolution 771 (S/RES/78o) (1992): http://ow.ly/CNox3092fAP.

UN, Special conditions for recruitment or placement of candidates successful in a competitive examination for posts requiring special language skills (ST/AI/200o/1) (2000): http://ow.ly/amgy30g22DH.

UN, Special conditions for recruitment or placement of candidates successful in a competitive examination for posts requiring special language skills (ST/AI/2003/1) (2003): http://ow.ly/JBdh30922LC.

$\mathrm{UN}$, Special conditions for recruitment or placement of candidates successful in a competitive examination for posts requiring special language skills (ST/AI/200o/1) (2000): http://ow.ly/amgy30922DH.

UN, Staff Regulations (ST/SGB/2014/2) (2014): http://ow.ly/pY5k308rgl8.

UN, Staff Rules and Staff Regulations (ST/SGB/2014/1) (2015): http://ow.ly/34Ur308IXWJ. 
UN, Statement by the UN Secretary General (2017), Secretary-General Urges Move beyond Conceptual Debate toward Better Protection against Atrocity Crimes, at Informal Dialogue on Responsibility to Protect: https://goo.gl/dfKkiJ.

UN, UN BoA Financial report and audited financial statements for biennium 2004-2005 ended 31 December 2005 (A/61/5/Add.12) (2006): http://ow.ly/EHM43097ZFO.

UN, UN BoA Financial report and audited financial statements for biennium 2002-2003 ended 31 December 2003 (A/59/5/Add.12) (2004): http://ow.ly/MRwK30g8oih.

UN, UN competencies for the future: http://ow.ly/DVTN3ogzecd.

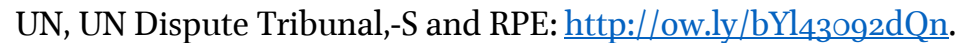

UN, UN General Assembly Resolution 152(II) on simultaneous interpreting (1947):

http://ow.ly/BiX $330 e n 3 n K$.

UN, UN Staff College courses: http://ow.ly/fcoN3ogzehg.

UN, UN University non-degree courses: http://ow.ly/6oRPzogzenF.

UN, UNESCO Recommendation on the Legal Protection of Translators and Translations and the Practical Means to improve the Status of Translators (1976): http://ow.ly/gBLyzogiZLZ.

UN, United Nations War Crimes Commission (1943-1948): http://ow.ly/YhH4308FS31.

UN, Verbatim Reporters: http://ow.ly/WB4H30947GH.

UN, Vetoes issued by UN Security Council permanent members: http://ow.ly/lSSj308ECqX.

\section{ICTY documents}

ICTY, Achievements: http://ow.ly/H1SszoamxpZ.

ICTY, Amalgamated Witness Statement: http://ow.ly/hfsR3oaL2pS.

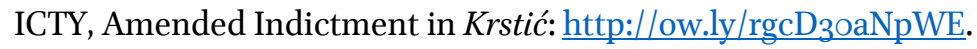

ICTY, Amended indictment in Sikirica et al: http://ow.ly/SVXszoeSjWg (English), http://ow.ly/jlNCzoeSjWN $(\mathrm{B} / \mathrm{C} / \mathrm{S})$.

ICTY, B/C/S translation of the Information on the Partially Dissenting Opinion of Judge Lattanzi in Judge-

ment in the case of Vojislav Šešelj (2016): http://ow.ly/YW1 G3o949b7.

ICTY, B/C/S translation of the Statement of the OTP on the Conviction of Radovan Karadžić (2016):

http://ow.ly/LiIT3og49gr.

ICTY, B/C/S translation of the Statement of the OTP on the Judgement of Vojislav Šešelj (2016):

http://ow.ly/yJQO3094937.

ICTY, Code of Ethics for Interpreters and Translators Employed by the Tribunal (1999): http://ow.ly/5YgP3o8IXCC.

ICTY, Code of Professional Conduct for Counsel Appearing Before the International Tribunal (2009): http://ow.ly/2cHb308G5jV.

ICTY, Completed cases: http://ow.ly/3KMG308G6BN.

ICTY, Decision on [Karadžić's] motion for revision of trial transcripts (2013): http://ow.ly/pTsk3oglD 5b.

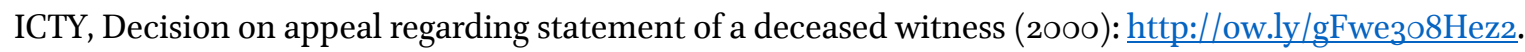

ICTY, Decision on Defence application for forwarding the documents in the language of the accused (1996): http://ow.ly/4siY308ICst.

ICTY, Decision on defendant's motions concerning the quality of interpreting (2008): http://ow.ly/Wuws308IP8R.

ICTY, Decision on matters relating to certain documents and transcripts (2014): http://ow.ly/eRPizoc4lPT.

ICTY, Decision on motion for admission of [witness] testimony pursuant to Rule 92quater (2009): http://ow.ly/OEirzo8HeZc.

ICTY, Decision on motion for exclusion of statement of accused (2005): http://ow.ly/3mNv308ZnyI.

ICTY, Decision on motion of Esad Landžo pursuant to Rule 73 (1997): $\underline{\text { http://ow.ly/Ksd7308HgiE. }}$

ICTY, Decision on motion to set aside confidential subpoena to give evidence (2002): http://ow.ly/qeMR308H6zN. 
ICTY, Decision on Prosecution motion seeking determination that the Accused understands English for the purposes of the [ICTY-S] and [ICTY-RPE] (2009): http://ow.ly/dTFRзoa6Luk.

ICTY, Decision on Prosecution request for extension of time to submit corrected translation of exhibit P942 (2007): http://ow.ly/gwgx3oc4lmy.

ICTY, Decision on Prosecution Rule 92quater motion (2013): http://ow.ly/OP2t308ZoaM.

ICTY, Decision on Prosecution's renewed motion for admission of evidence of Antonio Russo pursuant to Rule 92quater (2009): http://ow.ly/fi33308H8i4.

ICTY, Decision on the Accused's request that all materials, including transcripts, be disclosed to him in Serbian and Cyrillic script (2008): http://ow.ly/wIYrzoa6L2n.

ICTY, Decision on the Defense motion on Prosecution practice of "proofing" witnesses (2004): http://ow.ly/195130aKOWV.

ICTY, Decision on the motion ex parte by the defence of Zdravko Mucić concerning the issue of subpoena to an interpreter (1997): http://ow.ly/LawM308H40M.

ICTY, Defense Counsel: Pre-Trial Legal Aid Policy (2006): http://ow.ly/G505308Q29B.

ICTY, Defense Counsel: Trial Legal Aid Policy (2009): $\underline{\text { http://ow.ly/92mc308Q } 2 \mathrm{fL}}$.

ICTY, Directive on the assignment of defense counsel (2006): http://ow.ly/3lPp308S62c.

ICTY, Directive on the assignment of defense counsel (undated): http://ow.ly/2Ybm308S8Ko.

ICTY, Ex parte confidential: Decision on the Prosecution motion under Rule 73 for a ruling concerning the testimony of a witness (1999): http://ow.ly/dkYG308H5jC.

ICTY, Facts and figures: $\underline{\text { http://ow.ly/EoXV3ohjXbL. }}$

ICTY, Former judges: http://ow.ly/8mTR3oeU2Ql.

ICTY, IFF Form: http://ow.ly/JVRS3097Xdd.

ICTY, Intercepts, Krstić, Ex. 364 (English): http://ow.ly/vpзазоevcsh.

ICTY, Intercepts, Krstić, Ex. 665a (English) and 665b (B/C/S): http://ow.ly/AMX23oevgxe.

ICTY, Intercepts, Krstić, Ex. 696a (English) and 696b (B/C/S): http://ow.ly/z5Lw3oevb35.

ICTY, Intercepts, Krstić, Ex. 699a (English) and 699b (B/C/S): http://ow.ly/YZGazoevaoG (full intercept), Ex. 7ooa (English) and 7oob (B/C/S): http://ow.ly/UzbDzoevaEI (partial intercept).

ICTY, Interview between OTP and Ivan Čermak (1998): http://ow.ly/SDCC 3ogxLQj (ENG)

http://ow.ly/orvg3ogxLNx (B/C/S).

ICTY, Judgment in Halilović (2005): http://ow.ly/DV2izoaLık1.

ICTY, Judgment in Krstić (2001): http://ow.ly/jfMJ3oaLiYd.

ICTY, Judgment on Appeals in Lukić and Lukić (2012): http://ow.ly/8LAk3oaYxSE.

ICTY, Judgment Summary in Šešelj: http://ow.ly/LUUI30949C7.

ICTY, Landmark cases: http://ow.ly/gbarzo8FUOG.

ICTY, Mandate and crimes under ICTY jurisdiction: http://ow.ly/YKIozoasTTP.

ICTY, Manual on Developed Practices (2009): http://ow.ly/aMl93oaxTg2.

ICTY, Order on Zdravko Mucić's oral request for Serbo-Croatian interpreting (1997): http://ow.ly/VjWV308IAP5.

ICTY, Order RE exhibit P1999 (2007): http://ow.ly/GDiezoc4lsl.

ICTY, Order RE exhibits 6D132 and 6D1496 (2008): http://ow.ly/EURF3oc4l4h.

ICTY, Order RE exhibits 6D202 (2008): $\underline{\text { http://ow.ly/fuhizoc4kYT. }}$

ICTY, Order RE exhibits P2166 and P1506 (2008): http://ow.ly/cDNb3oc4lIq.

ICTY, Outreach Documentaries: http://ow.ly/xojMzoatWe5.

ICTY, Prosecution Brief in Blagojević (undated): http://ow.ly/zFOC 3oazoha.

ICTY, Public redacted version of 30 November 2012 decision on request to terminate appellate proceedings in relation to Milan Gvero (2013): http://ow.ly/Eeok308H8yr.

ICTY, Qualification requirements to be admitted to the Rule 45 list: http://ow.ly/D77w3ohhkk5.

ICTY, Redacted public version of ICTY statement of RM148 (2013): http://ow.ly/RJnN3oglCJI.

ICTY, Registrar's Certificate on Technical Error in Translation (2001): http://ow.ly/Cu8L3oc4lg3. 
ICTY, Remuneration scheme for persons assisting indigent self-represented accused (2010): http://ow.ly/AYhS308SmF6.

ICTY, Response to urgent defence motion concerning failure of prosecution to comply with Rule 68 (2008): http://ow.ly/2ldC308G6Ho.

ICTY, Rules of Procedure and Evidence (2015): http://ow.ly/EUfL308FTEg.

ICTY, Second order on exhibits P2885, 1D279, 1D671, 4D3, 4D95, 4D1o6, and 5D272 (2008): http://ow.ly/jDXh3oc4laI.

ICTY, Selected Documents in Šešelj: http://ow.ly/HMmizoeTHsU (English), http://ow.ly/vKCozoeTHvT (French), http://ow.ly/MmiazoeTHyJ (B/C/S).

ICTY, Selected Documents in Stanišić and Župljanin: http://ow.ly/Q7Ad308G7aA (English), http://ow.ly/Ruk1308G7dc (B/C/S), http://ow.ly/Yoa8308G7bU (French).

ICTY, Standard of Professional Conduct for Prosecution Counsel (1999): http://ow.ly/oZMI308G5fg.

ICTY, Statute (2009): http://ow.ly/1eAY308FTCb.

ICTY, The Prosecutor vs. Popović et al, Notice of disclosure of an expert witness report pursuant to Rule 94bis (2008): http://ow.ly/CoIazoaLib4.

ICTY, Translation and interpreting: http://ow.ly/OvoC3097YQ9.

ICTY, Voice of the victims: $\underline{\mathrm{http}: / / \text { ow.ly/5ebr3oamxst. }}$

\section{Newspaper articles and press releases}

BBC, Sarajevo 1992-1995: looking back after 20 years (2012): http://ow.ly/rLiO $30 a K{ }_{3} \mathrm{C}$.

Bošnjaci Agency, Pravda je zakasnila, ali nije opovrgnuta (1993): http://ow.ly/Cehv308FUlg.

Center on law and globalization, Politics and Justice in Creating the International Criminal Court (2003):

http://ow.ly/VAI8308FU6B.

Committee on Collection of Data on Crimes against Humanity and International Law (1998), BH Muslim

and Croat's preparations for violent separation from Yugoslavia and organized character of genocide against the Serbs in Sarajevo: http://ow.ly/6o2S 30 hfIm5.

Daily Star (Lebanon), 2017 state budget still has to clear major hurdles (2016): http://ow.ly/m6R33oboEqy.

E-life, New War Crimes Tribunal (1993): http://ow.ly/gKrm308FU4y.

Fra Antun Knežević, Bosanski prijatelj. Duh Bosne (2012): http://ow.ly/4RPF308FWc1.

Huffington Post, L'ONU: une grosse machine imparfaite... mais indispensable (2013): http://ow.ly/geRd3o8EBNY.

ICC Press Release (2017), Assembly activates Court's jurisdiction over crimes of aggression: https://goo.gl/YnQKX7.

International Law Middle East and North Africa Programmes, The STL and the Quest for Truth, Justice and Stability (2010): http://ow.ly/qEXC308FUMk.

L'express, L'impossible nouveau Nuremberg (1993): $\underline{\text { http://ow.ly/Fe6E308FUg1. }}$

La Vanguardia, La OTAN no asume el plan aliado para Bosnia por ser poco preciso (1993): http://ow.ly/sSyizo8FUoU.

Mapping Ignorance, Mandela was right: the foreign language effect (2014): http://ow.ly/N5z63092fO8.

Naše vijesti, Sit političar gladnog radnika ne razumije. Mjesečna plaća 5.00o KM (2015): http://ow.ly/vZnuzog8WiR.

NBC News, Kofi Annan: 'Hell, no,' he won't quit (2005): http://ow.ly/WFLd3o8Hgv7.

NBC, At 6o, Nuremberg trials still send a message: Prosecution of leading Nazis set a pattern for future prosecution of tyrants (2005): http://ow.ly/1v2z308FSh7.

Novi Horizonti, Profesor Amira Turbić-Handžić: Ako bosanski jezik nije postojao, zašto je Burian onda donio odluku o ukidanju bosanskogjezika (2015): http://ow.ly/KOl33oevjOE.

Novi Magazin, Plata Kolinde Grabar Kitarović 5.100 eura (2015): http://ow.ly/igTa3og8WhO.

NPR book reviews, The secret operation to bring Nazi scientists to America (2014):

http://ow.ly/qo6v3oaZ5po. 
Pass Blue, Franz Baumann: UN Bureaucracy? No, thanks (2016): https://goo.gl/t6hrpQ.

Političke analize, Problemi i pogreške Haškog suda (undated): http://ow.ly/g4YB308FUqh.

PolitPros, Югославия - первая жертва германского реваншизма (undated): http://ow.ly/JNq63o8FTXW. Rave utopia, Elie Wiesel: Bosnia was not Auschwitz, but it was genocide (2012): $\underline{\mathrm{http}} / / / \mathrm{ow} . \mathrm{ly} / \mathrm{HKdv} 3 \mathrm{ohfGWt}$. Republika, Medjunarodni krivicni tribunal za bivsu Jugoslaviju (Haski tribunal) (1998): http://ow.ly/cuEazo8FUnQ.

Tavnier, 前南斯拉夫和卢旺达国际刑事法庭的经验(1993): http://ow.ly/pYdS308FUcZ.

Telegraf, Povišica: Nikolićeva nova plata 150.00o dinara (2013): http://ow.ly/tIBQ $3098 \mathrm{WgT}$.

The Guardian, The UN is failing. Is it heading the way of the League of Nations? (2016): https://goo.gl/k8fg8s. The Independent, Bosnian guilt: ancient hatreds or wicked leaders? (1994): http://ow.ly/n7yazo8FTUl.

The New York Times, Milosevic to face charges covering 3 wars in Balkans (2001): http://ow.ly/4mLAzohhlNu. The New York Times, No way to fund a war crimes tribunal (2012): $\underline{\text { http://ow.ly/Er42308FUTT. }}$

UN News Centre, UN human rights expert deplores Saddam's trial and execution (2007): http://ow.ly/CcqEzo8FUBn.

UN Security Council Press Release, SCSL faces funding crisis as Charles Taylor gets under way (2007): http://ow.ly/yagx3o8FUSX.

Voice of America, Gaddafi burial delayed (2011): http://ow.ly/VX1C308FUDA.

Xinhua News Agency, UN chief hails achievements as SCSL closes (2014): http://ow.ly/qbzozo8FUG4.

\section{Miscellaneous}

AIIC, CEB/AIIC Agreement: http://ow.ly/C5zQ3obwwEt.

AIIC, Code of Professional Ethics: http://ow.ly/LIch30920pP.

AIIC, Frequently Asked Questions: http://ow.ly/oejg3098Wjp.

AIIC, Interpreting in conflict zones: http://ow.ly/CAIyzohioGz.

AIIC, List of members by location: http://ow.ly/rgDd30920ZQ.

AIIC, Professional Standards: http://ow.ly/dRyczogzour.

AITC, AITC Constitution: http://ow.ly/FhWyzogiZUL.

AITC, CEB/AITC Agreement: http://ow.ly/SrBzzobwwv7.

AITC, Guidelines on External Translation: http://ow.ly/nkdc309205V.

AITC, Professional Code of Conduct: http://ow.ly/VvSL3ogiZYT.

B\&H Court Criminal Defense Section, OKO Reporter: http://ow.ly/ff6Y3o8WUvs.

Betranslated.com, Translation schools: http://ow.ly/FtDQ3oabHBB.

Broz, S. (2008) (excerpts), Good people in times of Evil (Ellen Elias-Bursac, translator): http://ow.ly/mfYW 30 obNktx.

Council for Defense of Radovan Karadžić: http://ow.ly/dQ 4 G308G6lP.

Defending Milošević! Defending Serbia!: http://ow.ly/THxE308G6nP.

ECCC, ECCC Law (2004): $\underline{\text { http://ow.ly/tc3U308FTNT. }}$

ECCC, Internal Rules (2015): http://ow.ly/AIr7308LmuS.

ECCC, Judgment in Case 002/o1 (2014): http://ow.ly/fzzG308G5H7.

ECCC, Judgment in Case File/Dossier No. oo1/18-07-2007/ECCC/TC (2010): http://ow.ly/j2Tr308G5Ke.

ECCC, Legal representation in the Victims Support Section: http://ow.ly/JjRC3ohhpXh.

ECCC, Order on translation rights and obligations of the parties (2008): http://ow.ly/jLp63ohhp2F.

eCPDWebinars: https://goo.gl/6QhJ62.

Ericsson.com, How does stenography work: http://ow.ly/Rcy73obBz2a.

EU, Interpreting for Europe: $\underline{\text { htp://ow.ly/ogpBzoboeUB. }}$

EU, Official Journal of the European Union L 142/3 (2012), Directive of the European Parliament and of the

Council on the right to information in criminal proceedings: http://ow.ly/417 $30 e S H r M$.

EU, Official Journal of the European Union L 280/1 (2010), Directive of the European Parliament and of the Council on the right to interpreting and translation in criminal proceedings: $\underline{\mathrm{http}: / / \mathrm{ow} . \mathrm{ly} / \mathrm{Tz} 3 g 30 e S H t e .}$ 
EU, Publications on translation, interpreting and linguistic issues: http://ow.ly/YzN1zobofgW.

EU, Translating for Europe: http://ow.ly/jhKQ $30 b q E n V$.

Federation Internationale de Traducteurs, Translator's Charter (1963-1994): http://ow.ly/7wRH3091ZFD.

Holocaust Education and Archive Research Team, The First Nuremberg Trial: https://goo.gl/GtxuLr.

Human Rights First, The Role of Human Rights NGOs in relation to ICC investigations (2004): http://ow.ly/Fw4L308G6ki.

ICC, G5-G7 Language Assistant (English, Ossetian, Russian and Georgian): $\underline{\text { http://ow.ly/vYVe30980G1. }}$

ICC, P-2 Associate Translator (Linguist) (Arabic): http://ow.ly/C6Je3og2f6p.

ICC, P-2 Court reporter (English): http://ow.ly/QZ6X30948v8.

ICC, Rome Statute (2002): http://ow.ly/tifd308FThl.

ICC, Rules of Procedure and Evidence (2013): $\underline{\text { http://ow.ly/FIok308LmDI. }}$

ICTR, Code of professional conduct for defense counsel (1998): http://ow.ly/Kv33 $\mathrm{G}_{3} 08 \mathrm{G}_{5} \mathrm{OL}$.

ICTR, Nahimana et al. CIS: http://ow.ly/G56g308FUNy.

ICTR, Rules of Procedure and Evidence (2000): $\mathrm{http}: / /$ w.ly/hC7w308FTIv.

ICTR, Statute: http://ow.ly/facv308FTHO.

IMT, Charter (1945): http://ow.ly/1FnV3ohhakH.

IMT, Control Council Law No. 10 (1945): http://ow.ly/eDBrzohhacv.

IMT, Rules of Procedure (1945): http://ow.ly/7cw83ohhau6.

IMTFE, Charter (1946): http://ow.ly/LbQM308FTyL.

IMTFE, Rules of Procedure (1946): $\underline{\text { http://ow.ly/2jy8308LmP1. }}$

IMTFE, Special proclamation by the Supreme Commander (1946): http://ow.ly/7xDw308FTbT.

Institute for International Criminal Investigations: $\mathrm{http}: / /$ w.ly/K22A308G5mu.

International Prosecutors Association, Standards of Professional Responsibility and Statement of the Essential Duties and Rights of Prosecutors (1999): http://ow.ly/YFZZ308G5ih.

Intersteno Homepage: $\underline{\text { http://ow.ly/t4qR30948Kd. }}$

Juliette Scott's blog on legal translation: http://ow.ly/mimq3ogzeWy.

Linguistic services, Oaths, Rules and Ethics: $\underline{\text { http://ow.ly/OgrczoaMX2A. }}$

LinkedIN, Ellen Elias-Bursać: http://ow.ly/3oZd3097YyM.

LinkedIN, Phillip Hepburn: http://ow.ly/VmhW3097YCj.

Mastersportal.eu: $\mathrm{http}: / /$ ow.ly/8wJOzobqn2d.

Milan Lukić: http://ow.ly/vFdJ308G6pi.

MTStars forum: http://ow.ly/A3Em3obD2ND.

National Court Reporting Association (USA): http://ow.ly/Rnbt3og48pl.

Netherlands Institute for War Documentation Report: http://ow.ly/gFAR308G6FN.

OSCE, Deployment of an OSCE Special Monitoring Mission to Ukraine (2014): $\underline{\text { http://ow.ly/5O8j3oabpVM. }}$

OSCE, Handbooks for fieldwork: Working with or as an interpreter (undated): http://ow.ly/XignzoaqZJz.

OSCE, Supporting the Transition Process: Lessons Learned and Best Practices in Knowledge Transfer (2009):

http://ow.ly/qKPT3oamunZ.

Petejan, S. (undated), Interview with Svetlana Broz: http://ow.ly/Hls23obNkja.

Principles of International Law of the Charter and Judgment of the Nuremberg Tribunal, Formulated by the International Law Commission, Second Session. International Organization, vol. 4, no. 4, 1950, pp. 714721.JSTOR, JSTOR, http://ow.ly/7mwizohfCng.

Savet za štampu, Odluka po žalbi Inicijative mladih protiv dnevnog lista Informer (2015): http://ow.ly/DaolzoaLodD.

Savet za štampu, Odluka po žalbi Praksisa protiv portal Telegraf.rs i lista Informer (2014): http://ow.ly/lM593oaLo2n.

SCSL, Code of professional conduct for defense counsel with the right of audience before the [SCSL] (2006): http://ow.ly/PBzl308G5QD.

SCSL, Rules of Procedure and Evidence (2012): http://ow.ly/4zoh308FTKI.

SCSL, Statute (2012): $\underline{\text { http://ow.ly/v5j9308FTJf. }}$ 
Senad Ahmetovic YouTube Channel: http://ow.ly/CpEU3oaL26v. Statement on release: Vojislav Šešelj: http://ow.ly/zQpf zoeBwVw.

Statement on release: Zoran Kupreškić, Mirjan Kupreškić and Vlatko Kupreškić: http://ow.ly/iR7P3oeCkUG. Statement on release: Biljana Plavšić: $\underline{\text { http://ow.ly/1Z7q3oeCOC4. }}$

Statement on release: Dario Kordić: http://ow.ly/oVjN3oeCndT.

Statement on release: Dragoljub Ojdanić: http://ow.ly/PUGU3oeCnni.

Statement on release: Duško Tadić: http://ow.ly/fthozoeCjt6.

Statement on release: Ljubomir Borovčanin: http://ow.ly/wLoQ3oeCmf4.

Statement on release: Momčilo Krajišnik: $\underline{\text { http://ow.ly/Dfb53oeBF} 3 s . ~}$

Statement on release: Momčilo Perišić: http://ow.ly/nXIM3oeBKoy.

Statement on release: Nikola Šainović: http://ow.ly/Dr5K3oeBHDE.

Statement on release: Radovan Karadžić: http://ow.ly/wQIZ3oeCR 3 G.

STL, Code of professional conduct for counsels appearing before the [STL] (2011): http://ow.ly/aRXW3ohhd 3 s.

STL, Code of professional conduct for defence counsel and legal representatives of victims appearing before the [STL] (2012): http://ow.ly/YhIh3ohhd4V.

STL, Decision on languages in the case of Ayyash et al. (2011): http://ow.ly/pYTB3ohhoCQ.

STL, Directive on victims' legal representation (2013): http://ow.ly/iBTuzohhpIU.

STL, Legal Aid Policy for Victim Participation (2014): http://ow.ly/7RenzohhpNo.

STL, Rules of Procedure and Evidence (2017): $\underline{\text { http://ow.ly/jgPJ } 30 h h a I H .}$

STL, Statute (2016): $\underline{\text { http://ow.ly/FEFj3ohhaEr. }}$

The history of public transport in Sarajevo: http://ow.ly/tvNuzoaKYWp.

Udruženje novinara Srbije, Neosnovana upotreba reči “Šiptar" (2015): http://ow.ly/lxzGzoaKZVU.

UK, Ministry of Justice (2017), Criminal court statistics quarterly, England and Wales, January to March 2017: https://goo.gl/tav4Fs.

UNDP Human Development Report, the Netherlands: http://ow.ly/wVgm3og7Zop.

WAHM forum: http://ow.ly/xkLr3obD2S3. 


\section{CURRICULUM VITAE}

Besmir Fidahić was born on 20 July 1977 in Tuzla, B\&H. He has a BA in French and Arabic at Rutgers University, and an MA in translation at the University of the West of England. As part of his undergraduate studies he spent one year studying abroad at a university in France and one year at a university in Lebanon before returning to the USA for his final exams.

Besmir has been with the UN as a translator, interpreter, and editor in conflict, post-conflict, humanitarian, development, and international criminal tribunals for his entire professional life. After a 15-year involvement with the conflict in the former Yugoslavia, which started in 1996 and ended in 2011 (partially documented in this study), Besmir found it hard to stop working with criminals, influenced by the adrenaline rush that accompanies the interview process. Now, he is freelancing for UN entities prosecuting internal UN wrongdoers, those investigating criminal organizations worldwide, and a number of other UN entities, mainly working in developing countries.

This is Besmir's first book on law and language. His second, a study on linguistic justice at the ICC, STL, SCSL and ECCC is due to be published soon. 